\title{
CONSERVAÇÃO DE COLEÇÕES GEOLÓGICAS UTILIZANDO O ACERVO DO MUSEU DE GEOCIÊNCIAS DA USP
}

\author{
Miriam Della Posta de Azevedo
}

Orientadora: Prof $^{\mathrm{a}}$ Dr$^{\mathrm{a}}$ Eliane Aparecida Del Lama

\author{
Dissertação de Mestrado
}

Programa de Pós-Graduação em Mineralogia e Petrologia

São Paulo

2013 
Ficha catalográfica preparada pelo Serviço de Biblioteca e Documentação do Instituto de Geociências da Universidade de São Paulo

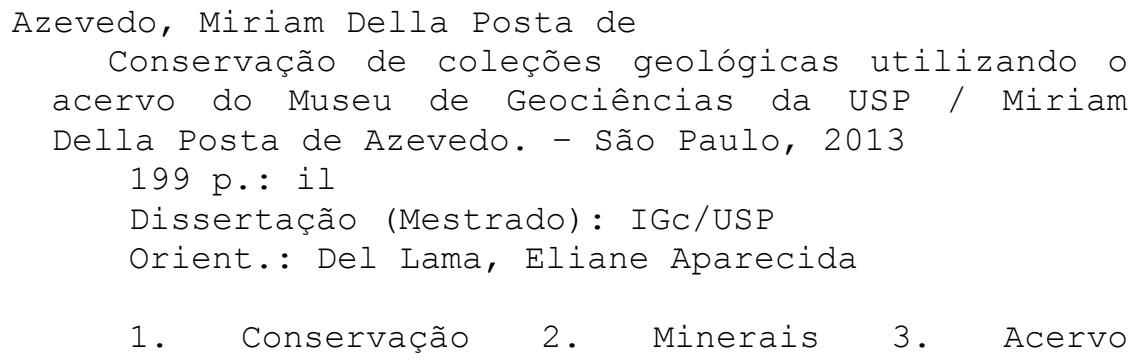


À Júlia, minha eterna fonte de inspiração e coragem. 


\section{Agradecimentos}

À minha filha Júlia, minha melhor amiga, por ser extraordinariamente compreensiva em meus momentos de ausência.

Aos meus pais, Francisco e Rosa, pela infinita dedicação em todos os sentidos.

A Prof ${ }^{a}$. Dr ${ }^{\mathrm{a}}$. Eliane Aparecida Del Lama por ter acreditado em mim quando ninguém (nem eu mesma!) acreditava.

Ao Prof. Dr. Paulo Roberto dos Santos, cuja assinatura permitiu a realização dos estudos que culminaram nesta dissertação, além da pronta disponibilidade em ajudar sempre que precisei.

Ao Prof. Dr. Colombo Celso Gaeta Tassinari, por ter colaborado para minha ida a Londres, quando diretor do IGc, sem a qual este trabalho perderia parte de seu conteúdo.

Ao Prof. Dr. Valdecir de Assis Janasi, atual diretor do IGc, que colaborou enormemente para minha ida à Alemanha e colabora pelo desenvolvimento do Museu de Geociências.

Ao Prof. Dr. Rainer A. Scultz Gütler pelo empréstimo das amostras de materiais essenciais à elaboração deste trabalho.

À FAPESP, pela colaboração na apresentação de parte desta pesquisa no $7^{\text {th }}$ Mineralogy and Museums Conference na Alemanha, por meio do Processo n ${ }^{\circ}$ 2012/10143-0.

A minha irmã, Patrícia Della Posta de Azevedo, pela revisão ortográfica e gramatical; e à Tata, por cuidar tão bem da Júlia durante minhas ausências e por sempre ter sido meu exemplo, apenas por ser como é.

A Beatrocas, por me fazer sorrir e gargalhar em momentos de desespero.

Ao meu esposo, Júlio César, por ter sido pai e mãe da Júlia pelas vezes em que estive ausente.

Ao Marcelo Ferreira Kawatoko, por me fazer acreditar que no universo do conhecimento, o centro está em toda parte, pela visão interdisciplinar da vida e pelas aulas de química.

Ao amor, carinho, apoio e compreensão incondicionais e inimagináveis que recebi, desde o início desta pesquisa, dos meus companheiros do Museu de Geociências: Daniel, Ideval e Rui. À Veridiana e à Tereza, que também participaram desta caminhada.

Ao Prof. Dr. Fábio Ramos Dias de Andrade, que me ajudou decisivamente na minha ida para os EUA (sem a qual este trabalho não teria existido) e pela infinita paciência em me ensinar conceitos básicos de mineralogia.

À Prof ${ }^{a}$. Dr ${ }^{\mathrm{a}}$. Sônia Maria Barros de Oliveira que prontamente assinou meu pedido de liberação para participar no curso do Smithsonian, sem o qual não haveria dissertação. 
Ao Prof. Dr. José Barbosa Madureira Filho, por ter tornado tão doces e agradáveis meus primeiros contatos com a Geologia.

Ao Prof. Dr. Luiz Eduardo Anelli, pela carta de apresentação necessária para a inscrição no mestrado.

A Leslie Hale, collection manager da coleção de rochas e minérios do Museu Nacional de História Natural do Smithsonian, pelo constante apoio prestado, em forma de dicas, doação de tempo e de materiais e conversas sobre geologia.

A Carol Buttler, fonte de inspiração, persistência e exemplo de como trabalhar para superar obstáculos.

Aos meus colegas mestrandos, Alexander e Alexandra pela colaboração nas aulas de mineralogia e pelo companheirismo.

Ao Dr. Nassib, Ivan e Dr ${ }^{\mathrm{a}}$. Ana Carolina, por me ajudarem a manter minha sanidade mental durante essa jornada.

Aos colegas da Seção de Pós Graduação do IGc Ana Paula, Leo e Magali.

A todos os colegas da biblioteca do IGc, em especial, Érica Beatriz, Brenda, Érica Celeste, Sandra, Sônia e Maristela.

Ao Isaac, do laboratório de Microscopia Eletrônica de Varredura (MEV), pela disponibilidade e competência em suas análises.

Aos colegas da Seção de Apoio Didático de Mineralogia e Geologia, Aninha, André, Bruno, Cristina e Zefinha.

Aos colegas da Seção de Informática, por me socorrerem nos momentos que o computador deu problema, me deixando em estado de pânico.

Aos colegas da Seção de Contabilidade e Finanças e Seção de compras, por me ajudarem sempre que precisei viajar.

Ao Manuel Rubira Herrada (Manolo), pelas informações preciosas sobre a composição química dos suportes das amostras.

À Prof ${ }^{\text {a }}$. Dr ${ }^{\mathrm{a}}$. Maria Júlia Chelini, do Museu de Geociências da UnB, pela boa vontade além dos limites, pelas conversas construtivas e pelo compartilhamento de informações imprescindíveis.

Às minhas grandes amigas, Daniele Tiffani Coelho e Miriam Paula Coradini, pela amizade infinita, compreensão extrema e ombros amigos em horas de desespero.

Ao querido amigo Roberto Pereira Silva, por me mostrar que alguém que arrastava chinelos na FFLCH é capaz de brilhar, trabalhando com seriedade!

Aos meus felinos, Gatíola, Esmeralda, ET e Valentim, por me fazerem companhia até altas horas e não me deixarem adormecer, fazendo brincadeirinhas ao lado do computador. 


\section{Resumo}

Este trabalho compreende um estudo geral sobre a conservação de coleções geológicas, utilizando como referência o acervo de minerais, rochas e meteoritos do Museu de Geociências do Instituto de Geociências da Universidade de São Paulo.

A sistemática de conservação de coleções geológicas foi compilada a partir das principais fontes bibliográficas sobre conservação de materiais geológicos, além do conhecimento adquirido em participação de seminários, congressos e cursos, visitas técnicas a museus de instituições estrangeiras, aliada à experiência cotidiana da autora como técnica do Museu de Geociências desde o ano de 2005.

O termo conservação, empregado neste trabalho, compreende um conjunto de condições ideais às quais devem ser submetidas amostras de exposição (luz, temperatura, umidade relativa, impurezas do ar) e de reserva técnica (ambiente e materiais para acondicionamento). A partir da acepção do termo conservação este trabalho apresenta uma descrição geral do estado das amostras do Museu de Geociências nos quesitos: deterioração devido à umidade relativa do ar (deliquescência ou desidratação), deterioração por oxidação, variações de cor nos minerais devido à exposição a luz, isolamento de minerais radioativos e asbestiformes.

O objetivo do presente estudo é criar instrumentos que subsidiem uma melhor atuação da equipe do Museu de Geociências, bem como de outros acervos geológicos, no que concerne ao cuidado de suas amostras, de forma que possibilite que os minerais estejam pelo maior tempo possível à disposição tanto de pesquisadores quanto do público geral. 


\begin{abstract}
This study comprises a general overview of the conservation of geological collections, namely the collection of minerals, rocks and meteorites from the Museum of Geosciences of University of São Paulo.

In order to perform this study, the researcher used the available bibliography about conservation of geological collections; the knowledge acquired throughout participations in congresses, lectures and other courses; technical visits to other geological museums around the world and, finally, her own experience as museum technician at the Museum of Geosciences since 2005.

Considering conservation a process which comprises a set of ideal conditions under which the exhibited samples and the storage samples should be submitted (light, temperature, relative humidity, and air pollutants), this study describes the general condition of museum samples in each one of the parameters mentioned.

The main conservational issues are: deterioration due to relative humidity (deliquescence or dehydration), oxidation, color changes by light exposition, isolation of radioactive and asbestos minerals.

The goal of this study is to create tools to support our Museum staff as well as the staff of other geological collections, regarding the care of the mineral collections to keep them available to researchers and general visitors for as long as possible.
\end{abstract}




\section{APRESENTAÇÃO}

Esta dissertação destina-se a todos os geólogos que trabalham com museus e a todos os museólogos, historiadores, geógrafos e técnicos que trabalham com Geologia.

O tema desta pesquisa trata da conservação de acervos geológicos, com ênfase na conservação de minerais.

A ideia de fazer um trabalho sobre conservação de coleções geológicas surgiu após a participação em um treinamento sobre "Gerenciamento de Coleções de História Natural"1 ocorrido no Smithsonian National Museum of Natural History, em Washington, DC.

Com o término do curso, pensou-se na possibilidade de traçar um paralelo quanto ao modo de se conservar uma coleção de minerais e rochas entre duas instituições, $\mathrm{O}$ Smithsonian Institution e o Museu de Geociências da USP, uma de grande, e outra de pequeno porte. Tal ideia amadureceu nesta dissertação, que não apenas utiliza o National Museum of Natural History para fazer este paralelo, mas também outros museus nacionais e estrangeiros $^{2}$.

Assim, durante o estudo, será utilizada a expressão museu parâmetro (ou exposição parâmetro), que faz referência a museus que apresentam o mesmo tipo de acervo ou de exposições que o Museu de Geociências da USP (base deste estudo), podendo, por isso, servir de parâmetro de adequação ou inadequação do Museu, com relação a sua exposição e tratamento do acervo. Serão utilizados, para isso, exemplos de museus que possuem exposições geológicas e que foram visitados no Brasil e no exterior, já que a museologia recente não possui uma metodologia definida no trato de exposições e conservação de peças geológicas, tema que será abordado no Capítulo 4.

Um fato que chamou a atenção foi a pequena quantidade de publicações sobre o tema, quando comparado a outros tipos de coleções de história natural, como as paleontológicas, botânicas e zoológicas. Concluiu-se que um trabalho abordando essa temática seria de grande interesse não só para o Museu de Geociências da USP, mas também para todos os museus brasileiros que abrigam coleções geológicas.

Deste modo, o trabalho busca sanar algumas das dificuldades do Museu de Geociências da USP, pois no Brasil não há cursos especializados no cuidado de coleções geológicas. Esse trabalho torna-se assim, um meio para o desenvolvimento de pesquisa no próprio museu, o que contribui para torná-lo um museu ativo, que não só transmite conhecimento, mas que também o gera.

\footnotetext{
${ }^{1}$ Latin American and Caribbean Professionals Collection Management Training Program 2010.

${ }^{2}$ Os museus citados nesta pesquisa encontram-se descritos no capítulo 4, item 4.5, que trata dos museus parâmetro.
} 


\section{ÍNDICE}

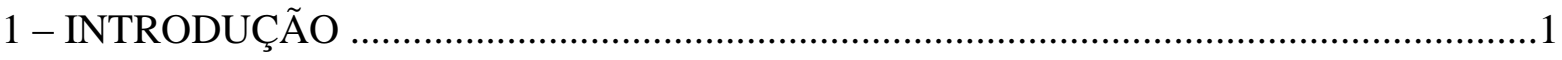

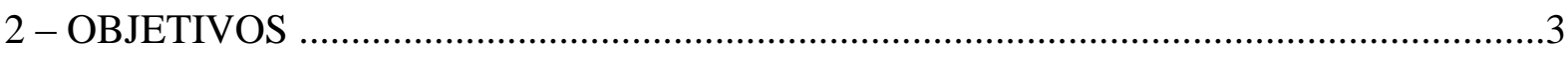

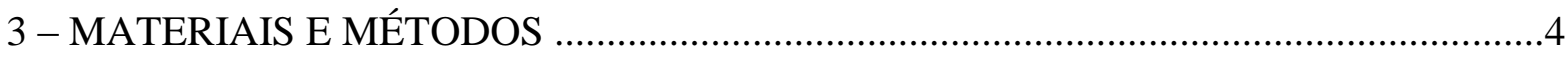

3.1 - Revisão Bibliográfica ................................................................................... 4

3.2 - Estudo do Acervo ............................................................................................ 4

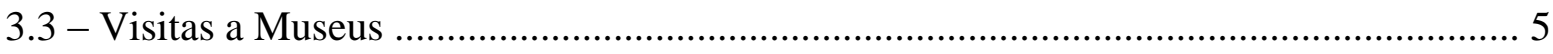

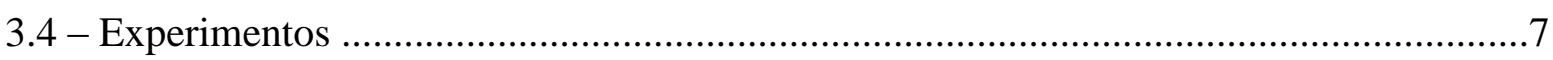

3.4.1 - Colorimetria em minerais ..............................................................................

3.4.2 - Difratometria de raios X e Microscopia Eletrônica de Varredura …………………....

3.5 - Integração dos dados ..........................................................................................

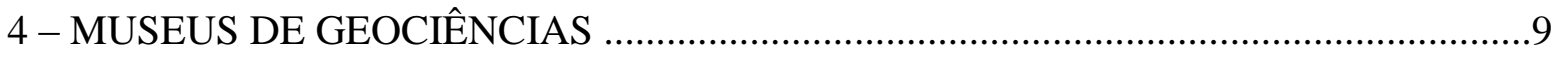

4.1 - Origem dos Museus de Mineralogia …………………........................................ 13

4.2 - Exposições mineralógicas ................................................................................ 19

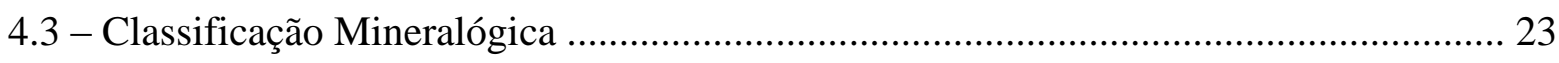

4.4 - Classificação Petrológica ………………………………………………………..... 27

4.5 - Museus Parâmetro ...........................................................................................29

4.5.1 - National Museum of Natural History - NMNH - Smithsonian Institution ...........30

4.5.2 - London Natural History Museum - LNHM ….......................................

4.5.3 - Oxford University Natural History Museum (Universidade de Oxford) ............ 38

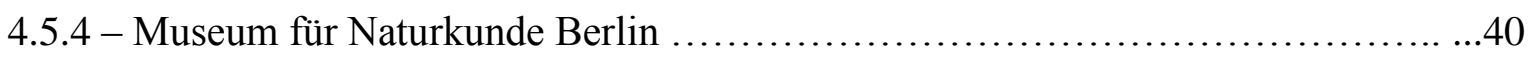

4.5.5 - Museu de Mineralogia Prof. Heinz Ebert .......................................................... 42

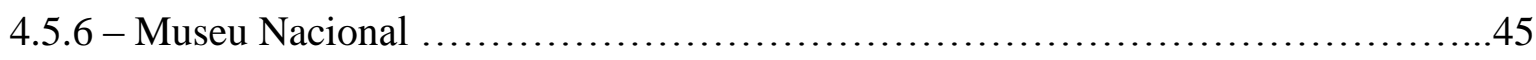

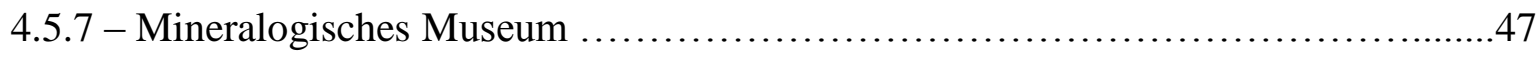

4.5.8 - Mineralogisches Sammlungen - Technische Universität Berlin ................... 50

4.5.9 - Mineralogisches Museum - Philipps-Universität Marburg ...................... 52

4.5.10 - Mineralogisches Sammlungen - Institut für Geowissenschaften - Universität Jena.52

4.5.11 - Mineralogisches Museum - Universität Würzburg .......................... 53

4.5.12 - Mineralogisches Museum am Steinmann-Institut der Universität Bonn .......... 55

4.5.13 - Museu de Ciências da Terra ……………………………………………….... 57

4.5.14 - Terra Mineralia - TU Bergakademie of Freiberg …………………………….... 59

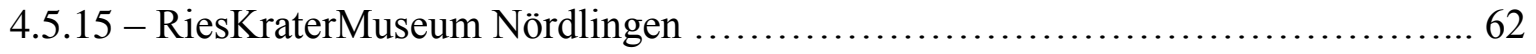

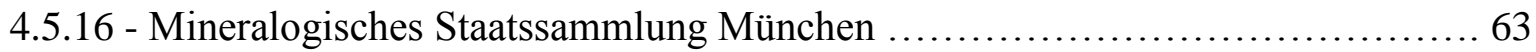

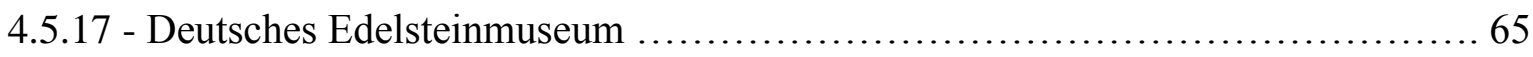




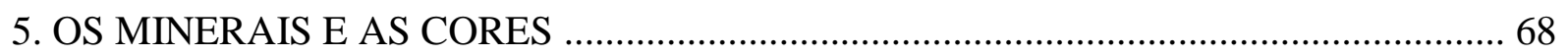

5.1 - Experimento com espectrofotômetro ................................................................. 81

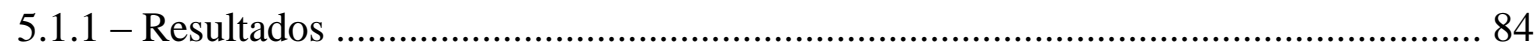

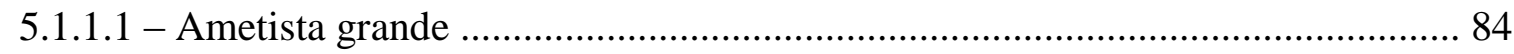

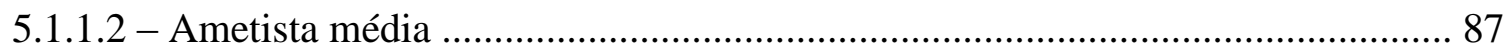

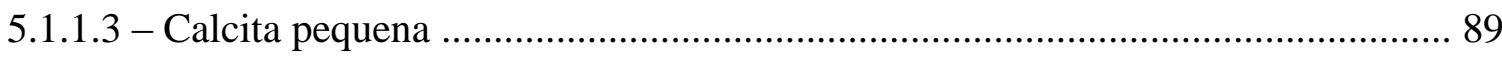

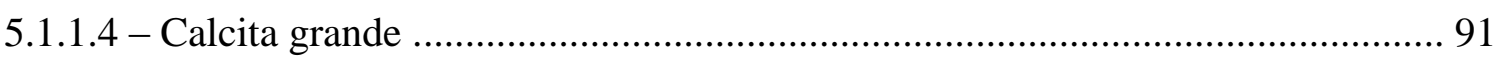

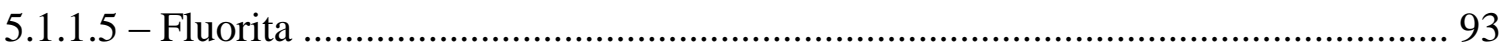

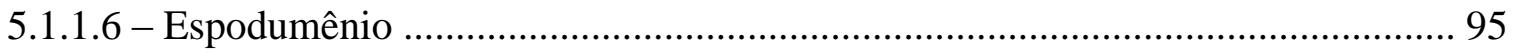

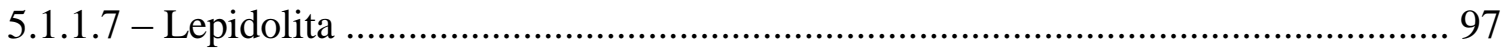

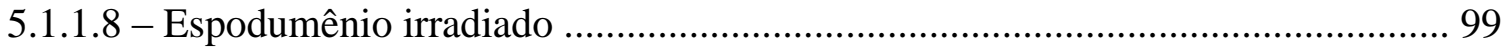

6 - CONSERVAÇÃO DE MATERIAIS GEOLÓGICOS ................................................ 103

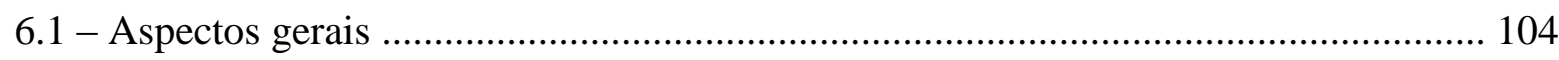

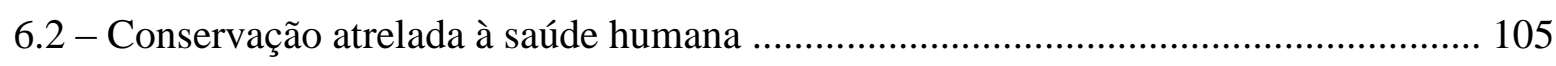

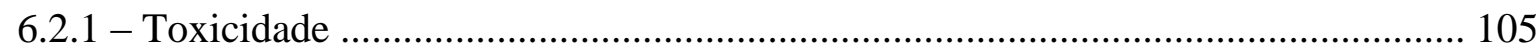

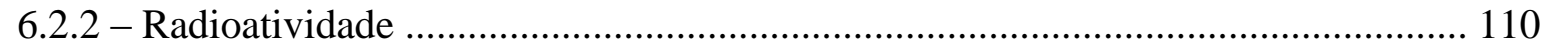

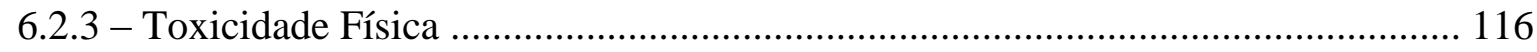

6.3 - Conservação de amostras museológicas ................................................................... 120

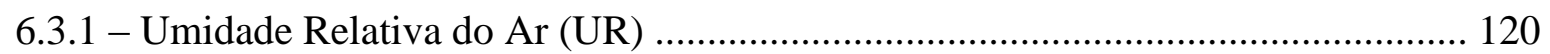

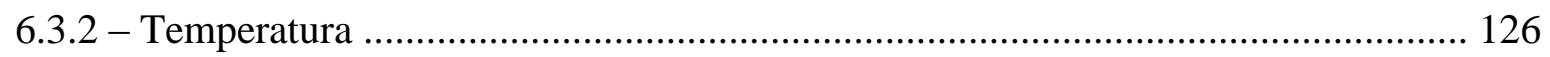

6.3.3 - Mudanças de cor em minerais induzidas pela ação da luz ................................ 128

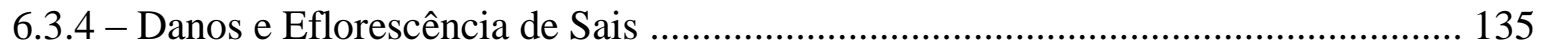

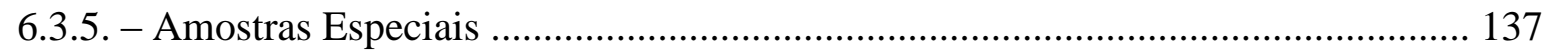

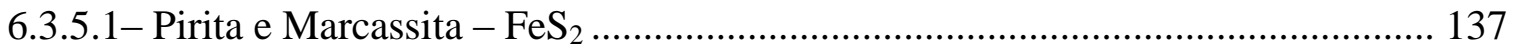

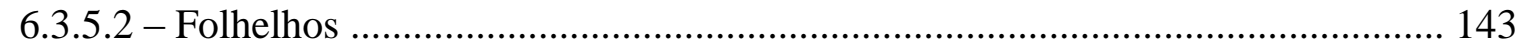

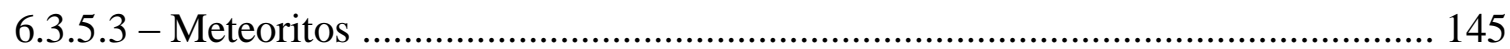

6.3.6 - Materiais para Conservação de Amostras .............................................................. 151

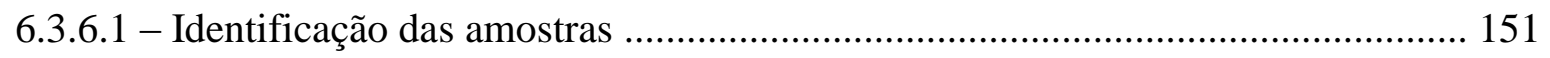

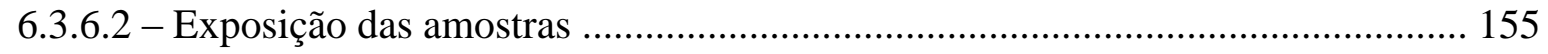

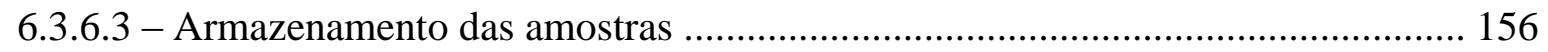

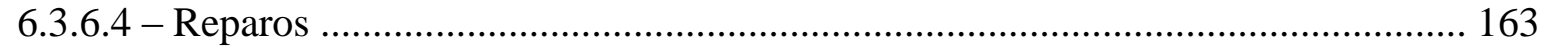

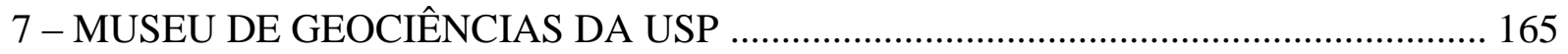

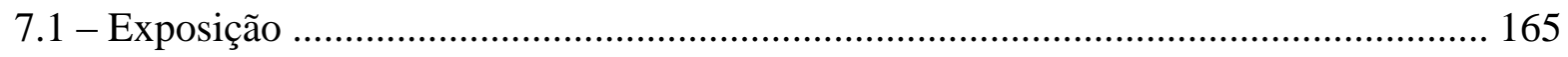

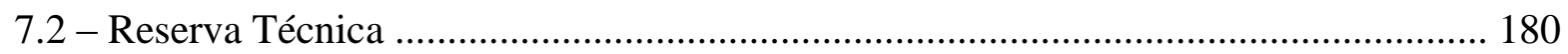


8 - Considerações Finais

Referências Bibliográficas

Sites Pesquisados

\section{ÍNDICE DAS TABELAS}

Tabela 1 - Instituições visitadas e exposições parâmetro

Tabela 2 - Principais museus de minerais e rochas do Brasil e as instituições às quais

pertencem.

Tabela 3 - Classes minerais agrupadas de acordo com a composição química e o ânion predominante, segundo Dana.

Tabela 4 - Classificação mineralógica de STRUNZ \& NICKEL (2001).

Tabela 5: Elementos cromóforos e as cores nos minerais idiocromáticos. Fonte: NASSAU (1978).

Tabela 6: Minerais alocromáticos coloridos por metais de transição como impurezas. Fonte:

NASSAU (1978).

Tabela 7. Causa da cor em alguns minerais comuns em coleções. Fonte: NASSAU (1978) . 79

Tabela 8. Parâmetros de L $a^{*} b^{*}$ para a amostra de ametista grande. 87

Tabela 9. Parâmetros de L $a^{*} b^{*}$ para a amostra de ametista média. 89

Tabela 10. Parâmetros de L $a * b *$ para a amostra de calcita pequena. 90

Tabela 11. Parâmetros de L $a^{*} b^{*}$ para a amostra de calcita grande. 92

Tabela 12. Parâmetros de L $a * b^{*}$ para a amostra de fluorita. 94

Tabela 13. Parâmetros de $L a^{*} b^{*}$ para a amostra de espodumênio. 96

Tabela 14. Parâmetros de L $a * b *$ para a amostra de lepidolita. 98

Tabela 15. Parâmetros de L $a^{*} b^{*}$ para a amostra de espodumênio irradiado verde escuro.. 101

Tabela 16. Parâmetros de $L a^{*} b^{*}$ para a amostra de espodumênio irradiado verde claro maior.

Tabela 17. Elementos químicos nocivos à saúde humana e os respectivos minerais nos quais são encontrados. Fonte: BRUNTON ET AL. (1985) e HOWIE (1992). 108

Tabela 18. Isótopos Naturais de Urânio. Fonte: Apostila Educativa-Radioatividade. CENEN.

Tabela 19. Minerais radioativos comumente encontrados em acervos mineralógicos e sua composição química. Fonte: BRUNTON ET AL. (1985) / LAMBERT (1994) ... 113

Tabela 20: Minerais fotossensíveis, modificações sofridas, tipo de suscetibilidade e condições de armazenamento. (Fonte: HORÁK, 1994). 


\section{ÍNDICE DAS FIGURAS}

Figura 1. Gráfico demonstrativo das porcentagens de museus de Geologia pertencente aos setores públicos, privados e universidades. Considera-se um total de 28 instituições.

Figura 2. Porcentagem de museus universitários de acordo com cada tipo de instituição universitária. Considera-se o total de 19 instituições.

Figura 3. Gravura na folha de rosto do livro Museum Wormiorum, catálogo do gabinete de curiosidades do médico e colecionador Owl Worm (1588-1655). Fonte: http://pt.wikipedia.org/wiki/Gabinete_de_curiosidades. 14

Figura 4. Vista Geral da Galeria de Minerais do London Natural HIstory Museum. Ao fundo, a entrada para The Vault.

Figura 5. Entrada do Vault, enfatizando impacto temporal entre uma exposição do século XIX e outra do século XXI. London Natural History Museum. 22

Figura 6. Exposição científica de rochas no Museu de Geociências da USP. 28

Figura 7. Vista geral de uma das exposições de rochas no London Natural History Museum. Nela está presente a classificação científica das rochas em seus três tipos, de maneira sedutora e didática. 28

Figura 8. Exposição de rochas sem a classificação científica usual. Escolheu-se mostrar as rochas atreladas a grandes monumentos da humanidade, relacionando Geologia e História. Pode ser considerada uma exposição interativa, uma vez que trabalha com o conhecimento prévio do visitante. London Natural History Museum ........28

Figura 9. Exposição de rochas no NMHN. Aqui o destaque é para as rochas que compõem as construções famosas de Washington. Foto: Eliane A. Del Lama........................ 28

Figura 10. Fachada principal do NMNH, localizado no National Mall.................................. 30

Figura 11. Fachada de um dos edifícios do MSC em Suitland, Maryland............................. 30

Figura 12. Exemplo de exposição moderna, na qual o visitante leigo pode ver uma das principais características físicas do mineral, a cor, sem a utilização de termos científicos que criem barreira entre o espectador e o conhecimento a ser transmitido.

Figura 13. Outro conceito básico da mineralogia, o hábito do mineral, aqui transmitido ao público leigo de forma sutil e agradável, sob o título de "um mineral, muitas formas". 
Figura 14. Vista parcial da reserva técnica de minerais no edifício do National Mall. Nota-se os móveis antigos, cujas gavetas não são acopladas, podendo cair ao serem manuseadas sem o devido cuidado. 32

Figura 15. Vista externa do cofre de gemas do NMNH, no edifício do National Mall. A porta abre mediante a digitação do código de acesso e só o funcionário responsável tem acesso ao local.

Figura 16. Sala especial para abrigar meteoritos lunares: climatização e controle de umidade, manuseio indireto das amostras por meio de luvas especiais, e amostra não sai da cabine onde está armazenada. 33

Figura 17. Vista parcial da reserva técnica da coleção de minerais do NMHN no MSC....... 33

Figura 18. Aspecto dos minerais armazenados no interior das cabines da Figura 17. .......... 33

Figura 19. Placa de etafon utilizada para forrar o fundo das gavetas onde são alocados materiais frágeis, a fim de evitar seu deslizamento durante a abertura da gaveta.

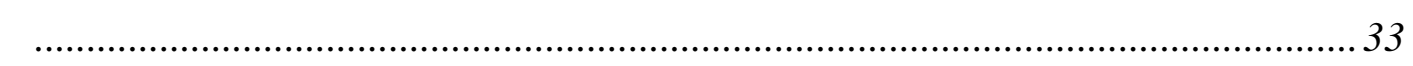

Figura 20. Amostras de rochas ornamentais são fixadas sobre as placas mostradas na Figura 19. 33

Figura 21. Amostra de mineral asbestiforme com fibras soltas, guardada sem proteção dentro da gaveta.

Figura 22. Todas as amostras da reserva técnica preservam a etiqueta original e a atual....34

Figura 23. Acondicionamento precário de amostras de sais de nitrato. Não há controle de umidade ou temperatura no local........................................................................34

Figura 24. Aspecto de testemunhos de sondagem armazenados no interior de caixas especiais. 34

Figura 25. As caixas são trazidas do campo e o material é acondicionado diretamente na estante, sem a necessidade de ser transferido de recipiente. 34

Figura 26. A cor do traço, uma das características mais importantes do mineral, é mostrada de forma simples na exposição clássica de minerais no LNHM.

Figura 27. No mesmo museu, porém em outro espaço expositivo, a cor do traço é mostrada ao público leigo de maneira moderna e interativa, permitindo a compreensão de um conceito básico de identificação mineral sem o apelo científico. 36

Figura 28. A luz natural na exposição clássica de minerais no LNHM atrapalha a apreciação do visitante.

Figura 29. Exibição moderna de minerais no LNHM. A exposição está em uma altura acessível, e a ausência de iluminação externa, mesclada a uma iluminação 
individual e direcionada para cada amostra, valorizam o mineral e proporcionam uma boa visão para o visitante.

Figura 30. Escala de dureza relativa de Mohs mostrada na exposição clássica do LNHM... 37

Figura 31. Outra forma de exibição da escala de dureza relativa de Mohs, LNHM. 37

Figura 32. Banco para descanso na exposição clássica de minerais do LNHM. .................... 38

Figura 33. Área de descanso na exposição geológica do LNHM. .......................................... 38

Figura 34. Edifício original do Ashmolean Museum, onde atualmente está situado o Museu de Ciência e Técnica da Universidade de Oxford. 38

Figura 35. Miniaturas de todas as amostras da coleção; o número de cada uma aparece assim que o mouse é colocado sobre a mesma. Nota-se a amostra $n^{\circ} 63 \mathrm{em}$

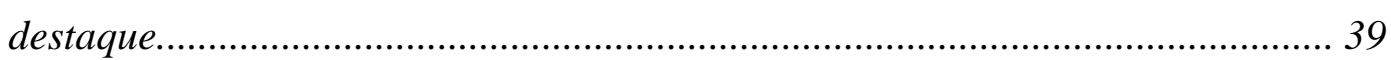

Figura 36. Ao passar o mouse sobre a imagem, o pesquisador pode vê-la em tamanho ampliado e decidir se quer abri-la ou não.

Figura 37. Aspecto geral do espaço expositivo do Museu de História Natural da Universidade de Oxford. A organização da exposição lembra um gabinete de curiosidades do século XVII. 40

Figura 38. Exposição de paleontologia ao lado da exposição de minerais. Mistura de assuntos deixa o visitante desorientado. Nota-se também a falta de preocupação com a conservação do acervo pela presença de goteiras que caem sobre as vitrinas. .40

Figura 39. Vista geral da exposição de mineralogia. Foto: Eliane A. Del Lama..... .41

Figura 40. Exposição inacessível a cadeirantes e pessoas de baixa estatura. Foto: Eliane A. Del Lama. 41

Figura 41. Vista geral da reserva técnica de minerais. Foto: Eliane A. Del Lama. 42

Figura 42. Detalhe do acondicionamento de amostras no interior dos armários da reserva técnica. Nota-se o mesmo mobiliário da Figura 40. Foto: Eliane A. Del Lama. . 42

Figura 43. Vista geral do espaço expositivo do Museu Heinz Ebert. 43

Figura 44. Mobiliário utilizado ao mesmo tempo como vitrina e como armário de reserva técnica. Bonito e funcional. 44

Figura 45. Parte inferior das vitrinas são armários que podem ser abertos para o pesquisador utilizar minerais não expostos.................................................... 44

Figura 46. Detalhe da disposição dos materiais dentro do armário....................................... 44

Figura 47. Detalhe da numeração das bandejas, a fim de colaborar na organização do acervo. 44 
Figura 48. Meteorito Bendegó na entrada do Museu: iluminação direta e suscetibilidade a flutuações de temperatura e UR ...................................................................... 46

Figura 49. Exposição petrológica voltada para alunos dos ensinos fundamental e médio..... 46

Figura 50. Detalhe da janela fechada, para evitar iluminação natural no fóssil.................... 46

Figura 51. Detalhe da janela com cortinas especiais para diluir a iluminação natural......... 46

Figura 52. Fóssil exposto em cabine preparada para evitar contato com o ambiente e luzes direcionadas ........................................................................................................ 46

Figura 53. Vista geral de parte da exposição paleontológica: layout moderno....................... 46

Figura 54. Detalhe da janela aberta sobre meteorito exposto...............................................46

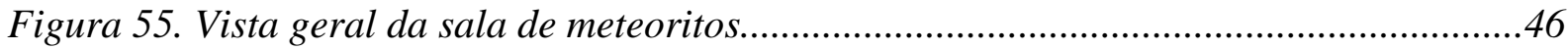

Figura 56. Vista geral do Museu de Mineralogia da Universidade de Hamburgo. ................ 47

Figura 57. Amostra de pirita exposta do museu. O número 8 ao lado do mineral refere-se à legenda (mostrada na Figura 58) que está posicionada na parte superior da vitrina. 48

Figura 58. Legenda onde está colocada a descrição da amostra de pirita da Figura 57. Notase o acúmulo de informações desconectadas do mineral, o que dificulta a visualização e compromete a compreensão por parte do visitante, tanto leigo quanto especializado. 48

Figura 59. Aspecto da vitrina com vinte amostras. Quantidade adequada ao espaço disponível, contribuindo para melhor apreciação do público.

Figura 60. Caixote onde são embutidas as lâmpadas das vitrinas. Elas ficam separadas do material, facilitando a manutenção e evitando a transmissão de calor para o mineral. 49

Figura 61. Crocoíta alaranjada por alteração de coloração devido à ação da luz. 49

Figura 62. Vitrina de exposição central, mostrando os minerais mais bonitos. Nota-se perto da janela um armário menor: é a exposição sistemática. 50

Figura 63. Reserva técnica na parte de baixo da vitrina central..............................................50

Figura 64. Acomodação das amostras no interior das gavetas. ............................................ 51

Figura 65. Amostras são armazenadas por espécies minerais. ............................................. 51

Figura 66. Cristal de realgar armazenado na reserva técnica. Nota-se um acolchoamento para a proteção do cristal. 51

Figura 67. Aspecto da treliça que separa a lâmpada das amostras. 51

Figura 68. Exposição de minerais fluorescentes com luz UV, vitrina coberta com cortina blackout........ 51

Figura 69. Interior da vitrina da Figura 68. 51 
Figura 70. Aspecto da treliça divisória entre a iluminação e as amostras.

Figura 71. Suportes de acrílico simples e adequados ao tamanho do mineral causam bom efeito visual. 52

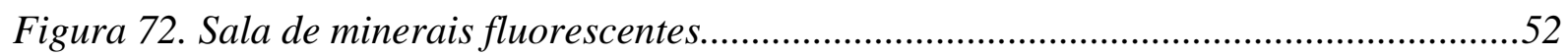

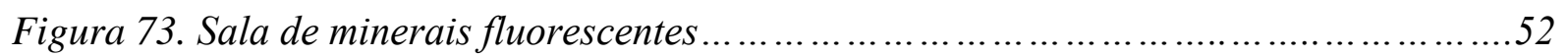

Figura 74. Vista da sala de exposição sistemática, a única privada de iluminação natural. . 53

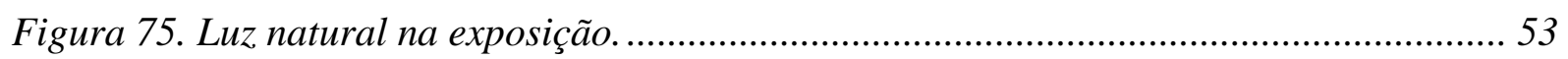

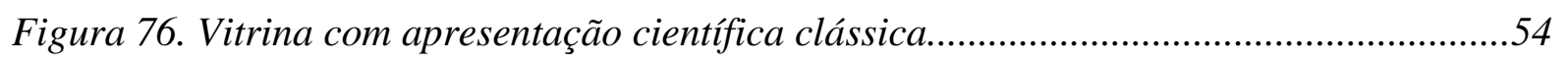

Figura 77. Vitrina didática sobre o uso de minerais sem atrativos visuais e legendas com

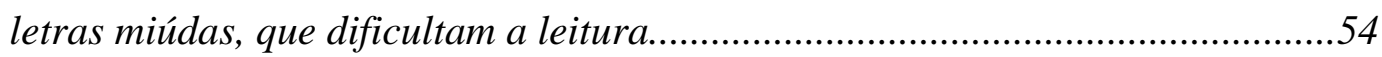

Figura 78. Espaço simples, porém bem demarcado, para exposições temporárias do museu. Neste caso, esculturas feitas com eclogito ........................................55

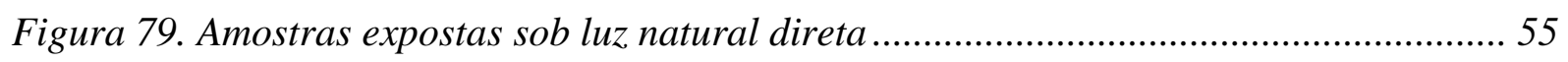

Figura 80. Vitrina com exposição de rochas e fotografia dos monumentos construídos com elas. Foto: Eliane A. Del Lama ......................................................................... 55

Figura 81. Detalhe de uma das vitrinas da exposição sistemática de minerais. Foto: Lauro K. Dehira. 56

Figura 82. Etiquetas transparentes dificultam a leitura das informações e muitas vezes passam despercebidas ao visitante. Foto: Lauro K. Dehira...... 56

Figura 83. Entrada para a exposição mineralógica do Museu de Ciências da Terra............ 57

Figura 84. Aspecto geral da exposição de minerais do Museu de Ciências da Terra............ 57

Figura 85. Mobiliário antigo e danificado, sem iluminação. .................................................. 58

Figura 86. Vitrina sem iluminação e fios desencapados, com possibilidade de ocorrência de

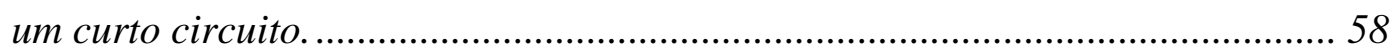

Figura 87. Detalhe de suporte improvisado e etiqueta danificada ...................................... 58

Figura 88. Etiqueta ilegível ao visitante e amostra em altura inadequada. ........................... 58

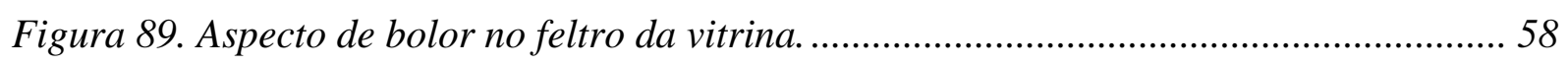

Figura 90. Amostra de carvão em estado avançado de degradação. Além disso, iluminação mal posicionada prejudica a visualização da amostra. 58

Figura 91. Aspecto da entrada de uma das salas de exposição. Nota-se apenas a utilização da identidade visual para explicar o conteúdo da mostra, além dos minerais separados por continentes.

Figura 92. Vista geral de uma das salas de exposição. 60

Figura 93. Detalhe da janela do castelo, especialmente escurecida para eliminar a interferência da luz externa. 60 
Figura 94. Detalhe da iluminação direcionada à amostra por pontos de Led. 60

Figura 95. Um dos recursos didáticos para crianças: no meio da exposição uma câmara produz a sensação tridimensional de estar no interior de uma cela unitária....... 61

Figura 96. Área da exposição alocada onde outrora esteve a cozinha do castelo. As diferenças de coloração no teto são herança da fuligem dos fogões a lenha. Foto: Eliane A. Del Lama.

Figura 97. Vista geral da reserva técnica doTerra Mineralia. Foto: Eliane A. Del Lama..... 61

Figura 98. Armários são visivelmente numerados para facilitar a localização e o acesso à informação.

Figura 99. Cobertura de acrílico com puxador em tecido auxilia a conservação, protegendo as amostras da ação de poeiras e da variação de UR, além de evitar o manuseio de muitas amostras apenas para a localização de um mineral.

Figura 100. Puxador em tecido evita o contato das mãos com o acrílico, sem gasto de tempo com a limpeza da tampa. Nota-se a numeração da gaveta, sempre do lado esquerdo da mesma..

Figura 101. Detalhe do armazenamento de amostras nas gavetas. As amostras mantêm as etiquetas originais e as do Museu.

Figura 102. Detalhe de uma das gavetas em seu conjunto. 62

Figura 103. Amostra lunar em suporte confeccionado sob medida. 63

Figura 104. Exposição utiliza interatividade para apresentar conceitos complexos sobre a origem dos meteoritos.

Figura 105. Neste painel, o espectador tem a possibilidade de se aprofundar no assunto sem que a exposição seja exaustiva para todos.

Figura 106. Meteoritos metálicos expostos sem qualquer tipo de proteção. 63

Figura 107. Aspecto da área didático-científica do museu... 64

Figura 108. Área da exposição destinada à contemplação, sem caráter científico. 64

Figura 109. Reserva Técnica do Museu. Nota-se o espaço inferior sem gavetas para as amostras grandes.

Figura 110. Exemplo de armazenamento de amostras nas gavetas da reserva técnica. 64

Figura 111. Grande quantidade de amostras pequenas e próximas dificulta a visualização. A distância das legendas causa desinteresse ao público.

Figura 112. Suporte improvisado para a amostra evidencia a falta de critérios básicos de conservação.

Figura 113. Estas gemas amarelas, possivelmente heliodoro, não possuem qualquer identificação. 
Figura 114. Visão parcial da exposição, com destaque para as vitrinas centrais, com iluminação própria, que valoriza as amostras. Foto: Eliane A. Del Lama. 67

Figura 115. Cristais de realgar com a coloração original (vermelho escuro) preservada. Fonte: http://www.mindat.org/photo-424844.html.Acesso em 08.01.2013. 68

Figura 116. Realgar em estado de alteração avançado, esfacelamento e coloração amarelo ouro devido à ação da luz. Acervo: Museum für Naturkunde Berlin.

Figura 117. Exemplar de prata nativa. Nota-se o brilho metálico característico desse mineral. Fonte: http://www.mindat.org/photo-813.html (Acesso em 21/11/2012). 69

Figura 118. Exemplar de prata nativa, com cobertura preta devido à oxidação do metal, que formou como produto final uma camada de acanthita sobre o mineral. Acervo: National Museum of Natural History.

Figura 119. Espectro eletromagnético, com destaque para o espectro da luz visível, em vermelho, os raios ultravioletas, em lilás, e os raios infravermelhos, em rosa. Fonte: BLOSS (1971), modificado.

Figura 120. Os dois principais defeitos causadores de centros de cor: O númerol, Frenkel, mostra um par de íons que se desloca do sítio original e acomoda-se em um interstício; O número 2, Schottky, mostra o deslocamento de um par de íons com cargas opostas, que se deslocam de seus sítios originais para a superfície do cristal, deixando lacunas na estrutura. ZHIGILEI, L. V. Fonte: http://people.virginia.edu/ lz2n/mse201/mse201-defects.pdf (acesso em

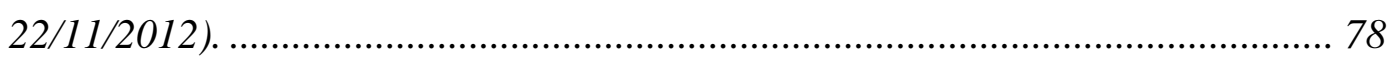

Figura 121a. Cabine de exposição para minerais fluorescentes no Museu de História Natural da Universidade de Oxford. 80

Figura 121b. Minerais sob luz UV demonstrando a propriedade de fluorescência no interior da cabine ao lado. Museu de História Natural da Universidade de Oxford. ....... 80

Figura 122. Amostra de crisoberilo amarelo (Olho de Gato) com chatoyance (POST, 1997).

Figura 123. Amostra de safira astérica, com efeito de tripla chatoyance ou asterismo (POST, 1997). 81

Figura 124. Processo de medição da refletância de um objeto pelo espectrofotômetro: o aparelho é colocado encostado em uma superfície plana do objeto. Ao ser acionado, o equipamento dispara um sensor espectral, que vai decifrar os comprimentos de onda de acordo com a reflexão. Um microcomputador dentro do 
aparelho traduz essa leitura em linguagem numérica e gera um gráfico, produto final do aparelho. Fonte: Konica Minolta, 2001. 82

Figura 125. Os minerais foram colocados sobre uma caixa de plástico. .83

Figura 126. A caixa foi posicionada em um ambiente externo, em exposição direta à luz solar...... .83

Figura 127. Medições realizadas sempre na mesma face do mineral. 84

Figura 128. Após as medições, os minerais eram recolocados na caixa, sempre com a mesma face voltada para cima. 84

Figura 129. Ametista grande. Acervo: Museu de Geociências da USP. 85

Figura 130. Gráficos espectrais obtidos da amostra de ametista grande.

a) No primeiro conjunto de medidas, a curva de refletância mostra maior reflexão da cor vermelha, em torno de 6\%, e da cor roxa, em torno de 5,5\%. 86 b) $O$ segundo conjunto de medidas mostrou um sutil aumento na refletância total, com uma regularidade maior de refletância entre os comprimentos de onda, mas ainda prevaleceu o vermelho. 86 c) O terceiro conjunto de medidas mostrou os mesmos níveis de refletância do primeiro mês, porém, a curva de reflexão vermelha desapareceu e a faixa roxa do espectro passou a mostrar maior refletância dentre as demais. A Amostra começou sofrer perda de cor. 86 d) Finalmente, o último conjunto de medidas confirmou a diminuição da refletância, de $\pm 5.5 \%$ em agosto para $\pm 3 \%$ em novembro, além da perda de cor, notada pela linha que indica mesma absorção em todas as faixas do espectro visível. 86

Figura 131. Ametista média. Acervo: Museu de Geociências da USP. 87

Figura 132. Gráficos espectrais obtidos da amostra de ametista média.

a) O primeiro conjunto de medidas mostra maior reflexão na faixa roxo-azul do espectro e também na faixa vermelha, além de uma refletância total baixa. 88 b) $O$ segundo conjunto de medidas apresenta um aumento da refletância total, com as mesmas faixas de reflexão do espectro.

c) $O$ terceiro conjunto de medidas mostra medidas próximas às do primeiro conjunto. 88

d) O último conjunto de medidas mostra uma diminuição geral da refletância, demonstrando perda de pigmentação da amostra. 88

Figura 133. Calcita pequena. Acervo: Laboratório Didático do IGc/USP. 89

Figura 134. Gráficos espectrais obtidos da amostra de calcita pequena. 
a) $O$ primeiro conjunto de medidas mostra refletância menor que $10 \%$. 90

b) O segundo conjunto de medidas mostra um visível aumento da refletância para cerca de $20 \%$. 90

c) O terceiro conjunto de medidas mostra ligeira queda na refletância que passou para $17,5 \%$.

d) Finalmente o ultimo conjunto de medidas mostra sutil aumento da refletância, evidenciando clareamento da amostra. 90

Figura 135. Calcita grande. Acervo: Laboratório Didático do IGc/USP. 91

Figura 136. Gráficos espectrais obtidos da amostra de calcita grande.

a) No primeiro mês a refletância média foi em torno de $9 \%$. 92

b) No Segundo mês a curva de refletância mostra aumento de mais de $10 \%$, que poderia evidenciar perda de cor, caso a curva permanecesse nesse patamar.... 92

c) No terceiro mês a curva volta a diminuir. 92

d) No último conjunto de medidas, há curvas em vários níveis do espectro, demonstrando a impossibilidade de inferir algum resultado. 92

Figura 137. Amostra de fluorita. Acervo: Museu de Geociências da USP. 93

Figura 138. Gráficos espectrais obtidos da amostra de fluorita.

a) A primeira medida mostra uma refletância geral baixa (cerca de 2\%) e um nível de refletância levemente elevado na cor vermelha.

b) Em setembro a refletância aumentou consideravelmente, e a curva perde um pouco da refletância do vermelho. 94

c) Em outubro a refletância voltou a diminuir e a curva mostra uma leve refletância na faixa roxa do espectro que não havia aparecido até então. 94

d) Finalmente em novembro a refletância atingiu seu patamar inicial de cerca de $2 \%$. A curva não demostrou refllexão de roxo.

Figura 139. Amostra de espodumênio levemente rosada. Acervo: Laboratório Didático do IGc/USP. 95

Figura 140. Gráficos espectrais obtidos da amostra de espodumênio.

a) No primeiro conjunto de medidas, o espodumênio mostra refletância geral de cerca de $20 \%$, com absorção preferencial da cor roxa. 96 b) Na segunda medição há significativo aumento da curva de refletância, com a manutenção da absorção da cor roxa.................................................................. 96

c) A amostra perdeu cerca de 2\% de refletância no segundo mês. ...................... 96

d) A refletância geral diminuiu, demonstrando escurecimento da amostra......... 96 
Figura 141. Lepidolita. Acervo: Museu de Geociências da USP.

Figura 142. Gráficos espectrais obtidos da amostra de lepidolita.

a) $O$ primeiro conjunto de medidas mostra uma refletância de cerca de $25 \%$ e maior reflexão das cores roxalazul e vermelha do espectro. 98

b) A amostra apresentou um aumento da refletância geral no primeiro mês $e$ manteve as mesmas faixas de reflexão do espectro.

c) No terceiro conjunto de medidas, a lepidolita manteve a refletância geral e as faixas de refletância.

d) Finalmente constata-se que a lepidolita apresentou pequena alteração no primeiro mês e depois manteve sua cor inalterada. 98

Figura 143. Amostras de espodumênio irradiadas de cor verde. .99

Figura 144. Após apenas um dia no sol, os minerais recuperaram a coloração original.......99

Figura 145. Espodumênio irradiado verde escuro mostra pico de refletância no verde. ..... 100

Figura 146. Espodumênio irradiado verde claro maior também mostra maior reflexão no verde, mesmo sem um pico tão elevado quanto da Figura 145. 100

Figura 147. Padrões irregulares devido à heterogeneidade da cor verde na amostra. 100

Figura 148. O espodumênio verde escuro, agora rosa, teve diminuição na refletância geral e perdeu o pico de reflexão verde.

Figura 149. A amostra verde clara maior, agora rosa clara, teve a refletância geral aumentada e maior absorção da faixa verde do espectro.

Figura 150. Dois minerais de bário: a whiterita à esquerda $\left(\mathrm{BaCO}_{3}\right)$, considerada tóxica por ser solúvel; à direita está a barita $\left(\mathrm{BaSO}_{4}\right)$, atóxica por não ser solúvel. Acervo do Museu de Geociências da USP. 107

Figura 151. Espectro eletromegnético. Em verde está destacado o intervalo onde se localizam os raios gama. Fonte: http://fisicasemmisterios.webnode.com.br/products/ondaseletromagneticas/ (modificado). Acesso em 18/06/2012.

Figura 152. Exemplo de contador Geiger de mão. http://lojageobiologia.webnode.com/images/200000016-2f0112ffb1/radex-.jpg

Figura 153. Vitrina especial para exibição de minerais radioativos. Nota-se que o visitante não tem sequer contato visual com as amostras, apenas com suas imagens. Notar também o posicionamento de aviso de radiação em local visível. Acervo: London Natural History Museum. 116

Figura 154. Exemplo de mineral asbestiforme. Note que a fibra se desprende facilmente do mineral. Acervo do Museu de Geociências da USP. 
Figura 155. Imagem ampliada de uma fibra de asbesto tentando ser envolvida pelas células macrofágicas do pulmão humano. Fonte: SCARPELLI, 2006.

Figura 156. Exemplo de armazenamento ideal de amostra de asbesto no Museum Support Center (MSC) do Smithsonian Institution, em Maryland, Suitland. O material é embalado em sacos plásticos numerados, junto com as etiquetas, e depois colocado em caixas.

Figura 157a. Falha na vedação de caixilhos das janelas do Museu de Geociências da USP permite a entrada de água diretamente sobre parte da coleção.

Figura 157b. Algumas amostras, como a muscovita da foto, são diretamente afetadas pela falta de manutenção no edifício, levando à alteração de minerais por elevação na $U R$.

Figura 158. Imagem de carnallita $\left(\mathrm{KMgCl}_{3} \cdot 6 \mathrm{H}_{2} \mathrm{O}\right)$ em duas fases, cristalina e solução. Acervo do Museu de Geociências da USP. 123

Figura 159a. Exemplar de hanksita em suporte de ferro. Acervo: Museu de Geociências da USP. .124

Figura 159b. Detalhe da ferrugem na região de contato entre o suporte e a amostra. Na base do suporte, mancha branca da parte da amostra que deliquesceu. 125

Figura 159c. Detalhe da região de contato entre amostra e suporte. 125

Figura 159d. Ferrugem na amostra, decorrente do contato com o material oxidado do suporte. .125

159e. Espectroscopia de Energia Dispersiva de raios $X$ (EDS) realizada via Microscopia Eletrônica de Varredura (MEV) do material coletado no suporte da hanksita. Os elementos $\mathrm{Na}$, Cl e K são provenientes da hanksita; já os elementos Zn e Fe são provenientes da interação da amostra com o suporte. O Zn é resultante de camada protetora acrescentada ao suporte no tempo de sua confecção e o Fe é o próprio material do suporte.

Figura 160a. A vivianita $\mathrm{Fe}_{3}{ }^{2+}\left(\mathrm{PO}_{4}\right)_{2} .8 \mathrm{H}_{2} \mathrm{O}$ é um mineral incolor que se torna azul (metavivianita) aos primeiros contatos com a luz. Acervo do Museu de Geociências da USP. 129

Figural60b. Detalhe do cristal de metavivianita (azul). Acervo do Museu de Geociências da USP. 129

Figura 161 a. Amostra de realgar completamente alterada para pararealgar. Acervo: Museu de Geociências da USP. 
Figura 161b. Amostra de cristais grandes de realgar que não é exposta. Nota-se visivelmente a diferença de cor entre a amostra sã, e a amostra ao lado. Acervo: Museu de Geociências da USP.

Figura 161c. Detalhe da amostra da figura 161a: um pequeno ponto da amostra resistiu ‘a alteração de cor.

Figura 161d. Detalhe do cristal de realgar da figura 161b: a amostra ficou menos de dois meses em exposição, sem luz direta, e já se notam estrias de alteração (laranja) no cristal.

Figura 162. Máscara ritual azteca/mixteca, séculos XV/XVI, denominada The Skull of the Smoking Mirror. Esse artefato antropológico tem turquesa na maior parte de sua composição e, na área dos olhos, dois discos de pirita. Fonte: http://www.britishmuseum.org/explore/highlights/highlight_objects/aoa.aspx.. 138

Figura 163. Todas as fases de alteração e degradação possíveis de ocorrerem na pirita em uma só amosta: alteração para limonita, oxidação, eflorescência e esfacelamento.

Figura 164. Detalhe das ocorrências citadas na Figura 163. Acervo: Museu de Ciências da Terra-DNPM. 140

Figura 165. Esfacelamento de amostra de pirita, causada pela oxidação do sulfeto. Acervo: Museu de Ciências da Terra-DNPM. 141

Figura 166. Esfacelamento de pirita. Acervo: Museu de Geociências da USP. 141

Figura 167. Esfacelamento de marcassita, decorrente da oxidação do sulfeto. Acervo: Museu de Ciências da Terra-DNPM. 141

Figura 168. Oxidação de pirita. Acervo: Museu de Geociências da USP. 141

Figura 169a. Aspecto de folhelho ressecado, com fissuras de grande espessura. Acervo: Museu de Geociências da USP.

Figura 169b. Aspecto de uma das camadas de delaminação do mesmo folhelho. Acervo: Museu de Geociências da USP. 145

Figura 170. Meteorito Itapuranga exposto no saguão do Instituto de Geociências da USP. A oxidação do ferro da amostra está proporcionando o aumento da quebra do material em seus planos de fraqueza. Foto: Daniel Machado.

Figura 171. No Museum für Naturkunde Berlin, os meteoritos metálicos são armazenados em vitrinas de vidro vedado como fundo forrado por sílica gel. Um higrômetro controla constantemente a umidade do local, sempre menor que 50\%.

Figura 172. Aspecto da vitrina de meteoritos do Museu de Geociências da USP. À exceção de dois exemplares, toda a coleção está exposta nessa vitrina...... 148 
Figura 173. A abertura lateral da vitrina propicia a contaminação dos espécimes pela umidade, variação de temperatura e poluentes do ambiente. 148

Figura 174. Condritos da coleção de meteoritos do Museu de Geociências da USP. 148

Figura 175. Manchas de oxidação do ferro em condrito. Acervo: Museu de Geociências da $S P$ 148

Figura 176. Rachadura em condrito provocada pela ferrugem 148

Figura 177. Aspecto da ferrugem no suporte do condrito. Note-se a eflorescência (parte branca) no suporte de ferro e as manchas de ferrugem. 148

Figura 178. Exemplo de reserva técnica específica para amostras de grandes dimensões, no MSC. No caso de meteoritos, o espaço deve ter controle de temperatura e UR, além de filtros de ar. 150

Figura 179. Meteorito Cranbourne, com 3,5 toneladas exposto no NHM em Londres. Ele está acondicionado em uma vitrina especialmente vedada a fim de manter a temperatura e umidade em seu interior. 150

Figura 180. Detalhe dos equipamentos para constante monitoramento de temperatura e umidade no interior da vitrina do meteorito Cranbourne, no LNHM. O nitrogênio seco garante a ausência de $\mathrm{O}_{2}$ do ambiente.

Figura 181. Vista da sala onde estão armazenados meteoritos lunares no Museum Support Center, do Smithsonian Natural History Museum, in, Suitland, Maryland. Cada cabine é abastecida com gás nitrogênio, livre de água e oxigênio. Este procedimento mantém os meteoritos e rochas lunares livres de sofrerem oxidação e interferência de poluentes do ambiente, como metais pesados e sais. Fonte: http://mineralsciences.si.edu/research/meteorites/antarctica/curation.htm 150

Figura 182. Meteorito lunar no Ries Crater Museum Nördlingen 151

Figura 183. O espécime fica exposto em uma redoma de vidro e possui um suporte especialmente produzido para mostrar a melhor face para os visitantes. 151

Figura 184a. Marcação errada feita no mineral matiolita.O mineral tem pequenas dimensões e se encontra sobre uma matriz branca. A tinta preta com a numeração está bem mais evidente que o mineral, confundindo a visão do observador. Acervo: Museu de Geociências da USP. 152

Figura 184b. Detalhe da marcação da amostra da Figura 184a. O mineral matiolita é o ponto azul abaixo da marcação, que se destaca mais que a amostra. Esse tipo de procedimento deve ser evitado. Acervo: Museu de Geociências da USP 152

Figura 185. A figura indica uma peça de cerâmica sendo identificada com utilização de acrilóide B-72. A seta preta indica a marcação já concluída, enquanto a seta 
amarela indica os dois tipos de vernizes utilizados: o branco para a base da marcação e o incolor para sua cobertura. Fonte: Catálogo da Archival Quality Materials for Conservation, Restoration, Preservation \& Exhibition de 2010... 154

Figura 186. Exemplo de medidor de radiação UV. Fonte: www.universityproducts.inc. Acesso em 06.12.2012. 156

Figura 187. Kit para microaspiração de amostras. Fonte:

http://www.universityproducts.com/cart.php? $m=$ product_list $\& c=1233 \&$ primary $=$ $1 \&$ parentId $=\&$ navTree []$=1262 \&$ navTree []$=1270 \&$ navTree []$=1233$. Acesso em 06.12.2012.

Figura 188. À esquerda, sílica gel insaturada. À direita, aspecto da sílica após absorver umidade. 158

Figura 189. Sílica gel laranja, que não possui cobalto em sua composição. Sobre a sílica, está um recipiente de alumínio, próprio para seu acondicionamento. Quando saturada, fica incolor. Fonte: www.universityproducts.inc 158

Figura 190. Amostra de halita acondicionada em caixa de acrílico. A sílica gel já está saturada. Acervo: Museu de Geociências da USP. .158

Figura 191. A mesma amostra da Figura 190 acomodada em sílica não saturada. Acervo: Museu de Geociências da USP..... 158

Figura 192. Aspecto de bloco com sílica gel utilizado em exposições. Fonte: Catálogo da Archival Quality Materials for Conservation, Restoration, Preservation \& Exhibition de 2010. 160

Figura 193. Exemplo de indicador de UR. A tira é colocada no ambiente desejado e a tabela indica como proceder na interpretação dos resultados. Fonte: Catálogo da Archival Quality Materials for Conservation, Restoration, Preservation \& Exhibition de 2010. 160

Figura 194. Exemplo de higrômetro digital que indica a temperatura e a UR. Fonte: http://www.universityproducts.com/cart.php? $m=$ product_list $\& c=944 \&$ primary $=1$ $\underline{\text { \&parentId }=\& \text { navTree }[]=1262 \& \text { navTree }[]=1375 \& \text { navTree }[]=944 .}$ Acesso em 06.12.2012. 161

Figura 195a. Embalagens de polietileno utilizadas para armazenamento de minerais. 161

Figura 195b. Exemplo de utilização de embalagens de polietileno no Museu de Geociências da USP. Alguns modelos permitem escrever na embalagem, facilitando a identificação da amostra. 161

Figura 196. Embalagens antioxidantes utilizadas também por outros tipos de museus que possuem amostras metálicas em seus acervos. Fonte http://www.universityproducts.com/cart.php? $m=$ product_list \&c $=75 \&$ primary $=1$ 
$\underline{\text { \&parentId }=\& \text { navTree }[]=1271 \& \text { navTree }[]=1294 \& \text { navTree }[]=75}$. Acesso em

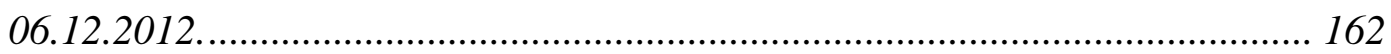

Figura 197. Ilustração referente ao procedimento correto de utilização do RP. Fonte: Site da Mitsubichi Gas Chemicals. Acesso em 28/11/2012...........................................163

Figura 198. Exemplo de selador térmico portátil para vedação de vários tipos de embalagens, incluindo RP. Fonte: Site da Mitsubichi Gas Chemicals. Acesso em $28 / 11 / 2012$. 163

Figura 199. Aspecto da vitrina com crisoberilos. Nota-se que muitas amostras estão em duplicata, pois além de ser o mesmo mineral, têm a mesma procedência. 166

Figura 200. Vitrina dos sulfetos, destacando-se a grande quantidade de amostras de piritas. 167

Figura 201. Belo exemplar de galena cristalizada sobre dolomita e calcopirita. 167

Figura 202. Aspecto da vitrina das galenas. A seta indica a amostra da Figura 201, que está escondida atrás de outras que não chamam tanto a atenção. Quase impossível reter detalhes da amostra.

Figura 203. Pequena amostra de ametista posicionada entre duas outras amostras maiores do mesmo mineral. $O$ visitante fixa sua atenção nos maiores, sendo que o do meio está sem função na exposição. Isto não aconteceria caso a exposição tivesse um apelo definido, como, por exemplo, os diferentes tamanhos que um mesmo mineral pode assumir.

Figura 204. Cristal de berilo em suporte desproporcional. Além de o suporte ser maior que a amostra, esta fica mimetizada no suporte, uma vez que apresenta quase a mesma coloração que o suporte. 168

Figura 205a. Aspecto de suporte especialmente confeccionado para a amostra que está sobre ele. O que se destaca é exatamente o que se quer mostrar, a amostra de cobre nativo. $O$ suporte não fica em evidência e não atrapalha a observação do mineral.

Figura 205b. Parte posterior do suporte mostrado na figura anterior. É possível ver que o artesão fez um estudo rigoroso da peça e encontrou o seu melhor ângulo de apoio.

Figura 206. Aspecto de suporte de acrílico com utilização correta para a amostra em questão.

Figura 207. Visão parcial da vitrina das turmalinas. A valiosa Turmalina Paraíba quase não é notada entre as adjacentes de maior tamanho. 170 
Figura 208. Amostra do mineral eudidimita em frasco de tamanho reduzido, entre um pedaço de algodão e uma legenda antiga. 170

Figura 209. Duas amostras do mesmo tipo de espinélio dispostas lado a lado na vitrina. $O$ tamanho diminuto das amostras não permite que o visitante tenha quaisquer informações visuais sobre o cristal de espinélio.

Figura 210. Solução encontrada pelo Museu de História Natural de Londres para mostrar os cristais dos minerais formadores do granito. Procedimento semelhante também poderia ser adotado para as amostras de tamanho reduzido expostas no Museu de Geociências. 171

Figura 211a. Forma correta de apresentação de minerais de dimensões reduzidas: O mineral exposto é quase imperceptível, por isso há uma imagem ampliada ao lado. Acervo: Museu de Geociências da USP.

Figura 211b. Imagem do diminuto mineral hidrokenomicrolita, exposto junto com sua imagem.

Figura 212. Aspecto de ferrugem sobre suporte de ferro. A camada protetora de zinco foi desgastada, e a umidade acelerou o processo de oxidação do ferro. 173

Figura 213. Suporte deteriorado da amostra de Hanksita da Figura 212. 173

Figura 214. Amostras de olho de tigre em suportes de acrílico. O suporte é quase imperceptivel ao observador. Acervo: Mineralogisches Museum - Universität Würzburg. Foto: Lauro K. Dehira. 173

Figura 215. A distribuição irregular de peso sobre os apoios do suporte, aliados à oxidação do meteorito, está danificando gravemente o Itapuranga. 173

Figura 216a. Suporte de ferro adequado à amostra, visível apenas o suficiente para que a amostra esteja segura. Acervo: Mineralogisches Museum - Universität Hamburg. Foto: Eliane A. Del Lama. 174

Figura 216b. Parte posterior do meteorito da Figura 216a. O suporte está fixado onde o olhar do visitante não alcança. Observa-se que o suporte envolve a amostra, sem privilegiar pontos de apoio. Acervo: Mineralogisches Museum - Universität Hamburg. Foto: Eliane A. Del Lama........................................................... 174

Figura 217. Aspecto de cristais de berilo fixados em bases de acrílico com massas de cor escura. Além de penetrar no mineral, essas massas prejudicam a estética da

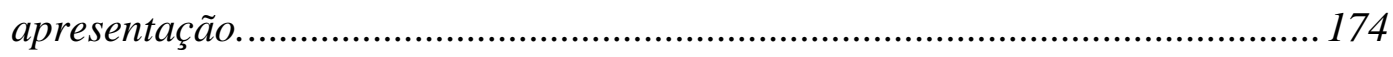

Figura 218. A padronização das informações é um aspecto importante da exposição. A diferença no tamanho das etiquetas leva a uma sensação de confusão na 
exposição, uma vez que interfere no espaço das amostras de maneira desigual. 175

Figura 219. A solução encontrada para as amostras de turmalina é conveniente: fórmula química geral para o grupo, em etiqueta separada, e as etiquetas de amostras permanecem em tamanho padrão. 176

Figura 220. Apesar de haver uma etiqueta com a fórmula geral das turmalinas, essa amostra de dravita traz uma etiqueta diferente em relação às outras, com fórmula química em detrimento às adjacentes e ainda com suporte que as outras não têm. Faltou uniformidade na informação, no layout e na exposição. 176

Figura 221. Informações em inglês são necessárias, no entanto, mais uma vez faltou padronização: ou todas as informações são bilíngues, ou se retira a informação em língua estrangeira. Além disso, nessa amostra, a informação está sendo fornecida exclusivamente em idioma estrangeiro. 176

Figura 222. A exposição conserva ainda a terminação errônea amianto para os minerais asbestiformes. Além disso, há três diferentes nomenclaturas na exposição: amianto, asbesto e o nome do próprio mineral (crisotila, por exemplo).

Figura 223. Os feldspatos e minerais Terras Raras ocupam a penúltima e a última vitrinas, respectivamente. Muitos dos visitantes já estão cansados e desestimulados ao chegarem ao fim da exposição e saem de um museu de mineralogia sem ao menos saber o que é um feldspato. As setas amarelas indicam o caminho que o visitante deve percorrer até alcançar os felsdpatos e minerais terras raras, indicados com a seta vermelha. 178

Figura 224. Localização dos feldspatos e minerais terras raras. Além de escondidos na exposição, disputam espaço com as cavernas, que chamam mais a atenção dos visitantes.. 178

Figura 225. Pessoas com alta estatura também têm dificuldade em apreciar a exposição. Qualquer fator que proporcione o desconforto dos visitantes é considerado falta de acessibilidade. 179

Figura 226. Pessoas com baixa estatura não conseguem alcançar todos os níveis das vitrinas. Foto: Veridiana Vianna. 179

Figura 227. Exposição acessível para crianças no National Museum of Natural History.. 179

Figura 228. Exposição de meteoritos do National Museum of Natural History. Informações principais estão localizadas na parte inferior das vitrinas, para garantir o acesso à informação. 179

Figura 229. Área de descanso no museu Terra Mineralia. 179 
Figura 230. Outro exemplo de exposição com acesso para crianças e pessoas com baixa estatura. Museu Nacional (UFRJ).

Figura 231. Vista do saguão onde está localizada a porta de acesso à reserva técnica, assinalada com a seta amarela...

Figura 232. Reserva Técnica do Museu de Geociências. À esquerda, percebe-se a janela, que permite a entrada de iluminação natural e troca de temperatura e UR com o ambiente externo.

Figura 233. Armários deslizantes na reserva técnica. Os círculos amarelos indicam as etiquetas com a discriminação geral do que há em cada armário. 181

Figura 234. Detalhe da etiqueta indicativa descrita na figura 233. Foto: Ideval Souza Costa.

Figura 235. Vista de dois armários deslizantes abertos. A seta vermelha indica as prateleiras, sobre as quais estão os minerais soltos.

Figura 236. Exemplo de amostras vulneráveis à queda e consequente perda do exemplar em caso de abertura constante do armário. 182

Figura 237. Galeria subterrânea cuja entrada é aberta e ao lado da reserva técnica. $O$ ambiente é úmido, sujo e com ocorrência de animais nocivos. 182

Figura 238. Galeria da foto 237 vista do interior da reserva técnica. A seta amarela indica a galeria e a seta vermelha indica um espeleotema, vulnerável à umidade vinda da galeria. 182

Figura 239. Etiqueta danificada pela ação de pestes frequentemente encontradas no local, traças e baratas. 182

Figura 240. Aranha se esconde no trilho de deslizamento dos armários. Risco a saúde dos funcionários caso seja uma espécie peçonhenta. Foto: Daniel Machado. 182

Figura 241. As quatro mapotecas localizadas no LIC. Acervo está bem acomodado no interior das gavetas, mas o espaço está descontextualizado. 183

Figura 242. Gavetas da mapoteca são forradas com plástico bolha, a fim de evitar o deslocamento do material em seu interior. Amostras também são envoltas por esse material. 183

Figura 243. A vitrina com muitos exemplares faz com que o visitante desvie sua atenção e perca o interesse. 184

Figura 244. O Mineralogisches Museum - Universität Hamburg coloca em média vinte exemplares por vitrina. 185 
Figura 245. Vitrina de minerais do museu Terra Mineralia. Poucos minerais na mesma vitrina e todos do mesmo tamanho. Dessa forma, nenhum mineral tem maior destaque. Foto: Eliane A. Del Lama. 185

Figura 246. Exemplo de resina fixadora transparente que não afeta a visibilidade da amostra. Acervo: Mineralogisches Sammlungen - Technische Universität Berlin.

Figura 247. Mineralogisches Sammlungen - Technische Universität Berlin. Os minerais mais atrativos estão em vitrinas grandes, no centro do museu, enquanto a exposição sistemática está no entorno, em armários menores, indicados pela seta vermelha. 186

Figura 248. Vitrina organizada de modo a destacar a variação de cor nos minerais. 187

Figura 249. Reserva técnica do Mineralogisches Staatssammlung München. Ao fundo encontram-se os armários deslizantes. Na porção frontal da imagem está a bancada de trabalho dos funcionários, e à direita existem mesas para os pesquisadores analisarem o material solicitado. Foto: Lauro K. Dehira.......... 188

Figura 250. Reserva técnica de meteoritos do NMNH, edifício do National Mall. A seta amarela indica as cabines climatizadas com meteoritos metálicos de pequenas dimensões; a seta vermelha indica armários para amostras maiores. No centro está a bancada para pesquisadores. Foto: Cristina Castilho.

Figura 251. Sem um espaço destinado à pesquisa, o acervo fica vulnerável. Atualmente, a pesquisa com o acervo é realizada sempre as segundas feiras, dia em que o museu é fechado ao público, para que se possa trabalhar em segurança. A foto mostra a situação de vulnerabilidade do acervo, bem como o desconforto do pesquisador, que trabalha em espaço improvisado. 189 


\section{1 - INTRODUÇÃO}

O presente trabalho compreende um estudo geral sobre a conservação de coleções geológicas, utilizando como referência o acervo de minerais, rochas e meteoritos do Museu de Geociências do Instituto de Geociências da Universidade de São Paulo.

Esta dissertação mostra o quanto as coleções geológicas, ou seja, fósseis, meteoritos, minerais, e rochas podem ser instáveis. $(\mathrm{Re})$ conhecendo o tipo de vulnerabilidade à qual cada material está exposto, é possível diagnosticar seu tratamento ou evitar seu desgaste.

Para que se possa discorrer sobre como conservar acervos geológicos, é preciso, antes, conhecer o comportamento de cada item da coleção. Este trabalho enfatiza os minerais, pois estes compõem a maior parte do acervo do Museu de Geociências da USP. Serão abordadas também, com menor ênfase, coleções de rochas, fósseis e meteoritos.

Por se tratar de um texto destinado a dois grupos distintos - um deles composto por indivíduos com as mais variadas formações e que atuam em acervos geológicos, e o outro, composto por geólogos que atuam em museus, sem possuírem algum background museológico - este trabalho aborda assuntos específicos referentes à museologia e também assuntos mais técnicos, voltados para a área geológica. Esta foi a forma encontrada para que se possa contemplar o maior número possível de pessoas atuantes nas duas áreas.

O Capítulo 4, Museus de Geociências, apresenta as principais instituições museológicas com acervos geológicos no Brasil, bem como algumas definições teóricas importantes. Apresenta ainda a instituição Museu, em especial museus de ciências, desde suas origens até a atualidade. O layout de exposições geológicas com exemplos adquiridos nas visitas técnicas realizadas também é mostrado, assim como os sistemas utilizados para classificar minerais e rochas em exposição. Por fim são apresentados de forma detalhada os museus utilizados como parâmetro de comparação com o Museu de Geociências da USP.

O Capítulo 5, Os Minerais e as Cores, discorre detalhadamente sobre o processo de formação das cores em certos minerais, a fim de que se possa ter em mente as modificações causadas pela ação da luz e calor nas amostras dessas espécies, presentes em coleções. Apresenta ainda os resultados e discussão de dados do experimento sobre colorimetria em minerais.

O Capítulo 6, Conservação de Materiais Geológicos, trata dos principais problemas de conservação enfrentados em acervos geológicos, advindos de fatores atmosféricos como umidade relativa do ar, temperatura, luz e oxigênio, além de fatores conservacionais 
relacionados à saúde humana, tais como toxicidade e radioatividade. Apresenta ainda os diversos tipos de materiais utilizados em museus para conservação de amostras geológicas.

O Capítulo 7, Museu de Geociências da USP, faz um diagnóstico desse Museu, no que concerne à exposição, cuidado com as amostras expostas e em reserva técnica, utilizando a comparação com os museus parâmetros, apresentados no Capítulo 4.

Pretende-se que este trabalho proporcione reflexões aos funcionários que atuam em museus, e para os quais muitas vezes não há bibliografia disponível para sanar dúvidas cotidianas. Para os muitos problemas diagnosticados, alguns considerados complexos do ponto de vista de estruturação do acervo, acondicionamento da reserva técnica, apresentação da exposição, foram observadas alternativas simples, adotadas por museus famosos (os museus parâmetros), e que podem ser adaptadas sem custo ou a um custo baixo. Não se trata de um manual de respostas prontas, mas de um trabalho em construção que discute propostas e alternativas a partir da observação e da vivência em um museu que, se não é considerado parâmetro entre os museus internacionais, com certeza o é do ponto de vista da Geociências no Brasil. 


\section{2-OBJETIVOS}

O objetivo deste trabalho é a busca por uma visão global dos principais problemas que atingem coleções geológicas (fósseis, meteoritos, minerais e rochas; espeleotemas não serão tratados neste trabalho ${ }^{3}$ ), especialmente minerais (estejam eles em exposição ou na reserva técnica), mesclando atividade museológica e conservação do acervo.

Pretende-se descrever, com base na bibliografia selecionada, as situações ideais de conservação de coleções geológicas e compará-las com a situação de conservação das amostras do Museu de Geociências. Além de minimizar os danos à própria coleção, é muito importante conhecer os riscos à saúde dos pesquisadores e da equipe técnica.

Far-se-á também uma breve análise da exposição de outros museus que tenham coleções geológicas expostas, destacando-se os pontos positivos e negativos, sempre com o intuito de compará-las ao Museu de Geociências da USP. Deste modo, este trabalho pretende colaborar para que, apontando falhas e acertos, o Museu de Geociências possa crescer como instituição museológica em seu segmento de atuação.

\footnotetext{
3 Não menos importantes, os espeleotemas representam a menor parte do acervo do Museu de Geociências da
} USP, e por essa razão não foram incluídos no âmbito dessa pesquisa. 


\section{3 - MATERIAIS E MÉTODOS}

\section{1 - Revisão Bibliográfica}

O principal método utilizado neste trabalho é a revisão do maior número possível de bibliografias que façam a intersecção entre conservação, mineralogia e museus. Para isso foram revisados artigos, painéis apresentados em seminários internacionais, livros e publicações diversas sobre os temas citados.

A maior parte do que foi escrito sobre conservação concentra-se no intervalo de tempo entre o fim da década de 1980 e início da década de 1990. Datam exatamente desse período os dois livros utilizados como referências básicas neste trabalho: The Care and Conservation of Geological Material: mineral, rocks, meteorites and lunar finds, de Frank M. Howie (1992) e Conservation of Geological Collections organizado por R.E. Chield e publicado pelo National Museum of Wales (1994). Este último foi resultado de uma conferência realizada em 04 de novembro de 1993 no Welsh Folk Museum, intitulada Conservation of Geological Collections e organizada pelos conservadores do departamento de Geologia do National Museum of Wales, decorrente de estudos que demonstravam que as coleções geológicas sem cuidados de conservação estavam sempre sob grave risco de deterioração, quer pelo meio ambiente natural, quer pelo acondicionamento inadequado.

\section{2 - Estudo do Acervo}

Além da revisão bibliográfica, a base deste trabalho está no estudo e análise do acervo do Museu de Geociências da USP. Somente conhecendo o acervo que está exposto e em reserva técnica é possível identificar verdadeira e detalhadamente os problemas de conservação enfrentados por uma coleção geológica.

Uma visita detalhada ao museu, atentando para todos os problemas concernentes à conservação e técnicas expositivas, resultou em um diagnóstico no qual os pontos sensíveis do museu foram tomados como base para serem comparados com outras exposições (as exposições parâmetro).

Esses pontos sensíveis serão oportunamente arrolados, explicados e exemplificados no Capítulo 6 deste trabalho. 


\section{3 - Visitas a Museus}

Com base no conhecimento adquirido com a observação e análise dos problemas conservacionais encontrados no acervo do Museu de Geociências, partiu-se para a visita a outros museus de geologia (sempre com ênfase na mineralogia).

Essas visitas a exposições e quando possível, também às reservas técnicas fizeram parte de uma metodologia de trabalho baseada na comparação.

Não há metodologia sistematizada para o estudo de acervos geológicos, assim, a metodologia comparativa foi a forma encontrada para posicionar o Museu de Geociências no rol dos museus de mineralogia capazes de oferecer um acervo bem cuidado ao público visitante e à comunidade científica.

A lista dos museus visitados, em ordem alfabética, e que foram utilizados como parâmetro de comparação com o Museu de Geociências é apresentada na Tabela 1. Resulta daí a utilização do termo museu parâmetro. O critério de escolha desses museus foi o fato de serem museus universitários (mesmo status administrativo do Museu de Geociências) ou por serem instituições de renome internacional, referências em quantidade de acervo (considerase, que, quanto mais peças o museu possui, mais difícil e custoso é cuidar delas; assim, esses museus tornam-se referência em pesquisas sobre métodos alternativos de conservação e exposição de suas peças) ou tecnologias de exposição que sejam relevantes para a conservação. A Tabela 1 mostra os museus visitados, a data das visitas, bem como as áreas visitadas em cada uma das instituições.

Tabela 1 - Instituições visitadas e exposições parâmetro.

\begin{tabular}{|c|c|c|c|}
\hline $\begin{array}{l}\text { INSTITUIÇÃO } \\
\text { Museu Parâmetro }\end{array}$ & LOCALIZAÇÃO & $\begin{array}{l}\text { DATA DA } \\
\text { VISITA }\end{array}$ & $\begin{array}{c}\text { ÁREAS } \\
\text { VISITADAS }\end{array}$ \\
\hline $\begin{array}{l}\text { Deutsches Edelsteinmuseum } \\
\text { (Museu Alemão de Gemas) }\end{array}$ & $\begin{array}{l}\text { Idar-Olberstein - } \\
\text { Alemanha }\end{array}$ & $\begin{array}{l}01 \text { de setembro } \\
\text { de } 2012\end{array}$ & Exposição \\
\hline $\begin{array}{c}\text { London Natural History } \\
\text { Museum }\end{array}$ & Londres - Reino Unido & $\begin{array}{c}12 \text { e } 13 \text { de Abril } \\
\text { de } 2011\end{array}$ & Exposição \\
\hline $\begin{array}{l}\text { Museu de Mineralogia Prof. } \\
\text { Heinz Ebert - UNESP }\end{array}$ & $\begin{array}{c}\text { Departamento de } \\
\text { Mineralogia e Petrologia } \\
\text { da UNESP - Rio Claro - } \\
\text { São Paulo - Brasil }\end{array}$ & $\begin{array}{c}11 \text { de março de } \\
2011\end{array}$ & $\begin{array}{l}\text { Exposição e } \\
\text { reserva técnica }\end{array}$ \\
\hline $\begin{array}{c}\text { Mineralogisches Museum am } \\
\text { Steinmann-Institut der } \\
\text { Universität Bonn (Museu de } \\
\text { Mineralogia no Instituto } \\
\text { Steinmann da Universidade de } \\
\text { Bonn) }\end{array}$ & $\begin{array}{l}\text { Instituto Steinmann - } \\
\text { Bonn - Alemanha }\end{array}$ & $\begin{array}{l}02 \text { de setembro } \\
\text { de } 2012\end{array}$ & Exposição \\
\hline
\end{tabular}




\begin{tabular}{|c|c|c|c|}
\hline $\begin{array}{c}\text { Mineralogisches Museum- } \\
\text { Philipps- Universität Marburg } \\
\text { (Museu de Mineralogia da } \\
\text { Philipps Universidade de } \\
\text { Marburg) }\end{array}$ & $\begin{array}{l}\text { Philipps Universidade de } \\
\text { Marburg - Marburg - } \\
\text { Alemanha }\end{array}$ & $\begin{array}{l}25 \text { de agosto de } \\
2012\end{array}$ & Exposição \\
\hline $\begin{array}{l}\text { Mineralogisches Museum - } \\
\text { Universität Hamburg (Museu de } \\
\text { Mineralogia da Universidade de } \\
\text { Hamburgo) }\end{array}$ & $\begin{array}{c}\text { Universidade de } \\
\text { Hamburgo - Alemanha }\end{array}$ & $\begin{array}{l}23 \text { de agosto de } \\
2012\end{array}$ & Exposição \\
\hline $\begin{array}{l}\text { Mineralogisches Museum - } \\
\text { Universität Würzburg (Museu de } \\
\text { Mineralogia da Universidade de } \\
\text { Würzburg) }\end{array}$ & $\begin{array}{c}\text { Universidade de } \\
\text { Würzburg - Würzburg - } \\
\text { Alemanha }\end{array}$ & $\begin{array}{l}30 \text { de agosto de } \\
2012\end{array}$ & Exposição \\
\hline $\begin{array}{c}\text { Mineralogisches Sammlungen - } \\
\text { Institut für Geowissenschaften - } \\
\text { Universität Jena (Coleção de } \\
\text { Mineralogia do Instituto de } \\
\text { Ciências da Terra da } \\
\text { Universidade de Jena) }\end{array}$ & $\begin{array}{c}\text { Instituto de Ciências da } \\
\text { Terra da Universidade de } \\
\text { Jena - Jena - Alemanha }\end{array}$ & $\begin{array}{l}26 \text { de agosto de } \\
2012\end{array}$ & Exposição \\
\hline $\begin{array}{c}\text { Mineralogisches Sammlungen - } \\
\text { Technische Universität Berlin } \\
\text { (Coleção de Mineralogia da } \\
\text { Universidade Técnica de } \\
\text { Berlim) }\end{array}$ & $\begin{array}{l}\text { Universidade Técnica de } \\
\text { Berlim - Berlim - } \\
\text { Alemanha }\end{array}$ & $\begin{array}{l}24 \text { de agosto de } \\
2012\end{array}$ & $\begin{array}{l}\text { Exposição e } \\
\text { reserva técnica }\end{array}$ \\
\hline $\begin{array}{c}\text { Mineralogisches } \\
\text { Staatssammlung München } \\
\text { (Coleção de Mineralogia do } \\
\text { Estado - Munique) }\end{array}$ & Munique - Alemanha & $\begin{array}{l}31 \text { de agosto de } \\
2012\end{array}$ & $\begin{array}{l}\text { Exposição e } \\
\text { reserva técnica }\end{array}$ \\
\hline $\begin{array}{l}\text { Museu de Ciências da Terra - } \\
\text { Departamento Nacional de } \\
\text { Produção Mineral (DNPM) }\end{array}$ & Rio de Janeiro - RJ & $\begin{array}{l}\text { 09 de Maio de } \\
2012\end{array}$ & Exposição \\
\hline $\begin{array}{l}\text { Museu Nacional - Universidade } \\
\text { Federal do Rio de Janeiro }\end{array}$ & Rio de Janeiro - RJ & $\begin{array}{l}09 \text { de Maio de } \\
2012\end{array}$ & Exposição \\
\hline $\begin{array}{c}\text { Museum für Naturkunde Berlin } \\
\text { (Museu de História Natural de } \\
\text { Berlim) }\end{array}$ & Berlim - Alemanha & $\begin{array}{l}24 \text { de agosto de } \\
2012\end{array}$ & $\begin{array}{l}\text { Exposição e } \\
\text { reserva técnica }\end{array}$ \\
\hline $\begin{array}{c}\text { National Museum of Natural } \\
\text { History - Smithsonian } \\
\text { Institution }\end{array}$ & $\begin{array}{l}\text { Washington - DC } \\
\text { Estados Unidos da } \\
\text { América }\end{array}$ & $\begin{array}{c}\text { Fevereiro e } \\
\text { Março de } 2010\end{array}$ & $\begin{array}{l}\text { Exposições, } \\
\text { reservas } \\
\text { técnicas e } \\
\text { centro de } \\
\text { apoio ao } \\
\text { pesquisador }\end{array}$ \\
\hline $\begin{array}{l}\text { Oxford University Natural } \\
\text { History Museum }\end{array}$ & $\begin{array}{l}\text { Universidade de Oxford, } \\
\text { Oxford - Reino Unido }\end{array}$ & $\begin{array}{l}14 \text { de Abril de } \\
2011\end{array}$ & Exposição \\
\hline
\end{tabular}




\begin{tabular}{|c|c|c|c|}
\hline $\begin{array}{c}\text { Ries Krater Museum Nördlingen } \\
\text { (Museu da Cratera de Ries em } \\
\text { Nördlingen) }\end{array}$ & Nördlingen - Alemanha & $\begin{array}{l}31 \text { de agosto de } \\
2012 .\end{array}$ & Exposição \\
\hline Terra Mineralia & Freiberg - Alemanha & $\begin{array}{l}28 \text { de agosto de } \\
2012\end{array}$ & $\begin{array}{l}\text { Exposição e } \\
\text { reserva técnica }\end{array}$ \\
\hline
\end{tabular}

\section{4 - Experimentos}

Foram realizados experimentos com amostras da reserva técnica do Museu de Geociências para que fossem testados alguns dos componentes de conservação. Esses testes foram realizados com a pretensão de observar o comportamento dos minerais frente a agentes deteriorantes. Não foram decisivos para esta pesquisa, mas importante didaticamente no manuseio de técnicas analíticas disponíveis.

Foram dois os principais conjuntos de experimentos realizados.

\subsection{1 - Colorimetria em minerais}

O experimento consistiu na análise da cor de minerais que foram colocados em ambiente externo, expostos aos efeitos da luz solar. A intenção foi observar o comportamento de alguns minerais em relação à presença de luz. A proposta foi verificar o grau de alteração cromática nos minerais devido à incidência de luz solar.

Para que a medição fosse realizada, utilizou-se um espectrofotômetro da marca Kônica Minolta CM 2500, com diâmetro de abertura de $8 \mathrm{~mm}$. As condições de medida foram fixadas em iluminante D65 (luz do dia, incluindo a região do espectro ultravioleta), componente especular incluso e excluso e observador a $10^{\circ}$. Os dados foram tratados com o software OnColor version 5.4.5.1.

\subsection{2 - Difratometria de raios X e Microscopia Eletrônica de Varredura}

Durante atividade rotineira de trabalho no Museu, notou-se em uma das vitrinas de exposição, uma amostra em cujo suporte aparecia um pó de cor branca. Tratava-se do mineral hanksita - $\mathrm{Na}_{22} \mathrm{~K}\left(\mathrm{SO}_{4}\right)_{9}\left(\mathrm{CO}_{3}\right)_{2} \mathrm{Cl}$. O exemplar foi retirado da exposição e o pó foi analisado.

Foi feita a análise por difração de raios X e posteriormente por Microscópio Eletrônico de Varredura (MEV) do resíduo encontrado no suporte da hanksita. A intenção foi descobrir a origem do resíduo depositado e diagnosticar a alteração.

Os dados analíticos foram obtidos nos laboratórios do Instituto de Geociências da USP. 
As análises de difração de raios $\mathrm{X}$ foram feitas em um difratômetro Siemens modelo D5000, com radiação $\mathrm{CuK} \alpha$ e avanço de $0,05^{\circ}$ /s.

As análises de microscopia eletrônica de varredura com EDS acoplado foram obtidas em um equipamento LEO 4401 com espectrômetro de energia dispersiva de Si-Li Oxford. As condições operacionais foram $20 \mathrm{kV}$ de potencial de aceleração, corrente de 1 a $10 \mathrm{n} \AA$ e diâmetro do feixe de 1 a $5 \mu \mathrm{m}$.

\section{5 - Integração dos dados}

A integração dos dados obtidos nos experimentos, nas visitas técnicas e nas interpretações das bibliografias citadas resultou nesta dissertação. 


\section{4 - MUSEUS DE GEOCIÊNCIAS}

Os principais museus que contêm acervos geológicos no Brasil estão, em sua maioria, atrelados às escolas de geologia.

É preciso salientar que não entram nessa relação os laboratórios didáticos dos cursos de Geologia e/ou Geociências. Muitos museus nasceram desses laboratórios; no entanto, utiliza-se neste trabalho a definição de museu do ICOM (International Council of Museum) adotada durante a XXI Conferência Geral em Viena, Áustria, em 2007, segundo a qual:

"Museu é uma instituição permanente sem fins lucrativos, a serviço da sociedade e seu desenvolvimento, aberta ao público e que adquire, conserva, pesquisa, comunica e exibe o legado tangível e intangível do ser humano e seu meio ambiente para propósitos educativos, de estudos e deleite." " 4 De acordo com esta definição considerar-se-ão apenas as coleções universitárias abertas ao público e/ou com alguma atividade de extensão universitária.

$\mathrm{Na}$ Tabela 2 estão listados os principais museus/acervos de minerais e rochas do Brasil, por ordem alfabética das instituições.

Tabela 2 - Principais museus de minerais e rochas do Brasil e as instituições às quais pertencem. Fonte: Guia dos Museus Brasileiros - IBRAM

\begin{tabular}{|c|c|c|c|}
\hline$\underline{\text { MUSEU }}$ & $\underline{\text { LOCALIZAÇÃO }}$ & $\frac{\text { TIPO DE }}{\text { INSTITUICÃO }}$ & INSTITUICCÃO \\
\hline $\begin{array}{c}\text { Casa da Glória } \\
\text { WWW.igc.ufmg.br/casad } \\
\text { agloria }\end{array}$ & Diamantina - MG & $\begin{array}{l}\text { Universidade } \\
\text { Pública Federal }\end{array}$ & $\begin{array}{c}\text { Universidade Federal De } \\
\text { Minas Gerais - UFMG }\end{array}$ \\
\hline $\begin{array}{c}\begin{array}{c}\text { Exposição de Minerais e } \\
\text { Rochas Orville Derby }\end{array} \\
\text { http://www.mineropar.pr. } \\
\text { gov.br/modules/conteudo/ } \\
\frac{\text { conteudo.php?conteudo=1 }}{\underline{38}}\end{array}$ & Curitiba - PR & $\begin{array}{l}\text { Instituição não } \\
\text { universitária - } \\
\text { privada }\end{array}$ & $\begin{array}{l}\text { MINEROPAR - Serviço } \\
\text { Geológico do Paraná }\end{array}$ \\
\hline $\begin{array}{l}\text { Museu Câmara Cascudo } \\
\text { http://acd.ufrn.br/geologia } \\
\text { /sbp/cascudo.htm } \\
\text { (desatualizado) }\end{array}$ & Natal - RN & $\begin{array}{l}\text { Universidade } \\
\text { Pública Federal }\end{array}$ & $\begin{array}{l}\text { Universidade Federal Do } \\
\text { Rio Grande Do Norte }\end{array}$ \\
\hline $\begin{array}{l}\text { Museu da Geodiversidade } \\
\frac{\text { www.geologia.ufrj.br/mus }}{\underline{\text { eu }}}\end{array}$ & Rio de Janeiro - RJ & $\begin{array}{l}\text { Universidade } \\
\text { Pública Federal }\end{array}$ & $\begin{array}{l}\text { Universidade Federal do } \\
\text { Rio De Janeiro - UFRJ }\end{array}$ \\
\hline
\end{tabular}

\footnotetext{
${ }^{4}$ "Le musée est une institution permanente sans but lucratif, au service de la société et de son développement, ouverte au public, qui acquiert, conserve, étudie, expose et transmet le patrimoine matériel et immatériel de l'humanité et de son environnement à des fins d'études, d'éducation et de delectation". STATUTS DU CONSEIL INTERNATIONAL DES MUSÉES (ICOM). Adoptés par la $22^{e}$ Assemblée générale tenue à Vienne (Autriche), le 24 août 2007. Article 3, Section1, Page 3.
} 


\begin{tabular}{|c|c|c|c|}
\hline $\begin{array}{l}\text { Museu das Culturas Dom } \\
\text { Bosco } \\
\text { http://www.mcdb.org.br/ }\end{array}$ & $\begin{array}{c}\text { Campo Grande - } \\
\text { MS }\end{array}$ & Universidade Privada & $\begin{array}{c}\text { Missão Salesiana do Mato } \\
\text { Grosso/Universidade } \\
\text { Católica Dom Bosco }\end{array}$ \\
\hline $\begin{array}{l}\text { Museu das Minas e do } \\
\text { Metal www.mmm.org.br/ }\end{array}$ & $\begin{array}{l}\text { Belo Horizonte - } \\
\text { MG }\end{array}$ & $\begin{array}{l}\text { Parceria Público } \\
\text { Privada (PPP) }\end{array}$ & $\begin{array}{l}\text { Governo Do Estado De } \\
\text { Minas Gerais e EBX }\end{array}$ \\
\hline $\begin{array}{c}\begin{array}{c}\text { Museu de Ciências da } \\
\text { Terra }\end{array} \\
\frac{\text { www.mme.gov.br/sgm/m }}{\text { enu/entidades vinculadas/ }} \\
\frac{\text { Museu.html }}{\underline{\text { Museuthe }}}\end{array}$ & $\begin{array}{c}\text { Rio de Janeiro - } \\
\text { RJ }\end{array}$ & $\begin{array}{l}\text { Instituição não } \\
\text { universitária - } \\
\text { pública }\end{array}$ & $\begin{array}{c}\text { Departamento Nacional } \\
\text { de Produção Mineral - } \\
\text { DNPM }\end{array}$ \\
\hline $\begin{array}{l}\text { Museu de Ciência e } \\
\text { Técnica da Escola de } \\
\text { Minas da Universidade } \\
\text { Federal de Ouro Preto } \\
\text { www.museu.em.ufop.br/ }\end{array}$ & Ouro Preto - MG & $\begin{array}{c}\text { Universidade Pública } \\
\text { Federal }\end{array}$ & $\begin{array}{l}\text { Universidade Federal de } \\
\text { Ouro Preto - UFOP }\end{array}$ \\
\hline $\begin{array}{c}\begin{array}{c}\text { Museu de Ciências } \\
\text { Naturais }\end{array} \\
\underline{\text { http://www.ucs.br/ucs/mu }} \\
\underline{\text { seu/areadeatuacao/geocie }} \\
\underline{\text { ncias/geociencias }}\end{array}$ & $\begin{array}{c}\text { Caxias do Sul - } \\
\text { RS }\end{array}$ & Universidade Privada & $\begin{array}{l}\text { Universidade de Caxias } \\
\text { do Sul }\end{array}$ \\
\hline $\begin{array}{c}\begin{array}{c}\text { Museu de Ciências } \\
\text { Naturais }\end{array} \\
\underline{\text { http://www.unicentro.br/ }} \\
\underline{\text { museu }}\end{array}$ & Guarapuava - PR & $\begin{array}{c}\text { Universidade Pública } \\
\text { Estadual }\end{array}$ & $\begin{array}{l}\text { Universidade Estadual do } \\
\text { Centro Oeste - } \\
\text { UNICENTRO }\end{array}$ \\
\hline $\begin{array}{l}\text { Museu de Geociências da } \\
\text { UFPA } \\
\text { http://www.gmga.ufpa.br/ }\end{array}$ & Belém - PA & $\begin{array}{c}\text { Universidade Pública } \\
\text { Federal }\end{array}$ & $\begin{array}{c}\text { Universidade Federal do } \\
\text { Pará - UFPA }\end{array}$ \\
\hline $\begin{array}{c}\text { Museu de Geociências da } \\
\text { UNB } \\
\text { vsites.unb.br/ig/exte/muse } \\
\text { u/index.html }\end{array}$ & Brasília - DF & $\begin{array}{c}\text { Universidade Pública } \\
\text { Federal }\end{array}$ & $\begin{array}{l}\text { Universidade de Brasília } \\
\text { - UNB }\end{array}$ \\
\hline $\begin{array}{c}\text { Museu de Geociências da } \\
\text { USP } \\
\text { www.igc.usp.br/museu }\end{array}$ & São Paulo - SP & $\begin{array}{c}\text { Universidade Pública } \\
\text { Estadual }\end{array}$ & $\begin{array}{l}\text { Universidade de São } \\
\text { Paulo - USP }\end{array}$ \\
\hline $\begin{array}{c}\text { Museu de Geologia da } \\
\text { CPRM } \\
\text { www.cprm.gov.br/publiq } \\
\frac{\text { ue/cgi/cgilua.exe/sys/start. }}{\underline{\text { htm?sid=93 }}}\end{array}$ & Porto Alegre - RS & $\begin{array}{l}\text { Instituição não } \\
\text { universitária - } \\
\text { pública }\end{array}$ & $\begin{array}{c}\text { CPRM - Serviço } \\
\text { Geológico do Brasil (Cia. } \\
\text { de Pesquisa de Recursos } \\
\text { Minerais) }\end{array}$ \\
\hline $\begin{array}{c}\text { Museu de História } \\
\text { Geológica do RS } \\
\text { http://www.unisinos.br/nit } \\
\text { /index.php }\end{array}$ & $\begin{array}{c}\text { São Leopoldo - } \\
\text { RS }\end{array}$ & Universidade Privada & $\begin{array}{c}\text { Universidade do Vale dos } \\
\text { Sinos - UNISINOS }\end{array}$ \\
\hline
\end{tabular}




\begin{tabular}{|c|c|c|c|}
\hline $\begin{array}{c}\text { Museu de História } \\
\text { Natural da UFAL } \\
\text { (temporariamente fechado } \\
\text { para reforma) }\end{array}$ & Maceió - AL & $\begin{array}{c}\text { Universidade Pública } \\
\text { Federal }\end{array}$ & $\begin{array}{c}\text { Universidade Federal de } \\
\text { Alagoas }\end{array}$ \\
\hline $\begin{array}{c}\text { Museu de História } \\
\text { Natural de Alta Floresta } \\
\text { http://afl.unemat.br/muhis } \\
\text { naf/ }\end{array}$ & $\begin{array}{c}\text { Alta Floresta - } \\
\text { MT }\end{array}$ & $\begin{array}{l}\text { Universidade Pública } \\
\text { Estadual }\end{array}$ & $\begin{array}{l}\text { Universidade do Estado } \\
\text { de Mato Grosso }\end{array}$ \\
\hline $\begin{array}{c}\text { Museu de História } \\
\text { Natural e Jardim Botânico } \\
\text { da UFMG } \\
\text { http://www.mhnjb.ufmg.b } \\
\text { r/index.html }\end{array}$ & $\begin{array}{c}\text { Belo Horizonte - } \\
\text { MG }\end{array}$ & $\begin{array}{c}\text { Universidade Pública } \\
\text { Federal }\end{array}$ & $\begin{array}{l}\text { Universidade Federal de } \\
\text { Minas Gerais }\end{array}$ \\
\hline $\begin{array}{l}\text { Museu de Minerais e } \\
\text { Rochas - MMR } \\
\text { www.ufpe.br/geologia }\end{array}$ & Recife - PE & $\begin{array}{c}\text { Universidade Pública } \\
\text { Federal }\end{array}$ & $\begin{array}{l}\text { Universidade Federal de } \\
\text { Pernambuco - UFPE } \\
\text { (Centro de Tecnologia e } \\
\text { Geociências) }\end{array}$ \\
\hline $\begin{array}{c}\text { Museu de Minerais e } \\
\text { Rochas da UFU } \\
\text { http://www.redemuseus.pr } \\
\underline{\text { oex.ufu.br/minerais.htm }}\end{array}$ & Uberlândia - MG & $\begin{array}{c}\text { Universidade Pública } \\
\text { Federal }\end{array}$ & $\begin{array}{c}\text { Universidade Federal de } \\
\text { Uberlândia }\end{array}$ \\
\hline $\begin{array}{l}\text { Museu de Mineralogia e } \\
\text { Petrologia "LUIZ } \\
\text { EGLERT" } \\
\text { www.museumin.urgs.br }\end{array}$ & Porto Alegre - RS & $\begin{array}{c}\text { Universidade Pública } \\
\text { Federal }\end{array}$ & $\begin{array}{l}\text { Universidade Federal do } \\
\text { Rio Grande do Sul - } \\
\text { Instituto de Geociências }\end{array}$ \\
\hline $\begin{array}{c}\text { Museu de Mineralogia } \\
\text { "PROF. HEINZ EBERT" } \\
\text { www.rc.unesp.br/museud } \\
\text { pm }\end{array}$ & Rio Claro - SP & $\begin{array}{l}\text { Universidade Pública } \\
\text { Estadual }\end{array}$ & $\begin{array}{l}\text { Universidade Estadual } \\
\text { Paulista - UNESP }\end{array}$ \\
\hline $\begin{array}{c}\text { Museu de Mineralogia } \\
\text { VICTOR DEQUECH } \\
\text { http://www.geosol.com.br } \\
\text { /geosol/site/php/default_i } \\
\text { nterna.php?id=5\&subId=1 } \\
\underline{1}\end{array}$ & $\begin{array}{c}\text { Belo Horizonte - } \\
\text { MG }\end{array}$ & $\begin{array}{l}\text { Instituição não } \\
\text { universitária - } \\
\text { privada }\end{array}$ & $\begin{array}{c}\text { GEOSOL } \\
\text { www.geosol.com.br }\end{array}$ \\
\hline $\begin{array}{l}\text { Museu de Pedras Ramis } \\
\text { Bucair } \\
\text { http://www.camaracba.mt } \\
\text {.gov.br/index.php?pag=tu } \\
\text { r_item\&id=22 }\end{array}$ & Cuiabá - MT & Iniciativa Privada & \\
\hline $\begin{array}{l}\text { Museu de Pré-História } \\
\text { Casa Dom Aquino } \\
\text { http://www.institutoecoss. } \\
\text { com.br/site/index.php?opt } \\
\text { ion=com_content\&view= } \\
\text { frontpage\&Itemid=1 }\end{array}$ & Cuiabá - MT & $\begin{array}{l}\text { Parceria Público } \\
\text { Privada }\end{array}$ & $\begin{array}{l}\text { Prefeitura Municipal de } \\
\text { Cuiabá e Instituto ECOSS }\end{array}$ \\
\hline
\end{tabular}




\begin{tabular}{|c|c|c|c|}
\hline $\begin{array}{c}\begin{array}{c}\text { Museu Geológico da } \\
\text { Bahia }\end{array} \\
\text { www.sicm.ba.gov.br/Pagi } \\
\text { na.aspx?pagina=mgb }\end{array}$ & Salvador - BA & $\begin{array}{l}\text { Instituição não } \\
\text { universitária - } \\
\text { pública }\end{array}$ & $\begin{array}{c}\text { Secretaria da Indústria, } \\
\text { Comércio e Mineração do } \\
\text { Estado da Bahia }\end{array}$ \\
\hline $\begin{array}{c}\text { Museu Geológico } \\
\text { VALDEMAR LEFÈVRE } \\
\text { www.mugeo.sp.gov.br }\end{array}$ & São Paulo - SP & $\begin{array}{l}\text { Instituição não } \\
\text { universitária - } \\
\text { pública }\end{array}$ & $\begin{array}{l}\text { Secretaria do Meio } \\
\text { Ambiente do Estado de } \\
\text { São Paulo - Instituto } \\
\text { Geológico }\end{array}$ \\
\hline Museu Jóias da Natureza & São Vicente - SP & $\begin{array}{l}\text { Organização Não } \\
\text { Governamental } \\
\text { (ONG) }\end{array}$ & $\begin{array}{c}\text { ADESAF - Associação } \\
\text { de Desenvolvimento } \\
\text { Econômico e Social às } \\
\text { Famílias }\end{array}$ \\
\hline Museu Nacional & $\begin{array}{l}\text { Rio de Janeiro - } \\
\text { RJ }\end{array}$ & $\begin{array}{l}\text { Universidade Pública } \\
\text { Federal }\end{array}$ & $\begin{array}{l}\text { Universidade Federal do } \\
\text { Rio de Janeiro - UFRJ }\end{array}$ \\
\hline $\begin{array}{c}\text { Museu Paraense EMÍLIO } \\
\text { GOELDI }\end{array}$ & Belém - PA & $\begin{array}{l}\text { Instituição não } \\
\text { universitária - } \\
\text { pública }\end{array}$ & $\begin{array}{c}\text { Ministério da Ciência e } \\
\text { Tecnologia }\end{array}$ \\
\hline
\end{tabular}

De acordo com o levantamento apresentado na Tabela 2 - baseado no Cadastro Nacional de Museus do Instituto Brasileiro de Museus (IBRAM) - no qual não constam as instituições cujos museus possuem apenas acervos paleontológicos, percebe-se que grande parte dos museus com acervos geológicos estão ligados às universidades. A Figura 1, elaborada com base na mesma tabela, apresenta as porcentagens de museus geológicos no Brasil, geridos por universidades (públicas ou privadas), pelo setor público e pelo setor privado.

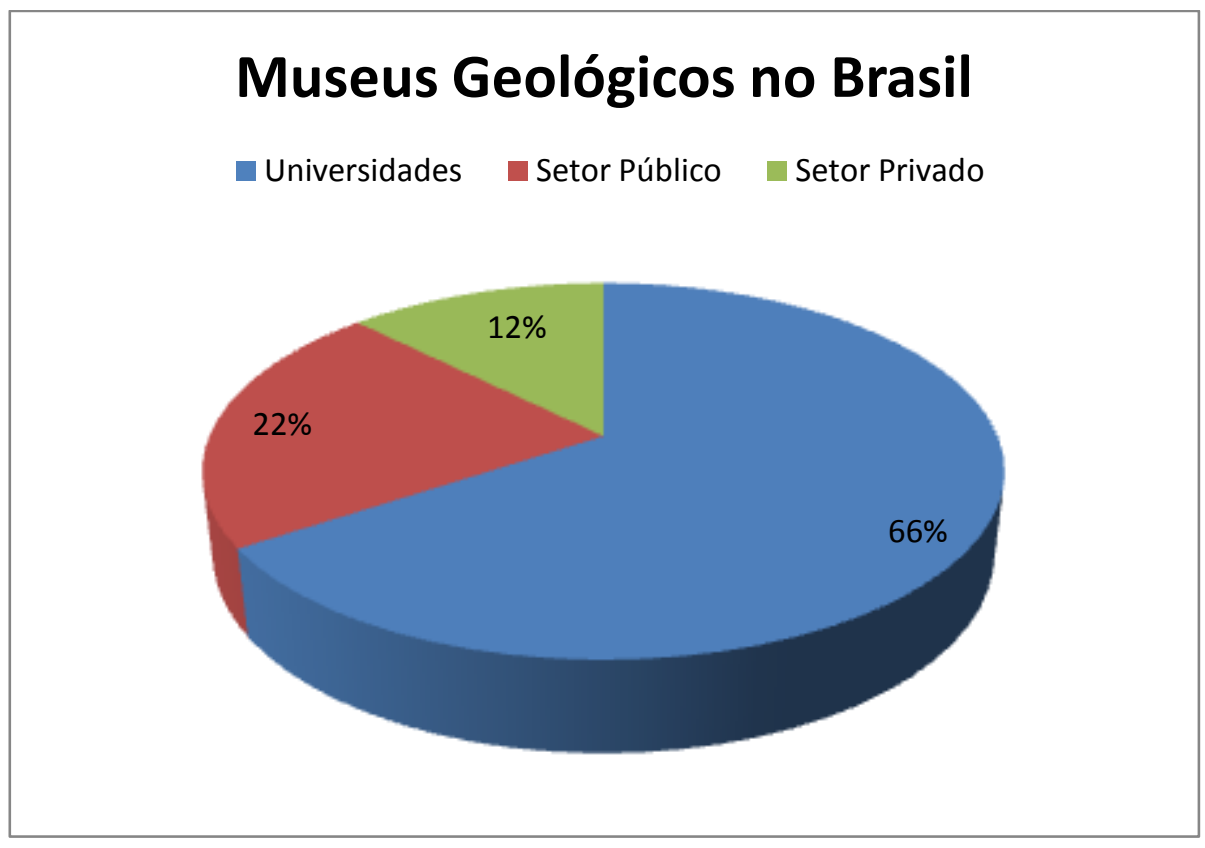

Figura 1. Gráfico demonstrativo das porcentagens de museus de Geologia pertencentes aos setores públicos, privados e universidades. Considera-se um total de 32 instituições. 
Dentre os museus universitários, a maioria pertence a universidades públicas federais, seguidos pelas universidades públicas estaduais. A porcentagem de museus universitários dividida entre instituições públicas federais, estaduais e privadas encontra-se demonstrada na Figura 2.

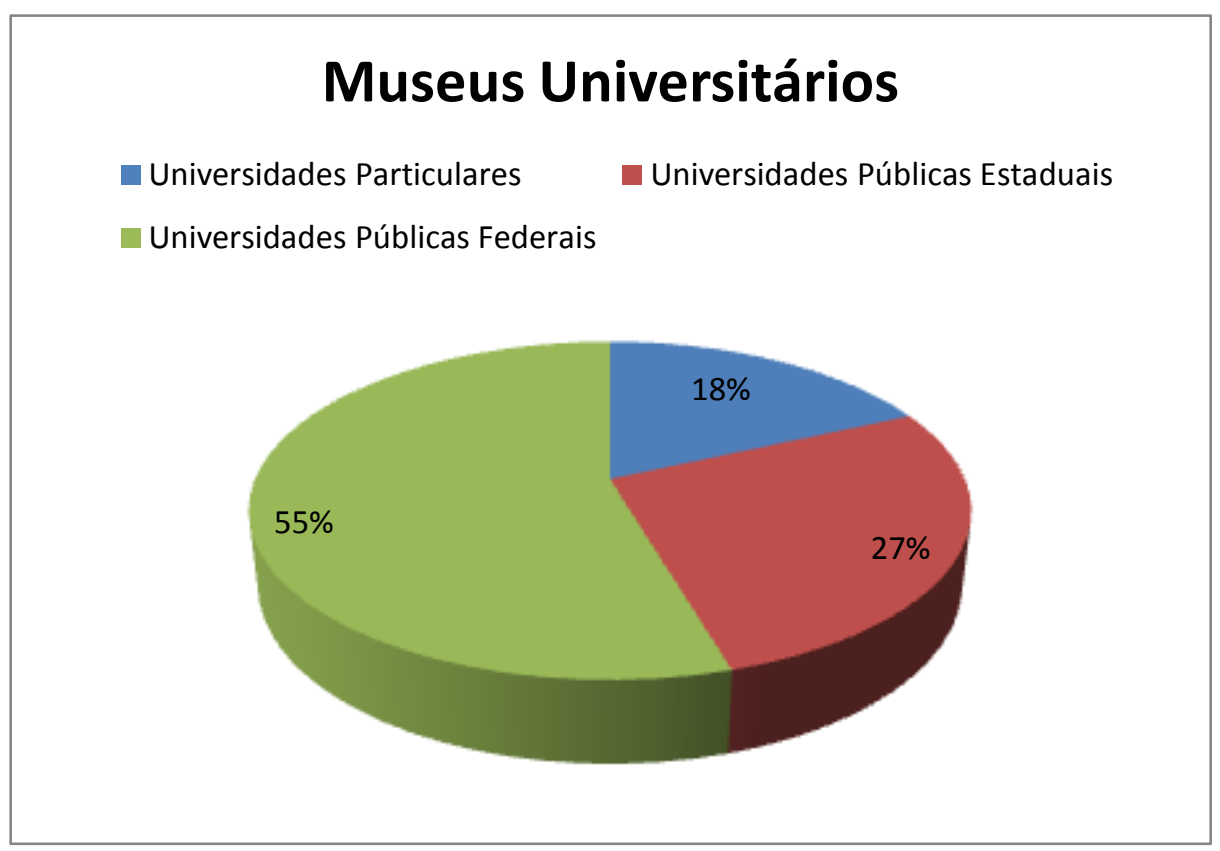

Figura 2. O gráfico acima mostra a porcentagem de museus universitários de acordo com cada tipo de instituição universitária. Considera-se o total de 22 instituições.

\section{1 - Origem dos Museus de Mineralogia}

Os museus em geral, incluindo as coleções mineralógicas, tiveram seu embrião na Europa entre os séculos XVI e XVII, um período marcado pelas grandes viagens exploratórias ao Oriente, África e Américas, descobertas de novas terras e culturas. Os viajantes que conseguiam retornar em segurança aos países de origem levavam consigo muitos objetos exóticos, como roupas, cerâmicas, animais, plantas e minerais. Lembrando-se de que apenas a nobreza participava dessas empreitadas, logo começaram a ser montados salões nas residências nobres, para a exposição desses objetos.

Essas coleções tinham caráter comprobatório, serviam para atestar que realmente as pessoas estiveram naqueles lugares e viram aqueles objetos. O objetivo inicial era reunir objetos que causassem espanto nos convivas de seus organizadores, por isso, quanto mais exótico e bizarro o salão de exposições, mais aceito pela comunidade colecionista. Esses salões, chamados de Gabinetes de Curiosidades ou Sala das Maravilhas (Figura 3), continham todo tipo de objetos: plantas tropicais, animais exóticos, deformidades embrionárias (fetos de animais com má formação), cerâmicas orientais, pergaminhos em 
idiomas desconhecidos, vestimentas rituais, fósseis, conchas, além de rochas ou minerais que tivessem características incomuns, ou fossem desconhecidos no Velho Mundo (GOMES, 2010).

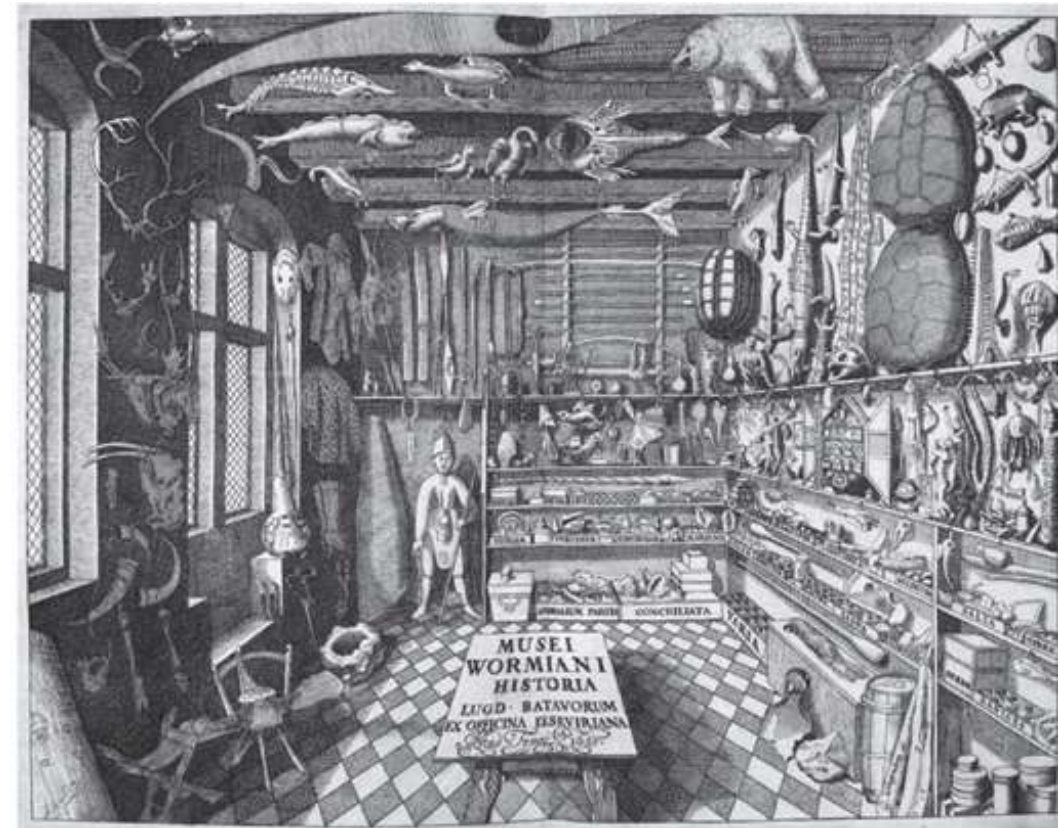

Figura 3. Gravura na folha de rosto do livro Museum Wormiorum, catálogo do gabinete de curiosidades do médico e colecionador Owl Worm (1588-1655).

Fonte: http://pt.wikipedia.org/wiki/Gabinete_de_curiosidades.

No início, os coletores de minerais estavam mais interessados em suas propriedades farmacológicas do que em sua beleza ou valor de mercado. Havia também os minerais com qualidades gemológicas que eram preservados como tesouros de famílias, sendo transmitidos de geração em geração, ou, como se sabe, mais tarde foram constituintes de tesouros de Estados. As cores e formas curiosas do reino mineral passaram a ser desafios que foram tentando ser explicados pelos estudiosos interessados em História Natural. Formação e jazidas eram os interesses principais.

Os Gabinetes de Curiosidades foram muito expressivos desde o fim do Renascimento (século XV) e durante todo o período Iluminista (entre os séculos XVII e XIX), marcando o estabelecimento de uma prática especial que ficou conhecida como colecionismo. A partir do século XVIII, os soberanos das nações recém-formadas (Portugal, Espanha, França e Inglaterra) entendiam que era responsabilidade pública a difusão do conhecimento, cabendo ao Estado promover ações para difundir o saber científico, grande impulsionador do progresso. Assim, as coleções particulares e bibliotecas passaram a ser alvo dos Estados que visavam à instrução popular. O colecionismo passou a ser sinônimo de poder. Por isso, durante todo o século XVIII e XIX, criou-se uma consciência coletiva de que as coleções eram um meio eficaz de aprimoramento dos conhecimentos de ciências, artes e letras. Os 
antigos gabinetes, antiquários e coleções privadas foram assim, paulatinamente sendo adquiridas pelos governos e fundidas, dando margem para a abertura de espaços públicos.

A evolução desses espaços culminou na criação das grandes Coleções de História Natural, sobretudo no século XVIII e XIX.

O primeiro museu moderno criado nesse contexto, e que recebeu oficialmente esse título foi o Ashmolean Museum, em Oxford, na Inglaterra. Ashmole, colecionador particular de objetos de história natural, arqueologia e antropologia era membro da Real Sociedade Inglesa, entidade criada em 1661 que tinha por finalidade a discussão de teorias científicas e pesquisas aplicadas (HASQUIN, 2009). Assim, Ashmole acabou por doar toda a sua coleção para a Universidade de Oxford, que veio a fundar o Ashmolean Museum em 1663.

É preciso apresentar aqui duas correntes básicas da museologia europeia, que tiveram grande repercussão no momento de criação dos museus brasileiros, a inglesa e a francesa. $\mathrm{O}$ século XVIII ficou marcado pelo início das atividades museológicas de grande porte na Inglaterra e França, cujas peculiaridades de estilo levaram à criação de dois modelos distintos de Museologia (BALERDI, 2008). No entanto, o privilégio dado a cada um dos tipos de instituições nesses dois países forjou um fazer museológico característico de cada um.

O London Natural History Museum (LNHM) foi o primeiro museu nacional a ser criado (o Ashmolean pertencia à Universidade de Oxford e não à Nação inglesa), em 1759. Tinha um caráter científico-pedagógico voltado à investigação e pesquisa científica. Essa postura cientificista, já presente no Ashmolean Museum e reforçada pelo LNHM caracterizou a criação de outros museus na Inglaterra (MARTINEZ, 2006) e, posteriormente nos países de colonização inglesa (destaca-se aqui o Smithsonian National Museum of Natural History SNMNH e o American Museum of Natural History - AMNH, ambos nos Estados Unidos).

Já o segundo museu nacional a ser criado na Europa foi o Museu do Louvre, em 1789. Diferente do LNHM em Londres, o Louvre tinha caráter artístico, voltado ao deleite da população. Apesar de não ser aberto a toda população francesa (apenas uma vez por semana o acesso era universal), era tido como um museu democrático, diferente do LNHM, que servia quase exclusivamente (apesar de ser aberto ao público geral) à comunidade científica. A arte era tida como um instrumento de libertação do indivíduo, característico da modernidade da sociedade francesa. A maioria dos museus europeus foi criada com inspiração na tradição francesa (MARTINEZ, 2006), exceto os portugueses. Por questões históricas que fogem ao tema deste trabalho, Portugal era muito mais próximo à Inglaterra que à França. Assim, os modelos de museus reproduzidos no território português foram os museus universitários e de ciências. Os museus de artes existiam, mas não com o peso social e o prestígio gozado pelos 
museus de ciência (donde se incluem os museus de mineralogia e petrologia). Por conseguinte, o Brasil também seguiu o estilo de museu anglo-saxão.

É imprescindível ressaltar neste trabalho a importância desses processos primitivos de musealização, especialmente no território português (que inclui o atual território brasileiro).

Durante o Período Pombalino (1750-1777) apareceram as estruturas universitárias que dariam origem aos atuais três principais museus universitários portugueses, das universidades de Coimbra, Porto e Lisboa, no momento em que o conhecimento teórico das ciências naturais passou a ser relacionado às práticas de laboratório (GOMES 2010). Essa forma de construção empírica do conhecimento científico deu origem às coleções didático-científicas que seriam os museus universitários portugueses, os quais por sua vez serviram de modelo para as instituições brasileiras. Neste contexto deu-se a criação do primeiro museu de História Natural do Brasil (na época, ainda Reino Unido de Portugal e Algarves), em 1818, o Museu Real (posteriormente, Museu Nacional). No final do século XIX e início do século XX, a comunidade científica passou a dar uma importância sem precedentes à investigação e resultados empiricamente comprovados. Nesta fase insere-se a criação de outros dois dos principais acervos de mineralogia e petrologia do país (já independente): O Museu Paraense Emílio Goeldi, em 1871 e o Museu Paulista, em 1894 (FIGUEIRÔA, 2000). Assim, o museu passou a ser visto como um espaço perfeito para a união entre teoria e prática, principalmente dentro das Universidades. O museu, assim, aproximou-se de um espaço laboratorial. Isso explica, portanto, porque a maioria dos museus geológicos no Brasil pertence ou está ligada às universidades.

Os museus e acervos de mineralogia passaram a ser criados com o objetivo de colocar à disposição dos professores de Ciências Naturais, os elementos práticos para complementarem as atividades teóricas. Muitas dessas coleções universitárias tiveram início com a doação da coleção particular do próprio docente responsável pela cadeira, e foram crescendo progressivamente com outras doações.

Foi também a partir da segunda metade do século XX que esses museus começaram a abrir as portas para o público geral. De início as pessoas apreciavam muito a beleza e raridade dos minerais, demonstrando interesse pelo estudo e conservação do acervo. Porém, com o passar dos anos, essas mostras deixaram de ser novidade e, quer pelas grandes dimensões do acervo exibido, quer pela inalteração das exposições, os museus começaram a perder gradualmente seus visitantes, sendo que, nas instituições mineralógicas universitárias, a maior parte do público é escolar (assim, o museu ainda aparece como laboratório de aula prática, e não consegue despertar a atenção do visitante espontâneo não especialista no assunto). 
O período áureo dos museus, na Europa, foi interrompido na segunda década do século XX, por ocasião da I Guerra Mundial, e essa pausa durou até o fim dos anos 40, com o término da II Guerra.

A ideia de museu, no século XX, ainda esteve atrelada ao colecionismo. Definia-se museu como "uma coleção de objetos artísticos, científicos ou históricos. Neste sentido, na hora de analisar o conceito de museu, tal como chegado aos nossos dias, descobre-se que corresponde fundamentalmente ao modelo europeu, e, em consequência, muitas de suas características vêm marcadas pelas exigências e preocupações que a sociedade ocidental tinha e experimentava no momento de sua criação" 5 .

Pelo fato de os museus terem sido construídos sobre o alicerce das tradições, o primeiro organismo pensado para gerir museus, o ICOM, foi criado, como uma Organização Não Governamental relacionada formalmente à UNESCO, em 1946, logo após o fím da II Guerra. Assim, em 1947, aprovada nos estatutos do ICOM, encontra-se a primeira definição oficial de museu: "Instituição permanente, que conserva e apresenta coleções de objetos de caráter cultural ou científico, com fins de estudo, educação e deleite" ". Nova definição passou a ser adotada, em 1974, incluindo o patrimônio: “uma instituição, sem fins lucrativos, a serviço da sociedade e seu desenvolvimento, aberto ao público, que adquire, conserva, investiga, comunica e exibe testemunhos materiais do homem e seu entorno, com fins de estudo, educação e deleite" ${ }^{7}$. Por fim, após um longo debate, em 2007 chegou-se à definição atual, já citada na abertura deste capítulo.

A Museologia é uma ciência recente; sua primeira definição data da década de 1950 (DESVALLÉES \& MAIRESSE, 2010) e, no Brasil, passou a ser difundida somente na década de 1970, apesar de o primeiro Curso Technico de Museus datar de 1932. O curso, com duração de dois anos, estava inicialmente ligado à direção do Museu Histórico Nacional e evoluiu para a atual Escola de Museologia da Universidade Federal do Rio de Janeiro $(\mathrm{UNIRIO})^{8}$. Por isso, a maioria das publicações científicas contempla os tipos de museus mais comuns no Brasil, os museus de arte e históricos. Os museus de mineralogia têm seguido uma organização expositiva baseada mais na tradição mineralógica que em bibliografias técnicas.

Os delineamentos para moldar uma teoria para a Museologia foram gerados e divulgados no plano internacional a partir dos anos 80 do século XX (CERÁVOLO, 2004) e se relacionam com a instauração do Comitê Internacional para a Museologia (ICOFOM), em

\footnotetext{
${ }^{5}$ Extraído de texto de aula online do curso Diploma em Museologia e Museografia ministrado pela professora Francisca Hernandez da Universidad Complutense de Madrid de janeiro a julho de 2012.

${ }^{6}$ Idem.

7 Idem.

${ }^{8}$ www.unirio.br/museologia/escolademuseologia. Acesso em 28 de janeiro de 2013.
} 
1977, vinculado ao Conselho Internacional de Museus (ICOM). O principal objetivo deste comitê é "difundir a Museologia como uma disciplina científica e acadêmica a qual irá encorajar o desenvolvimento de Museus e profissionais de museus por meio de pesquisas, estudos e disseminação das principais correntes do pensamento museológico" (DESVALLEÉS \& MAIRESSE, 2010).

A exposição de minerais no Brasil esteve desde sua origem relacionada às iniciativas particulares ou científicas (universidades), sendo incomum a presença do Estado na organização de museus mineralógicos, ao contrário do que acontece no campo da História, Antropologia e das Artes (muito comum em vários municípios a existência de um museu histórico municipal, o que não ocorre, por exemplo, com museus de minerais e rochas).

Por esses fatores não há ainda bibliografia científica sobre normatização técnica de exibição de minerais e rochas. Como toda ciência em fase inicial, a museologia de exposições minerais começou a tomar forma a partir dos anos 2000, com a observação de exposições já existentes, diagnósticos dessas exposições e publicações de artigos. Não há museologia oficial $^{9}$ sobre coleções de minerais, nem estudos de mineralogia de campo em museus. Por isso os trabalhos existentes são de cunho experimental, numa área de conhecimento ainda não definida, que transita entre a Geologia, Museologia e Educação.

É sensível que nos últimos anos está havendo um movimento para repensar os museus de ciências de um modo geral. As exposições estão mais interativas e os conceitos tendem a ser apresentados de modo que o público leigo consiga apreender senão o todo, pelo menos grande parte do que é exposto. A comunicação, interface entre público e coleção, tem sido o aspecto mais relevante na construção de exposições recentes.

Merecem destaque espaços como o Museu das Minas e do Metal, em Belo Horizonte, Minas Gerais, que conseguiu aglutinar em um mesmo museu, exposições contemplativas e interativas. Esse novo espaço incorporou o acervo do antigo Museu de Mineralogia Professor Djalma Guimarães. No Brasil, iniciativas deste porte só foram possíveis com o auxílio da iniciativa privada.

Outro exemplo é o Museu da Geodiversidade, da Universidade Federal do Rio de Janeiro. A exposição de minerais nesse museu não se encontra organizado segundo critérios científicos mineralógicos, mas sim de forma a chamar a atenção do público leigo (Minerais, frutos da Terra). Além disso, há, assim como no Museu das Minas e do Metal, bastante utilização de recursos multimídia e interatividade. Museus como o Museu de Geociências da

\footnotetext{
9 Entende-se aqui museologia oficial como o conjunto de documentos internacionais assinados pelo ICOM, ou nacionais assinados pelo Instituto Brasileiro de Museus.
} 
UnB, o Museu Geológico da Bahia e o Museu Nacional estão atualmente passando por processos de reformulação, a fim de atualizar e dinamizar seus acervos e exposições.

Os museus e acervos mineralógicos universitários enfrentam atualmente um problema de difícil solução: a oposição entre a burocracia administrativa arcaica das universidades públicas e o apelo multimídia cada vez maior de que se servem as instituições museológicas privadas.

Os museus, em geral, e os universitários em específico, reféns da estrutura governamental brasileira, formam um corpo tido como "espécime marginal, no esquema das prioridades culturais de poder" (BALERDI, 2008). E tal afirmação demonstra-se clara quando se lança um olhar geral sobre o corpo funcional dos museus universitários.

A maioria do corpo funcional dos museus universitários de pequeno porte possui funcionários não especializados, que não demonstram ter mais que uma vaga ideia de que a Museologia é uma ciência. A maioria vai parar por acaso nesses setores; alguns, felizmente compreendem do que se trata e vão à busca de informações e conhecimento específico; outros continuam por desempenhar fracamente suas funções, pois seus superiores nada exigem de diferente. Assim, os museus universitários que alcançam algum sucesso, devem isso a uma excepcionalidade, não a um planejamento.

"Com poucos meios se deve fazer, e se tem feito, mais do que cabe esperar: o trabalhador se multiplica, desempenha funções ou assume como próprios trabalhos que não lhe correspondem, sacrifica suas energias e se rouba tempo livre, com a finalidade de demonstrar a validade de seus postulados (e assim, está claro que realiza uma tarefa louvável - quase militante - a que não está obrigado)" (BALERDI, 2008).

\section{2 - Exposições mineralógicas}

A primeira catalogação sistemática de um museu universitário português (Museu Nacional de História Natural da Universidade de Lisboa) teve início em 1863 e, após várias mudanças, concretizou-se em 1926 (LEITE, 2009), ordenando os minerais quimicamente de acordo com sua classificação aniônica (este assunto será convenientemente abordado no Capítulo 4, Item 4.3). Essa ainda é a sistemática adotada pela maioria dos museus e acervos brasileiros.

Há de se dizer, no entanto, que essa sistemática, apesar de ser a que mais se adapta aos minerais, coloca-os, ao mesmo tempo, num patamar de total incompreensão por parte do público geral. Essa classificação é, portanto, seguramente perfeita para a comunidade geológica, mas absolutamente ineficaz para o grande público. 
Pode-se assim, distinguir atualmente dois tipos básicos de exposições mineralógicas:

1. Exposições contemplativas (ou clássicas): nesse tipo de exibição, não há interação entre objeto e visitantes. Estes são meros expectadores das peças expostas, não podendo manipulá-las ou experimentá-las de outras formas que não seja a visual. Destinadas à comunidade científica, são baseadas em classificações mineralógicas internacionais (Dana ou Strunz);

2. Exposições interativas: de caráter mais recente, destinadas a diversos tipos de públicos, como educação informal, que explora as características minerais associadas ao conhecimento prévio do visitante (aprendizagem significativa). Possuem dispositivos manipuláveis, que possibilitam ao visitante interagir com o que é exposto. Por isso, na ausência de um manual de exposições mineralógicas que diga ao corpo funcional dos museus como fazer (pessoas que na grande maioria das vezes não são museólogos), há alguns parâmetros que devem ser seguidos em qualquer tipo de exposição, sendo, por isso, ponto de partida também para as exposições mineralógicas.

Tomando como base que "exposições são intermediários entre o acervo do museu e seu público", deve-se definir o público alvo a quem a exposição se destina, pois é ele quem vai direcionar o espaço a ser utilizado, a linguagem adequada, os recursos didáticos, entre outros aspectos. Definição de objetivos, equipe adequada aos projetos (incluindo profissionais convidados), e aspectos materiais, como recursos financeiros e espaço físico, são alguns dos pontos a serem discutidos na concepção de uma exposição.

Som, iluminação, textura e imagens são fatores que influenciam na comunicação da exposição com o visitante. A Museums \& Galleries Comission (2001), Instituição Britânica que normatiza regras para museus e galerias de arte, sugere uma plataforma básica para a montagem de exposições, perfeitamente aplicável às exibições de minerais:

1 - Definir a função da exposição no museu (a partir da missão da instituição);

2 - Definir o público alvo;

3 - Conhecer os recursos financeiros disponíveis;

4 - Procurar conhecimento especializado no assunto antes de formatar a exposição (tema tratado, salvaguarda do acervo, curadoria, design, educação, marketing e segurança);

5 - Escolher os profissionais envolvidos;

6 - Fixar um cronograma apropriado e realista;

7 - Redigir um projeto de exposição;

8 - Organizar a segurança da exposição (dos objetos, funcionários e visitantes);

9 - Maximizar o acesso à exposição. 
No Brasil, a maioria dos museus de mineralogia tem exposições em estilo clássico, privilegiando exibições destinadas ao público científico, sem levar em conta a mudança do perfil de visitante nos últimos dez anos e os critérios museológicos de exposição. Não se quer dizer, com isso, que critérios científicos devam ser abolidos das exposições. Pelo contrário, devem permanecer, contudo, abrindo espaços para novas formas expositivas. A coexistência dos estilos clássico e moderno é uma boa alternativa para se contemplar diversos tipos de públicos alvo.

Leite (2009), em um estudo embasado no público visitante do Museu de História Natural da Universidade de Lisboa, constatou "que o público prefere exposições com abordagens mistas, isto é, exposições com elementos de uma índole contemplativa e elementos de índole interactiva".

Um exemplo bem ilustrativo é a exposição do LNHM. Por possuir um edifício que propicia uma ampla utilização do espaço, optou-se por manter os dois tipos de exposições mineralógicas citadas.

O visitante que quiser voltar no tempo (tanto que a publicidade desta exposição é step back in time) pode visitar a Galeria de Minerais (Figura 4). Trata-se de um enorme salão, no qual está a exposição de minerais tal qual se encontrava em 1881. Esta é uma típica exposição mineralógica clássica contemplativa, na qual o visitante observa vitrina por vitrina, com poucas legendas e muitas amostras. Por isso, percebe-se que esse tipo de exibição é focada em um público que já possui um conhecimento mínimo do assunto abordado (deve-se saber, por exemplo, o que são elementos nativos, sulfetos, halóides, etc..., ou então olhar cada vitrina até se deparar com o mineral desejado).

Já se o visitante quiser apenas apreciar o mundo mineral, sem vínculo com nomenclaturas científicas pode dirigir-se ao The Vault (Figura 5) um espaço contíguo a Galeria dos Minerais, e que possui uma exposição moderna, com técnicas expositivas adequadas ao público leigo, com um caráter mais interativo e menos contemplativo. 


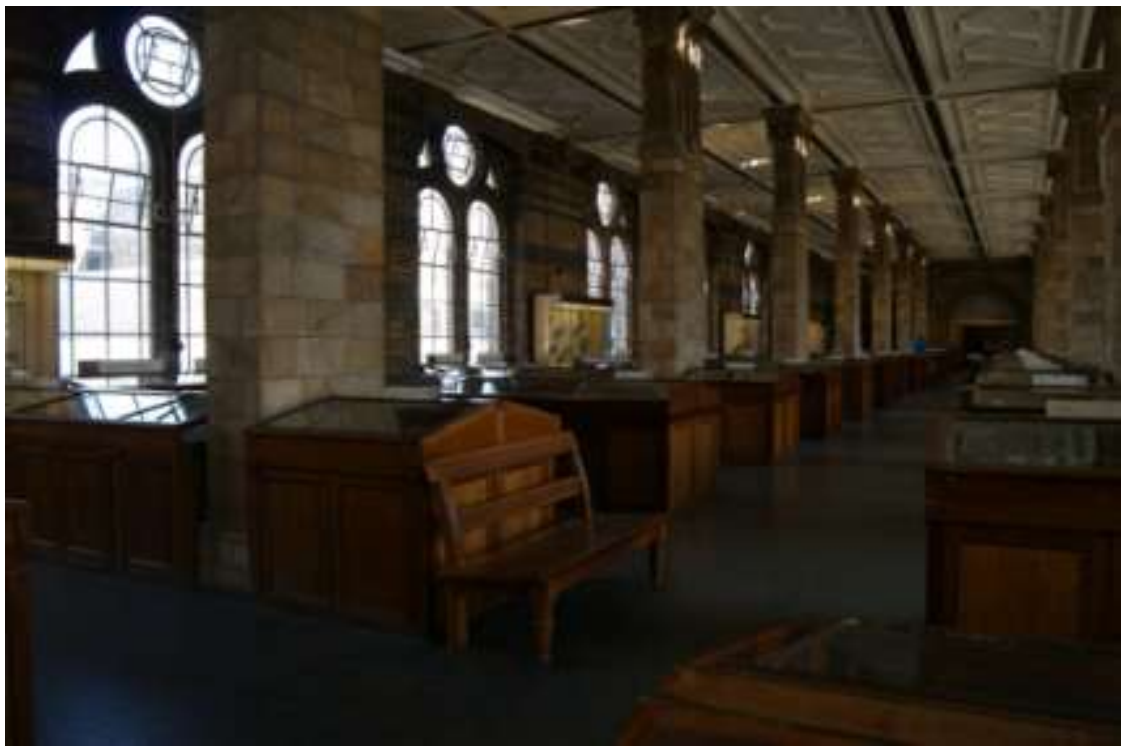

Figura 4. Vista Geral da Galeria de Minerais do London Natural HIstory Museum. Ao fundo, a entrada para The Vault.

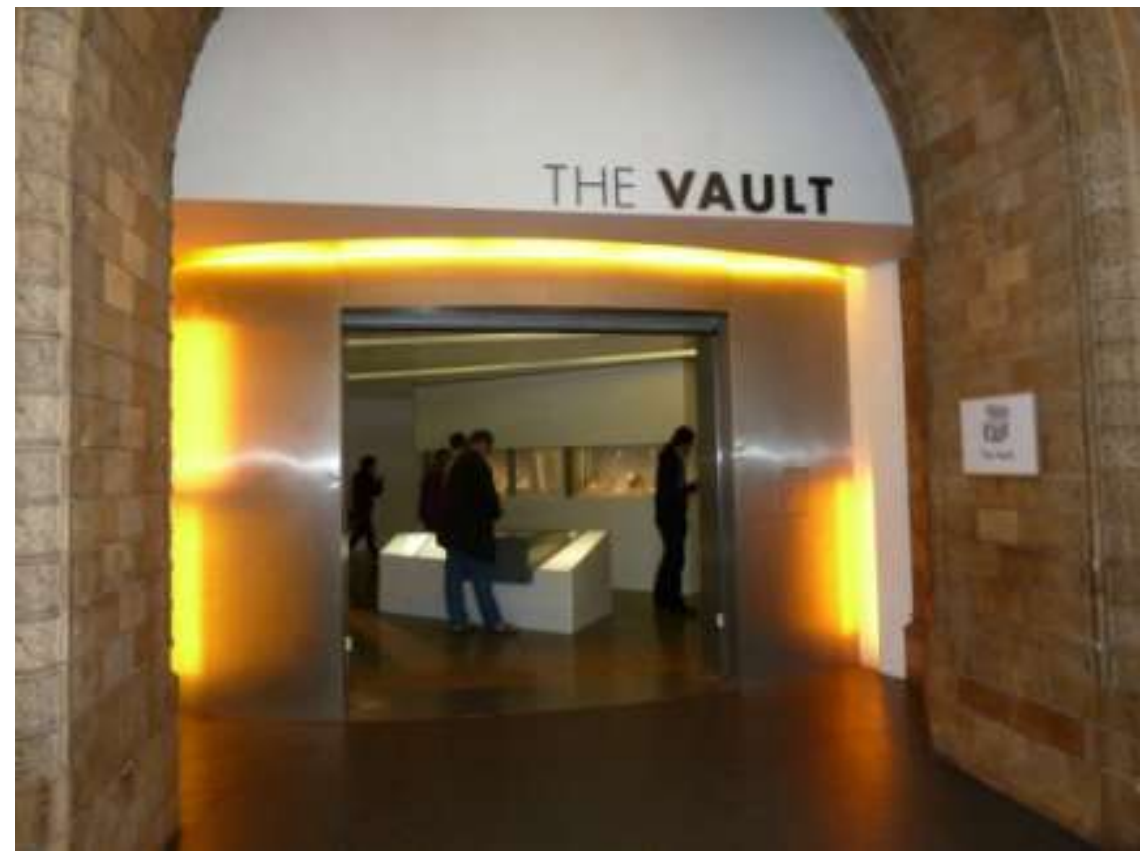

Figura 5. Entrada do Vault, enfatizando impacto temporal entre uma exposição do século XIX e outra do século XXI. London Natural History Museum.

Uma vez que não há especificação científica para montagem de exposições mineralógicas, prevalece sempre o bom senso na observação do público alvo do museu e nas constantes demandas dos visitantes.

\section{3 - Classificação Mineralógica}

Para que se entenda melhor a classificação sistemática dos minerais, tal como é utilizada pelos mineralogistas e, por conseguinte, refletidas na organização expositiva de 
muitos museus, recorre-se à composição química de cada mineral, reunindo-os em grupos de acordo com suas afinidades químicas aniônicas ou estruturais. Os dois mineralogistas que mais se destacaram na sistematização de minerais em classes de acordo com sua composição química foram James D. Dana e Hugo Strunz. Por isso não é raro ouvir que certo acervo está organizado de acordo com Dana ou segundo Strunz.

James Dwight Dana (1813-1895) publicou a primeira versão de seu sistema de mineralogia (System of Mineralogy) em 1937. A oitava edição do sistema, utilizada neste estudo, descreve, cataloga e classifica todos os minerais conhecidos no período (1997). O sistema de classificação de Dana dá a cada mineral descrito um número contendo quatro partes separadas por períodos. A classificação é feita com base nas semelhanças químicas entre as composições dos minerais, enfatizando-se o ânion predominante na fórmula química. Todos os museus citados neste trabalho, com exceção dos museus alemães, utilizam essa classificação. A seguir tem-se um exemplo da numeração do mineral esfalerita $(\mathrm{ZnS})$, 2.8.2.1 de acordo com o sistema de Dana:

$\begin{array}{cccc}2 . & 8 . & 2 . & 1 \\ \uparrow & \uparrow & \uparrow & \uparrow \\ \text { Classe dos } & \text { Minerais } & \text { Grupo da } & \text { Esfalerita } \\ \text { Sulfetos } & \text { isoestruturais } & \text { esfalerita } & \\ & \text { com fórmula } & & \\ & \text { química } & & \end{array}$

$\mathrm{AB}$

A separação dos minerais de acordo com os ânions ou grupos aniônicos dominantes é utilizada devido a alguns fatores:

1 - Os minerais que têm em comum o mesmo ânion ou grupo aniônico dominante têm afinidades familiares inconfundíveis (KLEIN \& DUTROW, 2012), o que não ocorre com os grupos catiônicos.

2 - Os minerais relacionados pelo mesmo ânion tendem a ocorrer em ambientes geológicos semelhantes ou até no mesmo ambiente.

No entanto, é importante salientar que apenas a composição química não fornece informações suficientes para a classificação de um mineral. A estrutura cristalina, organização espacial dos átomos que compõem o mineral, é de fundamental importância no processo de identificação. Estrutura cristalina e composição química constituem, juntas, os parâmetros fundamentais para a classificação mineral. Um curador que não tenha essas informações não está apto a organizar uma coleção científica de minerais. 
Com exceção dos elementos nativos, cujos átomos são suficientemente inertes para se apresentarem em estado elementar na natureza, as demais classes minerais são agrupadas de acordo com o ânion ou grupo aniônico predominante na composição química. A Tabela 3 mostra o nome das classes minerais segundo a classificação de Dana e os ânions correspondentes, nas valências predominantes.

Tabela 3 - Classes minerais agrupadas de acordo com a composição química e o ânion predominante, segundo Dana.

\begin{tabular}{|c|c|}
\hline CLASSE & COMPOSIÇÃO QUÍMICA \\
\hline Elementos Nativos e Ligas & $\begin{array}{l}\text { Minerais compostos por apenas um elemento } \\
\text { químico }(\mathrm{Ag}, \mathrm{Au}, \mathrm{C}, \mathrm{Cu}, \mathrm{Fe}, \mathrm{Pt}, \mathrm{S}, \mathrm{Sb} \text {, são os } \\
\text { mais importantes) }\end{array}$ \\
\hline Sulfetos e Compostos Relacionados & $\mathrm{S}^{2-}$ ou $\mathrm{As}^{3-}$ \\
\hline Óxidos & $\mathrm{O}^{--}$combinado com um ou mais metais \\
\hline Halogenetos & $\mathrm{Cl}^{-}, \mathrm{Br}^{-}, \mathrm{F}^{-}$e $\mathrm{I}^{-}$ \\
\hline Carbonatos & $\left(\mathrm{CO}_{3}\right)^{2-}$ \\
\hline Nitratos & $\left(\mathrm{NO}_{3}\right)^{-}$ \\
\hline Iodatos & $\left(\mathrm{IO}_{3}\right)^{-}$ \\
\hline Boratos & $\left(\mathrm{BO}_{3}\right)^{3-}$ \\
\hline Sulfatos & $\left(\mathrm{SO}_{4}\right)^{2-}$ \\
\hline Selenatos e Teluratos; Selenitos e Teluritos & $\left(\mathrm{SeO}_{4}\right)^{2-},\left(\mathrm{TeO}_{4}\right)^{2-},\left(\mathrm{SeO}_{3}\right)^{2-},\left(\mathrm{TeO}_{3}\right)^{2-}$ \\
\hline Cromatos & $\left(\mathrm{CrO}_{4}\right)^{2^{-}}$ \\
\hline Fosfatos, Arsenatos e Vanadatos & $\left(\mathrm{PO}_{4}\right)^{3-},\left(\mathrm{AsO}_{4}\right)^{3-},\left(\mathrm{VO}_{4}\right)^{3-}$ \\
\hline Antimonatos, Antimonitos e Arsenitos & $\left(\mathrm{Sb}_{2} \mathrm{O}_{6}\right)^{2-},\left(\mathrm{SbO}_{3}\right)^{-},\left(\mathrm{AsO}_{3}\right)^{-}$ \\
\hline \multicolumn{2}{|l|}{ Oxissais de Vanádio } \\
\hline Molibdatos e Tungstatos & $\left(\mathrm{MoO}_{4}\right)^{2-},\left(\mathrm{WO}_{4}\right)^{2-}$ \\
\hline \multicolumn{2}{|l|}{ Sais de Ácidos Orgânicos } \\
\hline Nesossilicatos & $\left(\mathrm{SiO}_{4}\right)^{4-}($ tetraedros isolados $)$ \\
\hline Sorossilicatos & $\left(\mathrm{Si}_{2} \mathrm{O}_{7}\right)^{6-}$ (duplas de tetraedros isolados) \\
\hline Ciclossilicatos & $\left(\mathrm{SiO}_{3}\right)^{2-}$ (anéis de tetraedros) \\
\hline Inossilicatos & $\begin{array}{l}\left(\mathrm{SiO}_{3}\right)^{2-}, \quad\left(\mathrm{Si}_{4} \mathrm{O}_{11}\right)^{6-} \quad \text { (tetraedros em cadeias, } \\
\text { simples ou dupla) }\end{array}$ \\
\hline
\end{tabular}




\begin{tabular}{l|l}
$\begin{array}{l}\text { Filossilicatos } \\
\text { Tectossilicatos }\end{array}$ & $\left(\mathrm{Si}_{2} \mathrm{O}_{5}\right)^{2-}$ (tetraedros em folhas) \\
\hline
\end{tabular}

As classes descritas na Tabela 3 "são subdivididas em famílias, com base nos tipos químicos, e as famílias, por sua vez, podem ser subdividas em grupos baseados na semelhança estrutural. Um grupo é constituído de espécies que podem formar séries entre si. Espécies têm a mesma estrutura, mas composições químicas diferentes. A espécie pode ser subdividida em variedades químicas, por modificadores adjetivantes, que refletem a presença de quantidades incomuns dos elementos químicos" (KLEIN \& DUTROW, 2012, pag. 358).

Karl Hugo Strunz (1910-2006) desenvolveu uma tabela mineralógica (Mineralogischen Tabellen) com a organização sistemática dos minerais baseada em suas propriedades cristaloquímicas. Foi publicada pela primeira vez em 1941 e hoje está em sua nona edição. Essa classificação combina as características químicas e os princípios estruturais do mineral, como o tamanho do cátion e o número de coordenação (STRUNZ \& NICKEL, 2001). Na última edição desta tabela, em 2001, Ernest Nickel e Hugo Strunz apresentam a divisão dos minerais em dez classes de acordo com suas características químicas. Tais classes são subdivididas de acordo com seus princípios químico-estruturais e levam uma codificação alfanumérica que permite a inserção futura de novas espécies minerais sem que haja mudança na estrutura básica de classificação. A numeração engloba preferencialmente grupos ao invés de minerais individuais. Na numeração de Strunz, o primeiro algarismo representa a classe do mineral; na sequência, a primeira letra representa a divisão e é seguida pela segunda letra que representa a subdivisão. Os dois últimos algarismos representam o grupo ou a espécie mineral. Veja o exemplo a seguir, com o mineral esfalerita, número 2.CB.05:

$\begin{array}{cccc}2 . & \mathrm{C} & \mathrm{B} . & 05 \\ \downarrow & \uparrow & \uparrow & \uparrow \\ \text { Classe dos } & \text { Metal Sulfetos, } & \mathrm{Com} \mathrm{Zn,} \mathrm{Fe,} & \text { Grupo da } \\ \text { Sulfetos e } & \mathrm{M}: \mathrm{S}=1: 1 & \mathrm{Cu}, \mathrm{Ag} & \text { esfalerita } \\ \text { Sulfossais } & & & \end{array}$

A Tabela 4 mostra as classes minerais segundo a classificação de STRUNZ \& NICKEL (2001) na nona edição da Tabela Mineralógica.

Tabela 4 - Classificação mineralógica de STRUNZ \& NICKEL (2001). 


\begin{tabular}{|c|c|}
\hline 1 - Elementos & $\begin{array}{l}\text { Metais e ligas intermetálicas, metaloides e não metais, carbetos, } \\
\text { silicietos, nitretos e fosfetos }\end{array}$ \\
\hline 2 - Sulfetos e Sulfossais & $\begin{array}{l}\text { Sulfetos, selenetos, teluretos, arsenietos, antimonídeos, bismutídeos, } \\
\text { sulfoarsenietos, etc...) }\end{array}$ \\
\hline 3 - Halóides & $\begin{array}{c}\text { ligações entre íons halogêneos }\left(\mathrm{Cl}^{-}, \mathrm{B}^{-}, \mathrm{F}^{-}, \mathrm{I}^{-}\right) \text {e metais ou metaloides, } \\
\text { hidratados ou não, com O e OH }\end{array}$ \\
\hline 4 - Óxidos & $\begin{array}{c}\text { Óxidos, hidróxidos, vanadatos, arseniatos, antimoniatos, sulfitos, } \\
\text { selenatos, teluratos, iodatos, etc...) }\end{array}$ \\
\hline 5 - Carbonatos & $\mathrm{CO}_{3}$ ou $\mathrm{NO}_{3}$, com ou sem ânions adicionais, hidratados ou não \\
\hline $6-$ Boratos & Triângulos de $\mathrm{BO}_{3}$, com ou sem ânions adicionais, hidratados ou não \\
\hline 7 - Sulfatos & $\begin{array}{c}\text { Tetraedros de } \mathrm{SO}_{4}, \mathrm{SeO}_{4}, \mathrm{TeO}_{4}, \mathrm{CrO}_{4}, \mathrm{MoO}_{4}, \mathrm{WO}_{4} \text {, hidratados ou } \\
\text { não, com ou sem ânions adicionais }\end{array}$ \\
\hline 8 - Fosfatos, Arsenatos, Vanadatos & $\begin{array}{c}\text { PO4, AsO4 e VO4 com ou sem ânions complementares, hidratados } \\
\text { ou não }\end{array}$ \\
\hline 9 - Silicatos & Tetraedros de $\mathrm{SiO}_{4}$ \\
\hline 10 - Compostos Orgânicos & Sais de ácidos orgânicos, hidrocarbonos e outros \\
\hline
\end{tabular}




\section{4 - Classificação Petrológica}

Assim como os minerais, as rochas apresentam uma organização museológica geralmente baseada em sua tipologia. Essa tipologia está relacionada ao seu ambiente de formação e as maneiras como ela pode ocorrer.

Os três tipos primários de rochas, diferente dos minerais, são estudados ainda no Ensino Fundamental II, no currículo de Geografia. São eles:

- Rochas Ígneas ou Magmáticas, formadas a partir do resfriamento do magma, no interior (magmáticas intrusivas ou plutônicas) ou no exterior da superfície terrestre (magmáticas extrusivas ou vulcânicas);

- Rochas Sedimentares, formadas a partir de fragmentos resultantes do intemperismo sofrido pelas massas rochosas previamente existentes na crosta ou pela precipitação de íons em solução;

- Rochas Metamórficas, formadas pela recristalização dos minerais presentes nas rochas ígneas, sedimentares ou mesmo metamórficas, devido à ação da pressão e temperatura.

A maioria dos museus que possui acervos petrológicos expostos, organizam-se de acordo com a divisão nos três tipos de rochas, geralmente enfatizando o ambiente de formação de cada uma ou, na maioria das vezes, apenas expondo os exemplares pertencentes a cada grupo (o que torna a exposição incompreensível e desestimulante). Um exemplo desse tipo de exposição é a coleção de rochas do Museu de Geociências da USP (Figura 6). No entanto, é possível utilizar a classificação petrológica científica e promover exposições atraentes.

Um exemplo de exposição petrológica não científica (ou seja, não classificada com os critérios citados anteriormente) pode ser vista no LNHM (Figura 7). Trata-se de uma exposição de rochas associadas a monumentos de renome internacional, como as rochas que formam Stonehenge (Figura 8), as rochas utilizadas na construção das pirâmides do Egito, entre outras. Outro exemplo é no NMHN, na exposição de rochas utilizadas nos monumentos da cidade de Washington (Figura 9).

Esses são apenas alguns dos muitos exemplos que poderiam ser citados para ilustrar a diversidade de possibilidades de exposições de minerais e rochas. Espera-se com isso, contribuir para a discussão acerca de exposições mineralógicas e petrológicas, tema tão insuficientemente abordado na Museologia brasileira. Num nível micro, espera-se contribuir para um melhor desenvolvimento expográfico do Museu de Geociências da USP. 


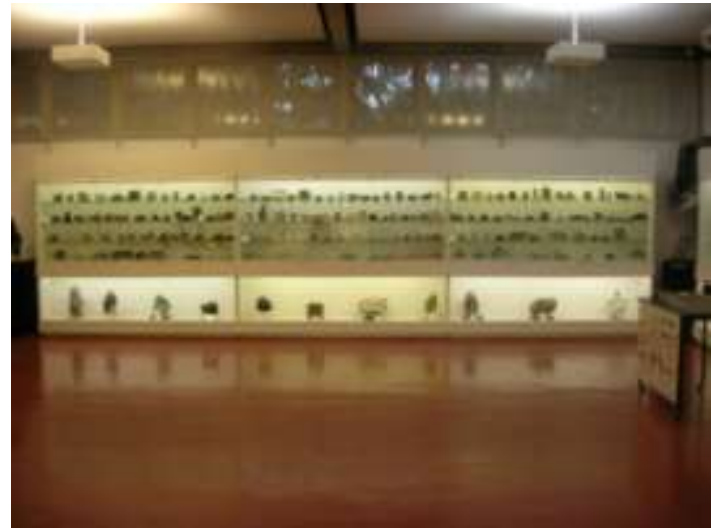

Figura 6. Exposição científica de rochas no Museu de Geociências da USP.

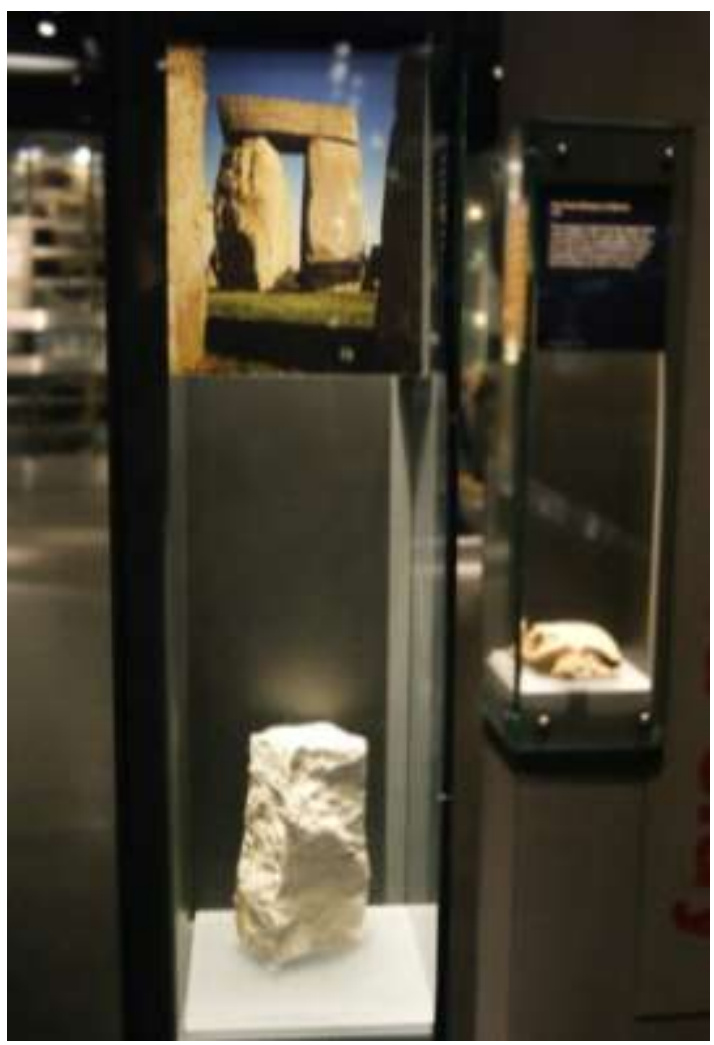

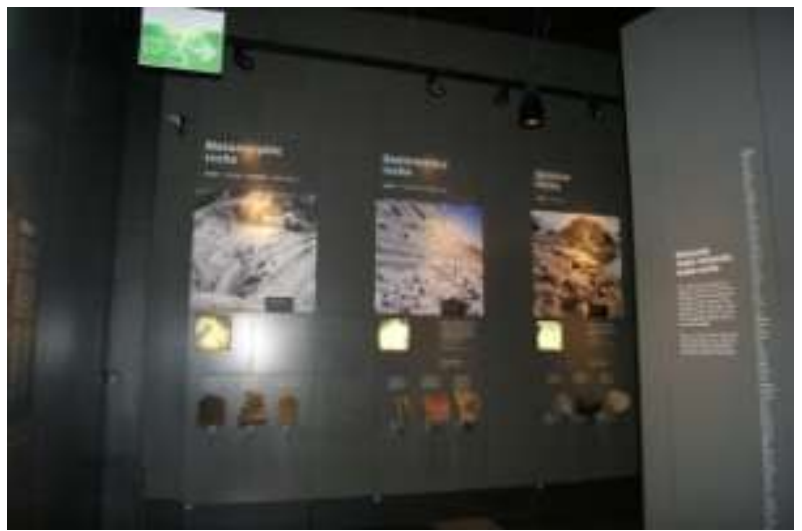

Figura 7. Vista geral de uma das exposições de rochas no London Natural History Museum. Nela está presente a classificação científica das rochas em seus três tipos, de maneira sedutora e didática.

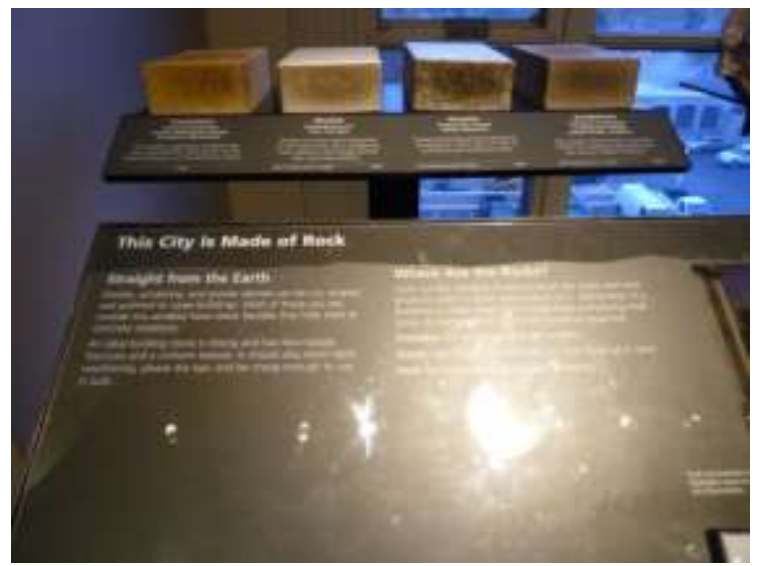

Figura 9. Exposição de rochas no NMHN. Aqui o destaque é para as rochas que compõem as construções famosas de Washington. Foto: Eliane A. Del Lama.

Figura 8. Exposição de rochas sem a classificação científica usual. Escolheu-se mostrar as rochas atreladas a grandes monumentos da humanidade, relacionando Geologia e História. Pode ser considerada uma exposição interativa, uma vez que trabalha com o conhecimento prévio do visitante. London Natural History Museum.

\section{5 - Museus Parâmetro}

Devido à ausência de bibliografias especializadas sobre exposições geológicas, mais especificamente mineralógicas, utiliza-se neste trabalho uma metodologia de comparação. $\mathrm{O}$ Museu de Geociências da USP, base deste estudo, será comparado a outros museus que 
compartilham o mesmo tipo de acervo geológico, quais sejam: minerais, rochas, meteoritos e gemas.

Os museus escolhidos para fins de comparação são chamados aqui de museus parâmetro, uma vez que servem de parâmetro norteador para análise da exposição e curadoria do Museu de Geociências da USP. O critério base para escolha dessas instituições é a tipologia das coleções. No entanto outros critérios foram relevantes, como se observa a seguir:

- Museus de grande porte: algumas instituições, por serem de grande porte possuem maior aporte financeiro para lidar com a coleção, dando um parâmetro do que deveria ser o universo ideal das coleções geológicas. Muitas das publicações da área são de autoria de experts dessas instituições. Encaixam-se nesta categoria: National Museum of Natural History (Smithsonian Institution); London Natural History Museum, Oxford University Natural History Museum e Museum für Naturkunde (Berlim).

- Museus universitários: estes museus foram escolhidos por possuírem o mesmo status jurídico do Museu de Geociências da USP, ou seja, estarem sob tutela de universidades públicas. Aqui se encaixam: Museu de Mineralogia Prof. Heinz Ebert (UNESP), Museu Nacional (UFRJ), Mineralogisches Museum - Universität Hamburg (Universidade de Hamburgo), Mineralogisches Sammlungen - Technische Universität Berlin (Universidade Técnica de Berlim), Mineralogisches Museum - PhilippsUniversität Marburg (Universidade Philipps de Marburg), Mineralogisches Museum Universität Würzburg (Universidade de Würzburg); Mineralogisches Sammlungen Institut für Geowissenschaften - Universität Jena (Instituto de Ciências da Terra da Universidade de Jena).

- Acervo: alguns museus têm o próprio acervo como razão da visita, seja pelo fato de sua especificidade, seja pela sua fama. Encontram-se nesta categoria o Museu de Ciências da Terra, do DNPM, cujo acervo é um dos mais famosos do país em termos de raridade e variedade mineralógica, além de ser um acervo histórico que remonta ao início do século XX; o Terra Mineralia, por ser uma das coleções privadas mais famosas do mundo, pela raridade e beleza dos exemplares; o Ries Krater Museum, por ser um museu específico sobre meteoritos; o Deutsches Edelsteinmuseum, por ser um acervo especializado em gemas.

Os museus visitados estão descritos sucintamente a seguir de acordo com a ordem dos critérios apresentados. 


\subsection{1 - National Museum of Natural History - NMNH - Smithsonian Institution}

(Washington, DC - EUA)

O Smithsonian Institution é hoje o maior complexo de museus do mundo, incluindo a Galeria de Arte Nacional, o Museu Aeroespacial, Jardim Zoológico, Museu do Índio Americano, Museu Nacional de História Natural, entre outros. O Museu foi criado em 1846, mas o atual edifício do Museu Nacional de História Natural foi inaugurado em 1910 (Figura 10) com o objetivo de abrigar todas as coleções oficiais de história natural dos Estados Unidos, bem como instalações para os pesquisadores da área. Durante a década de 1980, o Museu estava necessitando de mais espaço, pois as coleções não paravam de crescer. Em 1983 foi inaugurado o Museum Support Center (MSC) (Figura 11) in Suitland, Maryland, para acomodar coleções e laboratórios de conservação e pesquisa.

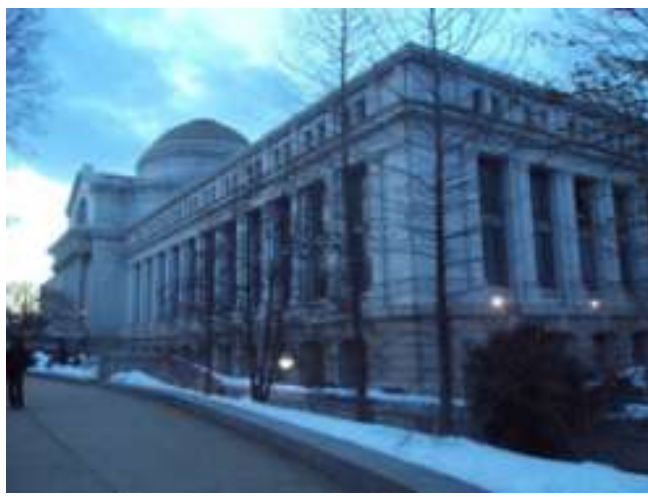

Figura 10. Fachada principal do NMNH, localizado no National Mall.

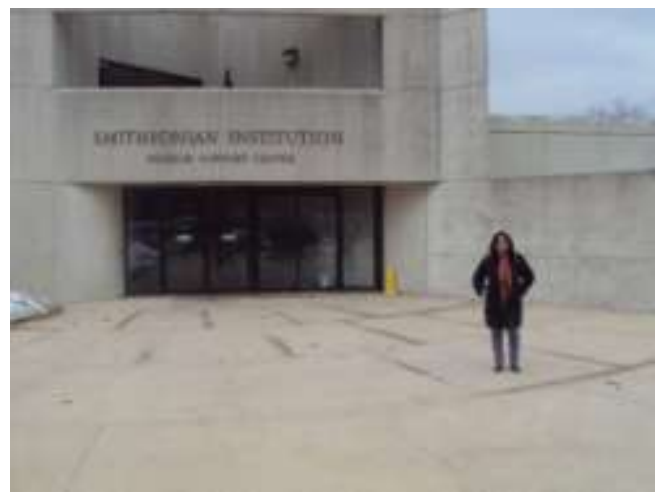

Figura 11. Fachada de um dos edifícios do MSC em Suitland, Maryland.

O edifício principal, localizado no National Mall possui $99.060 \mathrm{~m}^{2}$ de área de exibições e 126 milhões de exemplares de história natural.

As principais áreas de pesquisa do museu são: mamíferos, aves, insetos, peixes, paleobotânica, paleontologia, mineralogia (na qual está inclusa uma grande e valiosa coleção de gemas) e minérios e rochas.

Apesar de abrigar um dos maiores acervos de minerais brutos e gemas do mundo, o Smithsonian Institution não tem o mesmo tratamento para todas coleções, sendo que algumas delas possuem mobiliário mais adequado e maior número de funcionários, e a coleção de minerais e rochas não possui funcionário específico para tratar da conservação.

A exposição geológica do museu é bem estruturada, com muitos recursos interativos e multimídias. A exposição de minerais é direcionada ao público leigo (Figuras 12 e 13), pois mostra os minerais e suas características sem o apelo científico da academia, que por muitas vezes assusta os visitantes ocasionais, pois a linguagem acadêmica, como observada no Museu de Geociências da USP e na exposição mineralógica clássica do Museu de História 
Natural de Londres, acaba por criar uma barreira psicológica entre o conhecimento e o visitante que não faz parte do meio.

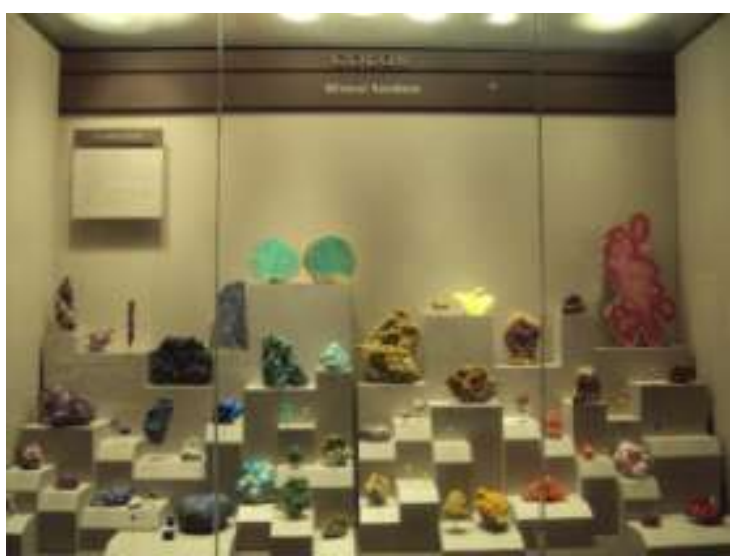

Figura 12. Exemplo de exposição moderna, na qual o visitante leigo pode ver uma das principais características físicas do mineral, a cor, sem a utilização de termos científicos que criem barreira entre o espectador e o conhecimento a ser transmitido.

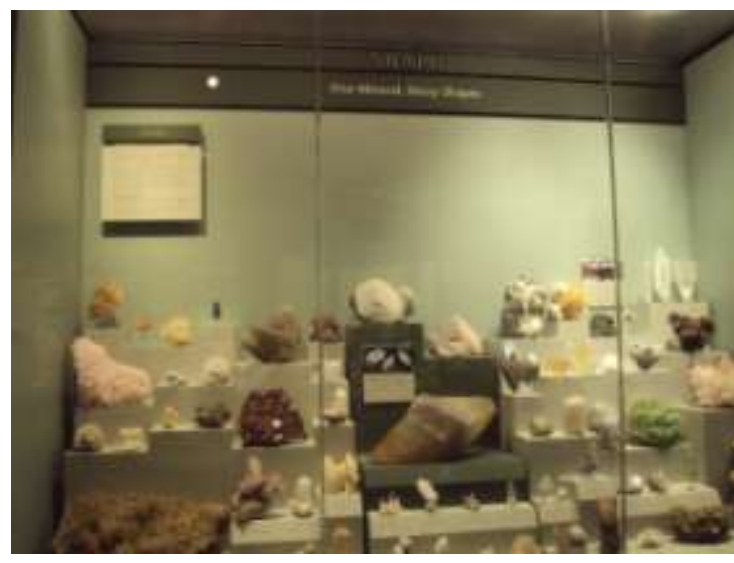

Figura 13. Transmissão de outro conceito básico da mineralogia, o hábito do mineral, aqui transmitido ao público leigo de forma sutil e agradável, sob o título de um mineral, muitas formas.

Com relação à reserva técnica, existem dois espaços principais utilizados para armazenar minerais e rochas: os materiais utilizados regularmente pelos pesquisadores do próprio museu ficam alocados no próprio departamento, em armários antigos e sem cuidado especial (Figura 14). As gemas são acondicionadas em local com segurança extra (Figura 15), e somente o funcionário credenciado tem acesso. Os pesquisadores não têm permissão para entrar nesse local, por isso não foi possível analisar o acondicionamento do material gemológico do museu. 


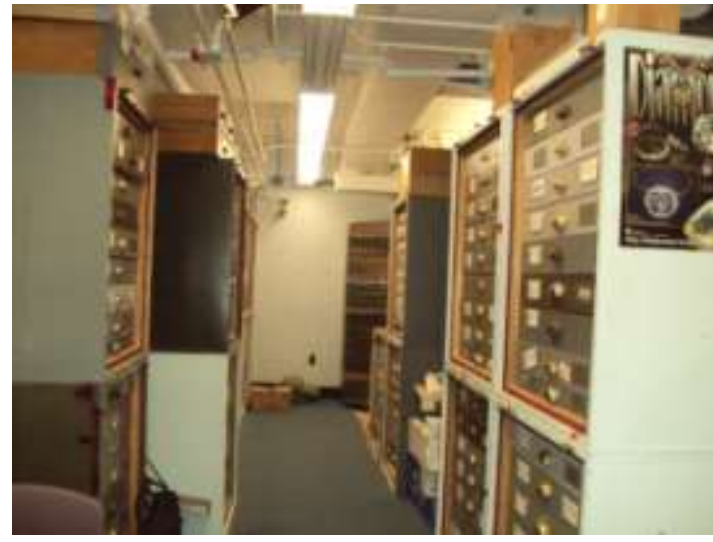

Figura 14. Vista parcial da reserva técnica de minerais no edifício do National Mall. Nota-se os móveis antigos, cujas gavetas não são acopladas, podendo cair ao serem manuseadas sem o devido cuidado.

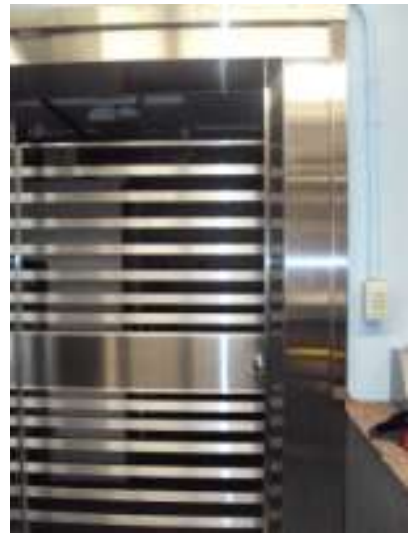

Figura 15. Vista externa do cofre de gemas do NMNH, no edifício do National Mall. A porta abre mediante a digitação do código de acesso e só o funcionário responsável tem acesso ao local.

No MSC estão os materiais que não são solicitados constantemente e os que requerem cuidados especiais, como é o caso das coleções de meteoritos lunares (Figura 16). Na coleção de minerais, minérios e rochas, há cuidados básicos de armazenamento, como bons armários e gaveteiros (Figuras 17 e 18), caixas em tamanho adequado para cada espécime, confeccionadas em papel de PH neutro e forro de etafon (Figura 19) nas gavetas onde há material mais delicado, para evitar que se desloquem durante a abertura das gavetas (Figura 20). Apesar disso, ainda podem ser encontrados minerais asbestiformes cujas fibras estão soltas, guardados sem a devida proteção dentro de caixas que ficam abertas nas gavetas (Figuras 21 e 22). Há também necessidade de armazenamento adequado para amostras de sais, como acondicionamento em ambiente sem umidade, o que evitaria que amostras frágeis sofressem deliquescência (Figura 23). Destaca-se o procedimento utilizado para os testemunhos de sondagem (Figuras 24 e 25). As amostras são recolhidas e já no campo são acomodadas em caixas especiais para esse tipo de material. Quando o lote chega ao MSC, é apenas conferido de acordo com as indicações na parte externa da caixa e já alocado na gaveta de destino, sem necessidade de manusear a amostra. No momento em que for solicitada para análise, é retirada pelo profissional responsável. Esse procedimento evita a superlotação de laboratórios de preparação de amostras, ou espaços de quarentena. 


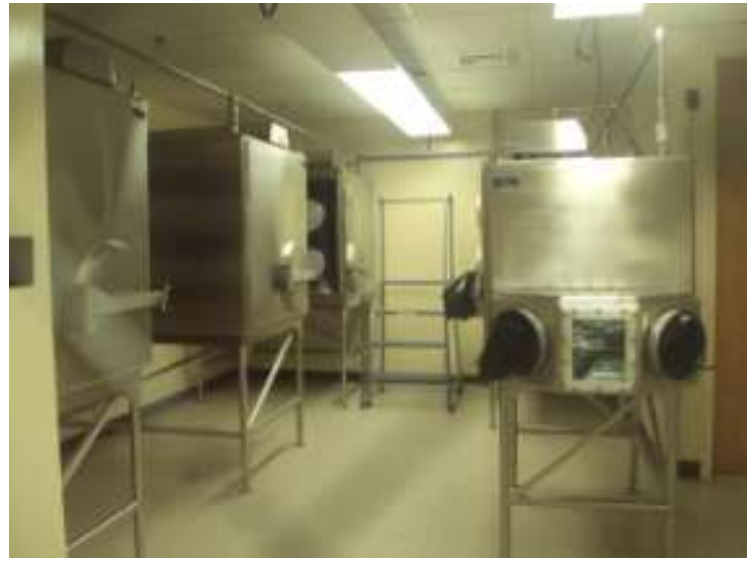

Figura 16. Sala especial para abrigar meteoritos lunares: climatização e controle de umidade, manuseio indireto das amostras por meio de luvas especiais, e amostra não sai da cabine onde está armazenada.

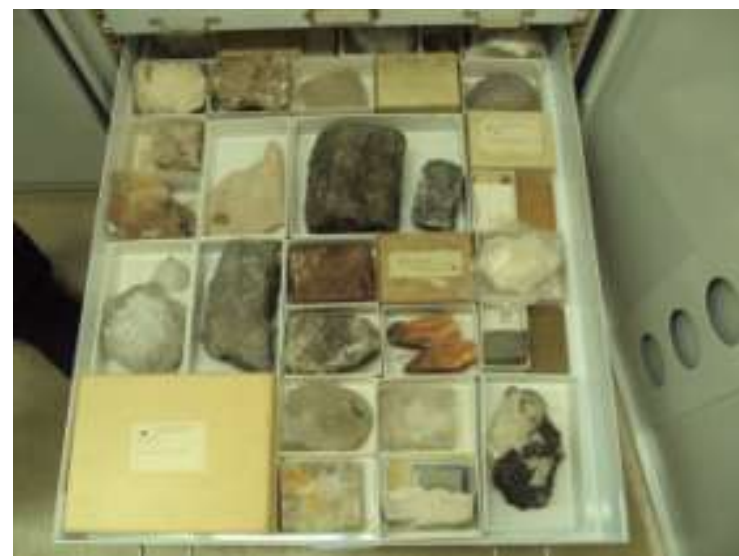

Figura 18. Aspecto dos minerais armazenados no interior das cabines da Figura 17.

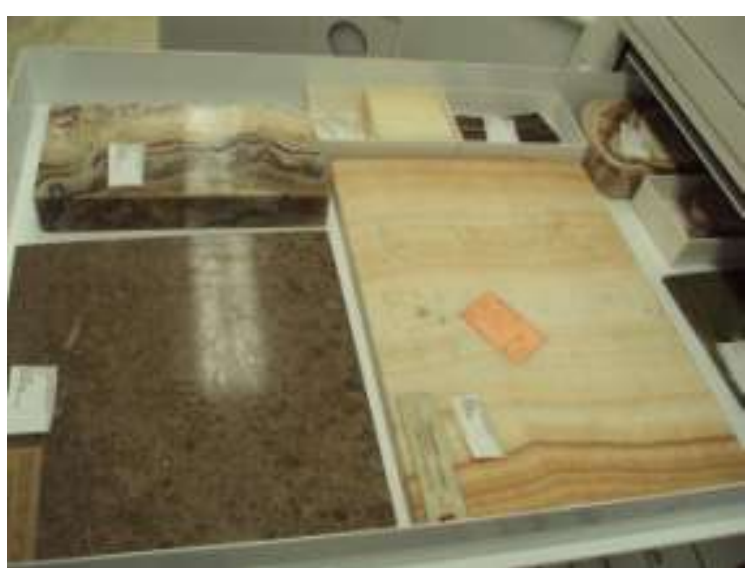

Figura 20. Amostras de rochas ornamentais são fixadas sobre as placas mostradas na Figura 19.

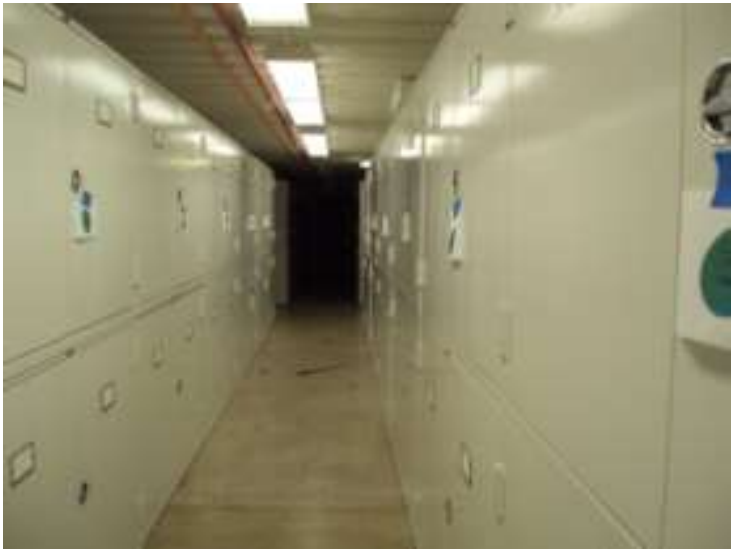

Figura 17. Vista parcial da reserva técnica da coleção de minerais do NMHN no MSC.

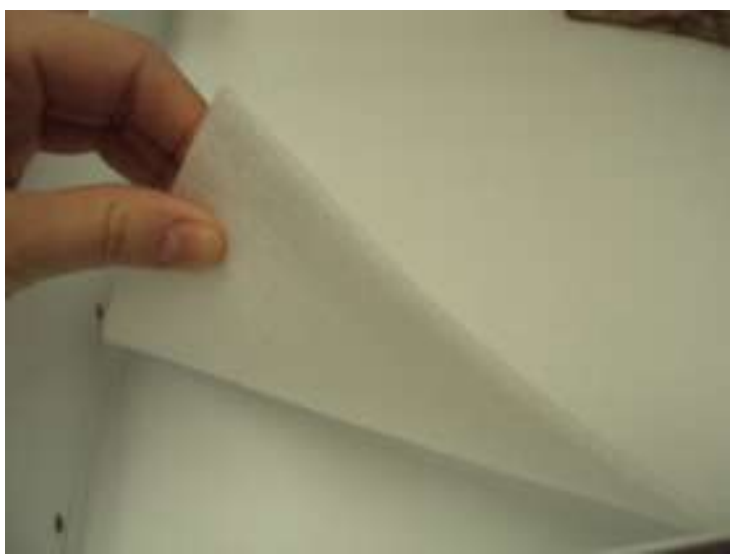

Figura 19. Placa de etafon utilizada para forrar o fundo das gavetas onde são alocados materiais frágeis, a fim de evitar seu deslizamento durante a abertura da gaveta.

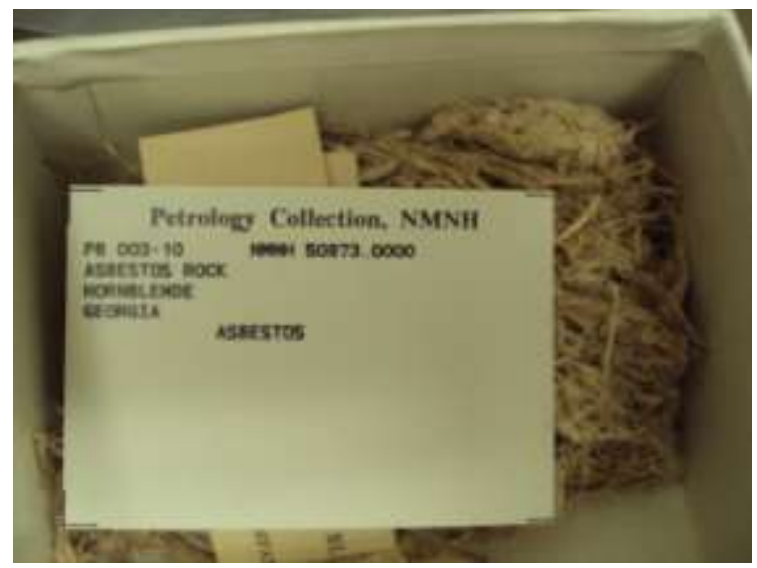

Figura 21. Amostra de mineral asbestiforme com fibras soltas, guardada sem proteção dentro da gaveta. 


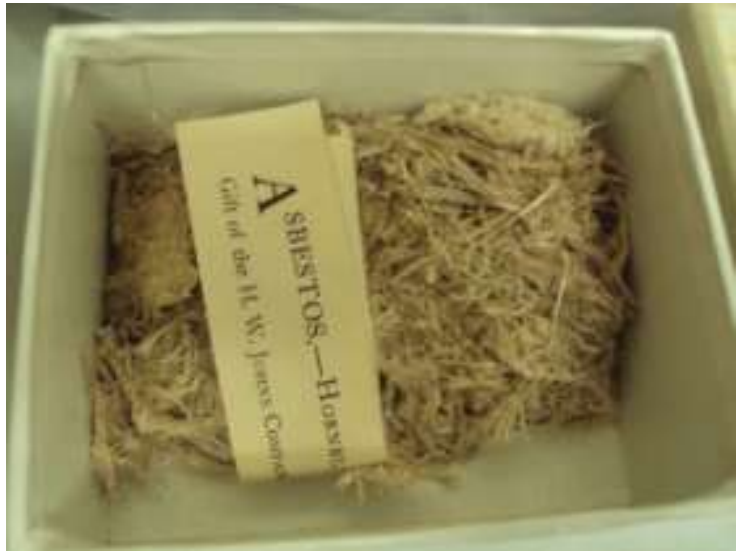

Figura 22. Todas as amostras da reserva técnica preservam a etiqueta original e a atual.

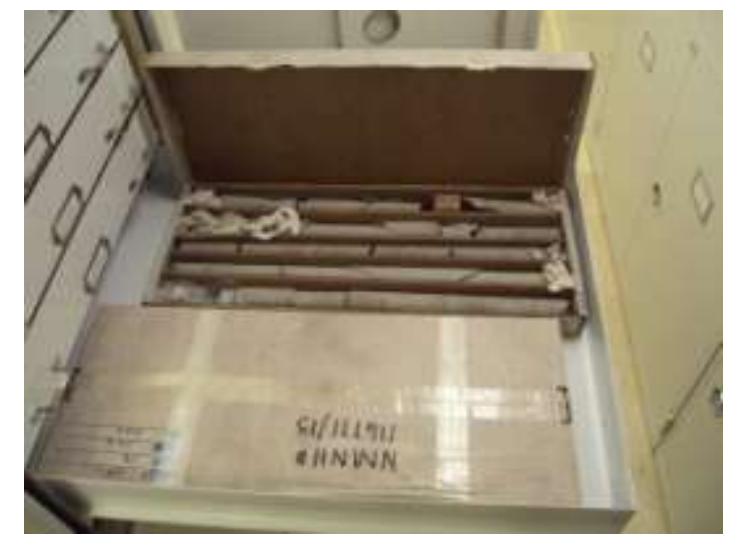

Figura 24. Aspecto de testemunhos de sondagem armazenados no interior de caixas especiais.

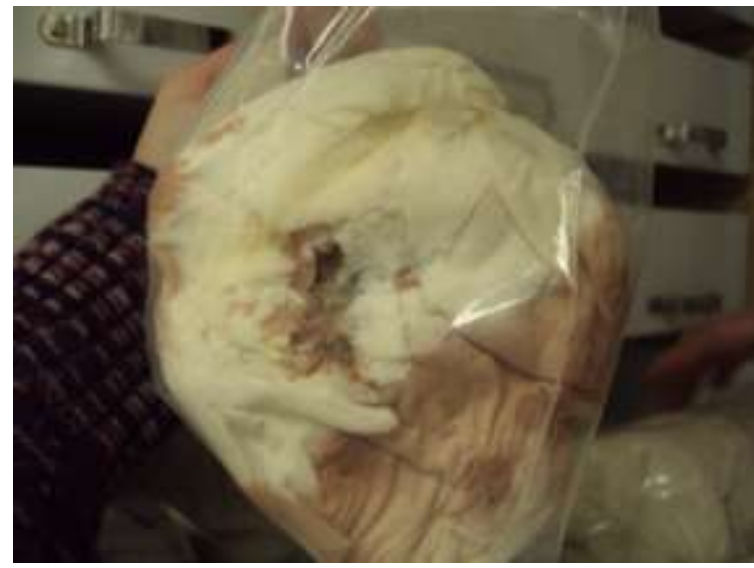

Figura 23. Acondicionamento precário de amostras de sais de nitrato. Não há controle de umidade ou temperatura no local.

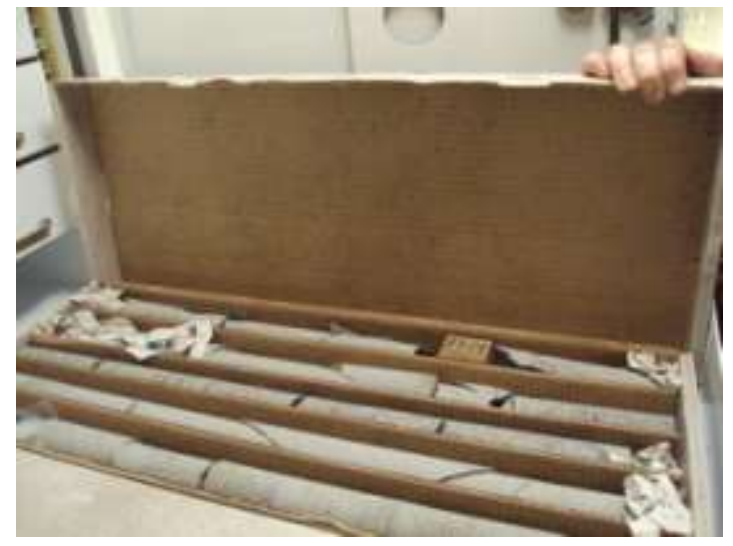

Figura 25. As caixas são trazidas do campo e o material é acondicionado diretamente na estante, sem a necessidade de ser transferido de recipiente.

\subsection{2 - London Natural History Museum - LNHM}

(Londres - Reino Unido)

Inaugurado em 1881, com peças reunidas nos últimos 400 anos por viajantes e colecionadores, o Museu de História Natural de Londres abriga mais de 70 milhões de peças em seu acervo, a maior e mais importante coleção de história natural do mundo.

Sua história remonta ao ano de 1753, quando o físico e colecionador de curiosidades naturais Sir Hans Sloan legou suas raridades à Coroa Britânica. Essa coleção originalmente era parte do acervo do British Museum, porém, com a adição da coleção do botânico Joseph Banks, coletada durante a viagem de 1768 a 1771 com o Capitão James Cook na famosa expedição a bordo do navio HMS Endeavour, a coleção necessitou de um espaço próprio só para a História Natural.

Sir Richard Owen, superintendente da coleção de história natural do Museu Britânico, persuadiu o governo de que um edifício novo era necessário. O edifício atual, erguido para ser utilizado na Exposição Internacional de 1862 e depois sem utilidade, foi o escolhido para 
abrigar o acervo. Uma curiosidade deste edifício é que a fachada, que à primeira vista parece ser de pedra, foi a primeira construção da Inglaterra cuja fachada foi feita de terracota.

A coleção de mineralogia complementou o acervo de história natural, que começou a ocupar o espaço atual em 1883. No entanto, foi somente em 1963 que a coleção passou a ser formalmente de propriedade do Museu de História Natural.

Suas exposições são direcionadas de forma a mostrar a Terra e a vida na Terra. Seu acervo é dividido em cinco grandes áreas de pesquisa, sendo elas: entomologia, botânica, paleontologia, mineralogia e zoologia.

O Museu tem hoje sua exposição permanente dividida em quatro partes, cada uma representada por uma cor, para que o visitante as identifique mais facilmente.

1 - Zona Laranja: inclui a entrada, o Jardim da Vida Selvagem, a parte de zoologia e o Attenborough Studio;

2 - Zona Azul: compreende a exposição paleontológica, dinossauros, peixes, anfíbios e répteis, biologia humana, imagens da natureza, uma área para exposições temporárias (Jerwood Gallery), invertebrados marinhos e mamíferos;

3 - Zona Verde: inclui botânica mesclada à vida animal selvagem: sequoia gigante, árvores, primatas, pássaros, ecologia, fósseis de répteis marinhos, centro de investigações. É na zona verde que está inserido o objeto de estudo deste trabalho, os minerais.

4 - Zona Vermelha: é nesta zona que o visitante irá encontrar a maior parte dos assuntos referentes às Geociências, como o Laboratório da Terra, exposições permanentes sobre a evolução do planeta, fósseis recentes de invertebrados, a geologia e geografia do planeta. Esse acervo formava o Museu Geológico, no The Geological Survey e foi incorporado ao LNHM em 1985.

O acervo geológico do museu é formado por 9 milhões de fósseis, 550 mil exemplares entre rochas e minerais e 3.200 meteoritos.

O museu é aberto ao público de todas as faixas etárias, com programas escolares direcionados e laboratórios interativos para descobertas individuais.

Devido ao seu grande espaço expositivo, o museu tem capacidade para abrigar exposições clássicas e modernas. A curadoria optou por mesclar a exposição mineralógica original (Figura 26) à exposição de minerais em moldes modernos (Figura 27). 


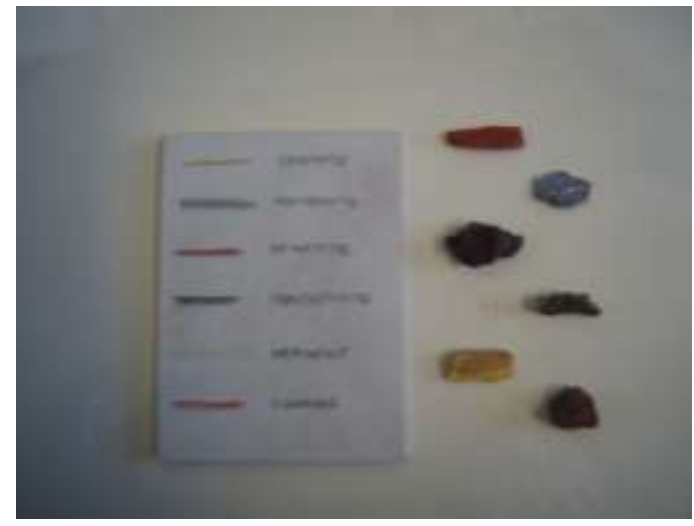

Figura 26. A cor do traço, uma das características mais importantes do mineral, é mostrada de forma simples na exposição clássica de minerais no LNHM.

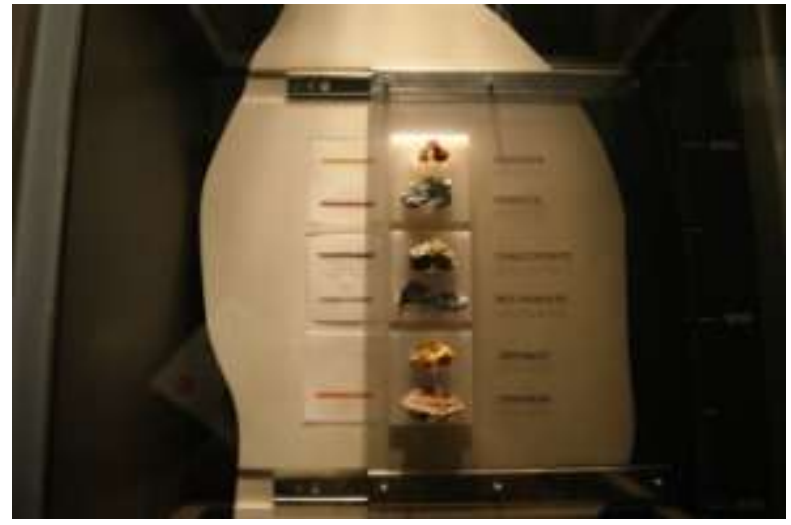

Figura 27. No mesmo museu, porém em outro espaço expositivo, a cor do traço é mostrada ao público leigo de maneira moderna e interativa, permitindo a compreensão de um conceito básico de identificação mineral sem o apelo científico.

A exposição clássica de mineralogia, assim como no Museu de Geociências da USP, segue uma disposição científica, de acordo com a classificação química. A exibição permanece inalterada desde sua inauguração, em 1883, dando ao visitante uma sensação de volta ao passado (por isso mesmo, a chamada para a exposição tem o slogan step back in time). O pensamento científico atrelado à doutrina positivista é o grande norteador dessa exposição. Há todo o tipo de minerais, em suas variedades de cor, hábito e estrutura cristalina. Por ser uma exposição concebida em outro contexto museológico, predomina o caráter expositivo, com etiquetas explicativas em termos científicos. É possível observar que essa exposição, em comparação com a outra mostra de minerais, recebe bem menos visitantes. Os visitantes dessa exposição são, em sua maior parte, fotógrafos de minerais, cientistas e pesquisadores da área.

Pode-se dizer que a preocupação com a conservação não é o fundamental nessa exposição. Talvez pela fidelidade à questão temporal, a arquitetura da sala deixa as amostras expostas à luz solar (Figura 28), sem preocupação com filtros de raios UV, vidros filmados ou outros recursos. Existem partes da vitrina em que não é possível enxergar o mineral devido ao reflexo da luz.

Já a outra sala de exibição de minerais, ao lado da sala de exibições descrita acima, tem uma atmosfera totalmente diferente. Os minerais estão expostos não horizontalmente, como na coleção científica, mas em vitrinas verticais que possibilitam uma melhor apreciação da amostra (Figura 29). Luzes direcionadas são utilizadas para melhor visualização, destacando cores e formas. As amostras têm suportes especiais (como algumas encontradas no Museu de Geociências da USP) que realçam o que se pretende mostrar. Além disso, características físicas que definem um mineral como, transparência, cor do traço, dureza e 
classificação relativa da escala de Mohs são mostradas de forma prática e mais moderna que na exposição clássica (Figuras 30 e 31), a ponto de que o visitante leigo em mineralogia também possa compreender e saber o que apreciar em um mineral.

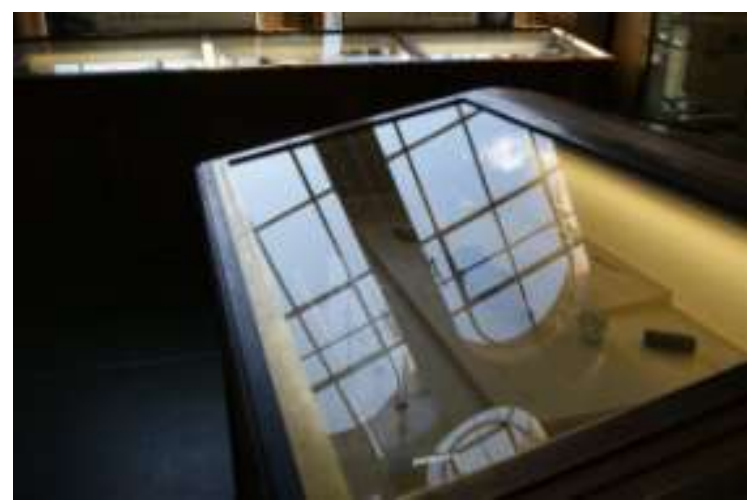

Figura 28. A luz natural na exposição clássica de minerais no LNHM atrapalha a apreciação do visitante.

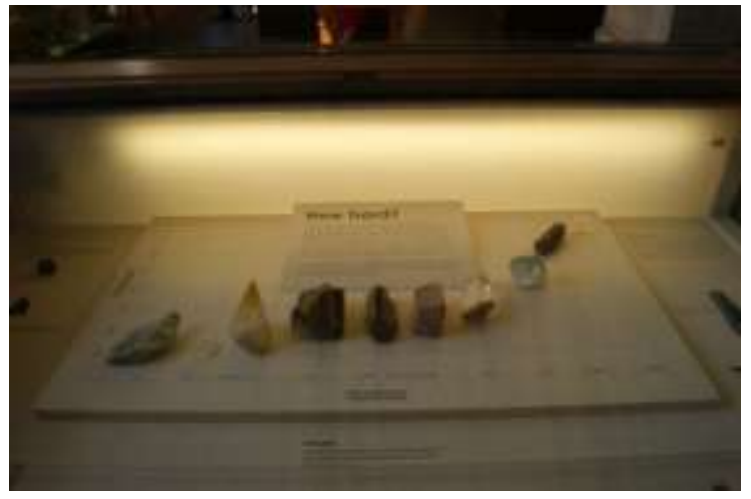

Figura 30. Escala de dureza relativa de Mohs mostrada na exposição clássica do LNHM.

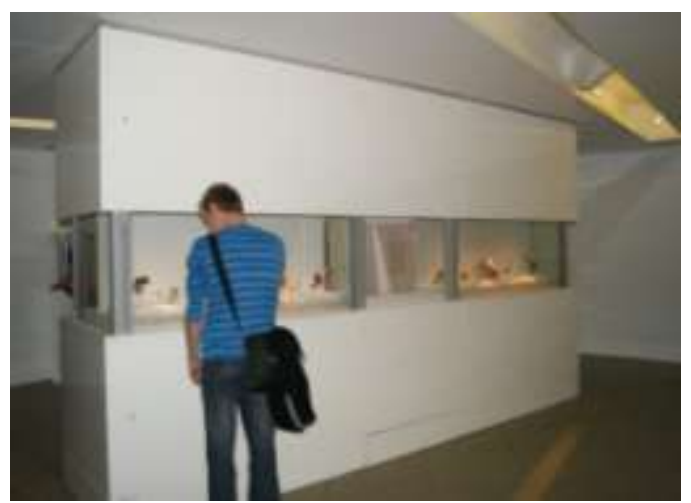

Figura 29. Exposição moderna de minerais no LNHM. A exposição está em uma altura acessivel e a ausência de iluminação externa, mesclada a uma iluminação individual e direcionada para cada amostra, valorizam o mineral e proporcionam uma boa visão para o visitante.

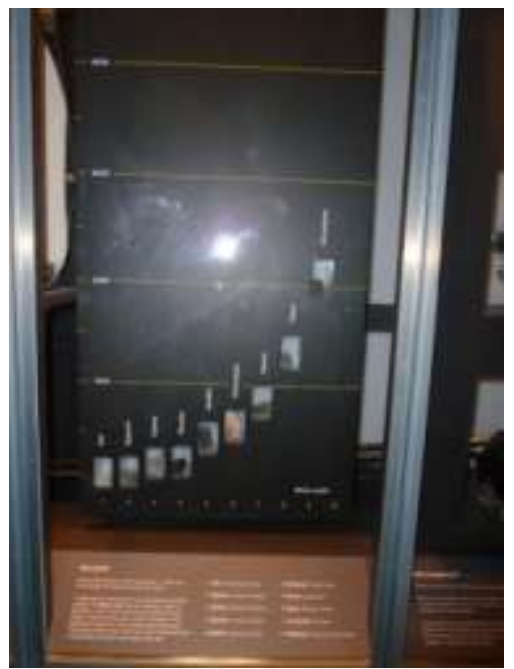

Figura 31. Outra forma de exibição da escala de dureza relativa de Mohs, LNHM.

Um detalhe importante são as áreas de descanso (Figuras 32 e 33). O tempo de concentração de um adulto em uma exposição é de cerca de quinze minutos. As áreas de descanso são, por isso, essenciais, uma vez que, se elas não existem, o visitante se cansa e vai embora sem ter visto toda a exposição. O Museu de Geociências da USP ainda não possui tais áreas. 


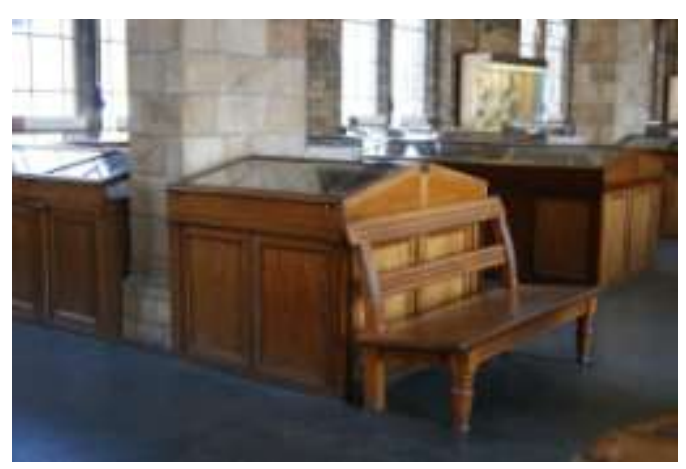

Figura 32. Banco para descanso na exposição clássica de minerais do LNHM.

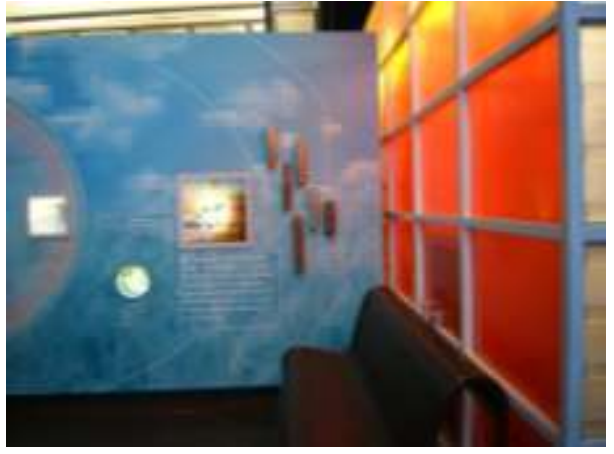

Figura 33. Área de descanso na exposição geológica do LNHM.

Cabe ressaltar aqui que a atual configuração da exposição de minerais do Museu de Geociências da USP está em torno de $90 \%$ próxima ao que foi uma exposição do século XIX.

\subsection{3 - Oxford University Natural History Museum (Universidade de Oxford)}

(Oxford - Reino Unido)

A Universidade de Oxford teve a honra de abrigar o primeiro museu europeu construído para esse fim: The Ashmolean Museum (Figura 34).

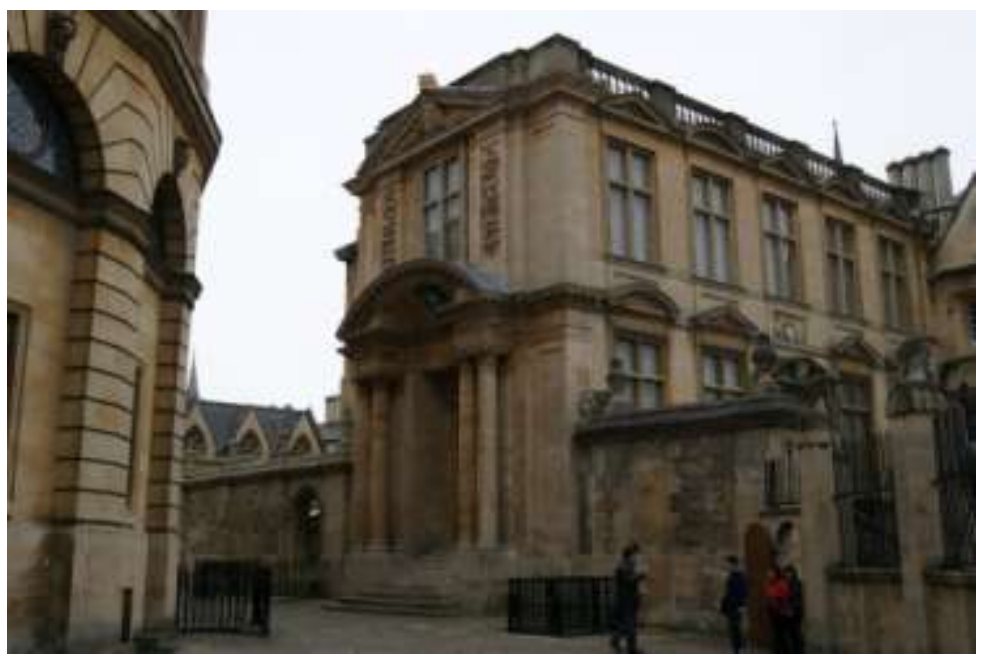

Figura 34. Edifício original do Ashmolean Museum, onde atualmente está situado o Museu de Ciência e Técnica da Universidade de Oxford.

Atualmente a coleção geológica do Museu de História Natural da Universidade de Oxford abriga 30 mil espécimes de minerais de diferentes localidades do mundo, além de coleções de gemas, meteoritos, instrumentos para técnicas de estudo mineralógicas, e um importante arquivo de correspondências e notas de pesquisa. Desde 1998 a equipe responsável pela coleção de minerais está também responsável pela coleção petrológica, que compreende 50 mil exemplares.

Os destaques da coleção geológica são: a coleção de pedras ornamentais de Faustino Corsi adquirida em 1827; as coleções históricas de Willian Buckland e sua esposa Mary 
Morland, John MacCulloch e Charles Daubeny; a coleção sistemática de minerais dos químicos Sir Henry Enfield e Dr. Hugo Müller e minerais britânicos coletados entre 1970 e 80 por Morrison Thomas. Dentre essas coleções merece destaque a Coleção Corsi, recém disponibilizada integralmente na internet (http://www.oum.ox.ac.uk/corsi/about/oxford). Acessando o site do Museu, há um link para a coleção, no qual o internauta pode ler sobre a história da coleção, descobrir curiosidades e entrar na coleção virtual. O pesquisador pode escolher dentre todas as miniaturas das amostras e clicar na amostra de seu interesse. Toda a ficha catalográfica da amostra, bem como sua imagem em tamanho maior é disponibilizada para consulta. As Figuras 35 e 36 mostram o acesso online à Coleção Corsi.

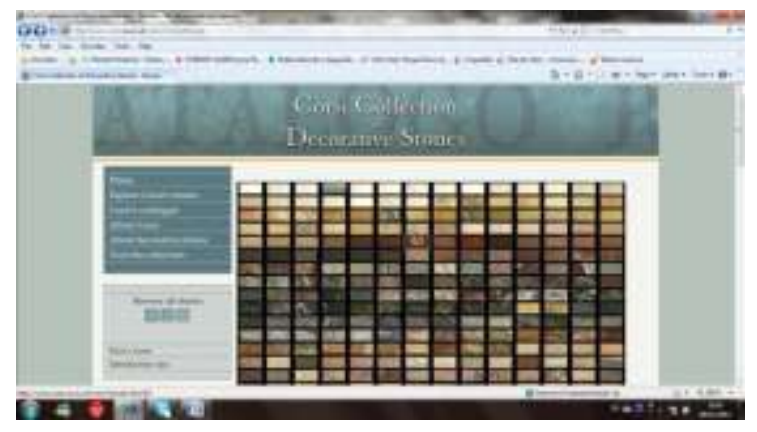

Figura 35. Miniaturas de todas as amostras da coleção; o número de cada uma aparece assim que o mouse é colocado sobre a mesma. Nota-se a amostra $n^{o} 63$ em destaque.

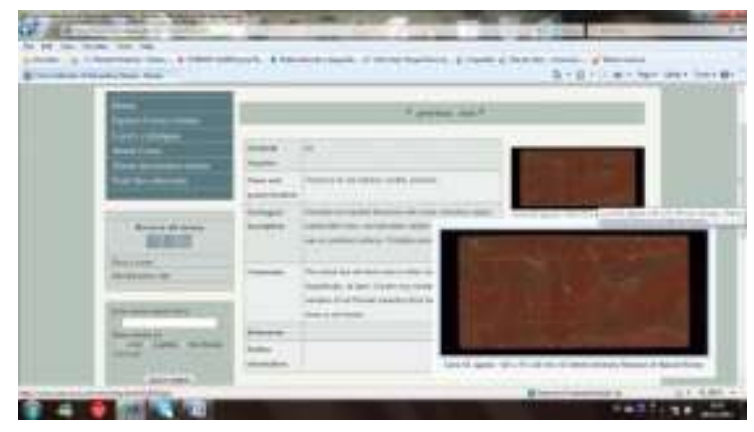

Figura 36. Ao passar o mouse sobre a imagem, o pesquisador pode vê-la em tamanho ampliado e decidir se quer abri-la ou não.

É importante ressaltar que a equipe responsável pela coleção geológica mantém uma política de aquisição ativa, o que contribui para que as exposições possam ser constantemente renovadas, atraindo público. O mesmo não ocorre com o Museu de Geociências da USP.

Quanto à organização expositiva, o MHN da Universidade de Oxford lembra um grande Gabinete de Curiosidades do século XVII (Figura 37). Em um mesmo saguão estão dispostos exemplares de animais empalhados, rochas, fósseis, minerais e rochas lunares (Figura 38). Não há um delineamento para os visitantes, tampouco sugestão de roteiro de visitação. O mesmo ocorre com o Museu de Geociências da USP. O visitante sente-se desorientado num espaço tão grande e cheio de objetos. 


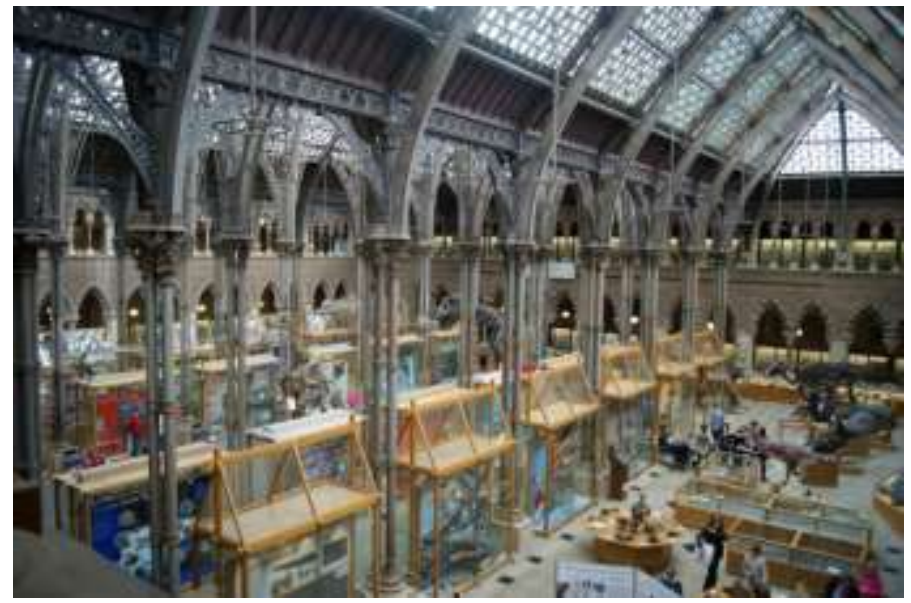

Figura 37. Aspecto geral do espaço expositivo do Museu de História Natural da Universidade de Oxford. A organização da exposição lembra um gabinete de curiosidades do século XVII.

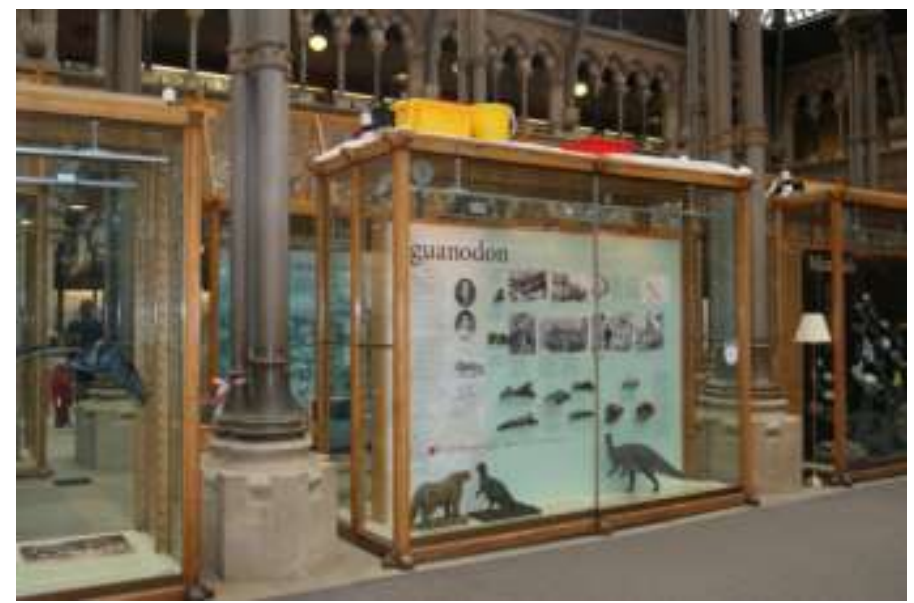

Figura 38. Exposição de paleontologia ao lado da exposição de minerais. Mistura de assuntos deixa o visitante desorientado. Nota-se também a falta de preocupação com a conservação do acervo pela presença de goteiras que caem sobre as vitrinas.

\subsection{4 - Museum für Naturkunde Berlin}

(Berlim - Alemanha)

O Museu de História Natural de Berlim possui uma grande coleção de minerais, dos quais muitos estão expostos de acordo com a classificação de Strunz de maneira científica.

A exposição mineralógica, de caráter clássico, não é atrativa ao público leigo, pois se caracteriza por uma exposição científica, em mobiliário antigo, sem recursos que chamem a atenção do público geral (Figura 39). Perfeita para pesquisadores da área.

Não há cuidados de conservação na exposição e nem na reserva técnica. Ambos os ambientes recebem iluminação natural. A exposição também não é acessível, uma vez que as vitrinas são muito altas (Figura 40).

Já no que concerne aos meteoritos, a reserva técnica possui armários de vidro climatizados e desumidificados com sílica gel para as amostras metálicas. A temperatura e a UR são visualizadas por fora do armário, a UR variando sempre entre 30 e $50 \%$. 
A reserva técnica de minerais está organizada nos mesmos mobiliários da exposição, disposta de acordo com a classificação Strunz e pode ser entendida como uma exposição que não é aberta ao público, uma vez que as vitrinas permitem a visualização dos minerais da mesma maneira que a exposição (Figuras 41 e 42).

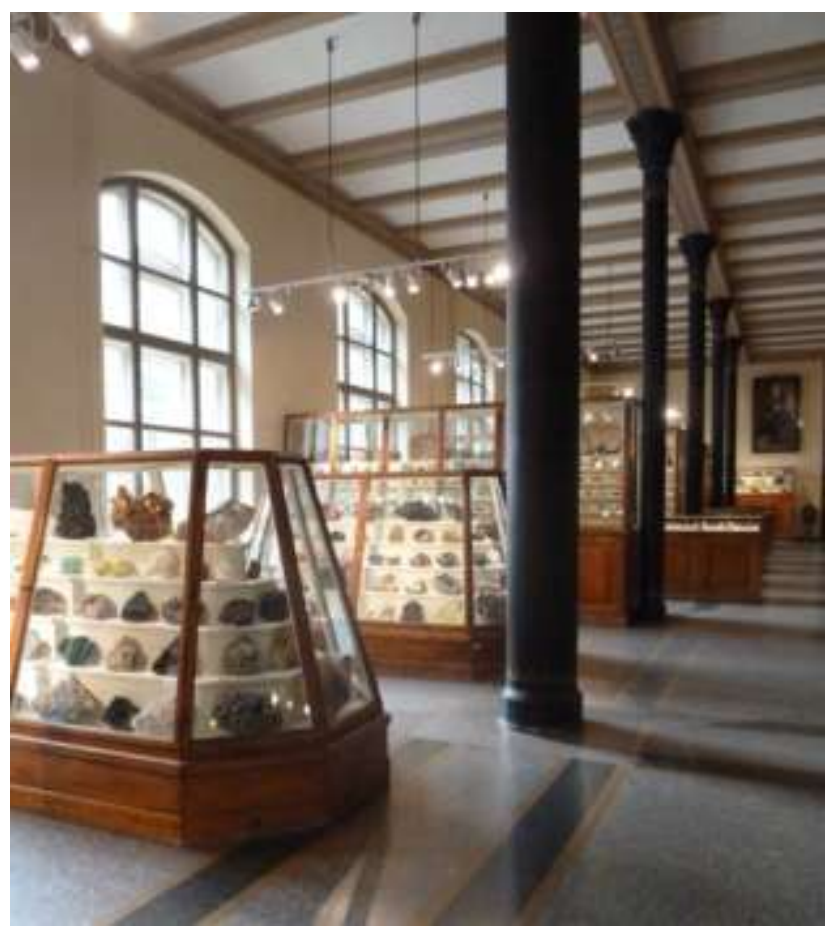

Figura 39. Vista geral da exposição de mineralogia. Foto: Eliane A. Del Lama.

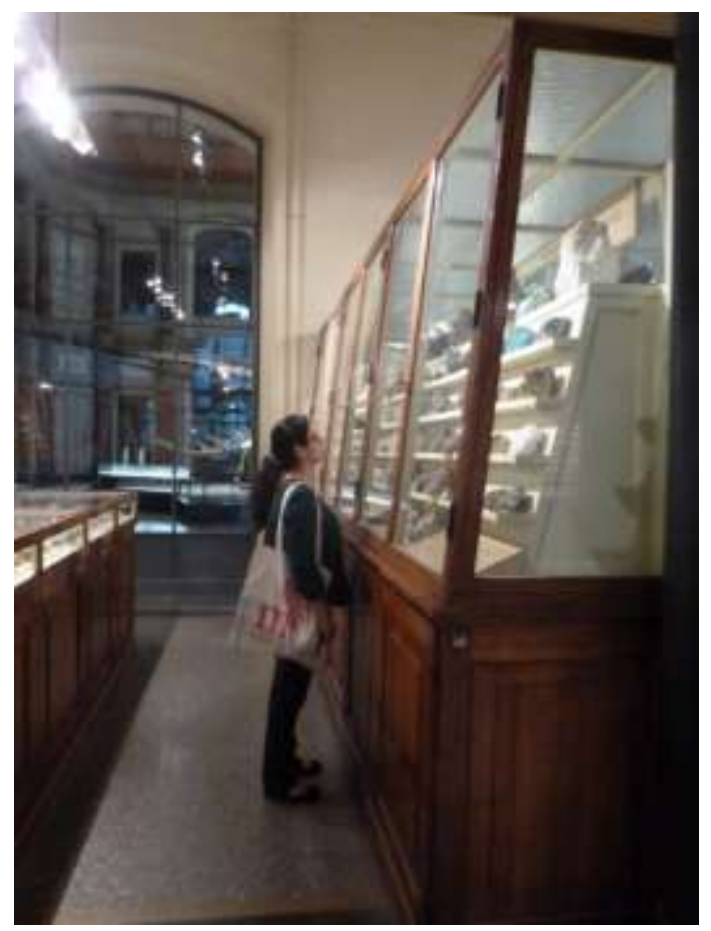

Figura 40. Exposição inacessível a cadeirantes e pessoas de baixa estatura. Foto: Eliane A. Del Lama. 


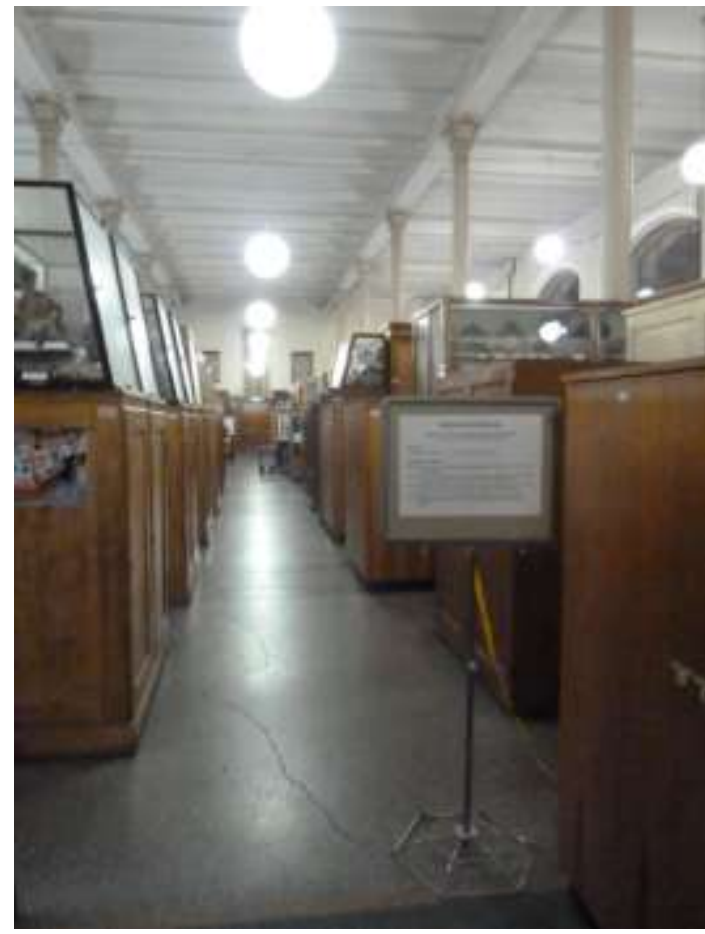

Figura 41. Vista geral da reserva técnica de minerais. Foto: Eliane A. Del Lama.

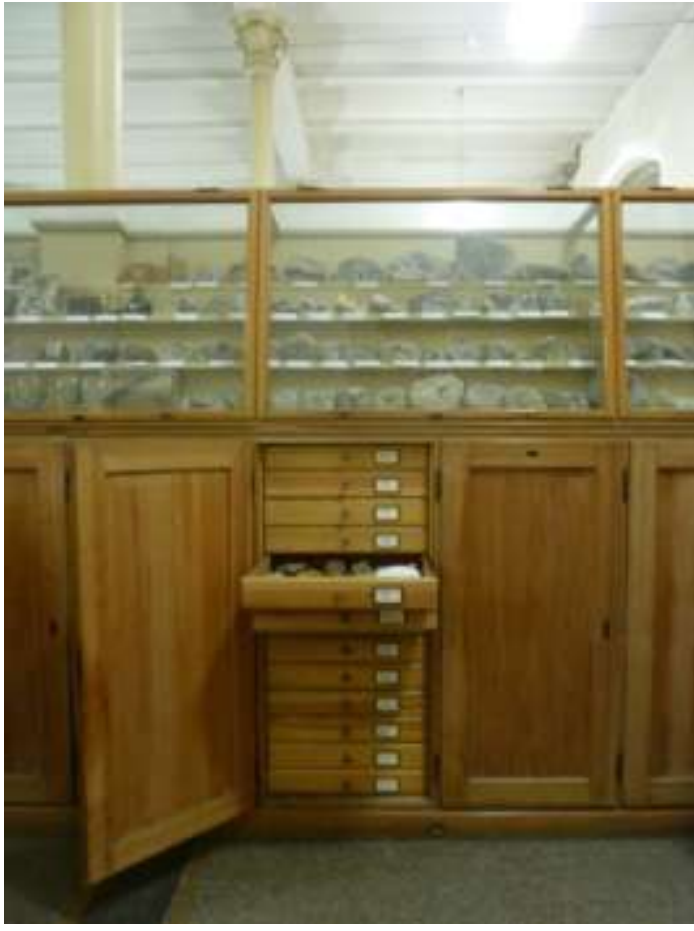

Figura 42. Detalhe do acondicionamento de amostras no interior dos armários da reserva técnica. Nota-se o mesmo mobiliário da Figura 40. Foto: Eliane A. Del Lama.

\subsection{5 - Museu de Mineralogia Prof. Heinz Ebert}

(Curso de Geologia da UNESP - Rio Claro, SP)

O Museu Professor Heinz Ebert teve sua origem atrelada à criação do curso de Geologia na Faculdade de Filosofia, Ciências e Letras de Rio Claro, no início da década de 1970. No ano de 1976, foi criado oficialmente como Museu Didático de Minerais, Minérios e Rochas Prof. Heinz Ebert.

$\mathrm{O}$ acervo que deu origem a esse museu foi proveniente da coleção pessoal do professor Heinz Ebert, que colecionou minerais, rochas e seções delgadas e polidas desde os anos 1950. Ao tornar-se professor da Faculdade de Filosofia, Ciências e Letras de Rio Claro, em 1962, o professor empenhou-se na formalização de um acervo didático. Ao conseguir, doou sua coleção para iniciar o museu, posteriormente enriquecido com outras doações. A feição atual data do ano 2000, quando foi realizada uma reestruturação, com o auxílio da FAPESP - Fundação de Amparo à Pesquisa do Estado de São Paulo (Figura 43). 


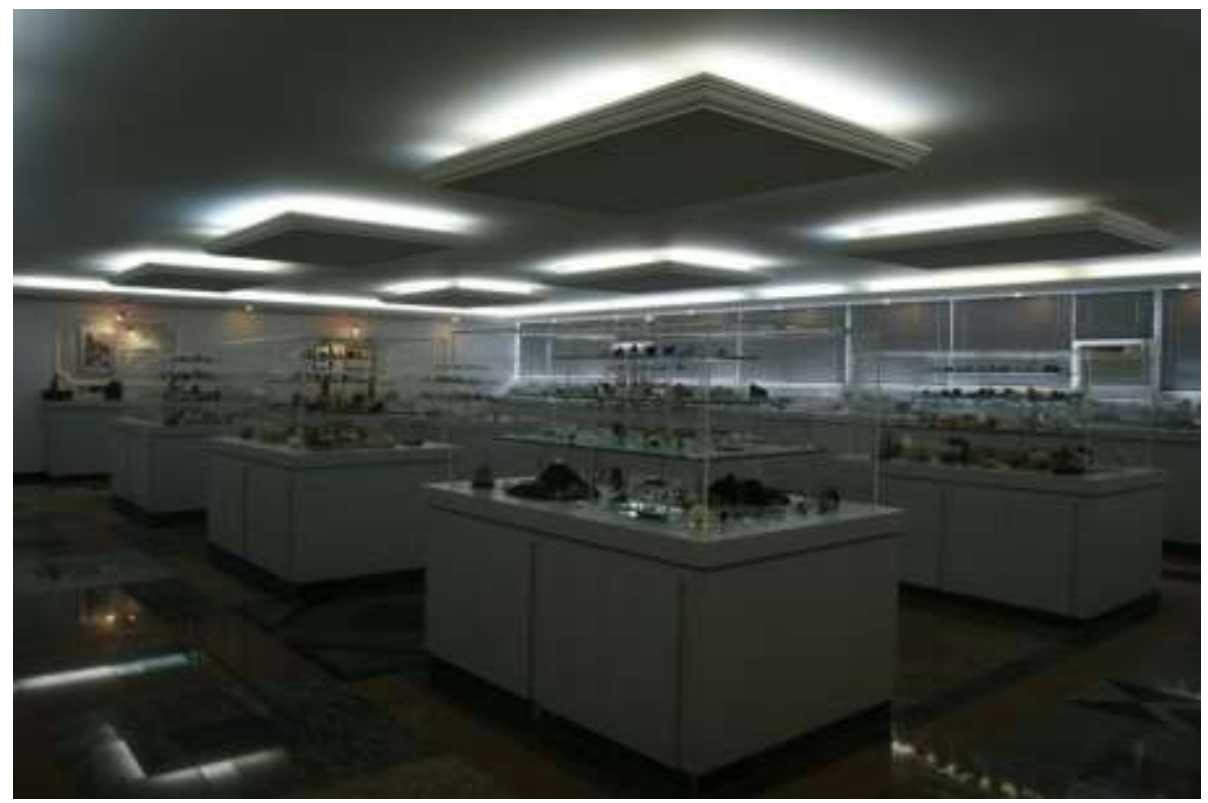

Figura 43. Vista geral do espaço expositivo do Museu Heinz Ebert.

O museu possui dois espaços expositivos: o salão de exposição, com $140 \mathrm{~m}^{2}$ e 5.600 amostras expostas; e o saguão do prédio, com algumas vitrinas antigas acomodadas ao longo dos corredores próximos ao museu.

O museu não é aberto à visitação pública, salvo algumas escolas locais que agendam visitas esporádicas. Isso ocorre devido à ausência de técnicos responsáveis pelo acervo. Como comparação, o Museu de Geociências da USP possui dois técnicos com a função de cuidar do acervo e um geólogo para gerir o museu, enquanto o Museu de Mineralogia da UNESP, possui um técnico, responsável pelo preparo das atividades didáticas de aula, laboratório didático, museu (organização, abertura a escolas e manutenção). Por isso, o funcionamento do museu é voltado para a comunidade acadêmica, atendendo pesquisadores e principalmente alunos de graduação do curso de Geologia da UNESP.

Quando o público alvo considerado são graduandos de Geologia, o espaço atende às necessidades dos visitantes. No entanto, quando se considera qualquer outro tipo de público alvo, a organização do espaço expositivo é menos eficaz. Não há quaisquer sinalizações indicando o tipo de divisão temática das vitrinas e qual orientação o visitante deve seguir para melhor compreender a exposição.

O mobiliário expositivo consiste em vitrinas de madeira e acrílico, vedadas e parafusadas. Se por um lado essas vitrinas não permitem rotatividade das amostras expostas, por outro são melhores na conservação dos minerais, que são mantidos por um período mais longo ao abrigo da poeira, necessitando ser manipulados menos vezes. Uma solução interessante para que os visitantes possam ver outros exemplares, foi a colocação de portas com gavetas nos armários embaixo das vitrinas (Figuras 44 a 47). Essa adaptação da mobília 
permite que alunos e pesquisadores manipulem minerais previamente selecionados para esse fim, além de servir como possível abrigo para amostras excedentes, que podem sair das vitrinas, mas continuar ao alcance do pesquisador. Esse é um recurso inteligente quando se dispõe de orçamento limitado: o mobiliário é ao mesmo tempo visualmente atraente e funcional, resolvendo em parte o problema de espaço para a reserva técnica, especialmente se o acervo possuir poucos exemplares. O mesmo recurso é utilizado na Coleção de Mineralogia da Universidade Técnica de Berlim.

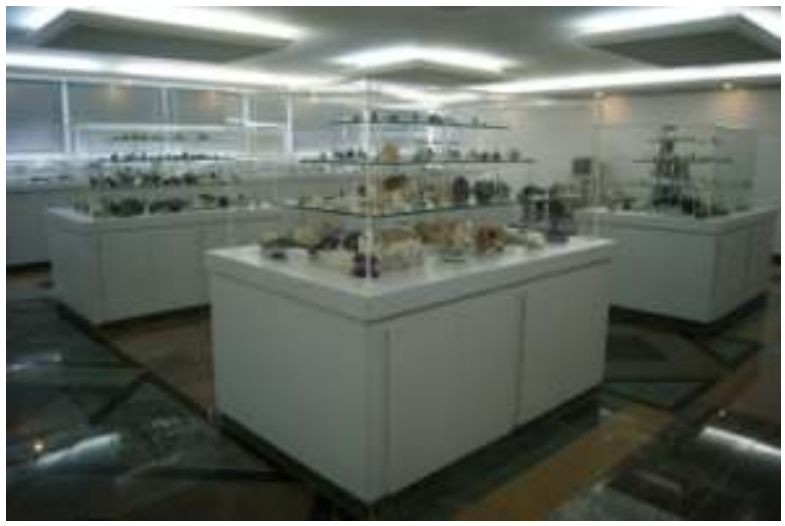

Figura 44. Mobiliário utilizado ao mesmo tempo como vitrina e como armário de reserva técnica. Bonito e funcional.

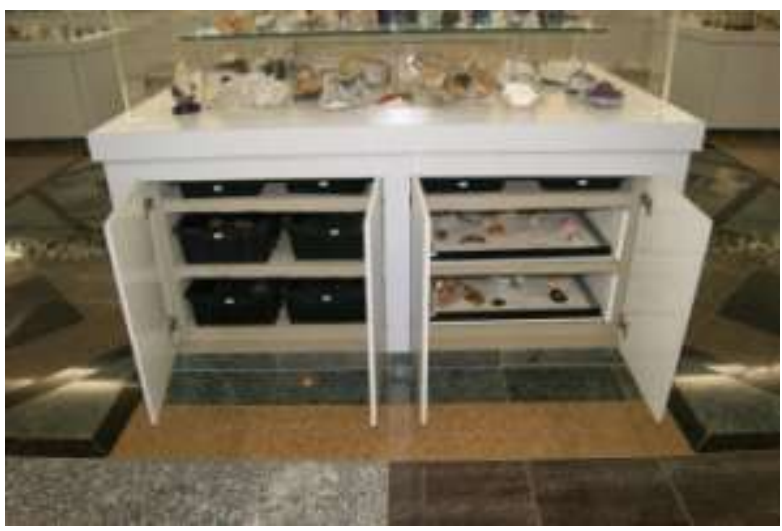

Figura 46. Detalhe da disposição dos materiais dentro do armário.

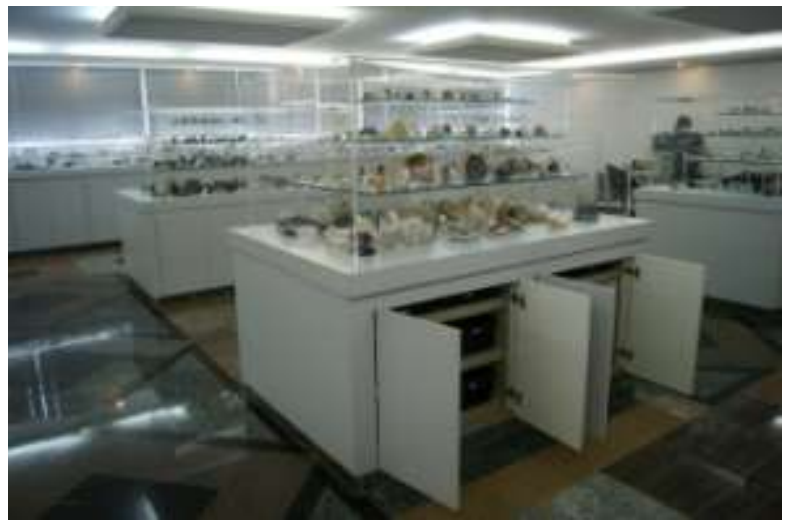

Figura 45. Parte inferior das vitrinas são armários que podem ser abertos para o pesquisador utilizar minerais não expostos.

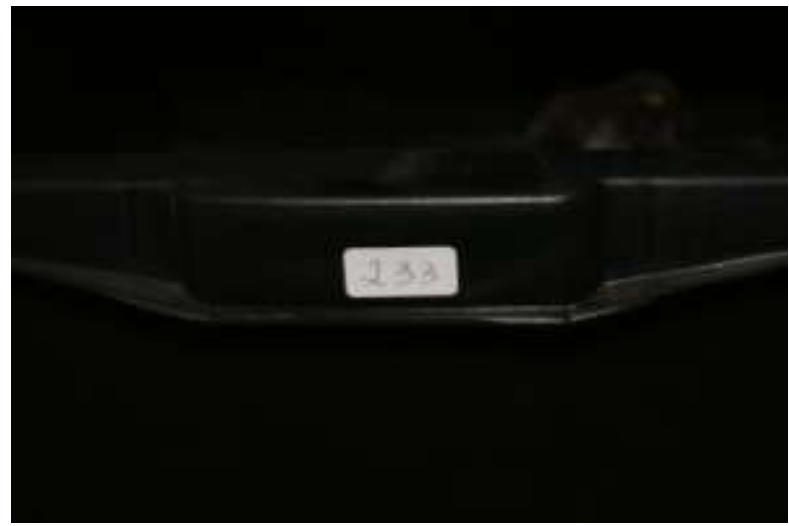

Figura 47. Detalhe da numeração das bandejas, a fim de colaborar na organização do acervo.

Assim como no Museu de Geociências da USP, há muitos minerais da mesma espécie em uma só vitrina, tornando o ambiente visualmente poluído.

Os minerais radioativos não recebem nenhum tratamento diferenciado, tanto na exposição quanto na conservação. Os minerais estão expostos no saguão do departamento, sem proteção especial. As amostras da reserva técnica também não possuem tratamento diferenciado, como o acondicionamento em embalagens vedadas ou separadas de outros minerais. 
Por outro lado, o museu possui um contador geiger com o objetivo de medir regularmente o nível de radiação emitido pela amostra, fator positivo na conservação das amostras e proteção dos trabalhadores e visitantes do museu, o que não ocorre no Museu de Geociências da USP.

\subsection{6 - Museu Nacional}

(Universidade Federal do Rio de Janeiro - Rio de Janeiro, RJ)

A origem do Museu Nacional remonta ao antigo Museu Real, criado por decreto do Rei Dom João VI, em 1818, e que abrigava uma grande coleção de história natural, com animais empalhados, minerais e rochas e a parte etnográfica, com objetos de arte e artefatos indígenas. Em 1824 o espaço foi rebatizado de Museu Imperial e em 1828 o acervo mineralógico foi transferido para a Academia Militar.

O destaque da exposição está na coleção de meteoritos, que inclui o maior meteorito encontrado no Brasil, o Bendegó (Figura 48). Há uma sala pequena, com alguns exemplares de rochas, e uma importante coleção paleontológica. A coleção de mineralogia, que inclui exemplares de minerais de José Bonifácio de Andrada e Silva, permanece em reserva técnica.

A coleção de rochas possui enfoque didático, próprio para alunos dos ensinos fundamental e médio (Figura 49). A exposição paleontológica é a mais bem organizada, com cuidados básicos de conservação (Figuras 50, 51 e 52) e layout moderno (Figura 53). Apesar de ser uma seção de imenso valor científico, a exposição de meteoritos está acondicionada em condições precárias, em mobiliário antigo e inadequado e sem cuidados de conservação (Figuras 54 e 55). O meteorito Bendegó, assim como o Itapuranga no Museu de Geociências da USP, encontra-se na entrada do Museu, sem nenhum tipo de proteção, à mercê da umidade e das variações térmicas. 


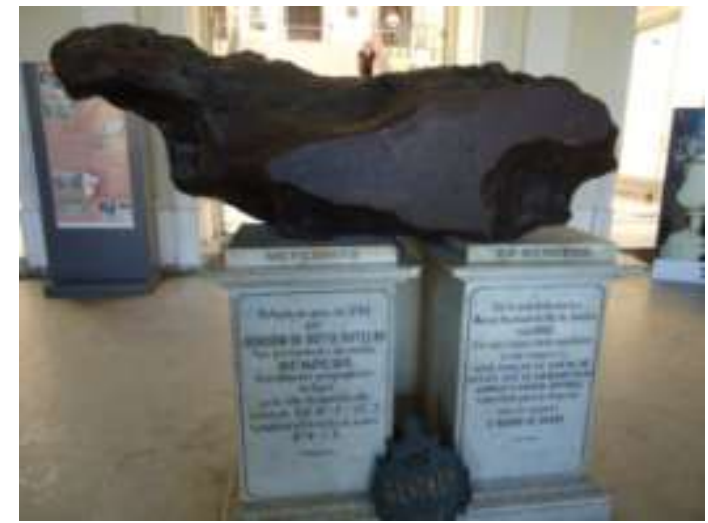

Figura 48. Meteorito Bendegó na entrada do Museu: iluminação direta e suscetibilidade a flutuações de temperatura e UR.

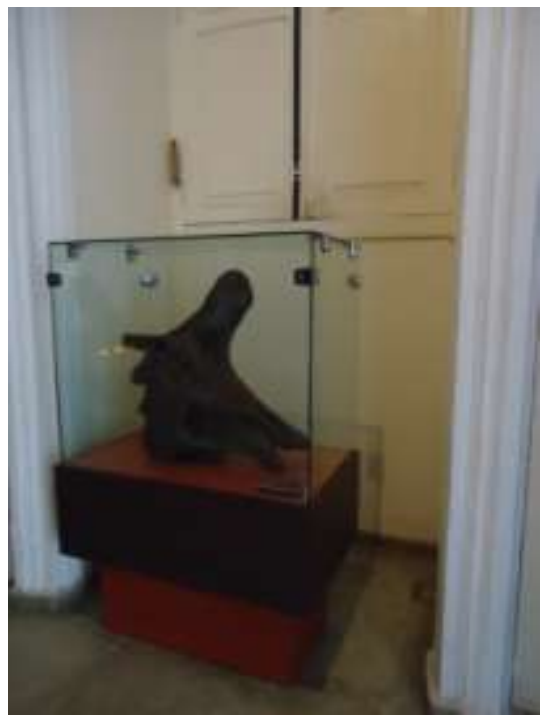

Figura 50. Detalhe da janela fechada, para evitar iluminação natural no fóssil.

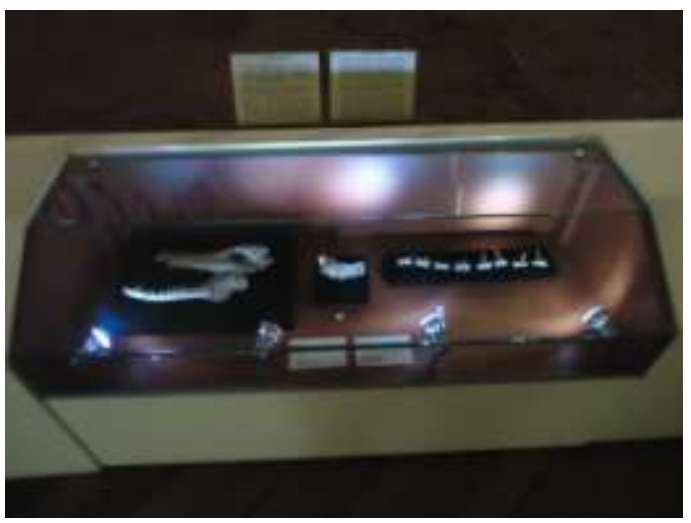

Figura 52. Fóssil exposto em cabine preparada para evitar contato com o ambiente e luzes direcionadas

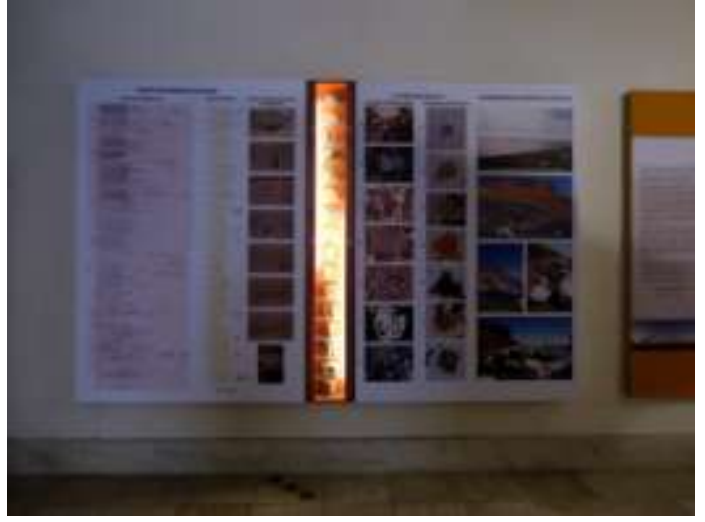

Figura 49. Exposição petrológica voltada para alunos dos ensinos fundamental e médio.

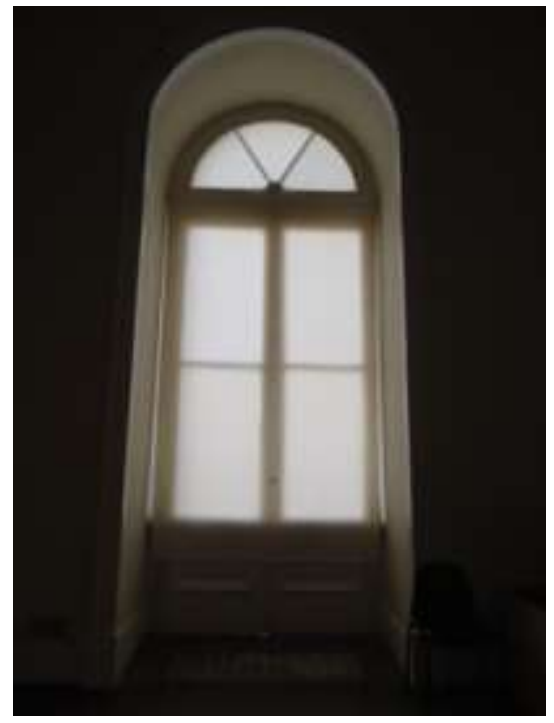

Figura 51. Detalhe da janela com cortinas especiais para diluir a iluminação natural.

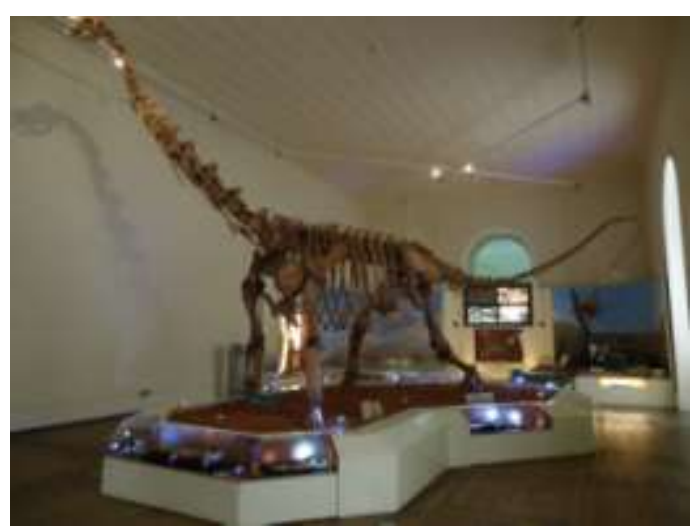

Figura 53. Vista geral de parte da exposição paleontológica: layout moderno. 


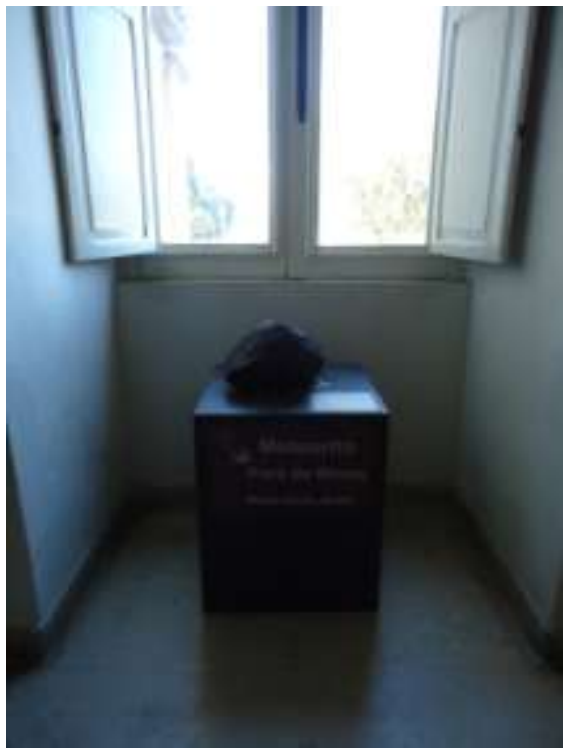

Figura 54. Detalhe da janela aberta sobre meteorito exposto.

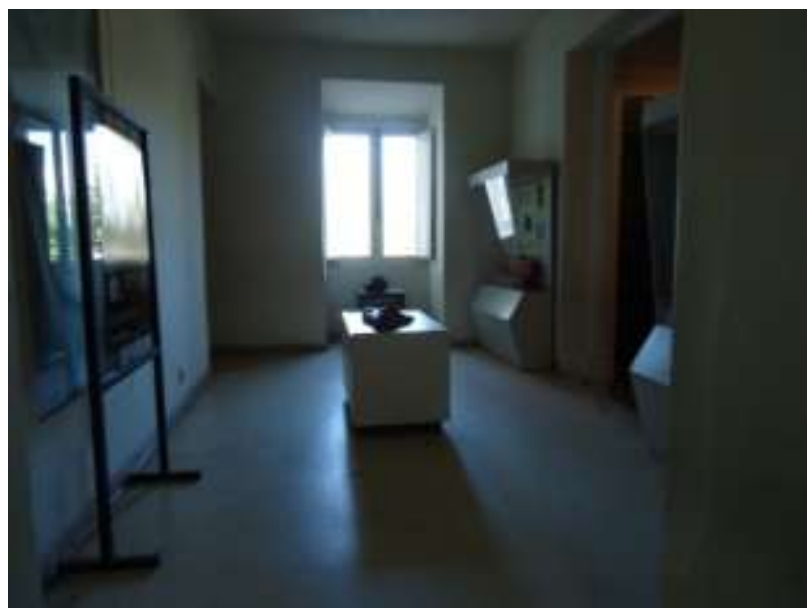

Figura 55. Vista geral da sala de meteoritos.

\subsection{7 - Mineralogisches Museum}

(Universidade de Hamburgo, Hamburgo - Alemanha)

O Mineralogisches Museum (Figura 56) é o único museu alemão visitado que classifica os minerais segundo a sistemática de Dana, e não de Strunz. Diferente dos outros museus com classificação sistemática, este apresenta em média vinte amostras em cada vitrina, o que facilita a visualização do visitante leigo.

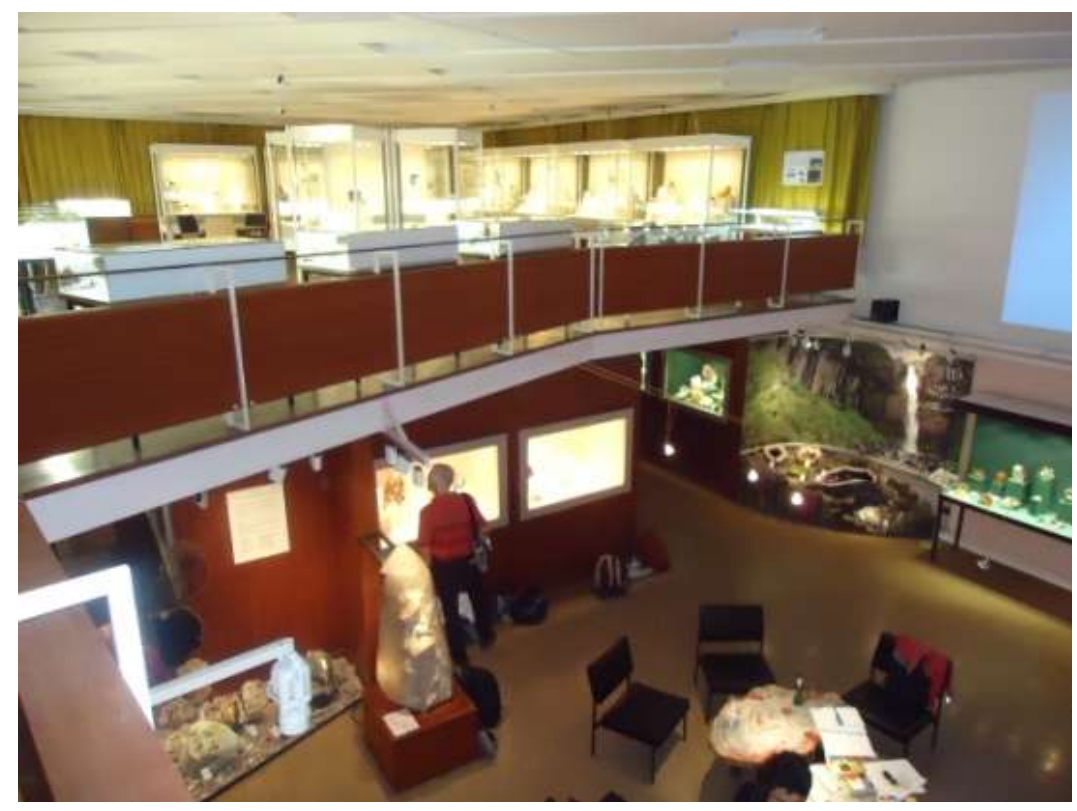

Figura 56. Vista geral do Museu de Mineralogia da Universidade de Hamburgo. 
Se por um lado as amostras estão bem apresentadas, por outro, o sistema de legendas não é eficaz. As amostras recebem uma numeração e a legenda é colocada no vidro da vitrina, fazendo o visitante deslocar o olhar da amostra para procurar a legenda (Figuras 57 e 58). Esse processo faz com que o espectador se desestimule, uma vez que o acesso à informação não está fácil de identificar.

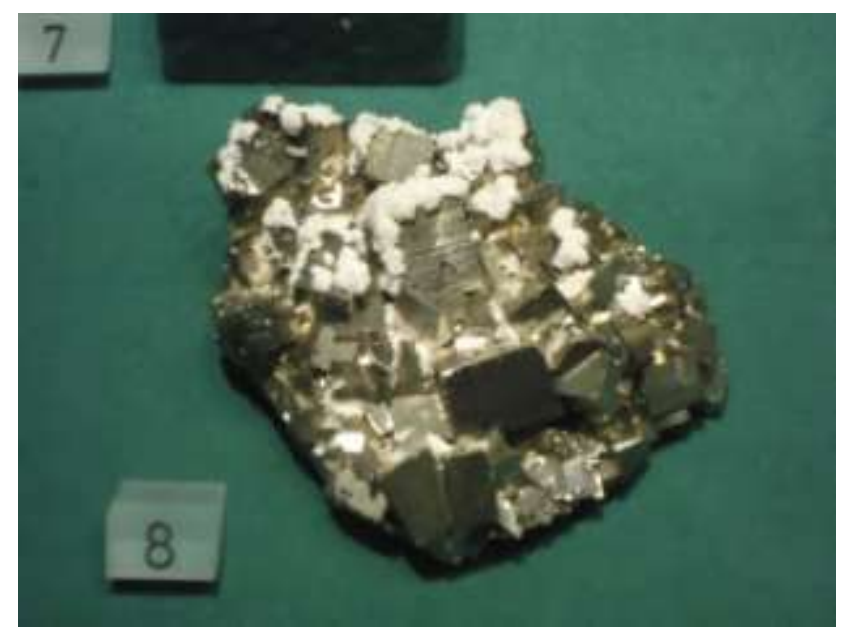

Figura 57. Amostra de pirita exposta do museu. $O$ número 8 ao lado do mineral refere-se à legenda (mostrada na Figura 58) que está posicionada na parte superior da vitrina.

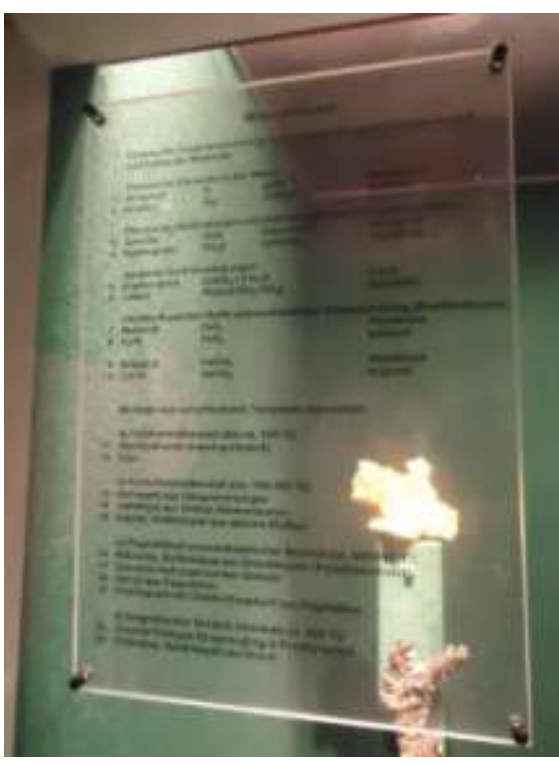

Figura 58. Legenda onde está colocada a descrição da amostra de pirita da Figura 57. Nota-se o acúmulo de informações desconectadas do mineral, o que dificulta a visualização e compromete a compreensão por parte do visitante, tanto leigo quanto especializado.

As amostras não possuem numeração da coleção, apenas número de exposição na vitrina, o que dificulta o processo de pesquisa, uma vez que o cientista deve referenciar a amostra com seu número e o da vitrina em que está, e não com um número único da amostra. A probabilidade de erro ao referenciar a amostra é grande. Apesar disso, o número de amostras por vitrina é adequado ao espaço disponível (Figura 59), sendo em média vinte amostras por vitrina, o que não ocorre no Museu de Geociências da USP ${ }^{10}$.

No tocante à conservação de amostras, não há adoção de procedimentos específicos. $\mathrm{O}$ ambiente é livre de iluminação natural por meio de cortinas tipo blackout nas janelas. Ponto positivo é a iluminação das vitrinas, cujas lâmpadas fluorescentes ficam protegidas em um tipo de caixote isolado das amostras (Figura 60). Assim, os minerais ficam livres das radiações luminosas diretas da lâmpada e do calor produzido por elas. Ressalta-se que o isolamento das lâmpadas no caixote mostrado não é um procedimento capaz de impedir a

\footnotetext{
${ }^{10}$ A descrição da organização do espaço museológico do Museu de Geociências da USP será apresentada no Capítulo 7.
} 
alteração de cores. Um exemplo é uma amostra de crocoíta, originalmente vermelha, que se encontrava na cor laranja, (Figura 61) e do calor produzido por elas. Destaca-se que a reposição de lâmpadas é facilitada, pois não há necessidade de deslocamento das amostras para a troca, o que não acontece no Museu de Geociências da USP, onde os técnicos têm de deslocar todas as amostras da vitrina a fim de substituir lâmpadas queimadas.

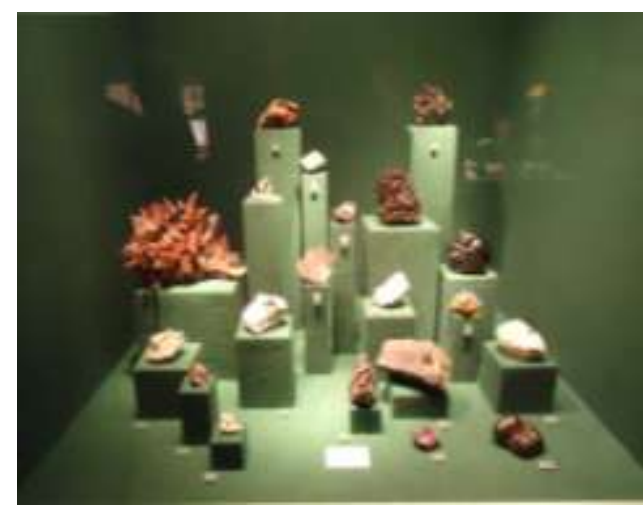

Figura 59. Aspecto da vitrina com vinte amostras.

Quantidade adequada ao espaço disponível, contribuindo para melhor apreciação do público.

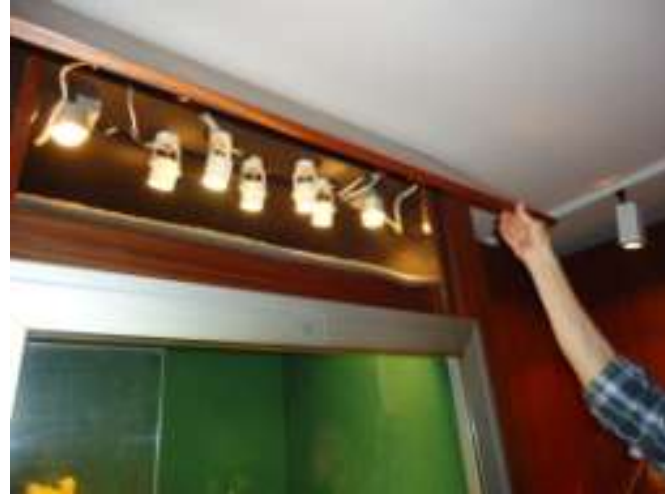

Figura 60. Caixote onde são embutidas as lâmpadas das vitrinas. Elas ficam separadas do material, facilitando a manutenção e evitando a transmissão de calor para o mineral.

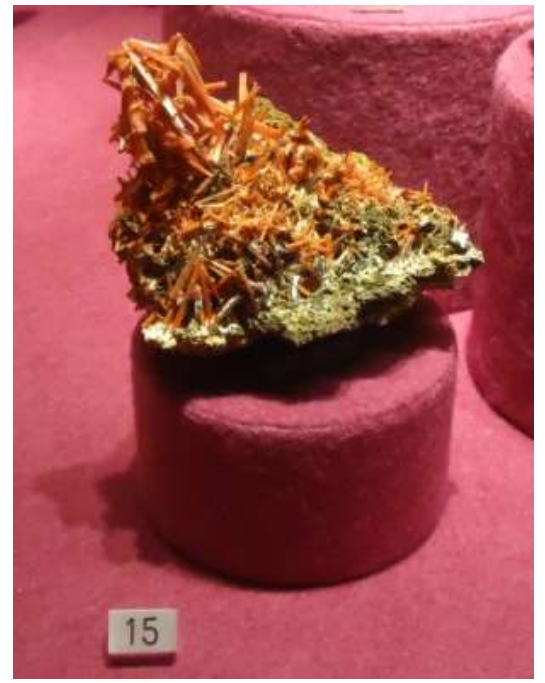

Figura 61. Crocoíta alaranjada por alteração de coloração devido à ação da luz. 


\subsection{8 - Mineralogisches Sammlungen - Technische Universität Berlin}

(Berlim - Alemanha)

A coleção de mineralogia da Universidade Técnica de Berlim foi recém-instalada em seu espaço atual e não estava oficialmente inaugurada na ocasião da visita técnica, motivo pelo qual não se pôde dizer qual público predomina como visitante.

A exposição possui belíssimos exemplares, dispostos de forma interessante e eficaz, e com pouco espaço expositivo: as vitrinas centrais foram contempladas com as amostras mais bonitas, de modo a atrair o olhar do visitante leigo; no entorno dessas vitrinas, estão outras mais antigas, organizadas sequencialmente de acordo com a sistemática de Strunz (Figura 62). Uma outra solução para a questão da falta de espaço foi a colocação da reserva técnica no mesmo móvel onde estão expostos os minerais. Em gavetas, na parte debaixo do armário, as amostras são cuidadosamente acomodadas em caixas de acordo com seu tamanho, sendo que as mais frágeis recebem um acolchoamento. Todas as etiquetas que acompanharam a vida do mineral, desde sua entrada na coleção, estão alocadas juntas com o espécime (Figuras 63 a 66).

Os armários possuem fechamento lateral que protege as amostras contra poeira, aumentando os intervalos de limpeza da vitrina, e é de fácil manejo. Um material plástico em forma de treliça protege as amostras contra a ação direta dos raios luminosos (Figura 67), mas assim como no Museu da Universidade de Hamburgo, não evita alterações de cor.

Um destaque é a exposição de minerais fluorescentes que estava sendo organizada na ocasião da visita. Uma vitrina comum, no mesmo espaço expositivo, foi coberta com um tipo de cortina blackout, com uma janela para a observação do fenômeno (Figuras 68 e 69). Boa solução de curadoria para otimização do espaço disponível e dos recursos financeiros.

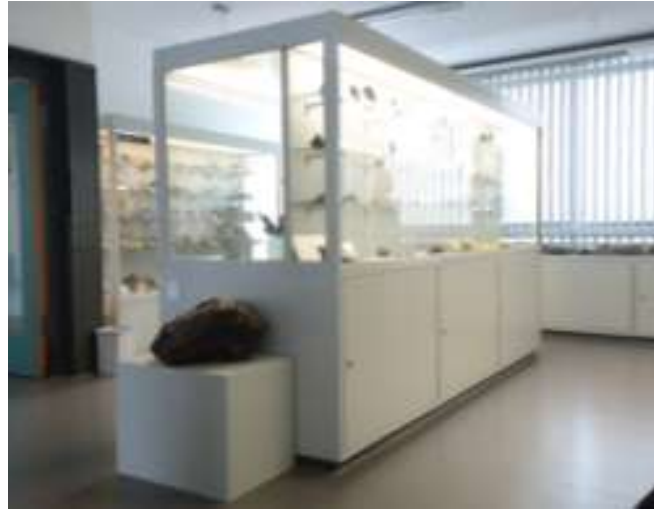

Figura 62. Vitrina de exposição central, mostrando os minerais mais bonitos. Nota-se perto da janela um armário menor: é a exposição sistemática.

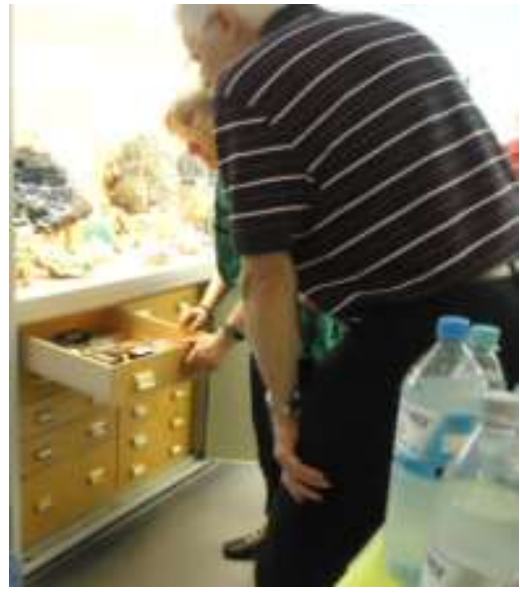

Figura 63. Reserva técnica na parte de baixo da vitrina central. 


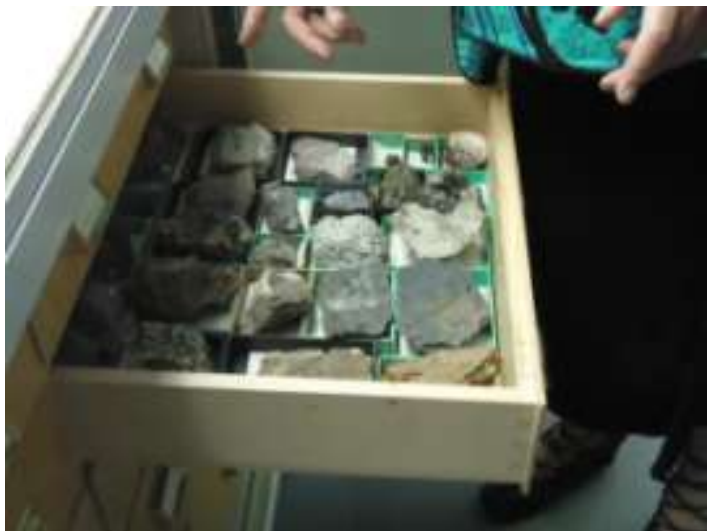

Figura 64. Acomodação das amostras no interior das gavetas.

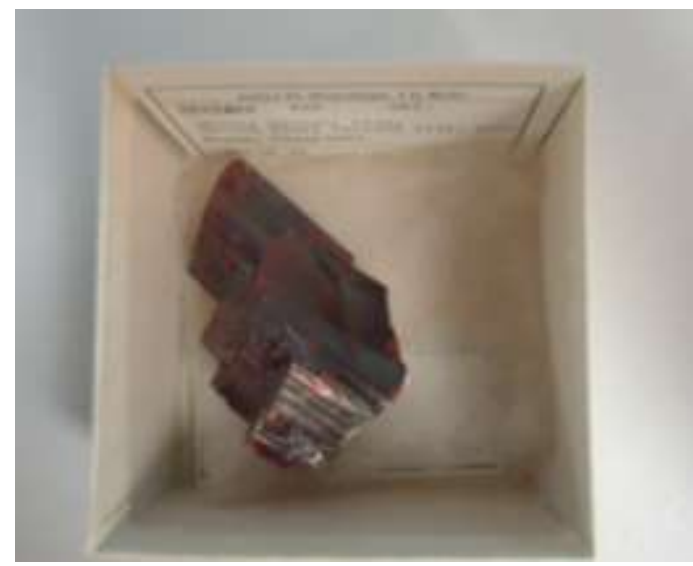

Figura 66. Cristal de realgar armazenado na reserva técnica. Nota-se um acolchoamento para a proteção do cristal.

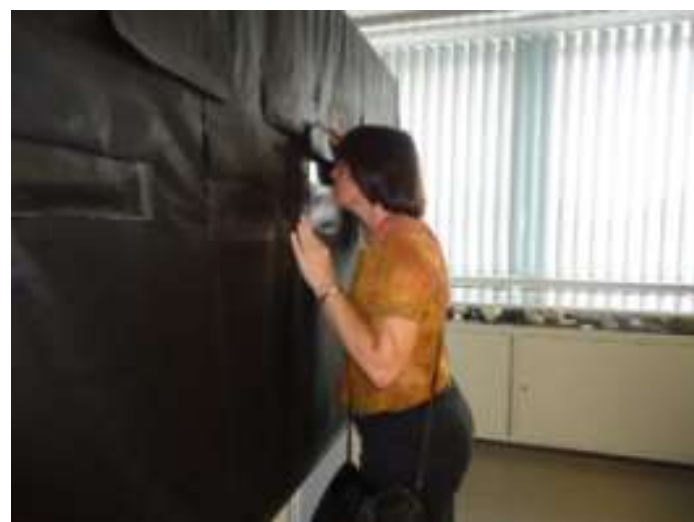

Figura 68. Exposição de minerais fluorescentes com luz $U V$, vitrina coberta com cortina blackout.

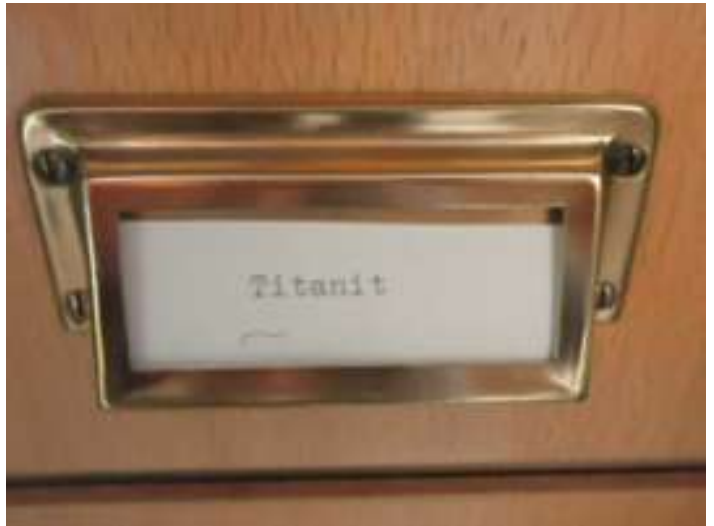

Figura 65. Amostras são armazenadas por espécies minerais.

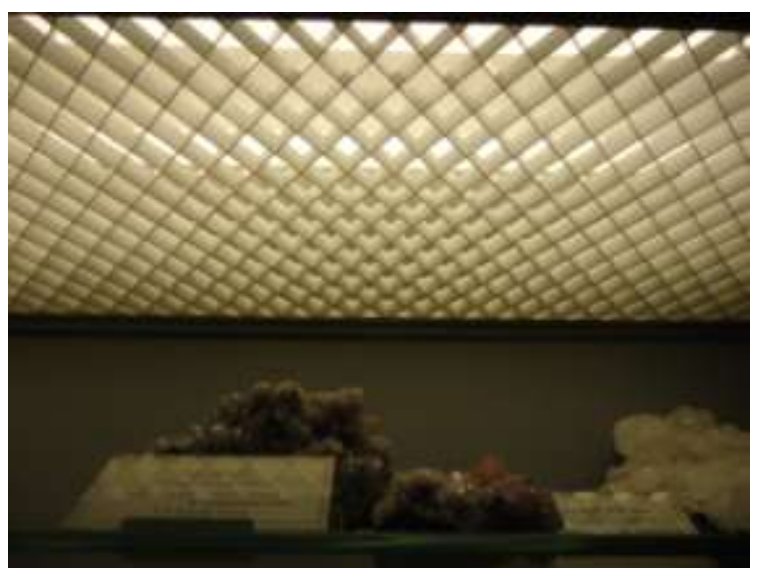

Figura 67. Aspecto da treliça que separa a lâmpada das amostras.

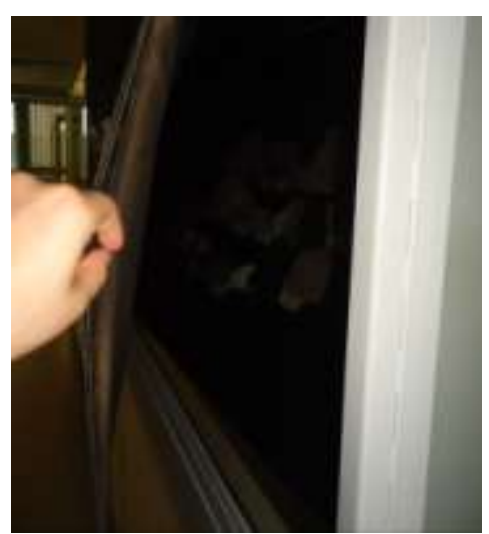

Figura 69. Interior da vitrina da Figura 68. 


\subsection{9 - Mineralogisches Museum - Philipps-Universität Marburg}

(Universidade Philipps de Marburg - Marburg - Alemanha)

O museu possui uma exposição bonita, agradável ao olhar e bem distribuída. No entanto são três andares de exposição, o que a torna não acessível para todos os públicos, pois situa-se num edifício de 500 anos, portanto, sem elevador. Está organizada de acordo com a sistemática de Strunz.

A exposição é livre de iluminação natural e as amostras são iluminadas com o mesmo sistema de treliças do salão de minerais da Universidade Técnica de Berlim (Figura 70). No Museu de Marburg, há também um vidro separando a lâmpada da treliça, fator que mantém o calor longe dos minerais. Os suportes das amostras são de acrílico, simples e adequados de acordo com a dimensão do mineral (Figura 71).

Não há cuidados especiais com amostras sensíveis à umidade, assim como nos museus alemães apresentados anteriormente, possivelmente devido às especificidades climáticas.

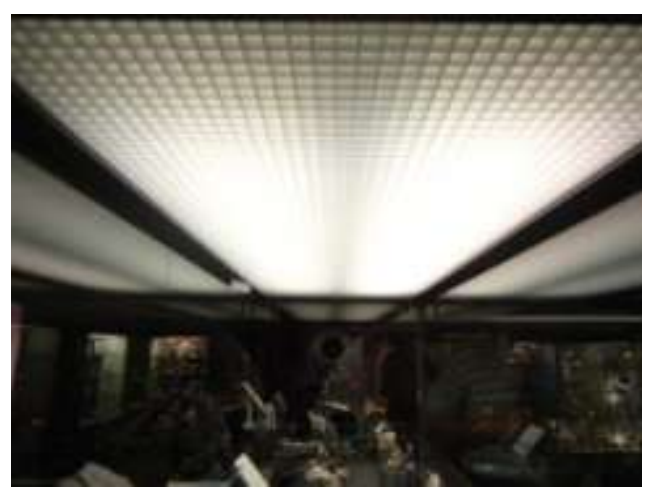

Figura 70. Aspecto da treliça divisória entre a iluminação e as amostras.

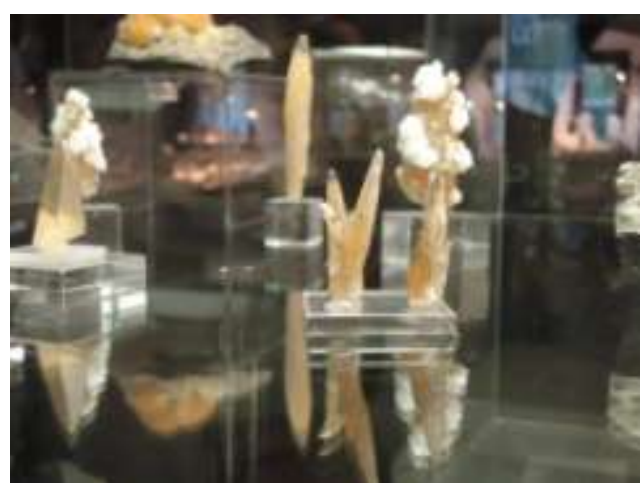

Figura 71. Suportes de acrílico simples $e$ adequados ao tamanho do mineral causam bom efeito visual.

\subsubsection{0 - Mineralogisches Sammlungen - Institut für Geowissenschaften - Universität Jena}

(Instituto de Ciências da Terra da Universidade de Jena - Jena - Alemanha)

A coleção de mineralogia do Instituto de Ciências da Terra da Universidade de Jena está dividida em cinco salas, abertas ao público, que cobrem cinco tópicos: história da coleção, minerais da região de Jena, meteoritos, mineralogia sistemática (organizada segundo a tabela de Strunz) e minerais fluorescentes sob luz UV (Figuras 72 e 73).

Não há cuidados especiais de conservação; apenas a sala de exibição sistemática de minerais é livre de iluminação natural (Figuras 74 e 75) por questão de estética, e não de conservação. Os meteoritos ficam na vitrina sem proteção de qualquer tipo. 


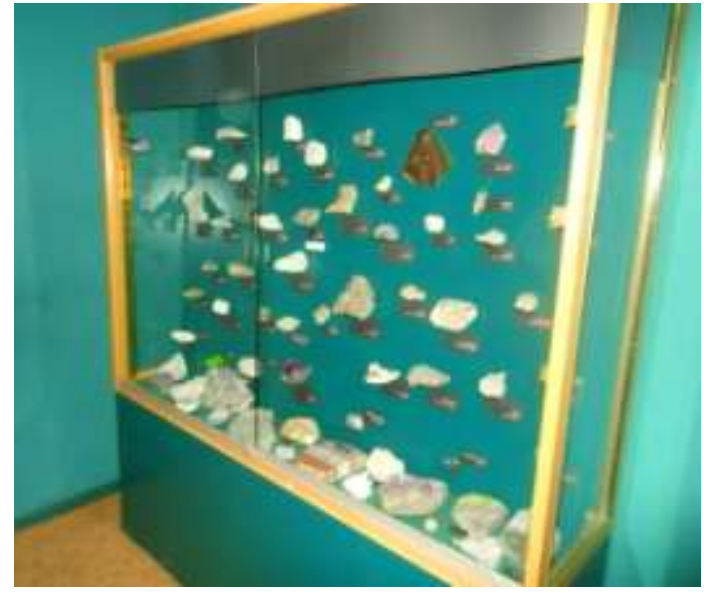

Figura 72. Sala de minerais fluorescentes.

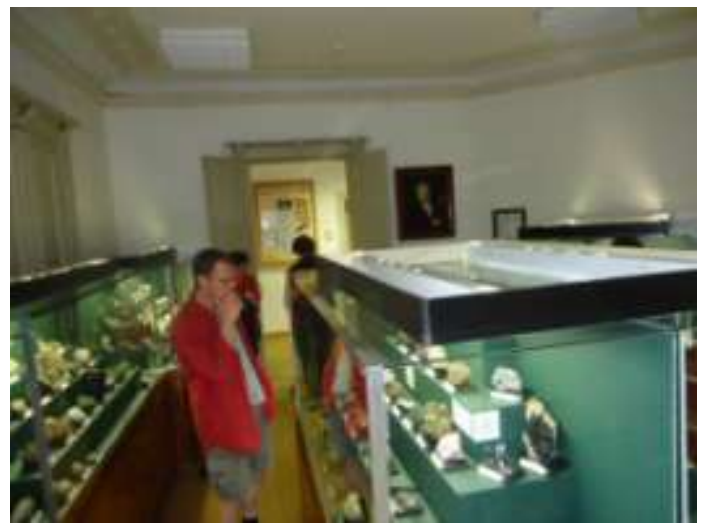

Figura 74. Vista da sala de exposição sistemática, a única privada de iluminação natural.

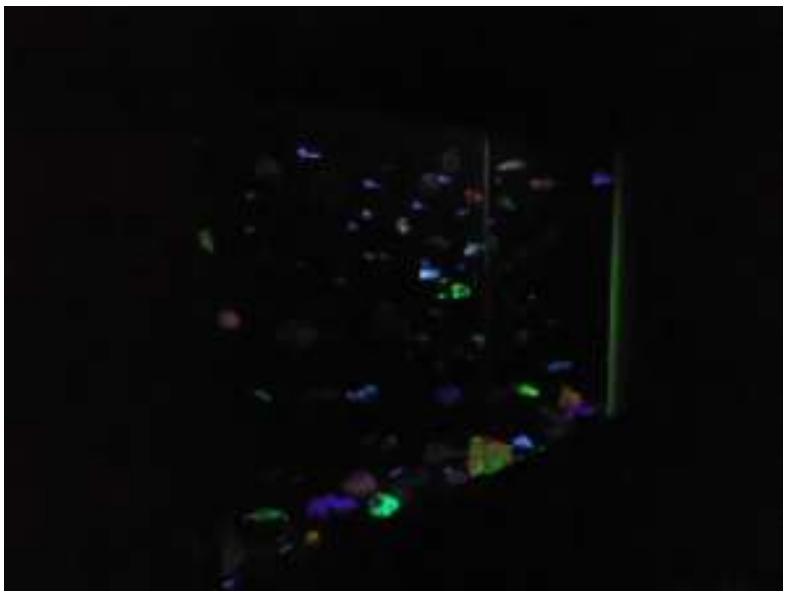

Figura 73. Sala de minerais fluorescentes.

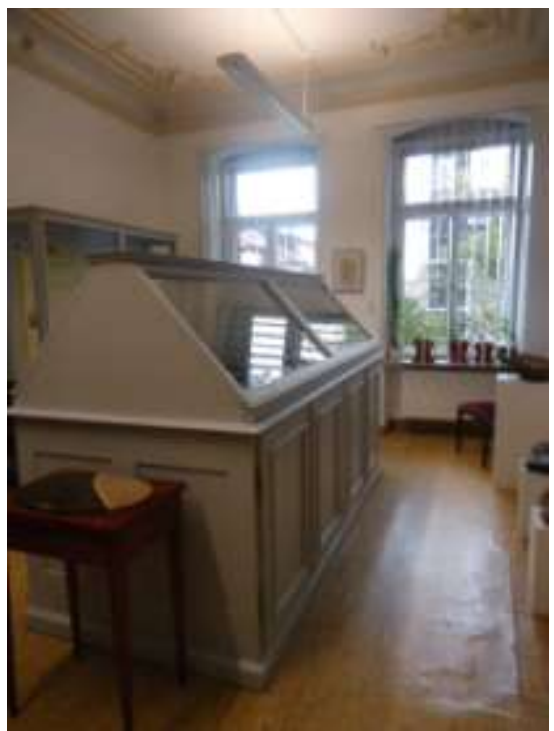

Figura 75. Luz natural na exposição.

\subsubsection{1 - Mineralogisches Museum - Universität Würzburg}

(Universidade de Würzburg - Würzburg - Alemanha)

O Museu Mineralógico da Universidade de Würzburg é dedicado ao ensino e à pesquisa científica, por isso sua exposição é voltada para pesquisadores (classificação sistemática de Strunz) e estudantes em geral (Figura 76). À exceção de atividades didáticas direcionadas ao público infantil, com mediação, a exposição não é atraente para o público leigo. Não há apelos visuais, a iluminação comum não destaca nenhuma peça em especial e as etiquetas são escritas em letras pequenas, que logo cansam a vista do espectador (Figura 77). Uma área que merece ênfase é o espaço destinado às exposições temporárias (Figura 78). Trata-se de um espaço pequeno, porém bem demarcado e bem iluminado, com teto de pirâmide de vidro, que difere do restante do museu. 
No momento da visita técnica, havia uma exposição sobre eclogitos. As esculturas desta rocha tão rara podiam ser adquiridas pelo visitante. A título de exemplo, uma escultura com $50 \times 20 \times 30 \mathrm{~cm}$ custava $€ 7.000$.

Destaca-se ainda a didática utilizada na exposição de rochas. Os exemplares expostos são localizados em um mapa e o exemplar da rocha é exposto em conjunto com uma fotografia de monumento construído com o exemplar em questão. Mesmo recurso utilizado por grandes museus e ilustrado nas Figuras 79 e 80, contudo, sem recursos visuais rebuscados e de alto custo. É importante ressaltar que nem sempre há orçamento para realização de grandes exposições; todavia, um conceito bem explorado, mesmo que em uma vitrina antiga e sem atrativos, é capaz de cativar o visitante.

Também não se encontra neste museu preocupação com questões de conservação. Muitas amostras estão expostas embaixo da janela, sob ação constante da luz natural.

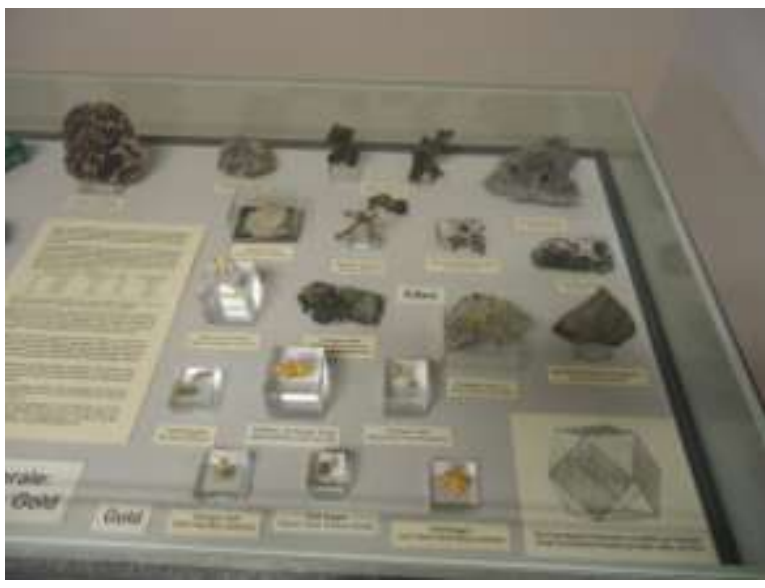

Figura 76. Vitrina com apresentação científica clássica.

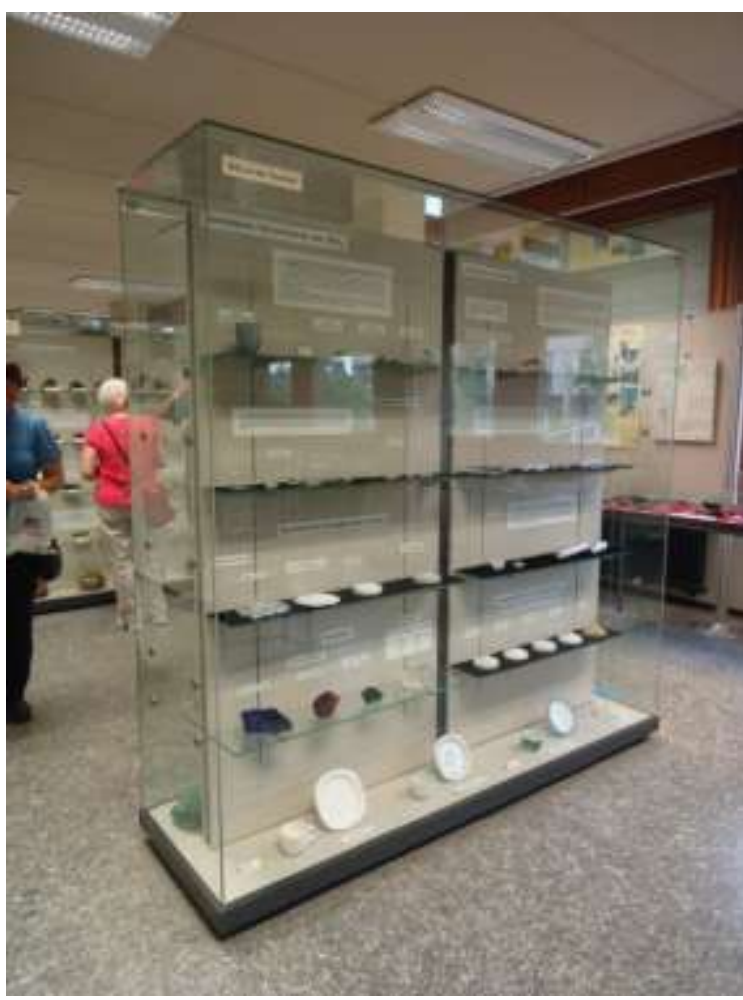

Figura 77. Vitrina didática sobre o uso de minerais sem atrativos visuais e legendas com letras miúdas, que dificultam a leitura. 


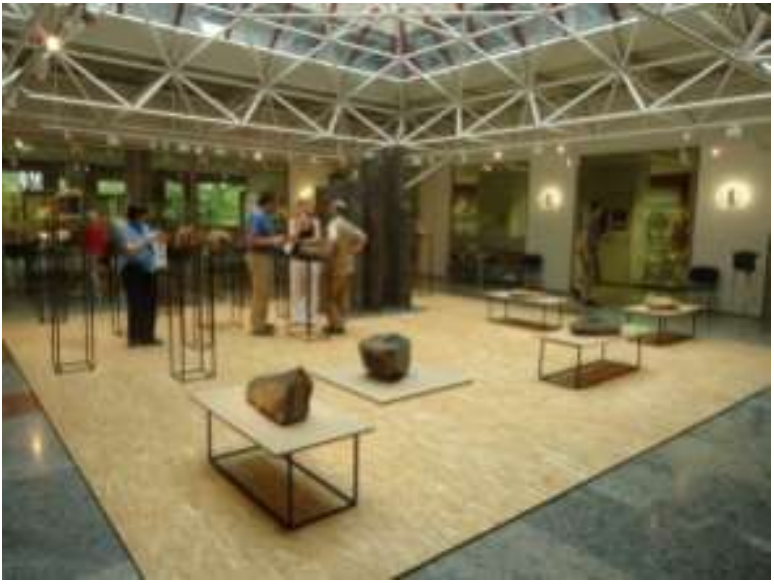

Figura 78. Espaço simples, porém bem demarcado, para exposições temporárias do museu. Neste caso, esculturas feitas com eclogito.

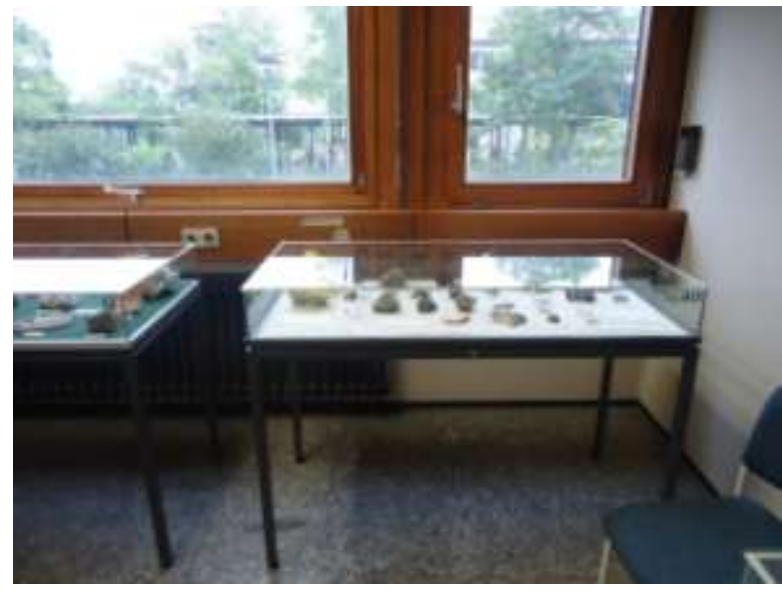

Figura 79. Amostras expostas sob luz natural direta.

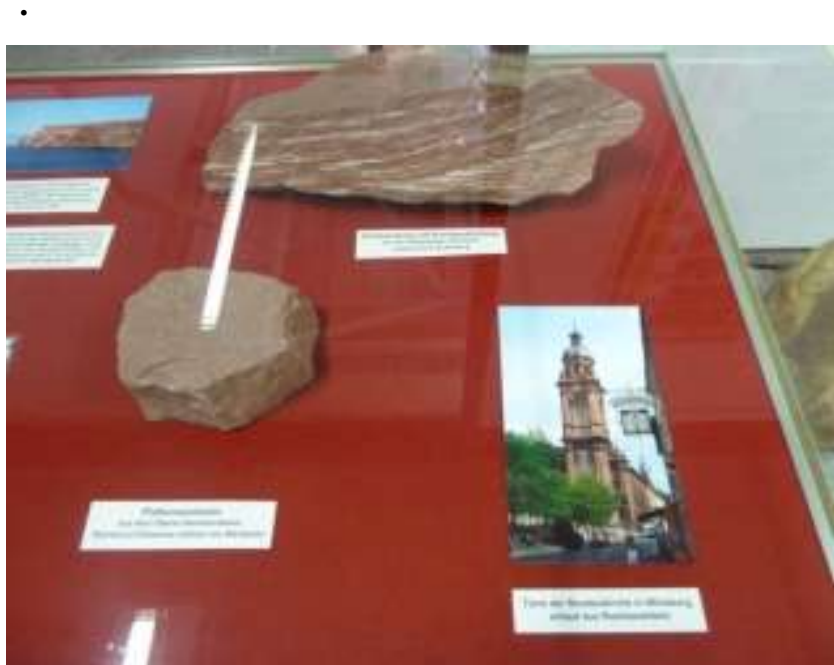

Figura 80. Vitrina com exposição de rochas e fotografia dos monumentos construídos com elas. Foto: Eliane A. Del Lama.

\subsubsection{2 - Mineralogisches Museum am Steinmann-Institut der Universität Bonn}

(Instituto Steinmann - Bonn - Alemanha)

A coleção é formada por aproximadamente 60 mil exemplares, entre minerais e minérios, 600 meteoritos e exemplares de rochas não contabilizados. As exibições estão divididas em quatro espaços, sendo o primeiro para minerais e sua classificação sistemática (Figura 81); o segundo para exposições temporárias e rochas e meteoritos; o terceiro, para minérios; e o quarto, para gemas e cristais sintéticos.

A exposição possui exemplares especiais, os quais não podem ser bem apreciados devido ao número excessivo de amostras em cada vitrina, e porque as legendas encontram-se impressas em acrílicos transparentes e muitas vezes não são vistas pelos visitantes (Figura 82). 


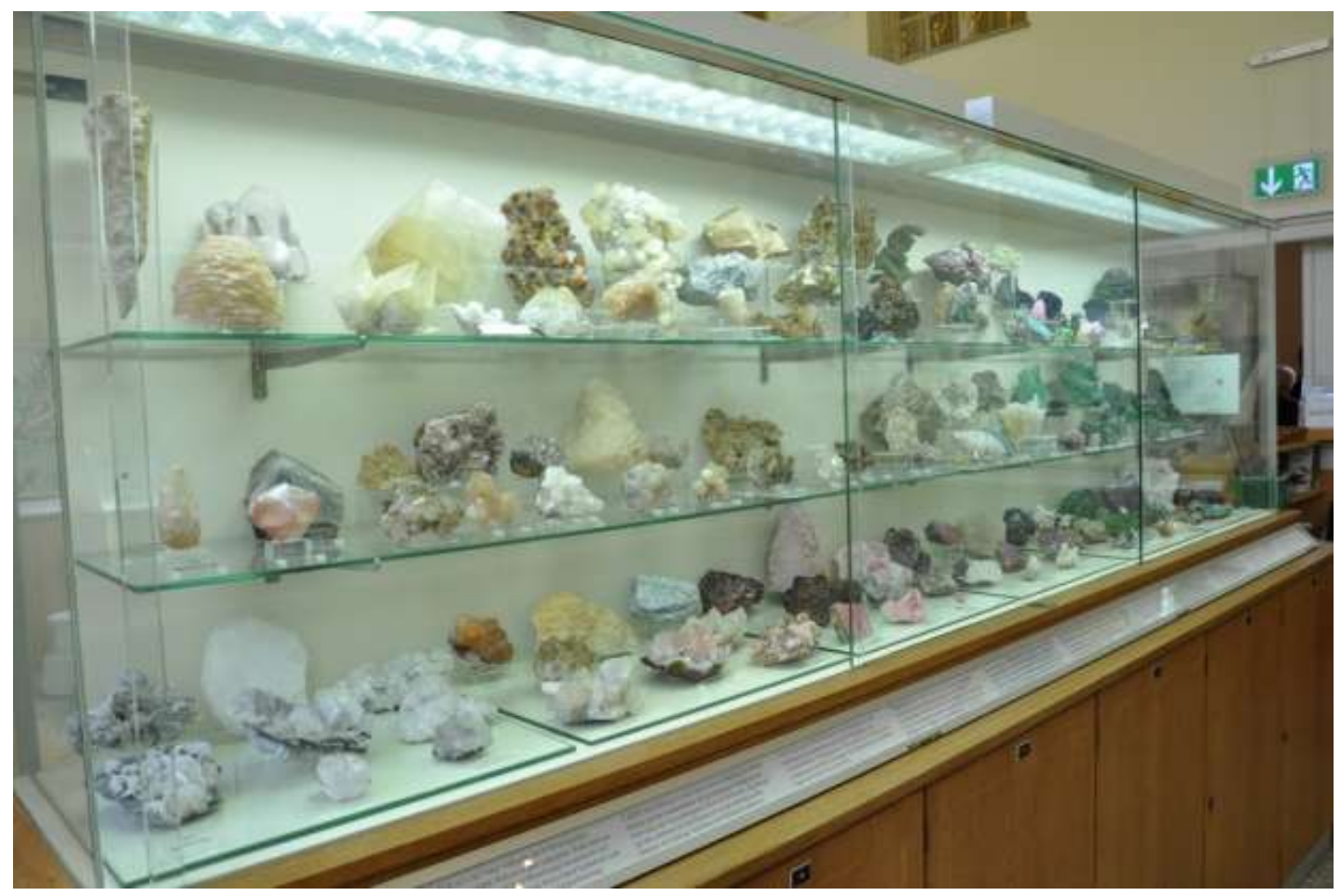

Figura 81. Detalhe de uma das vitrinas da exposição sistemática de minerais. Foto: Lauro K. Dehira.

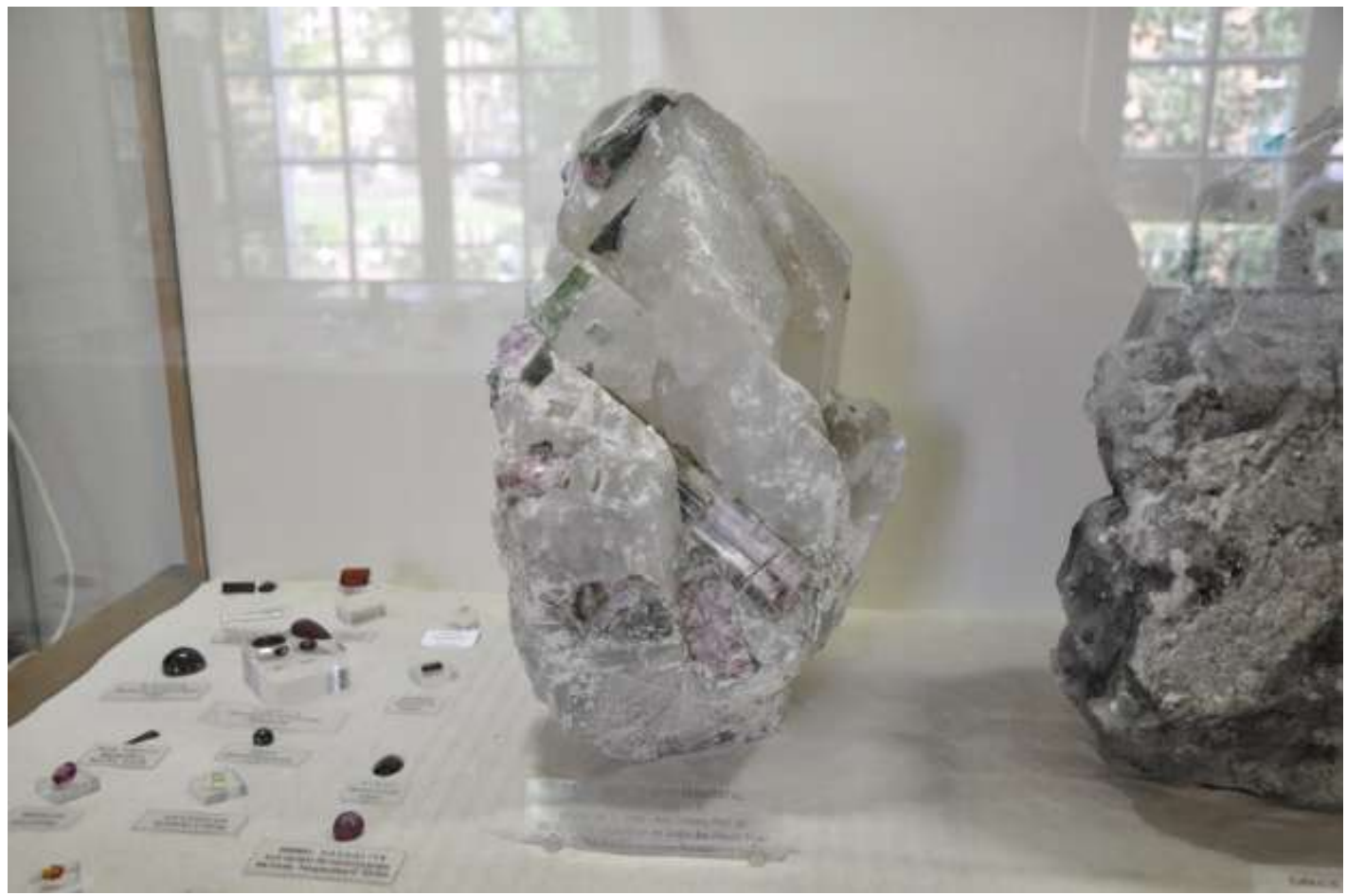

Figura 82. Etiquetas transparentes dificultam a leitura das informações e muitas vezes passam despercebidas ao visitante. Foto: Lauro K. Dehira. 


\subsubsection{3 - Museu de Ciências da Terra}

(Departamento Nacional de Produção Mineral - Rio de Janeiro - RJ)

O acervo mineralógico do Departamento Nacional de Produção Mineral (DNPM) consta como um dos mais importantes do Brasil, devido ao número de exemplares e qualidade mineralógica. Está instalado em um edifício histórico na Praia Vermelha, Rio de Janeiro. O prédio foi construído em 1880 para abrigar a Exposição Nacional e posteriormente passou a abrigar o Serviço Mineralógico e Geológico do Brasil, que teve seu nome alterado para o atual DNPM em 1934. Em 1907, o geólogo Orville Adelbert Derby organizou as amostras em forma de Museu (CORNEJO e BARTORELLI, 2010).

O Museu abriga coleções paleontológica e mineralógica (Figura 83). Esta, ainda hoje, possui a feição expositiva de uma exibição clássica do século XIX. As vitrinas de exposição em madeira imitam com exatidão a exposição mineralógica clássica do LNHM (Figura 84). A mostra está organizada de acordo com a sistemática de Dana, com muitos exemplares em uma mesma vitrina. A exposição apresenta-se inadequada para atender ao público leigo, uma vez que as amostras, organizadas sistematicamente, não possuem quaisquer referências indicativas do que deve ser observado em um mineral. $\mathrm{O}$ espaço apresenta-se igualmente inadequado à comunidade científica, pois as amostras, mobiliário e instalação estão em péssimo estado de conservação, e as etiquetas informativas estão degradadas (Figuras 85 a 88). A iluminação natural, aliada a luminárias sem direcionamento, prejudicam a visibilidade do visitante, tal qual ocorre no LNHM. Muitos dos principais problemas de conservação que afetam coleções geológicas podem ser vistos na exposição, tais como esfacelamento de piritas e marcassitas (Figuras 89 e 90), sais deliquescentes, proliferação de micro-organismos decorrente de umidade excessiva, entre outros.

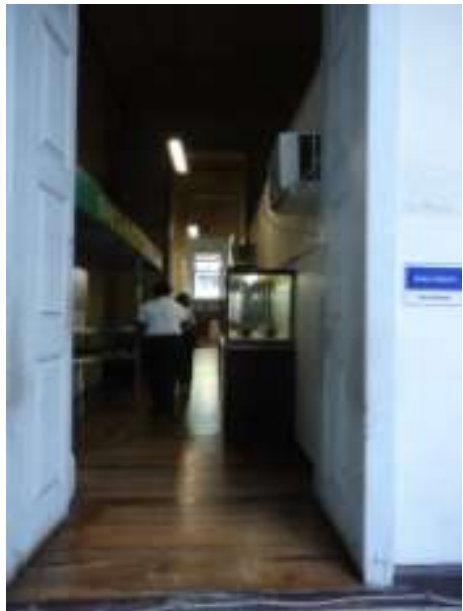

Figura 83. Entrada para a exposição mineralógica do Museu de Ciências da Terra.

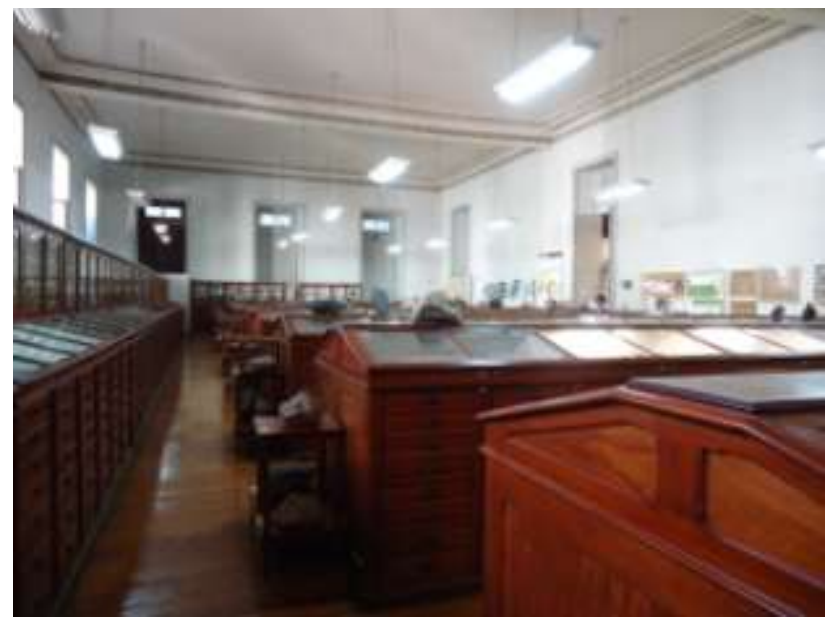

Figura 84. Aspecto geral da exposição de minerais do Museu de Ciências da Terra. 


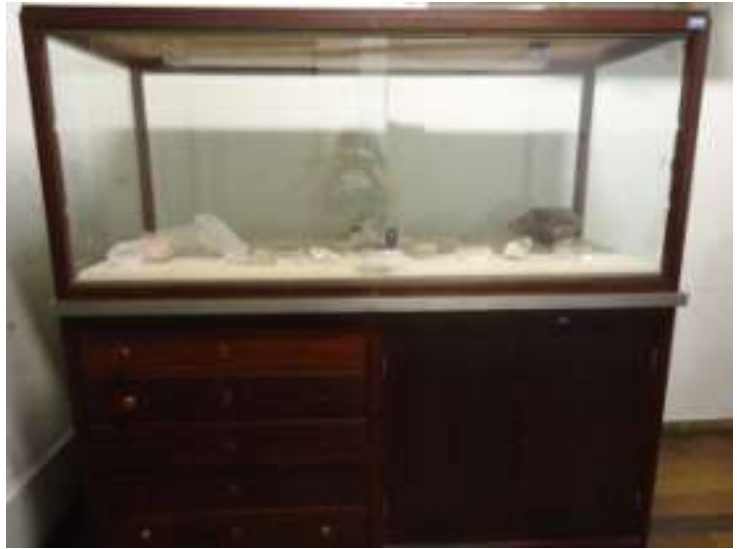

Figura 85. Mobiliário antigo e danificado, sem iluminação.

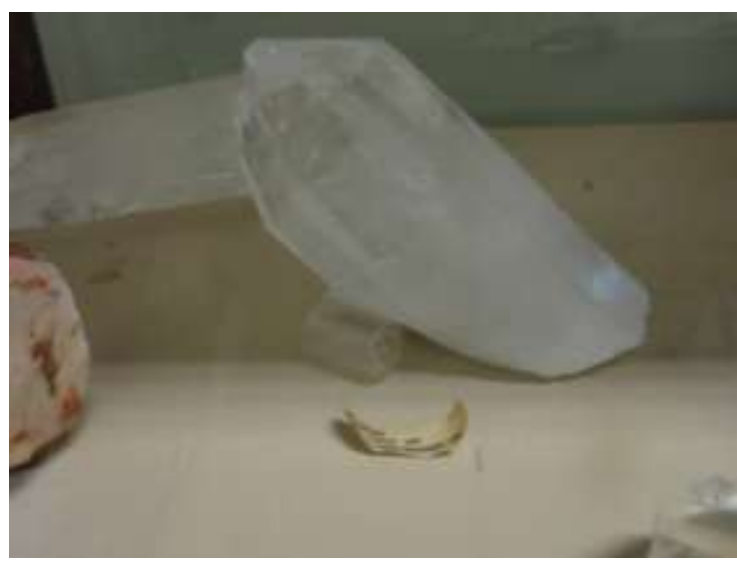

Figura 87. Detalhe de suporte improvisado e etiqueta danificada.

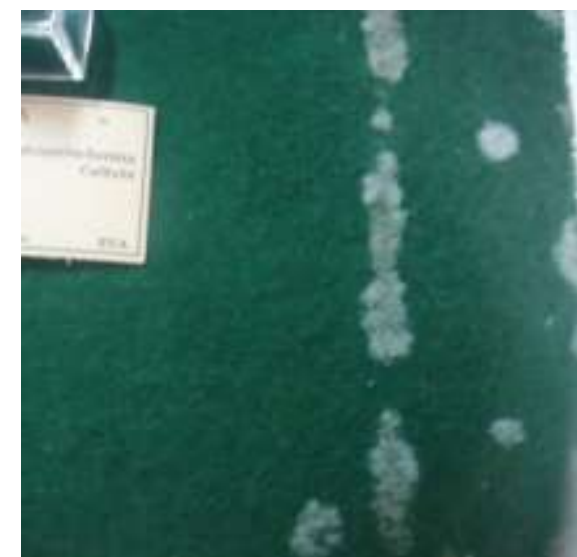

Figura 89. Aspecto de bolor no feltro da vitrina.

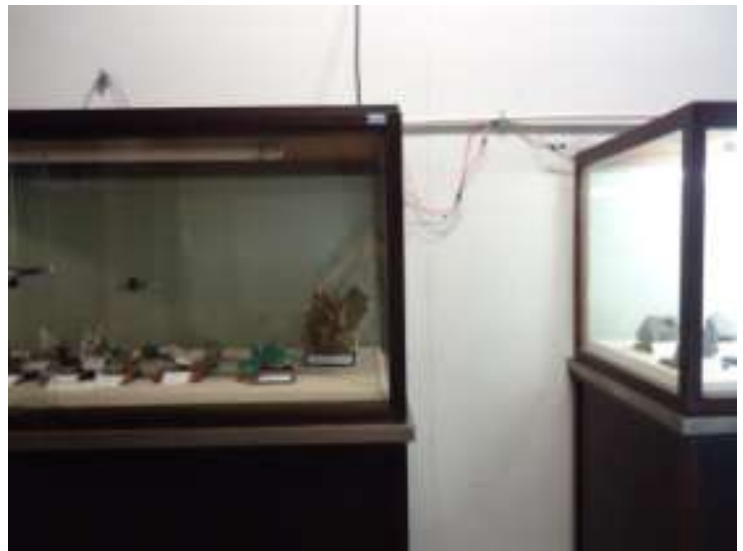

Figura 86. Vitrina sem iluminação e fios desencapados, com possibilidade de ocorrência de um curto circuito.

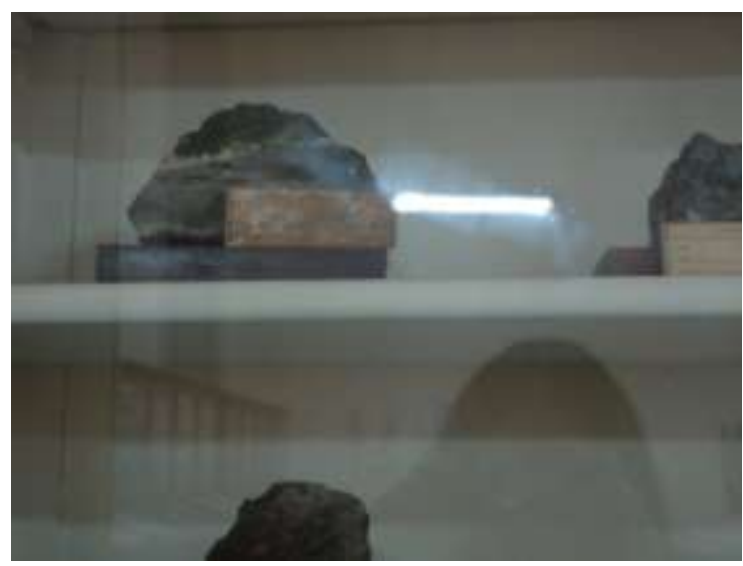

Figura 88. Etiqueta ilegível ao visitante e amostra em altura inadequada.

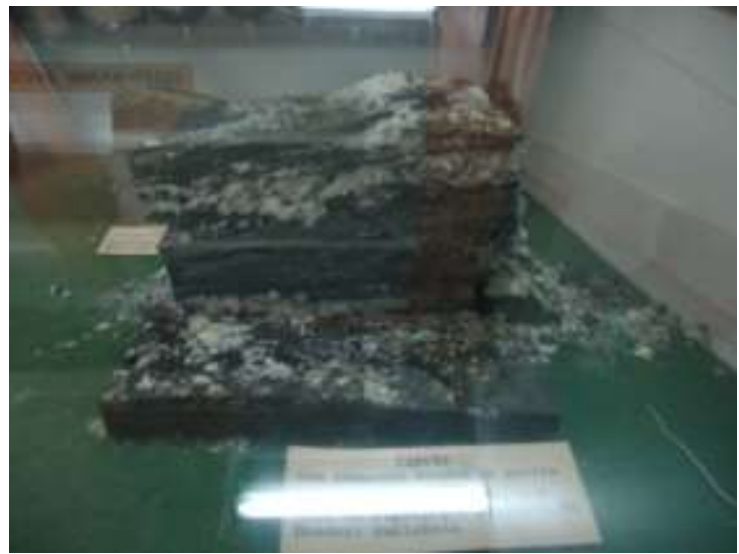

Figura 90. Amostra de carvão em estado avançado de degradação. Além disso, iluminação mal posicionada prejudica a visualização da amostra. 


\subsubsection{4 - Terra Mineralia - TU Bergakademie of Freiberg}

(Freiberg - Alemanha)

Terra Mineralia foi o nome dado à exibição da coleção pessoal da Sra. Erika PohlStröher no castelo Freudenstein, em Freiberg, a maior e mais antiga cidade de montanha da Alemanha. Essa coleção é considerada internacionalmente como a mais importante do mundo. Em 2004, a colecionadora doou seu acervo para a Fundação Pohl-Ströher, em caráter de empréstimo permanente. A escolha do local deveu-se ao fato de a doadora ser originária da Saxônia.

A Sra. Pohl-Ströher colecionou minerais da África, América, Ásia, Austrália e Europa durante quarenta anos. Organizou sua coleção particular por proveniência das amostras, de acordo com os continentes de onde foram coletadas. Tal organização foi respeitada e reproduzida na exposição Terra Mineralia (Figura 91).

Apesar de a doação ter ocorrido em 2004, a exposição apenas foi aberta à visitação em 2008, devido à necessidade de se encontrar um espaço ideal para o acervo. O Castelo de Freudenstein foi o local escolhido e, após muitas intervenções para reabilitação do espaço, a exposição pôde ser inaugurada.

A construção do castelo data do século XII (1170-1175) e foi utilizado primeiramente pelo governo de Freiberg para a proteção das atividades de mineração e metalurgia. Sofreu várias intervenções ao longo dos séculos e teve seu uso redirecionado a funções variadas. No século XX foi utilizado pela República de Weimar, em 1945, como base militar, e depois como silo, para depósito de milho. Em 1979 essa atividade cessou e começou a ser cogitado seu uso para fins culturais. Com a reunificação da Alemanha, em 1990, pensou-se a possibilidade de instalar no local um asilo para aposentados, mas a ideia não vingou. Apenas em 2003 o município de Freiberg entrou em acordo com o Governo da Saxônia e o Freudenstein foi direcionado a depositar a coleção de minerais da Bergakadmie e o Arquivo Saxão de Mineração.

Atualmente são 3.500 minerais expostos, o que não representa a totalidade da coleção da Sra. Pohl-Ströher. As exposições são divididas por continentes, e dentro de cada sala há a divisão por países. As salas são todas ausentes de luz externa, não como cuidado de conservação, mas como ambientação e melhor visualização, com iluminação direcionada aos minerais (Figuras 92 a 94). Não há cuidados específicos para a conservação da exposição.

Embora pertença a uma universidade, trata-se de um museu não científico, cujas exibições são destinadas a mostrar a beleza e variedade do mundo mineral aos mais diversos tipos de público. Apesar do público variado, a instituição tem uma política educacional 
voltada para crianças (Figura 95), por acreditar que é a partir delas que o interesse pela mineralogia será difundido num futuro próximo. A exposição ocupa cinco andares, o que também a torna não acessível a portadores de necessidades especiais, por se tratar de um edifício do século XII (Figura 96).

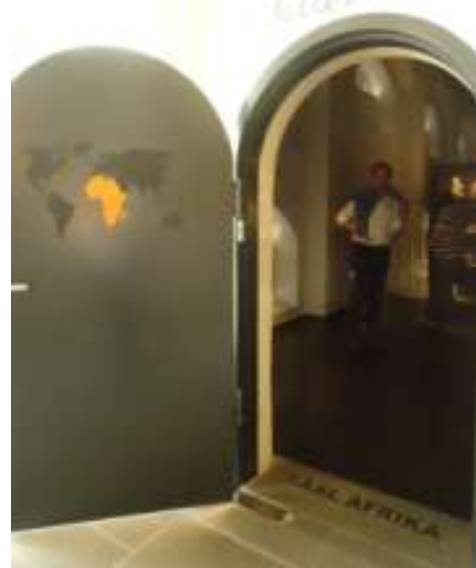

Figura 91. Aspecto da entrada de uma das salas de exposição. Nota-se apenas a utilização da identidade visual para explicar o conteúdo da mostra, além dos minerais separados por continentes.

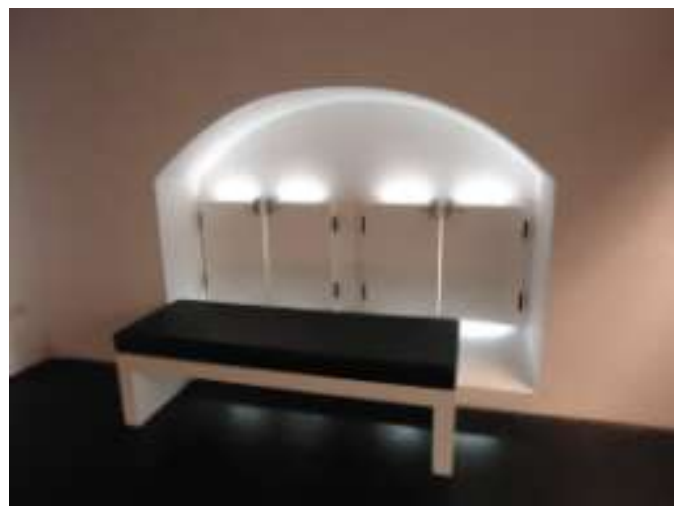

Figura 93. Detalhe da janela do castelo, especialmente escurecida para eliminar a interferência da luz externa.

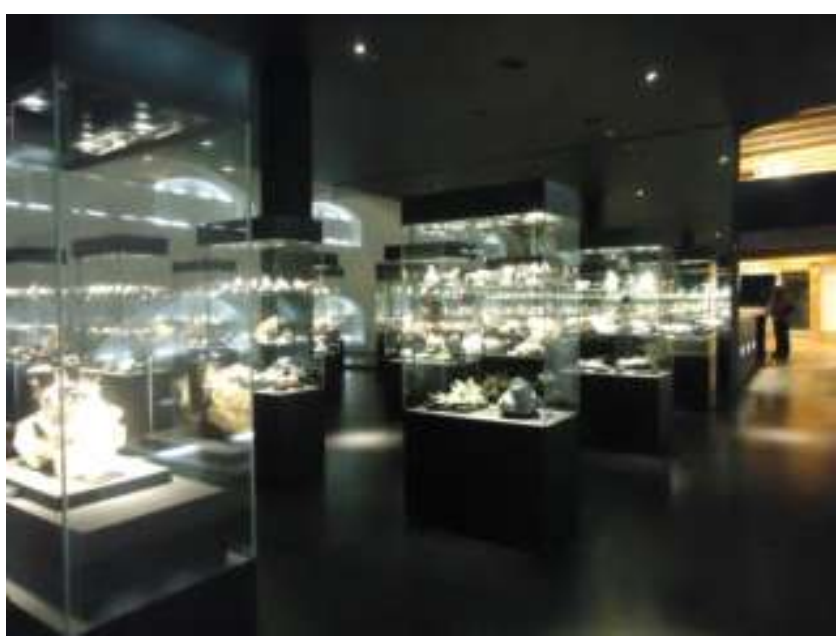

Figura 92. Vista geral de uma das salas de exposição.

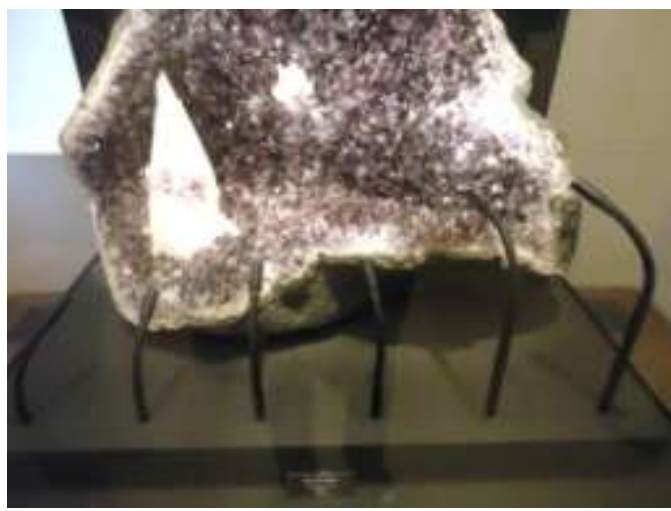

Figura 94. Detalhe da iluminação direcionada à amostra por pontos de Led. 


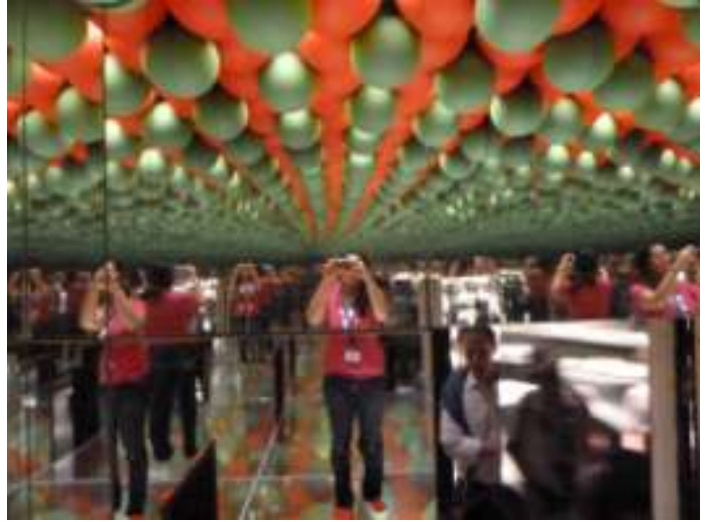

Figura 95. Um dos recursos didáticos para crianças: no meio da exposição uma câmara produz a sensação tridimensional de estar no interior de uma cela unitária.

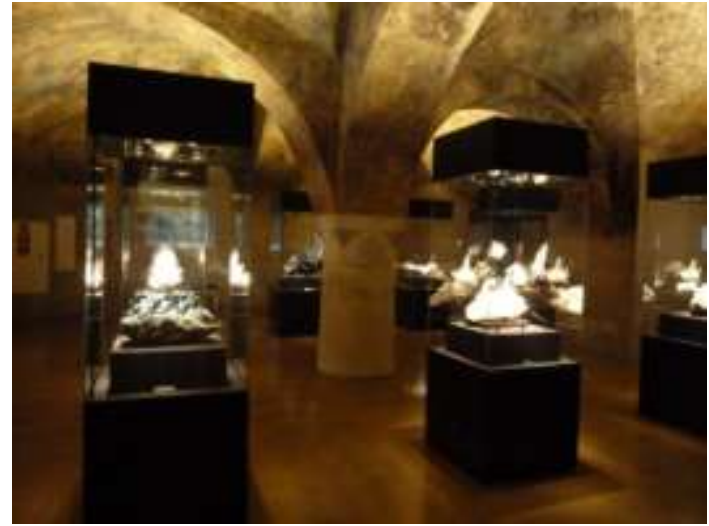

Figura 96. Área da exposição alocada onde outrora esteve a cozinha do castelo. As diferenças de coloração no teto são herança da fuligem dos fogões a lenha. Foto: Eliane A. Del Lama.

A reserva técnica foi cercada de alguns cuidados básicos, mas eficientes. É muito bem organizada, com mobiliário adequado (Figuras 97 e 98) e temperatura constante. As amostras são organizadas de acordo com os depósitos em que ocorrem. Os armários e as gavetas são numerados em ordem sequencial, desde a número 1 , no armário 1 , até a última gaveta no último armário. Tal procedimento evita a repetição dos números das gavetas, evitando que o pesquisador se confunda.

As gavetas são protegidas com uma tampa de acrílico, que possibilita a visualização das amostras sem a necessidade de abrir as gavetas (Figuras 99 a 102), o que evita o manuseio desnecessário de amostras. Essa simples medida protege as amostras de poeira e variação de umidade do ar.

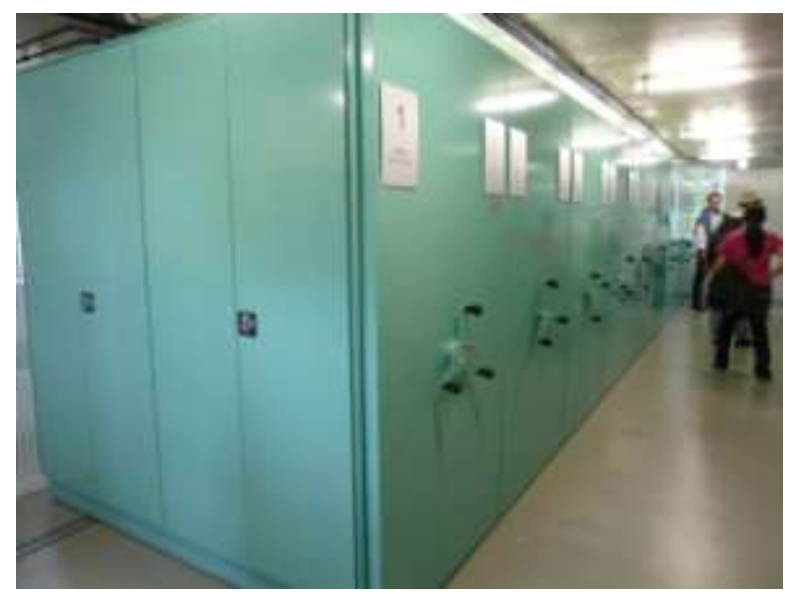

Figura 97. Vista geral da reserva técnica doTerra Mineralia.

Foto: Eliane A. Del Lama.

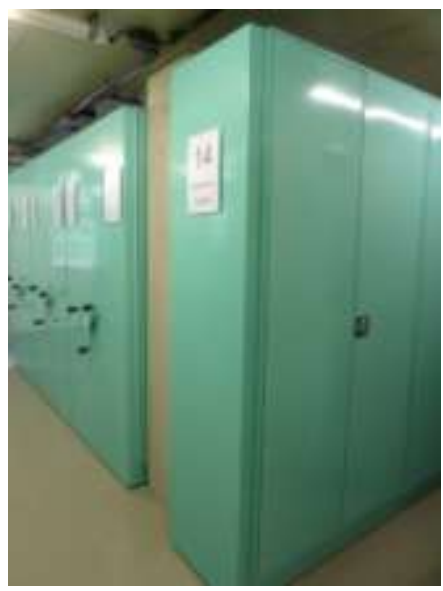

Figura 98. Armários são visivelmente numerados para facilitar a localização e o acesso à informação. 


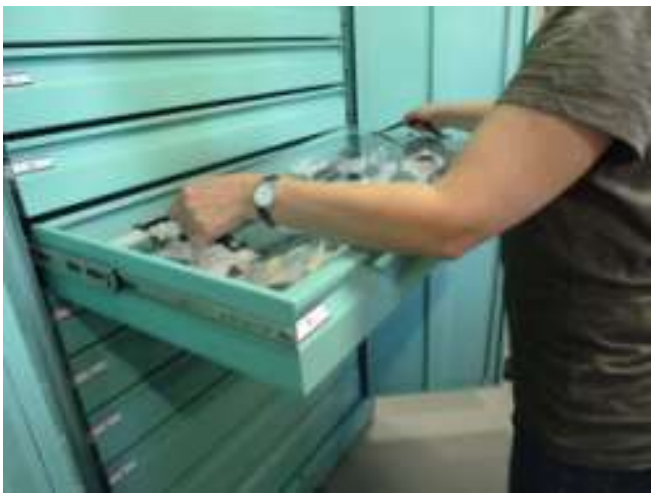

Figura 99. Cobertura de acrílico com puxador em tecido auxilia a conservação, protegendo a amostras da ação de poeiras e da variação de

$U R$, além de evitar o manuseio de muitas amostras apenas para a localização de um mineral.

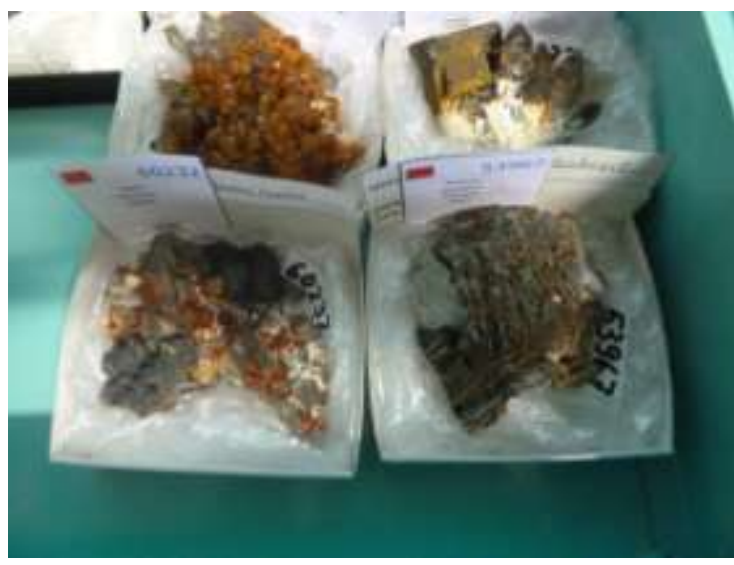

Figura 101. Detalhe do armazenamento de amostras nas gavetas. As amostras mantêm as etiquetas originais e as do Museu.

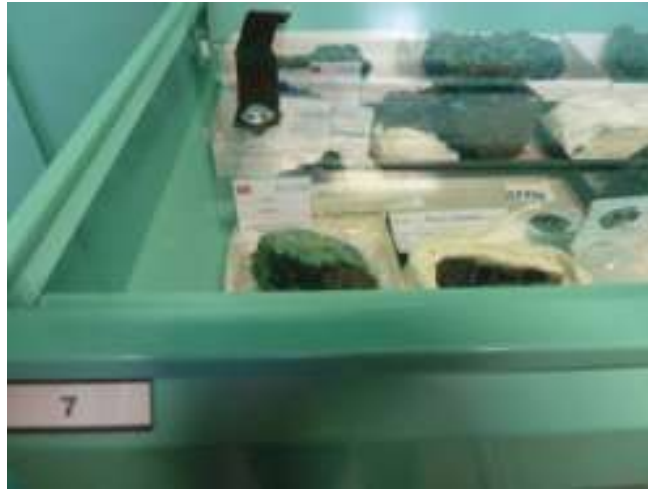

Figura 100. Puxador em tecido evita o contato das mãos com o acrílico, sem gasto de tempo com a limpeza da tampa. Nota-se a numeração da gaveta, sempre do lado esquerdo da mesma.

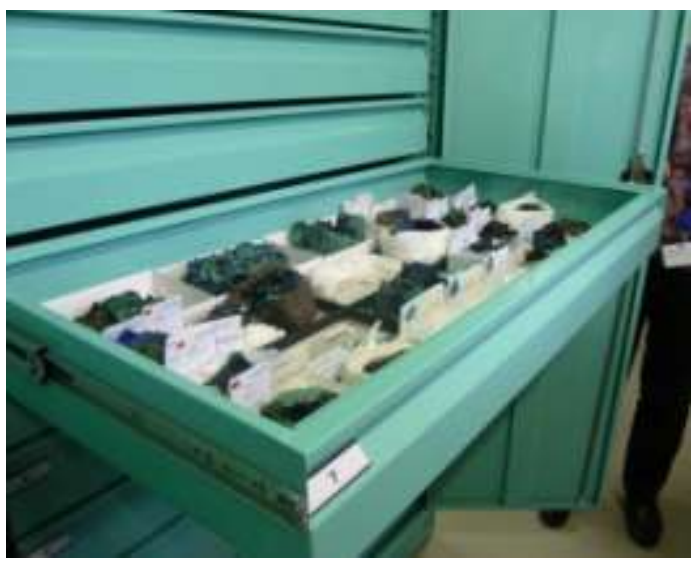

Figura 102. Detalhe de uma das gavetas em seu conjunto.

\subsubsection{5 - RiesKraterMuseum Nördlingen}

(Nördlingen - Alemanha)

O Museu da Cratera de Ries (Rieskrater) faz parte do Geoparque Nacional de Ries, uma das mais importantes crateras de impacto de meteorito do mundo, com $25 \mathrm{~km}$ de diâmetro, formada há aproximadamente 15 milhões de anos. O museu está localizado em uma construção medieval na cidade de Nördlingen e abriga, além de meteoritos, amostras de Marte e da Lua (Figura 103). A exposição tem feições modernas (Figura 104) e interativas (Figura 105), dando um contraste interessante com a construção antiga. No tocante à conservação, algumas amostras especiais, como a da Figura 103, são exibidas em redomas, mas não há preocupação com umidade ou temperatura na exposição (Figura 106). 


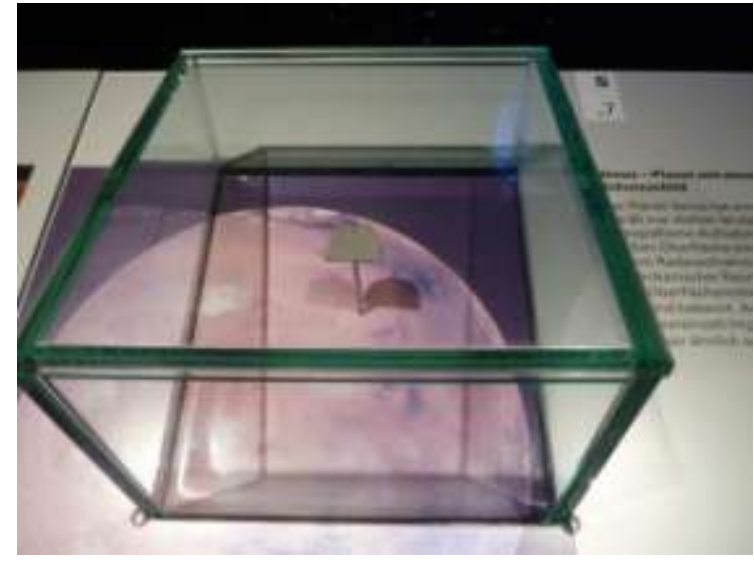

Figura 103. Amostra lunar em suporte confeccionado sob medida.

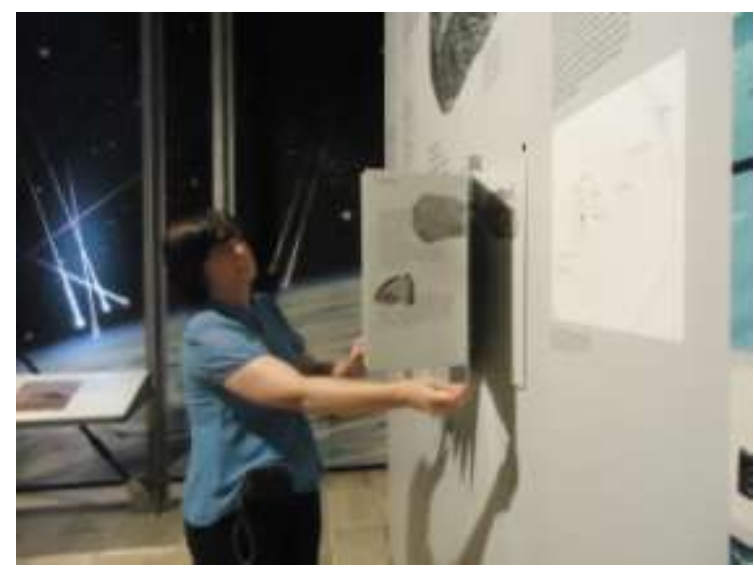

Figura 105. Neste painel, o espectador tem a possibilidade de se aprofundar no assunto sem que a exposição seja exaustiva para todos.

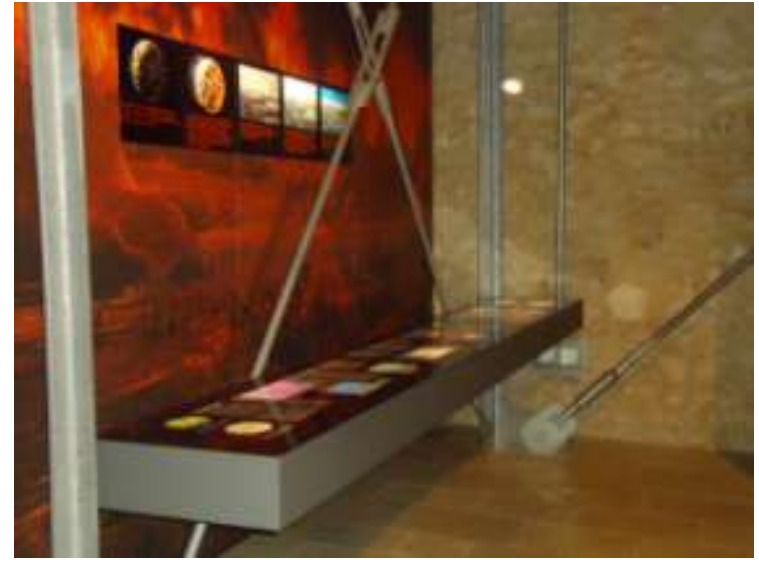

Figura 104. Exposição utiliza interatividade para apresentar conceitos complexos sobre a origem dos meteoritos.

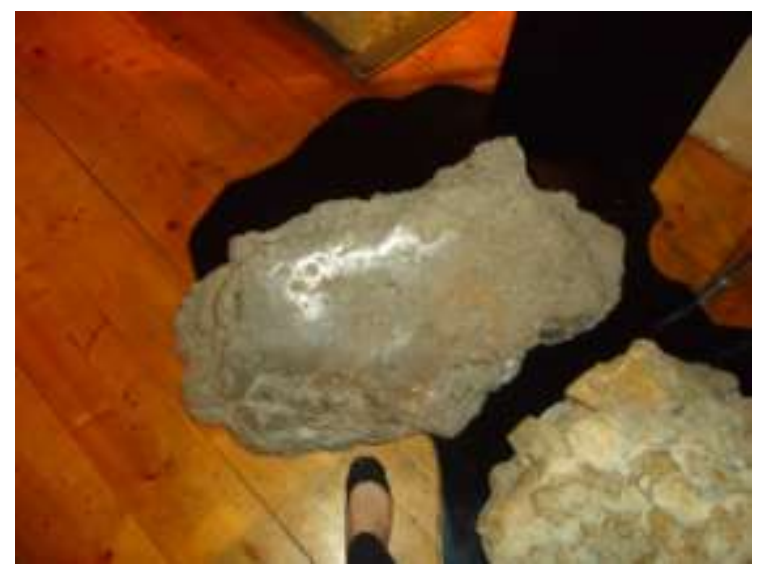

Figura 106. Meteoritos metálicos expostos sem qualquer tipo de proteção.

\subsubsection{6 - Mineralogisches Staatssammlung München}

(Munique - Alemanha)

A Coleção Mineralógica do Estado é uma instituição de pesquisa que pertence à Coleção de História Natural da Bavária, e que tem por finalidade coletar, armazenar e pesquisar minerais. O Museu Império dos Cristais (Museum Reich der Kristalle) é a parte da coleção mineralógica destinada à educação, cujos pontos fortes são minerais, com variadas formas cristalinas e gemas.

A coleção é dividida em dois ambientes, sendo um mais científico, com claros propósitos didáticos (Figura 107) e outro em ambiente especialmente escurecido, com amostras iluminadas diretamente, mais destinado à apreciação (Figura 108).

A reserva técnica é um local que propicia o armazenamento das amostras e também a pesquisa, o que não ocorre na maioria dos museus universitários. No mesmo espaço é feita a catalogação de amostras já guardadas e a pesquisa com as amostras que chegam. No interior 
dos armários deslizantes foram colocadas gavetas de madeira que não são encaixadas na estante (Figuras 109 e 110). Se por um lado as gavetas deixam o mineral protegido contra queda, por outro, dificultam a visualização dos minerais que estão acondicionados na parte superior, já que a gaveta não tem apoio ao ser aberta. Assim como no Museu de Geociências, os minerais grandes, que não podem ser acomodados em gavetas, ficam alocados na parte inferior do armário. Os minerais são separados por critério de origem, e não por espécie mineral, e o banco de dados é feito em Access. Não há controle de temperatura e umidade no ambiente da reserva técnica. As amostras de pirita que sofrem esfacelamento são simplesmente descartadas para não contaminar as demais.

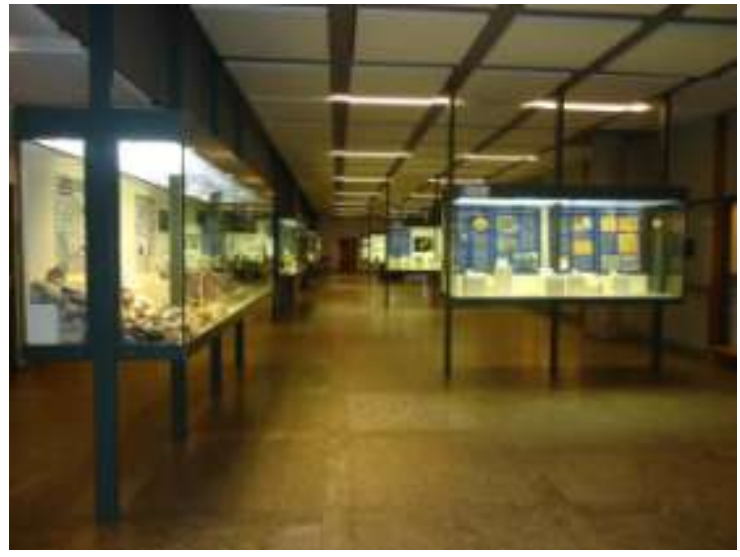

Figura 107. Aspecto da área didático-científica do тиseu.

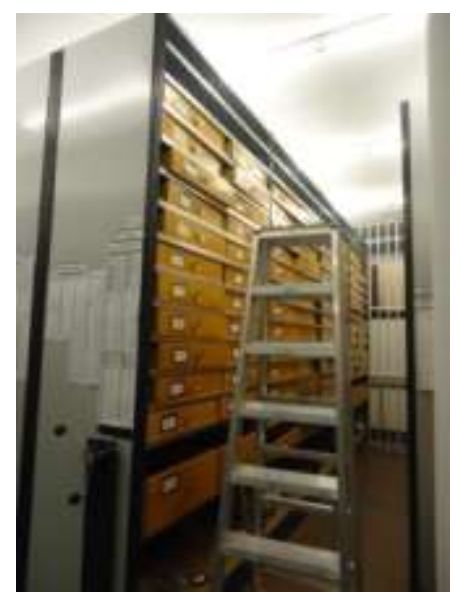

Figura 109. Reserva Técnica do Museu. Nota-se o espaço inferior sem gavetas para as amostras grandes.

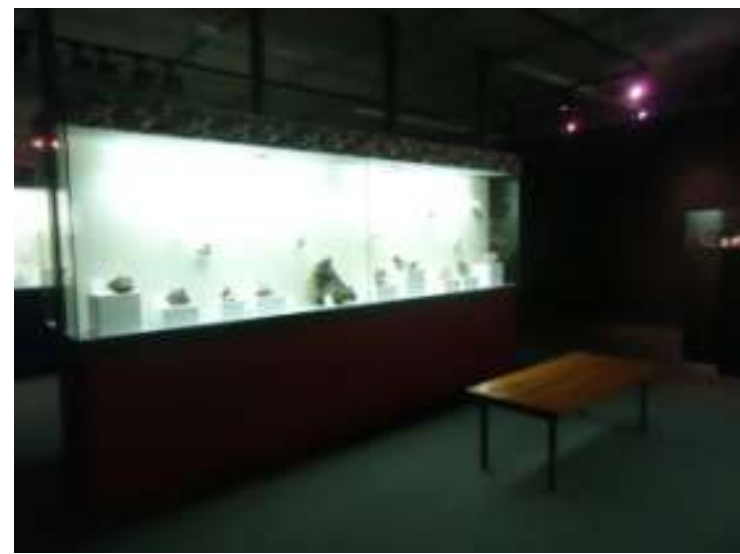

Figura 108. Área da exposição destinada à contemplação, sem caráter científico.

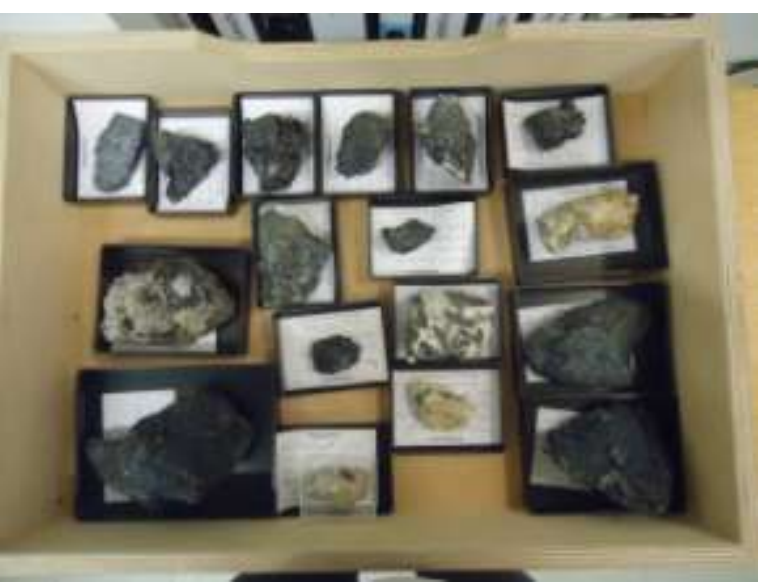

Figura 110. Exemplo de armazenamento de amostras nas gavetas da reserva técnica. 


\subsubsection{7 - Deutsches Edelsteinmuseum}

(Idar-Olberstein - Alemanha)

O Museu Alemão de Gemas é dedicado à apreciação de formas belas de minerais e de obras manuais feitas com esses minerais. Não há, nesse caso, quaisquer preocupações com disposição científica, numeração catalográfica ou organização sistemática. Os minerais são divididos por regiões que mais os produzem, como, por exemplo, as ágatas de Idar-Oberstain e do Brasil, que ocupam todo um ambiente no piso térreo.

Assim como em outros museus visitados, a ausência de informações em inglês e a dissociação entre amostra e legenda são pontos negativos (Figura 111). Não há também neste caso preocupação com a conservação; as amostras não recebem luz natural por questões estéticas, e não de cuidados. Muitos minerais estão sobre suportes inadequados, o que pode causar sua queda e consecutivo prejuízo estético (Figura 112). É possível encontrar também conjuntos de gemas sem identificação, caso das gemas amarelas da Figura 113. O ambiente é próprio para a apreciação de admiradores de gemas, com iluminação direcionada dentro das vitrinas (Figura 114).

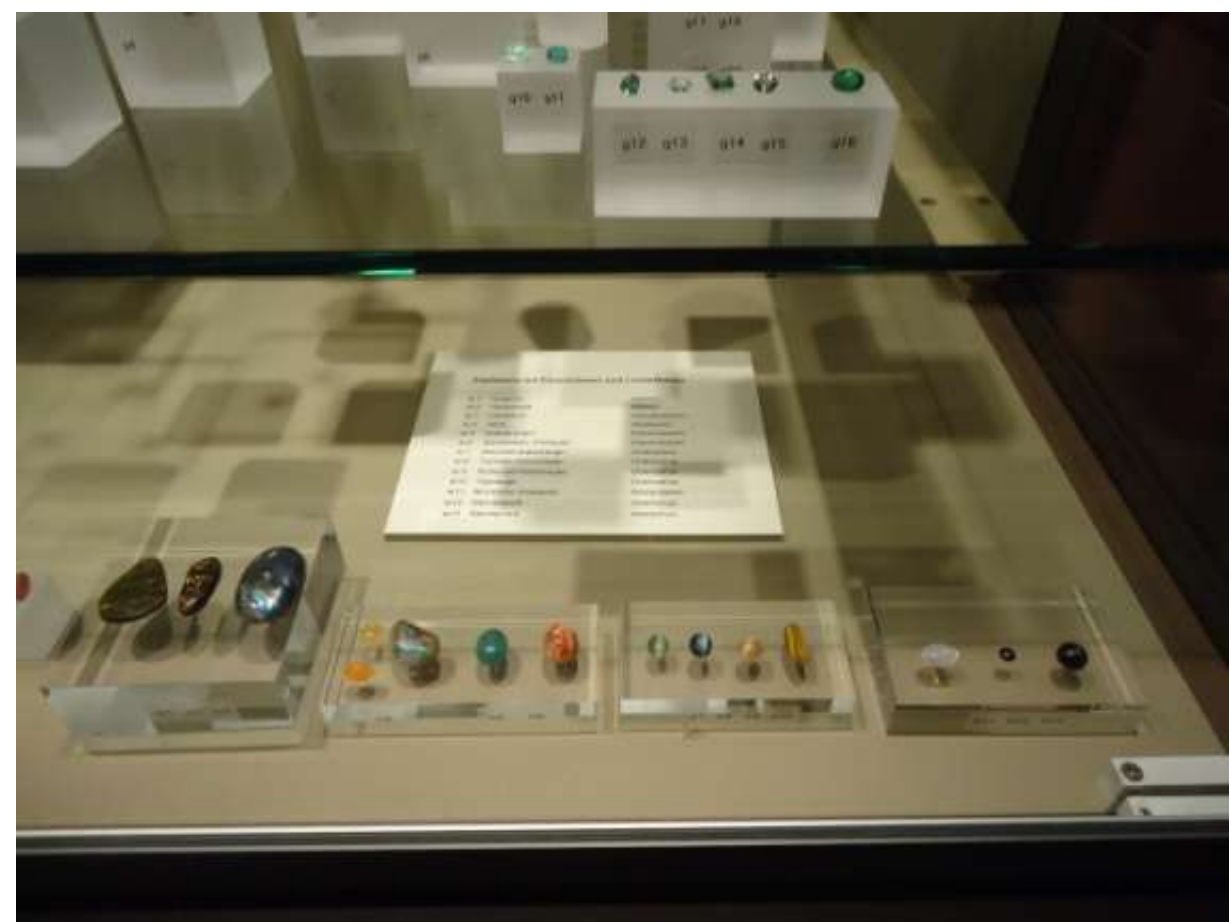

Figura 111. Grande quantidade de amostras pequenas e próximas dificulta a visualização. A distância das legendas causa desinteresse ao público. 


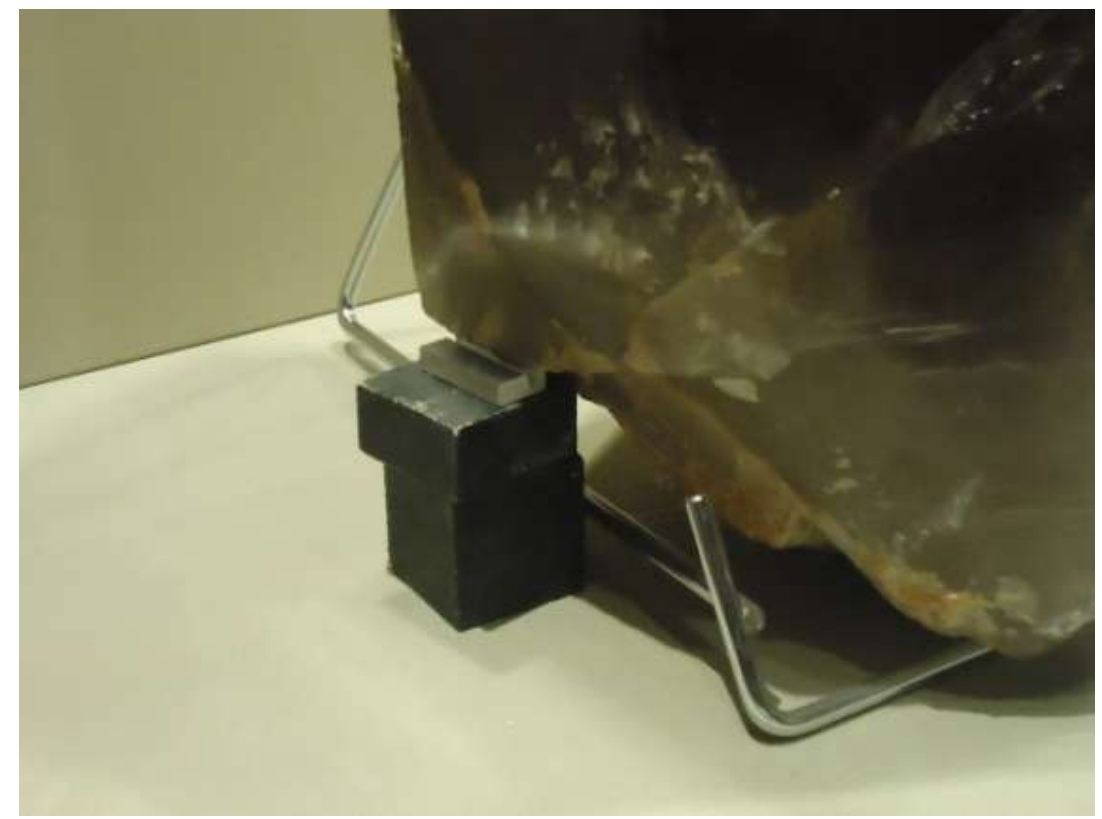

Figura 112. Suporte improvisado para a amostra evidencia a falta de critérios básicos de conservação.

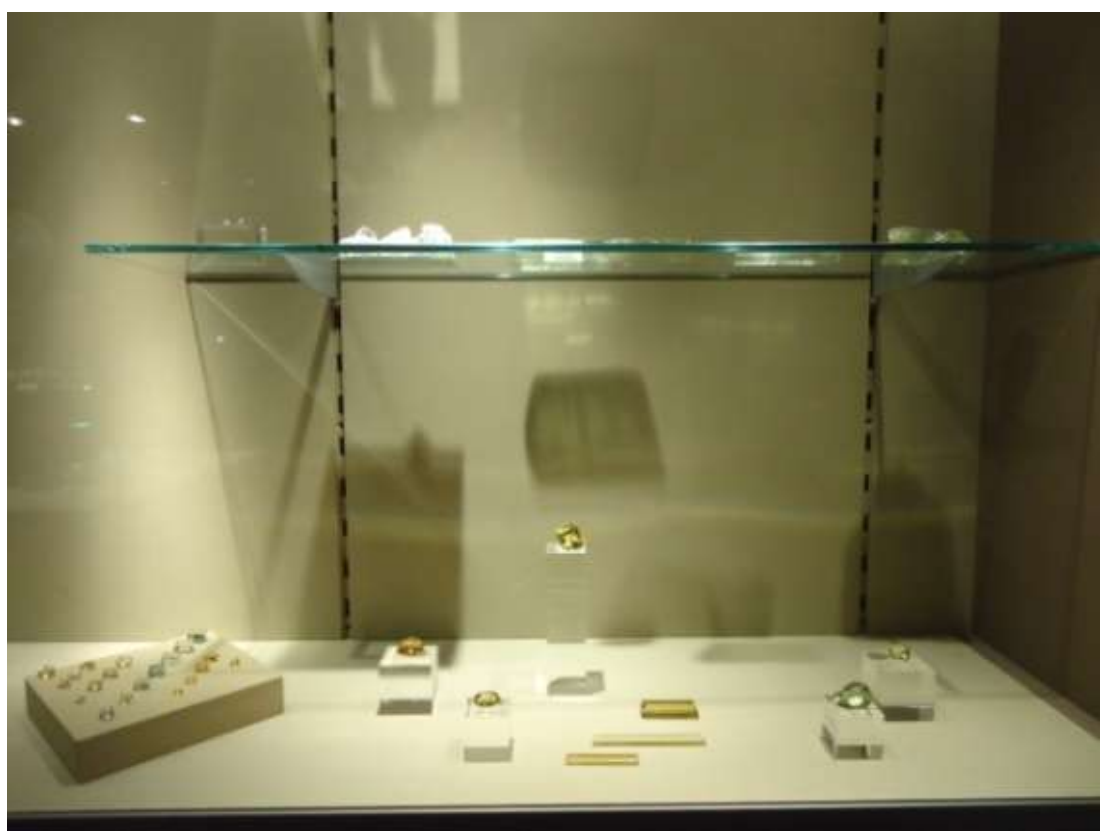

Figura 113. Estas gemas amarelas, possivelmente heliodoro, não possuem qualquer identificação. 


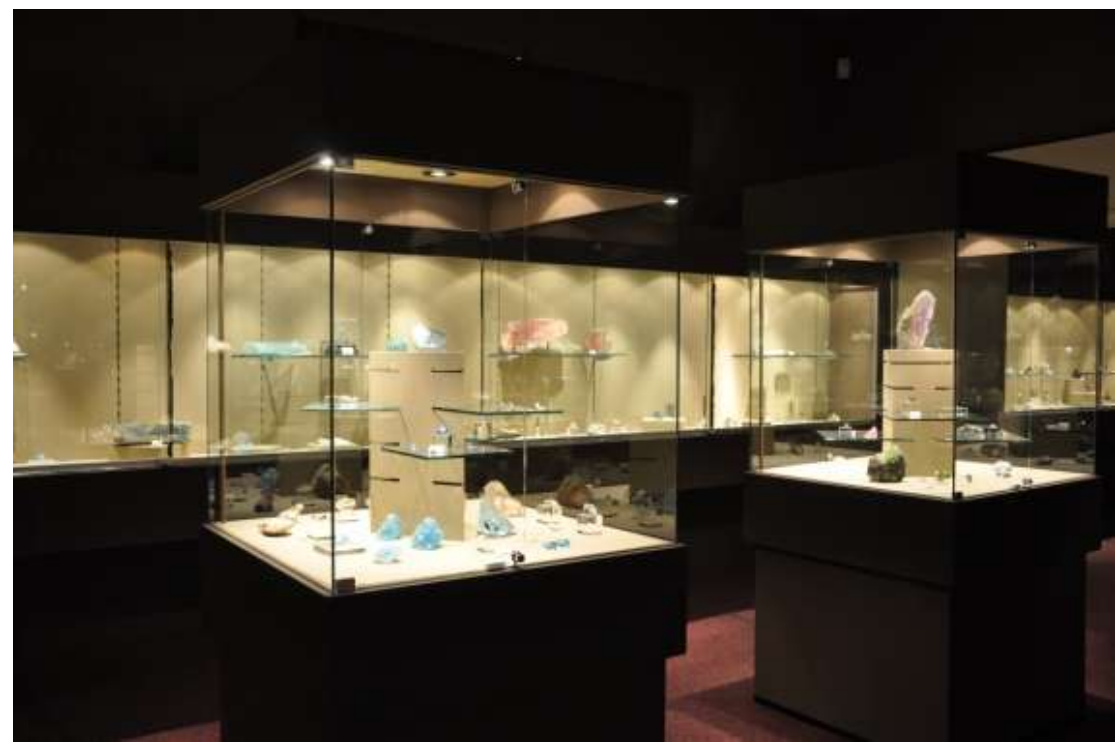

Figura 114. Visão parcial da exposição, com destaque para as vitrinas centrais, com iluminação própria, que valoriza as amostras. Foto: Eliane A. Del Lama.

Dado o exposto, as visitas técnicas aos dezessete museus aqui citados permitem que seja traçado um paralelo entre essas instituições e o Museu de Geociências da USP sob os mais variados aspectos museológicos. Nas exposições puderam ser analisados vários critérios expositivos, recursos didáticos, multimídias e mediação, quando houve. Nas reservas técnicas foram observados ausência ou presença de critérios de conservação, critérios de organização dos minerais e acesso às informações.

Um dado comum a todos os museus, com exceção àqueles localizados em países de língua inglesa, é o fato de que não há legendas bilíngues. Alguns minerais comuns e com nomes parecidos com o português são de fácil identificação (como a fluorita; em inglês fluorite e alemão, fluorit), mas quando não há semelhança entre os nomes, as amostras não podem ser compreendidas por visitantes estrangeiros. Seria indicado que todos os museus (inclusive o Museu de Geociências da USP) utilizassem a língua inglesa como forma de estabelecer uma comunicação mais acessível e efetiva. 


\section{OS MINERAIS E AS CORES}

A cor é uma importante propriedade dos minerais, pois suas variações muitas vezes permitem a distinção entre espécies. As variações de cor nos minerais ocorrem devido a uma série de fatores, não somente à presença de constituintes colorantes intrínsecos, mas também devido à presença de substâncias estranhas à sua composição química, além de fatores físicos, como defeitos na estrutura cristalina.

Existem três principais fatores de mudança de coloração nos minerais: calor, luz e ionização por radiação.

NASSAU (1992) descreve muito bem o paradoxo entre a luz e a cor nos minerais: ao mesmo tempo em que a luz é primordial para que o mineral tenha cor, muitos minerais só preservarão sua cor se estiverem em completa ausência de luz. Esse é o caso comum de muitos minerais de coleção, como a prata, o realgar, a vivianita, entre outros (Figuras 115 a 118). Como a influência da luz sobre os minerais se dá em forma de alteração das cores, este capítulo trata simultaneamente da constituição de cores nos minerais, e do tratamento de espécimes cuja cor é afetada pela luz.

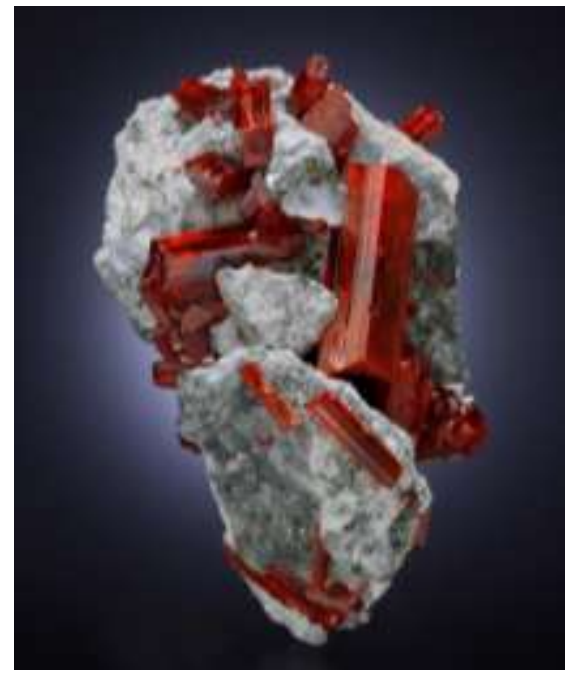

Figura 115. Cristais de realgar com a coloração original (vermelho escuro) preservada. Fonte:

http://www.mindat.org/photo424844.html.Acesso em 08.01.2013.

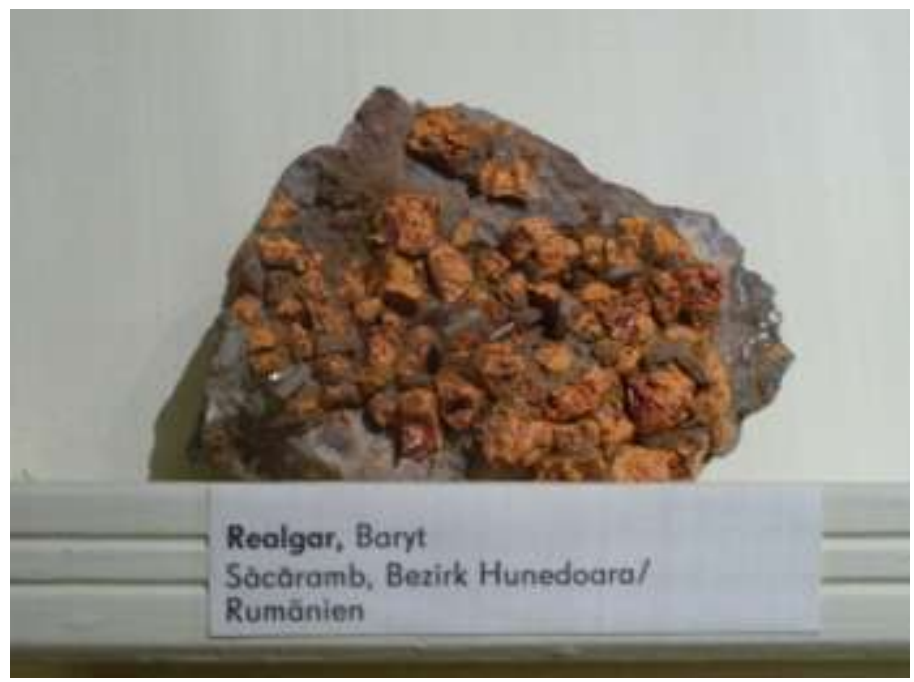

Figura 116. Realgar em estado de alteração avançado, esfacelamento e coloração amarelo ouro devido à ação da luz. Acervo: Museum für Naturkunde Berlin. 


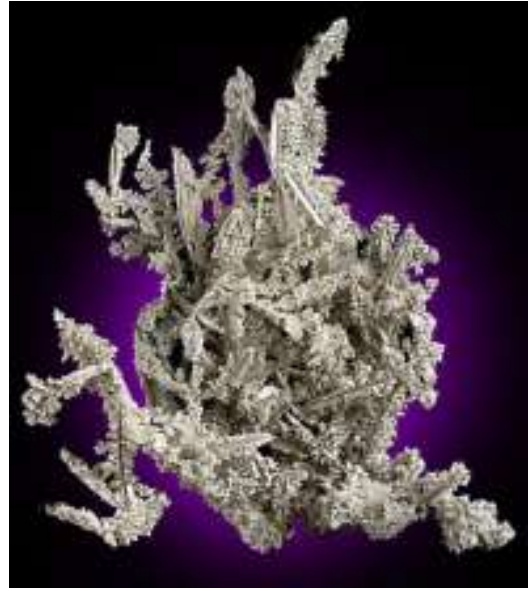

Figura 117. Exemplar de prata nativa. Notase o brilho metálico característico desse mineral. Fonte: http://www.mindat.org/photo813.html (Acesso em 21/11/2012).

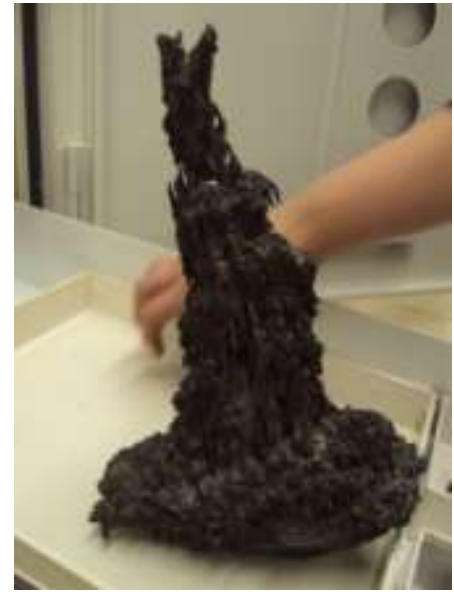

Figura 118. Exemplar de prata nativa, com cobertura preta devido à oxidação do metal, que formou como produto final uma camada de acanthita sobre o mineral. A luz, nesse caso, funciona como catalisadora no processo de oxidação. Acervo: National Museum of Natural History.

Antes de discorrer sobre a influência da luz nos minerais, é necessário identificar como ocorrem as cores nesses compostos, e para tanto, alguns conceitos como luz, luz visível, cor, entre outros, são necessários.

A cor em dado mineral resulta essencialmente da interação da luz com os elétrons dos átomos que o constituem, e representa um agregado de todos os comprimentos de onda não absorvidos por este mineral (HORÁK, 1994). Os átomos presentes na estrutura cristalina dos minerais absorvem certos comprimentos de ondas em detrimento a outros. Os comprimentos de onda não absorvidos chegam aos olhos humanos em forma de cor.

A luz é um tipo de radiação eletromagnética situada no espectro de ondas eletromagnéticas visíveis e não visíveis ao olho humano (Figura 119).

Entende-se por cor o resultado da combinação entre a percepção que o olho humano tem de cada comprimento de onda do espectro visível, o tipo de iluminação a que dado objeto é submetido, e por fim, as características físico-químicas do objeto.

Luz visível é a faixa de comprimentos de onda, dentre todas as ondas do espectro eletromagnético, perceptível ao olho humano (de aproximadamente $380 \mathrm{~nm}$ a $740 \mathrm{~nm}$ ). Assim, o que fisicamente distingue uma cor da outra é o seu comprimento de onda (ou frequência). Na luz visível, a cor vermelha é a de menor frequência, menor energia e maior comprimento de onda; e a cor violeta é a de maior frequência, maior energia e menor comprimento de onda. 


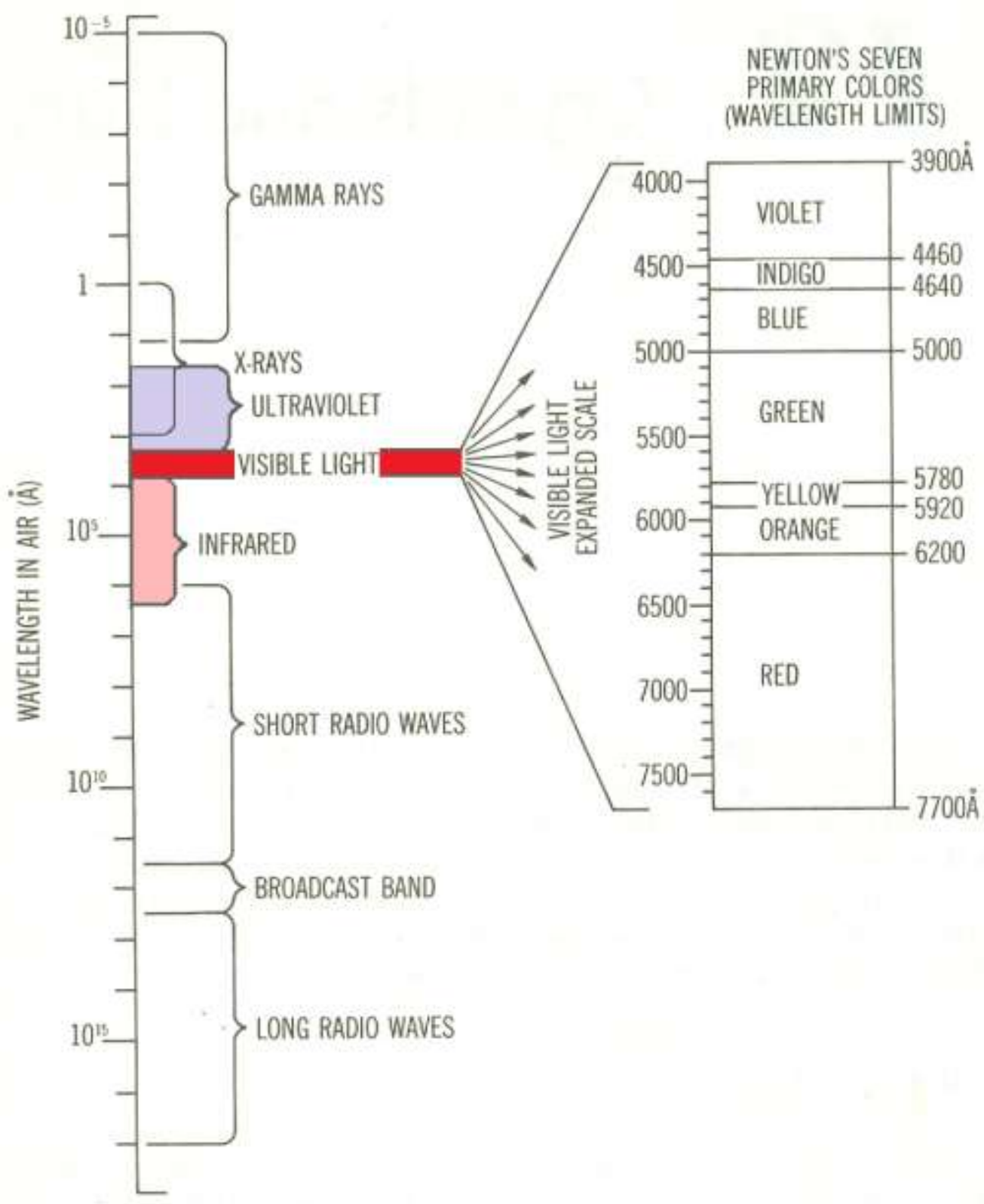

Figura 119. Espectro eletromagnético, com destaque para o espectro da luz visível, em vermelho, os raios ultravioletas, em lilás, e os raios infravermelhos, em rosa. Fonte: BLOSS (1971), modificado.

A quantidade de energia da cor está contida em um fóton, a menor unidade de luz que pode existir sozinha. Quanto maior a energia de um fóton, maior a probabilidade de produção de alguma alteração. Assim, a luz azul será geralmente mais fotoativa que a vermelha, e a radiação ultravioleta é sempre mais ativa que a infravermelha, devido à sua maior frequência.

Com base no espectro da luz visível, foram descritas seis cores espectrais, componentes do espectro visível. São elas: vermelho, alaranjado, amarelo, verde, azul e violeta. A mistura de todas as cores espectrais produz a luz branca.

A frequência corresponde ao número de vibrações do raio luminoso por segundo. A frequência é dada pela razão entre a velocidade da luz e o comprimento de onda. $\mathrm{O}$ comprimento de onda é indicado pela letra grega $\lambda$ e corresponde à relação entre a velocidade 
de propagação da luz e a frequência de vibração do raio luminoso. As medidas de comprimento de onda mais utilizadas são o mícron $(\mu)$, milimícron $(m \mu)$ e o angströn $(\mathrm{A})$. A medida indicada no Sistema Internacional (SI) é o nanômetro (nm).

A equação para o $\lambda$ é:

$$
\lambda=\frac{V}{f}
$$

onde $\lambda$ é o comprimento de onda, $\mathrm{V}$ é a velocidade de propagação da luz no vácuo e $f$ é a frequência do raio luminoso da luz no vácuo.

Como se pode notar pela equação acima, frequência e comprimento de onda são grandezas inversamente proporcionais. Isso é um dado importante para compreender, por exemplo, que os raios infravermelhos têm pouca energia, apesar de terem grande comprimento de onda.

Colorimetria é a expressão das cores em números. O termo foi criado por volta de 1860 por químicos que necessitavam determinar a cor dos líquidos para precisarem as substâncias químicas que eles continham.

Refletância é a luz refletida por determinado objeto, ou seja, sua própria cor, pois todas as outras são absorvidas por ele. Ela é composta pelas refletâncias especular (reflexão da luz em um ângulo oposto ao da luz incidente, em uma superfície lisa) e difusa (reflexão da luz incidente em direções variadas em superfícies rugosas). A componente difusa da luz refletida reage mais intimamente com o material, por isso causa uma sensação de cor mais forte que a componente especular da mesma luz, no mesmo material (NASSAU, 2001).

A fim de medir numericamente as cores nos minerais, são utilizados dois equipamentos: o colorímetro e o espectrofotômetro. O colorímetro faz medições mais simples, pois utiliza sempre a mesma fonte de luz e o mesmo método de iluminação, seja dia ou noite, em ambientes internos ou externos.

Quando a luz incide sobre certo mineral, alguns comprimentos de onda são absorvidos, e outros, refletidos. Os raios de luz refletidos correspondem à própria cor do mineral. O espectrofotômetro mede a quantidade de luz refletida pelo objeto em questão, em cada comprimento de onda do espectro da luz visível, e emite como resultado, além de valores numéricos, gráficos da refletância espectral da cor. Isso permite resultados mais precisos e melhor visualização no que diz respeito à comparação de dados.

O que determina a absorção de certos comprimentos de ondas em detrimento de outros é a interação que os comprimentos de onda da luz incidente terão com os átomos, moléculas e ligações químicas que compõem a estrutura do mineral. 
Se uma luz branca (ou seja, todos os comprimentos de onda do espectro visível) atravessa um cristal sem absorção, o cristal será transparente e incolor. Se toda a luz incidente for absorvida, o mineral será percebido como preto. Se todos os comprimentos de onda forem absorvidos no mesmo grau, a amostra será branca opaca ou cinzenta. Finalmente, se alguns comprimentos de ondas são preferencialmente absorvidos, a combinação do espectro remanescente (ou seja, todos os comprimentos de onda que não foram absorvidos pelo cristal) é percebida como cor.

Quando a radiação eletromagnética entra em contato com o mineral, os comprimentos de onda cuja energia corresponde exatamente à diferença de energia entre os níveis eletrônicos dos átomos, serão absorvidos, resultando na excitação de elétrons de um nível para o outro. Nos minerais coloridos, as diferenças energéticas entre níveis eletrônicos estão no campo da luz visível. Desta forma, quando uma luz branca incide sobre um mineral, certos comprimentos de onda são absorvidos, e, assim, removidos do espectro, causando excitação dos elétrons nesses níveis.

A cor é uma importante propriedade óptica do mineral, talvez a primeira característica observada. Em alguns minerais ela é marcante e serve como forma de distinção daquela espécie. No entanto, para muitos minerais, a cor é variável e, por esta razão, não é uma característica distintiva confiável. Em oposição aos minerais de brilho metálico, que quase não variam em cor, os minerais não metálicos variam em uma gama enorme de tonalidades. Por isso existem poucos minerais cuja coloração pode ser utilizada como diagnóstico confiável da espécie mineral. Tem-se assim, a classificação de minerais idiocromáticos (o mineral apresenta cor característica) e minerais alocromáticos (minerais que não apresentam cor característica).

Minerais idiocromáticos são aqueles nos quais a cor é produzida essencialmente pelos elementos que o formam. Esse é o caso da malaquita $\left(\mathrm{Cu}_{2}\left(\mathrm{CO}_{3}\right)(\mathrm{OH})_{2}\right)$, azurita $\left(\mathrm{Cu}_{3}\left(\mathrm{CO}_{3}\right)_{2}(\mathrm{OH})_{2}\right)$, realgar (AsS) e ouropigmento $\left(\mathrm{As}_{2} \mathrm{~S}_{3}\right)$, entre outros. Metais de transição da tabela periódica $(\mathrm{Cr}, \mathrm{Co}, \mathrm{Cu}, \mathrm{Fe}, \mathrm{Mn}$ e $\mathrm{Ni}$ ), quando comprovadamente responsáveis pela coloração do mineral, são chamados de elementos cromóforos (Tabela 5). A palavra cromóforo é derivada do grego e significa aquilo que causa a cor. "Desta forma, a cor pode ser usada como propriedade diagnóstica apenas quando o elemento causador da cor é essencial para o mineral" (KLEIN \& DUTROW, 2012). Diferentes configurações dos elétrons dos átomos cromóforos permitem que um único elemento produza muitas cores. É o que acontece com o cobre na malaquita (cor verde) e na azurita (cor azul). 
Já os minerais alocromáticos são incolores em sua forma pura, mas a presença de pequenas quantidades de impurezas em sua estrutura molecular (geralmente os mesmos metais de transição citados anteriormente, que ocorrem apenas como traço, vide Tabela 6) ou pequenas imperfeições nas lacunas atômicas são capazes de produzir diferentes colorações. Radiação natural produzida por elementos radioativos é geralmente responsável pela produção de centros de cor nos minerais alocromáticos.

Tabela 5: Elementos cromóforos e as cores nos minerais idiocromáticos. Fonte: NASSAU (1978).

\begin{tabular}{|c|c|c|c|}
\hline Elemento & Cor & Mineral & Fórmula Química \\
\hline Cromo $(\mathrm{Cr})$ & Laranja & Crocoíta & $\mathrm{Pb}\left(\mathrm{CrO}_{4}\right)$ \\
\hline \multirow[t]{6}{*}{ Cobre $(\mathrm{Cu})$} & Azul & Azurita & $\mathrm{Cu}_{3}\left(\mathrm{CO}_{3}\right)_{2}(\mathrm{OH})_{2}$ \\
\hline & & Turquesa & $\mathrm{Cu}\left(\mathrm{Al}, \mathrm{Fe}^{3+}\right)_{6}\left(\mathrm{PO}_{4}\right)_{4}(\mathrm{OH})_{8} \cdot 4 \mathrm{H}_{2} \mathrm{O}$ \\
\hline & & Crisocola & $\mathrm{Cu}_{2-\mathrm{x}} \mathrm{Al}_{\mathrm{x}}\left(\mathrm{H}_{2-\mathrm{x}} \mathrm{Si}_{2} \mathrm{O}_{5}\left(\mathrm{OH}_{4}\right) \cdot n \mathrm{nH}_{2} \mathrm{O}(\mathrm{X}<1)\right.$ \\
\hline & Verde & Dioptásio & $\mathrm{CuSiO}_{3} \cdot \mathrm{H}_{2} \mathrm{O}$ \\
\hline & & Malaquita & $\mathrm{Cu}_{2}\left(\mathrm{CO}_{3}\right)(\mathrm{OH})_{2}$ \\
\hline & Vermelho & Cuprita & $\mathrm{Cu}_{2} \mathrm{O}$ \\
\hline \multirow[t]{4}{*}{ Ferro $(\mathrm{Fe})$} & Azul & Lazulita & $\left(\mathrm{Mn}, \mathrm{Fe}^{2+}\right) \mathrm{Al}_{2}\left(\mathrm{PO}_{4}\right)_{2}(\mathrm{OH})_{2}$ \\
\hline & Verde & Olivina & $\left(\mathrm{Mg}, \mathrm{Fe}^{2+}\right)_{2} \mathrm{SiO}_{4}$ \\
\hline & Vermelho & Almandina & $\mathrm{Fe}_{3}^{2+} \mathrm{Al}_{2}\left(\mathrm{SiO}_{4}\right)_{3}$ \\
\hline & Amarelo & Goethita & $\alpha-\mathrm{Fe}^{3+} \mathrm{O}(\mathrm{OH})$ \\
\hline \multirow[t]{3}{*}{ Manganês (Mn) } & Rosa & Rodocrosita & $\mathrm{MnCO}_{3}$ \\
\hline & & Rodonita & $\mathrm{MnSiO}_{3}$ \\
\hline & Laranja & Espessartita & $\mathrm{Mn}_{3}{ }^{2+} \mathrm{Al}_{2}\left(\mathrm{SiO}_{4}\right)_{3}$ \\
\hline \multirow[t]{2}{*}{ Urânio (Ur) } & Amarelo & Autunita & $\mathrm{Ca}\left(\mathrm{UO}_{2}\right)_{2}\left(\mathrm{PO}_{4}\right)_{2} \cdot 11 \mathrm{H}_{2} \mathrm{O}$ \\
\hline & & Carnotita & $\mathrm{K}_{2}\left(\mathrm{UO}_{2}\right)_{2}\left(\mathrm{VO}_{4}\right)_{2} \cdot 3 \mathrm{H}_{2} \mathrm{O}$ \\
\hline
\end{tabular}


Tabela 6: Minerais alocromáticos coloridos por metais de transição como impurezas. Fonte: NASSAU (1978).

\begin{tabular}{|c|c|c|c|}
\hline Elemento & Cor & Mineral & Fórmula Química \\
\hline Cromo $(\mathrm{Cr})$ & Verde & $\begin{array}{l}\text { Esmeralda } \\
\text { Grossulária } \\
\text { Turmalina com } \\
\text { Cr } \\
\\
\text { Jade }\end{array}$ & $\begin{array}{l}\mathrm{Be}_{3} \mathrm{Al}_{2}\left(\mathrm{Si}_{6} \mathrm{O}_{18}\right) \\
\mathrm{Ca}_{3} \mathrm{Al}_{2}\left(\mathrm{SiO}_{4}\right)_{3} \\
\mathrm{~A}(\mathrm{D})_{3} \mathrm{Cr}_{6}^{3+}\left(\mathrm{Si}_{6} \mathrm{O}_{18}\right)\left(\mathrm{BO}_{3}\right)_{3} \mathrm{X}_{3} \mathrm{Z} \\
\mathrm{A}=\mathrm{Ca}, \mathrm{Na}, \mathrm{K} \\
\mathrm{D}=\mathrm{Al}, \mathrm{Fe}^{2+}, \mathrm{Fe}^{3+}, \mathrm{Li} \mathrm{Mg}^{2+}, \mathrm{Mn}^{2+} \\
\mathrm{X}=\mathrm{O} \text { e/ou OH } \\
\mathrm{Y}=\mathrm{F}, \mathrm{O} \text { e/ou OH } \\
\mathrm{Na}\left(\mathrm{AlFe}^{3+}\right) \mathrm{Si}_{2} \mathrm{O}_{6}\end{array}$ \\
\hline \multirow[t]{2}{*}{ Ferro $(\mathrm{Fe})$} & Verde & Turmalina & $\begin{array}{l}\mathrm{A}(\mathrm{D})_{3} \mathrm{G}_{6}\left(\mathrm{Si}_{6} \mathrm{O}_{18}\right)\left(\mathrm{BO}_{3}\right)_{3} \mathrm{X}_{3} \mathrm{Z} \\
\mathrm{A}=\mathrm{Ca}, \mathrm{Na}, \mathrm{K} \\
\mathrm{D}=\mathrm{Al}, \mathrm{Fe}^{2+}, \mathrm{Fe}^{3+}, \mathrm{Li}, \mathrm{Mg}^{2+}, \mathrm{Mn}^{2+} \\
\mathrm{G}=\mathrm{Al}, \mathrm{Fe}^{3+}, \mathrm{Cr}^{3+}, \mathrm{V}^{3+} \\
\mathrm{X}=\mathrm{O} \text { e/ou OH } \\
\mathrm{Y}=\mathrm{F}, \mathrm{O} \text { e/ou OH }\end{array}$ \\
\hline & Amarelo & $\begin{array}{l}\text { Crisoberilo } \\
\text { Citrino } \\
\text { Ortoclásio }\end{array}$ & $\begin{array}{l}\mathrm{BeAl}_{2} \mathrm{O}_{4} \\
\mathrm{SiO}_{2} \\
\mathrm{KAl}\left(\mathrm{Si}_{3} \mathrm{O}_{8}\right)\end{array}$ \\
\hline Manganês (Mn) & Rosa & $\begin{array}{l}\text { Morganita } \\
\text { Espodumênio } \\
\text { Turmalina }\end{array}$ & $\begin{array}{l}\mathrm{B}_{3} \mathrm{Al}_{2}\left(\mathrm{Si}_{6} \mathrm{O}_{18}\right) \\
\mathrm{LiAl}\left(\mathrm{Si}_{2} \mathrm{O}_{6}\right) \\
\mathrm{A}(\mathrm{D})_{3} \mathrm{G}_{6}\left(\mathrm{Si}_{6} \mathrm{O}_{18}\right)\left(\mathrm{BO}_{3}\right)_{3} \mathrm{X}_{3} \mathrm{Z} \\
\mathrm{A}=\mathrm{Ca}, \mathrm{Na}, \mathrm{K} \\
\mathrm{D}=\mathrm{Al}, \mathrm{Fe}^{2+}, \mathrm{Fe}^{3+}, \mathrm{Li}, \mathrm{Mg}^{2+}, \mathrm{Mn}^{2+} \\
\mathrm{G}=\mathrm{Al}, \mathrm{Fe}^{3+}, \mathrm{Cr}^{3+}, \mathrm{V}^{3+} \\
\mathrm{X}=\mathrm{O} \text { e/ou OH } \\
\mathrm{Y}=\mathrm{F}, \mathrm{O} \text { e/ou OH }\end{array}$ \\
\hline Níquel (Ni) & Verde & Crisoprásio & $\mathrm{SiO}_{2}$ \\
\hline Vanádio (V) & Verde & $\begin{array}{l}\text { Apofilita } \\
\text { Grossulária } \\
\text { Esmeralda com V }\end{array}$ & $\begin{array}{l}\mathrm{KCa}_{4}\left(\mathrm{Si}_{8} \mathrm{O}_{20}\right)(\mathrm{F}, \mathrm{OH}) \cdot 8 \mathrm{H}_{2} \mathrm{O} \\
\mathrm{Ca}_{3} \mathrm{Al}_{2}\left(\mathrm{SiO}_{4}\right)_{3} \\
\mathrm{~B}_{3} \mathrm{Al}_{2}\left(\mathrm{Si}_{6} \mathrm{O}_{18}\right)\end{array}$ \\
\hline
\end{tabular}

De acordo com NASSAU (2001), existem quinze causas para o aparecimento da cor, dez delas aplicáveis aos minerais.

Neste trabalho serão apresentados quatro processos mais relevantes para a formação da cor nos minerais, sendo três tipos de processos eletrônicos (transições de campo cristalino, transição de orbitais moleculares e centros de cor) e um processo físico (impurezas sólidas). 


\section{1 - Transições do Campo Cristalino}

$\mathrm{Na}$ estrutura cristalina, as cargas negativas dos íons coordenados criam um campo eletrônico sobre o íon central do metal de transição. Este campo eletrônico que é formado, chamado de campo cristalino, possui forma e simetria específicas, como resultado do número de ânions, sua distância com relação ao cátion e suas cargas.

As transições de campo cristalino são transições de elétrons entre os orbitais $3 d$ parcialmente preenchidos dos elementos de transição ( $\mathrm{Ti}, \mathrm{V}, \mathrm{Cr}, \mathrm{Mn}, \mathrm{Fe}, \mathrm{Co}, \mathrm{Ni}$ e $\mathrm{Cu}$ ) ou orbitais $4 d$ parcialmente preenchidos dos lantanídeos e actinídeos (Família 3 da tabela periódica). Desses elementos, o Fe é o mais abundante na crosta terrestre, razão pela qual é o elemento responsável pela cor na maioria dos minerais (KLEIN \& DUTROW, 2012).

Os elétrons instáveis do orbital $3 d$ podem ser excitados pela energia dos raios do espectro visível. Essas transições eletrônicas são a base para a formação da cor. Pode-se entender esse mecanismo utilizando-se do contraste com os gases nobres, naturalmente estáveis. Neles não há essa transição energética, portanto, são todos incolores.

Um campo cristalino qualquer, com o orbital $d$ parcialmente preenchido, divide-se em dois diferentes níveis de energia, o nível de base (ground state, o estado de menor energia iônica, momento em que o íon não está interagindo eletricamente com nenhum tipo de energia) e o estado de excitação (estado no qual o íon está em seu alto nível energético). Essa diferença energética $(\Delta \mathrm{E})$ corresponde a comprimentos de ondas de fótons no campo da luz visível. Assim, tem-se a presença da cor.

As interações de campo cristalino podem ocorrer devido a alguns fatores: a geometria exata do espaço onde o elemento de transição está hospedado; a força do campo cristalino (tipos de ligação química) e a maneira como o olho humano interpreta os padrões de transmissão dos comprimentos de onda.

Alguns dos minerais que têm sua cor devido a interações de campo cristalino são berilo (esmeralda e morganita), coríndon (rubi), turmalina (rubelita), granada (espessartita, andradita e alamandina), crisoberilo, turquesa e olivina (peridoto).

Tanto o coríndon $\left(\mathrm{Al}_{2} \mathrm{O}_{3}\right)$ quanto o berilo $\left(\mathrm{Be}_{3} \mathrm{Al}_{2} \mathrm{Si}_{6} \mathrm{O}_{18}\right)$ são incolores quando sua composição química corresponde à fórmula ideal, já que não possuem nenhum elemento de transição em sua composição química. Em ambos os casos os octaedros de $\mathrm{Al}^{3+}$ podem ser substituídos por $\mathrm{Cr}^{3+}$, causando divisão de campo cristalino com dois picos de absorção no espectro, que produz a variedade verde do berilo (esmeralda) e a variedade vermelha do córindon (rubi). 
No caso do rubi, as ligações são predominantemente iônicas, por isso a divisão do campo cristalino é mais forte. A separação causa absorção com um pico no violeta e o outro no amarelo. Subtraindo essas duas cores do espectro branco sobra vermelho, laranja e azul, cores entre as quais transita o vermelho típico do rubi.

$\mathrm{Na}$ esmeralda, como em todos os silicatos, a ligação química predominante é a iônicacovalente, e, assim como no rubi, o $\mathrm{Cr}^{3+}$ substitui o $\mathrm{Al}^{3+}$. No entanto, a divisão do campo cristalino é mais fraca que no coríndon (pois na esmeralda há ligações covalentes e no coríndon, não). Assim, as bandas de absorção são substituídas em direção a níveis mais baixos de energia. Comprimentos de ondas mais altos, com picos no azul e laranja, resultam na cor verde da esmeralda. A quantidade de elementos de transição presentes influencia na intensidade da cor. Por isso, quanto mais cromo presente, mais forte será o verde da esmeralda.

\section{2 - Transições de Orbitais Moleculares (ou transições de transferência de carga)}

As transições de orbitais moleculares ou de tranferência de carga ocorrem se a valência dos elétrons for transferida para cátions adjacentes que tenham cargas variáveis, compartilhando orbitais. Um elétron que está numa dada posição, absorve radiação e ganha energia. Essa energia absorvida permite que o elétron ocupe o lugar dos elétrons com nível de energia mais alto. Quando essa energia é perdida, o elétron volta ao seu nível inicial.

Quando um elétron muda para uma posição já ocupada por outro, os dois se repelem, e por isso ficam continuamente mudando de lugar, o que confere formas geométricas diferentes aos átomos. Esse lugar confere ora uma carga, ora outra carga ao átomo. Isso faz com que as mudanças de valência ocorram. As mais comuns são: $\mathrm{Fe}^{2+}$ para $\mathrm{Fe}^{3+}$ (e vice-versa) e $\mathrm{Fe}^{2+}$ para $\mathrm{Ti}^{4+}$ (e vice-versa).

A energia absorvida nesse processo reversível corresponde a fótons de comprimentos de onda do espectro da luz visível e é típico dos minerais com tonalidade azul intensa, como glaucofânio (anfibólio azul), crocidolita, cianita (variedade azul) e safira (variedade azul do córindon).

Nesses casos, os elementos cromóforos ocorrem apenas como traços, em quantidades mínimas suficientes para causar a cor nos minerais, mas não para constituir sua fórmula química. 


\section{3 - Centros de Cor}

Em alguns minerais, a cor é causada por defeitos na estrutura cristalina do mineral, mais comumente vacâncias ou impurezas intersticiais. Esses defeitos são chamados de centros de cor.

Tais defeitos podem ser elétrons em excesso, livres de qualquer átomo, ou presos em algum defeito estrutural, como a falta de um íon ou impurezas intersticiais. O oposto também ocorre e a ausência de elétrons tem o mesmo efeito. Esses defeitos são conhecidos como Centros de Cor e são causados basicamente por três fatores:

- $\quad$ pela exposição do mineral a altos níveis de radiação;

- $\quad$ pela alta quantidade de cátions no ambiente durante o crescimento cristalino;

- $\quad$ pela remoção de íons do cristal por aplicação de campo eletrônico.

Em certo mineral, um elétron ${ }^{11}$ pode ser expulso do seu local inicial por alta quantidade de radiação, ou há ausência de elétrons devido à alta quantidade do cátion correspondente durante o crescimento do cristal. Essa vacância pode ser preenchida por um elétron qualquer, para que se mantenha o equilíbrio. Esse novo elétron é controlado pelos outros que o rodeiam e pode estar em qualquer nível de energia. O movimento desses elétrons por diferentes orbitais pode provocar absorção de cores ou até mesmo fluorescência.

Existem dois defeitos de estrutura cristalina mais conhecidos como responsáveis pelos centros de cor, o defeito de Frenkel e o defeito de Schottky (Figura 120).

No defeito de Frenkel os íons são desalojados de seu sítio habitual devido às vibrações térmicas e migram para outro local na estrutura, onde normalmente não haveria íons. Assim, tem-se contraditoriamente dois defeitos em uma única estrutura cristalina: vacância e excedente de íons, que podem ser tanto negativos quanto positivos. Este tipo de defeito é decorrente de alterações térmicas.

Já no defeito de Schottky, há dois íons vacantes, um par positivo-negativo na busca pelo equilíbrio local, removidos de diferentes sítios da estrutura cristalina para a superfície do cristal, criando lacunas na estrutura.

Ambos os defeitos são possíveis porque não importa para onde os elétrons se movam dentro da estrutura cristalina, desde que esta mantenha-se sempre com a carga total neutra (NASSAU, 2001).

\footnotetext{
${ }^{11}$ É necessário pensar na estrutura mineral ao nível da cela unitária; é a repetição dos eventos atômicos que ocorrem nas celas que resultará na cor final do mineral.
} 


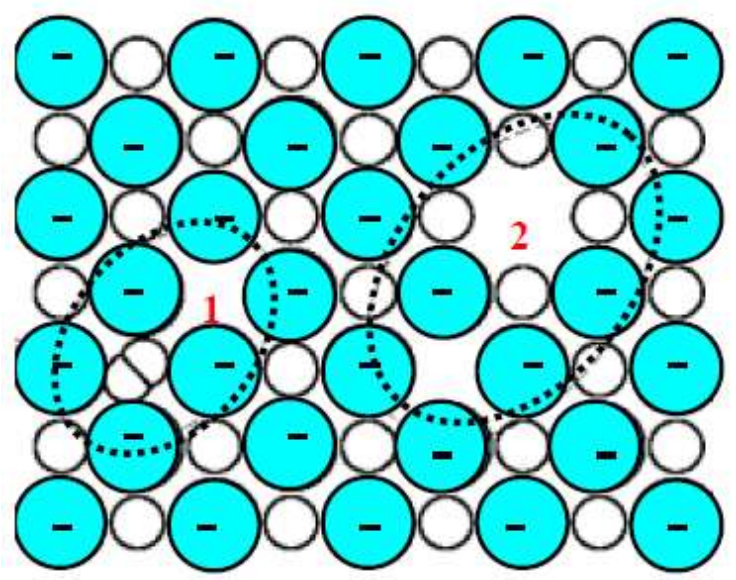

Figura 120. Os dois principais defeitos causadores de centros de cor: O número1, Frenkel, mostra um par de íons que se desloca do sítio original e acomoda-se em um interstício; O número 2, Schottky, mostra o deslocamento de um par de íons com cargas opostas, que se deslocam de seus sítios originais para a superficie do cristal, deixando lacunas na estrutura. ZHIGILEI, $L$. V. Fonte: http://people.virginia.edu/ lz2n/mse201/mse201-defects.pdf(acesso em 22/11/2012).

A maior parte dos minerais coloridos devido a centros de cor são estáveis à luz e somente alteram sua cor quando aquecidos. Outros, que particularmente interessam neste trabalho, possuem centros de cor instáveis e perdem sua coloração quando expostos à luz por tempo prolongado. Centros de cor podem ser induzidos artificialmente por aquecimento, caso da coloração artificial de diamantes verdes, amarelos e azuis. Os centros de cor são responsáveis pelas tonalidades fumê, violeta e amarela do quartzo e pela cor púrpura da fluorita.

\section{4 - Mistura Mecânica de Impurezas}

Além de processos de instabilidade eletrônica vistos anteriormente, a mistura de impurezas ocorre quando um mineral, normalmente incolor, é misturado com impurezas de outros minerais durante seu processo de formação. Um exemplo é o quartzo verde, tingido por resíduos de clorita dispersos no ambiente de formação. Outro exemplo é a hematita, um dos minerais mais conhecidos por sua larga utilização como pigmento ao longo da História, é responsável pela coloração de alguns tipos de jaspe, feldspato e calcita. Uma vez que se trata de um processo ocasional, a cor desses minerais não pode ser tomada como propriedade diagnóstica.

Uma relação completa das dez possíveis causa da ocorrência de cor nos minerais pode ser encontrada em NASSAU (2001).

A Tabela 7 discrimina a causa de cor de alguns minerais. 
Tabela 7. Causa da cor em alguns minerais comuns em coleções. Fonte: NASSAU (1978).

\begin{tabular}{l|l}
\hline CAUSA DA COR & MINERAL \\
\hline Centro de Cor & $\begin{array}{l}\text { Ametista, quartzo fumê, topázio azul, fluorita, } \\
\text { halita (azul e amarela) }\end{array}$ \\
Transições de Transferência de Carga & $\begin{array}{l}\text { Safira azul, tanzanita, cianita (azul), crocoíta, } \\
\text { lazurita e vivianita } \\
\text { Azurita, rubi }\end{array}$ \\
Mistura Mecânica de Impurezas & Quartzo verde \\
\hline
\end{tabular}

Além das cores, a luz é responsável por outros fenômenos, tais como luminescência, fluorescência, fosforescência, chatoyance, asterismo, entre outros.

A fluorescência tem esse nome porque o fenômeno foi primeiramente observado na fluorita, apesar de também ocorrer em outros minerais quando são submetidos à radiação ultravioleta - UV (Figuras 121a e 121b). Esses minerais reemitem a radiação aplicada neles em forma de luz do espectro visível. Esse termo é usado genericamente em casos de emissão de radiação eletromagnética, produzido por transição energética, não só no espectro visível. A fluorescência é um tipo especial de luminescência, no qual a transição de energia ocorre por radiação eletromagnética incidental. Outras causas de luminescência são: reações químicas, decaimento radioativo e corrente elétrica.

É comum haver confusão entre os termos fluorescência e fosforescência. Esses fenômenos diferem apenas no tempo em que o elétron demora para retornar ao nível de base. $\mathrm{Na}$ fluorescência, níveis de energia mais baixos, que ficam vacantes durante a excitação dos elétrons, são preenchidos em frações de segundos. Já na fosforescência, o material pode continuar retransmitindo energia até horas após o término da incidência de radiação (KLEIN \& DUTROW, 2012). Uma vez que o processo de reposição eletrônica configura absorção de radiação eletromagnética, quando os elétrons retornam aos seus estágios iniciais, eles emitem radiação. Essa radiação emitida pelos elétrons é sempre de menor energia que a emitida para desalojá-los ao nível mais alto, no estado de excitação. A energia emitida pelo elétron em seu retorno tem um comprimento de onda específico, correspondendo à diferença entre a energia no estado de excitação e no estado inicial. Os elementos U, Cr, Mn e W são ativadores de fluorescência; já os elementos Fe, Co e Ni inibem-na. 


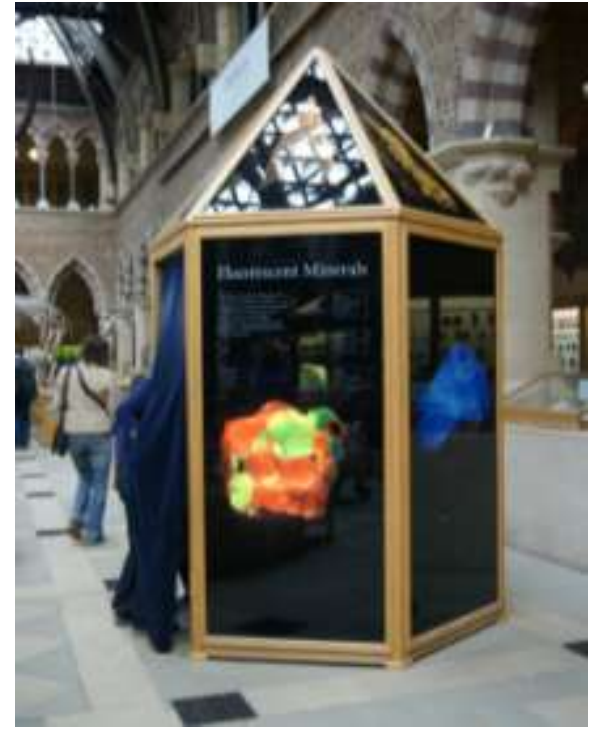

Figura 121a. Cabine de exposição para minerais fluorescentes no Museu de História Natural da Universidade de Oxford.

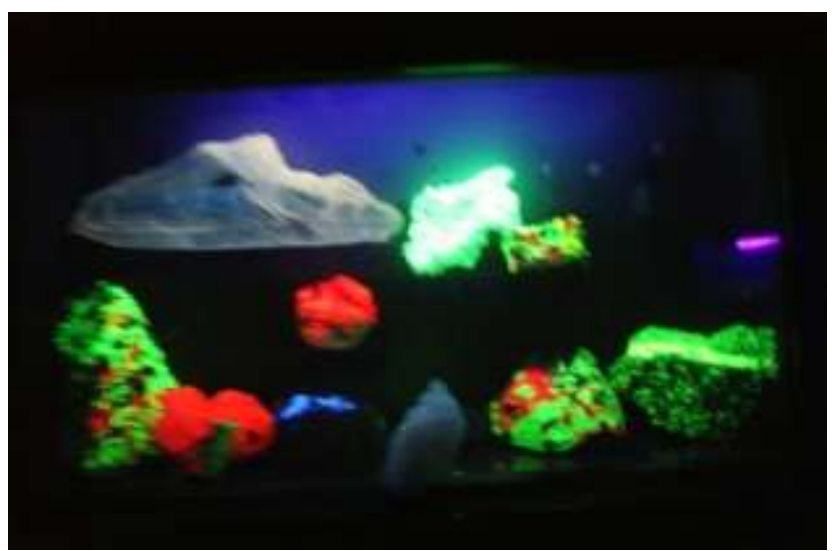

Figura 121b. Minerais sob luz UV demonstrando a propriedade de fluorescência no interior da cabine ao lado. Museu de História Natural da Universidade de Oxford.

Sob ação da luz, alguns minerais têm aparência sedosa, que resulta da forma paralelamente compacta das fibras ou de arranjos paralelos de inclusões ou cavidades. Quando uma gema é lapidada em forma de cabochão, ela mostra uma faixa de luz em ângulos retos com o comprimento das fibras ou a direção das inclusões. A esse fenômeno dá-se o nome de Chatoyance (Figura 122), ou efeito olho de gato, já que tal característica é observada no mineral olho de gato (variedade gemológica do crisoberilo) e no olho de tigre (crocidolita fibrosa preenchida por quartzo).

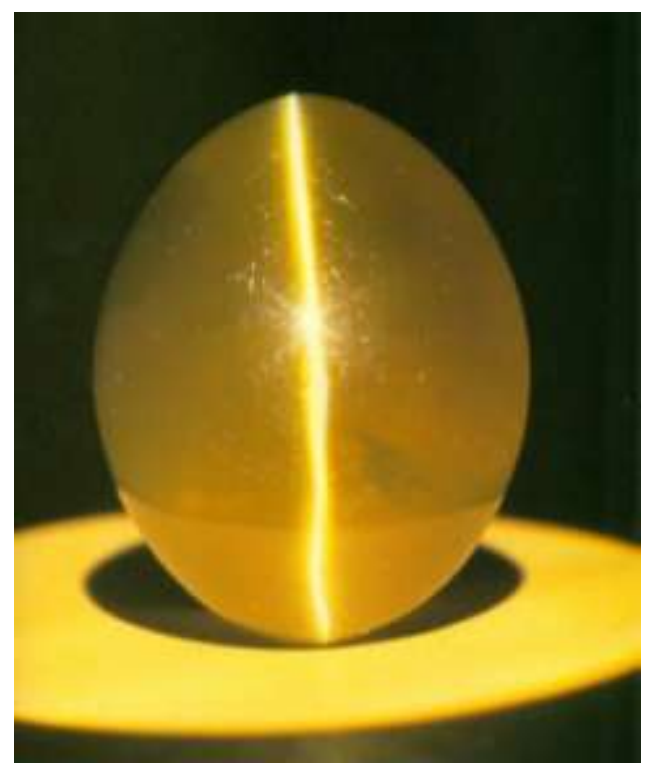

Figura 122. Amostra de crisoberilo amarelo (Olho de Gato) com chatoyance (POST, 1997). 
Em alguns cristais, mais comumente do sistema hexagonal, as inclusões podem ser arranjadas em três direções cristalográficas de $120^{\circ}$ uma da outra. Um cabochão lapidado de um mineral como este apresenta um efeito de tripla chatoyance chamado de asterismo (Figura 123). Este fenômeno pode ser observado em rubi e safira estrelados ou quartzo rosa, originado pela inclusão de rutilo em três direções cristalográficas preferenciais.

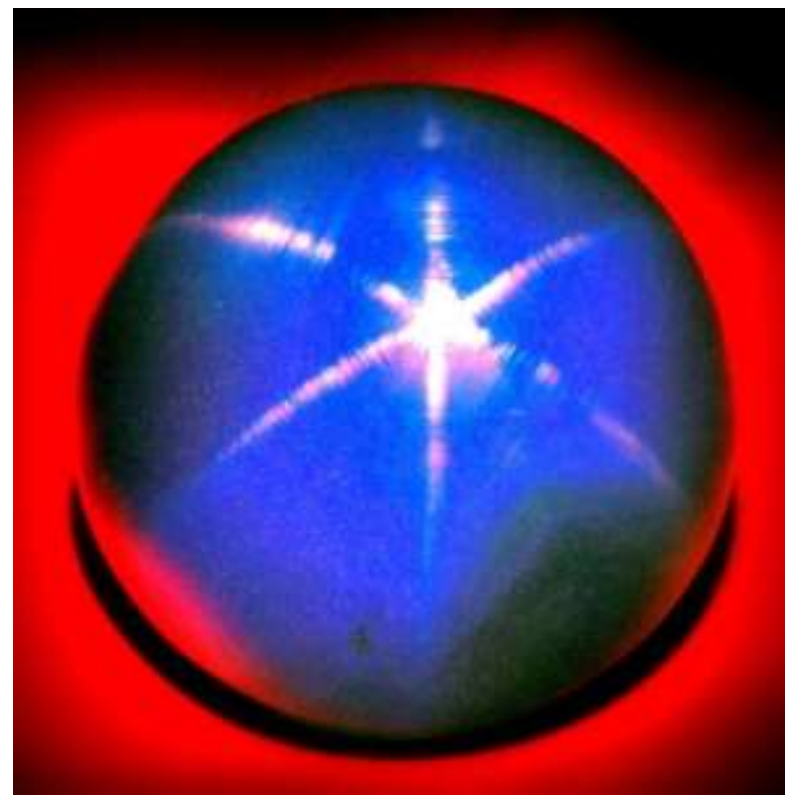

Figura 123. Amostra de safira astérica, com efeito de tripla chatoyance ou asterismo (POST, 1997).

\section{1 - Experimento com espectrofotômetro}

Duas das muitas tentativas em qualificar as cores numericamente deram origem aos sistemas de cor utilizados atualmente e importantes para o experimento realizado.

A.H. Munsell (1905) classificou as cores de acordo com três parâmetros: tonalidade, luminosidade e saturação. A partir da atualização desses parâmetros foi desenvolvido o Sistema de Notação Munsell, utilizado até hoje.

A Comission Internacionale d'Eclairage (CIE) é uma organização internacional dedicada ao estudo da luz e da cor. Em 1931, foi divulgada a criação dos espaços de cor Yxy (baseados em valores tristímulos XYZ, que indicam a composição da cor observada) e em 1976 foi criado o espaço tridimensional L*a*b*. Nesse sistema, classifica-se cor de acordo com os critérios de tonalidade (vermelho, amarelo, azul, etc...), de claridade (claro ou escuro) e de saturação (pureza das cores). Esse sistema, conhecido por CIELa*b*, é o mais utilizado atualmente.

No sistema CIELa*b*:

- L* é a escala que representa luminosidade (brilho) e varia entre preto (zero) e branco (100); 
- a* e b* são coordenadas cromáticas (matiz e saturação);

- $\mathrm{a}^{*}$ - varia entre vermelho (valores positivos) e verde (valores negativos);

- b* - varia entre amarelo (valores positivos) e azul (valores negativos);

O experimento com espectrofotômetro pretendeu demonstrar a aplicação dos estudos sobre teoria de cores e utilização de procedimentos de medição de cores nos minerais. Para correta medição e interpretação numérica da cor, é necessário que se padronizem os três elementos envolvidos na percepção da cor: o observador (definido como observador de $10^{\circ}$ em 1964), o tipo de luz incidente (fluorescente, incandescente ou luz do dia) e o objeto.

Para a realização da medição utilizou-se um espectrofotômetro da marca Kônica Minolta CM 2500, com diâmetro de abertura de $8 \mathrm{~mm}$. As condições de medida foram fixadas em iluminante D65 (luz do dia, incluindo a região do espectro ultravioleta), componente especular incluso e excluso e observador a $10^{\circ}$. Os dados foram tratados com o software OnColor version 5.4.5.1. É importante dizer que o aparelho funciona bem em superfícies planas, por isso foram escolhidas amostras de cristais ou minerais que tivessem faces planas. A sequência de imagens mostradas na Figura 124 representa o modo como a luz é medida no espectrofotômetro.

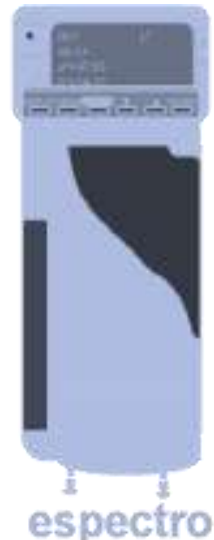

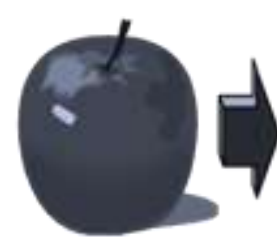

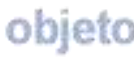

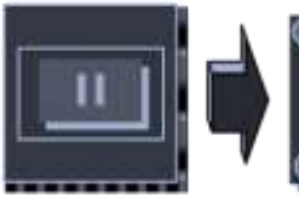

sensor

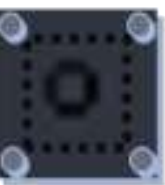

micro-

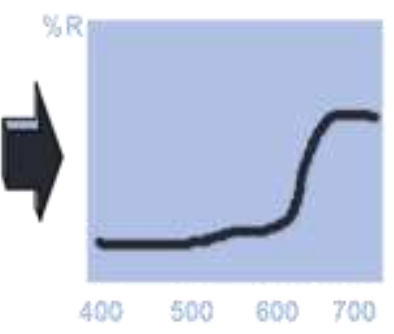

curva

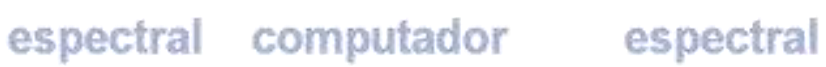

Figura 124. Processo de medição da refletância de um objeto pelo espectrofotômetro: o aparelho é colocado encostado em uma superfície plana do objeto. Ao ser acionado, o equipamento dispara um sensor espectral, que vai decifrar os comprimentos de onda de acordo com a reflexão. Um microcomputador dentro do aparelho traduz essa leitura em linguagem numérica e gera um gráfico, produto final do aparelho. Fonte: Konica Minolta, 2001. 
O experimento em questão consistiu na análise da medição de cor de minerais que foram colocados em ambiente externo, expostos aos efeitos da luz solar. Foram realizadas medições mensais em sete amostras de minerais: duas ametista, duas calcita, uma fluorita, um espodumênio e uma lepidolita. Para fins de identificação, os dois minerais que se repetem foram nomeados de ametista grande (o maior exemplar), ametista média (o menor exemplar), calcita grande e calcita pequena.

As amostras foram posicionadas em ambiente externo (Figuras 125 e 126) para que se pudesse verificar alteração cromática devido à incidência de luz solar. O objetivo foi estimar o tempo que os minerais levariam até começar a ocorrer alterações cromáticas.

Antes das amostras serem colocadas no local escolhido, foram feitas as primeiras medidas de cada uma das amostras, que foram tomadas como medidas padrão.

As amostras foram então posicionadas no local escolhido e após trinta dias foi feita a segunda medição, e assim sucessivamente, até completar quatro medidas. Com a utilização do espectrofotômetro foram realizadas mensalmente trinta medidas de cada amostra (Figura 127 e 128). A média dessas trinta medidas foi comparada com a média dos outros meses para verificar se houve ou não alteração de cor no mineral.

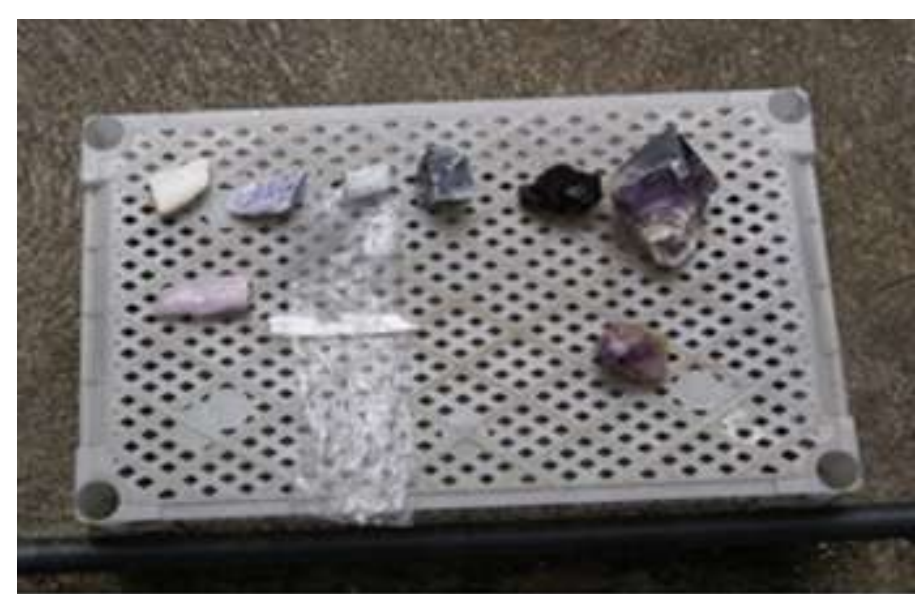

Figura 125. Os minerais foram colocados sobre uma caixa de plástico.

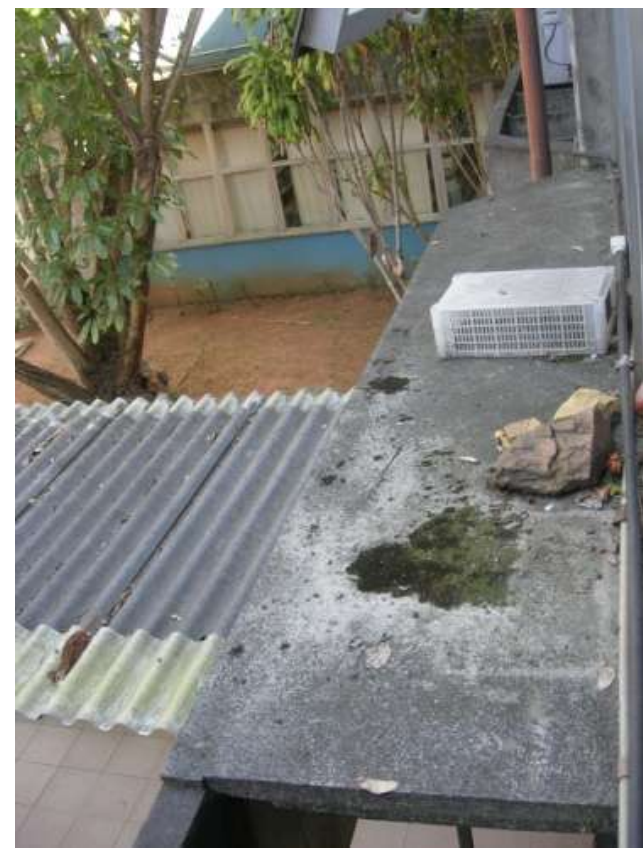

Figura 126. A caixa foi posicionada em um ambiente externo, em exposição direta à luz solar. 


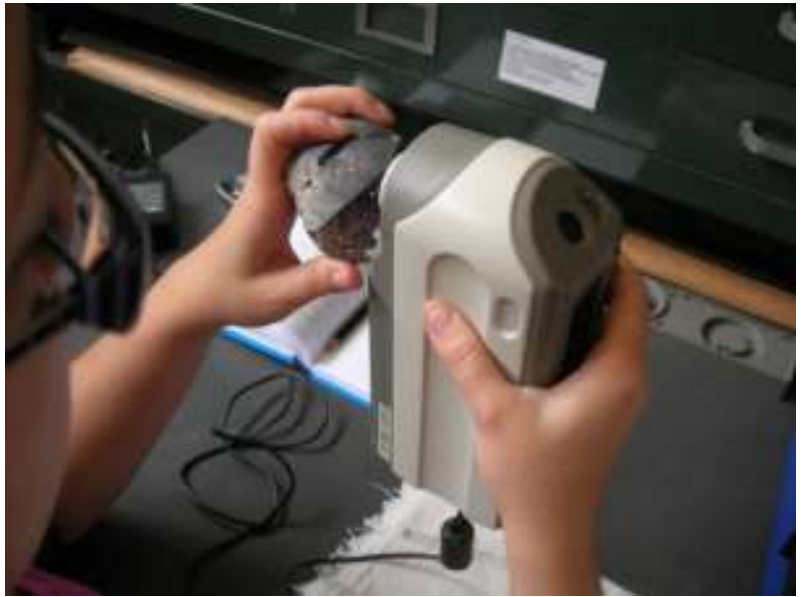

Figura 127. Medições realizadas sempre na mesma face do mineral.

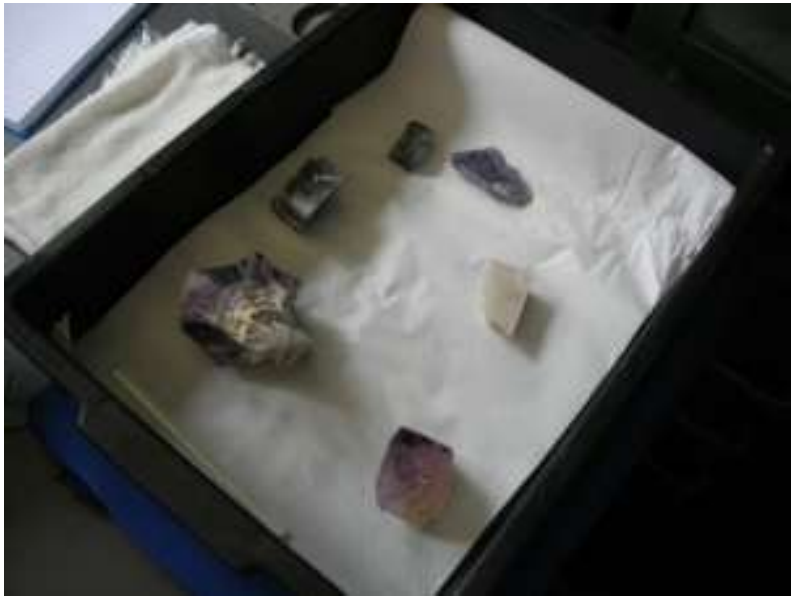

Figura 128. Após as medições, os minerais eram recolocados na caixa, sempre com a mesma face voltada para cima.

É importante ressaltar que o espectrofotômetro é um aparelho preciso na medição de minerais opacos. Minerais translúcidos ou transparentes, caso do presente experimento, irão inevitavelmente sofrer alterações de medida, pois há fuga de luz no momento da medição.

\subsection{1 - Resultados}

Os resultados dos experimentos estão apresentados em gráficos que exprimem a refletância em porcentagem (eixo Y) e os comprimentos de onda do espectro visível (eixo X). Quanto maior a refletância da amostra, menos escura ela será. Gráficos com linhas retas ao invés de curvas com picos em alguns comprimentos de onda indicam absorção uniforme dos comprimentos de onda do espectro visível. Na ocasião dos experimentos foi considerada a luz incidente sobre a amostra. No entanto, a variável calor, à qual a amostra também foi submetida (impossível considerar a luz do sol sem calor), não foi contemplada nos resultados, devido à impossibilidade de ser medida.

\subsubsection{1 - Ametista grande}

A amostra selecionada apresenta faces de pirâmide bem formadas, adequadas à realização de medições, cor roxa escura nas faces e clareamento gradual da cor em direção à base do cristal (Figura 129). 


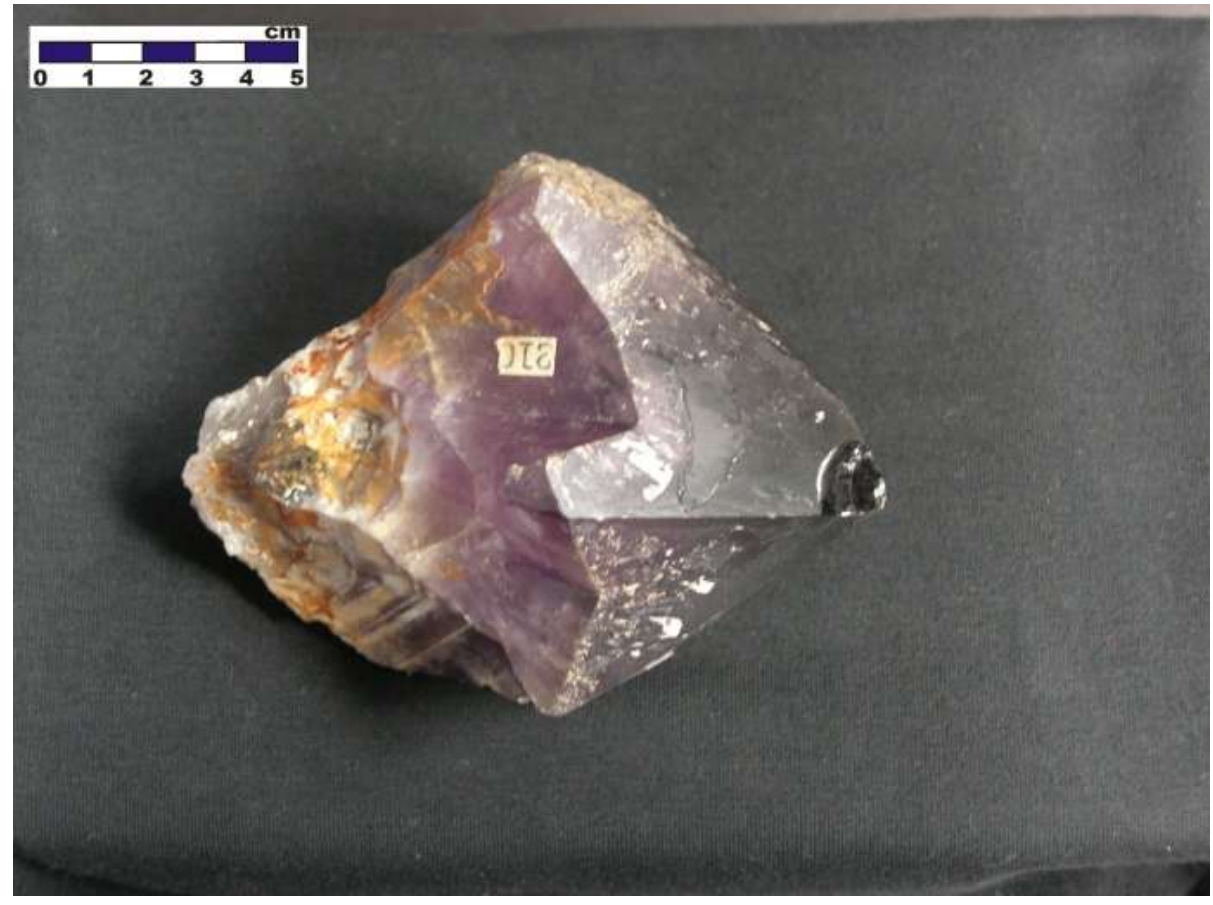

Figura 129. Ametista grande. Acervo: Museu de Geociências da USP.

Observou-se, pelos gráficos, que nesta amostra não ocorreu alteração de cor significativa no período entre os meses de agosto a outubro. Entre os meses de outubro e novembro nota-se que houve diminuição no pico de reflexão da cor roxa, bem como na linha da refletância geral. Tais dados demonstram que a amostra só começou a perder a coloração após três meses de exposição ao sol, por isso o experimento não registrou mudanças significativas de cor.

É importante considerar que a amostra começou a ser exposta à luminosidade mais fraca nos meses de agosto e setembro, pois era inverno. Somente após o início de novembro as amostras estiveram expostas à luz solar de maior radiação. Tal fato contribuiu para que a perda de refletância total e de coloração fosse acentuada no último mês de análise.

A Figura 130 mostra a evolução mensal da refletância da amostra de ametista. 


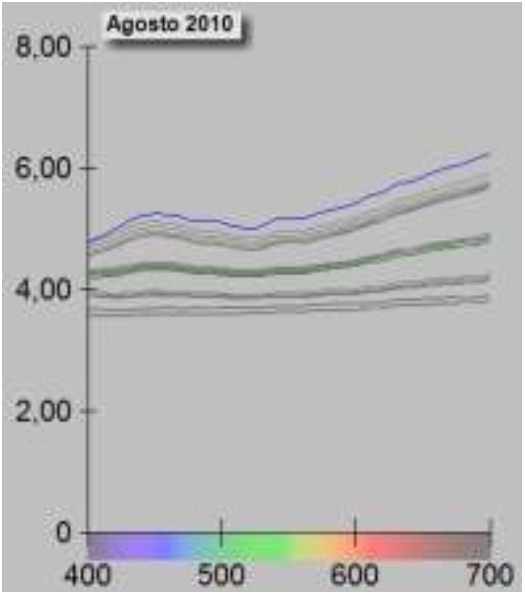

a) No primeiro conjunto de medidas, a curva de refletância mostra maior reflexão da cor vermelha, em torno de 6\%, e da cor roxa, em torno de $5,5 \%$.

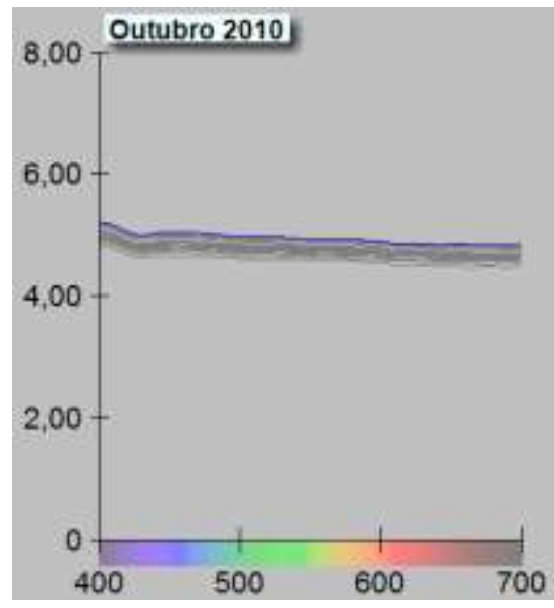

c) O terceiro conjunto de medidas mostrou os mesmos níveis de refletância do primeiro mês, porém, a curva de reflexão vermelha desapareceu e a faixa roxa do espectro passou a mostrar maior refletância dentre as demais. A Amostra começou sofrer perda de cor

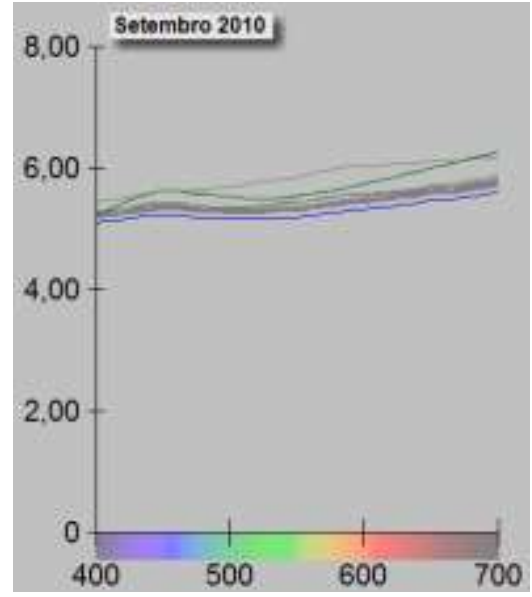

b) O segundo conjunto de medidas mostrou um sutil aumento na refletância total, com uma regularidade maior de refletância entre os comprimentos de onda, mas ainda prevaleceu o vermelho.

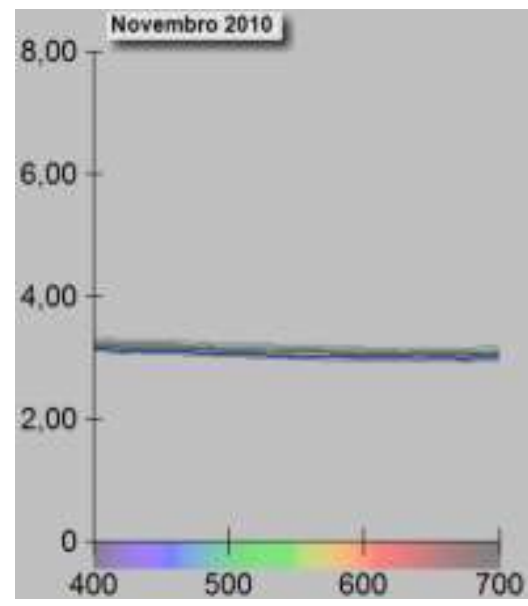

d) Finalmente, o último conjunto de medidas confirmou a diminuição da refletância, de $\pm 5.5 \%$ em agosto para \pm 3 em novembro, além da perda de cor, notada pela linha que indica mesma absorção em todas as faixas do espectro visível.

Figura 130. Gráficos espectrais obtidos da amostra de ametista grande.

A Tabela 8 mostra os dados dos parâmetros L, a* e b* em cada conjunto de medidas. $\mathrm{O} \Delta$ representa a diferença entre os valores finais e iniciais medidos.

Tabela 8. Parâmetros de L $a * b *$ para a amostra de ametista grande.

\begin{tabular}{c|c|c|c}
\hline & $\mathbf{L}$ & $\mathbf{a}^{*}$ & $\mathbf{b}^{*}$ \\
\hline AGOSTO & 24,586 & 0,815 & 0,082 \\
SETEMBRO & 27,82 & 0,605 & 0,304 \\
OUTUBRO & 26,093 & $-0,131$ & $-0,43$ \\
NOVEMBRO & 20,311 & $-0,083$ & $-0,496$ \\
$\Delta$ & $-4,275$ & $-0,898$ & $-0,578$ \\
\hline
\end{tabular}


A variação de $\mathrm{L}$ permite dizer que a amostra teve sua claridade aumentada no primeiro mês, e após o segundo, começou a baixar sua claridade gradualmente até a última medida. A diferença de claridade $(\Delta \mathrm{L})$ foi de $-4,275$, ou seja, a amostra perdeu pouco mais de 4 unidades de claridade em quatro meses, ficando ligeiramente mais escura no último mês.

Os valores de $a^{*}$ permitem afirmar que a amostra perdeu um pouco da coloração vermelha, confirmando o que pode ser visto nas linhas de reflexão a partir do mês de setembro (Figuras $130 \mathrm{~b}, 130 \mathrm{c}$ e $130 \mathrm{~d}$ e $\Delta \mathrm{a}^{*}$ ).

Os valores de $b^{*}$ apontam que a amostra perdeu pigmentação amarela, refletindo mais a cor azul que no início das medidas.

\subsubsection{2 - Ametista média}

A outra amostra de ametista escolhida para o experimento também apresenta faces de pirâmide com dimensões menores que a primeira amostra, e demonstrando maior transparência a olho nu. A cor roxa designativa da ametista não era homogênea ao longo das faces (Figura 131), o que interferiu na precisão das medidas, pois ainda que tenham sido realizadas sempre na mesma face, é impossível demarcar o local exato da ametista.

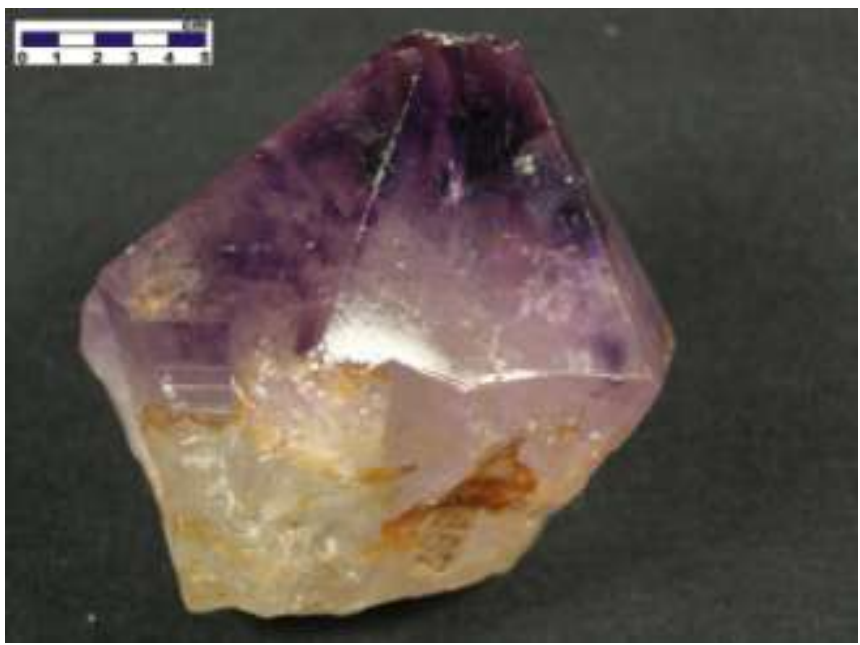

Figura 131. Ametista média. Acervo: Museu de Geociências da USP.

Esta amostra teve grande alteração entre os meses de agosto e setembro: houve aumento da refletância do roxo (de aproximadamente $0,6 \%$ em agosto para aproximadamente $5,2 \%$ em setembro) e também da refletância total (em torno de 11,5\% em agosto para aproximadamente 5,5\% em setembro), indicando um clareamento da amostra, como indica a Figura 132 e a Tabela 9.

Uma possível explicação para essa alteração drástica de comportamento está na readequação dos átomos da amostra ao novo ambiente. Passado o primeiro mês, os outros gráficos registraram o mesmo comportamento inicial da cor. No último mês, houve uma diminuição da refletância. 
O motivo de a amostra ter clareado em um primeiro momento e escurecido posteriormente não foi identificado.

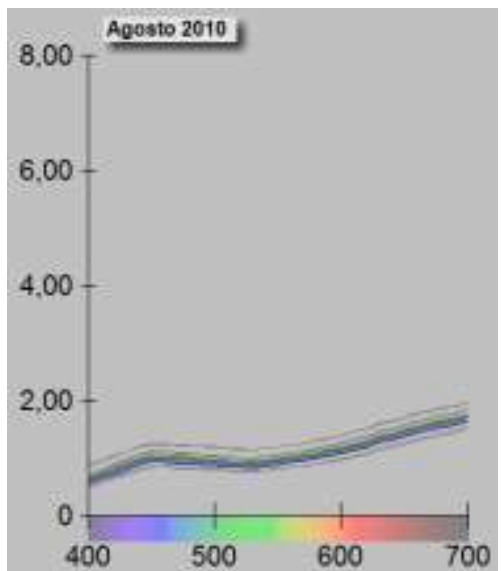

a) O primeiro conjunto de medidas mostra maior reflexão na faixa roxo-azul do espectro e também na faixa vermelha, além de uma refletância total baixa.

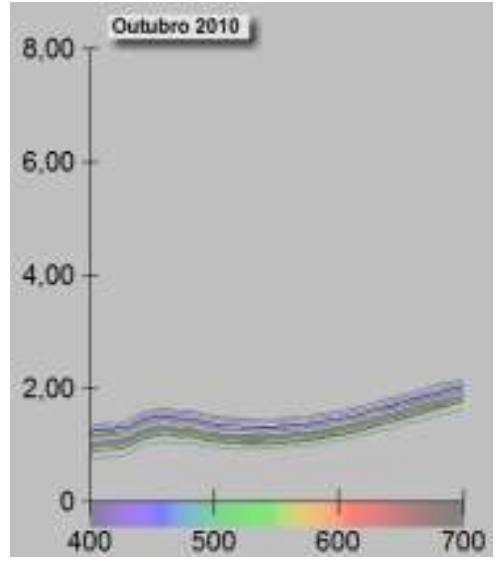

c) O terceiro conjunto de medidas mostra medidas próximas às do primeiro conjunto.

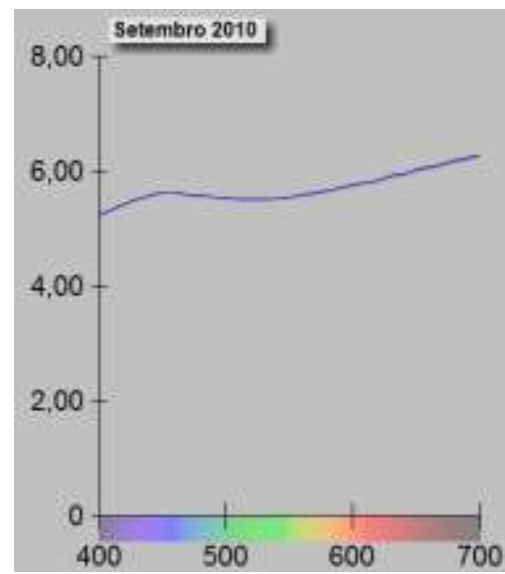

b) O segundo conjunto de medidas apresenta um aumento da refletância total, com as mesmas faixas de reflexão do espectro.

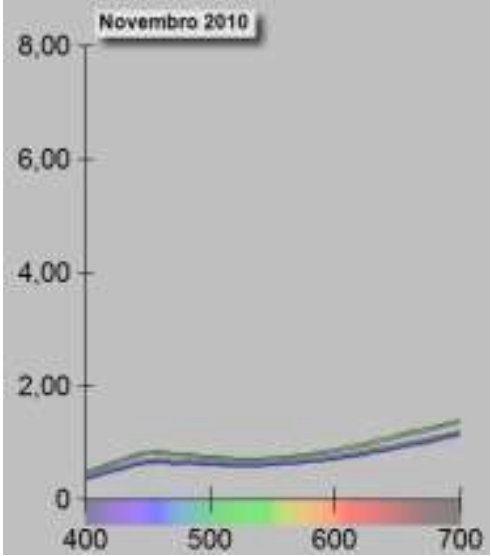

d) O último conjunto de medidas mostra uma diminuição geral da refletância, demonstrando perda de pigmentação da amostra.

Figura 132. Gráficos espectrais obtidos da amostra de ametista média.

A Tabela 9 mostra os dados dos parâmetros L, a* e b* em cada conjunto de medidas.

Tabela 9. Parâmetros de $L a^{*} b^{*}$ para a amostra de ametista média.

\begin{tabular}{c|c|c|c}
\hline & $\mathbf{L}$ & $\mathbf{a}^{*}$ & $\mathbf{b}^{*}$ \\
\hline AGOSTO & 9,076 & 2,616 & 1,165 \\
SETEMBRO & 28,394 & 0,89 & 0,193 \\
OUTUBRO & 10,749 & 0,177 & 0,055 \\
NOVEMBRO & 6,119 & 1,7 & 0,518 \\
$\Delta$ & $-2,957$ & $-0,916$ & $-0,647$ \\
\hline
\end{tabular}


De acordo com as variações de $\mathrm{L}$, houve um aumento na claridade de agosto para setembro (variação de cerca de 19 unidades), que voltou a diminuir em outubro e assim continuou em novembro, mostrando um $\Delta \mathrm{L}$ de 3 , o que significa um ligeiro escurecimento da amostra.

Os valores de $a^{*}$ permitem inferir que a amostra perdeu coloração vermelha, passando a refletir mais a cor verde após os quatro meses.

Os valores de $b^{*}$ demonstram que a amostra passou a refletir, após os quatro meses, mais a cor azul.

\subsubsection{3 - Calcita pequena}

Essa calcita tem dimensões de $3 \mathrm{~cm}$ de comprimento, $1 \mathrm{~cm}$ de altura e $1 \mathrm{~cm}$ de largura. A amostra é composta por mesclas brancas e pretas, o que dá uma certa tonalidade cinza ao exemplar (Figura 133).

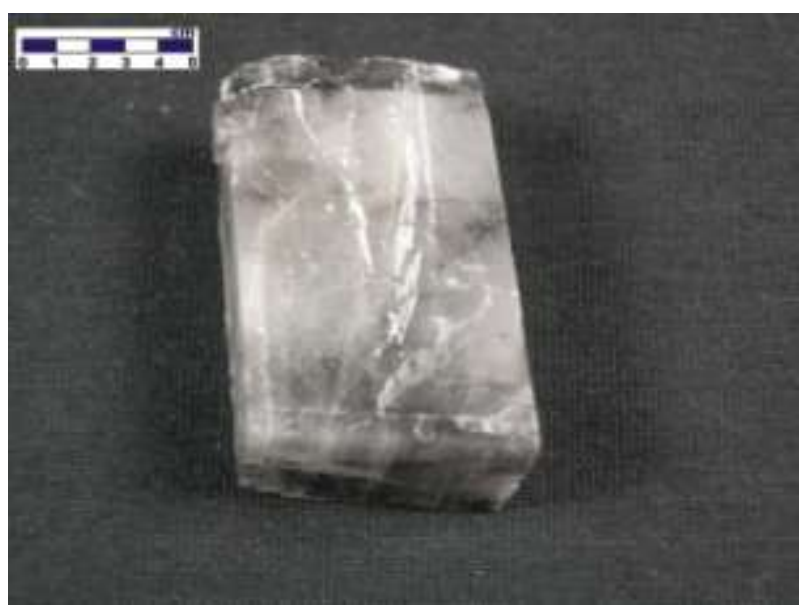

Figura 133. Calcita pequena. Acervo: Laboratório Didático do IGc/USP.

Esta amostra é a única cujo padrão de comportamento correspondeu ao esperado, ou seja, teve diferença visível na curva de refletância no primeiro mês e depois manteve o nível (Figura 134). A amostra teve sua refletância total aumentada de agosto para setembro, resultando em perda de pigmentação e depois manteve uma linha constante até o fim do experimento. 


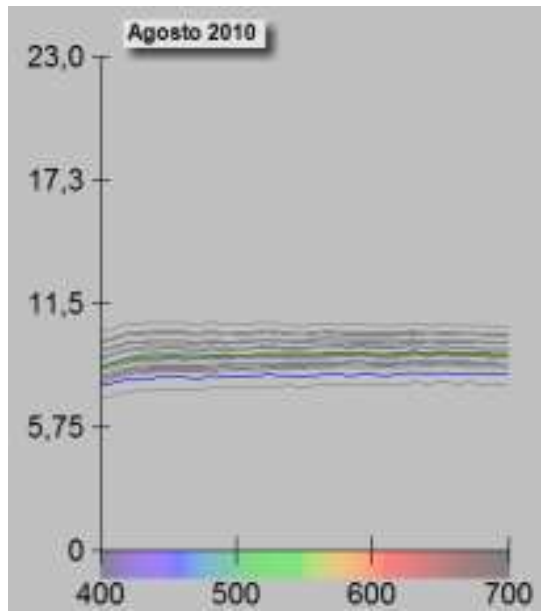

a) O primeiro conjunto de medidas mostra refletância menor que $10 \%$.

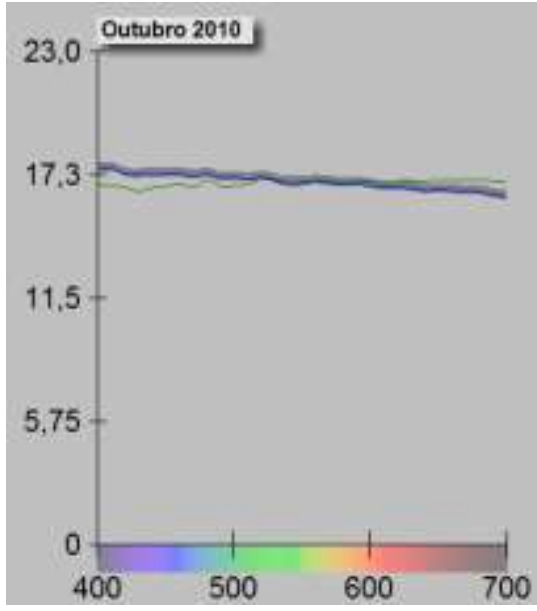

c) O terceiro conjunto de medidas mostra ligeira queda na refletância que passou para $17,5 \%$.

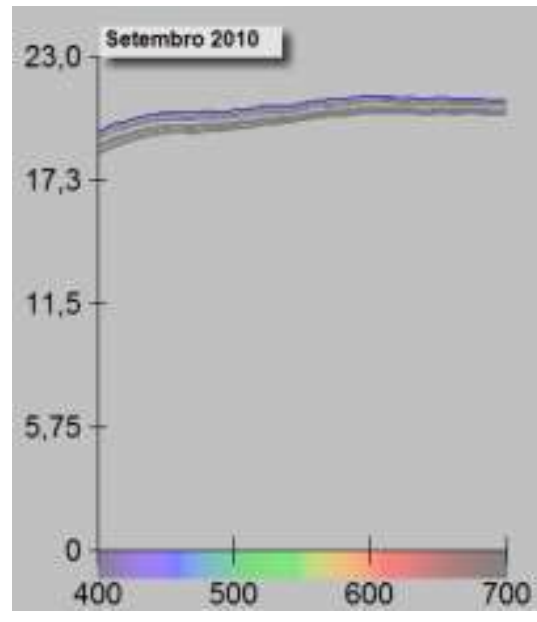

b) O segundo conjunto de medidas mostra um visível aumento da refletância para cerca de $20 \%$.

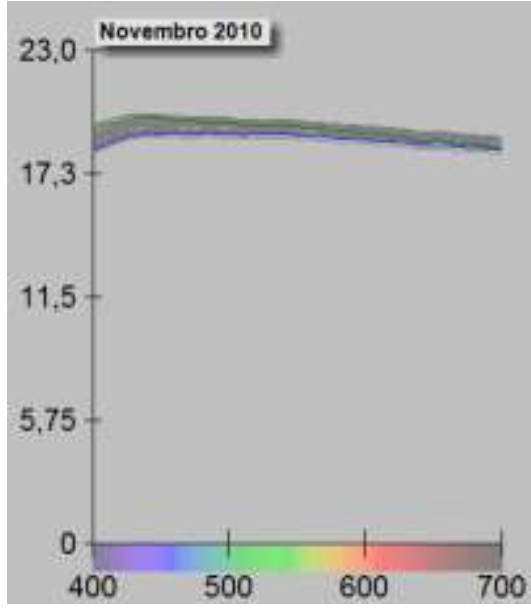

d) Finalmente o ultimo conjunto de medidas mostra sutil aumento da refletância, evidenciando clareamento da amostra.

Figura 134. Gráficos espectrais obtidos da amostra de calcita pequena.

A Tabela 10 mostra os dados dos parâmetros de L, a* e b* em cada conjunto de medidas.

Tabela 10. Parâmetros de L $a * b *$ para a amostra de calcita pequena.

\begin{tabular}{c|c|c|c}
\hline & $\mathbf{L}$ & $\mathbf{a}^{*}$ & $\mathbf{b}^{*}$ \\
\hline AGOSTO & 36,198 & 0,041 & 0,393 \\
SETEMBRO & 51,699 & 0,285 & 1,080 \\
OUTUBRO & 48,233 & $-0,286$ & $-0,735$ \\
NOVEMBRO & 51,065 & $-0,418$ & $-0,325$ \\
$\Delta$ & 14,867 & $-0,459$ & $-0,718$ \\
\hline
\end{tabular}


A variação de L demonstra que a calcita teve sua claridade aumentada em 15 unidades no primeiro mês, diminuída em 3 unidades em outubro, e voltando a aumentar mais 3 unidades em novembro. $\mathrm{O} \Delta \mathrm{L}$ mostra que a calcita teve sua claridade final aumentada em quase 15 unidades, com consequente perda de pigmentação.

A variação de $a^{*}$ foi pequena, e após exposição ao sol, apresentou tonalidade mais esverdeada não visível a olho nu.

O mesmo se dá com o parâmetro b*, que demonstra um aumento da tonalidade azul.

\subsubsection{4 - Calcita grande}

A calcita grande possui dimensões de 3,5 cm de comprimento, $2,5 \mathrm{~cm}$ de altura e $3 \mathrm{~cm}$ de largura (Figura 135). Possui a mesma coloração da calcita pequena, com mesclas brancas e pretas, o que permite inferir que as duas amostras faziam parte do mesmo cristal. Apesar disso, os gráficos de refletância mostram comportamentos muito diferentes para as duas amostras.

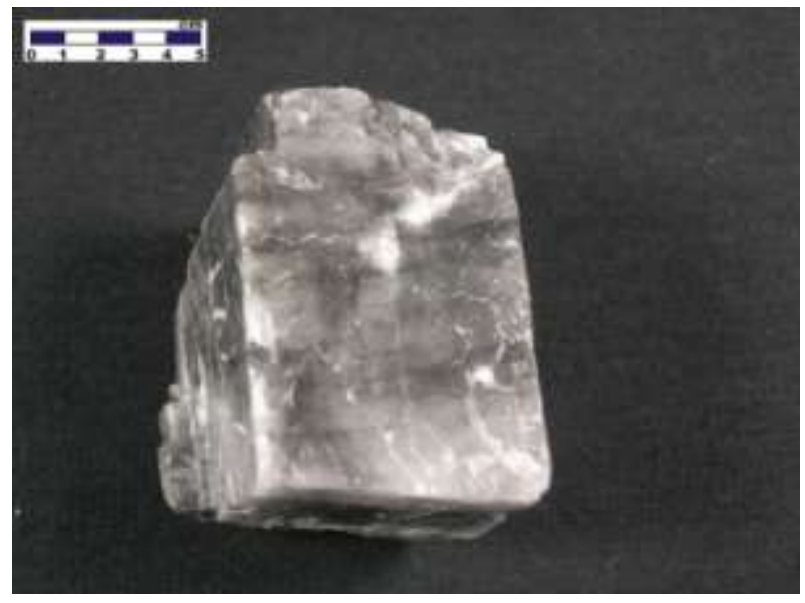

Figura 135. Calcita grande. Acervo: Laboratório Didático do IGc/USP.

Nesta amostra, os espectros se comportaram de maneira muito distinta em cada medição, como se observa na Figura 136. Tal comportamento pode ser relativo ao fato de a amostra ter mesclas de branco e cinza. No entanto, o exemplar de calcita pequena também possuía tais mesclas, e os gráficos não se apresentaram tão díspares. Como é difícil delimitar a área exata de medição, pode ser que as medidas tenham sido extraídas de regiões distintas do mineral.

Por essas razões, tem-se que a análise desta amostra foi inconclusiva. 


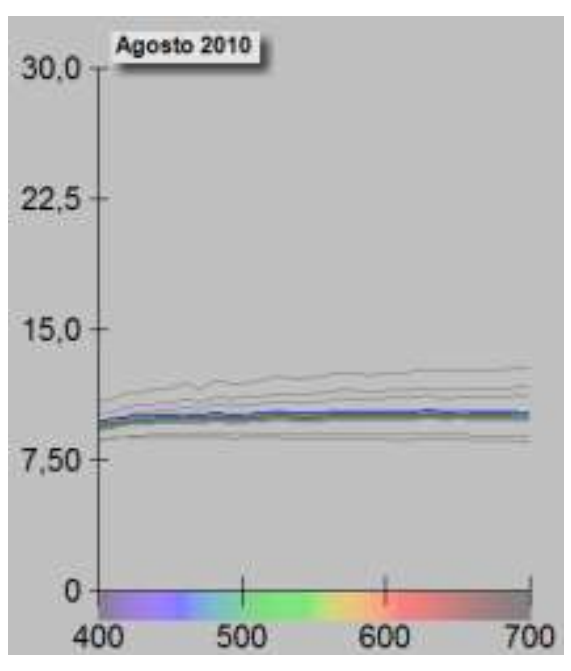

a) No primeiro mês a refletância média foi em torno de $9 \%$.

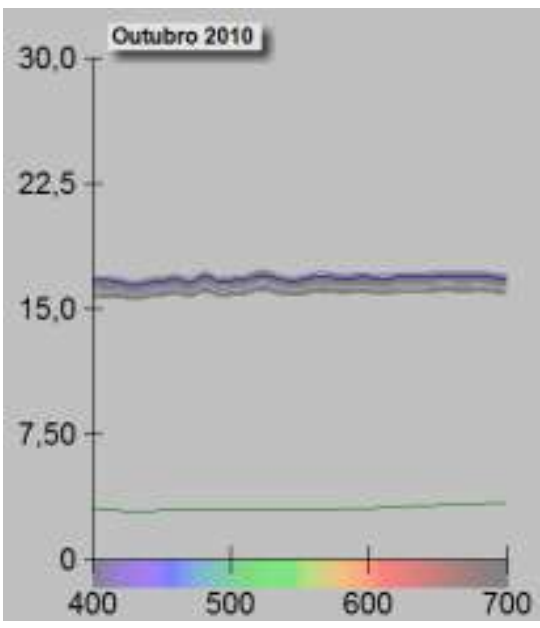

c) No terceiro mês a curva volta a diminuir.

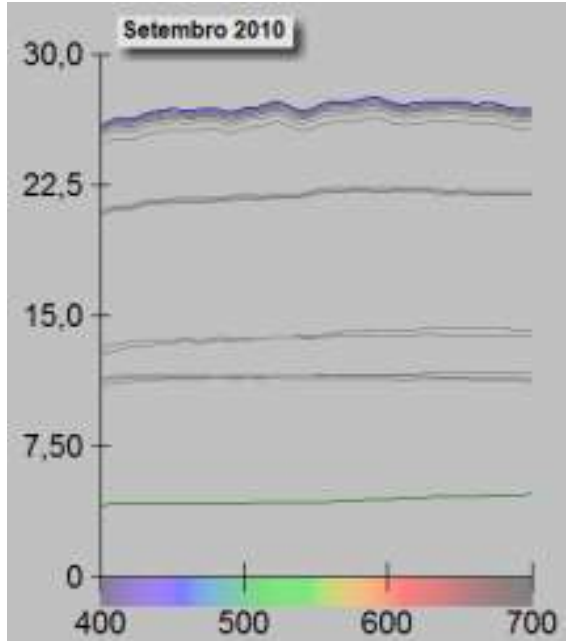

b) No Segundo mês a curva de refletância mostra aumento de mais de $10 \%$, que poderia evidenciar perda de cor, caso a curva permanecesse nesse patamar.

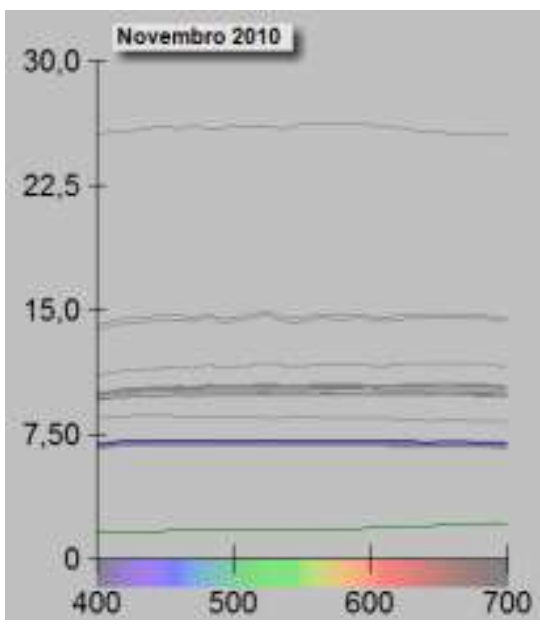

d) No último conjunto de medidas, há curvas em vários níveis do espectro, demonstrando a impossibilidade de inferir algum resultado.

Figura 136. Gráficos espectrais obtidos da amostra de calcita grande.

A Tabela 11 mostra os dados dos parâmetros de L, a* e b* em cada conjunto de medidas.

Tabela 11. Parâmetros de L $a^{*} b^{*}$ para a amostra de calcita grande.

\begin{tabular}{c|c|c|c}
\hline & $\mathbf{L}$ & $\mathbf{a}^{*}$ & $\mathbf{b}^{*}$ \\
\hline AGOSTO & 37,804 & 0,054 & 0,517 \\
SETEMBRO & 54,869 & 0,104 & 0,636 \\
OUTUBRO & 47,691 & $-0,065$ & 0,372 \\
NOVEMBRO & 35,808 & $-0,097$ & 0,083 \\
$\boldsymbol{\Delta}$ & $-1,996$ & 0,043 & $-0,434$ \\
\hline
\end{tabular}


$\mathrm{O} \Delta \mathrm{L}$ apresenta um clareamento da amostra no primeiro mês, com escurecimento nos meses subsequentes. Os parâmetros de $a^{*}$ e $b^{*}$ apresentam variação muito pequena, com tonalidades mais esverdeadas e azuladas, respectivamente.

\subsubsection{5 - Fluorita}

A amostra de fluorita apresenta-se como um agregado cúbico e dimensões de $6 \mathrm{~cm}$ de comprimento, $3 \mathrm{~cm}$ de largura e $3 \mathrm{~cm}$ de altura, com cor roxa escura (Figura 137) e com apenas uma face própria para a realização de medidas.

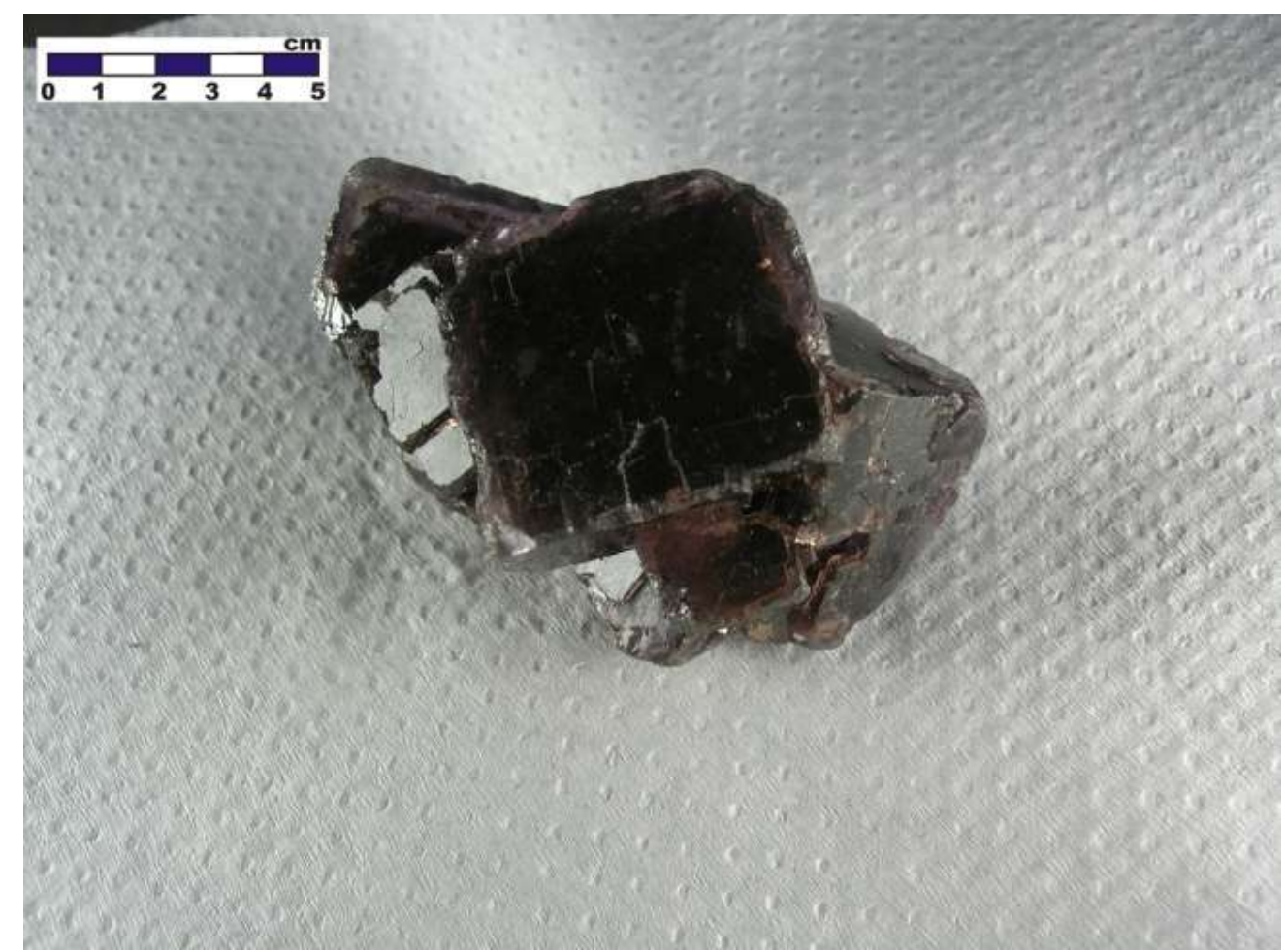

Figura 137. Amostra de fluorita. Acervo: Museu de Geociências da USP.

Nota-se que a fluorita teve sua refletância total aumentada no primeiro mês, mas a partir de setembro, a refletância diminuiu até a última medida, como mostra a Figura 138. Isso denota que inicialmente houve perda de cor nessa amostra, com recuperação da cor ao final. 


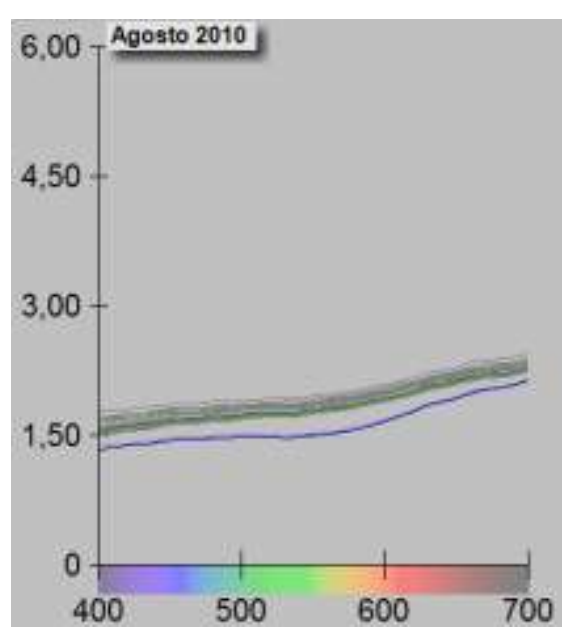

a) A primeira medida mostra uma refletância geral baixa (cerca de 2\%) e um nivel de refletância levemente elevado na cor vermelha.

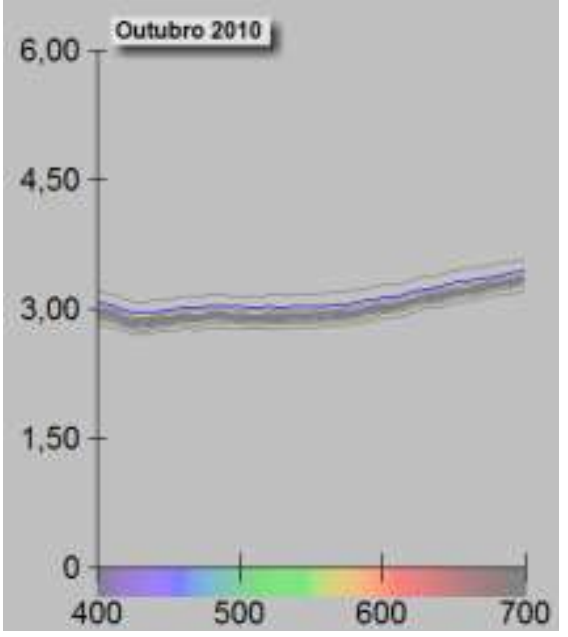

c) Em outubro a refletância voltou a diminuir e a curva mostra uma leve refletância na faixa roxa do espectro que não havia aparecido até então.

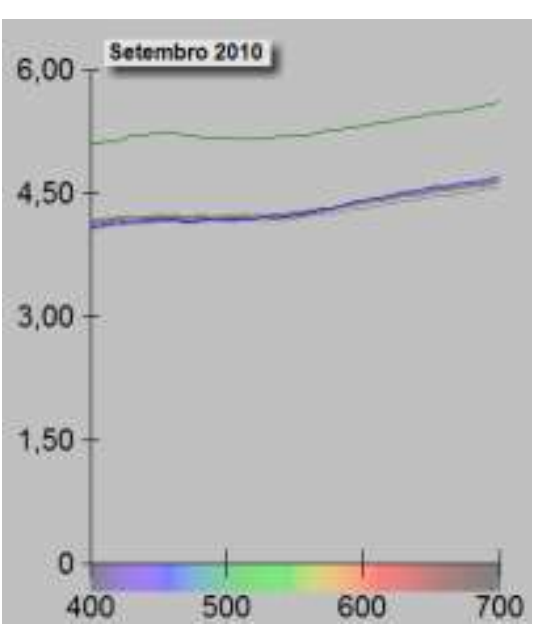

b) Em setembro a refletância aumentou consideravelmente, e a curva perde um pouco da refletância do vermelho.

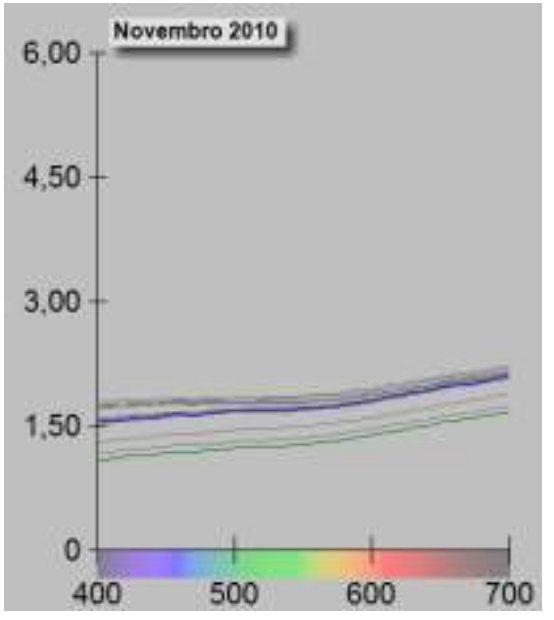

d) Finalmente em novembro a refletância atingiu seu patamar inicial de cerca de $2 \%$. A curva não demostrou refllexão de roxo.

Figura 138. Gráficos espectrais obtidos da amostra de fluorita.

A Tabela 12 mostra os dados dos parâmetros de L, a* e b* em cada conjunto de medidas.

Tabela 12. Parâmetros de $L a^{*} b^{*}$ para a amostra de fluorita.

\begin{tabular}{c|c|c|c}
\hline & $\mathbf{L}$ & $\mathbf{a}^{*}$ & $\mathbf{b}^{*}$ \\
\hline AGOSTO & 14,460 & 1,096 & 1,473 \\
SETEMBRO & 24,581 & 0,626 & 0,453 \\
OUTUBRO & 19,849 & 0,595 & 0,471 \\
NOVEMBRO & 13,977 & 0,784 & 0,932 \\
$\Delta$ & $-0,483$ & $-0,312$ & $-0,541$ \\
\hline
\end{tabular}


A variação de L evidencia um clareamento da amostra e posterior escurecimento, mas, ao final quase não se observa alteração.

A variação de $a^{*}$ demonstra uma diminuição da reflexão vermelha, também imperceptível ao observador.

A variação de $b^{*}$ demonstra uma maior reflexão de azul, mas também imperceptível na amostra de mão.

\subsubsection{6 - Espodumênio}

A amostra possui $4,5 \mathrm{~cm}$ de comprimento, $1,5 \mathrm{~cm}$ de altura e $3 \mathrm{~cm}$ de largura e uma coloração levemente rosada (Figura 139).

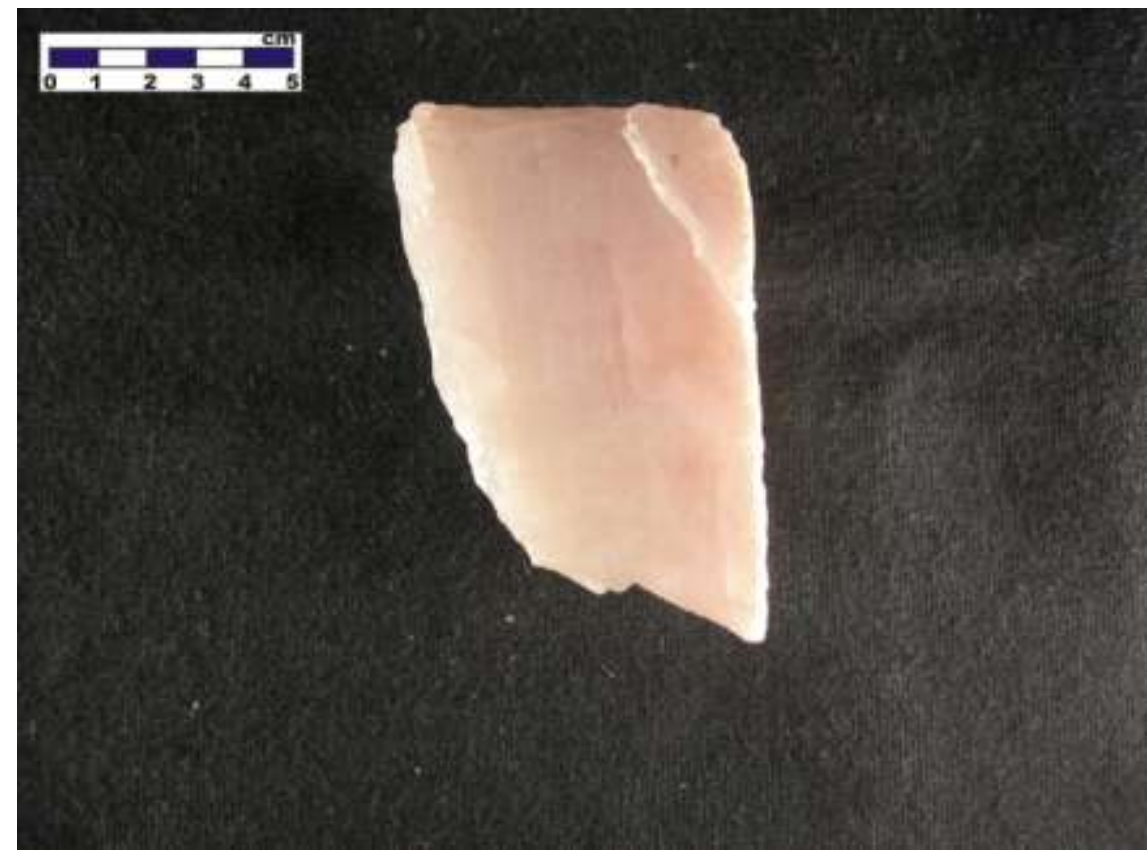

Figura 139. Amostra de espodumênio levemente rosada. Acervo: Laboratório Didático do IGc/USP.

Seguindo o padrão de comportamento das outras amostras, o espodumênio teve sua refletância aumentada no primeiro mês ( $21 \%$ em agosto para $28,5 \%$ em setembro), e perdeu refletância nos meses subsequentes (as medidas de novembro indicam refletância em torno de 20\%), Figura 140. A curva de refletância mostra absorção um pouco mais acentuada de cor roxa.

De todas as amostras analisadas, o espodumênio é a que tem maior refletância. Isso se deve ao fato de que é a amostra mais translúcida de todas (opaca na amostra de mão), portanto, com menos fuga de luz durante a medição. 


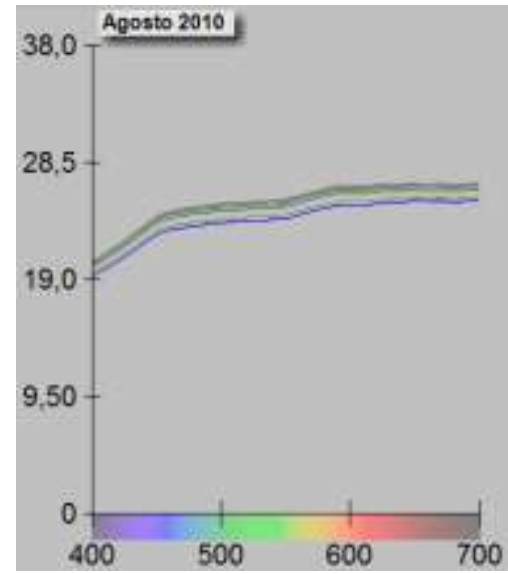

a) No primeiro conjunto de medidas, o espodumênio mostra refletância geral de cerca de $20 \%$, com absorção preferencial da cor roxa.

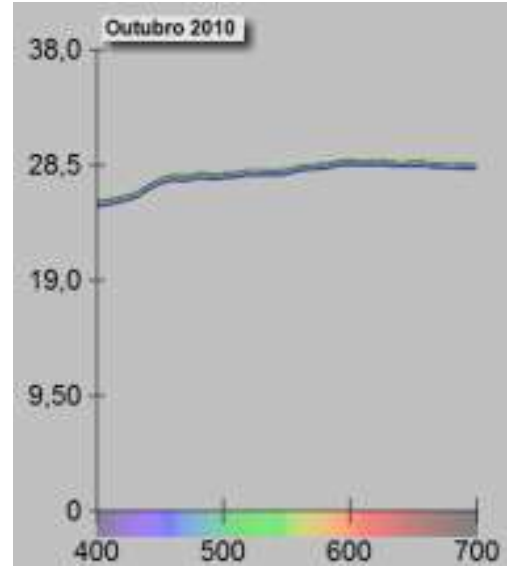

c) A amostra perdeu cerca de $2 \%$ de refletância no segundo mês.

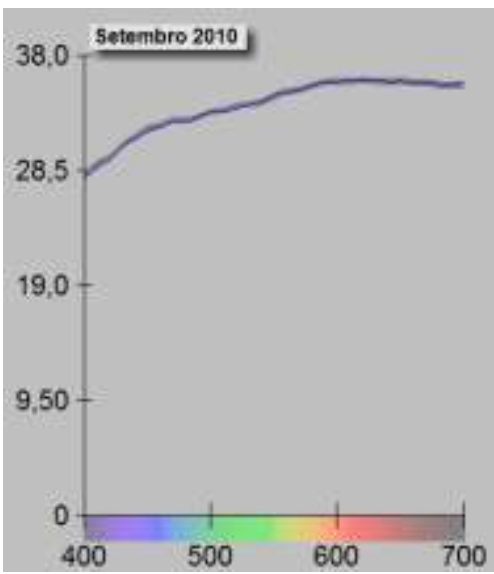

b) Na segunda medição há significativo aumento da curva de refletância, com a manutenção da absorção da cor roxa.

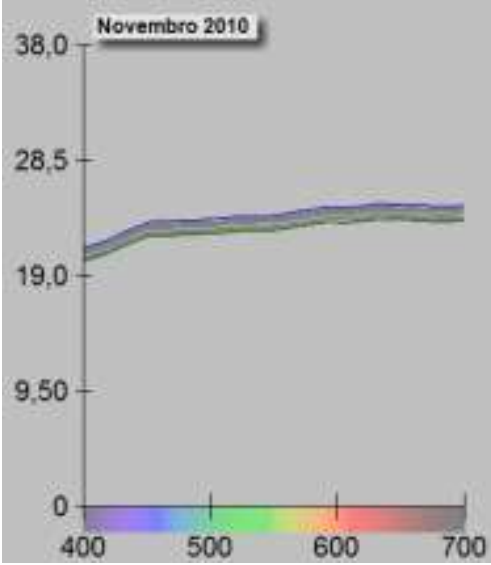

d) A refletância geral diminuiu, demonstrando escurecimento da amostra.

Figura 140. Gráficos espectrais obtidos da amostra de espodumênio.

A Tabela 13 mostra os dados dos parâmetros L, a* e b* em cada conjunto de medidas.

Tabela 13. Parâmetros de L $a^{*} b^{*}$ para a amostra de espodumênio.

\begin{tabular}{c|c|c|c}
\hline & $\mathbf{L}$ & $\mathbf{a}^{*}$ & $\mathbf{b}^{*}$ \\
\hline AGOSTO & 57,200 & 0,328 & 3,176 \\
SETEMBRO & 65,060 & 0,503 & 3,880 \\
OUTUBRO & 59,792 & 0,189 & 1,815 \\
NOVEMBRO & 55,466 & 0,376 & 1,692 \\
$\boldsymbol{\Delta}$ & $-1,734$ & 0,048 & $-1,484$ \\
\hline
\end{tabular}

$\mathrm{O} \Delta \mathrm{L}$ permite observar uma variação pequena de perda na claridade.

A variação de $\mathrm{a}^{*}$ é muito pequena e o $\Delta \mathrm{b}^{*}$ mostra coloração mais azulada ao final das medidas. 


\subsubsection{7 - Lepidolita}

A amostra possui $5 \mathrm{~cm}$ de comprimento, $1,5 \mathrm{~cm}$ de altura e largura de cerca de $3 \mathrm{~cm}$. Apresenta o brilho característico das micas e cor lilás (Figura 141).

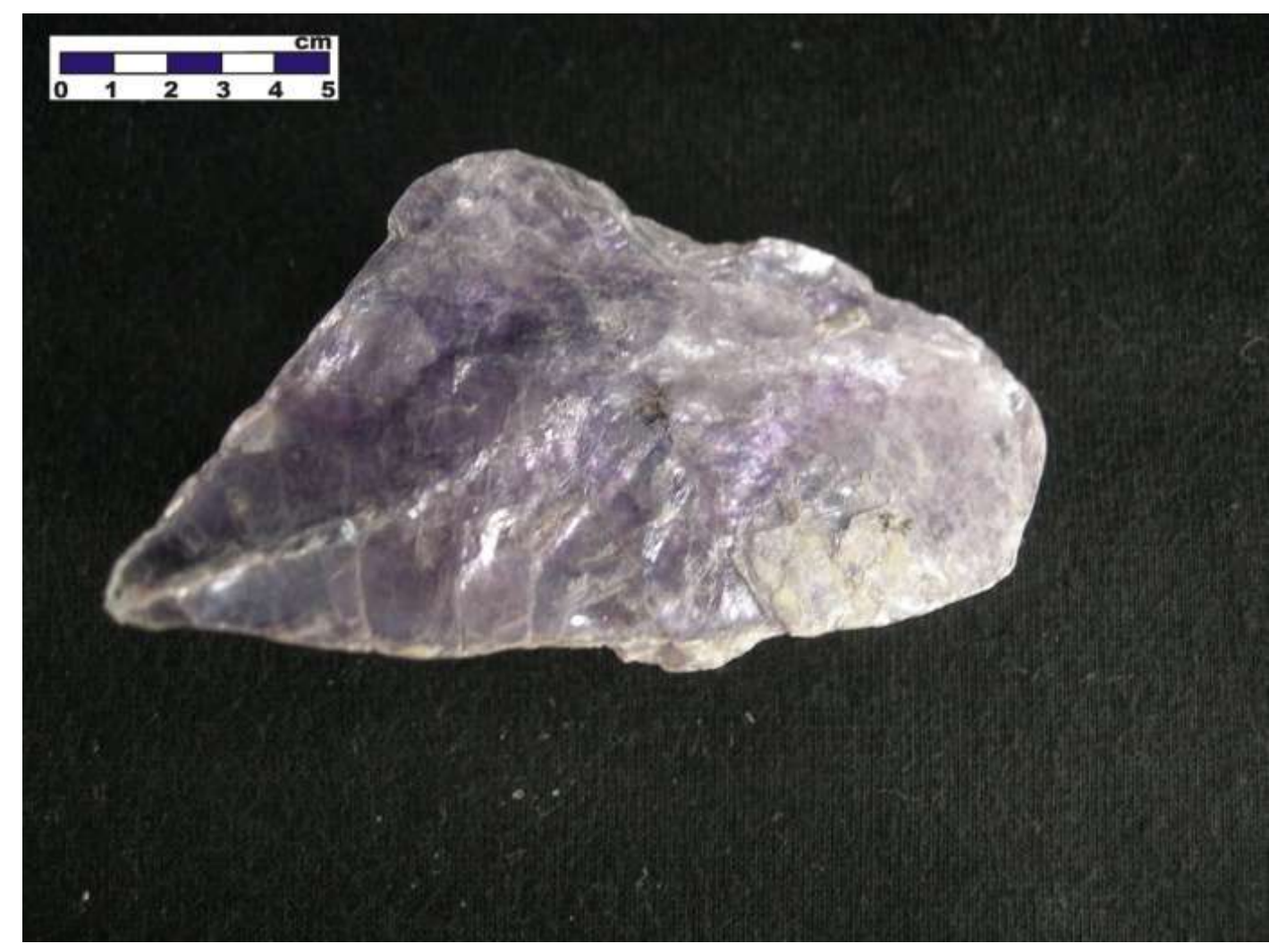

Figura 141. Lepidolita. Acervo: Museu de Geociências da USP.

No primeiro mês, a refletância da lepidolita aumentou, mas após o segundo mês diminuiu e se manteve até a última medida, como mostra a Figura 142. Apresentou picos de refletância inalterados no azul e no vermelho, o que denota que não houve perda de cor e nem alteração nas bandas de absorção do espectro. 


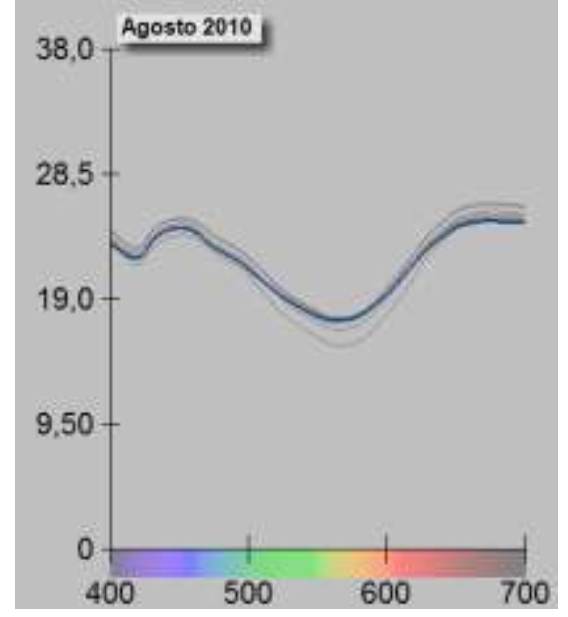

a) O primeiro conjunto de medidas mostra uma refletância de cerca de $25 \%$ e maior reflexão das cores roxa/azul e vermelha do espectro.

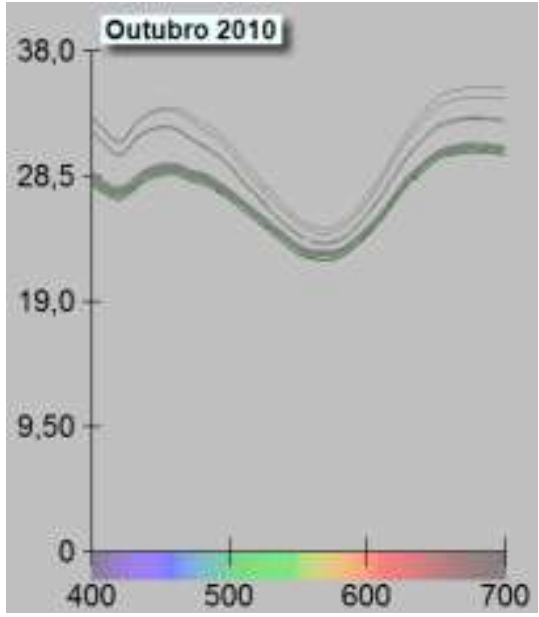

c) No terceiro conjunto de medidas, a lepidolita manteve a refletância geral e as faixas de refletância.

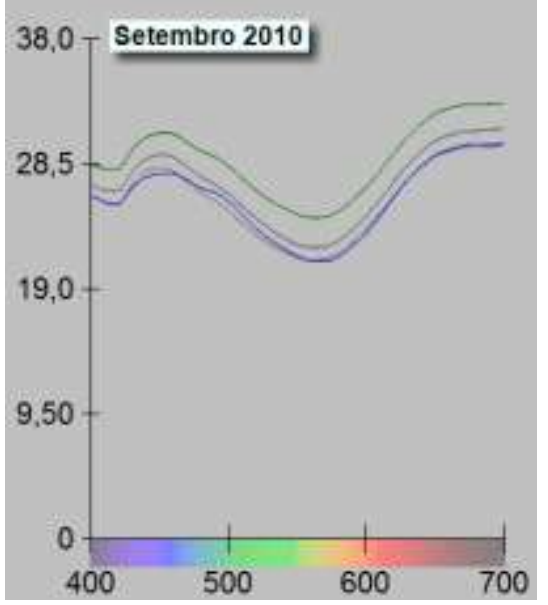

b) A amostra apresentou um aumento da refletância geral no primeiro mês e manteve as mesmas faixas de reflexão do espectro.

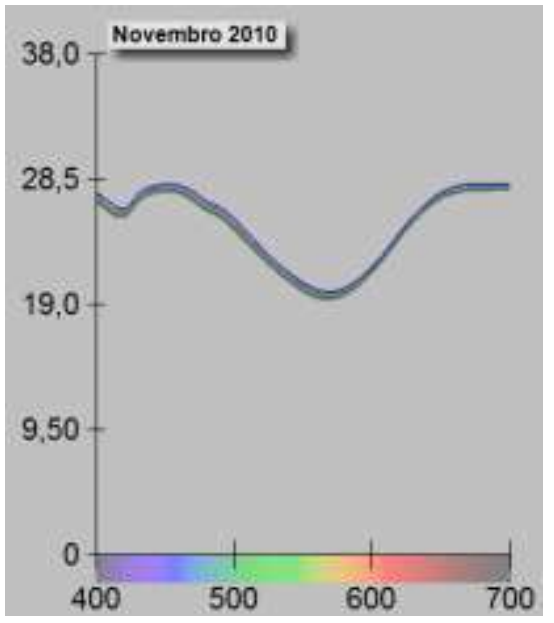

d) Finalmente constata-se que a lepidolita apresentou pequena alteração no primeiro mês e depois manteve sua cor inalterada.

Figura 142. Gráficos espectrais obtidos da amostra de lepidolita.

A Tabela 14 mostra os dados dos parâmetros L, a* e b* em cada conjunto de medidas.

Tabela 14. Parâmetros de L $a^{*} b^{*}$ para a amostra de lepidolita.

\begin{tabular}{c|c|c|c}
\hline & $\mathbf{L}$ & $\mathbf{a}^{*}$ & $\mathbf{b}^{*}$ \\
\hline AGOSTO & 51,087 & 4,633 & $-7,719$ \\
SETEMBRO & 56,766 & 4,161 & $-5,786$ \\
OUTUBRO & 57,419 & 2,841 & $-6,022$ \\
NOVEMBRO & 54,292 & 3,453 & $-8,245$ \\
$\Delta$ & 3,205 & $-1,180$ & $-0,526$ \\
\hline
\end{tabular}


A variação de $L$ permite afirmar que a amostra teve um pequeno aumento na claridade (cerca de 3 unidades), não tendo sofrido alteração significativa.

A variação de $a^{*}$ mostra que a lepidolita passou a refletir mais a faixa verde do espectro, porém imperceptível a olho nu.

A variação de $b^{*}$ mostra que o mineral passou a refletir um pouco mais a faixa azul do espectro.

\subsubsection{8 - Espodumênio irradiado}

O único mineral que apresentou nitidamente perda de cor foram as amostras de espodumênio irradiado (Figura 143). Tratava-se de três amostras de espodumênio verdes irradiadas com $\mathrm{Co}^{60}$ em conjunto. Duas dessas amostras foram medidas e colocadas no sol. A outra foi mantida em um recipiente escuro. As duas amostras colocadas no sol tiveram a cor alterada do verde para o rosa claro, cor original da amostra (Figura 144). Essas medidas foram feitas com intervalo de uma semana.

No segundo dia de exposição das amostras à luz, já se notou a diferença de coloração. Radiação intensa (como raios gama) tem energia necessária para desalojar elétrons para um estágio de excitação. Radiação menos intensa, como a luz do sol, contribui para o elétron superar a barreira de ativação e voltar para seu estágio inicial. Foi o que aconteceu com as amostras de espodumênio irradiadas.

O espodumênio irradiado de coloração verde escura aponta nítido pico de refletância na cor verde (Figura 145), pico este menos desenvolvido para a amostra de coloração verde mais clara (Figura 146).

A amostra irradiada verde clara menor apresenta-se nesta coloração de forma heterogênea, por isso, as curvas espectrais mostram padrões diferentes (Figura 147).

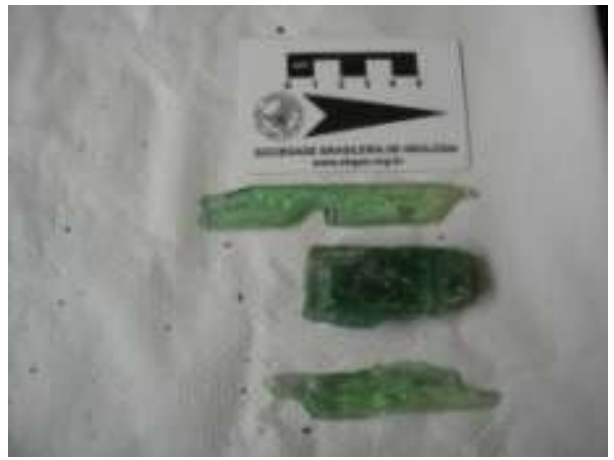

Figura 143. Amostras de espodumênio irradiadas de cor verde.

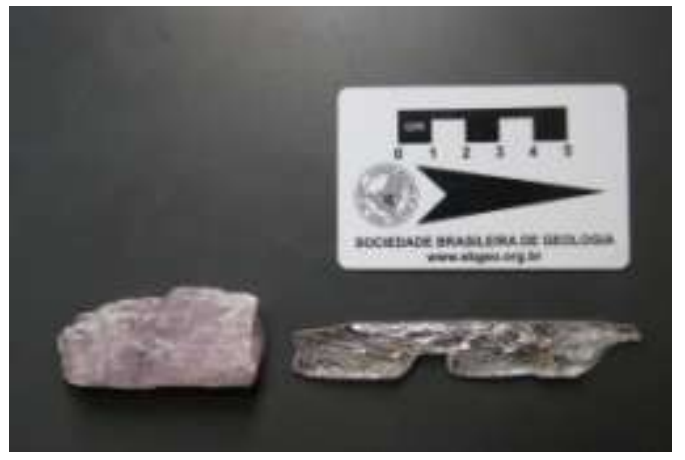

Figura 144. Após apenas um dia no sol, os minerais recuperaram a coloração original. 


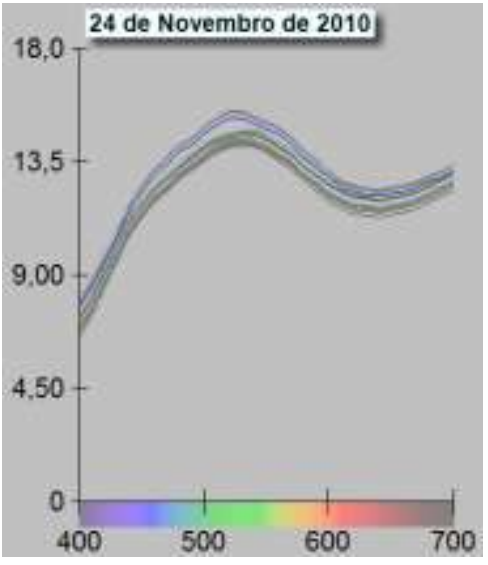

Figura 145. Espodumênio irradiado verde escuro mostra pico de refletância no verde.

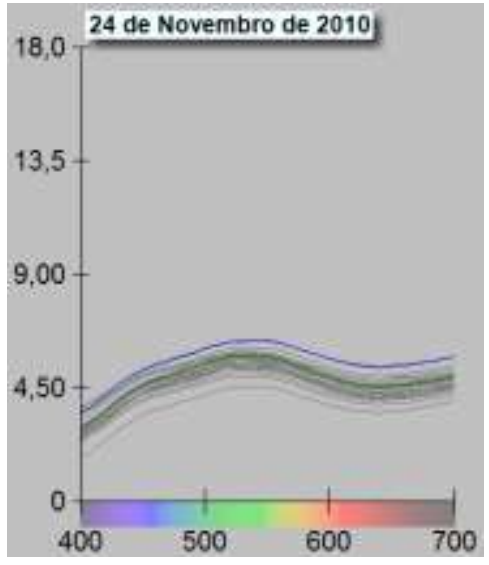

Figura 146. Espodumênio irradiado verde claro maior também mostra maior reflexão no verde, mesmo sem um pico tão elevado quanto da Figura 145.

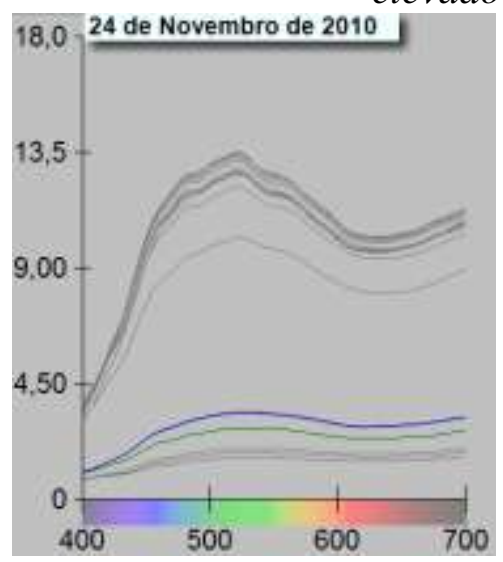

Figura 147. Padrões irregulares devido à heterogeneidade da cor verde na amostra.

Após a exposição ao sol, o pico de refletância na cor verde desapareceu, mostrando absorção relativamente homogênea de todas as faixas do espectro da luz visível (Figuras 148 e 149).

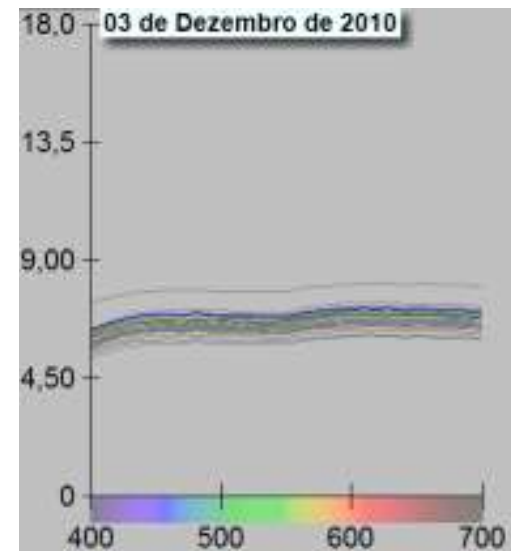

Figura 148. O espodumênio verde escuro, agora rosa, teve diminuição na refletância geral e perdeu o pico de reflexão verde.

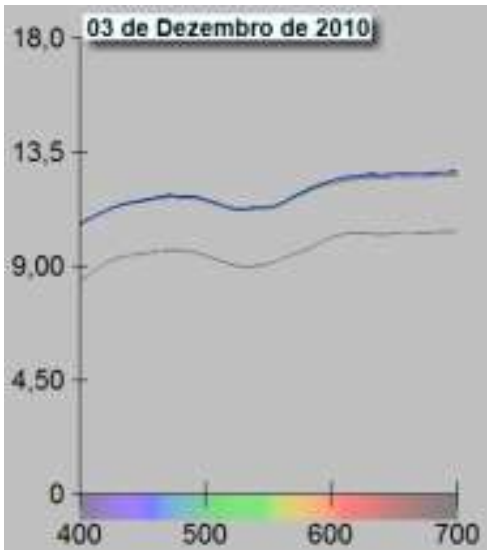

Figura 149. A amostra verde clara maior, agora rosa clara, teve a refletância geral aumentada e maior absorção da faixa verde do espectro. 
A Tabela 15 mostra os dados dos parâmetros L, a* e b* em cada conjunto de medidas para o espodumênio irradiado verde escuro.

Tabela 15. Parâmetros de L $a^{*} b^{*}$ para a amostra de espodumênio irradiado verde escuro.

\begin{tabular}{c|c|c|c}
\hline & $\mathbf{L}$ & $\mathbf{a}^{*}$ & $\mathbf{b}^{*}$ \\
\hline $\begin{array}{c}\text { 24 de } \\
\text { Novembro }\end{array}$ & 43,488 & $-6,030$ & 5,139 \\
$\begin{array}{c}\mathbf{0 3} \text { de } \\
\text { Dezembro }\end{array}$ & 31,033 & 0,598 & 0,459 \\
$\Delta$ & -12.455 & 6,628 & $-4,680$ \\
\hline
\end{tabular}

$\mathrm{O} \Delta \mathrm{L}$ do espodumênio verde escuro teve a cor alterada para rosa, mostrando que houve uma perda de cerca de 12 unidades de claridade de uma semana para outra, evidenciando um escurecimento do mineral. Esses números não parecem compactuar com a mudança de coloração da amostra, que passou de verde escuro para uma tonalidade mais rosada (mais clara a olho nu).

Já a variação de a* permite afirmar que a amostra perdeu pigmentação verde, ou seja, passou a refletir mais vermelho que na primeira medida.

As medidas de $b^{*}$ demonstram que a amostra passou a refletir mais a cor azul.

A Tabela 16 mostra os dados dos parâmetros L, a* e b* em cada conjunto de medidas para o espodumênio irradiado verde claro.

Tabela 16. Parâmetros de $L a^{*} b^{*}$ para a amostra de espodumênio irradiado verde claro maior.

\begin{tabular}{c|c|c|c}
\hline & $\mathbf{L}$ & $\mathbf{a}^{*}$ & $\mathbf{b}^{*}$ \\
\hline $\begin{array}{c}\mathbf{2 4} \mathbf{d e} \\
\text { Novembro }\end{array}$ & 27,171 & 4,354 & 3,713 \\
$\begin{array}{c}\mathbf{0 3} \text { de } \\
\text { Dezembro }\end{array}$ & 40,458 & 1,722 & 0,411 \\
$\boldsymbol{\Delta}$ & 13,287 & $-2,632$ & $-3,302$ \\
\hline
\end{tabular}

$\mathrm{O} \Delta \mathrm{L}$ da amostra verde clara maior, que se tornou rosa clara após uma semana da primeira medição, mostrou que o mineral teve a claridade aumentada em 13,3, ou seja, houve um clareamento da amostra, como era esperado.

As variações de $a^{*}$ mostram que o mineral perdeu pigmentação na faixa do vermelho.

$\mathrm{O} \Delta \mathrm{b}^{*}$ permite afirmar que a amostra perdeu refletância na faixa amarela do espectro.

No geral, os minerais tiveram pequena variação cromática após três meses de exposição ao sol.

As amostras analisadas não foram suficientes para entender o comportamento da variação cromática desses minerais quando expostos à luz solar. Percebe-se a variação, mas a explicação do comportamento heterogêneo encontrado não é compreensível. 
Estudos mais sistemáticos são necessários para avançar no entendimento da variação cromática nos minerais. 


\section{6 - CONSERVAÇÃO DE MATERIAIS GEOLÓGICOS}

A preservação de materiais geológicos é uma questão de suma importância para a pesquisa sobre as mais diversas questões relativas à formação da Terra, uma vez que cada amostra, seja mineral ou rocha, é única, no que diz respeito à geologia de determinado local em determinado ponto no tempo. Perdendo-se uma destas referências, pode-se estar perdendo a chance de responder a muitas perguntas acerca da formação da Terra.

Um engano comum no que diz respeito à conservação de coleções de Geologia é que minerais e rochas, bem como outros materiais geológicos, são invariavelmente duráveis. Esse engano tem conduzido à perda de muitos elementos de coleções geológicas em várias partes do Brasil, pois uma vez que se tomam esses acervos como duráveis e estáveis, as coleções geológicas não recebem maior atenção de curadores de museus, professores universitários ou diretores de institutos de pesquisa.

Um ponto importante a ser considerado por um curador ou responsável por coleções geológicas é o fato de que os minerais e rochas são estáveis apenas em seu local de formação (isso pode ser pressuposto para um geólogo, no entanto, não são eles, em sua maioria os zeladores das coleções). Por isso, logo que esse material é retirado de seu meio ambiente e transportado para um museu, as alterações têm início. A única diferença é que algumas delas ocorrem em escala de tempo humana, por isso são perceptíveis e podem ser evitadas, enquanto outras ocorrem em escala geológica, dando a falsa impressão de estabilidade. Assim, o princípio mais importante da conservação de materiais geológicos é manter uma condição ambiental (seja durante o transporte do campo, na reserva técnica de um museu ou em exposição) que proporcione o retardamento dessas alterações, uma vez que é impossível evitá-las.

Um dos primeiros cientistas a atentar para a importância dos cuidados com coleções de minerais foi A. L. Parsons, da Universidade de Toronto, já na década de 1920. As primeiras publicações foram feitas em formato de artigo para o periódico American Mineralogist. Esses artigos citam a possibilidade da luz e umidade relativa do ar (UR) serem responsáveis pelos maiores incidentes envolvendo perdas de amostras de minerais em museus.

Os casos mais conhecidos de danos por interferência de luz referiam-se a proustita e pirargirita (ruby silver), que perdiam a cor vermelha, tornando-se pretas ao entrarem em contato com a luz; e o realgar, também vermelho, que se altera para ouropigmento. Já com relação à UR, conhecia-se a carnallita, que se solubiliza em altas umidades e a laumontita, que perde água para o ambiente (PARSONS, 1922). 
De modo geral, até o início da década de 1990, os exemplares de rochas eram vistos como indestrutíveis e inofensivos. Eram manipulados sem o cuidado adequado e raras vezes manuseados e acondicionados tendo em vista sua conservação e seus efeitos nocivos em longo prazo.

Neste período, o National Museum of Wales fez uma publicação, resultado de uma conferência realizada em 1993 no Welsh Folk Museum, denominada The Conservation of Geological Collections e organizada pelos conservadores do National Museum of Wales, decorrente de estudos que demonstravam que as coleções geológicas sem cuidados de conservação estão sempre sob grave risco de deterioração, quer pelo ambiente natural, quer pelo acondicionamento inadequado. Além dos danos à própria coleção, é muito importante ressaltar o risco à saúde dos pesquisadores e da equipe técnica que manuseia as amostras.

\section{1 - Aspectos gerais}

A conservação de minerais e rochas pode ocorrer de duas formas: conservação preventiva ou de remediação.

A conservação preventiva engloba um conjunto de medidas profiláticas específicas para cada mineral, tomadas a fim de evitar, retardar ou reduzir, à menor taxa possível, os danos naturalmente causados às amostras de coleção.

Já a conservação de remediação é a reversão, quando possível, do dano causado ao mineral, ou o reparo ao material já danificado (PRICE, 1992).

A conservação profilática deve receber mais atenção por parte de curadores, gerentes de coleção e diretores, uma vez que, minerais, como compostos químicos naturais, deixam poucas possibilidades de interferência sem sua alteração química. Por isso, conservá-los em seu estado natural é de extrema importância para que se evite o dispêndio com métodos caros de recuperação, ou com a própria perda do mineral.

O processo de conservação não é restrito apenas ao ambiente em que a amostra está hospedada. Os registros que a acompanham (dados da coleta, da aquisição, ou seu histórico, caso seja uma doação) devem ser igualmente preservados, pois auxiliam não só na preservação do material em longo prazo, como também para o uso em exibições, atividades educativas e pesquisa (PRICE, 1992). Para que esse tipo de proposta seja bem sucedida, é imprescindível que o museu tenha uma Política de Gestão de Acervos bem desenvolvida, pois os funcionários, por maior conhecimento que tenham da coleção, ou por maior tempo de trabalho que possam ter com ela, um dia invariavelmente deixarão de trabalhar no Museu. A 
memória humana é sempre passível de falhas; registros continuam imutáveis através dos tempos.

São três os principais fatores que promovem alterações em minerais expostos em museus: efeitos da luz, efeito da temperatura e efeitos químicos. Não são conhecidos casos em que uma vitrina de exposição apresente proteção contra essas três ocorrências (PARSONS, 1926).

O ambiente de um museu é geralmente construído a fim de balancear o bem estar dos trabalhadores e visitantes com a preservação dos objetos exibidos. Quando não se pode atender às duas demandas, o bem estar do visitante sempre prevalece. No entanto, há possibilidades de melhorar o ambiente e promover condições satisfatórias de acondicionamento e exibição, sem prejudicar os aspectos expositivos ou o conforto e saúde dos visitantes.

Os fatores considerados na conservação de coleções geológicas são:

- $\quad$ Temperatura $(\mathrm{T})$

- Umidade relativa do ar (UR)

- Iluminação

- Poluição

- Manuseio e danos mecânicos às amostras

Este capítulo será dividido em duas etapas:

1 - Fatores de conservação atrelados à saúde humana (considerando, como já foi dito, a saúde do corpo funcional do museu e dos visitantes), como toxicidade, radioatividade, doenças decorrentes da inalação de gases ou de poeiras perigosas;

2 - Fatores de conservação das amostras em si, como objetos museológicos que são. Tem-se aqui o esfacelamento de piritas, laminação de folhelhos, mudança de cores nos minerais, entre outros.

\section{2 - Conservação atrelada à saúde humana}

\subsection{1 - Toxicidade}

Não existe mineral de coleção que seja suficientemente tóxico para causar envenenamento por simples manipulação (BRUNTON ET AL., 1985). Todavia, alguns minerais são tóxicos em caso de ingestão, inalação, aspiração ou contato prolongado da pele com a amostra (manipulação frequente). Casos de envenenamento extremo são raros, embora 
minerais de arsênio (As), chumbo $(\mathrm{Pb})$, mercúrio $(\mathrm{Hg})$ e Tálio $(\mathrm{Tl})$ sejam considerados de alta toxicidade.

A toxicidade dos minerais está relacionada aos seguintes fatores: composição química, estado de coesão e solubilidade, dose consumida (em caso de ingestão ou inalação) e propensão pessoal (BRUNTON ET AL., 1985). No entanto, é necessário ressaltar que, apesar da importância da precaução com minerais tóxicos, é a exposição prolongada ao elemento químico presente na amostra que irá causar a intoxicação. Eventuais manipulações acidentais não serão responsáveis por danos graves à saúde. Por isso, são técnicos de museu e curadores os alvos principais desse estudo, uma vez que são eles que estão em contato direto, prolongado e permanente com as amostras e ambientes tóxicos.

A composição química está relacionada à toxicidade dos elementos químicos presentes nos minerais. Amostras com grande quantidade de metais pesados em sua composição, certamente serão tóxicas.

O estado de coesão dos minerais também interfere no seu potencial tóxico. Amostras que formam pó podem ser facilmente absorvidas pelas vias inalatórias (o pó fica suspenso no ar e é rapidamente respirado, atingindo as vias aéreas). Partículas sólidas, como poeiras ou sujeiras, fumaças ou gases nos quais esses elementos estejam presentes também devem ser evitadas. A poluição interna é controlada pela escolha correta de armazenamento e exposição dos materiais, um bom design e manutenção do espaço.

Já os minerais solúveis em água são rapidamente absorvidos no estômago. Assim, um mineral solúvel é sempre mais perigoso do que um equivalente não solúvel (um exemplo clássico são os minerais de bário: whiterita, mineral solúvel, por isso tóxico, e a barita, não solúvel, por isso atóxica - Figura 150) (BRUNTON ET AL., 1985). 


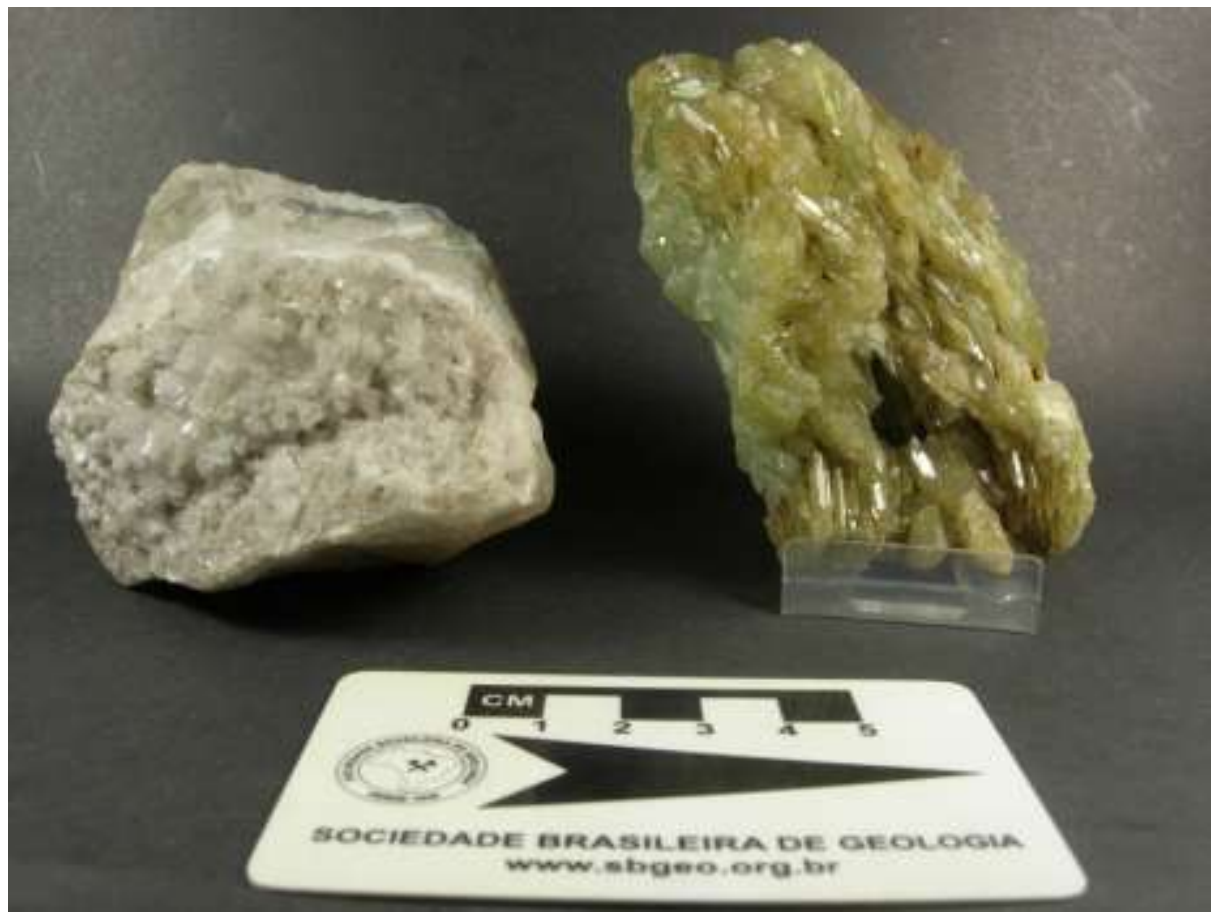

Figura 150. Dois minerais de bário: a whiterita à esquerda ( $\left.\mathrm{BaCO}_{3}\right)$, considerada tóxica por ser solúvel; à direita está a barita $\left(\mathrm{BaSO}_{4}\right)$, atóxica por não ser solúvel. Acervo do Museu de Geociências da USP.

A propensão pessoal à intoxicação relaciona-se a fatores fisiológicos individuais, como idade, peso e estado de saúde. Por isso, o relato de experiências com relação à toxicidade em minerais pode ser bem diverso.

Os elementos químicos considerados perigosos e seus respectivos compostos estão apresentados na Tabela 17. 
Tabela 17. Elementos químicos nocivos à saúde humana e os respectivos minerais nos quais são encontrados. Fonte: BRUNTON ET AL. (1985) e HOWIE (1992).

\begin{tabular}{|c|c|c|}
\hline $\begin{array}{c}\text { ELEMENTO } \\
\text { QUÍMICO }\end{array}$ & FÓRMULA & MINERAL \\
\hline Antimônio & $\mathrm{Sb}$ & $\begin{array}{ll}\text { - } & \text { Nativo } \\
\text { - } & \text { Sulfetos }\end{array}$ \\
\hline Arsênio & As & $\begin{array}{ll}\text { - } & \text { Nativo } \\
\text { - } & \text { Sulfetos: } \\
& \text { arsenopirita FeAsS } \\
& \text { realgar AsS } \\
& \text { ouro-pigmento } \mathrm{As}_{2} \mathrm{~S}_{3} \\
\text { - } & \text { Óxidos: } \\
& \text { claudetita } \mathrm{As}_{2} \mathrm{O}_{3} \\
& \text { arsenolita } \mathrm{As}_{2} \mathrm{O}_{3} \\
\text { - } & \text { Arsenatos } \\
& \text { adamita } \mathrm{Zn}_{2}\left(\mathrm{AsO}_{4}\right)(\mathrm{OH}) \\
& \text { anabergita } \mathrm{Ni}_{3}\left(\mathrm{AsO}_{4}\right)_{2} \cdot 8 \mathrm{H}_{2} \mathrm{O} \\
& \text { conicalcita } \mathrm{CaCu}\left(\mathrm{AsO}_{4}\right)(\mathrm{OH}) \\
& \text { farmacolite } \mathrm{Ca}\left(\mathrm{HAsO}_{4}\right) \cdot 2 \mathrm{H}_{2} \mathrm{O}\end{array}$ \\
\hline Bário & $\mathrm{Ba}$ & $\begin{array}{l}\text { frankdicksonita } \mathrm{BaF}_{2} \\
\text { (mineral raro) } \\
\text { nitrobarita } \mathrm{Ba}\left(\mathrm{NO}_{3}\right)_{2} \\
\text { whiterita (solúvel) } \mathrm{BaCO}_{3}\end{array}$ \\
\hline Bismuto & $\mathrm{Bi}$ & - Nativo \\
\hline Boro & B & - Todos os minerais de boro, pois são geralmente solúveis \\
\hline Cobre & $\mathrm{Cu}$ & - Todos os minerais solúveis \\
\hline Chumbo & $\mathrm{Pb}$ & $\begin{array}{l}\text { - Arsenatos } \\
\text { - Carbonatos } \\
\text { - Cloretos } \\
\text { - Óxidos } \\
\text { - Fosfatos } \\
\text { - Sulfatos }\end{array}$ \\
\hline Flúor & $\mathrm{F}$ & - Todos os minerais solúveis \\
\hline Mercúrio & $\mathrm{Hg}$ & $\begin{array}{l}\text { - } \\
\text { - }\end{array}$ \\
\hline Selênio & $\mathrm{Se}$ & $\begin{array}{l}\text { - Nativo } \\
\text { olsacherita } \mathrm{Pb}_{2}\left(\mathrm{SeO}_{4}\right)\left(\mathrm{SO}_{4}\right)\end{array}$ \\
\hline
\end{tabular}




\begin{tabular}{|c|c|c|}
\hline Tálio & $\mathrm{Tl}$ & $\begin{array}{l}\text { - Sulfetos } \\
\text { carlinita } \mathrm{Tl}_{2} \mathrm{~S} \\
\text { crookesita } \mathrm{Cu}_{7}(\mathrm{Tl}, \mathrm{Ag}) \mathrm{Se}_{4} \\
\text { lorandita } \mathrm{TlAsS}_{2} \\
\text { pierrotita } \mathrm{Tl}_{2} \mathrm{Sb}_{6} \mathrm{As}_{4} \mathrm{~S}_{16} \\
\text { routhierita } \mathrm{Tl}(\mathrm{Cu}, \mathrm{Ag})(\mathrm{Hg}, \mathrm{Zn})_{2}(\mathrm{As}, \mathrm{Sb})_{2} \mathrm{~S}_{6} \\
\text { - Óxido } \\
\text { - Todos os produtos de decomposição dos conjuntos } \\
\text { anteriores }\end{array}$ \\
\hline Urânio & $\mathrm{U}$ & $\begin{array}{l}\text { - Todos os minerais, pois além de sua radioatividade, } \\
\text { causa danos renais }\end{array}$ \\
\hline Zinco & $\mathrm{Zn}$ & $\begin{array}{l}\text { - Nativo }(\mathrm{Zn}) \\
\text { köttigita } \mathrm{Zn}_{3}\left(\mathrm{AsO}_{4}\right)_{2} \cdot 2 \mathrm{H}_{2} \mathrm{O} \\
\text { zincita }\left(\mathrm{Zn}, \mathrm{Mn}^{2+}, \mathrm{Fe}^{2+}\right) \mathrm{O} \\
\text { goslarita } \mathrm{Zn}\left(\mathrm{SO}_{4}\right) \cdot 7 \mathrm{H}_{2} \mathrm{O}\end{array}$ \\
\hline
\end{tabular}

A seguir, estão apresentados os elementos químicos que, presentes em minerais os tornam tóxicos e os problemas de saúde associados a eles.

Antes de tratar do problema, é necessário ler as etiquetas dos minerais suspeitos com sua exata procedência (minerais procedentes de certa região são atestadamente nocivos, enquanto o mesmo mineral, procedente de outra região, é inofensivo) e submetê-lo a uma nova análise química.

O Arsênio ocorre em quatro estados de oxidação: arsenato $\left(\mathrm{As}^{5+}\right)$, arsenito $\left(\mathrm{As}^{3+}\right)$, o gás, arsina $\left(\mathrm{As}^{3-}\right)$, e o metal, ou forma nativa, sem valência (As). As ocorrências solúveis, por isso as mais tóxicas, encontram-se nas espécies tri e pentavalentes, sendo a primeira muito mais nociva. As associações mais comuns são com o enxofre $(\mathrm{S})$, oxigênio $(\mathrm{O})$ e ferro $(\mathrm{Fe})$ (LOPES JR. ET AL., 2006).

Um curador que manuseia constantemente amostras de arsênio ou minerais oxidados de chumbo está sob risco de sofrer intoxicações crônicas devido a esses elementos. Intoxicação por arsênio inclui queimação nas mucosas bucal e nasal, distúrbios de estômago e espasmos musculares. $\mathrm{O}$ arsênio e seus compostos inorgânicos são considerados cancerígenos. A principal via de contaminação em ambientes museológicos dá-se pela ingestão do pó das amostras, podendo ocorrer, em menor escala, a inalação do gás (FIGUEIREDO, 2006) em ambientes fechados com grande acúmulo desses minerais. A dose letal de arsênio pode ser menor que $20 \mathrm{mg}$. A dose letal de tálio como óxido para um adulto está entre 100 e 200 mg (HOWIE, 1992). 
Intoxicação por vapor de mercúrio (proveniente da evaporação de minérios de mercúrio como o cinábrio) causa transtornos emocionais e tremores.

Procedimentos a serem adotados:

1. Minerais de arsênio ou tálio devem ser manuseados com luvas apropriadas (látex ou neoprene). É sensato usar luvas todas as vezes nas quais haja manuseio de qualquer tipo de mineral tóxico e lavar as mãos imediatamente após o contato, mesmo se tiver utilizado luvas.

2. Não utilizar ácidos em minerais com arsênio em sua composição, devido ao risco de liberação de arsina $\left(\mathrm{AsH}_{3}\right)$. Exposições a doses menores que 10 ppm podem ser fatais.

3. As estantes, gavetas ou recipientes que contenham minerais tóxicos devem estar devidamente etiquetadas com um aviso do potencial de toxicidade do mineral.

4. Não permitir o manuseio desses minerais sem supervisão de um responsável e nem deixá-los ao alcance de crianças.

5. Todos os processos mecânicos (corte, moagem, trituração, serragem, limpeza e polimento) devem ser executados em uma capela, por profissionais treinados.

6. Nunca deixar as amostras espalhadas em locais onde pessoas alheias ao trabalho tenham acesso e possam manuseá-las sem ciência do perigo que causam.

7. Nunca utilizar-se do paladar como forma de identificação de minerais, não importando o quão seguro se está acerca de sua composição. As vias digestivas são as mais eficientes em espalhar toxicidade pelo corpo.

Por fim, armazenar esses minerais em caixas e somente as manusear quando estiver analisando-os. Se os minerais não estiverem sendo utilizados, as caixas devem permanecer guardadas.

\subsection{2 - Radioatividade}

Acidentes causados por espécimes museológicos radioativos não são normalmente comuns; medições precisas e constantes são as formas mais eficientes de evitar possíveis problemas. No entanto, existem alguns minerais que devem ser cuidadosamente acompanhados pelo curador ou responsável.

A radioatividade ocorre quando um átomo se quebra espontaneamente, originando elementos filhos decorrentes dessa quebra. Durante essa atividade, ocorre grande liberação de energia eletromagnética, conhecida genericamente por radiação. 
A emissão de radiação está relacionada ao número atômico de alguns elementos. Quanto maior o número atômico, maior será o nível de energia em atividade em seu núcleo. O urânio (92) é o elemento químico natural de maior número atômico. Explica-se assim, porque é o mais utilizado para a obtenção de energia nuclear. O tório (90), o rádio (88) e o radônio (86) são também importantes elementos radioativos e devem ser atentamente observados em uma coleção, embora os minerais mais comumente encontrados em acervos mineralógicos sejam uraniníferos.

A radiação ocorre em consequência da tentativa de estabilização de átomos muito carregados energeticamente. O resultado dessa estabilização é a emissão de partículas alfa ou beta e de ondas eletromagnéticas (raios gama).

A estabilização de um núcleo com excesso de nêutrons pode ocorrer de duas formas:

1) Emissão de partículas: possuem massa e carga elétrica. A velocidade depende da quantidade de energia envolvida.

a) Partículas alfa: emissão de um grupo de partículas positivas (dois prótons e dois nêutrons) em forma de gás hélio e da energia associada a elas.

b) Partículas beta:

- emissão de elétrons, resultantes da conversão de nêutrons em prótons (partículas beta negativas, mais conhecidas por partículas beta);

- emissão de pósitrons (ou partículas beta positivas) resultantes da conversão de nêutrons excedentes em prótons.

2) Emissão de radiação eletromagnética: não possuem massa e a velocidade envolvida no processo é invariável $(300.000 \mathrm{~km} / \mathrm{s})$. Após a emissão de partículas, o núcleo atômico, ainda com excesso de energia, tenta novamente se estabilizar, porém, liberando a energia do núcleo em formas de ondas do espectro eletromagnético, os raios gama.

No caso específico dos minerais de coleção, o único elemento radioativo importante presente em alguns minerais é o urânio (U). A radiação acontece, nestes casos, quando o urânio decai, emitindo partículas alfa e beta (pedaços do núcleo atômico) e raios gama. Os raios gama são os que liberam mais energia dentre os raios do espectro eletromagnético (Figura 151). Esses raios são os mais penetrantes, por isso são os responsáveis pelos danos causados pela radioatividade aos seres humanos. 


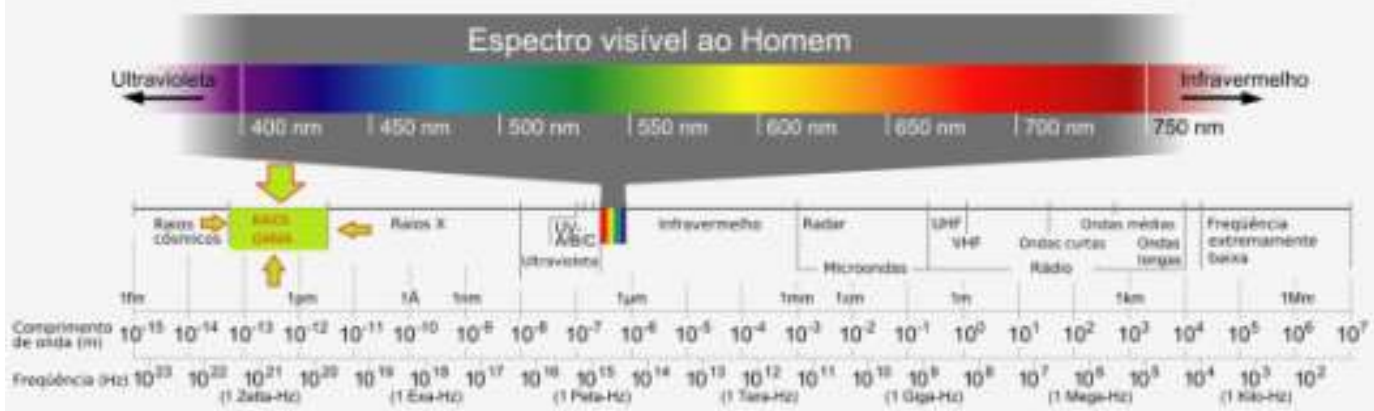

Figura 151. Espectro eletromegnético. Em verde está destacado o intervalo onde se localizam os raios gama. Fonte: http://fisicasemmisterios.webnode.com.br/products/ondas-eletromagneticas/ (modificado). Acesso em 18/06/2012.

É importante ressaltar que as reações nucleares liberam gases tóxicos, sendo o radônio o principal produto e um dos gases mais tóxicos. Deve-se por isso, prestar atenção não só nos minerais, mas no ambiente em que eles se encontram armazenados. O radônio é muito encontrado nos materiais da crosta, mas a quantidade é inofensiva. O Urânio existe na natureza na forma de três isótopos, como mostra a Tabela 18:

Tabela 18. Isótopos Naturais de Urânio. Fonte: Apostila Educativa - Radioatividade. CENEN.

\begin{tabular}{c|c|c}
\hline Isótopos - $\mathbf{Z = 9 2}$ & $\mathbf{N}^{\mathbf{0}}$ de Nêutrons no núcleo & Ocorrência na natureza \\
\hline $\mathbf{U}^{\mathbf{2 3 4}}$ & $142(50$ "nêutrons excedentes") & $\begin{array}{c}\text { Quantidade desprezível } \\
\mathbf{U}^{\mathbf{2 3 5}}\end{array}$ \\
& 143 (51 "nêutrons excedentes") & $\begin{array}{c}0,7 \% \text { (utilizado em reatores após } \\
\text { enriquecimento) }\end{array}$ \\
$\mathbf{U}^{\mathbf{2 3 8}}$ & $146(54$ "nêutrons excedentes") & $99,3 \%$ \\
\hline
\end{tabular}

Essas emissões são classificadas como radiação iônica, e os níveis de exposição são classificados em uma tabela de proteção radiológica nacional, criada pela CNEN (Comissão Nacional de Energia Nuclear). As medidas e dosagens recomendadas internacionalmente (Comissão Internacional de Proteção Radiológica e Comissão Internacional de Medidas e Unidades de Radiação) ainda estão sendo estudadas pela CNEN antes de serem recomendadas para aplicação em território nacional. ${ }^{12}$ Para que se possa mensurar a radioatividade deve-se conhecer algumas unidades de medida importantes ${ }^{13}$ :

- Bequerel $(\mathrm{Bq})$ : número de desintegrações por segundo (afere a atividade de determinado material radioativo)

\footnotetext{
${ }^{12}$ Aprovada pela Resolução CNEN N ${ }^{\circ}$ 102, DE 22.12.2010, publicada no D.O.U. em 10.05.2011. Disponível em http://www.in.gov.br/imprensa/visualiza/index.jsp?jornal=1\&pagina=7\&data=10/05/201.

${ }^{13}$ Todas as unidades citadas são pertencentes ao Sistema Internacional (SI).
} 
- $\operatorname{Gray}(\mathrm{Gy}): 1$ Joule de energia absorvido por um quilograma de material (mede a dose absorvida por um organismo atingido por radiação ionizante)

$$
1 \mathrm{~Gy}=1 \mathrm{~J} / \mathrm{Kg}
$$

- Fator de Qualidade (F): também chamado de eficiência biológica relativa. Depende da eficácia do tipo de radiação na produção de danos

Raios X, Raios Gama e
Partículas Beta: $\mathrm{F}=1$

\section{Partículas alfa e nêutrons:$$
F=20
$$

- Sievert (Sv): é o equivalente de dose e caracteriza os danos provocados pela radiação em organismos vivos. Depende da energia envolvida no processo, da massa do organismo que sofre a radiação e do fator de qualidade $(\mathrm{F})$ da mesma

$$
\text { Sv }=\mathbf{G y} \cdot \mathbf{F}
$$

Uma coleção média de seis espécimes de minerais radioativos apresenta um risco insignificante se for esporadicamente manuseada (uma hora por ano, por exemplo).

Existe um grande número de espécimes de minerais radioativos, no entanto são raros na natureza e dificilmente encontrados em coleções. Os minerais radioativos encontrados com maior frequência em coleções são os minérios de urânio.

Os minerais radioativos mais comumente encontrados em acervos mineralógicos estão dispostos na Tabela 19.

Tabela 19. Minerais radioativos comumente encontrados em acervos mineralógicos e sua composição química. Fonte: BRUNTON ET AL. (1985) / LAMBERT (1994)

\begin{tabular}{l|l|l}
\hline MINERAL & FÓRMULA QUÍMICA & OBSERVAÇÃO \\
\hline Uraninita & $\mathrm{UO}_{2}$ & $\begin{array}{l}\text { Contém mais de } 80 \% \text { de U na } \\
\text { composição }\end{array}$ \\
Gumita & Produto de alteração da uraninita & $\begin{array}{l}\text { Superfície de alteração é } \\
\text { geralmente pó }\end{array}$ \\
\hline $\begin{array}{l}\text { Autunita } \\
\text { Torbernita }\end{array}$ & $\begin{array}{l}\mathrm{Ca}\left(\mathrm{UO}_{2}\right)_{2}\left(\mathrm{PO}_{4}\right)_{2} \cdot 11 \mathrm{H}_{2} \mathrm{O} \\
\mathrm{Cu}\left(\mathrm{UO}_{2}\right)_{2}\left(\mathrm{PO}_{4}\right)_{2} \cdot 12 \mathrm{H}_{2} \mathrm{O}\end{array}$ \\
\hline Metatorbernita & $\mathrm{Cu}\left(\mathrm{UO}_{2}\right)_{2}\left(\mathrm{PO}_{2}\right)_{2} \cdot 8 \mathrm{H}_{2} \mathrm{O}$ & \\
\hline
\end{tabular}


Por ter muito urânio em sua composição, a uraninita merece muita atenção quando presente em coleções, tanto se estiver exposta quanto em reserva técnica. É considerado o mineral de coleção mais radioativo.

A gumita é uma crosta laranja avermelhada ou amarela, produto de alteração da uraninita, resultando em vários minerais que recobrem a parte central deste mineral de urânio. É menos radioativa que a uraninita pura, mas sua superfície geralmente forma pó, o que faz esse aglomerado mineral necessitar dos mesmos cuidados da uraninita.

Os minerais secundários de urânio (fosfatos, arsenatos, vanadatos, silicatos e carbonatos) são bem menos radioativos, no entanto, apresentam-se geralmente em amostras de muita massa, devendo, por isso, receber atenção adequada. Se as amostras forem pequenas, o risco é mínimo. Entretanto, muitas amostras pequenas, dispostas no mesmo espaço, apresentam risco, necessitando de medição constante. A autunita, torbernita e metatorbernita encontram-se nessa classificação.

Para medir a radiação presente em um ambiente com minerais ou rochas radioativos, utiliza-se um contador Geiger (Figura 152). Trata-se de um aparelho que mede a radiação emitida utilizando a propriedade de ionização da radiação.

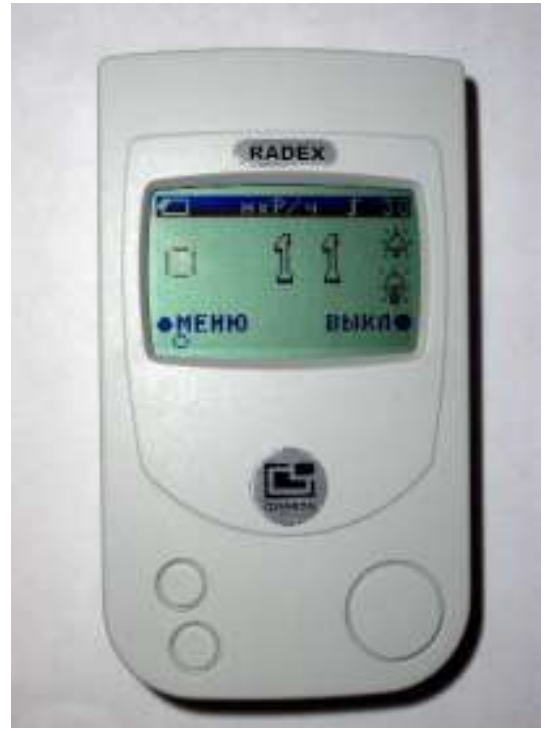

Figura 152. Exemplo de contador Geiger de mão. http://lojageobiologia.webnode.com/images/200000016-2f0112ffb1/radex-.jpg.

Os cuidados de conservação evidenciam a necessidade de que o mineral tenha sempre etiqueta. Se a etiqueta tiver indicação de radioatividade, é necessário utilizar um contador Geiger para verificar o nível de radiação, antes de qualquer contato com a amostra. Se o nível de radiação for baixo, a amostra pode ser manuseada apenas com o uso de luvas. Caso haja dúvidas, o procedimento correto a ser adotado é isolar a amostra e procurar ajuda competente. Não manusear de forma alguma. 
Procedimentos a serem adotados (a partir do índice de contaminação da uraninita):

1. Minimizar o manuseio.

2. Se for indispensável o manuseio, usar luvas de borracha descartáveis (jamais reaproveitar luvas utilizadas no manuseio de minerais radioativos).

3. Após o manuseio, lavar abundantemente as mãos, mesmo se foram usadas luvas.

4. Sempre utilizar máscaras de proteção com filtros para evitar a inalação do ar, possivelmente contaminado de gavetas recém-abertas, ou o ar empoeirado devido ao manuseio de minerais.

5. Não comer, beber ou fumar próximo a esses minerais.

6. Não manuseá-los se a pele estiver machucada ou fissurada, mesmo com a utilização de luvas.

7. Etiquetar estantes, prateleiras e recipientes das amostras com aviso de radioatividade.

8. Armazenar as amostras radioativas juntas e em ambiente separado das demais amostras, numa área denominada área de radiação controlada, que não seja frequentemente visitada. Essa área deve ser ventilada, a fim de retardar o acúmulo de gases tóxicos e evitar o aumento do nível de radioatividade. Uma boa ventilação deve ser providenciada numa sala externa. Para essa sala deve ser executado um monitoramento de radiação constante (a periodicidade deve ser estabelecida por autoridades competentes, como mineralogistas ou pessoas especializadas em radiação).

9. Utilizar caixas de chumbo para a armazenagem - caso as amostras sejam muito grandes ou em grande quantidade - a fim de diminuir ou até eliminar o perigo de contaminação. Lembrar que, no interior dessas caixas, podem se acumular gases, sendo o gás radônio o mais prejudicial, e por isso devem ser abertas em local arejado, longe dos outros minerais. A pessoa que estiver manipulando as amostras deve utilizar máscaras para não inalar o gás contido no interior das caixas.

A Figura 153 é um exemplo de acondicionamento adequado para exposição de minerais de urânio. 


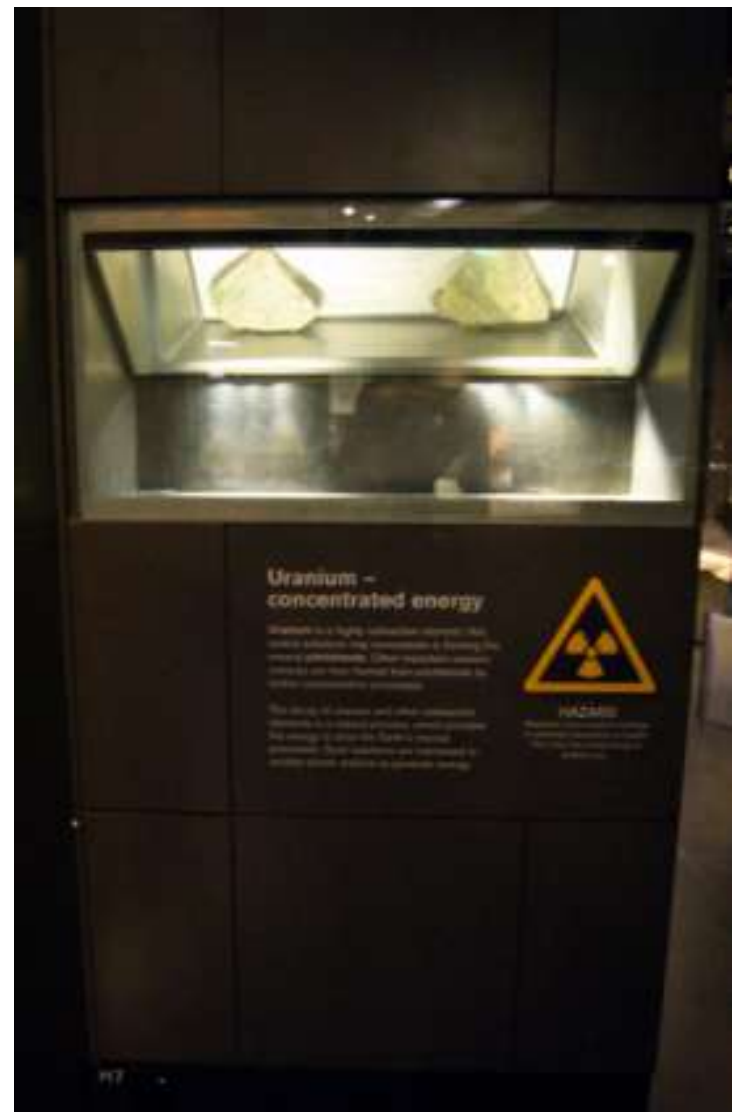

Figura 153. Vitrina especial para exibição de minerais radioativos. Nota-se que o visitante não tem sequer contato visual com as amostras, apenas com suas imagens. Notar também o posicionamento de aviso de radiação em local visível. Acervo: London Natural History Museum.

\subsection{3 - Toxicidade Física}

Trata-se aqui, por toxicidade física, minerais cujas características físicas são consideradas perigosas e/ou tóxicas e que, em si mesmos, representam risco à saúde (diferente dos radioativos e tóxicos, cujos danos são causados não diretamente por eles, mas pelos elementos químicos que os compõem). A partir dessa definição, alguns minerais apresentam perigo porque são fibrosos ou porque têm pontas ou bordas muito afiadas, facilmente cortantes durante simples manipulação. Outros têm característica de serem cobertos por cristais aciculares facilmente quebráveis, sendo de fácil penetração na pele.

Em geral, qualquer mineral pode apresentar bordas afiadas, mas são os minerais com fratura conchoidal, principalmente os do grupo do quartzo (quartzo e suas variedades, ágata, calcedônia, ônix, jaspe e opala) que oferecem maior perigo, uma vez que são os mais comuns em coleções geológicas (desde um grande museu a uma pequena coleção infantil), e também os mais manipulados, principalmente com propósitos didáticos. Qualquer poeira inalada é um perigo em potencial, por isso, os minerais que necessitam de um cuidado maior sob este aspecto são: quartzo e argilas, em escala industrial, olivina, magnetita, talco, minerais que contêm berílio, cádmio, óxido de ferro, vanádio, cromo e níquel. 
A precaução é usar luvas, preferencialmente as de borracha mais grossa. Os minerais fibrosos devem ser tratados com muito cuidado, manipulados com o uso de luvas e máscaras, e não manuseados, se possível, pois além do perigo de inalação, o manuseio prejudica a amostra.

Sempre utilizar máscaras ao manusear amostras com pó, e evitar lugares geradores de poeira. Para esses lugares, como laboratórios de corte, polimento, etc., usar ventiladores e máscaras.

\section{Minerais Asbestiformes}

Asbesto ou amianto $^{14}$ é o nome comercial que se dá a certos tipos de minerais silicáticos que apresentam hábito fibroso (Figura 154), pertencentes ao grupo dos anfibólios e ao grupo das serpentinas.

Os minerais asbestiformes foram largamente utilizados em papéis, pinturas, pastilhas de frenagem, cerâmicas, cimentos, enchimentos e filtros. Mas foi sua excepcional resistência ao calor que os tornou o isolante térmico mais utilizado no mundo até meados da década de 1970, quando os estudos sobre seu potencial cancerígeno tiveram início.

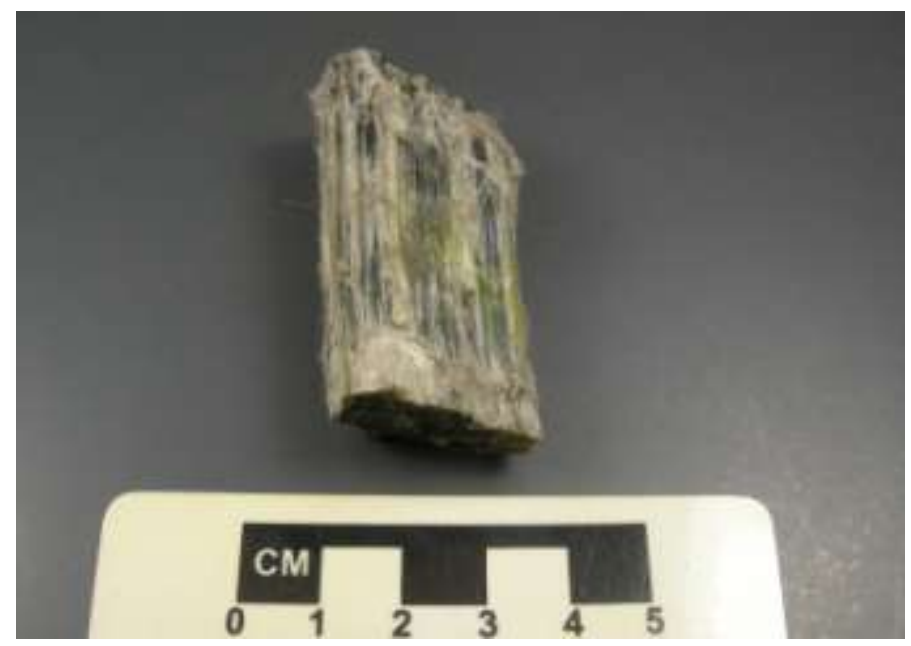

Figura 154. Exemplo de mineral asbestiforme. Note que a fibra se desprende facilmente do mineral. Acervo do Museu de Geociências da USP.

Os minerais asbestiformes são: serpentinas e anfibólios.

Entre as serpentinas está a crisotila. Já entre os anfibólios estão a actinolita, antofilita, riebeckita (mais conhecida como asbesto azul), grunerita e tremolita.

\footnotetext{
14 Apesar de o termo amianto ser largamente conhecido e utilizado, a IMA (International Mineralogical Association) indica que se utilize apenas a terminação asbesto ou mineral asbestiforme.
} 


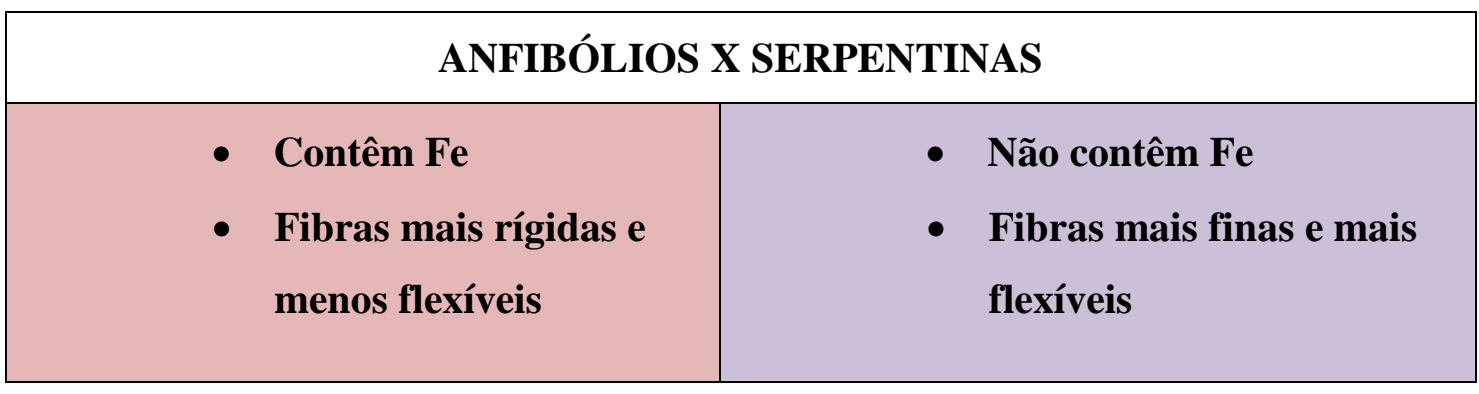

Os asbestos afetam a saúde humana por meio da inalação de material particulado, dispersado das amostras por ação do ar.

A asbestose é a principal doença causada pela inalação do pó de asbestos, que pode causar câncer de pulmão, mesotelioma maligno e falência respiratória.

As narinas humanas possuem mecanismos para deter e remover impurezas do ar. Ainda assim, muitas impurezas, geralmente em frações menores que 10 micra, conseguem atingir os pulmões. Nos pulmões, essas partículas são envolvidas por células macrofágicas, formando resíduos que são expelidos pela tosse.

O problema ocorre quando as microfibras de asbesto não são expelidas e atingem os pulmões (Figura 155). Isso se dá porque não conseguem ser englobadas pelas células macrofágicas, pois são prismáticas e rígidas, instalando-se definitivamente nos pulmões e proporcionando crescimento celular anormal. Os minerais que contêm Fe (anfibólios) são os piores nesse processo, pois o ferro sofre oxidação dentro do tecido pulmonar. Ao envolver as fibras minerais que contêm ferro, as células macrofágicas reagem com elas, oxidando o ferro bivalente para trivalente. Essa reação causa a formação de hidróxidos de ferro, como goethita ou limonita, que aderem às paredes dos pulmões e não podem ser removidas. Mesmo os asbestos que não contêm ferro em sua composição química, como a crisotila, também devem ser evitados, uma vez que as fibras causam irritações e inflamações nos tecidos pulmonares.

Não há cura para asbestose. Os sintomas da doença avançada são controlados por medicamentos paliativos, que diminuem o desconforto do paciente, mas que nada influem na regressão do quadro. Após diagnosticada, deve-se interromper o contato do paciente com o asbesto. $\mathrm{Na}$ fase crítica, o doente é tratado com oxigenação artificial. 


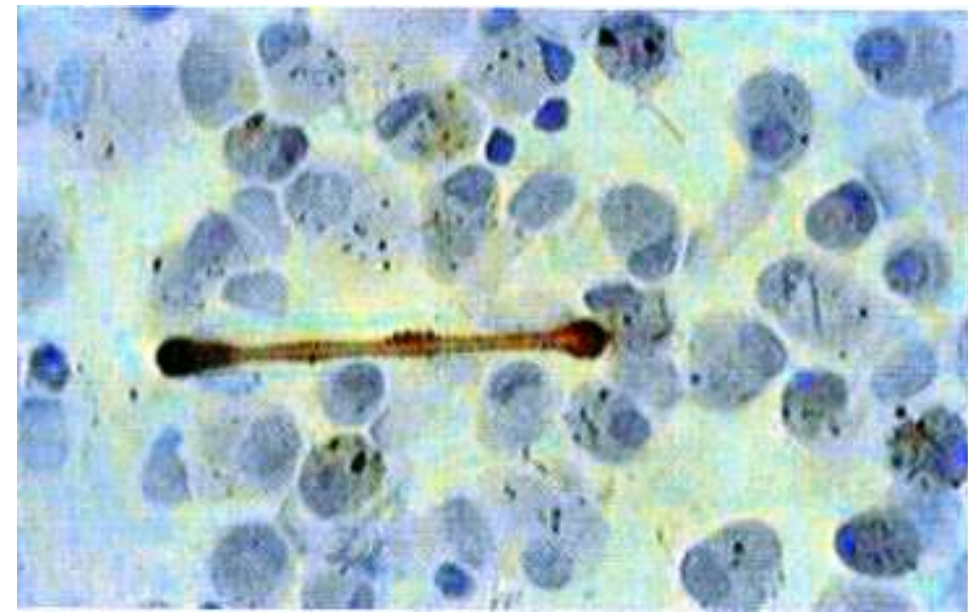

Figura 155. Imagem ampliada de uma fibra de asbesto tentando ser envolvida pelas células macrofágicas do pulmão humano. Fonte: SCARPELLI, 2006.

De maneira geral, pode ser nocivo à saúde aspirar o pó de qualquer mineral. No ambiente museológico, as fibras de asbestos podem ser facilmente inaladas durante a manipulação para limpeza e preparação dos exemplares na exposição ou na reserva técnica. Minerais de asbestos são reconhecidamente causadores de vários tipos de cânceres nos seres humanos. Não há, por isso, nível de exposição aceitável.

Assim, é imprescindível garantir um ambiente saudável e seguro para o visitante e para o funcionário.

Algumas recomendações para o tratamento de minerais fibrosos em museus:

- Ler sempre as etiquetas e tratar sempre como suspeito qualquer mineral fibroso. $\mathrm{Na}$ maioria das coleções, esses minerais são simplesmente descritos como asbestos.

- Classificar criteriosamente os minerais asbestiformes, a fim de que não haja dúvidas se se trata dos espécimes mais perigosos ou não.

- Acondicionar minerais fibrosos como a byssolita ${ }^{15}$ preferencialmente em caixas fechadas.

- Utilizar, como recomendação internacional, o uso de luvas de látex e máscaras para a limpeza de vitrinas que contenham minerais asbestiformes.

- Na reserva técnica, armazenar esses minerais em recipientes vedados. Manipulálos apenas se necessário.

\footnotetext{
${ }^{15}$ Byssolite: variedade mineral pertencente ao grupo dos anfibólios, cujos cristais possuem massas de fibras finas como fios de cabelo, e estão presentes em minerais da série actinolita, ferroactinolita e tremolita. Fonte: www.mindat.org. Acesso em 23 de setembro de 2012.
} 
- Colocar o espécime em embalagens plásticas vedadas, como mostra a Figura 156 (pelo menos duas vedações). Ao manusear, utilizar máscara, luvas e avental de laboratório. Etiquetar as gavetas com informes de perigo.

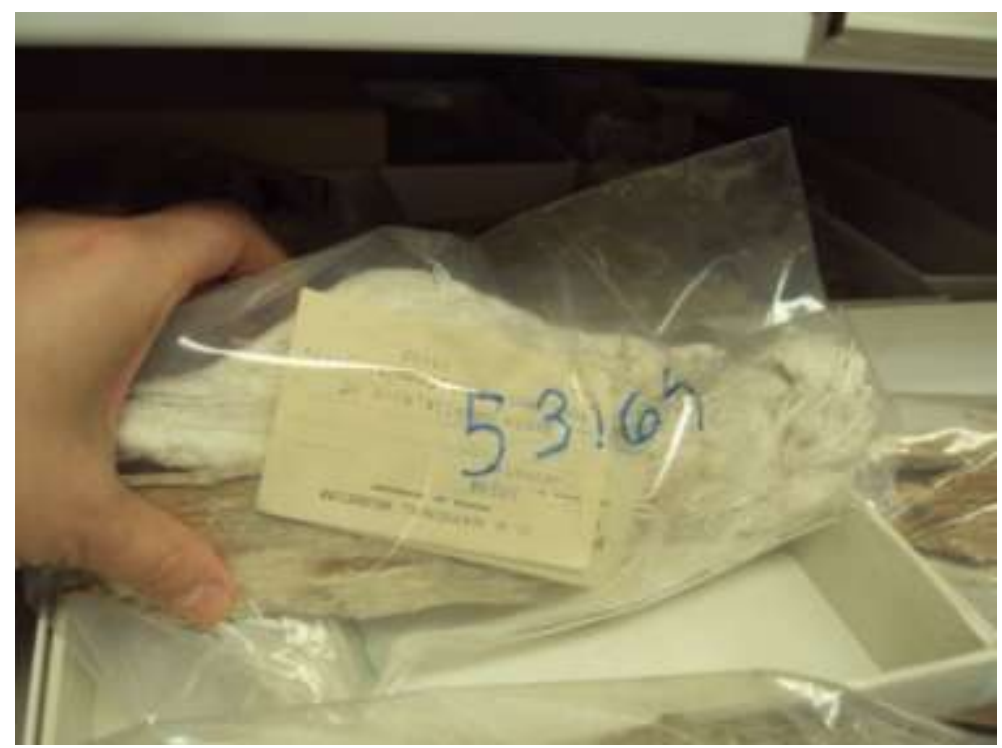

Figura 156. Exemplo de armazenamento ideal de amostra de asbesto no Museum Support Center (MSC) do Smithsonian Institution, em Maryland, Suitland. O material é embalado em sacos plásticos numerados, junto com as etiquetas, e depois colocado em caixas.

\section{3 - Conservação de amostras museológicas}

\subsection{1 - Umidade Relativa do Ar (UR)}

Mudanças na temperatura, principalmente abruptas (o que geralmente acontece em países tropicais), ocasionam mudanças na umidade relativa do ar (UR), alterando a quantidade de água no ar atmosférico. Na maioria das vezes, UR e temperatura têm relação direta, e dependem da latitude onde se localiza o Museu (que vai determinar o clima predominante no ambiente museológico).

Muitos minerais, rochas e fósseis são sensíveis à UR e danificam-se, podendo até mesmo ser destruídos em ambientes com umidade inadequada. Alta umidade pode gerar mudanças químicas, tais como o esfacelamento da pirita, ou alteração de alguns materiais, como sais, pela absorção da água do ambiente. A manutenção correta do edifício onde a coleção está abrigada também influi na conservação, como mostra a Figura 157. 


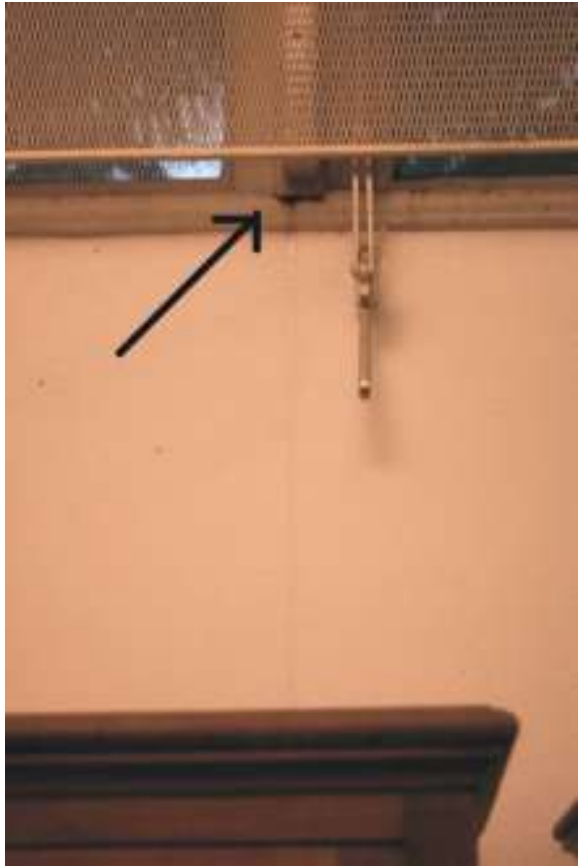

Figura 157a. Falha na vedação de caixilhos das janelas do Museu de Geociências da USP permite a entrada de água diretamente sobre parte da coleção.

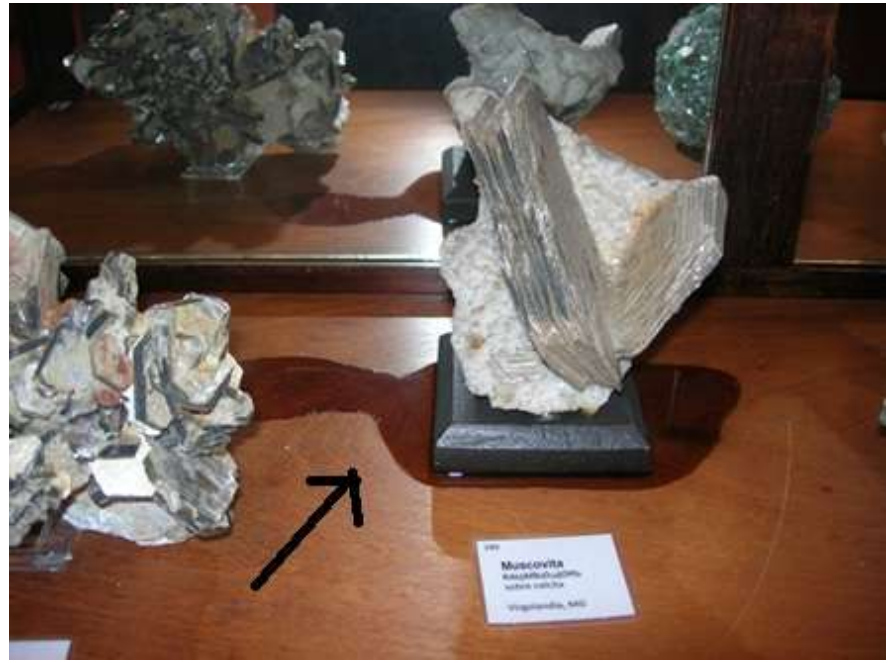

Figura 157b. Algumas amostras, como a muscovita da foto, são diretamente afetadas pela falta de manutenção no edifício, levando à alteração de minerais por elevação na UR.

Bolores e algumas pestes insetívoras, tais como tisanuros (traças) ou cupins proliferam-se, destruindo etiquetas e outros tipos de documentação sobre a coleção. Por outro lado, níveis baixos de umidade podem causar eflorescência e encolhimento de alguns exemplares que desidratam, como o folhelho.

Não existe padrão de umidade relativa ideal para toda a coleção geológica. A prioridade é estabilizar a umidade para evitar grandes variações de uma norma estabelecida. As variações abruptas (novamente muito frequentes em países tropicais) causam deterioração da amostra, mesmo dentro do museu.

Um nível geralmente aceitável de umidade relativa é de 50\%, variando para mais ou menos 5\%. A maioria dos higrômetros e outros instrumentos utilizados para medir a umidade do ar não têm precisão menor que $5 \%$, por isso, um controle aguçado da umidade não é possível. Espécimes que necessitam de controle fora deste leque de possibilidades devem ser embalados separadamente, em microclimas criados de acordo com cada necessidade.

Em ambientes museológicos existem quatro principais danos que a UR inadequada causa a minerais: corrosão, mudanças de fase mineral, desidratação (perda de água), principalmente nas zeólitas, e quebras resultantes de tensões higroscópicas (HOWIE, 1992). Para uma listagem completa dos minerais suscetíveis à UR, ver WALLER (1992).

A corrosão inclui quaisquer transformações sofridas pelo mineral pela reação com um ou mais gases atmosféricos, além do vapor de água (HOWIE, 1992). Tratar-se-á 
principalmente das reações de oxidação, cujo exemplo clássico é a oxidação da pirita, transformando-se em limonita $\left(\mathrm{FeO}(\mathrm{OH}) \cdot \mathrm{nH}_{2} \mathrm{O}\right)$, fenômeno conhecido em museus e coleções por mal da pirita. A pirita faz parte de um grupo de minerais suscetíveis ao processo de oxidação (principalmente minerais da classe dos sulfetos, que são estáveis em um ambiente ausente de oxigênio) e tem esse potencial aumentado em ambientes com alta UR; se a taxa ultrapassar os $60 \%$ de UR, essa alteração ocorre rapidamente. Por isso, é importante que o nível de UR no ambiente onde estão acondicionados esses minerais seja menor que $60 \%$, preferencialmente perto dos $30 \%$ (HOWIE, 1992). A corrosão do ferro é a reação de oxidação mais conhecida, e é representada pela seguinte equação geral:

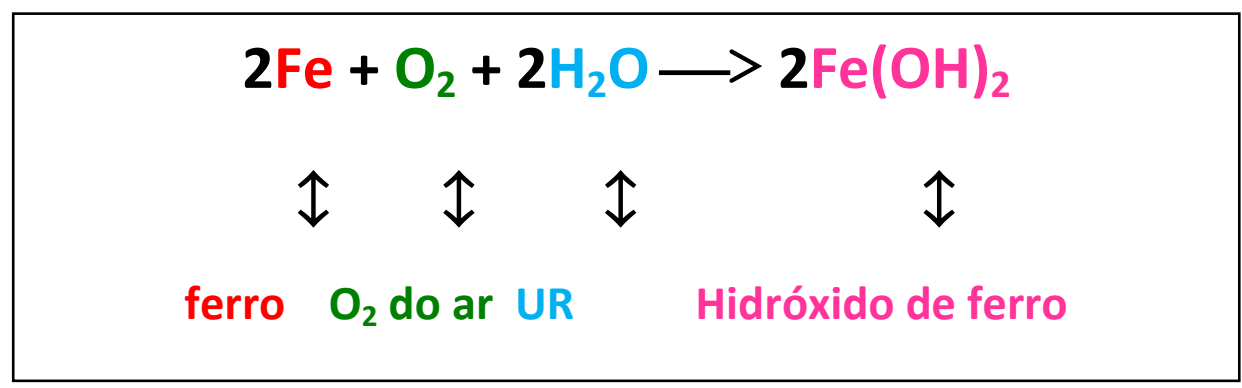

Para evitar a formação da ferrugem, sugere-se a utilização de um material de sacrifício, que tenha maior tendência à oxidação, para se unir ao ferro; ou a galvanização, que é a aplicação de uma camada de zinco sobre a superfície do ferro.

Outro dano relativo à UR é a deliquescência, que pode ser simplificadamente definida como a absorção da água do ambiente por um mineral, resultando em sua dissolução. Ocorre quando o nível da UR está acima do necessário para garantir a estabilidade do mineral. A deliquescência pode ocorrer sazonalmente, ou ser contínua, levando à decomposição do mineral. Outras vezes, pode ocorrer junto com outras reações, como hidrólise (decomposição de uma substância pela água) ou oxidação. Quando a deliquescência ocorre, o mineral pode se apresentar em duas fases distintas, como forma cristalina e como solução (Figura 158). Se a UR continuar a aumentar, esse processo pode levar à perda da amostra, uma vez que ocorrerá a mudança de fase do mineral. 


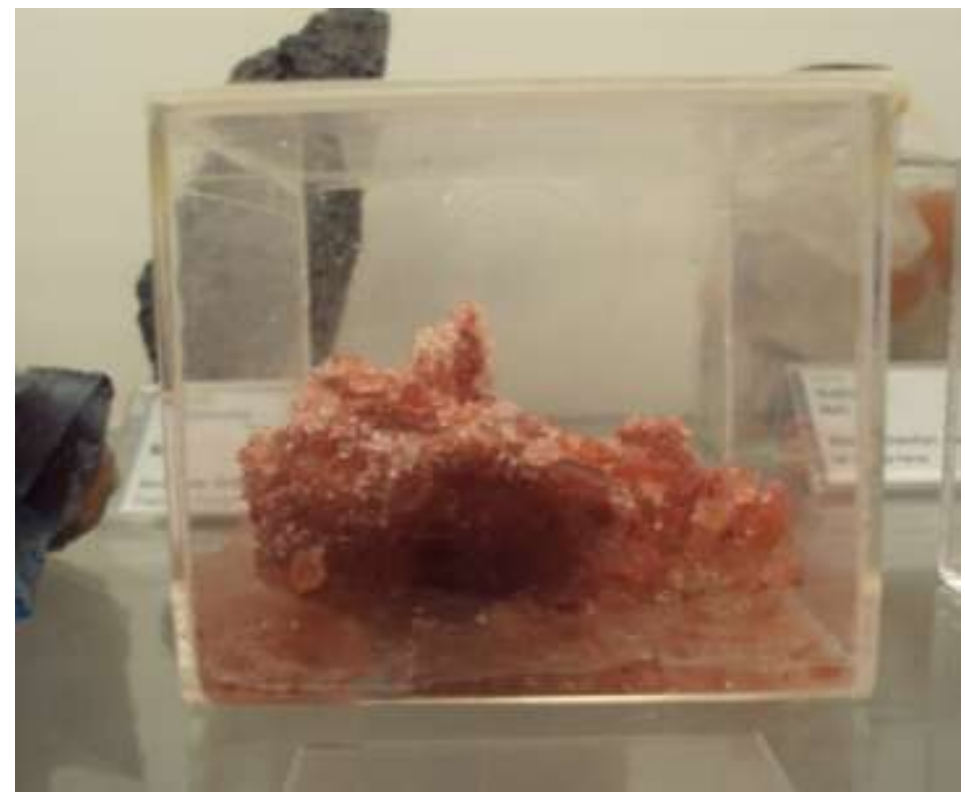

Figura 158. Imagem de carnallita $\left(\mathrm{KMgCl}_{3} \cdot 6 \mathrm{H}_{2} \mathrm{O}\right)$ em duas fases, cristalina e solução. Acervo do Museu de Geociências da USP.

Um exemplo de mineral que sofre deliquescência é a hanksita - $\mathrm{KNa}_{22}\left(\mathrm{SO}_{4}\right)_{9}\left(\mathrm{CO}_{3}\right)_{2} \mathrm{Cl}$ - que deliquesce quando a UR atinge 72\%, a altas temperaturas (HOWIE, 1992). Imagens de exemplar de hanksita do Museu de Geociências, no qual ocorreu deliquescência e oxidação do suporte, podem ser visualizadas na Figura 159.

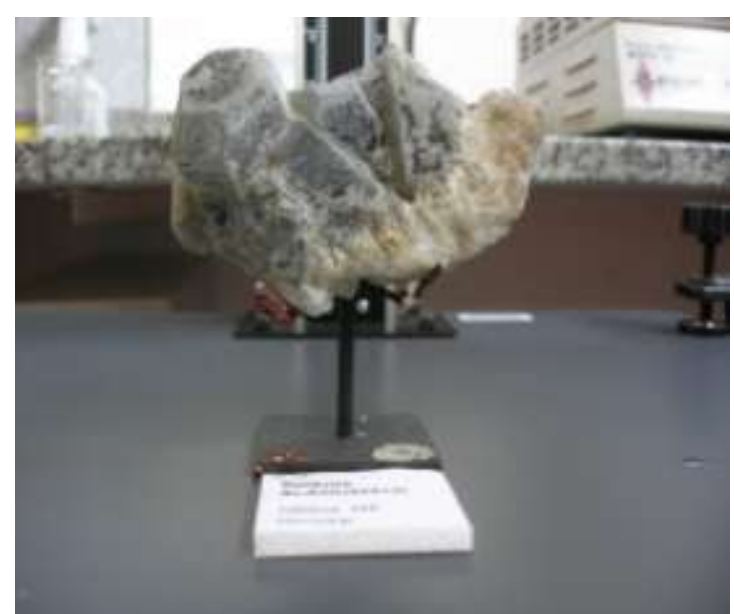

Figura 159a. Exemplar de hanksita em suporte de ferro. Acervo: Museu de Geociências da USP.

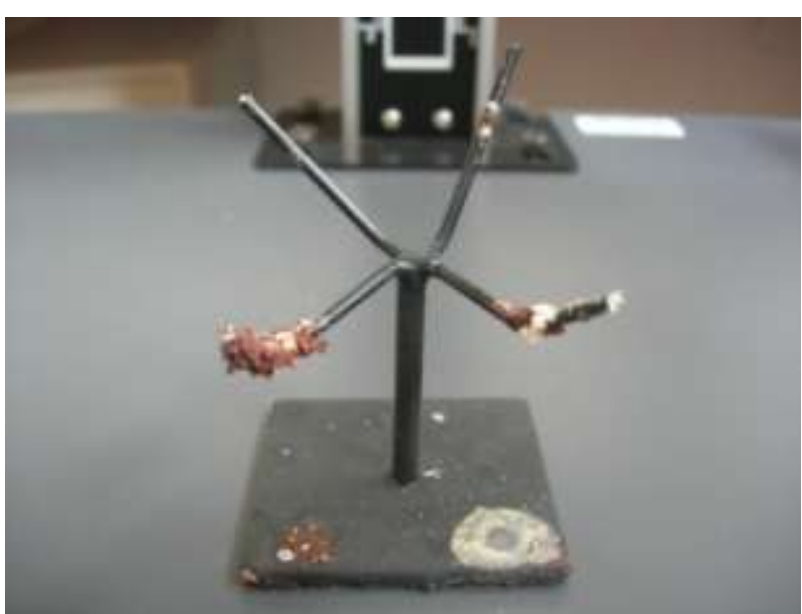

Figura 159b. Detalhe da ferrugem na região de contato entre o suporte e a amostra. Na base do suporte, mancha branca da parte da amostra que deliquesceu. 


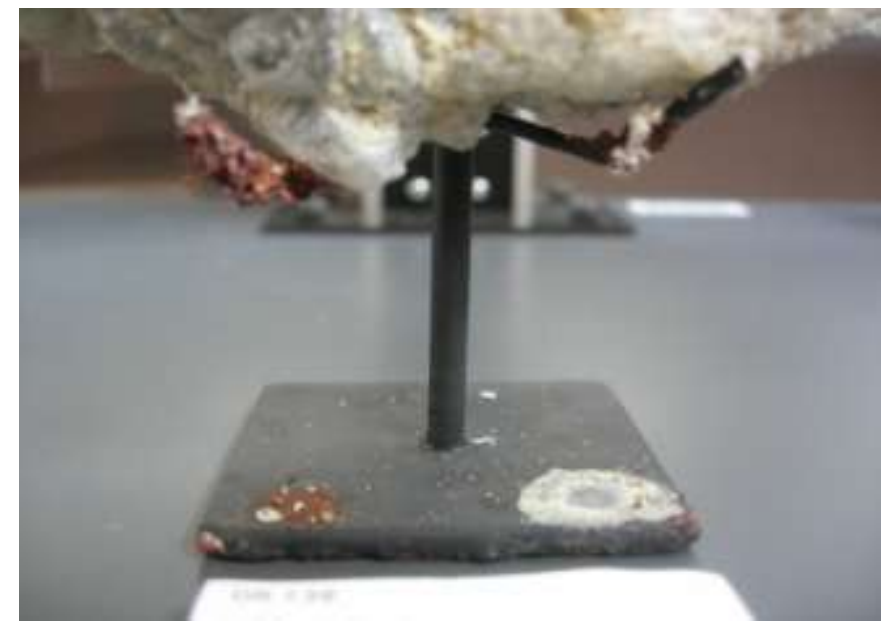

Figura 159c. Detalhe da região de contato entre amostra e suporte.

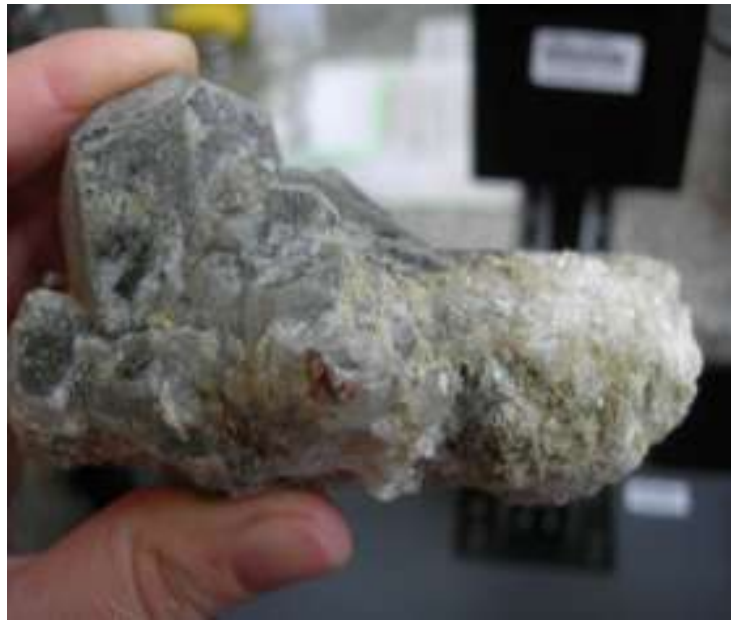

Figura 159d. Ferrugem na amostra, decorrente do contato com o material oxidado do suporte.

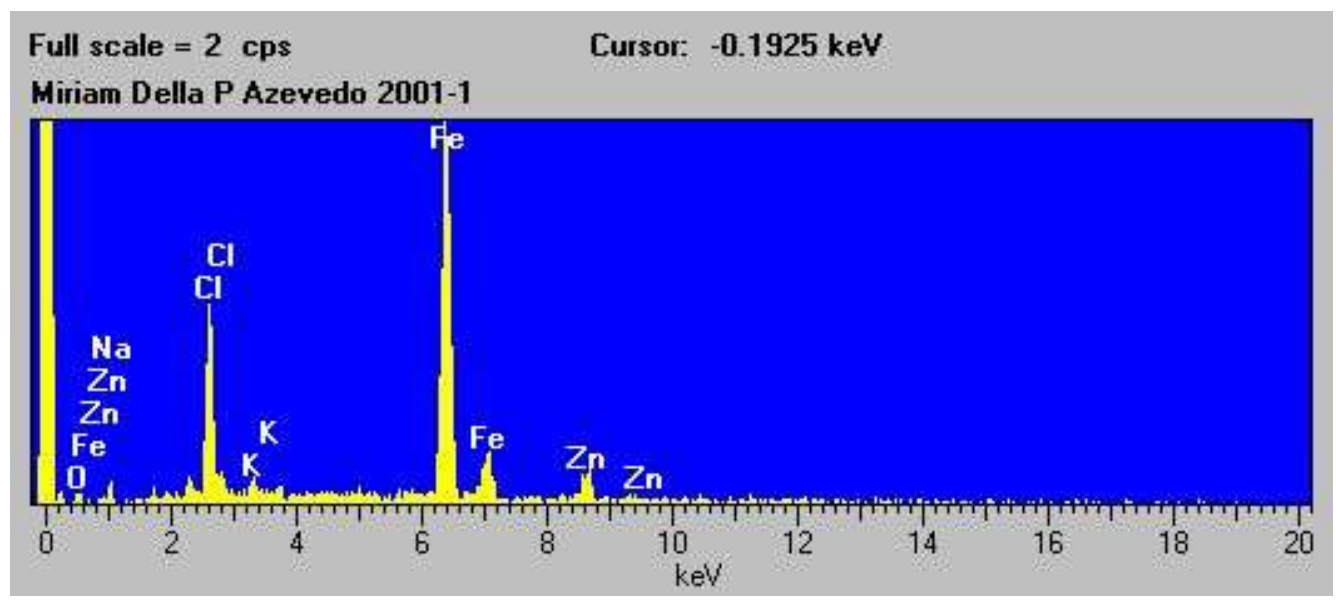

Figura 159e. Espectroscopia de Energia Dispersiva de raios $X$ (EDS) realizada via Microscopia Eletrônica de Varredura (MEV) do material coletado no suporte da hanksita. Os elementos Na, Cl e K são provenientes da hanksita; já os elementos Zn e Fe são provenientes da interação da amostra com o suporte. $\mathrm{O} Z \mathrm{Zn}$ é resultante de camada protetora acrescentada ao suporte no tempo de sua confecção e o Fe é o próprio material do suporte.

Outra consequência da interferência da UR é a eflorescência, cujo nome deriva do latim florescere e significa florescer. $\mathrm{Na}$ geologia, por alusão, refere-se à reação de desidratação, na qual ocorre a perda de água de cristalização do mineral, cujas consequências variam desde uma fratura no mineral até a transformação de seus cristais em pó, que florescem na superfície do mineral, dependendo de suas características. Ocorre quando a UR do ar está abaixo do nível necessário para a estabilidade do mineral.

A eflorescência dos minerais ocorre quando os minerais hidratados (que associaram água em seu processo de cristalização) perdem alguma quantidade ou a totalidade da água contida em sua estrutura cristalina, ao serem submetidos a mudanças para ambientes mais 
secos. A perda de água das moléculas leva ao encolhimento do tamanho da amostra, evento estrutural que reflete na forma externa do mineral, sendo visível macroscopicamente. A consequência visual deste evento é que as fraturas delgadas ou divisões nas estruturas cristalinas podem ocasionar a total transformação do mineral em pó, resultando em sua completa desintegração.

Um exemplo representativo é o natron, um carbonato de sódio hidratado, que se cristaliza no sistema monoclínico $\left(\mathrm{Na}_{2} \mathbf{C O}_{3} \cdot \mathbf{1 0 H}_{2} \mathrm{O}\right)$. O natron é estável apenas em ambientes com UR entre $76,6 \%$ e $93,6 \%$, aos $25^{\circ} \mathrm{C}$. Em ambientes com UR maiores que o máximo descrito, o mineral desfaz-se em solução saturada. Já em níveis de UR inferiores ao mínimo de 76,6\%, o natron efloresce, perdendo nove moléculas de água e transformando-se em termonatrita $\left(\mathrm{Na}_{2} \mathrm{CO}_{3} \cdot \mathbf{H}_{2} \mathrm{O}\right)$ que se cristaliza no sistema ortorrômbico, até chegar à porcentagem de 20,4\%. Ao atingir essa porcentagem de UR, a termonatrita perde a última molécula de água, tranformando-se em outro mineral, a natrita $\left(\mathbf{N a}_{2} \mathbf{C O}_{3}\right)$, carbonato anidro que se cristaliza no sistema monoclínico. Sua superfície, em contato com o ar, altera-se rapidamente para termonatrita.

Minerais higroscópicos são aqueles cuja água em sua estrutura pode variar em função da disponibilidade de água presente no ar em forma de umidade. Eles tornam-se inchados, caso absorvam muita água, em ambientes de alta UR e encolhem, caso percam água para o ambiente, se a UR do ar estiver menor que a necessária para manter sua estabilidade. Alguns minerais conseguem suportar essa alternância entre secagem e umidificação da estrutura. No entanto, outras estruturas minerais não suportam esse ciclo de expansão e encolhimento, o que pode levar ao rompimento da estrutura do mineral, ocasionando seu esfacelamento ou quebra (HOWIE, 1992).

Para armazenar os minerais sensíveis à UR, os melhores materiais utilizados como selantes são aqueles que permitem o mínimo de permeabilidade, pois, caso contrário, a amostra se desidrata por completo, uma vez que as reações ocorrem com mais rapidez em atmosferas menores. O melhor para esse propósito é o PVDC (cloreto de polivinilideno) ${ }^{16}$. A maioria dos vernizes tem impermeabilidade entre cem e dez mil vezes maior que a do PVDC, o que significa que, uma amostra que demoraria em torno de 150 anos para se desidratar com o PVDC, com outros selantes demoraria apenas dois anos (WALLER, 1992). É importante ressaltar que uma amostra sujeita a esse tipo de intervenção, deve ser utilizada somente para exposição, pois perde o interesse científico uma vez que não está mais em seu estado natural. Os demais tipos de recipientes de armazenamento (vidro, plástico ou metal) são todos

${ }^{16}$ O polivinilideno é uma fibra sintética produzida pela copolimerização do cloreto de vinilideno e do cloreto de vinilo. Fonte: http://www.infopedia.pt - Acesso em 08/08/2012. 
imperfeitos, no que concerne à troca de umidade entre o interior do contêiner e o ambiente que circunda a amostra. A sílica gel, descrita no item 6.3.6 é a melhor forma de proteger um mineral, para a criação de microclimas intermediários ou definitivos. É o único material não contaminante e que não produz poeira. Por isso, é sempre necessário que o ambiente de armazenamento esteja de acordo com a gama de possibilidades de estabilidade do mineral em determinada UR.

\subsection{2 - Temperatura}

A maioria dos minerais é estável somente quando são mantidas as condições de temperatura de sua formação, geralmente altas (acima de $300^{\circ} \mathrm{C}$ ). Por isso, a maior parte dos minerais de museus, se já não estão alterados, encontram-se em situação metaestável. A temperatura afeta os minerais de museus de quatro formas: pela volatilização, pela dissociação de hidratos, pela decrepitação de inclusões fluidas (crepitação e desintegração de cristais sob ação do calor, que dilui a água contida neles) e por choque térmico.

A volatilização configura-se na perda de substâncias químicas voláteis do mineral por meio de sua conversão em vapor. Pode ocorrer na forma de sublimação ou dissociação (WALLER, 1992). É causada devido à diferença entre as pressões de vapor dos elementos químicos presentes no mineral e do ambiente que circunda a amostra, visto que a pressão de vapor é uma grandeza dependente da temperatura.

Já a dissociação de minerais hidratados libera vapor de água e sólidos. Na maior parte dos casos, é possível evitar a volatilização mantendo espécimes voláteis a baixa temperatura, porém o mais indicado é manter os exemplares em recipientes hermeticamente vedados.

As crepitações de inclusões fluidas ocorrem quando a pressão é suficiente para estourar espontaneamente as cavidades nas quais os líquidos (geralmente água com $\mathrm{CO}_{2}$ ou alguma solução salina) estão inseridos. É possível que alguns tipos de iluminações incidentes diretamente sobre essas amostras, principalmente a luz do dia, aqueçam suficientemente o mineral a ponto do coeficiente termal no interior das inclusões ser maior que o coeficiente termal do mineral. As crepitações dependem de vários fatores, além da temperatura, que não serão discutidos neste trabalho. Por esse motivo, não é possível estabelecer um limite seguro de temperatura para tais amostras. O que deve ser feito, como medida de cautela, é não transportar amostras que contenham inclusões fluidas em climas quentes, ou sob o sol; escolher uma fonte luminosa que não libere muito calor sobre a amostra, na hora de expô-la, e controlar a iluminação utilizada em fotografias. 
Os choques térmicos acontecem quando os danos no mineral, geralmente fraturas, ocorrem como consequência direta da variação da temperatura. Os minerais possuem entre um a três coeficientes de expansão termal, de acordo com o sistema cristalino ao qual pertencem. Esses coeficientes determinam a direção e o tipo de expansão a que o mineral será submetido, caso seja aquecido.

Os coeficientes de expansão termal linear, de acordo com o sistema cristalino, são apresentados a seguir.

\begin{tabular}{|c|c|}
\hline Sistemas Cristalinos & $\mathbf{N}^{\mathbf{0}}$ de coeficientes \\
\hline Isométrico ou cúbico & $\mathbf{1}$ \\
\hline Trigonal, Hexagonal e Tetragonal & $\mathbf{2}$ \\
\hline Ortorrômbico, monoclínico ou triclínico & $\mathbf{3}$ \\
\hline
\end{tabular}

A maioria dos minerais possui coeficientes positivos, o que faz com que as expansões ocorram em todas as direções de aquecimento. Essa movimentação resultará em um estresse compressional na parte externa do mineral, e um estresse tensional na parte interna. Essas tensões acabam resultando em fraturas com ângulos de $45^{\circ}$ ao longo da superfície mineral. Ao contrário, caso haja um resfriamento desses mesmos minerais, haverá o tensionamento oposto: estresse tensional na parte de fora e estresse compressional na parte interna. As fissuras, então, serão perpendiculares às faces do cristal.

Alguns carbonatos, em especial os que possuem a estrutura da calcita, possuem coeficientes positivos e negativos, o que permite haver dois tipos de tensões opostas na mesma face do mineral. Quando o mineral possui plano de clivagem, a quebra ocorre na direção do plano; caso o mineral não possua clivagem, a fratura ocorrerá nas áreas de menor tensão, podendo levar à partição total do exemplar. Algumas características contribuem para que ocorra choque térmico: altos coeficientes de expansão térmica, baixa condutibilidade térmica, baixa tenacidade, clivagem perfeita, fraturas ou clivagens pré-existentes, e presença de inclusões fluidas. Com relação ao ambiente, grandes variações de temperatura e constantes trocas de calor com o espécime são propensas a desenvolver o choque (WALLER, 1992).

As temperaturas indicadas para armazenamento são de $15^{\circ} \mathrm{C}$, variando para mais ou menos cinco graus. Temperaturas abaixo de $10^{\circ} \mathrm{C}$ devem ser evitadas, pois há o risco de aumento da umidade relativa e consequente condensação.

Indica-se medir a temperatura constantemente com termômetros comuns, com precisão ajustada para mais ou menos $3^{\circ} \mathrm{C}$. Os termostatos dos aquecedores, quando necessários, devem ser ajustados com a mesma precisão. 


\subsection{3 - Mudanças de cor em minerais induzidas pela ação da luz}

A maioria das $4.681^{17}$ espécies minerais conhecidas apresenta estabilidade de cores em exposição à luz. Cerca de $4 \%$ desse total apresenta algum tipo de suscetibilidade em relação à luz.

Em algumas reações de foto decomposição os produtos resultantes do processo acabam por retardar a degradação; em outras, esses produtos podem acelerar o processo, caso sejam ácido, alcalino, sulfeto de hidrogênio, peróxido de hidrogênio, entre outros (NASSAU, 2001).

A preocupação em conservar a coloração original dos minerais é oportuna, uma vez que os minerais mais suscetíveis à luz, como o realgar (AsS), mostram mudança de coloração em poucos dias após sua exposição em ambientes museológicos. Por isso, todas as amostras de realgar observadas em visitas técnicas durante este estudo apresentavam-se amarelo ouro, e não mais vermelhas.

As mudanças de cor em minerais são divididas em dois grupos:

1 - Mudanças de coloração sem alteração na estrutura do mineral, não afetando, portanto, sua estabilidade;

2 - Mudanças de cor associadas a alterações físico-químicas no mineral (aqui incluem-se também minerais nos quais as reações de oxidação são aceleradas pela presença da luz). Neste caso, as mudanças estruturais podem resultar na formação de reagentes metaestáveis, por isso, necessitam de uma conservação em longo prazo.

É importante frisar que nem todas as mudanças de coloração nos minerais são permanentes. Alguns minerais, como nefelina $\left((\mathrm{Na}, \mathrm{K}) \mathrm{AlSiO}_{4}\right)$, celestina $\left(\mathrm{SrO}_{4}\right)$ e hackmanita (variedade de sodalita, $\mathrm{Na}_{8} \mathrm{Al}_{6} \mathrm{Si}_{6} \mathrm{O}_{24} \mathrm{Cl}_{2}, \mathrm{~S}$ ) retomam sua coloração original após um período específico de armazenamento ao abrigo da luz. Embora muitos espécimes não revertam naturalmente sua coloração à inicial, esta pode ser retomada por meio de tratamento de aquecimento ou irradiação.

As mudanças de cor resultantes de interferência de luz nos minerais ocorrem porque a luz é uma forma de energia, e por isso consegue ativar reações químicas na estrutura do mineral, causando mudanças no arranjo dos elétrons, que se acomodam em nova organização espacial a fim de manterem o equilíbrio. Tal rearranjo faz com que os elementos presentes no mineral permaneçam os mesmos, porém, com uma nova estrutura cristalina, que por sua vez modifica a absorção da luz, resultando em novas cores.

\footnotetext{
${ }^{17}$ Número conhecido de minerais e mineralóides. Fonte: www.mindat.org - Acesso em 07/08/2012.
} 
A vivianita $\left(\mathrm{Fe}_{3}{ }^{2+}\left(\mathrm{PO}_{4}\right)_{2} .8 \mathrm{H}_{2} \mathrm{O}\right)$ exemplifica a situação descrita anteriormente: o mineral fresco é incolor, e, assim que entra em contato com a luz, um fóton atinge o cristal transparente e reage com um núcleo de hidrogênio de uma das oito moléculas de água, convertendo-a em um ânion de hidroxila $\left(\mathrm{OH}^{-}\right)$. Essa carga negativa é equilibrada pela oxidação de um átomo de ferro, cujo estado de valência vai de $\mathrm{Fe}^{2+}$ para $\mathrm{Fe}^{3+}$. O próton hidrogênio liberado facilmente migra através da rede cristalina (PETROV, 2006). Essa reação provoca modificação no arranjo atômico da vivianita e em sua absorção de luz. Logo, qualquer vivianita encontrada em ambiente de museu será em tom azulado, ou seja, já oxidada (Figura 160).

Em consequência às reações descritas, pode-se aferir que os minerais encontrados em coleções não são mais vivianitas, e sim metavivianitas, cuja fórmula química é $\mathrm{Fe}_{2}{ }^{2+} \mathrm{Fe}^{3+}\left(\mathrm{PO}_{4}\right)_{2}(\mathrm{OH})\left(\mathrm{H}_{2} \mathrm{O}\right)_{7}$.

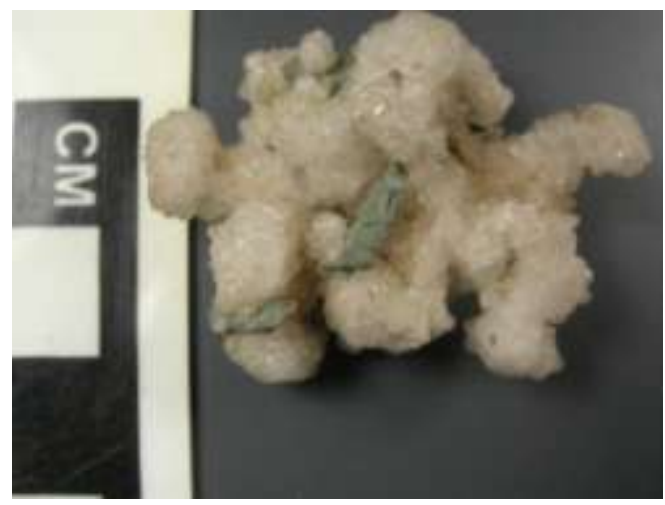

Figura 160a. A vivianita $\mathrm{Fe}_{3}^{2+}\left(\mathrm{PO}_{4}\right)_{2} .8 \mathrm{H}_{2} \mathrm{O}$ é um mineral incolor que se torna azul (metavivianita) aos primeiros contatos com a luz. Acervo do Museu de Geociências da USP.

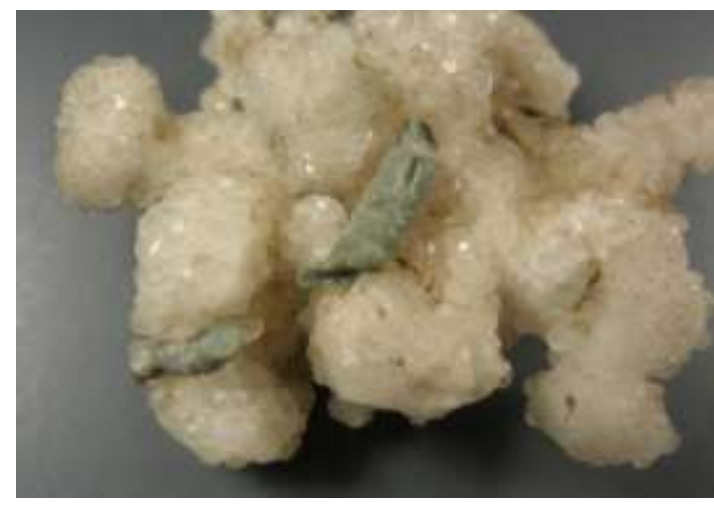

Figura160b. Detalhe do cristal de metavivianita (azul). Acervo do Museu de Geociências da USP.

A razão pela qual a maioria dos minerais é estável na presença da luz visível e ultravioleta está no fato de que o nível energético presente nessas luzes é muito baixo para que haja alteração da configuração eletrônica do mineral. Quando a cor de um mineral provém de um centro de cor, a energia presente nessas luzes pode remover o elétron responsável pela impureza formadora da cor, alterando ou até mesmo eliminando o centro de cor. A eliminação do centro de cor resulta no desaparecimento da cor do mineral, e sua alteração resulta na absorção de outros comprimentos de onda e consecutiva alteração de cor.

A energia requerida para que haja remoção do centro de cor é conhecida como nível alvejante. A maioria dos centros de cor é alterada somente por alta radiação iônica, da ordem de aproximadamente 1.000.000 electron-volts ou por aquecimento. 
Exceções a essa regra são exemplificadas pelos seguintes minerais alocromáticos: fluorita $\left(\mathrm{CaF}_{2}\right)$, barita $\left(\mathrm{BaSO}_{4}\right)$ e celestina $\left(\mathrm{SrSO}_{4}\right)$, que têm baixo nível alvejante, por isso seus centros de cor são facilmente modificados pela absorção da luz UV e visível.

Recomenda-se que todos os minerais que apresentem fluorescência sob a luz UV sejam protegidos contra prolongadas exposições a quaisquer fontes luminosas. Gemas que tiveram sua coloração realçada por processos de aquecimento ou irradiação iônica também são suscetíveis à luz em geral. Nessa categoria ressalta-se o topázio marrom, a safira amarela e o berilo azul.

A luz também induz reações de oxidação que geram produtos de decomposição e geralmente ocorrem em minerais idiocromáticos, podendo causar uma completa transformação do espécime, caso haja exposição prolongada à luz, a menos que os próprios produtos finais criem algum tipo de proteção na amostra que limitem a penetração dos raios luminosos.

Os principais minerais de coleções museológicas que apresentam esse comportamento são: cuprita $\left(\mathrm{Cu}_{2} \mathrm{O}\right)$, realgar (AsS) e compostos de prata $(\mathrm{Ag})$. O realgar vermelho, frequentemente conhecido por se transformar em ouro-pigmento (Figuras 161a a 161d), na verdade busca o equilíbrio e se adequa na fase pararealgar, com a mesma composição química do realgar vermelho, porém, com outra estrutura cristalina. Um exemplar de realgar começa a se reestruturar em pararealgar a partir de 60 horas em exposição à luz do sol filtrada. Sem filtro, essa reestruturação começa a partir da primeira hora de exposição (HORÁK, 1994).

Uma reação similar ocorre com o cinábrio $(\mathrm{HgS})$, que após a oxidação pela luz se estabiliza em metacinábrio $(\mathrm{HgS})$. 


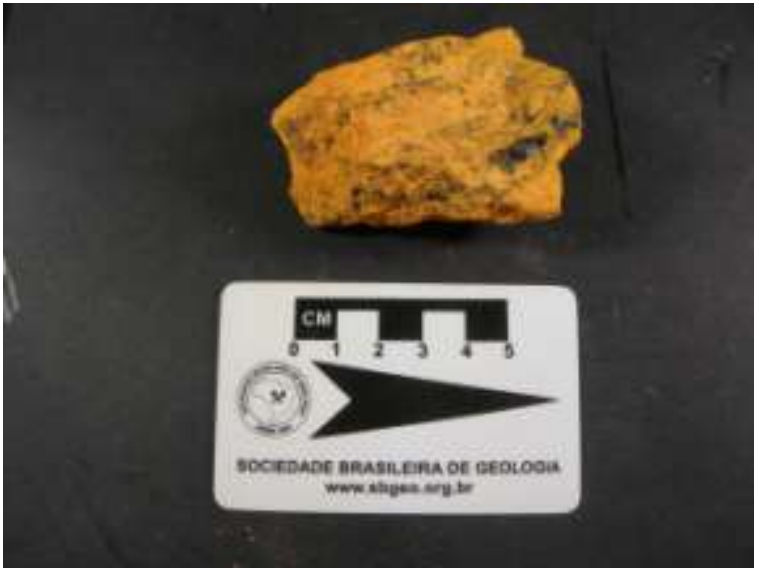

Figura 161 a. Amostra de realgar completamente alterada para pararealgar. Acervo: Museu de Geociências da USP.

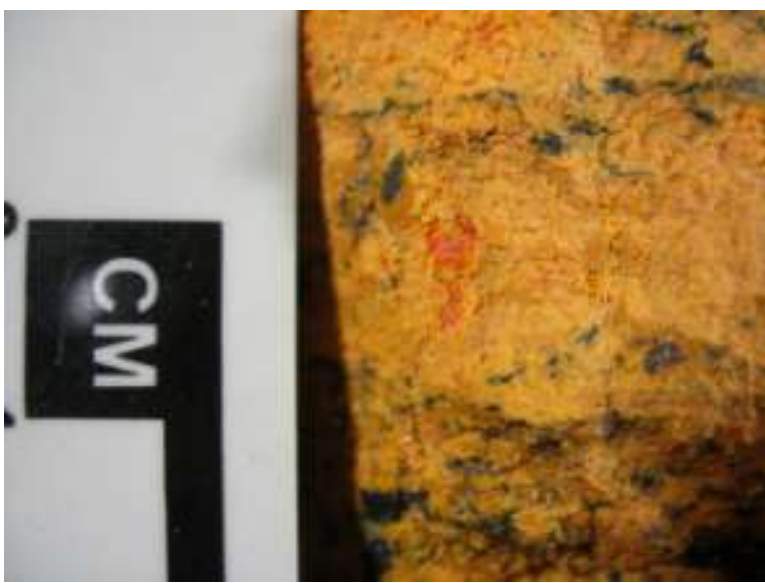

Figura 161c. Detalhe da amostra da figura 161a: um pequeno ponto da amostra resistiu `a alteração de cor.

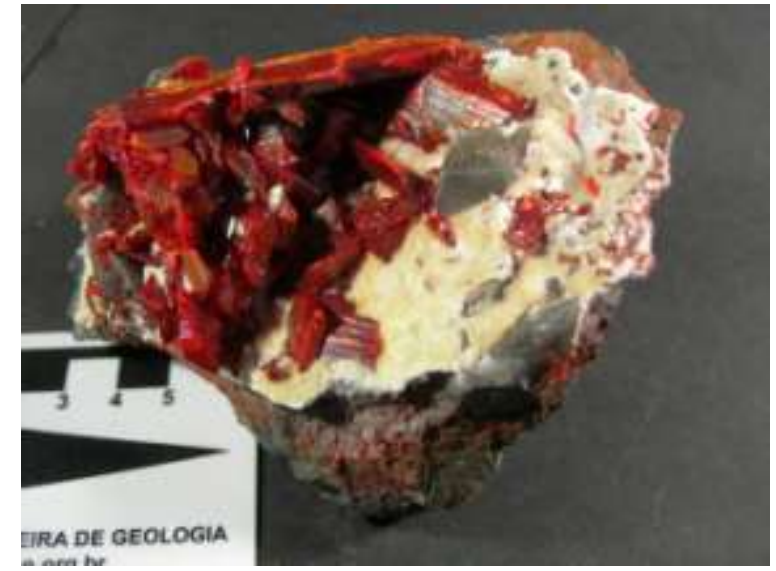

Figura 161b. Amostra de cristais grandes de realgar que não é exposta. Nota-se visivelmente a diferença de cor entre a amostra sã, e a amostra ao lado.

Acervo: Museu de Geociências da USP.

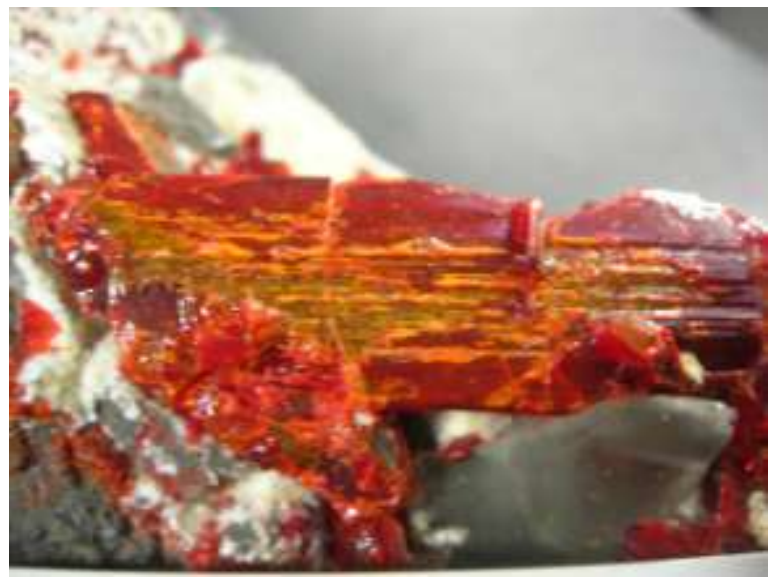

Figura 161d. Detalhe do cristal de realgar da figura 161b: a amostra ficou menos de dois meses em exposição, sem luz direta, e já se notam estrias de alteração (laranja) no cristal.

A Tabela 20 mostra os minerais fotossensíveis mais comuns em coleções geológicas, a descrição da mudança ocorrida e as condições de armazenamento indicadas. 
Tabela 20: Minerais fotossensíveis, modificações sofridas, tipo de suscetibilidade e condições de armazenamento. (Fonte: HORÄK, 1994).

\begin{tabular}{|c|c|c|c|c|}
\hline Espécie Mineral & $\begin{array}{l}\text { Fórmula } \\
\text { Química }\end{array}$ & $\begin{array}{l}\text { Tipo de Mudança } \\
\text { de Cor }\end{array}$ & $\begin{array}{l}\text { Comprimento } \\
\text { de onda } \\
\text { envolvido }\end{array}$ & $\begin{array}{l}\text { Condições de } \\
\text { armazenamento }\end{array}$ \\
\hline Acantita/Argentita $^{18}$ & $\mathrm{Ag}_{2} \mathrm{~S}$ & Escurecimento & Luz visível & $\begin{array}{l}\text { Sob luz de baixa } \\
\text { intensidade/50 a } \\
200 \text { lux }\end{array}$ \\
\hline Berilo & $\mathrm{Be}_{3} \mathrm{Al}_{2} \mathrm{Si}_{6} \mathrm{O}_{18}$ & $\begin{array}{l}\text { Do azul para rosa } \\
\text { ou incolor }\end{array}$ & Luz Visível & $\begin{array}{l}\text { Proteção contra } \\
\text { luzes visível e UV }\end{array}$ \\
\hline Bromargirita & $\mathrm{AgBr}$ & $\begin{array}{l}\text { De prateado para } \\
\text { escuro, devido à } \\
\text { liberação de prata }\end{array}$ & Luz Visível & \\
\hline Calcocita $^{19}$ & $\mathrm{Cu}_{2} \mathrm{~S}$ & De azul para verde & Luz Visível & $\begin{array}{l}\text { Sob luz de baixa } \\
\text { intensidade/50 a } \\
200 \text { lux }\end{array}$ \\
\hline Celestina & $\mathrm{SrSO}_{4}$ & $\begin{array}{l}\text { De azul para } \\
\text { incolor (reversível) }\end{array}$ & Luz Visível & $\begin{array}{l}\text { Sob luz de baixa } \\
\text { intensidade/50 a } \\
200 \text { lux }\end{array}$ \\
\hline Fluorita & $\mathrm{CaF}_{2}$ & $\begin{array}{l}\text { De rosa para } \\
\text { incolor; } \\
\text { De verde para } \\
\text { incolor azulado; } \\
\text { De roxo para } \\
\text { incolor rosado }\end{array}$ & Ultravioleta & $\begin{array}{l}\text { Sob luz de baixa } \\
\text { intensidade/50 a } \\
200 \text { lux }\end{array}$ \\
\hline $\begin{array}{l}\text { Hackmanita }^{20} \\
\text { (variedade de } \\
\text { sodalita) }\end{array}$ & $\mathrm{Na}_{4} \mathrm{Al}_{3} \mathrm{Si}_{3} \mathrm{O}_{12} \mathrm{Cl}$ & $\begin{array}{l}\text { Desbotamento } \\
\text { (a cor original é } \\
\text { magenta) }\end{array}$ & $\begin{array}{l}\text { Luzes visível e } \\
\text { UV }\end{array}$ & $\begin{array}{l}\text { Ambiente à prova } \\
\text { de luz }\end{array}$ \\
\hline Iodargirita & $\mathrm{AgI}$ & $\begin{array}{l}\text { Escurecimento pela } \\
\text { liberação de prata }\end{array}$ & Luz Visível & $\begin{array}{l}\text { Proteção contra } \\
\text { luzes visível e UV }\end{array}$ \\
\hline $\begin{array}{l}\text { Lepidolita } \\
\text { (variedade de mica) }\end{array}$ & $\begin{array}{l}\mathrm{K}(\mathrm{Li}, \mathrm{Al})_{3}(\mathrm{Si}, \mathrm{Al}) \\
{ }_{4} \mathrm{O}_{10}(\mathrm{~F}, \mathrm{OH})_{2}\end{array}$ & De roxo para cinza & Luz visível & $\begin{array}{l}\text { Sob luz de baixa } \\
\text { intensidade/50 a } \\
200 \text { lux }\end{array}$ \\
\hline
\end{tabular}

18 Apesar de argentita e acantita aparecerem sempre como sinônimos, há uma diferença entre esses dois minerais: ambos possuem a mesma fórmula química. No entanto, sob pressão atmosférica, a argentita é estável acima de $177^{\circ} \mathrm{C}$, quando se apresenta no sistema cúbico, enquanto a acantita é estável abaixo dessa temperatura e se apresenta sob o sistema monoclínico. Todo sulfeto de prata encontrado em ambientes museológicos será, portanto, acantita, e não argentita.

${ }^{19}$ A calcocita é geralmente confundida com a djurleíta, um outro mineral de sulfeto de cobre. A identificação correta só pode ser feita por difração de raios $\mathrm{X}$. A djurleíta, $\mathrm{Cu}_{31} \mathrm{~S}_{16}$, pertence ao sistema monoclínico, enquanto a calcocita, $\mathrm{Cu}_{2} \mathrm{~S}$, também pertencente ao sistema monoclínico, rearranja-se no sistema hexagonal após $105^{\circ} \mathrm{C}$ (calcocita de alta temperatura).

${ }^{20}$ Assim como a vivianita, a hackmanita perde a cor logo que entra em contato com a luz. A cor pode ser resgatada pelo armazenamento em local escuro, mas geralmente só resgata a cor sob radiação UV. (NASSAU, 2001). 


\begin{tabular}{|c|c|c|c|c|}
\hline Proustita & $\mathrm{Ag}_{3} \mathrm{AsS}_{3}$ & Escurecimento & Luz Visível & $\begin{array}{l}\text { Proteção contra } \\
\text { luzes visível e UV }\end{array}$ \\
\hline Pirargirita & $\mathrm{Ag}_{3} \mathrm{SbS}_{3}$ & Escurecimento & Luz Visível & $\begin{array}{l}\text { Proteção contra } \\
\text { luzes visível e UV }\end{array}$ \\
\hline $\begin{array}{l}\text { Pirostilpnita } \\
\text { (dimorfo de } \\
\text { pirargirita) }\end{array}$ & $\mathrm{Ag}_{3} \mathrm{SbS}_{3}$ & $\begin{array}{l}\text { De laranja } \\
\text { avermelhado para } \\
\text { preto }\end{array}$ & Luz Visível & $\begin{array}{l}\text { Sob luz de baixa } \\
\text { intensidade/50 a } \\
200 \text { lux }\end{array}$ \\
\hline Quartzo rosa & $\mathrm{SiO}_{2}$ & $\begin{array}{l}\text { Desbotamento } \\
\text { (reversível se } \\
\text { colocado em } \\
\text { ambiente escuro) }\end{array}$ & Luz Visível & $\begin{array}{l}\text { Sob luz de Baixa } \\
\text { intensidade/50 a } \\
200 \text { lux }\end{array}$ \\
\hline Realgar & AsS & $\begin{array}{l}\text { De vermelho para } \\
\text { amarelo } \\
\text { (pararealgar) }\end{array}$ & Luz Visível & $\begin{array}{l}\text { Ambiente à prova } \\
\text { de luz }\end{array}$ \\
\hline Vivianita $^{21}$ & $\begin{array}{l}\mathrm{Fe}_{3}{ }^{2+}\left(\mathrm{PO}_{4}\right)_{2} \cdot 8 \mathrm{H}_{2} \\
\mathrm{O}\end{array}$ & $\begin{array}{l}\text { De incolor à azul } \\
\text { ou preto, podendo } \\
\text { desintegrar-se }\end{array}$ & Luz Visível & $\begin{array}{l}\text { Ambiente à prova } \\
\text { de luz }\end{array}$ \\
\hline
\end{tabular}

Uma relação completa de amostras fotossensíveis pode ser encontrada em NASSAU (1992).

As mudanças de cor em minerais são geralmente irreversíveis por dois motivos: ou porque as mudanças de cor envolvem produtos de decomposição, ou porque a reversão do processo inclui tratamento da amostra com altas quantidades de energia, como aquecimento ou irradiação. Exceções: sulfeto de prata $(\mathrm{AgS})$ e minerais de sulfoarsenitos como a proustita $\left(\mathrm{Ag}_{3} \mathrm{AsS}_{3}\right)$. Nesses casos, as reações de oxidação envolvem produtos que formam apenas uma camada fina de cobertura sobre as amostras, podendo, assim, ser removida com cuidados especiais sem danos. Os demais minerais nos quais não podem ser aplicados procedimentos de reparação, há de se trabalhar com a profilaxia.

Medidas iniciais de prevenção incluem medições dos níveis de iluminação das áreas de armazenamento e exibição das amostras, bem como avaliação do montante de luz ultravioleta que poderá agir sobre os minerais.

A intensidade da luz visível é medida em unidades de lux, utilizando-se um medidor padrão que geralmente varia entre $0-5.10^{3}$ lux para medidores portáteis e entre $0-10^{6}$ lux para medidores mais potentes. Em exposições que contêm materiais fotossensíveis, a indicação é que a iluminação tenha até 200 lux. Ao se tratar especificamente de minerais fotossensíveis, a iluminação deve ter, no máximo, 50 lux.

$21 \mathrm{Na}$ verdade, o mineral que se encontra em exibições museológicas é a metavivianita, $\mathrm{Fe}_{2}{ }^{2+} \mathrm{Fe}^{3+}\left(\mathrm{PO}_{4}\right)_{2}(\mathrm{OH})\left(\mathrm{H}_{2} \mathrm{O}\right)_{7}$ uma fase já alterada da vivianita, cujas transformações iniciam-se ao primeiro contato do mineral com qualquer tipo de luz. 
Após a avaliação das fontes luminosas da exposição e reserva técnica, deve ser medida a proporção de luz ultravioleta por meio de um medidor de luz UV, no qual as medidas são expressas em microwatts por lúmen $(\mu \mathrm{W} / \mathrm{lm})$, onde:

\section{1 lux $=1$ lumen $/ \mathrm{m}^{2}$}

A regra geral para lidar com minerais fotossensíveis se resume a minimizar a exposição desses objetos a fontes de luz prejudiciais. Medidas mais específicas de preservação relacionam-se com a filtragem da luz UV (por meio da retenção dos comprimentos de onda correspondentes) por meio de quatro instrumentos citados a seguir (HORÁK, 1994). Embora todos eles eliminem as ondas componentes da luz que estiverem abaixo de $400 \mathrm{~nm}$, alguns podem filtrar parte das componentes da luz visível, resultando em uma fonte de luz levemente escurecida.

Formas de acondicionamento para minerais fotossensíveis:

1 - Vidros laminados contendo intercamadas de absorventes de luz UV.

2 - Placas especiais de acrílico ou policarbonato usadas em substituição ao vidro (se não houver restrições relativas à segurança do material) ou folhas difusoras para luzes fluorescentes. Exemplos de materiais são o Perspex VE ou VA, Pexiglass 201 ou 209 ou Lexan 9034. As placas têm duração média de dez anos, enquanto as folhas podem ser utilizadas em até três lâmpadas.

3 - Placas de acetato, cortadas de forma a encaixá-las nos vidros das janelas ou acetato em forma de folhas para envolver os bulbos de lâmpadas fluorescentes.

4 - Vernizes que contenham filtros UV. Têm duração média de cinco anos.

Nenhum dos métodos citados é permanente, e mesmo durante o período de validade dos filtros escolhidos, o nível de luz UV deve ser periodicamente medido. Essa medida serve para manutenção preventiva das amostras e, ao mesmo tempo, para verificar a eficácia do método de filtragem escolhido.

Nas reservas técnicas, os minerais devem ser idealmente armazenados em ambiente sem luz, e serem observados somente com luz de baixa intensidade (50 lux) e com filtros UV. O armazenamento dos espécimes mais sensíveis deve ser feito em caixas fechadas, marcadas com documentação do lado de fora, e ter inspeção periódica. A luz UV não deve representar um problema na reserva técnica, uma vez que a filtragem de luz (geralmente tubos fluorescentes) e das janelas é facilmente alcançada e geralmente de baixo custo. 
Na exposição, os minerais fotossensíveis sofrem os maiores danos. É necessária uma análise cuidadosa para que se tenha certeza de que a exibição deve ocorrer. Uma vez exposto, a ação da luz visível é cumulativa. É imprescindível ter em mente que, se o espécime fotossensível for exposto, o dano irá ocorrer.

A avaliação prévia deve considerar:

1 - a real necessidade de exposição do mineral suscetível;

2 - a existência de outro mineral da mesma espécie na reserva técnica, que possa ser consultado pelo pesquisador;

3 - O controle da iluminação para que os danos sejam retardados; e

4 - A disponibilidade de outra amostra do mesmo mineral que possa fazer rodízio com a amostra exposta.

NASSAU (2001) apresenta uma tabela das fontes luminosas mais utilizadas atualmente e suas respectivas eficácias, medidas em lumens por watt. De acordo com esse levantamento, os bulbos de luz incandescente, como as lâmpadas de tungstênio, seriam a opção menos danosa para amostras fotossensíveis, uma vez que possuem a menor eficácia (de 10 a 20 lúmens por watt), seguidas por lâmpadas incandescentes (30 lúmens por watt). As fontes luminosas de maior eficácia são as de vapor de sódio e mercúrio, devendo, portanto, serem evitadas. Pesquisas recentes realizadas pela equipe do Museu de Geociências da UnB revelam serem as lâmpadas de LED a melhor opção para amostras fotossensíveis.

\subsection{4 - Danos e Eflorescência de Sais}

Nas rochas, materiais de construção ou cerâmicas porosas, eflorescência refere-se à deterioração desses materiais pela cristalização de sais em suas superfícies. Nesse caso, vários tipos de sais se formam devido a diferentes fatores, principalmente os associados ao movimento de água, dependendo do ambiente em que estão. A água reage com os sais solúveis da superfície das rochas, criando uma solução saturada. Mais tarde, com a evaporação dessa água de superfície, o sal se cristaliza nos poros da rocha, formando a eflorescência. Quando a cristalização ocorre próximo à superfície (subflorescência), as forças de cristalização podem romper a estrutura da rocha, levando à quebra da superfície e consequente fragmentação. A cristalização na superfície é física e esteticamente prejudicial, e as tentativas de remoção podem igualmente resultar no esfacelamento da rocha por meio da abrasão da superfície, causada tanto pela utilização dos métodos molhados (químicos) quanto secos de limpeza e remoção de sais. 
A eflorescência depende do tipo de ambiente em que a amostra se encontra. Museus em cidades litorâneas tendem a perder muitos exemplares com esse problema, pois o contato do material com ambiente marinho propicia a formação de halita $(\mathrm{NaCl})$ em sua superfície. Outra possibilidade é a absorção de sais atmosféricos provenientes das reações com gases poluentes.

É importante ressaltar que, quanto menor o poro, maior a degradação sofrida pela rocha, pois, se o poro for grande, há possibilidade de o cristal se formar dentro dele, não atingindo suas bordas e não comprometendo a estrutura da rocha. Já se o poro for pequeno, o cristal crescerá e romperá os limites do poro, causando fraturas na rocha.

Quando há alta UR no ambiente, e a rocha possui sais solúveis em sua superfície, a deliquescência causa a dissolução do sal por si só, pois ele absorve a água do ambiente. A solução saturada formada a partir da dissolução do sal com a água do ambiente tende a migrar para uma superfície mais seca da rocha. Em períodos em que a UR do ar estiver mais baixa, a solução perderá água para o ambiente, por meio da evaporação, causando a recristalização dos sais.

Alguns sais eflorescem na forma de duras camadas de concreções brancas (pois penetram de forma mais profunda na superfície da rocha, de acordo com a intensidade com que se deu a situação descrita), particularmente sulfato de cálcio $\left(\mathrm{CaSO}_{4}\right)$, mas mais comumente sulfato de sódio $\left(\mathrm{NaSO}_{4}\right)$ que causam as maiores massas brancas nas superfícies das rochas, usualmente confundidas com fungos.

Esse é um problema sério, pois muitas vezes a eflorescência pode ser amenizada com tratamento químico (inertização dos sais formados por imersão da amostra em soluções supersaturadas do mesmo sal). Se houver um engano no diagnóstico, levando a um tratamento errôneo do problema, pode causar o manchamento da superfície rochosa ou destruição da amostra, caso seja uma rocha já com grande quantidade de sais.

O tratamento da eflorescência, nesse caso, é vinculado ao conhecimento do tipo de rocha. Cada tipo de rocha requer um tratamento adequado a sua composição química e características relacionadas ao ambiente de formação.

Especialmente em coleções antigas, a documentação de coleta da amostra é uma fonte importantíssima para determinar o sítio de coleta e, consequentemente, diagnosticar o tratamento da amostra. No entanto, essa é uma possibilidade remota à maioria dos museus e coleções brasileiros, os quais, em sua maioria, não apresentam documentação precisa da amostra. As documentações foram perdidas ou por ação do tempo (desgaste físico no manuseio, incêndios, umidade, enchentes) ou por desconhecimento do responsável pela 
documentação. No Brasil, é muito comum as pessoas terem o ímpeto de descartarem objetos e papéis que consideram velharias sem importância.

A maneira menos invasiva de tratamento é o controle do ambiente onde está a rocha. Os espécimes são removidos do local onde podem absorver sais solúveis e colocados em outro ambiente, com temperatura e UR constantes, os quais minimizarão a interação da rocha com as soluções salinas.

As coleções geológicas, independente da tipologia, devem ser armazenadas em embalagens inertes. Estantes de aço são as mais seguras, especialmente se revestidas de tintas não solventes. Madeiras em geral, especialmente carvalho, devem ser evitadas.

A eflorescência em coleções geológicas demonstra más condições do ambiente museológico, inspeção inadequada e, principalmente, ineficiência no gerenciamento das coleções.

Para que a prevenção seja bem sucedida, através de acompanhamento adequado, é imprescindível que haja identificação exata dos minerais suscetíveis a esse tipo de dano (uma extensa lista pode ser encontrada em HOWIE, 1992), além de um preciso monitoramento das condições de UR do ambiente de exposição e do ambiente de reserva técnica, ou outro tipo de armazenamento, como as quarentenas.

Minerais suscetíveis devem ser expostos, armazenados ou pesquisados sob severo controle de UR e temperatura, sendo a UR de 50\% (variável para mais ou menos $5 \%$ ) e a temperatura de $15^{\circ} \mathrm{C}$ (variando em mais ou menos $5^{\circ} \mathrm{C}$ ).

\subsection{5. - Amostras Especiais}

Alguns materiais são mais suscetíveis que outros com relação à necessidade de cuidados de conservação, pois estão especialmente sensíveis a fatores como temperatura, luminosidade e UR. Entre esses materiais destacam-se alguns minerais comumente encontrados em coleções geológicas (pirita, realgar e halita, por exemplo), meteoritos e fósseis que contêm piritas em sua composição. A seguir, apresentar-se-á a descrição de alguns desses materiais, com os principais problemas relacionados a cada um, bem como as possíveis soluções.

\subsubsection{1 - Pirita e Marcassita - $\mathrm{FeS}_{2}$}

O decaimento de sulfetos, em especial pentlandita, pirrotita, pirita e marcassita, é um dos principais problemas que afetam as coleções geológicas. A bibliografia destaca a pirita e seu polimorfo, a marcassita, como problemas recorrentes. Por possuírem as mesmas 
tendências ao esfacelamento e decomposição, o tratamento de ambos os minerais deve ser feito da mesma maneira.

A pirita cristaliza-se no sistema cúbico, podendo apresentar hábito cúbico com cristais bem formados, visíveis macroscopicamente, ou em microcristais presentes nos três tipos de rochas. O tamanho dos cristais, bem como sua disseminação, é de grande influência no processo de decomposição.

Já a marcassita cristaliza-se no sistema ortorrômbico e possui hábito tabular ou piramidal.

Esses minerais podem apresentar-se em estado cristalino puro, em forma de cristais individuais, associados às rochas (microcristais finamente espalhados em rochas sedimentares, principalmente folhelhos) ou fósseis e ocorrerá perda total do material, caso este não seja tratado a tempo. Artefatos etnológicos ou arqueológicos (Figura 162) também podem ser danificados caso tenham pirita em sua confecção. Animais vertebrados, mineralizados durante a fossilização, podem possuir pirita em sua formação.

A única prevenção possível para o esfacelamento da pirita é o rigoroso controle do ambiente museológico, principalmente no que concerne à UR.

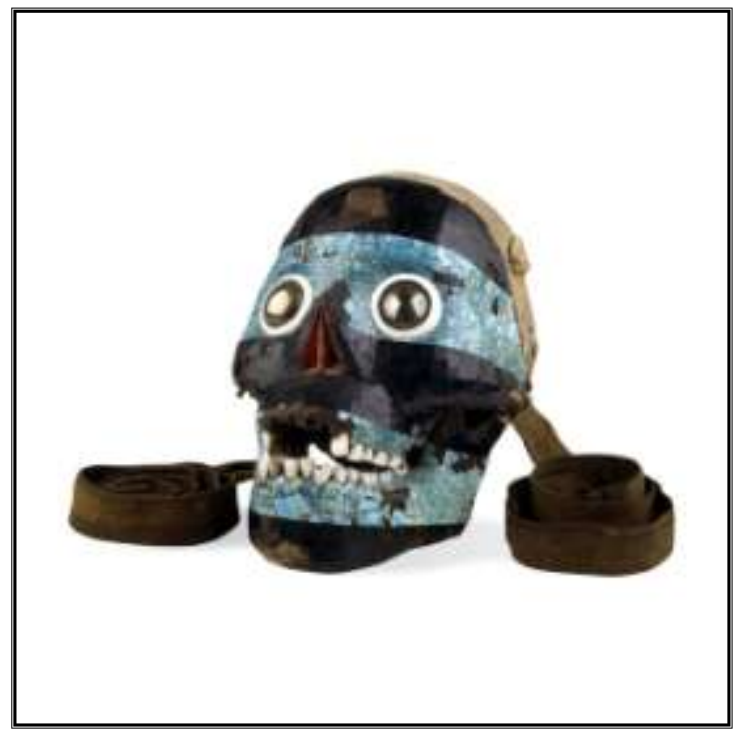

Figura 162. Máscara ritual azteca/mixteca, séculos XV/XVI, denominada The Skull of the Smoking Mirror. Esse artefato antropológico tem turquesa na maior parte de sua composição e, na área dos olhos, dois discos de pirita. Fonte: http://www.britishmuseum.org/explore/highlights/highlight_objects/aoa.aspx.

O decaimento da pirita é caracterizado por eflorescências amarelas ou brancas que provocam a quebra do mineral, um forte cheiro ácido, aspecto de queimadura ou chamuscados nas embalagens, etiquetas e até mesmo em algumas gavetas. A taxa das reações é variável, e nas piores situações pode chegar a causar a destruição total do espécime. A bibliografia tem tratado esse 
assunto como decaimento ou apodrecimento da pirita, doença do fóssil ou, de forma mais correta e apurada, oxidação do sulfeto (BUTTLER, 1994), uma vez que qualquer sulfeto está propenso a esse tipo de reação, apesar de serem pirita e marcassita os minerais mais comumente afetados.

O decaimento da pirita é causado pela oxidação do ferro presente no mineral, que, em contato com o oxigênio presente na água e no ar libera íons, e desta reação surge a ferrugem, que provoca paulatinamente a deterioração da peça original.

$\mathrm{Na}$ presença de oxigênio, a pirita decompõe-se em sulfato de ferro e dióxido de enxofre (responsável pelo odor). Quando há presença de água (um ambiente com alta UR) há também a formação de ácido sulfúrico, o responsável pela queima das embalagens e etiquetas. Uma vasta gama de produtos da oxigenação pode ser fabricada dependendo da matriz à qual o mineral está associado, ou a outros minerais adjacentes. Simplificadamente, as reações que ocorrem com a oxigenação da pirita e da marcassita estão representadas a seguir.

1. Ao primeiro contato com o $\mathrm{O}_{2}$ atmosférico, as piritas já começam a sofrer a seguinte transformação:

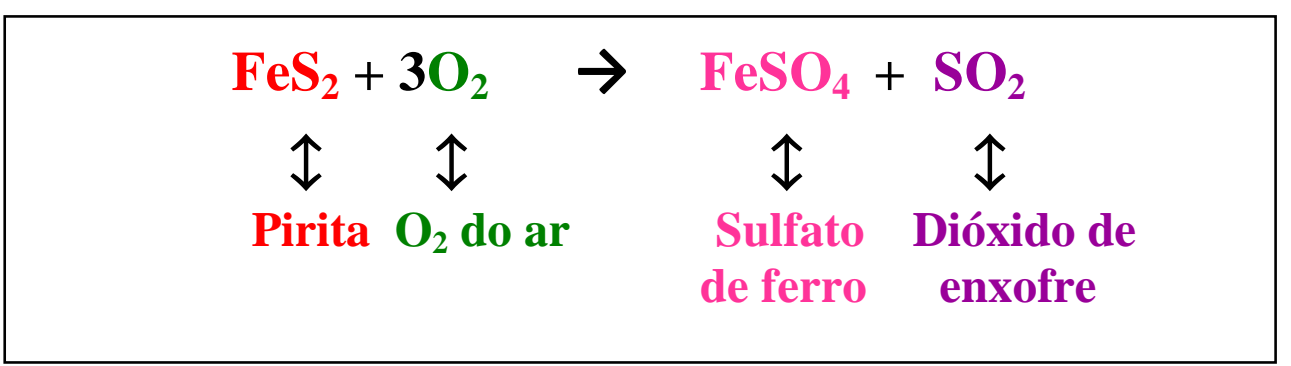

2. Se a atmosfera possuir grande quantidade de vapor de água, ou seja, elevada UR, normalmente acima de $60 \%$, a água dispersa no ar também reagirá com o ferro, liberando, além de dióxido de enxofre, ácido sulfúrico.

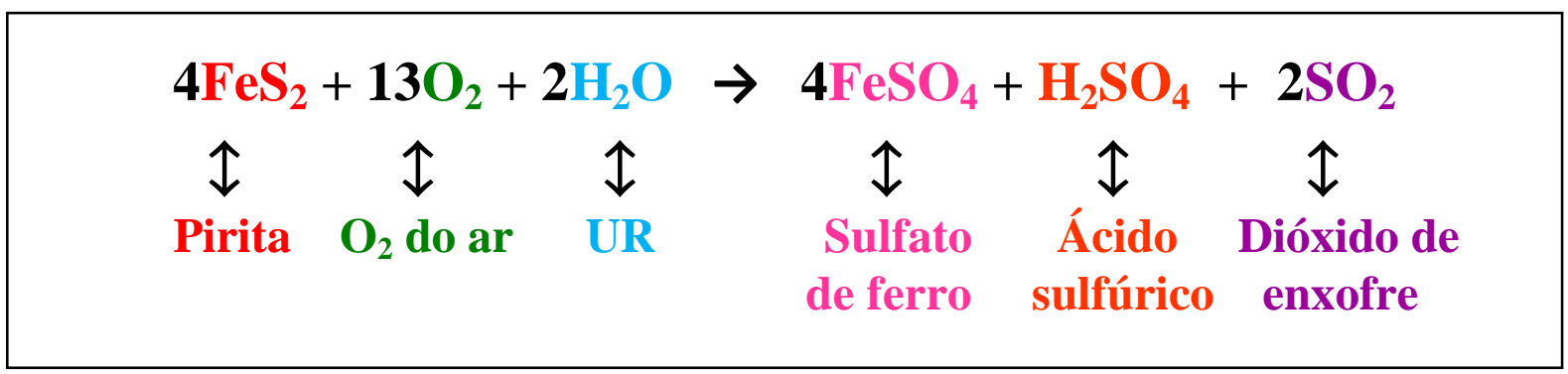

A consequência física da mudança de fase associada à transformação do sulfeto em sulfato é o aumento do volume dos cristais da amostra, causando tensionamento das estruturas internas, o que resulta no esfacelamento da amostra.

Tal reação ocorre porque a pirita, assim como todos os sulfetos, foi formada em um ambiente no qual ainda não havia oxigênio livre na atmosfera. Dessa forma, ao ficar exposta 
numa atmosfera diferente da de sua formação, com muito oxigênio (elemento estranho ao mineral), este passa a interagir com a amostra, causando a oxidação. Quando o ambiente está com umidade relativa muito elevada, as partículas de água ficam soltas no ar, interferindo também na formação original do cristal. Devido a esses fatores é que ocorre a equação descrita.

Apesar de ser um problema comum em coleções geológicas por todo o mundo (Figuras 163 a 168), não são todas as piritas que sofrem decaimento. As amostras mais facilmente atingidas são as que não estão bem cristalizadas, estruturadas na forma de microcristais ou microesferas. Os maiores cristais, com hábito perfeito, são mais estáveis. A estabilidade do mineral está, portanto, relacionada ao tamanho do grão do cristal. No entanto, HOWIE (1992) destaca que até os maiores cristais podem desenvolver manchas amarronzadas ou alaranjadas, ou surgir eflorescência.

As manchas nos cristais individuais ou agregados bem formados que aparecem na forma de discreta perda de brilho nas amostras ou na forma de coberturas alaranjadas ou marrons também são um problema comum de pirita e marcassita em museus. Tais manchas desenvolvem-se em superfícies lisas de intercrescimento euhedrais de pirita estável, aparecendo primeiro como iridescência e após poucos dias, tornando-se alaranjada ou marrom (HOWIE, 1992). O polimento da superfície causa diferenças de adsorção do oxigênio e do vapor de água do ar pelas faces do mineral. Além disso, pirita e marcassita possuem pequenas diferenças entre as propriedades físicas nas diversas faces.

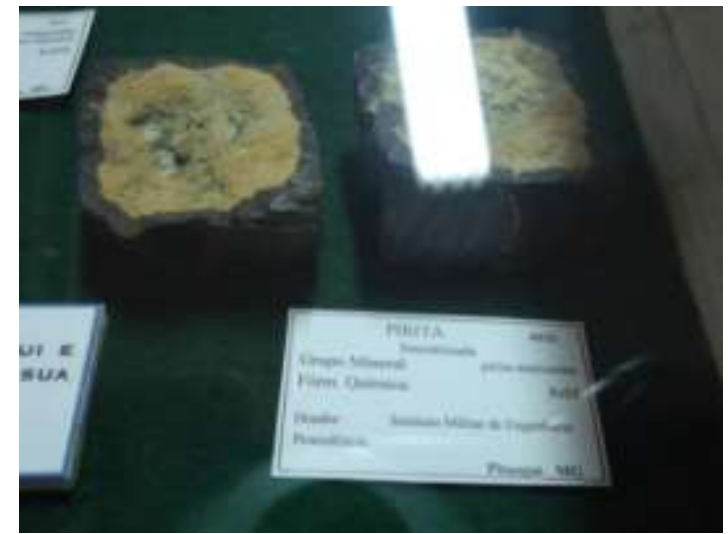

Figura 163. Todas as fases de alteração e degradação possíveis de ocorrerem na pirita em uma só amosta: alteração para limonita, oxidação, eflorescência e esfacelamento. Acervo: Museu de Ciências da Terra-DNPM.

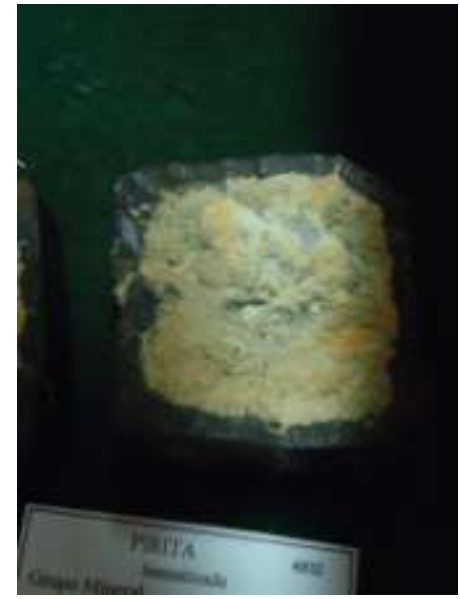

Figura 164. Detalhe das ocorrências citadas na Figura 163. Acervo: Museu de Ciências da Terra-DNPM. 


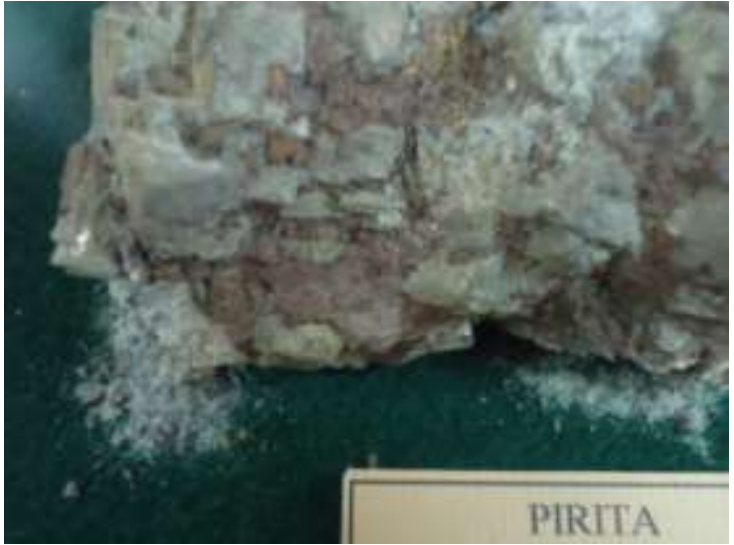

Figura 165. Esfacelamento de amostra de pirita, causada pela oxidação do sulfeto. Acervo: Museu de Ciências da Terra-DNPM.

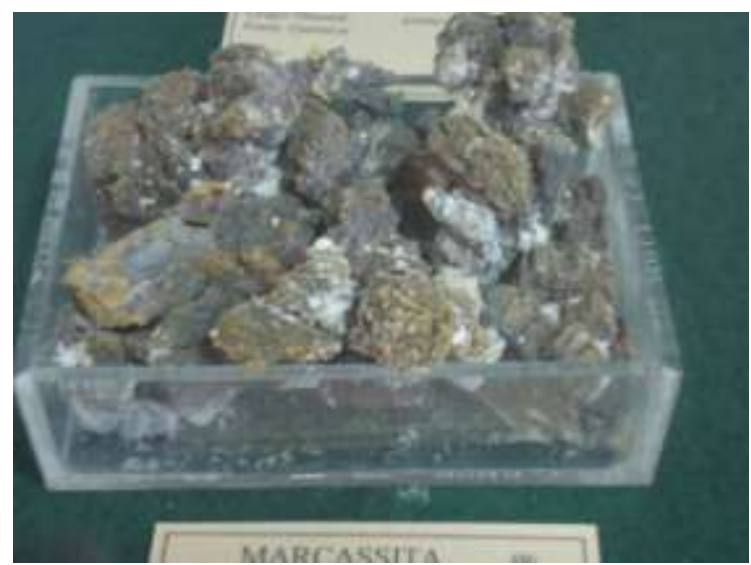

Figura 167. Esfacelamento de marcassita, decorrente da oxidação do sulfeto. Acervo: Museu de Ciências da Terra-DNPM.

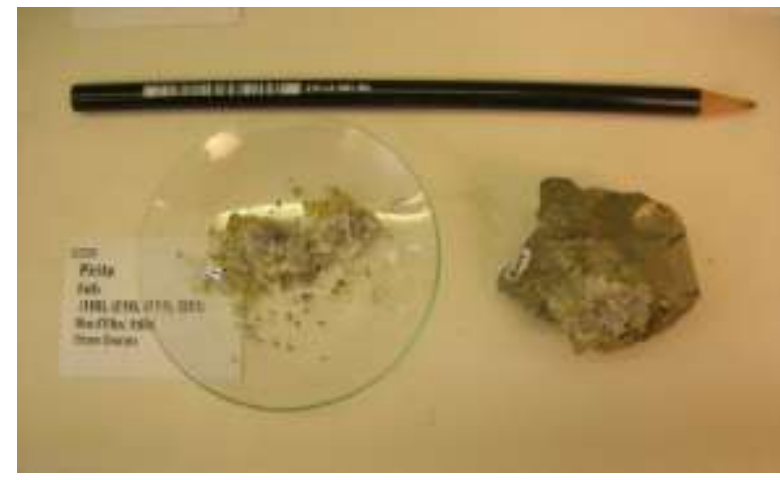

Figura 166. Esfacelamento de pirita. Acervo: Museu de Geociências da USP.

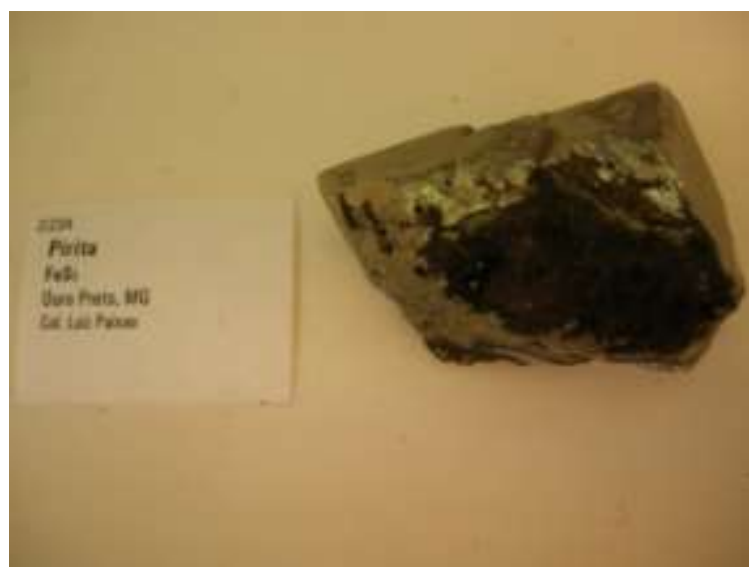

Figura 168. Oxidação de pirita. Acervo: Museu de Geociências da USP.

Ao longo do tempo, muitas técnicas foram utilizadas na tentativa de tratar as piritas alteradas. Desde o século XIX reconhece-se que a exposição da pirita ao ar causa danos ao mineral. Nessa época, o armazenamento era recomendado junto com produtos como linhaça ou óleo de parafina. No início do século XX, sugeria-se que o ácido produzido no decaimento fosse neutralizado submetendo a amostra a um banho de carbonato de sódio, ou solução de hidróxido, finalizado por impregnação com goma-laca. Na década de 1950, pensava-se que o decaimento da pirita fosse por ação bacteriana. Desse modo, os espécimes contaminados eram tratados com produtos antibacterianos. Por fim, o gás de amônia foi amplamente utilizado até a década de 1970.

Na década de 1990, os espécimes suscetíveis ao decaimento passaram a ser tratados quimicamente apenas se a reação química já tivesse tido início e se parecesse estar em processo adiantado de decomposição. A meta do tratamento era neutralizar e/ou remover os 
produtos ácidos resultantes da oxidação. Se os produtos da oxidação não fossem removidos, a taxa de deterioração da amostra aumentaria. Nos anos 90 eram utilizados dois métodos principais:

- Tratamento à base de Tioglicolato de Etanolamina, desenvolvido por CORNISH \& DOYLE (1984, apud BUTTLER, 1994) do LNHM.

- Método de tratamento por neutralização, com utilização de vapores básicos de hidróxidos de amônia, desenvolvido por Waller (1987, apud BUTTLER, 1994).

A fim de prevenir a oxidação de amostras recém coletadas, não se deve utilizar nenhum agente de limpeza à base de água, seja de natureza ácida ou básica. Recomenda-se a utilização de limpeza a seco ou com solventes orgânicos seguidos de armazenamento sob 30\% de UR (HOWIE, 1992). Não se deve remover os minerais da paragênese a menos que seja para análise. No entanto, a pirita pode sofrer oxidação, mesmo em baixas taxas de UR quando associada à galena $(\mathrm{PbS})$ ou esfalerita $(\mathrm{ZnS})$. Embalar espécimes reativos em embalagens de polietileno ou PVDC desencadeiam as reações de oxidação dentro de um ou dois dias, uma vez que há oxigênio preso na embalagem. Por outro lado, se os espécimes forem secos e embalados a vácuo, essas embalagens podem ser utilizadas. As amostras também não devem ser secas em forno, pois assim que o calor da amostra se dissipa (fora do forno), ela recomeça a absorver á água do ar.

Para as amostras vindas do campo, o ideal é que sejam transferidas direto do laboratório para um dissecador, ou então imersas em solventes orgânicos, como acetona seca ou isopropanol seco, por um ou dois dias, a fim de que a água absorvida seja removida, e então transferida para um recipiente com sílica gel (HOWIE, 1992).

Muitos materiais utilizados como selantes, para criar um revestimento protetor nas amostras, não são eficientes, uma vez que não impedem a penetração de ar e vapor de água no interior dos exemplares, onde o processo de oxidação ainda pode ocorrer. Materiais muito utilizados no passado para esse fim eram a goma-laca, baquelite, acetato de polivinil ou metacrilato de polibitil, muitas vezes simultaneamente. Adesivos e consolidantes devem ser orgânicos e sem água em sua composição, além de reversíveis (BUTTLER, 1994).

O melhor método para tratar o decaimento da pirita é a prevenção. Não há tratamento químico possível para a pirita já esfacelada, apenas para a oxidação em andamento. Uma vez que a amostra apresenta sinais de decaimento, é possível interrompê-lo, tomando as medidas de controle de UR e temperatura, além de verificar as interações desta com outros minerais. $\mathrm{O}$ mineral, ou material suscetível ao decaimento (caso dos fósseis) deve ser mantido em 
ambiente de baixa UR, menor que 50\%, sendo o ambiente ideal de $30 \%$ de UR. Em ambas as taxas, o importante é que a UR deve sempre ser constante, como descrito no item 6.3.1.

Pequenas cabines ou caixas com boa vedação podem ser mantidas por longo período com a UR entre 30 e $40 \%$ apenas com a utilização de sílica gel. Vitrinas maiores ou reservas técnicas devem ter a UR controlada por climatizadores, sempre em torno de $30 \%$. Vale ressaltar que, dependendo do espaço e dos recursos financeiros disponíveis, a taxa de UR ideal deve ser encontrada pelo curador levando em conta todos os materiais sensíveis a ela, e as taxas de que necessitam. Para os sulfetos em geral, as taxas devem estar em torno de $30 \%$, mas se houver material que necessite de um pouco mais de umidade, o curador deve avaliar e, dependendo, é possível procurar uma alternativa desde que não ultrapasse $50 \%$ de UR.

\subsubsection{2 - Folhelhos}

Folhelho é uma rocha sedimentar detrítica formada por partículas com diâmetro menor que $0,0625 \mathrm{~mm}$. É composta principalmente por minerais argilosos (silicatos hidratados de alumínio, com algumas substituições de ferro e magnésio) e quartzo com pequenas quantidades de feldspato, carbonatos e minerais contendo ferro (pirita). Os folhelhos são formados por meio de deposição de sedimentos tanto em água doce quanto em água salgada. $\mathrm{O}$ pH da água doce é ácido (aproximadamente 4,7). Já os materiais provenientes da água salgada são levemente básicos (aproximadamente pH de 7,8), por isso os folhelhos de água doce que contêm pirita estão mais suscetíveis ao decaimento (DOLLERY, 1994).

Trata-se de um tipo de rocha muito comum em coleções petrológicas e paleontológicas e também um dos materiais de coleções geológicas mais sensíveis ao ambiente, tendendo a dividir-se em lâminas de maneira irreversível, causando assim, a destruição da rocha e dos elementos associados, no caso fósseis ou outros materiais associados a ela.

A cor dos folhelhos é produzida pela quantidade de óxidos de ferro presentes na rocha. A presença do $\mathrm{Fe}$ no estado férrico $\left(\mathrm{Fe}^{3+}\right)$ produz folhelhos avermelhados e a presença de $\mathrm{Fe}$ no estado ferroso $\left(\mathrm{Fe}^{2+}\right)$ leva à coloração esverdeada ou preta do folhelho. A coloração escura também pode provir da presença de matéria orgânica na amostra, já que a mesma é comum em terrenos sedimentares. Quanto mais escuro o folhelho, maior a presença de matéria orgânica (material carbonáceo) presente na amostra.

Muitos folhelhos têm predisposição para dividir-se ou separar-se em camadas ao longo de superfícies relativamente lisas e paralelas ao plano bandado. As laminações produzidas 
como resultado das fissuras abrangem espessuras de 0.05 a $1 \mathrm{~mm}$, tendo início entre 0.1 a 0.4 mm. As fissilidades crescem quanto maior for o conteúdo orgânico da rocha e, ao contrário, diminuem quanto maior a quantidade de sílica ou calcário presentes. As fissilidades também têm relação com a taxa de deposição, assim, um folhelho resultante de uma deposição uniforme e por tempo prolongado é menos suscetível a sofrer laminações.

Há três razões para a deterioração dos folhelhos:

1 - Danos físicos causados por mau acondicionamento e manuseio;

2 - (De) laminação causada por ambiente museológico inadequado;

3 - Decaimento da pirita presente no folhelho (ver decaimento da pirita no item 6.3.5.1).

Os folhelhos sofrem delaminação em ambientes muito secos. Isso ocorre devido à desidratação e consequente encolhimento dos argilominerais que compõem o folhelho. As estruturas cristalinas de alguns argilominerais expandem e/ou contraem de acordo com o conteúdo de água na amostra. Entretanto, existe um ponto crítico (cerca de $35 \%$ de UR), abaixo do qual os argilominerais perderão a plasticidade devido à perda da capacidade de absorção (DOLLERY, 1994). Uma vez ocorrido isto, não há possibilidade de restaurar a rocha reidratando seus minerais. Como no caso das piritas, não há solução para a delaminação dos folhelhos, apenas medidas profiláticas para que tal dano não ocorra. A melhor maneira de garantir uma vida longa aos folhelhos é exibi-los ou acondicioná-los em ambientes cuja UR esteja rigorosamente controlada (em constância e valores) em $50 \%$. Esta meta pode ser atingida, por uso do ar condicionado, caso seja um ambiente que envolva outras amostras; ou armazenando-a em caixas hermeticamente fechadas de polietileno, condicionadas à presença de sílica gel ou outro agente desumidificante.

Uma vez que o folhelho já esteja ressecado e delaminado (Figura 169), deve-se preencher as fendas entre as laminações para evitar que o manuseio indevido a destrua completamente com o aumento das fissilidades. Um bom preenchimento é produzido com uma mistura de 15 a 20\% de solução de Paralóide ou Acrilóide B72 em acetona. Caso não haja interesse científico na amostra, apenas comprometimento estético com a exposição, podem ser adicionados pigmentos a essa mistura, ou pintar a amostra com tinta acrílica quando o preenchimento já estiver seco. 


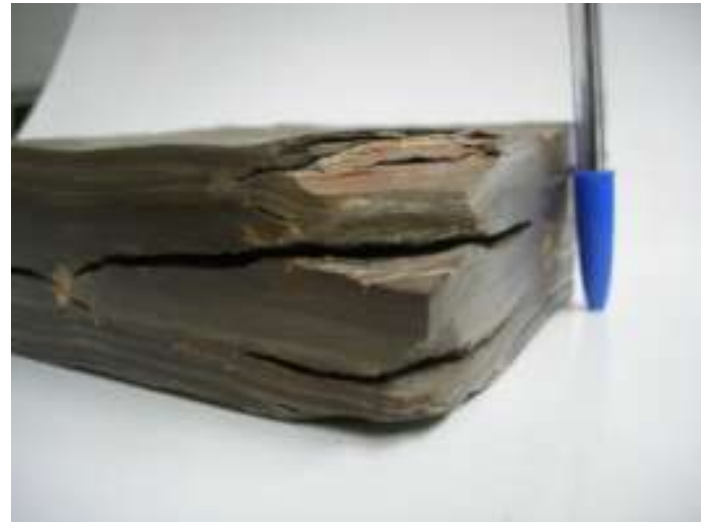

Figura 169a. Aspecto de folhelho ressecado, com fissuras de grande espessura. Acervo: Museu de Geociências da USP.

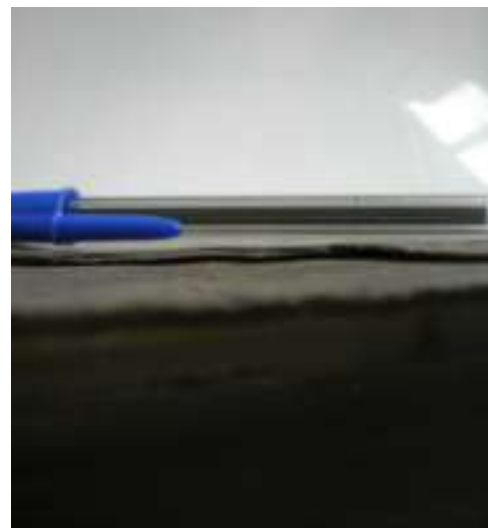

Figura 169b. Aspecto de uma das camadas de delaminação do mesmo folhelho. Acervo: Museu de Geociências da USP.

\subsubsection{3 - Meteoritos}

Em linhas gerais, meteoritos são fragmentos naturais de matéria extraterrestre, que, durante sua trajetória no espaço, acabam por ser desviados pela força do campo gravitacional terrestre e são atraídos para a atmosfera. Durante a queda, esses corpos sofrem perda de massa devido ao calor gerado pelo atrito com o ar, e muitos nem chegam a tocar o solo. Os meteoritos são uma fonte única de informação sobre uma vasta gama de eventos associados à origem do sistema solar; daí seu inestimável valor científico e necessidade primordial de conservação em coleções geológicas.

De acordo com TEIXEIRA ET AL. (2009), os meteoritos podem ser simplificadamente assim divididos:

- Meteoritos rochosos: são cerca de 95\% dos exemplares encontrados na superfície da Terra. São subdivididos em condritos (olivinas, piroxênios e liga metálica Fe-Ni) e acondritos (olivinas, piroxênios e plagioclásio).

- Meteoritos ferro-pétreos ou siderólitos: apenas 1\% dos meteoritos encontrados na superfície, formados por mistura de minerais silicáticos e ligas de ferro e níquel.

- Meteoritos metálicos ou sideritos: somam 4\% das descobertas de meteoritos na

Terra. São constituídos essencialmente por liga metálica de ferro e níquel.

Muitos meteoritos são compostos por agregados de minerais, alguns dos quais são desconhecidos na Terra (BEVAN, 1992), tornando a presença desses minerais em amostras desconhecidas uma das formas de diagnosticar meteoritos. Em geral, as seguintes associações minerais são encontradas em meteoritos, como mostra a Tabela 21. 
Tabela 21. Principais Associações Minerais em Meteoritos. Fonte: BEVAN (1992).

\begin{tabular}{l|l|l|l}
\hline Grupo Mineral & Classificação & Características & Fórmula Química \\
\hline Olivinas & $\begin{array}{l}\text { Silicato } \\
\text { (Nesossilicato) }\end{array}$ & $\begin{array}{l}\text { Ricos em Fe ou } \mathrm{Mg} \\
\text { Cor verde clara a } \\
\text { amarela } \\
\text { Brilho vítreo }\end{array}$ & $\left(\mathrm{Mg}, \mathrm{Fe}^{2+}\right)_{2} \mathrm{SiO}_{4}$ \\
Piroxênios & $\begin{array}{l}\text { Silicato } \\
\text { (Inossilicato) }\end{array}$ & $\begin{array}{l}\text { Ricos em Fe, } \mathrm{Mg}, \mathrm{Ca} \\
\text { Cor verde escura } \\
\text { Brilho vítreo }\end{array}$ & $(\mathrm{Fe}, \mathrm{Mg}, \mathrm{Ca})_{2} \mathrm{Si}_{2} \mathrm{O}_{6}$ \\
$\begin{array}{l}\text { Minerais } \\
\text { Metálicos }\end{array}$ & $\begin{array}{l}\text { Elementos de Fe-Ni nativos } \\
\text { Nativos }\end{array}$ & $\mathrm{FeNi}$ \\
\hline
\end{tabular}

Os meteoritos são formados em ambientes ausentes de oxigênio livre (mesmo caso dos sulfetos, já descrito no item 6.3.5.1), por isso, devido a sua composição metálica, muitos que caem em climas tropicais ou temperados desintegram-se muito rápido, pois o ferro, em contato com o $\mathrm{O}_{2}$ do ar e a grande oferta de água no ambiente (alta UR) nesses tipos de clima, aceleram o processo de oxidação, que se inicia assim que o corpo entra em contato com a atmosfera terrestre. Já os que caem em climas desérticos, preservam-se muito mais tempo desde sua queda. No caso de meteoritos recuperados logo após sua queda, a meta de conservação passa a ser minimizar tanto quanto possível futuras contaminações pelo ambiente terrestre. Ao mesmo tempo, a crosta de fusão (camada externa do meteorito, que derrete devido ao atrito com o ar da atmosfera terrestre durante sua queda), consequência primeira da contaminação terrestre, age como uma proteção temporária, vedando o interior do meteorito (BEVAN, 1992).

Diferentemente das formas de conservação anteriormente abordadas, que dependiam muito mais de medidas profiláticas simples do que grandes intervenções, a conservação de meteoritos está relacionada à necessidade de grande aporte financeiro. Compreender o processo de formação dos diferentes tipos de meteoritos pode auxiliar na prevenção de alguns danos.

A alta concentração de ferro existente na maioria dos meteoritos torna-os muito propícios a sofrer corrosão, provocada por reações de oxidação, consequentes da alta UR do ar, já citadas. É um dos problemas que mais afetam coleções de meteoritos. Quanto maior o teor de ferro na composição química da amostra, mais o exemplar será afetado. Como produto da oxidação, pode ocorrer a formação de hidróxidos de ferro, sendo a goethita $(\mathrm{FeOOH})$ o mineral mais conhecido. O aumento de volume provocado pela formação do novo mineral 
pode resultar em um rompimento da amostra em seus planos de fraqueza (BEVAN, 1992), como mostra a Figura 170.

Para prevenir o avanço da ferrugem, é necessário diminuir ao mínimo a umidade do ambiente de armazenamento, uma vez que conseguir uma atmosfera sem oxigênio é muito custoso para a maioria das coleções. A melhor forma de atingir esse objetivo é utilizar um recipiente bem vedado para guardar a amostra e colocar junto a ela, um material absorvente de umidade. Embalagens de polietileno de calibre pesado são à prova d'água e por isso viáveis para guardar meteoritos. Os exemplares com maior teor de ferro devem ser armazenados em duas embalagens, e a mais interna deve ter um indicador de absorção de umidade com sílica gel. O monitoramento da UR no entorno desses meteoritos (Figura 171) deve ser feito em intervalos regulares, com troca da sílica gel e das embalagens. A periodicidade desse monitoramento deve constar na política de coleções do Museu.

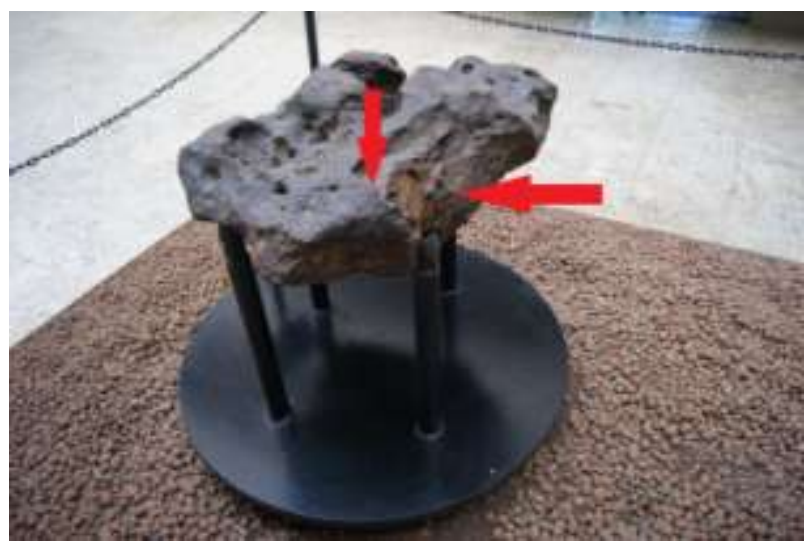

Figura 170. Meteorito Itapuranga exposto no saguão do Instituto de Geociências da USP. A oxidação do ferro da amostra está proporcionando o aumento da quebra do material em seus planos de fraqueza. Foto: Daniel Machado.

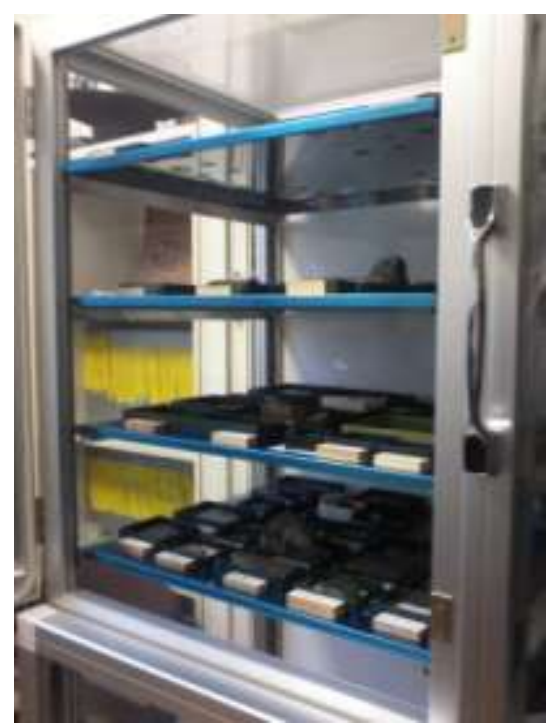

Figura 171. No Museum für Naturkunde Berlin, os meteoritos metálicos são armazenados em vitrinas de vidro vedado como fundo forrado por sílica gel. Um higrômetro controla constantemente a umidade do local, sempre menor que $50 \%$. 
As Figuras 172 a 177 mostram alguns meteoritos do Museu de Geociências da USP.

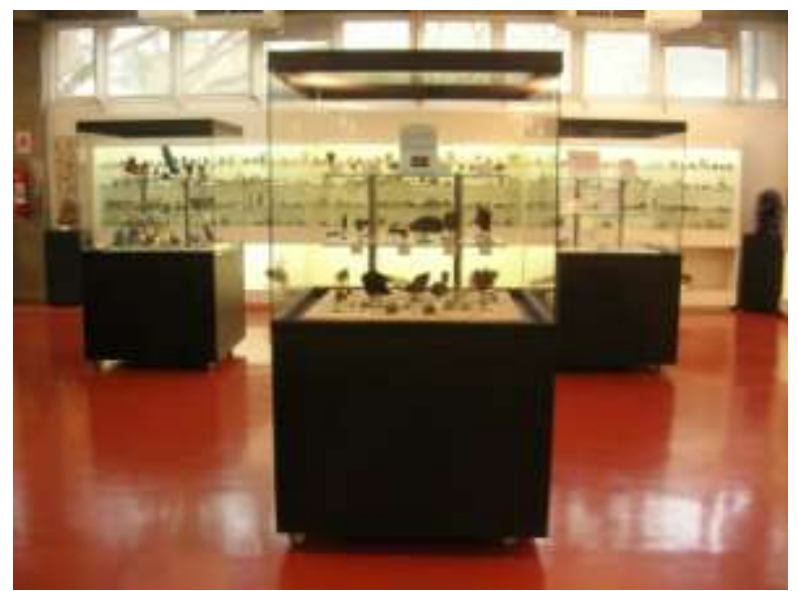

Figura 172. Aspecto da vitrina de meteoritos do Museu de Geociências da USP. À exceção de dois exemplares, toda a coleção está exposta nessa vitrina.

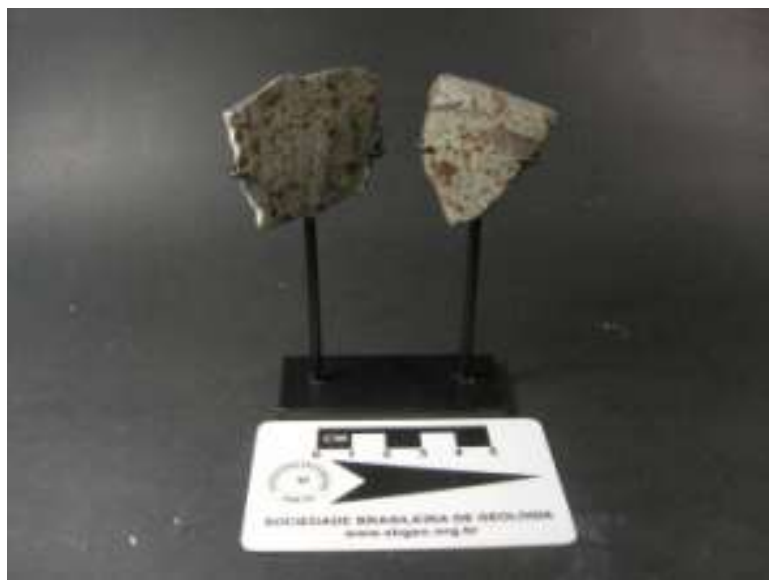

Figura 174. Condritos da coleção de meteoritos do Museu de Geociências da USP.

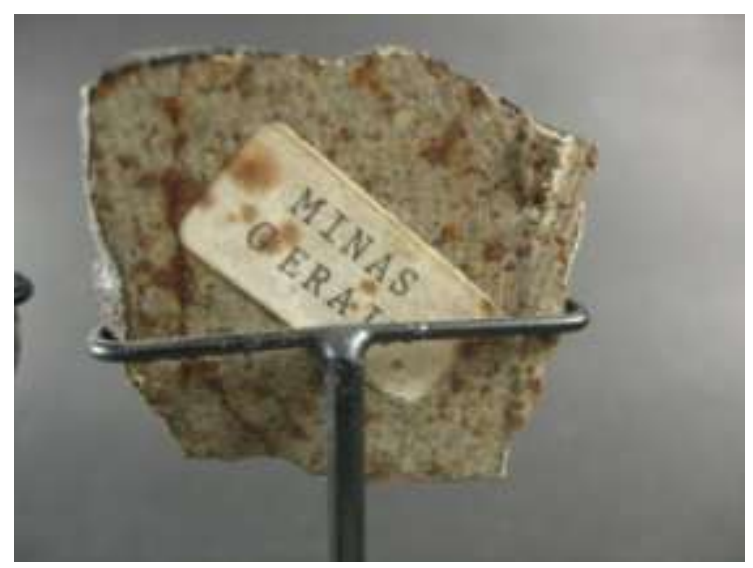

Figura 176. Rachadura em condrito provocada pela ferrugem.

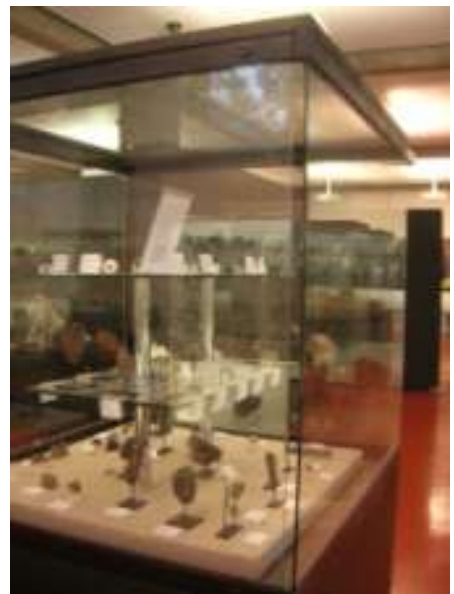

Figura 173. A abertura lateral da vitrina propicia a contaminação dos espécimes pela umidade, variação de temperatura e poluentes do ambiente.

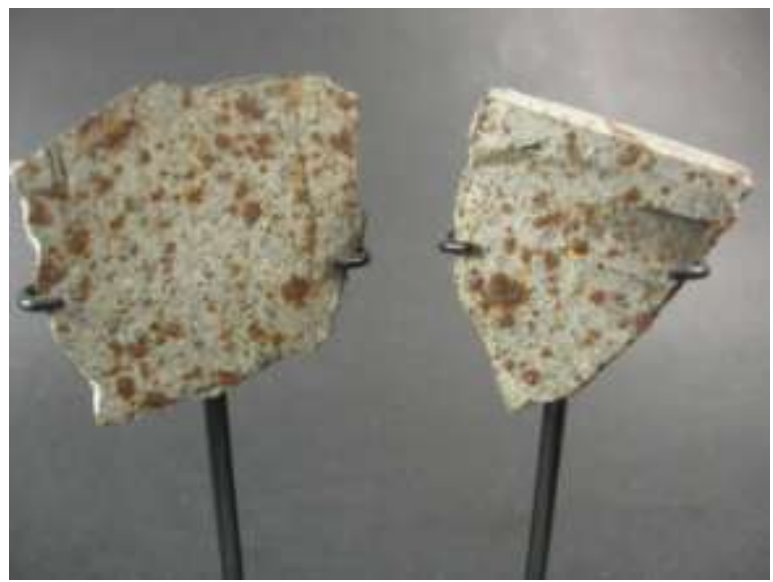

Figura 175. Manchas de oxidação do ferro em condrito. Acervo: Museu de Geociências da USP.

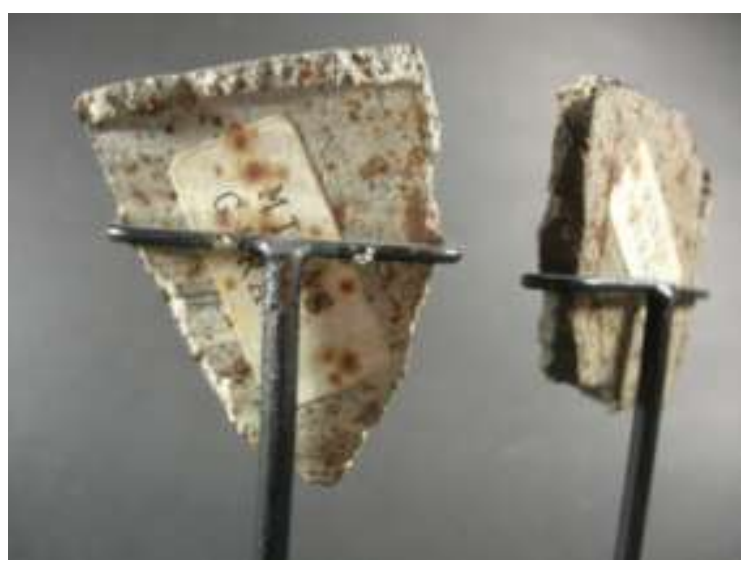

Figura 177. Aspecto da ferrugem no suporte do condrito. Note-se a eflorescência (parte branca) no suporte de ferro e as manchas de ferrugem. 
Outro problema de maior proporção refere-se às interações entre os minerais meteoríticos e os sais do ambiente: eflorescência e deliquescência.

Um exemplo são os condritos carbonáceos, que contêm o mineral epsomita $\left(\mathrm{MgSO}_{4} \cdot 7 \mathrm{H}_{2} \mathrm{O}\right)$ em sua composição, muitas vezes em grande quantidade. Esse mineral dissolve-se rapidamente em altas umidades, eflorescendo no meteorito e podendo resultar na perda do espécime ao qual está associado. Por conterem cerca de $20 \%$ de água em sua composição, na forma de sulfato hidratado, os condritos têm grande tendência a autodestruírem-se ao longo do tempo (BEVAN, 1992).

No ambiente museológico é necessário que os meteoritos tenham um acondicionamento especial, no que concerne à temperatura, UR, e vedação das embalagens. É necessário que estejam armazenados em reservas técnicas com temperatura baixa a moderada, ambiente livre de poeiras (com filtro de ar) e vedação maior possível (da sala com relação a ambientes externos)

Há casos, como o Museu de Geociências, em que a coleção de meteoritos é pequena (em tamanho e número dos exemplares), o que inviabiliza manter os exemplares em reserva técnica, estando os mesmos em exposição permanente. Em casos como este, é recomendável a confecção de uma vitrina especial, bem vedada, com controle interno de temperatura e umidade. Por tratar-se de materiais com alta densidade, é necessário que as gavetas ou prateleiras que armazenem os exemplares sejam constituídas de material forte o bastante para suportar o peso. Para exemplares maiores, é necessário embalar a amostra em polietileno e estocar em estantes fortes. Para amostras muito grandes, maiores que as amostras de mão, (isso depende do espaço de que cada museu pode dispor para o armazenamento de material), é necessária a confecção de depósitos especiais para a(s) amostra(s), que levem em consideração a necessidade de boa fixação no espaço escolhido (a fim de não haver queda do material), a logística do armazenamento (o material não poderá ser retirado regularmente desse espaço) e a criação de um microclima para evitar contaminação, ferrugem, eflorescência ou deliquescência do meteorito.

Em relação à numeração dos exemplares, vale destacar que as tintas e colas normalmente utilizadas na marcação de materiais geológicos são contaminantes em meteoritos. Exemplares comuns podem ter o número afixado na crosta de fusão da superfície meteorítica, enquanto que os materiais raros, como condritos carbonáceos, devem permanecer na coleção sem numeração na amostra. A coleção deve ser monitorada constantemente e os dados atualizados e registrados na forma de organização corrente do museu.

As Figuras 178 a 183 mostram exemplos de acondicionamento de meteoritos. 


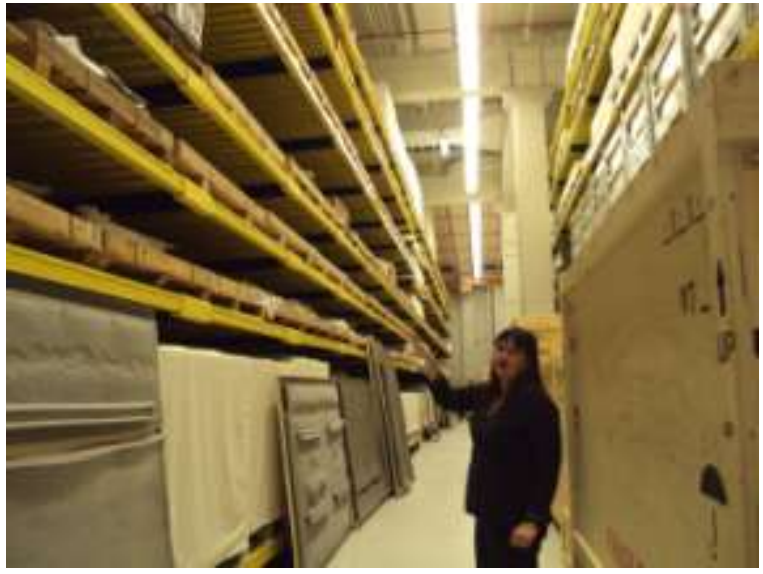

Figura 178. Exemplo de reserva técnica específica para amostras de grandes dimensões, no MSC. No caso de meteoritos, o espaço deve ter controle de temperatura e UR, além de filtros de ar.

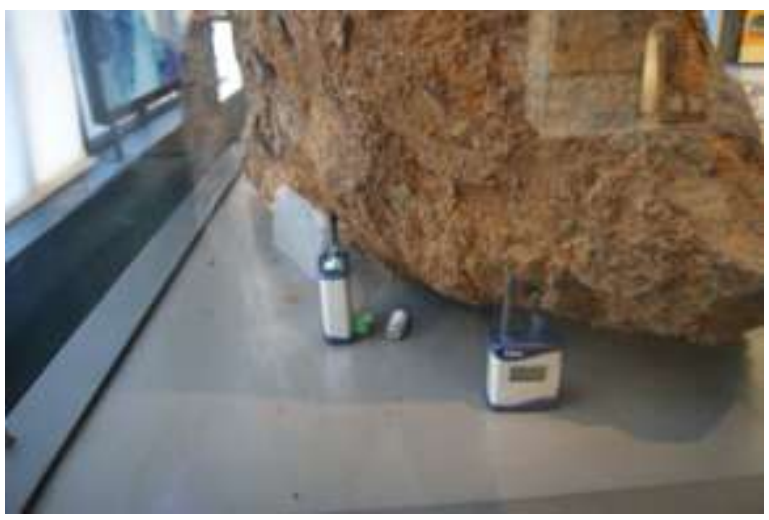

Figura 180. Detalhe dos equipamentos para constante monitoramento de temperatura e umidade no interior da vitrina do meteorito Cranbourne, no LNHM. O nitrogênio seco garante a ausência de $\mathrm{O}_{2}$ do ambiente.

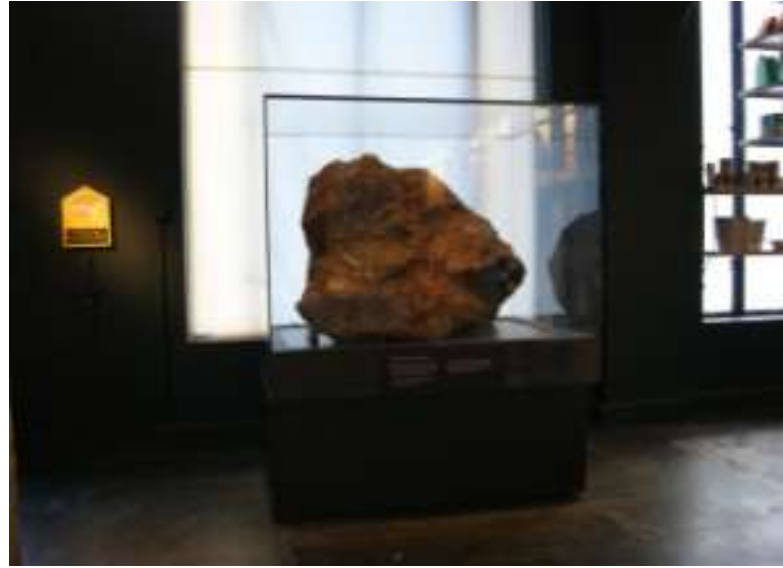

Figura 179. Meteorito Cranbourne, com 3,5 toneladas exposto no NHM em Londres. Ele está acondicionado em uma vitrina especialmente vedada a fim de manter a temperatura e umidade em seu interior.

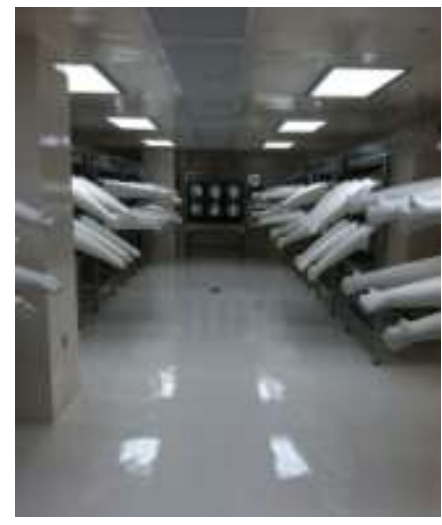

Figura 181. Vista da sala de armazenamento de meteoritos lunares no Museum Support Center, do Smithsonian Natural History Museum, in, Suitland, Maryland. Cada cabine é abastecida com gás nitrogênio, livre de água e oxigênio. Este procedimento mantém os meteoritos e rochas

lunares livres de sofrerem oxidação e interferência de poluentes do ambiente, como metais pesados e sais. Fonte:

http://mineralsciences.si.edu/research/meteorites/ antarctica/curation.htm 


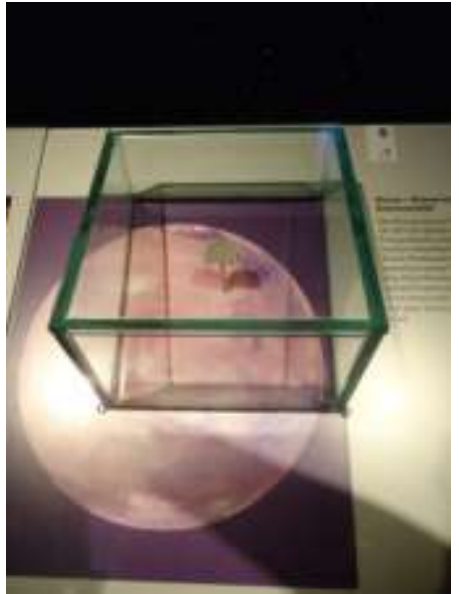

Figura 182. Meteorito lunar no Ries Crater Museum Nördlingen.

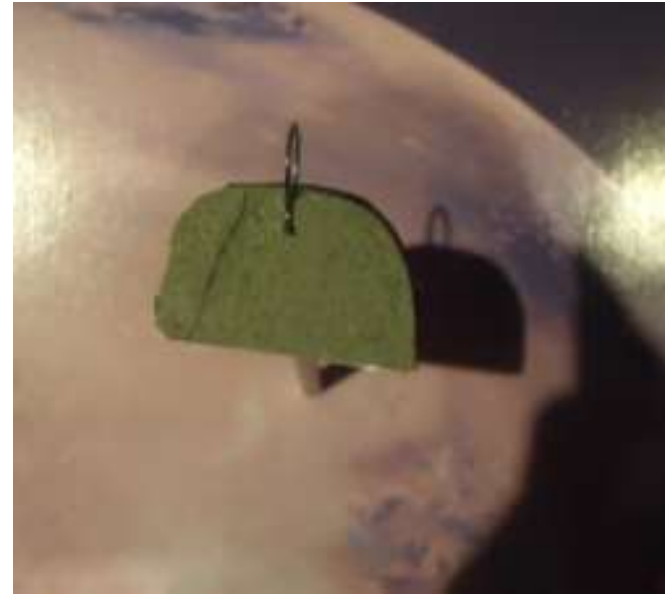

Figura 183. O espécime fica exposto em uma redoma de vidro e possui um suporte especialmente produzido para mostrar a melhor face para os visitantes.

\subsection{6 - Materiais para Conservação de Amostras}

Poucos são os materiais que podem ser utilizados para reparo de amostras sem produzirem efeitos colaterais, por isso a conservação prévia da coleção deve ser prioridade. Este item identificará os principais materiais utilizados para o tratamento de amostras geológicas em cada uma das etapas de conservação.

\subsubsection{1 - Identificação das amostras}

É imprescindível que os minerais sejam corretamente identificados, a fim de que casos perigosos, como minerais asbestiformes, tóxicos ou radioativos, sejam prontamente reconhecidos antes do contato manual com a amostra. Tal procedimento inclui identificação na sala de armazenamento, nas estantes, gavetas e, o mais difícil e delicado, na própria amostra.

Para identificação dos exemplares geológicos, é necessário que as etiquetas e materiais para numeração de amostras (assim como qualquer material que for entrar em contato com as amostras) tenham algumas características:

1) Estabilidade: devem ser quimicamente o mais estável possível, para que não haja reação com os minerais componentes da amostra, ou com os produtos de alteração da mesma.

2) Longevidade: devem ter durabilidade, a fim de garantir a legibilidade das informações pelo máximo tempo possível. 
3) Impermeabilidade: devem prevenir a absorção de tintas de marcação por materiais porosos

4) Reversibilidade: deve ser reversível, caso a amostra tenha que ser renumerada (embora tal procedimento não seja indicado) ou realocada em outra coleção.

Como regras gerais para marcação do número nas amostras (MUNYER, 1997) devese escolher o local mais acessível do exemplar, fora do olhar do público (Figura 184). Escolher a superfície mais plana, e que não vá sofrer possíveis abrasões (em minerais metálicos é uma regra difícil de seguir, pois não é possível prever onde a corrosão irá ocorrer). Não colocar a marcação perto da base de apoio da amostra, a fim de evitar manuseio excessivo durante a procura da numeração. Se o mineral ou rocha for exposto com todas as faces à mostra, a marcação deve ser feita na parte inferior.

As marcações podem ser feitas com fita, verniz e adesivo.

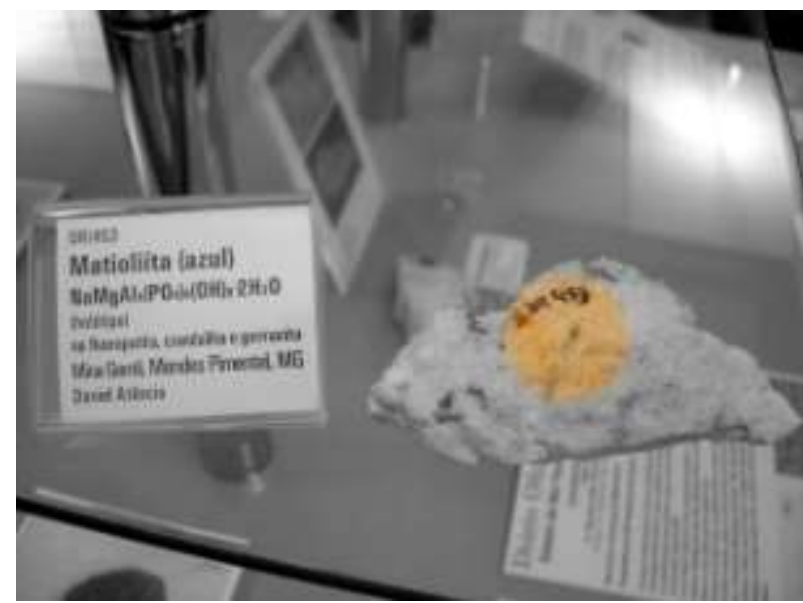

Figura 184a. Marcação errada feita no mineral matiolita.O mineral tem pequenas dimensões e se encontra sobre uma matriz branca. A tinta preta com a numeração está bem mais evidente que o mineral, confundindo a visão do observador. Acervo: Museu de Geociências da USP.

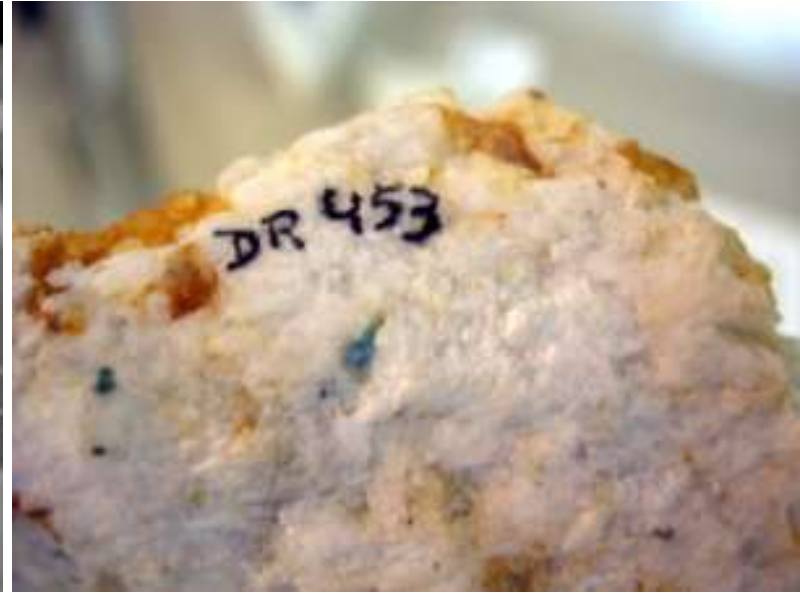

Figura 184b.Detalhe da marcação da amostra da Figura 184a. O mineral matiolita é o ponto azul abaixo da marcação, que se destaca mais que a amostra. Esse tipo de procedimento deve ser evitado. Acervo: Museu de Geociências da USP.

Fitas

Filmoplast $P$ Tape: trata-se de uma fita de papel transparente, de $\mathrm{pH}$ neutro, revestida com adesivo solúvel em água, sendo por isso adequada para utilização de marcação em amostras, já que é um procedimento reversível.

\section{Vernizes e Adesivos}

Paralóide B-72 (Paraloyd-B72) ou Acrilóide B-72 (Acryloid B-72): é um copolímero acrílico que responde afirmativamente a todos os critérios citados. É uma resina útil para a prevenção de ondulações, descamação e perda da legibilidade da informação e não é reativa a 
baixas umidades. Em concentrações baixas (5\% de resina e $95 \%$ de solvente) é verniz ideal para cobertura em descamações e decaimentos. Para utilizar como adesivo, a concentração deve ser mais alta (20\% de produto e $80 \%$ de solvente). Para diluir a resina sólida, utiliza-se a acetona por ser menos prejudicial para as pessoas encarregadas dessa atividade, mas é solúvel também em tilueno e xileno. Não se dilui em tinners.

Utilização em numeração de amostras (SULLIVAN \& CUMBERLAND, 1993):

- Solução de 25\% de Acrilóide B-72 verniz incolor em frasco com pincel aplicador na tampa;

- Solução de 25\% de Acrilóide B-72 verniz branco em frasco com pincel aplicador na tampa (utiliza-se a resina branca para a aplicação em espécimes escuros ou coloridos);

- Tinta preta permanente, com maior teor de carbono possível (tintas acrílicas fluidas causam corrosão em metais, especialmente cobre);

- Acetona;

- Pincéis artísticos;

- Papel toalha;

- Cotonetes;

- Água.

Este procedimento de numeração não se aplica a papéis, tecidos, superfícies de madeira, metais e superfícies com pó.

As marcações devem ser feitas em local ventilado, a fim de evitar intoxicação. A escolha do local ideal deve ser o primeiro passo para numerar as amostras.

A seguir, escolhe-se a área da amostra a ser identificada. Essa área deve ser a menor possível, a fim de interferir minimamente na composição química e na estética do mineral. No entanto, a identificação deve ser clara e visível, a fim de que a identificação visual seja rápida e minimize a manipulação da amostra. Em superfícies vítreas ou brilhantes é indicada uma limpeza prévia do local a ser numerado com acetona ou álcool, a fim de retirar resíduos de gordura.

Sugere-se que a pessoa responsável por fazer a marcação tenha boa caligrafia e traços firmes, a fim de evitar o desperdício de material em consertos de marcações mal sucedidas e também para poupar a amostra de mais intervenções que o necessário. Molhar o pincel na solução de acrilóide tomando o cuidado de não encharcá-lo, pois o excesso certamente pingará sobre a amostra, atrapalhando a marcação. O traço deve ser feito com calma e 
regularidade em uma só direção, de tamanho suficiente para caber apenas o número desejado. Para utilizar toda a solução do pincel, deve-se fazer o mesmo movimento na direção oposta. Para superfícies não porosas, essa aplicação única é suficiente. Para superfícies porosas, é necessária mais de uma aplicação. Devido à rápida evaporação da acetona, o intervalo de um minuto já é suficiente para a aplicação da segunda camada. Quando a superfície estiver consistente e suficientemente opaca, a aplicação estará concluída. Na ausência de exemplos visuais de utilização do Acrilóide B-72 em coleções geológicas, utiliza-se aqui (Figura 185) um exemplo de aplicação em material cerâmico, cujo procedimento de marcação é muito semelhante a uma amostra geológica.

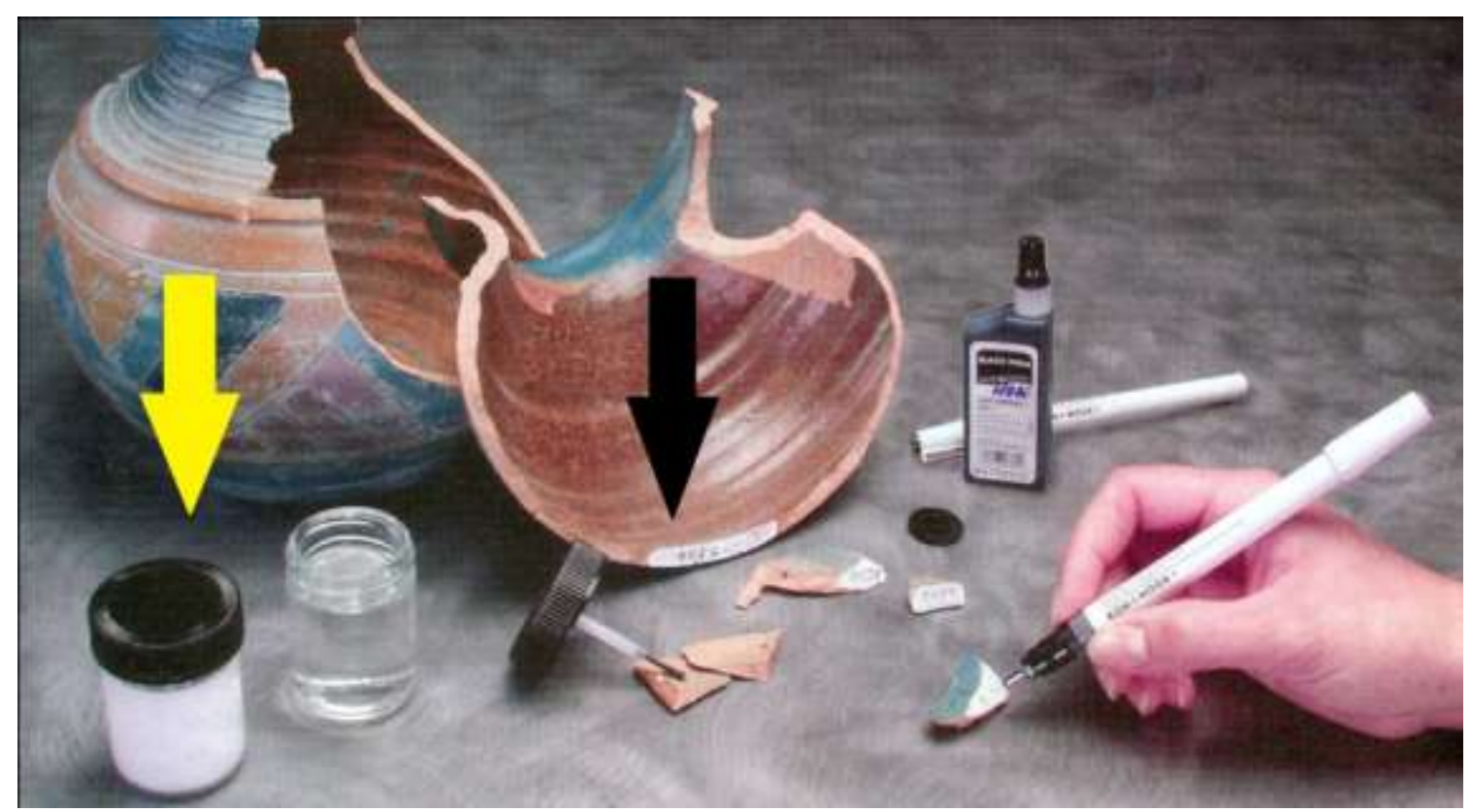

Figura 185. A figura indica uma peça de cerâmica sendo identificada com utilização de acrilóide B-

72. A seta preta indica a marcação já concluída, enquanto a seta amarela indica os dois tipos de vernizes utilizados: o branco para a base da marcação e o incolor para sua cobertura.

Fonte: Catálogo da Archival Quality Materials for Conservation, Restoration, Preservation \& Exhibition de 2010.

O tempo necessário para que se possa proceder ao registro é curto; sendo suficiente o tempo de fechamento e recolhimento do material utilizado na pintura e a preparação das canetas de marcação. Caso haja erro na marcação, um cotonete umedecido em água é suficiente para retirar a tinta da caneta. Caso seja necessária a remoção de toda a numeração, utiliza-se acetona para retirar o verniz e a tinta da caneta.

Após a marcação do número com a caneta, é necessário aplicar a última camada de verniz, que protegerá o número. O tempo de secagem da caneta é relativo, dependendo do tipo de caneta utilizada, a espessura do traço e da UR do ambiente. Após certificar-se de que a 
tinta secou, passar a camada de verniz transparente, com o mesmo método utilizado para a camada de base.

Nos casos em que a amostra não tiver superfície disponível para ser numerada, a amostra deve ser acondicionada em um recipiente e este receber o número de catálogo.

Esporadicamente é necessário verificar a viscosidade do acrilóide, pois a acetona utilizada como solvente evapora-se mesmo com o recipiente vedado. Se a viscosidade estiver alta, utiliza-se um conta-gotas para colocar acetona até atingir a viscosidade apropriada. É possível também armazenar a acetona em um porta-solvente com válvula de precisão. Devese reservar $250 \mathrm{ml}$ de acetona para esse fim.

Butvar 76 (Polyvinyl Butyral): verniz semelhante ao acrilóide e ao paralóide, porém é solúvel em álcool, substância menos tóxica que a acetona, o que torna seu manuseio mais seguro. Assim como os outros selantes citados anteriormente, não funcionam bem para materiais úmidos.

\subsubsection{2 - Exposição das amostras}

É durante a exibição que as amostras estão mais suscetíveis a danos, devendo, por isso, serem constantemente monitoradas e receberem conservação preventiva. Altas temperaturas, variações de UR e poluentes do ar são os maiores responsáveis por degradações nas exposições.

A seguir estão apresentadas algumas sugestões de produtos e procedimentos para conservação de amostras a serem expostas.

O primal B-60 A é uma emulsão aquosa de base acrílica, utilizada para proteção de objetos contra luz UV e calor. Quando aplicada ao objeto, forma um filme transparente, de longa duração e que não amarela, podendo assim ser utilizado em revestimentos e embalagens para minerais fotossensíveis. O pH é levemente básico, variando entre 9 e 9,5. Não é aconselhável sua utilização diretamente sobre o mineral ou rocha, pois se trata de um procedimento irreversível.

O acetato de polivinil (PVDA) é um polímero utilizado na forma de filme, com alta resistência à luz UV e calor. Por outro lado, apresenta baixa resistência à água e outros solventes polares, como etanol e acético. Em um ambiente com alta UR, seus produtos de deterioração liberam ácido sulfúrico.

Pode-se medir a luz UV com um aparelho portátil (Figura 186), que mede a radiação emitida por certa fonte luminosa em Lux ou Vela, unidade não pertencente ao sistema internacional (uma vela equivale aproximadamente 10 lux). 


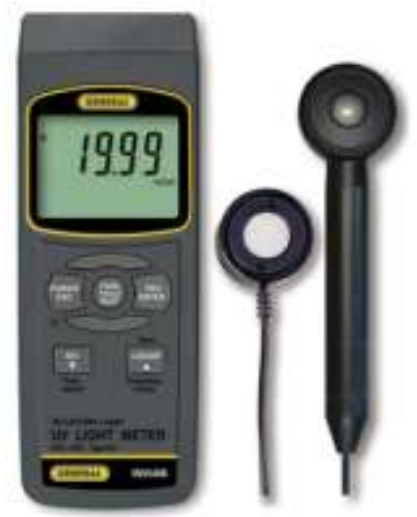

Figura 186. Exemplo de medidor de radiação UV. Fonte: www.universityproducts.inc. Acesso em 06.12.2012.

Para se eliminar a poeira existem microaspiradores de pó, em kits com diversos tipos de pincéis para diferentes necessidades de objetos pequenos (Figura 187). O kit consta de um adaptador que deve ser acoplado à mangueira de aspiradores comuns e nele se encaixam os bicos e pincéis adequados a cada amostra. Eficiente para limpeza de espécies delicadas, em exposição ou reserva, nos quais a trincha ou outros pincéis podem causar danos mecânicos.

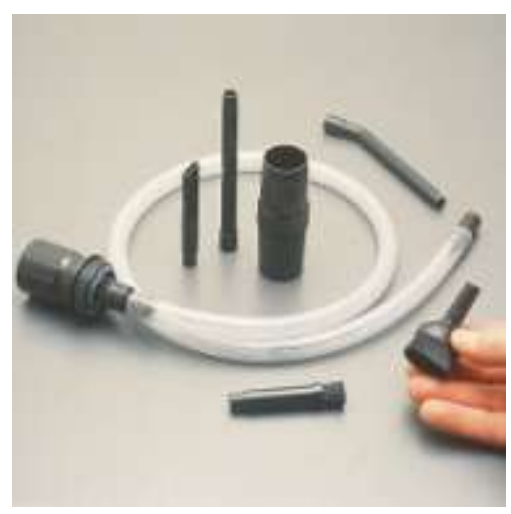

Figura 187. Kit para microaspiração de amostras. Fonte:

http://www.universityproducts.com/cart.php? $m=$ product_list \&c $=1233 \&$ primary $=1 \&$ parentId $=\&$ navT ree []$=1262 \&$ navTree $[=1270 \&$ navTree []$=1233$. Acesso em 06.12.2012.

\subsubsection{3 - Armazenamento das amostras}

Para se armazenar amostras, pode ser utilizada espuma de polietileno (Ethafoam). Trata-se de espuma de células fechadas, inerte e não abrasiva. Pode ser utilizada para preenchimento, vedação, embrulho de amostras, mas a utilização mais comum em coleções geológicas é como forro em gavetas de reserva técnica, a fim de deixar o material imóvel dentro de gavetas e armários deslizantes. 
Ageless é um absorvente de oxigênio, em forma de fitas e sachês, patenteado pela Mitsubishi Gas Chemical Company com o objetivo de criar um microclima próprio para materiais cuja deterioração é acelerada pelo ar. No caso dos minerais, os mais sensíveis são os sulfetos e metais ferrosos, uma vez que são compostos estáveis em atmosfera ausente de $\mathrm{O}_{2}$. Apesar das muitas variedades do produto, apenas o Ageless $Z$ é indicado para conservação museológica. A fim de maximizar o funcionamento do produto, as seguintes etapas são sugeridas por DANIEL (1995):

a) Calcular o volume da embalagem $\mathrm{em}^{3}$;

b) Dividir o resultado por cinco $^{22}$;

c) Dividir o resultado pela especificação milimétrica indicada na embalagem.

Por questões de segurança, devem ser utilizados de dois a três pacotes a mais que o calculado.

Apesar do sucesso em sua utilização, é necessário atentar para o fato de que a reação de Ageless com o $\mathrm{O}_{2}$ é exotérmica, por isso o produto não deve ficar em contato direto com a amostra. Gases inertes, sobretudo o nitrogênio, são bastante utilizados na conservação de meteoritos metálicos ou lunares. No entanto, esse é um procedimento que necessita maior aporte financeiro e espaço para os procedimentos de retirada de $\mathrm{O}_{2}$ do local e inserção do gás inerte.

O uso de sílica gel é a maneira mais difundida e de menor custo para a retirada de umidade de pequenos recipientes. Trata-se de esferas de sílica $\left(\mathrm{SiO}_{2}\right)$ que podem conter indicador de umidade. A sílica absorve a umidade do ar, secando o ambiente e se saturando de umidade. Quando atinge a saturação, a sílica muda de cor e deve ser retirada do ambiente e substituída. A sílica pode ser reaproveitada, sendo seca em forno de alta temperatura.

As cores mais conhecidas são a sílica azul (que se altera para rosa, Figura 188) e a sílica laranja (Figura 189), que perde a coloração, tornando-se incolor. No Museu de Geociências utiliza-se a sílica azul para as amostras de sais (Figuras 190 e 191). Recomendase a utilização da sílica laranja, pois não possui dicloreto de cobalto em sua composição $\left(\mathrm{CoCl}_{2}\right.$, responsável pela coloração azul), considerado tóxico.

\footnotetext{
${ }^{22}$ A porcentagem de $\mathrm{O}_{2}$ no ar é um quinto do volume (DANIEL, 1995).
} 

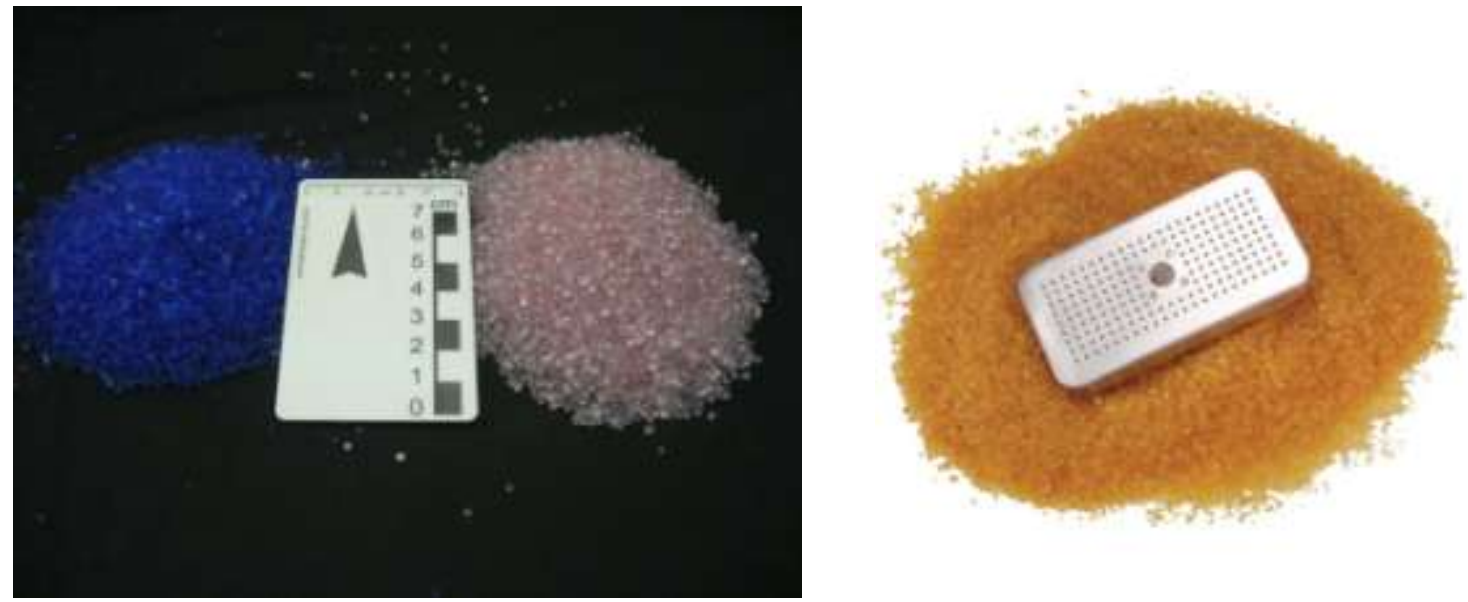

Figura 188. À esquerda, sílica gel insaturada. À direita, aspecto da sílica após absorver umidade.

Figura 189. Sílica gel laranja, que não possui cobalto em sua composição. Sobre a sílica, está um recipiente de alumínio, próprio para seu acondicionamento. Quando saturada, fica incolor. Fonte: www.universityproducts.inc

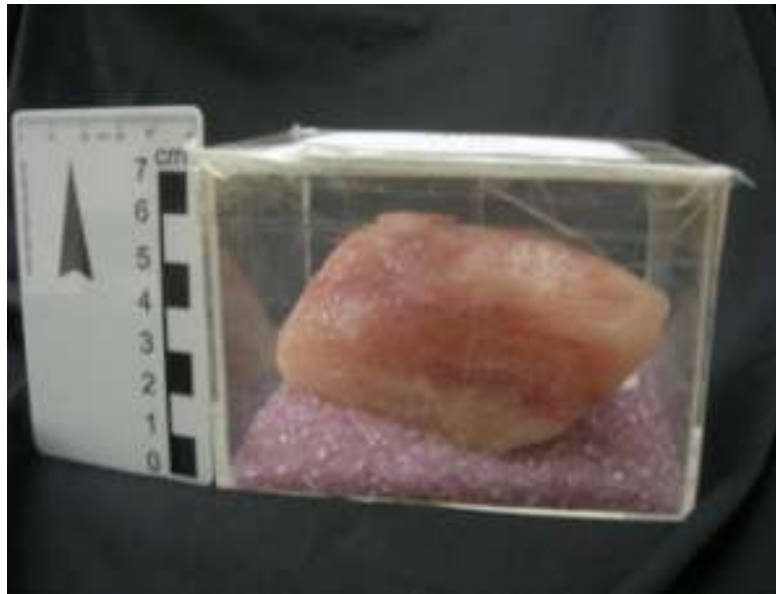

Figura 190. Amostra de halita acondicionada em caixa de acrílico. A sílica gel já está saturada. Acervo: Museu de Geociências da USP.

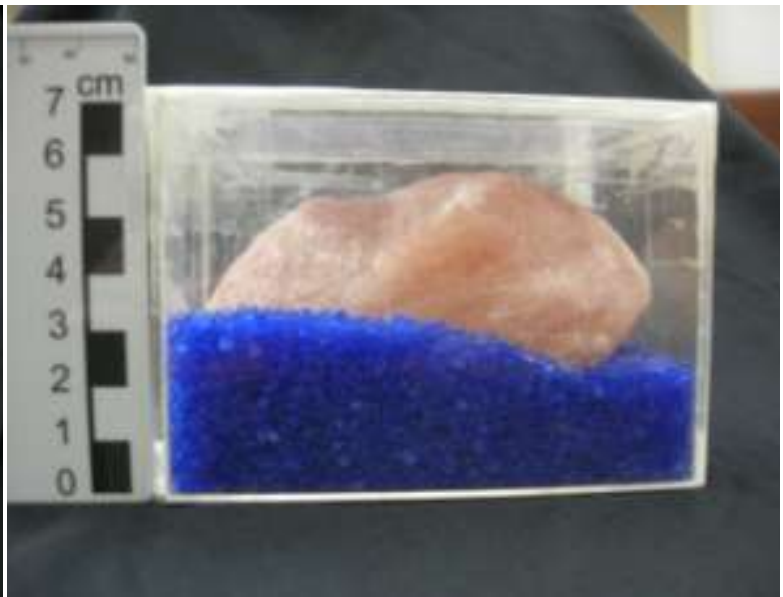

Figura 191. A mesma amostra da Figura 190 acomodada em sílica não saturada. Acervo: Museu de Geociências da USP.

O desumidificador é um aparelho que atua na captura do ar úmido do ambiente por meio de uma ventoinha, que direciona o ar para uma espiral gelada no interior do aparelho. Lá dentro, o ar seco é direcionado a uma espiral aquecida, que retorna o ar a sua temperatura inicial, para que seja devolvido ao ambiente.

Tiras anti-manchas são tiras que protegem metais (ouro, prata, cobre, estanho) contra a oxidação, evitando o escurecimento. Devem ser colocadas junto aos minerais durante transporte, armazenamento ou até durante a exposição (contanto que esteja fora do alcance do visitante). Não deixam resíduos e podem ser utilizadas com embalagens de polietileno, caixas de papelão ou vidros. Evitam o manchamento do mineral, atuando no ambiente prendendo o dióxido de enxofre e sulfeto de hidrogênio proveniente das amostras, evitando esses 
contaminantes no ambiente onde está o material. Cada tira dura aproximadamente seis meses em ambiente hermeticamente fechado.

$\mathrm{O}$ cloreto de polivinilideno $(P V D C)$ é um material plástico produzido pela copolimerização do cloreto de vinilideno $\left(\mathrm{C}_{2} \mathrm{H}_{2} \mathrm{Cl}_{2}\right)$ e do cloreto de vinila $\left(\mathrm{C}_{2} \mathrm{H}_{3} \mathrm{Cl}\right)$. Sua propriedade mais marcante é a termoplastia, que faz o material contrair-se em temperatura menor que $75^{\circ} \mathrm{C}$ e amolecer após os $115^{\circ} \mathrm{C}$. É um material bom para ser utilizado em amostras sensíveis à UR e oxigênio, pois tem baixa permeabilidade ao oxigênio e vapor de água, sendo resistente a ácidos e bases. No entanto, não é resistente a solventes orgânicos e o aumento excessivo de temperatura (mais que $115^{\circ} \mathrm{C}$ ) pode ocasionar a liberação de ácido clorídrico.

O estabilizador de umidade (ProSorb) é um tipo de sílica gel formado por 97\% de $\mathrm{SiO}_{2}$ e $3 \%$ de $\mathrm{Al}_{2} \mathrm{O}_{3}$ para ser utilizado na criação de microclimas em vitrinas, gavetas ou armários. É capaz de absorver vapor de água entre os limites de 40 a $60 \%$ de UR e é confeccionado de acordo com a necessidade do ambiente. Possui capacidade de atuação mínima de dois anos, podendo chegar até cinco, dependendo da umidade local. O produto está disponível em duas versões: grânulos soltos (como as sílicas gel comuns) ou blocos de polipropileno permeável, cujo interior é formado por tecido de poliéster contendo grânulos de prosorb. Os blocos são abertos de um lado só e têm a forma plana para serem colocados em vitrinas e outros tipos de mobiliários expositivos.

Os blocos completos têm dimensões de $335 \mathrm{~mm}$ de largura por $44 \mathrm{~mm}$ de altura. Utiliza-se um bloco por $\mathrm{m}^{3}$ de ar. Os meio-blocos têm dimensões de $335 \mathrm{~mm}$ de largura por $24 \mathrm{~mm}$ de altura e utiliza-se um meio-bloco para cada $0,7 \mathrm{~m}^{3}$ de ar.

Menores gradientes de umidade requerem maior quantidade de produto. Se a variação desejável for $3 \%$, necessitar-se-á de maior quantidade de prosorb que uma variação de $6 \%$, por exemplo.

Os estabilizadores de umidade possuem diferentes indicações, sendo que o prosorb é indicado a ambientes com gradiente de UR entre 40 e 60\%. Outro tipo, o artsorb (Figura 192), é indicado a ambientes mais úmidos, com UR variando entre 60 e $75 \%$.

É importante ressaltar que vitrinas feitas de materiais higroscópicos como madeira ou $M D F$, limitam a ação do produto, uma vez que há maior troca de umidade entre a vitrina e o ambiente externo. Mesmo se a vitrina for impermeabilizada, ainda haverá pequena troca de gases. As unidades de prosorb não devem estar diretamente em contato com zinco ou aço, pois a umidade contida nelas favorece a corrosão do material. 


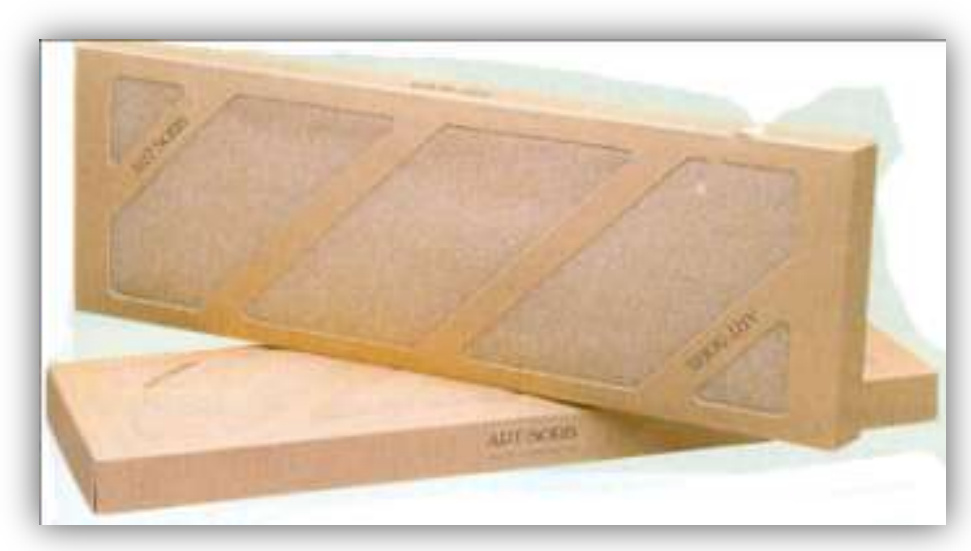

Figura 192. Aspecto de bloco com sílica gel utilizado em exposições.

Fonte: Catálogo da Archival Quality Materials for Conservation, Restoration, Preservation \& Exhibition de 2010.

As tiras indicadoras de umidade são tiras de papel sensíveis à UR, com variação de cores entre azul claro, que indica ambiente seco, e azul escuro (Figura 193), que indica ambiente úmido. Não possui a precisão de um higrômetro, no entanto é útil para monitoramento rápido e de baixo custo.

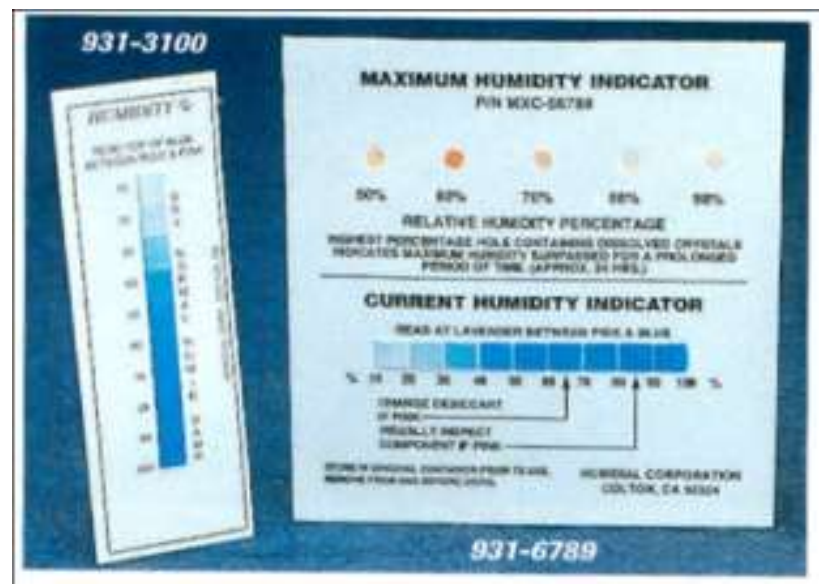

Figura 193. Exemplo de indicador de UR. A tira é colocada no ambiente desejado e a tabela indica como proceder na interpretação dos resultados. Fonte: Catálogo da Archival Quality Materials for Conservation, Restoration, Preservation \& Exhibition de 2010.

Os higrômetros são equipamentos que permitem monitorar a UR com precisão. Existem modelos analógicos e digitais (Figura 194), portáteis ou fixáveis em vitrinas. De acordo com os modelos, podem ou não aferir a temperatura. É um equipamento indispensável para a conservação de materiais geológicos, tanto em exposição quanto em reserva técnica. 


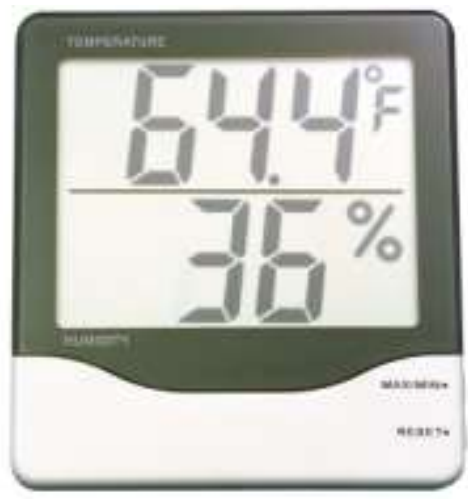

Figura 194. Exemplo de higrômetro digital que indica a temperatura e a UR. Fonte:

http://www.universityproducts.com/cart.php? $m=$ product_list \& $c=944 \&$ primary $=1 \&$ parentId $=\&$ navTr ee []$=1262 \&$ navTree []$=1375 \&$ navTree []$=944$. Acesso em 06.12.2012.

\section{Embalagens}

O polietileno (sacos plásticos zip lock) é um material inerte e altamente estável, sendo resistente a soluções aquosas de sais, ácidos inorgânicos e álcalis. É, por isso, indicado para armazenar os minerais em reserva técnica. Apesar de os minerais mais sensíveis serem os asbestiformes e os de hábito fibroso, é indicado que todos os minerais sejam acondicionados nessas embalagens, com exceção dos minerais fotossensíveis, que necessitam de embalagens escuras, pois o polietileno, assim como o polipropileno, é altamente sensível à luz UV. O Museu de Geociências utiliza essas embalagens, disponíveis em vários tamanhos, para acondicionamento dos espécimes (Figura 195).

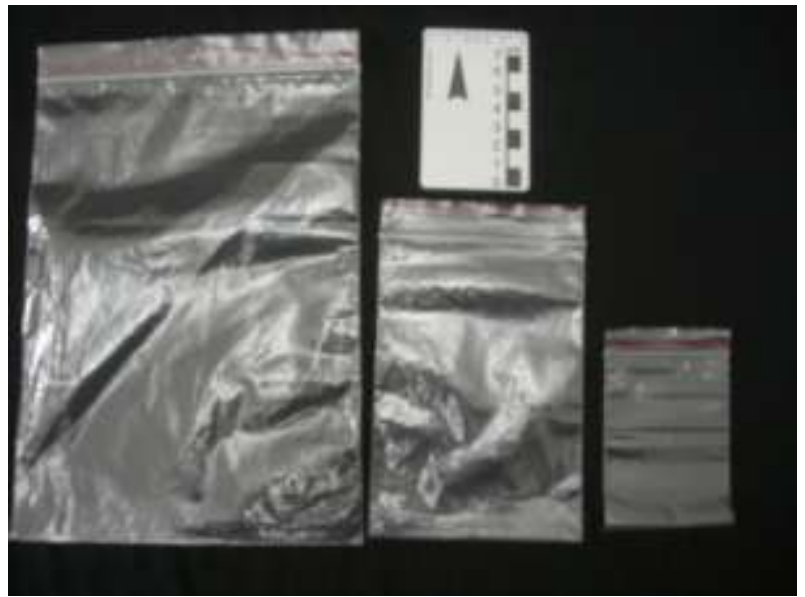

Figura 195a. Embalagens de polietileno utilizadas para armazenamento de minerais.

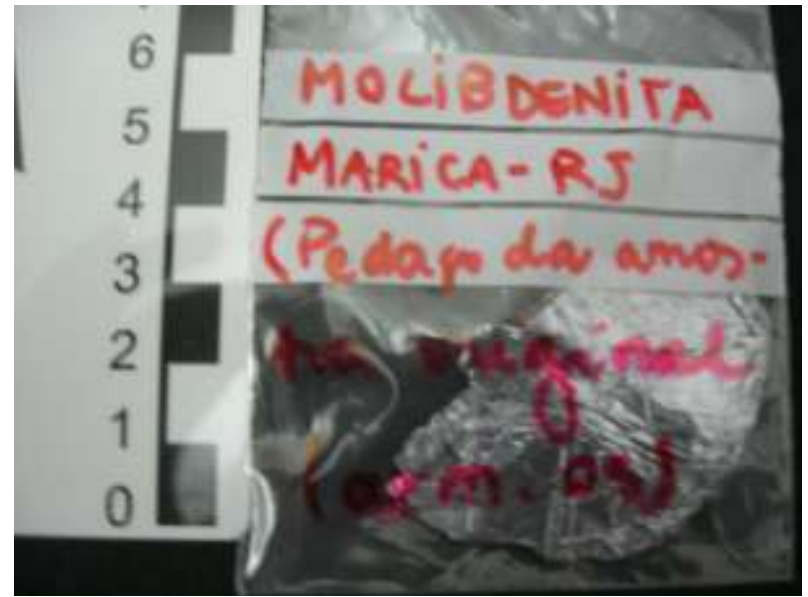

Figura 195b. Exemplo de utilização de embalagens de polietileno no Museu de Geociências. Alguns modelos permitem escrever na embalagem, facilitando a identificação da amostra. 
Embalagens Anti-Corrosão são sacos como os zip lock, porém possuem camada protetora anti-corrosiva, constituídas por partículas de cobre ligadas a polímeros (Figura 196). $\mathrm{O}$ filme protetor reage com os gases que iriam reagir com o mineral, neutralizando-os. $\mathrm{O}$ material que reveste a embalagem não é afetado pela umidade ou temperatura e possui indicador de saturação, tornando a cor cobre, característica da embalagem, escurecida. Ideal para armazenamento de amostras metálicas ferrosas e não ferrosas em reserva técnica.

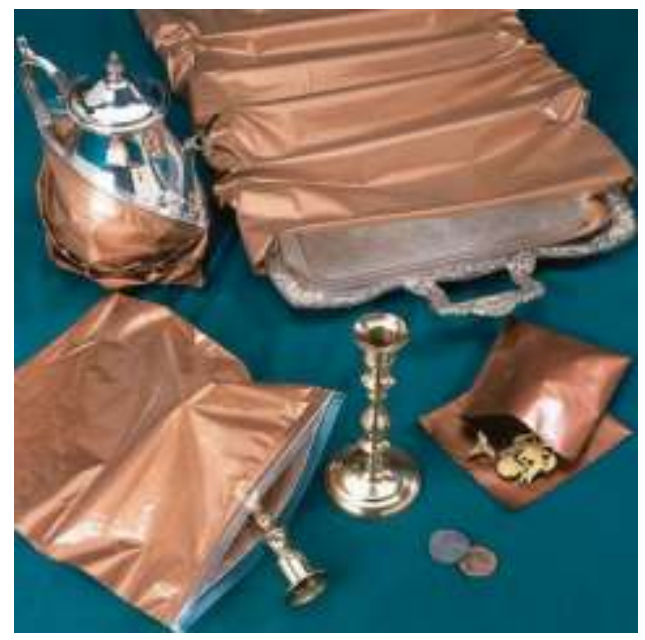

Figura 196. Embalagens antioxidantes utilizadas também por outros tipos de museus que possuem amostras metálicas em seus acervos. Fonte http://www.universityproducts.com/cart.php? $m=$ product_list\&c=75\&primary=1\&parentId=\&navTre e[]=1271\&navTree[]=1294\&navTree[]=75. Acesso em 06.12.2012.

Embalagens anti-oxigênio ( $R P$ System) referem-se a um sistema desenvolvido pela Mitsubishi Gases and Chemical para extração de oxigênio e água do ambiente que combina um absorvente orgânico de oxigênio com um dissecante inorgânico. É comercializado em forma de embalagens que absorvem oxigênio, umidade e gases que provoquem corrosão, prevenindo oxidação e descoloramento, ideal para preservação em longo prazo, evitando, assim, a oxidação de metais e minerais sensíveis, como muitos sulfetos. A largura de vedação recomendada é de no mínimo $10 \mathrm{~mm}$ para que a vedação seja eficaz. Uma vez vedada, tem início a desumidificação, que reduz a umidade a $10 \%$ em apenas alguns minutos. A seguir tem início a absorção de $\mathrm{O}_{2}$, que leva algumas horas. As embalagens são de $300 \mathrm{ml}, 500 \mathrm{ml}$ ou $2000 \mathrm{ml}$ (considerando o volume total de ar a ser tratado).

Um dos pontos negativos é que o $R P$, diferente da sílica gel, não pode ser reutilizado, pois as reações de absorção de $\mathrm{O}_{2}, \mathrm{CO}_{2}$ e umidade são irreversíveis. No entanto, se não houver entrada de ar no sistema, o produto mantém sua validade. A Figura 197 mostra a série de procedimentos para armazenamento de amostras em $R P$. 

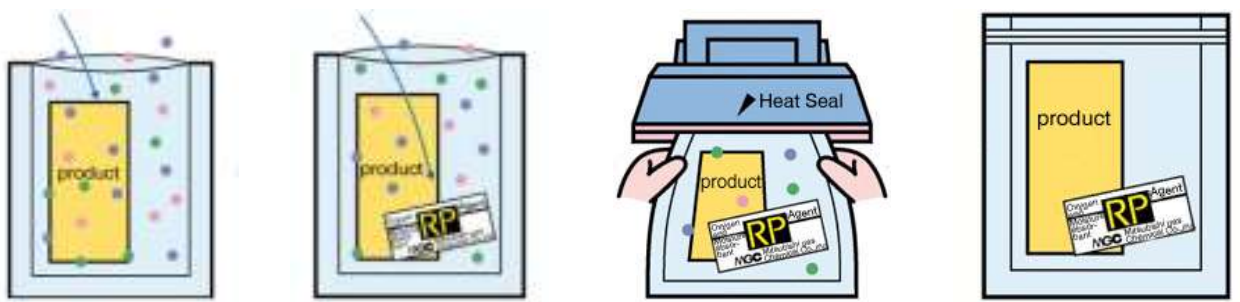

Figura 197. Ilustração referente ao procedimento correto de utilização do RP. Fonte: Site da Mitsubichi Gas Chemicals. Acesso em 28/11/2012.

A amostra, representada pelo produto em amarelo, deve ser inserida na embalagem, sem nenhuma proteção. Após colocar o produto, posicionar o sachê de $R P$ na embalagem. A próxima etapa é a vedação a quente, feita por um selador térmico (Figura 198). Por fim, temse a amostra protegida do ambiente externo por tempo indeterminado, até que a embalagem seja novamente aberta.

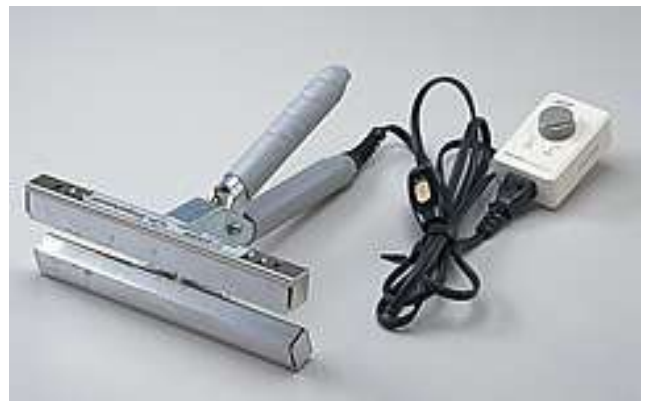

Figura 198. Exemplo de selador térmico portátil para vedação de vários tipos de embalagens, incluindo RP. Fonte: Site da Mitsubichi Gas Chemicals. Acesso em 28/11/2012.

\subsubsection{4 - Reparos}

Epóxis são famílias diversas de compostos termoplásticos que têm em comum a presença do grupo funcional epoxídeo. Adesivos de epóxis normalmente consistem de duas partes: uma resina e um endurecedor, que, quando misturados, reagem para formar um polímero rígido (THORNTON, 2005). São resinas que não necessitam de solvente e encolhem muito pouco depois de secas, além de serem à prova de água. Ao longo do tempo, não perdem aderência, mas escurecem. Funcionam bem para colagem de metais e preenchimento de fissuras em rochas fragmentadas (especialmente mármore e granito). Os epóxis mais viscosos são utilizados para colagem, enquanto os de baixa viscosidade são indicados para preenchimento.

O paraloide B-72, já citado no item de identificação das amostras, também pode ser usado para colar amostras. É muito utilizado na colagem de fósseis. 
Estes foram alguns exemplos de procedimentos e materiais que podem ser utilizados em conservação preventiva e reparos nas amostras. A ausência de bibliografia específica para as coleções geológicas obriga o profissional a recorrer a catálogos e sites de conservação geral ou, mais precisamente, conservação de coleções de história natural. Muitos dos produtos são adaptados do uso em outros tipos de coleções para as coleções geológicas. São necessárias pesquisas sistemáticas no teste de muitos dos produtos disponíveis no mercado de conservação para a descoberta dos produtos específicos para utilização em coleções geológicas. 


\section{7 - MUSEU DE GEOCIÊNCIAS DA USP}

O Museu de Geociências originou-se em 1934, por iniciativa do Professor Ettore Onorato, que doou sua coleção particular de minerais para que fossem utilizados como material de apoio em aulas práticas da disciplina de Geologia do curso de História Natural da Faculdade de Filosofia, Ciências e Letras da Universidade de São Paulo. A coleção foi crescendo com a coleta de amostras de campo dos alunos e durante os anos 40 e 50, quando foi adquirida a coleção particular de Luiz Paixão de Araújo, pelo governo do Estado de São Paulo e recebida a doação da coleção de Araújo Ferraz. Em 1981, o museu recebeu sua última grande doação, a Coleção Schnyder. Atualmente o crescimento do acervo depende de doações particulares.

$\mathrm{O}$ acervo atual do museu, entre minerais, rochas, meteoritos, gemas e espeleotemas, conta com cinco mil amostras em exposição e cerca de mil na reserva técnica.

Pretende-se aqui mostrar alguns aspectos importantes a serem observados durante a montagem de uma exposição de coleções geológicas e também os critérios de conservação dessas coleções, em exposição e reserva técnica. Para isto será utilizada como base a exposição de minerais e rochas do Museu de Geociências da USP.

\section{1 - Exposição}

Durante uma visita de cerca de uma hora e meia ao acervo exposto foram notados alguns detalhes importantes que não devem ser reproduzidos em uma nova montagem de exposição. Os critérios observados foram: quantidade de amostras expostas e sua localização nas vitrinas, critérios de proporcionalidade e uniformidade, exposição de amostras de volume reduzido, padronização de informações (etiquetas e nomenclaturas), suportes e fixadores, e adequação didática (ou adequação ao público alvo).

É importante salientar que, antes de se fazer qualquer diagnóstico de exposição, é necessário que se conheça seu público alvo. Uma dada exposição pode ser altamente eficiente para um público de jovens, por exemplo, mas ineficaz para visitantes de terceira idade. Após os apontamentos que serão feitos ao longo deste estudo, será possível identificar se a exposição do museu está ou não adequada ao público que recebe.

Deste modo, leva-se em conta que o público alvo do museu é, em sua maioria, composto por alunos de escolas dos ensinos básico, fundamental, médio e superior. Considera ainda que a função dos minerais na exposição é a de mostrar ao visitante leigo o que são 
minerais, de onde vêm, por que ocorrem em tantas variações e que impacto têm na existência humana no Planeta.

Aos graduandos, em especial dos cursos de Licenciatura em Geociências e Educação Ambiental e Geologia, há a necessidade de abordagem mais específica, como os diferentes hábitos de um mesmo mineral, sua variação de cores, classificação na Escala de Mohs, classificação mineralógica, entre outros. Apesar dessa necessidade, não é imprescindível que este conhecimento siga apresentado no layout atual, com etiquetas que poucos alunos leem, sem identificação visual clara e sem a utilização mínima de recursos didáticos.

A seguir estão os aspectos observados ao longo da exposição:

1. Número de amostras expostas: Notou-se que a quantidade de minerais expostos é maior que a necessidade do visitante. Tendo como base de análise a importância das informações geológicas que a amostra deve transmitir ao visitante, muitos exemplares não cumprem função alguma, pois são duplicatas. Além disso, essas amostras ociosas acabam por atrapalhar a organização da exibição, ocupando espaços que poderiam ser aproveitados com textos informativos, ou mesmo sendo deixados livres para uma melhor apreciação por parte do visitante (Figuras 199 e 200). Existe um número ideal de amostras que deve estar na exposição. Este número é variável e baseia-se em alguns critérios, como diferentes hábitos que o mineral possa apresentar, variedade de cores, procedência, e, se o curador julgar necessário, variedade de tamanho.

A um visitante leigo em mineralogia, basta conhecer cada um dos hábitos e cores diferentes de cada mineral. Tudo o que vier além disso, torna-se uma repetição desnecessária que não é apreendida por ele, e faz com que o indivíduo se canse mais rápido, não apreciando de forma igual o início e o fim da exposição.

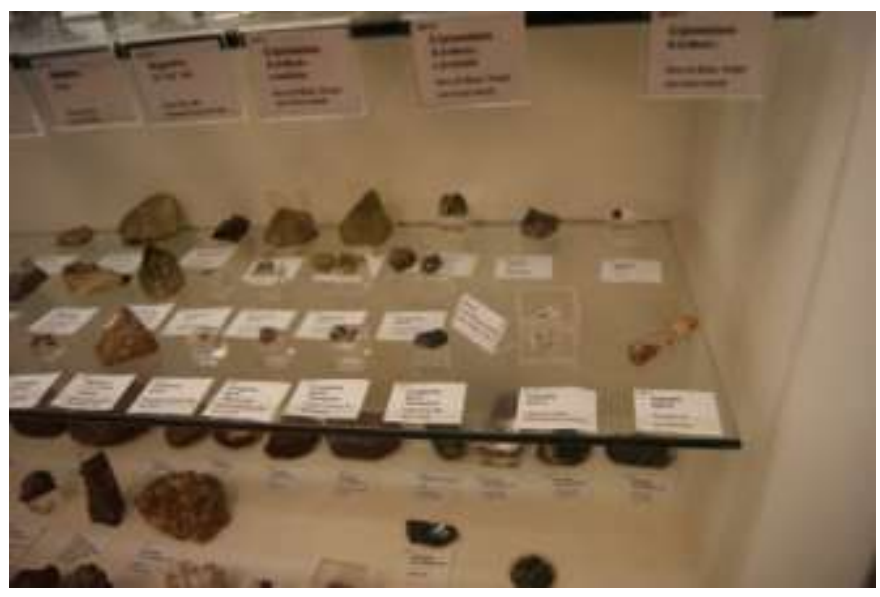

Figura 199. Aspecto da vitrina com crisoberilos. Nota-se que muitas amostras estão em duplicata, pois além de ser o mesmo mineral, têm a mesma procedência. 


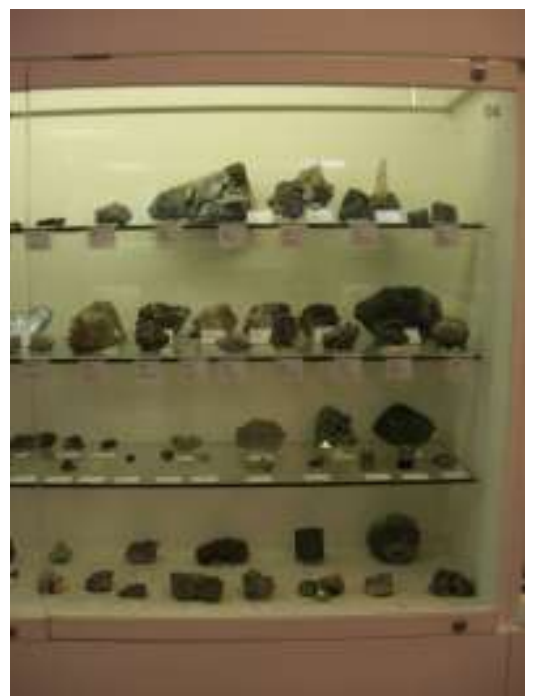

Figura 200. Vitrina dos sulfetos, destacando-se a grande quantidade de amostras de piritas.

2. Localização das amostras nas vitrinas: Muitos minerais estão mal posicionados na vitrina, escondidos atrás de outros maiores, e passam despercebidos aos olhos dos visitantes (Figuras 201 e 202). Há também minerais muito pequenos, os quais, colocados entre outros maiores, não recebem a devida atenção (Figura 203).

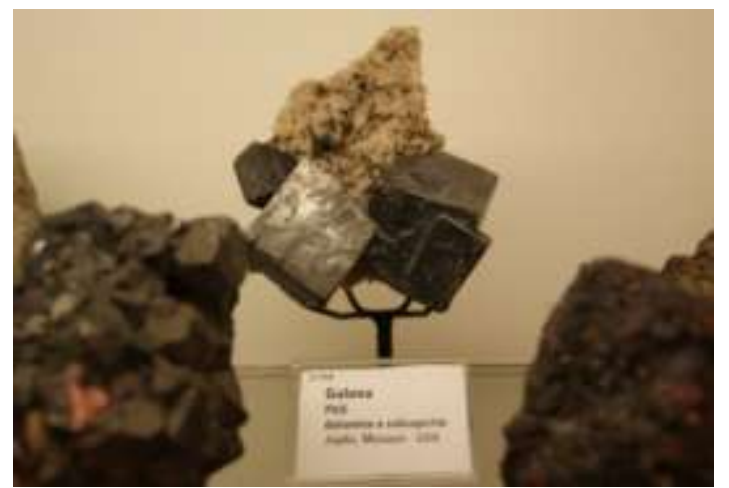

Figura 201. Belo exemplar de galena cristalizada sobre dolomita e calcopirita.

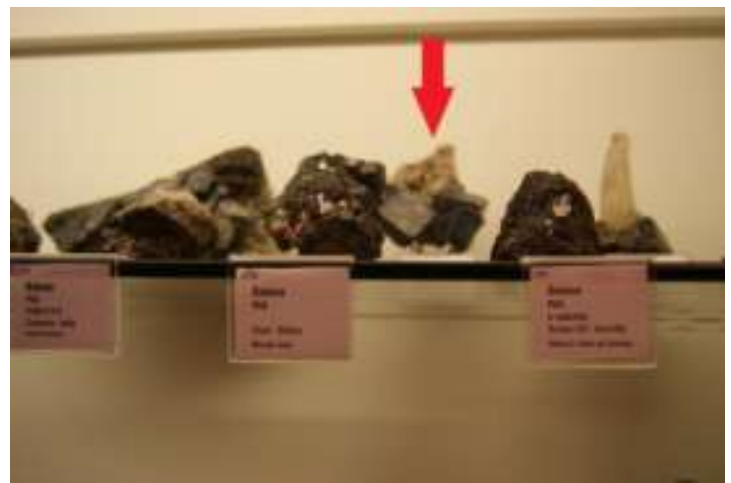

Figura 202. Aspecto da vitrina das galenas. A seta indica a amostra da Figura 201, que está escondida atrás de outras que não chamam tanto a atenção. Quase impossível reter detalhes da amostra. 


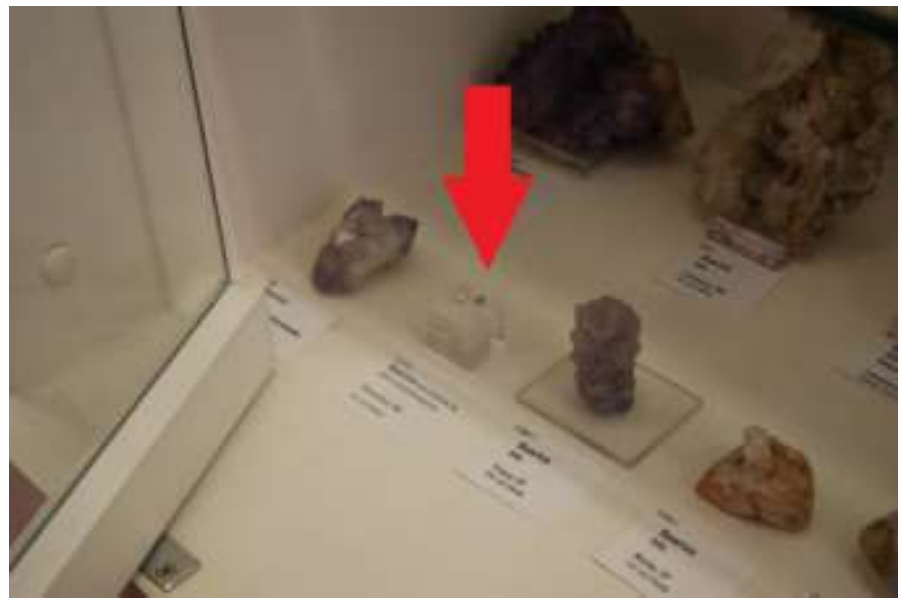

Figura 203. Pequena amostra de ametista posicionada entre duas outras amostras maiores do mesmo mineral. O visitante fixa sua atenção nos maiores, sendo que o do meio está sem função na exposição. Isto não aconteceria caso a exposição tivesse um apelo definido, como, por exemplo, os diferentes tamanhos que um mesmo mineral pode assumir.

3. Desproporcionalidade: Muitas amostras são pequenas e estão em suportes bem maiores. Nesse caso, o destaque acaba sendo para o suporte, e não para a amostra (Figura 204). O suporte ideal deve ser moldado especialmente para cada exemplar (Figura 205 a e b). Como muitas vezes não há recurso para esse tipo de serviço, utilizam-se suportes de acrílico padronizados. No entanto, o material deve apenas apoiar o objeto, não ficando exposto aos olhos do visitante e jamais ganhar destaque maior que o mineral (Figura 206).

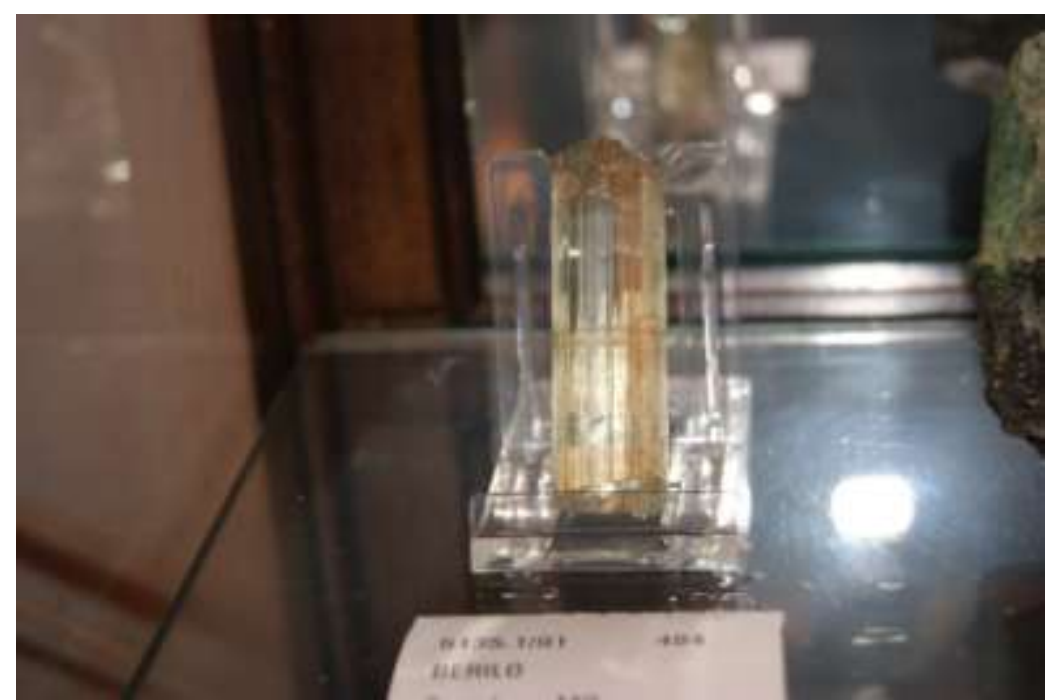

Figura 204. Cristal de berilo em suporte desproporcional.

Além de o suporte ser maior que a amostra, esta fica mimetizada no suporte, uma vez que apresenta quase a mesma coloração que o suporte. 


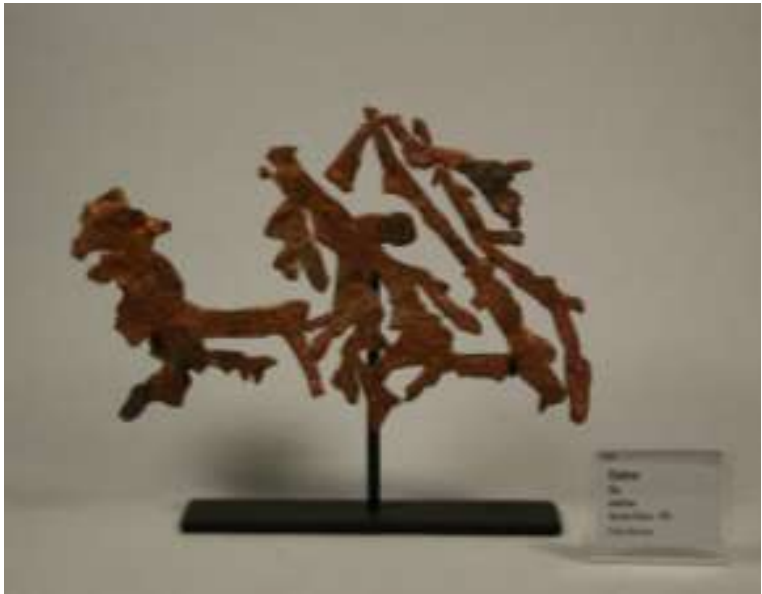

Figura 205a. Aspecto de suporte especialmente confeccionado para a amostra que está sobre ele.

O que se destaca é exatamente o que se quer mostrar, a amostra de cobre nativo. $O$ suporte não fica em evidência e não atrapalha a observação do mineral.

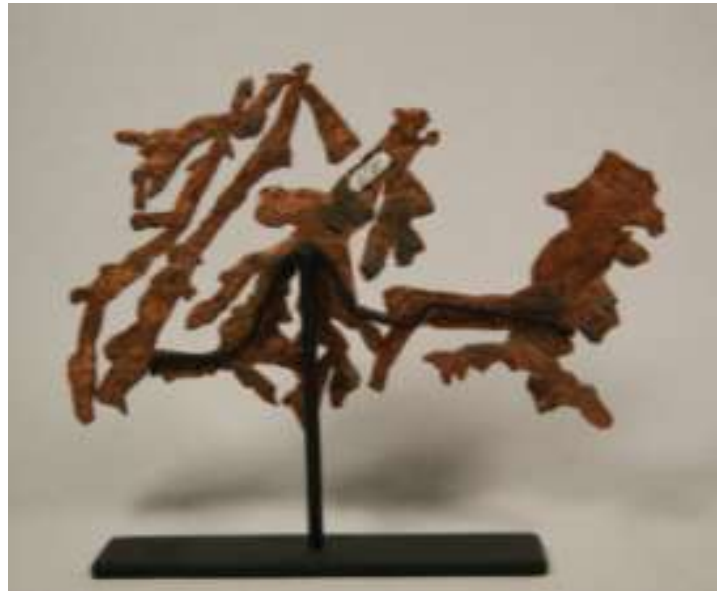

Figura 205b. Parte posterior do suporte mostrado na figura anterior. É possível ver que o artesão fez um estudo rigoroso da peça e encontrou o seu melhor ângulo de apoio.

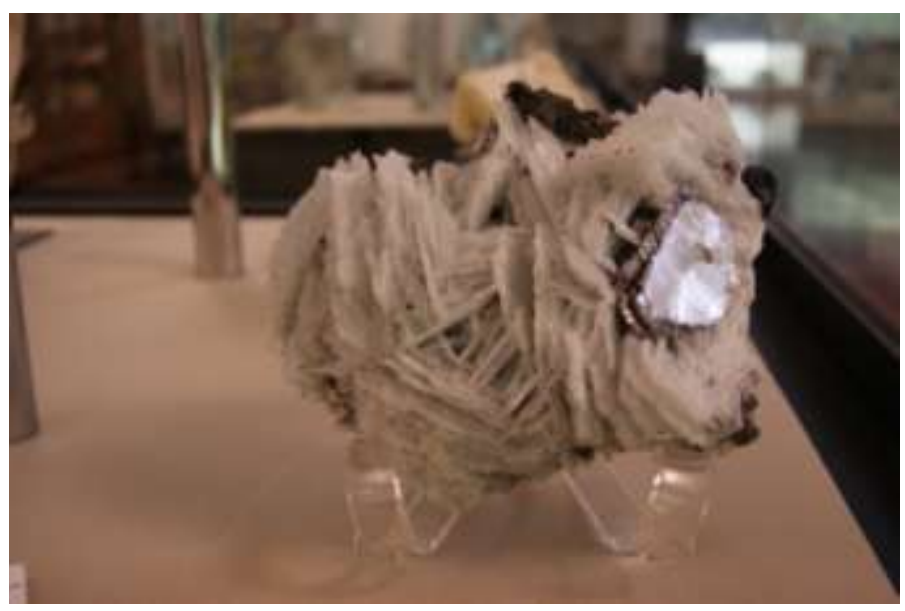

Figura 206. Aspecto de suporte de acrílico com utilização correta para a amostra em questão.

4. Uniformidade: É indicado, na medida do possível, que minerais adjacentes sejam aproximadamente de mesmo tamanho. É comum na exposição do Museu de Geociências (Figura 207) que amostras de tamanhos muito diferentes estejam dispostas lado a lado. Tal fato também atrapalha a apreciação do visitante, que acaba passando sem ver o mineral de menor tamanho. Além disso, a estética de uma exposição é melhor quando há padronização das medidas. A diferença de volumes traz uma sensação caótica ao ambiente. 


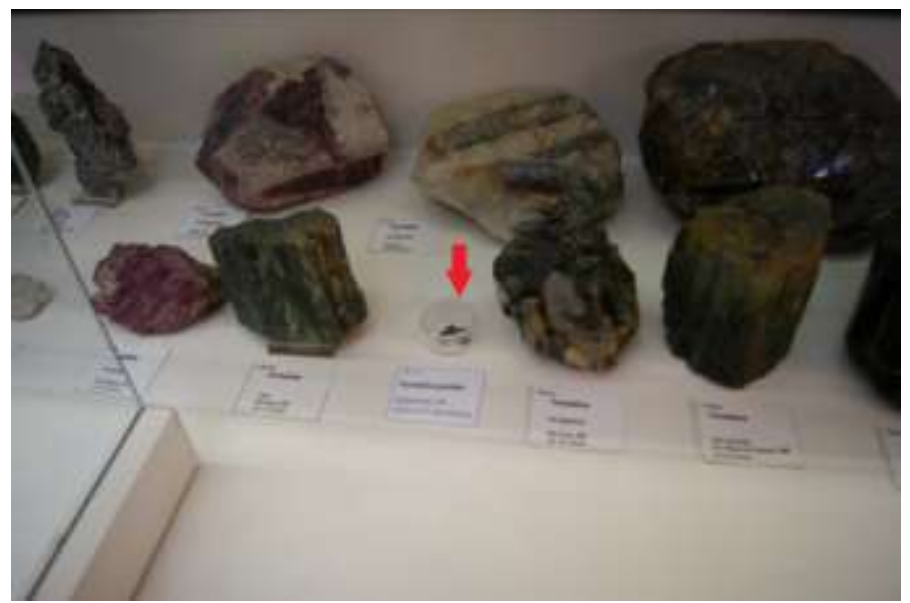

Figura 207. Visão parcial da vitrina das turmalinas. A valiosa Turmalina Paraíba quase não é notada entre as adjacentes de maior tamanho.

5. Amostras com volume reduzido: Observaram-se, no decorrer da exposição, muitos minerais em pó. Alguns deles estão como representantes únicos de certas espécies minerais. No entanto, não é possível para o visitante compreendê-los. Essas amostras são expostas em recipientes fechados, que por muitas vezes atrapalham a visão do observador (Figuras 208 e 209). É necessário que estejam sob uma lente de aumento (Figura 210), ou apresentem-se com uma imagem ampliada ao lado (Figura 211). Nos casos em que esses minerais não se caracterizem como representantes únicos da espécie mineral, não devem ser expostos.

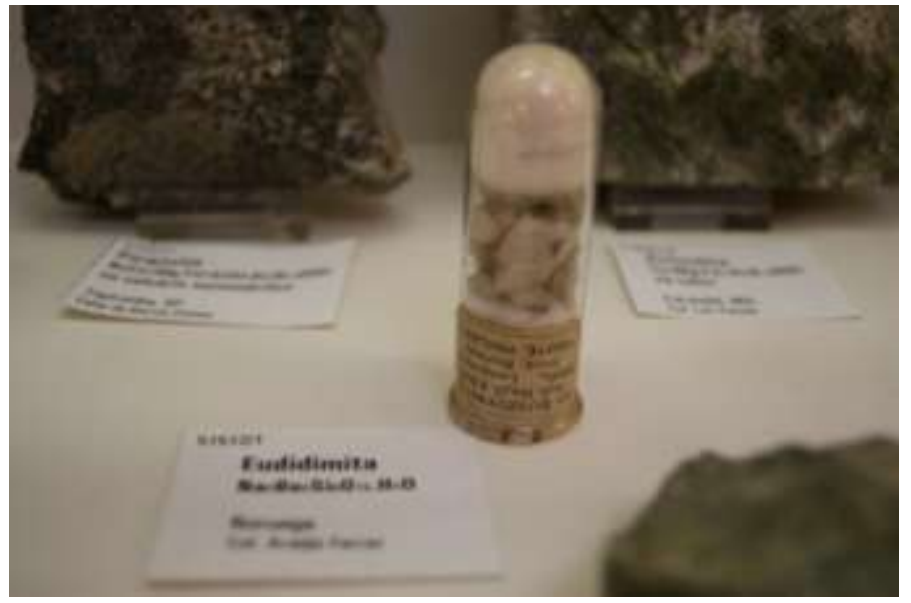

Figura 208. Amostra do mineral eudidimita em frasco de tamanho reduzido, entre um pedaço de algodão e uma legenda antiga. 


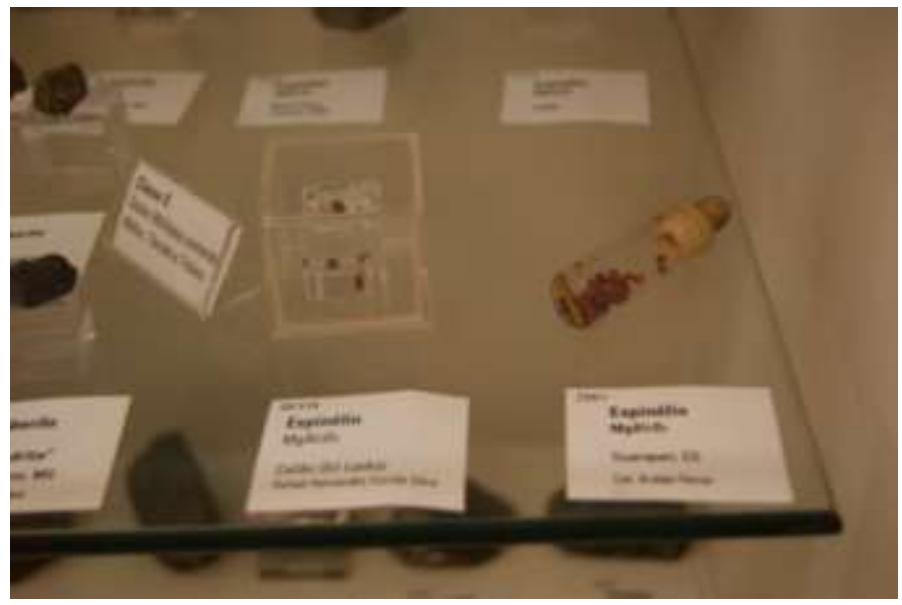

Figura 209. Duas amostras do mesmo tipo de espinélio dispostas lado a lado na vitrina.

O tamanho diminuto das amostras não permite que o visitante tenha quaisquer informações visuais sobre o cristal de espinélio.

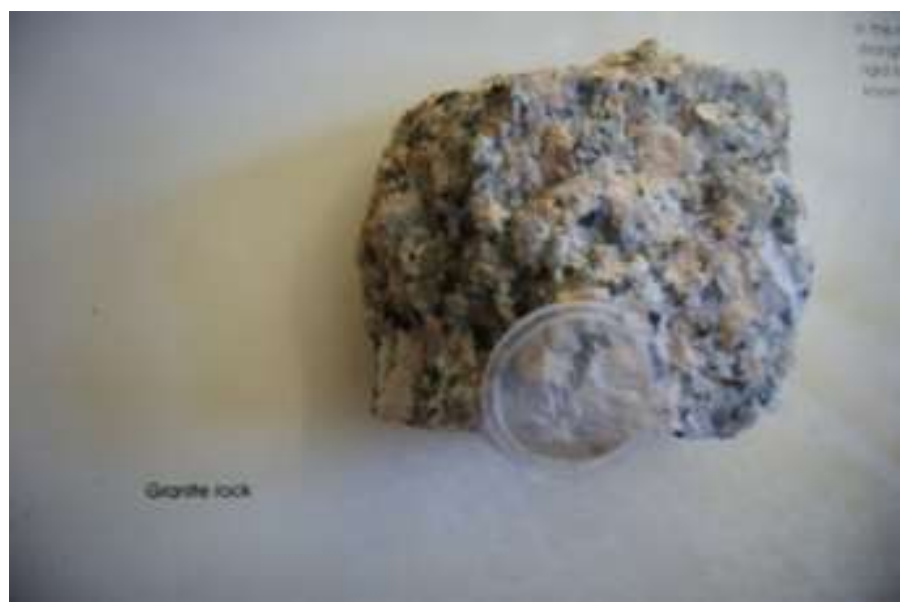

Figura 210. Solução encontrada pelo Museu de História Natural de Londres para mostrar os cristais dos minerais formadores do granito. Procedimento semelhante também poderia ser adotado para as amostras de tamanho reduzido expostas no Museu de Geociências.

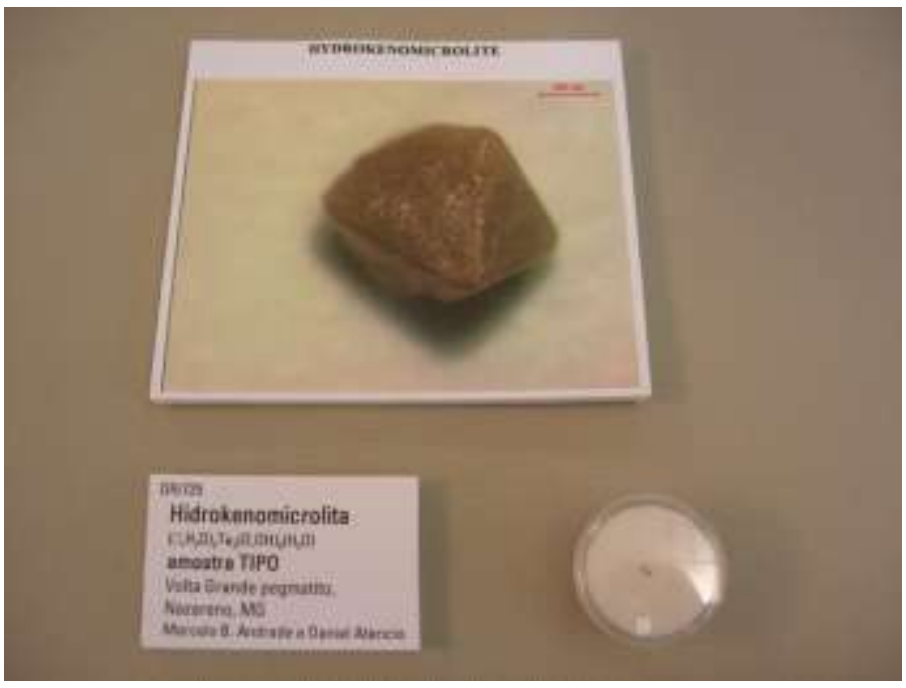

Figura 211a. Forma correta de apresentação de minerais de dimensões reduzidas: O mineral exposto é quase imperceptível, por isso há uma imagem ampliada ao lado. Acervo: Museu de Geociências da USP. 


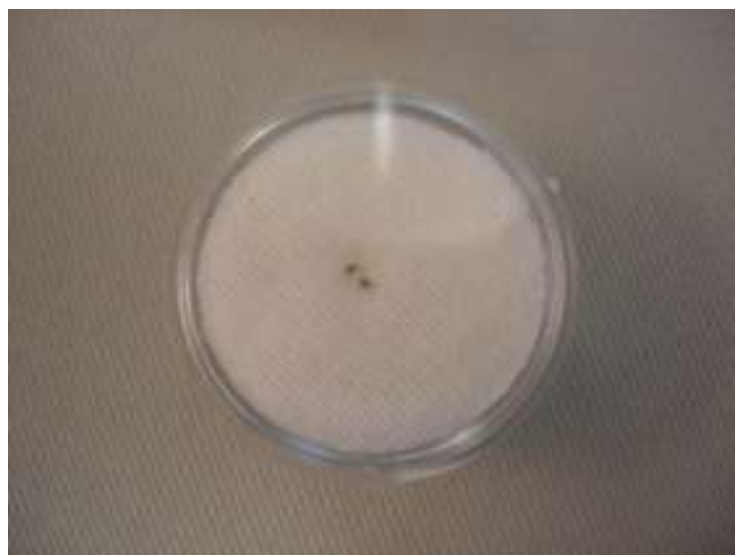

Figura 211b. Imagem do diminuto mineral hidrokenomicrolita, exposto junto com sua imagem.

6. Suportes: O suporte pode ofuscar completamente a beleza ou prejudicar consideravelmente a compreensão que se pode ter de um mineral. O suporte ideal é feito em ferro, por profissional especializado, moldado na própria amostra e com acabamento de material inerte, para que a oxidação do ferro não reaja com a composição química da amostra (Figuras 212 e 213). Se for feito dessa forma, o suporte realça a beleza do mineral e produz o efeito desejado. Caso não seja possível optar por esse tipo de suporte, há outras opções em acrílico. Em alguns casos é possível fazer suportes moldados sob medida. O importante é que o material seja inerte e que fique o mínimo possível visível ao observador (Figura 214). O suporte deve ser trocado regularmente, pois o acrílico, em longos períodos de exposição à luz, tende a ficar amarelado, conferindo à exposição um aspecto de sujeira e descuido. $\mathrm{O}$ mesmo ocorre com o ferro, que, mesmo com cobertura antioxidante, ao contato com determinados tipos de minerais, começa a oxidar, após aproximadamente dez anos de uso. Vale destacar que os suportes para amostras de grande porte devem ser cuidadosamente planejados, de modo que a peça fique com peso igualmente distribuído, pois se o peso do material ficar desigual, a amostra pode sofrer danos físicos, como rachaduras, fissuras e até desprendimento. Como exemplo, o meteorito Itapuranga, terceiro maior do Brasil, com $628 \mathrm{Kg}$, está exposto no saguão do IGc sob um suporte de quatro pontos, que mantém seu peso mal distribuído. Tal fato, somado à oxidação da amostra pela alta UR, está danificando o meteorito (Figura 215). O ideal, nesse caso, seria o apoio da amostra em um pilar de concreto, com um berço de areia ou material semelhante, para que houvesse distribuição natural do peso do exemplar, ou um suporte que envolvesse a amostra por completo, sem apoio preferencial de peso, como ocorre no Museu de Mineralogia da Universidade de Hamburgo (Figura 216). 


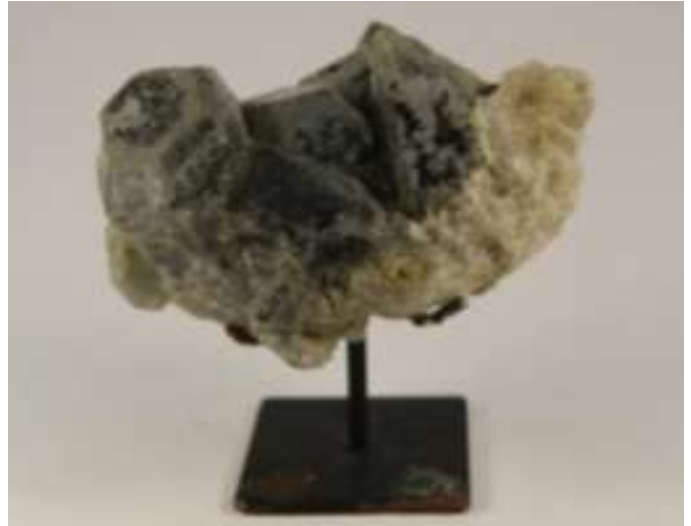

Figura 212. Aspecto de ferrugem sobre suporte de ferro. A camada protetora de zinco foi desgastada, e a umidade acelerou o processo de oxidação do ferro.

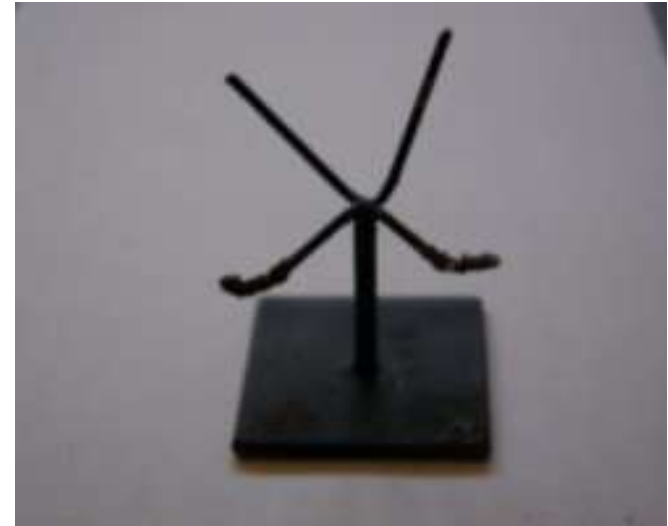

Figura 213. Suporte deteriorado da amostra de Hanksita da Figura 212.

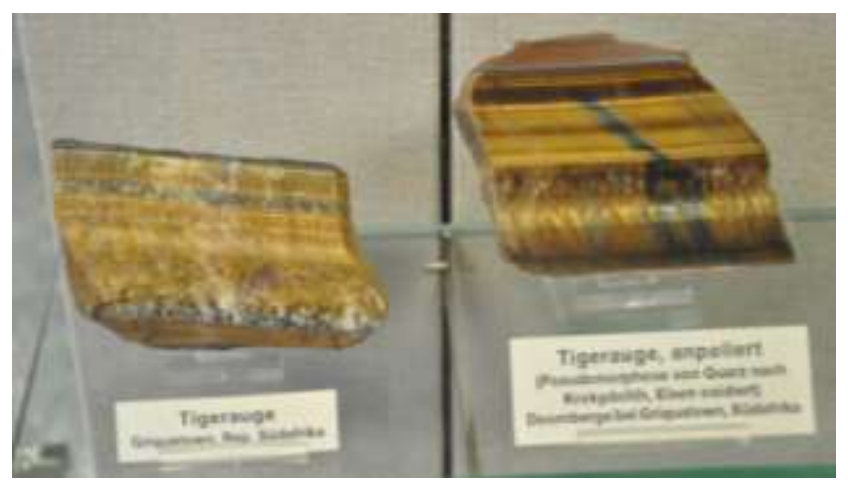

Figura 214. Amostras de olho de tigre em suportes de acrílico. O suporte é quase imperceptível ao observador. Acervo: Mineralogisches Museum Universität Würzburg. Foto: Lauro K. Dehira.

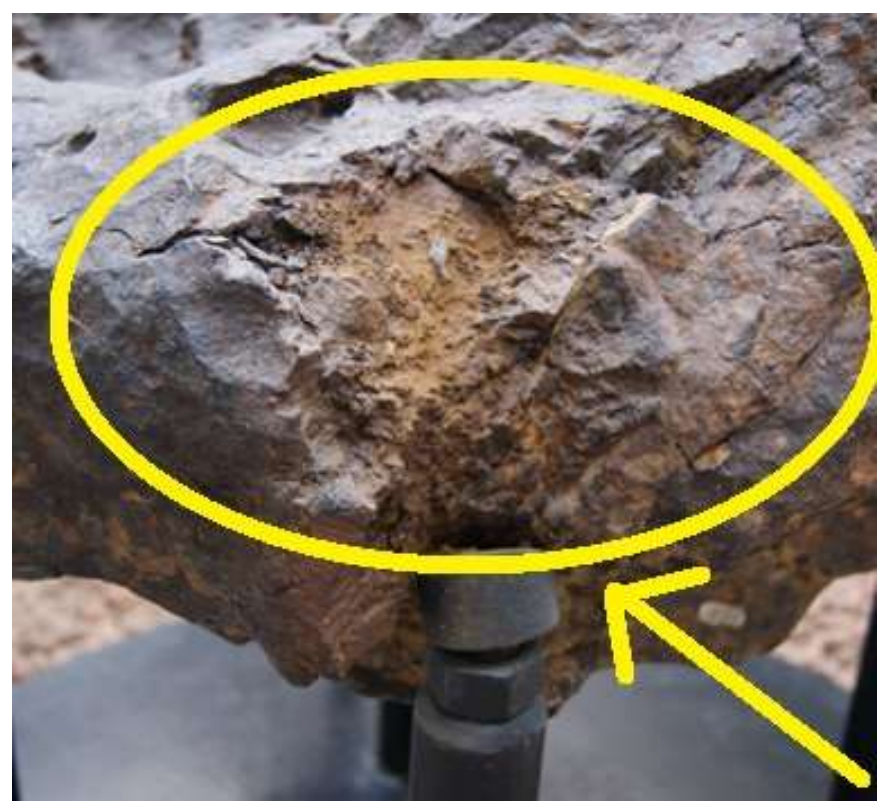

Figura 215. A distribuição irregular de peso sobre os apoios do suporte, aliados à oxidação do meteorito, está danificando gravemente o Itapuranga. 


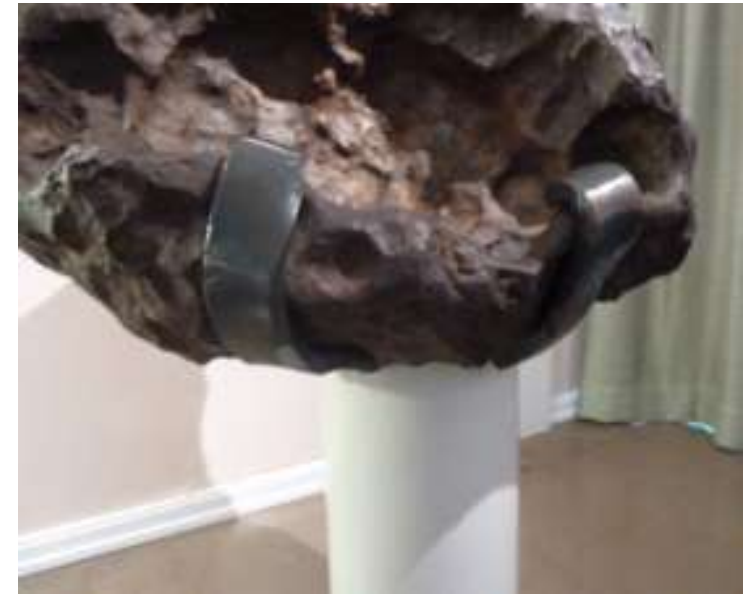

Figura 216a. Suporte de ferro adequado à amostra, visível apenas o suficiente para que a amostra esteja segura. Acervo: Mineralogisches Museum - Universität Hamburg.

Foto: Eliane A. Del Lama

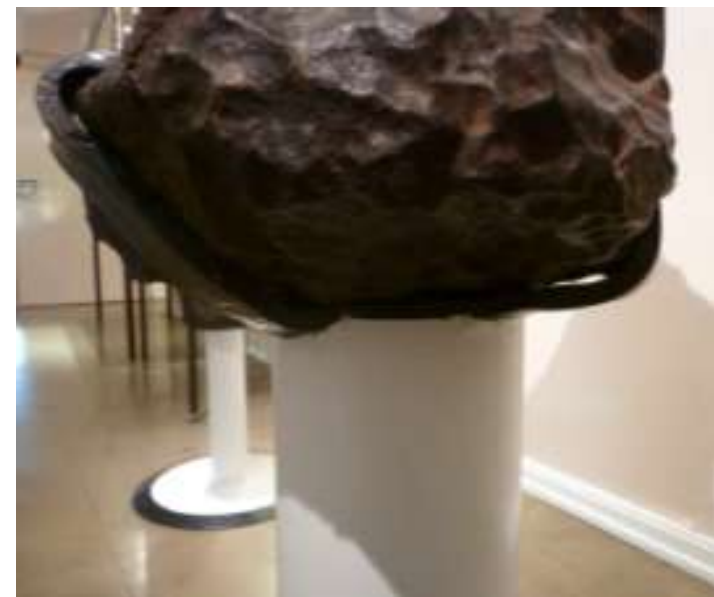

Figura 216b. Parte posterior do meteorito da Figura 216a. O suporte está fixado onde o olhar do visitante não alcança. Observa-se que o suporte envolve a amostra, sem privilegiar pontos de apoio. Acervo: Mineralogisches

Museum - Universität Hamburg.

Foto: Eliane A. Del Lama.

7 Fixadores: É necessário que se esteja atento ao tipo de material utilizado para fixar amostras em suas bases. Além de observar a composição química do produto, deve-se notar o efeito estético que tal procedimento terá na exposição. Muitas amostras observadas no museu estão fixadas em bases de acrílico por massas de cor escura (Figura 217), muito visível ao visitante. Além disso, deve-se utilizar apenas a quantidade necessária para que a amostra se sustente. $\mathrm{O}$ excesso de material na base causa um efeito de poluição visual na exposição. Isso prejudica a beleza do mineral e a exposição fica com aparência de descuido.

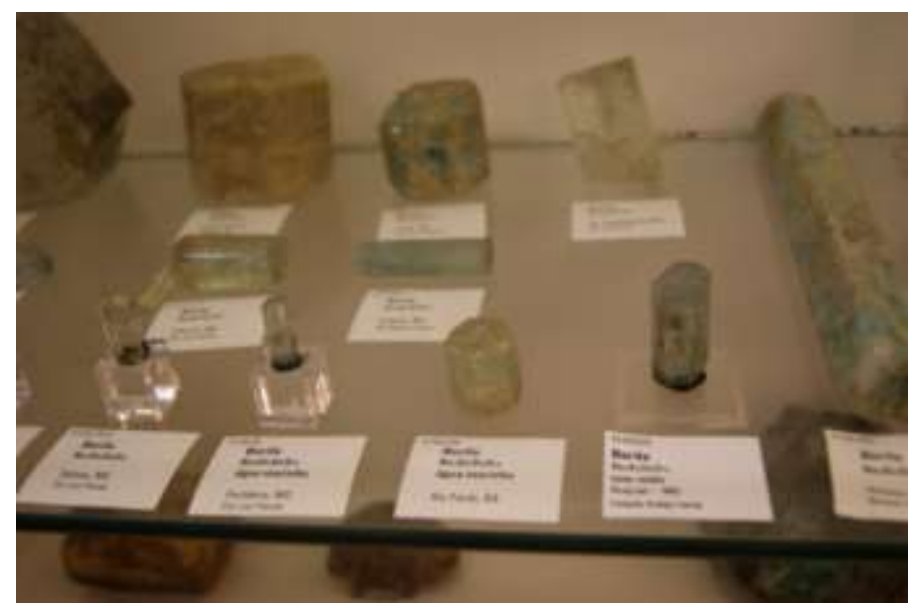

Figura 217. Aspecto de cristais de berilo fixados em bases de acrílico com massas de cor escura. Além de penetrar no mineral, essas massas prejudicam a estética da apresentação. 
8 Padronização de etiquetas: A etiqueta é o principal meio de comunicação entre a curadoria e o visitante. Se o público não é especializado no assunto e a visita não é guiada, o único meio de comunicação entre a intenção do curador e o visitante são as etiquetas. No caso analisado, há poucas etiquetas com textos informativos, a maioria traz apenas informações básicas sobre a peça. Além disso, as etiquetas não são padronizadas quanto à fórmula química. Muitas delas não apresentam fórmula química e outras, por terem uma fórmula muito extensa, ficaram maiores que as outras etiquetas (Figura 218). Nesse caso, é adequado optar-se por uma etiqueta cujo tamanho é definido pela maior fórmula química da coleção, ou eliminar essa informação da etiqueta. A fórmula química também pode ser definida de forma geral para o grupo mineral (Figura 219), eliminando-se a necessidade dessa informação em todos os minerais do mesmo grupo (Figura 220). Informações em outro idioma, principalmente o Inglês, são necessárias, mas é preciso observar padronização dessas informações ao longo da exposição (Figura 221).

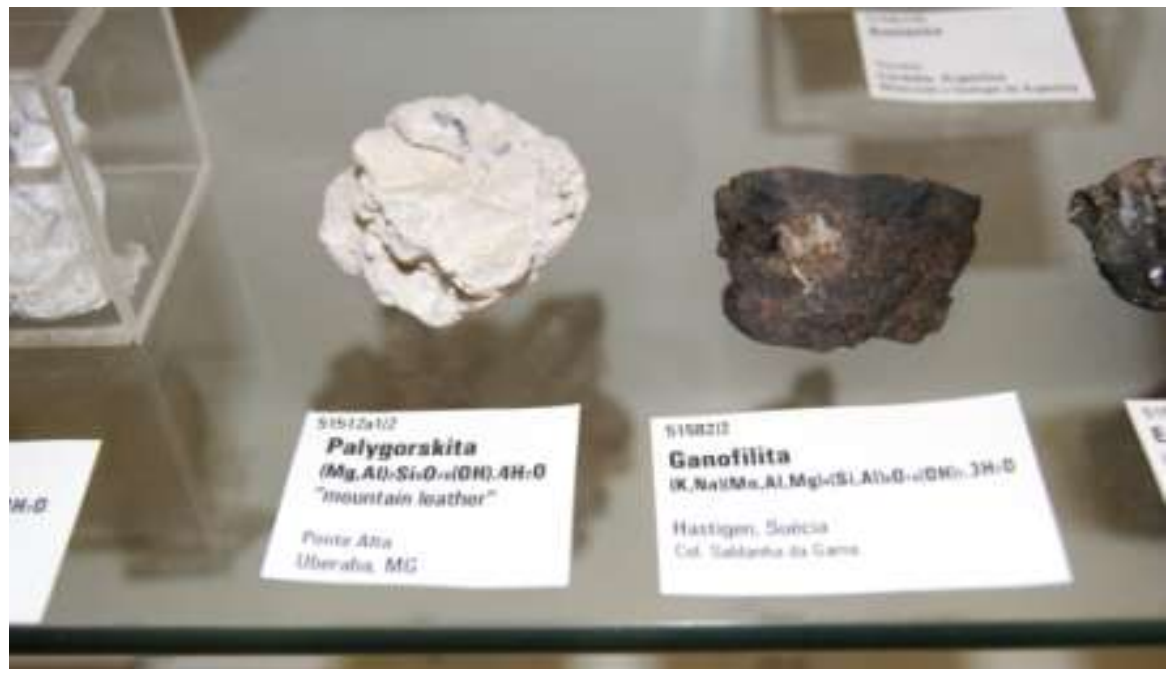

Figura 218. A padronização das informações é um aspecto importante da exposição. A diferença no tamanho das etiquetas leva a uma sensação de confusão na exposição, uma vez que interfere no espaço das amostras de maneira desigual. 


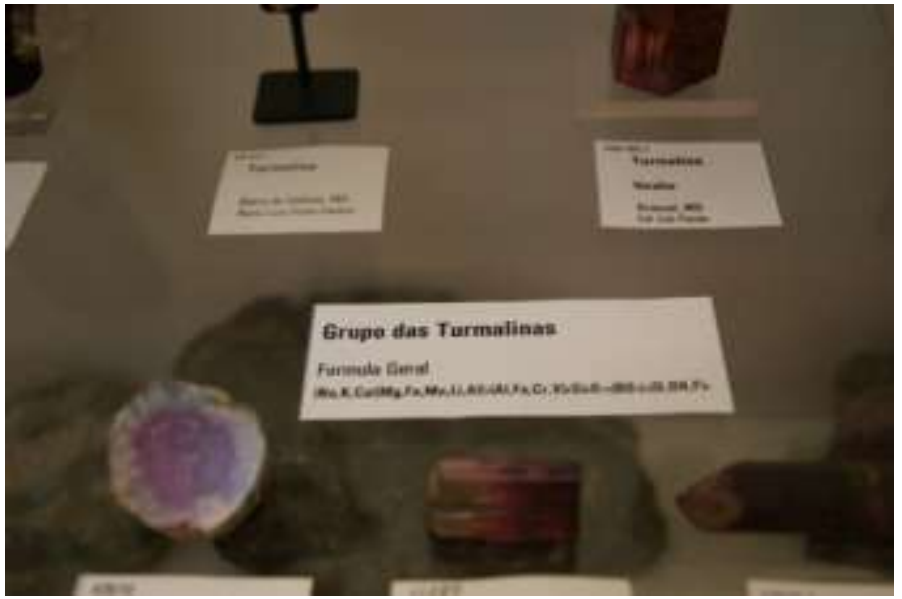

Figura 219. A solução encontrada para as amostras de turmalina é conveniente: fórmula química geral para o grupo, em etiqueta separada, e as etiquetas de amostras permanecem em tamanho padrão.

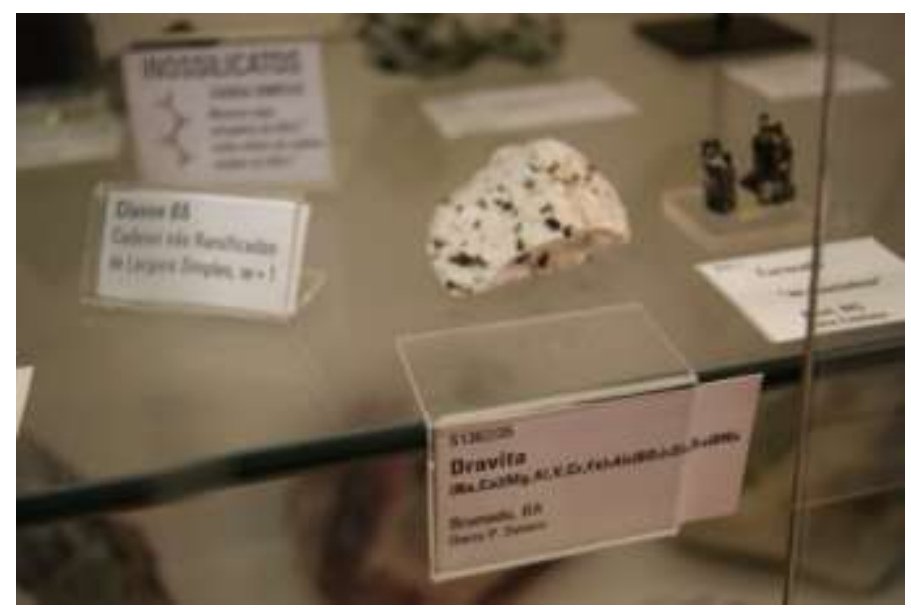

Figura 220. Apesar de haver uma etiqueta com a fórmula geral das turmalinas, a amostra de dravita traz uma etiqueta diferente em relação às outras, com fórmula química em detrimento às adjacentes e ainda com suporte que as outras não têm. Faltou uniformidade na informação, no layout e na exposição.

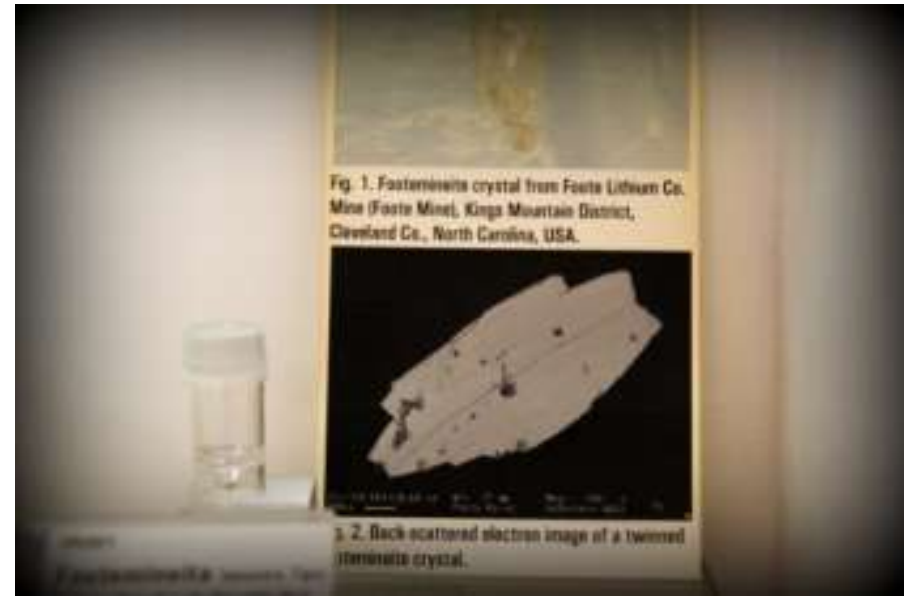

Figura 221. Informações em inglês são necessárias, no entanto, mais uma vez faltou padronização: ou todas as informações são bilíngues, ou se retira a informação em língua estrangeira. Além disso, nessa amostra, a informação está sendo fornecida exclusivamente em idioma estrangeiro. 
9 Uniformização das nomenclaturas: Em uma coleção mineralógica, é comum que haja mais de um nome para a mesma amostra mineral. Muitas amostras possuem um nome científico, um nome pelo qual é conhecida no garimpo e um nome comercial. Nesse caso, é necessário que todas as amostras desse mesmo mineral sejam expostas com o mesmo nome, caso contrário, o visitante leigo pensará que se trata de minerais distintos (Figura 222). No caso analisado, essa confusão ocorre com o amianto, que é um termo comercial e engloba seis minerais de hábito asbestiforme (crisotila, riebeckita, grunerita, antofilita, tremolita e actinolita). Apesar de amplamente difundido o termo amianto, outro nome para asbesto, essa nomenclatura não deve mais ser utilizada por recomendação da International Mineralogical Association. Em um primeiro momento, o observador pode concluir que todas as formas de minerais fibrosos são asbestos, e isso não corresponde à realidade. Por isso, uma nomenclatura clara e uniforme é de grande importância na exposição.

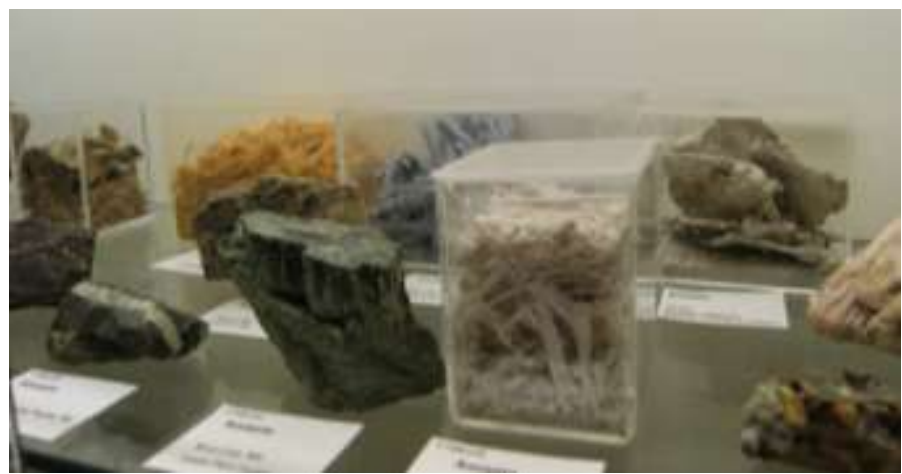

Figura 222. A exposição conserva ainda a terminação errônea amianto para os minerais asbestiformes. Além disso, há três diferentes nomenclaturas na exposição: amianto, asbesto e o nome do próprio mineral (crisotila, por exemplo).

10 Ordenação por importância: A ordem de uma exposição, qualquer que seja o assunto, deve primar por ordenar nas melhores vitrinas, ou nos acessos mais fáceis, os objetos mais importantes. O mesmo acontece com uma coleção de minerais. No Museu de Geociências, muitos minerais importantes estão em posição inadequada. Um exemplo são os feldspatos, que constituem mais de $50 \%$ da crosta terrestre. Minerais dessa magnitude devem ser evidenciados na exposição, com etiquetas claras, que os valorizem, ou posicionados em vitrinas mais destacadas, ao invés de estarem no fundo do museu (Figura 223). Outro exemplo é a coleção de minerais Terras Raras. Hoje são minerais em evidência devido a sua importância econômica. É necessário realocá-los para um lugar de mais destaque (Figura 224). 


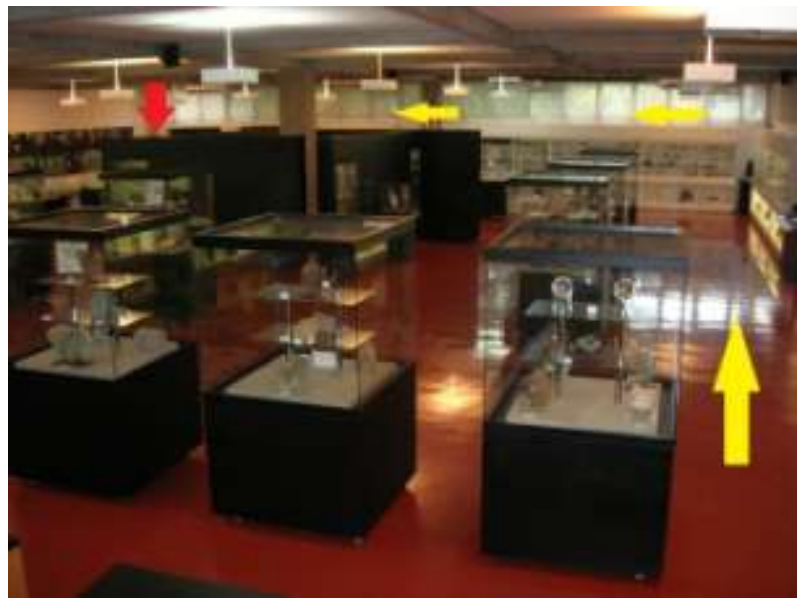

Figura 223. Os feldspatos e minerais Terras Raras ocupam a penúltima e a última vitrinas, respectivamente. Muitos dos visitantes já estão cansados e desestimulados ao chegarem ao fim da exposição e saem de um museu de mineralogia sem ao menos saber o que é um feldspato. As setas amarelas indicam o caminho que o visitante deve percorrer até alcançar os felsdpatos e minerais terras raras, indicados com a seta vermelha.

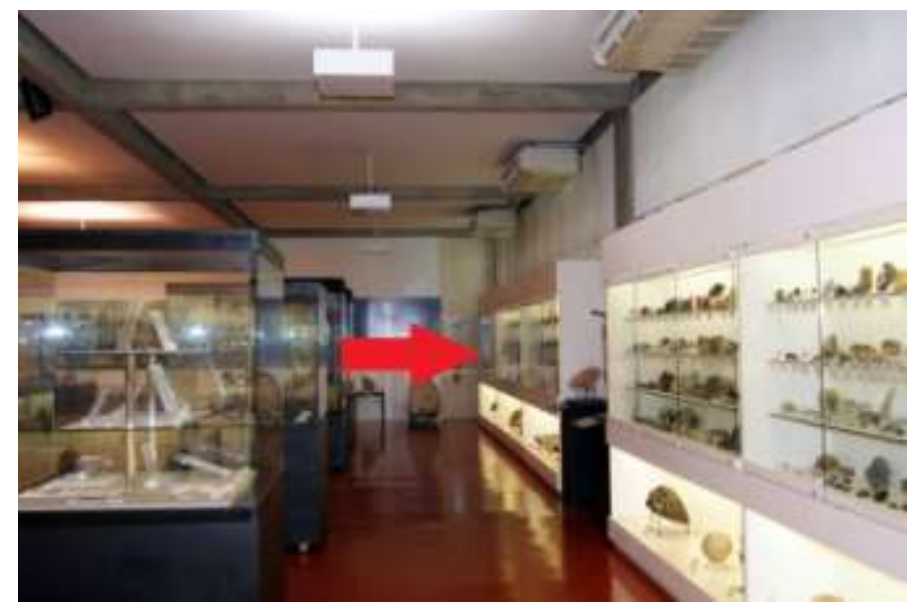

Figura 224. Localização dos feldspatos e minerais terras raras. Além de escondidos na exposição, disputam espaço com as cavernas, que chamam mais a atenção dos visitantes.

11 Acessibilidade: $\mathrm{O}$ edifício do Instituto de Geociências garante o acesso às pessoas com deficiência motora, pois possui rampas de acesso, elevadores e banheiros adaptados. No entanto, a exposição no Museu não é acessível. Pessoas em cadeiras de rodas não têm acesso à maioria dos minerais expostos, pois se encontram expostos verticalmente. $\mathrm{O}$ mesmo ocorre com crianças pequenas e pessoas com baixa estatura, que não alcançam as vitrinas. Idosos e pessoas com restrições de locomoção têm dificuldade em caminhar por toda a exposição, pois não há bancos no museu. Deficientes auditivos também não podem compreender o espaço, pois não há pessoas fluentes em LIBRAS. Já os deficientes visuais recebem uma atenção maior, pois há algumas amostras com etiquetas em Braille e uma apostila também em Braille para explicação das peças, além de amostras especiais para toque. As Figuras 225 a 230 
mostram diferentes exemplos de acessibilidade e sua ausência em diferentes exposições.

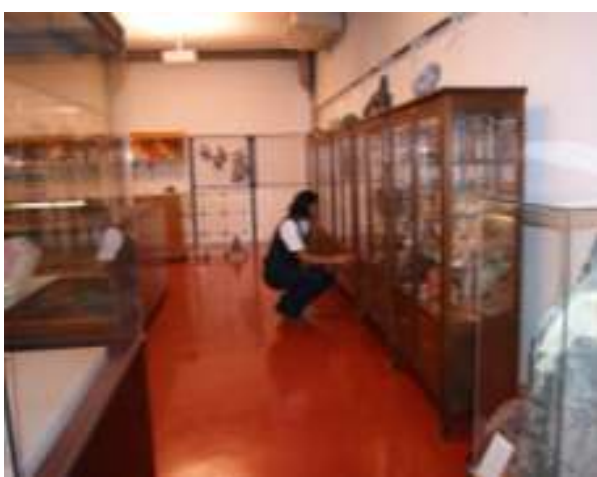

Figura 225. Pessoas com alta estatura também têm dificuldade em apreciar a exposição. Qualquer fator que proporcione o desconforto dos visitantes é considerado falta de acessibilidade.

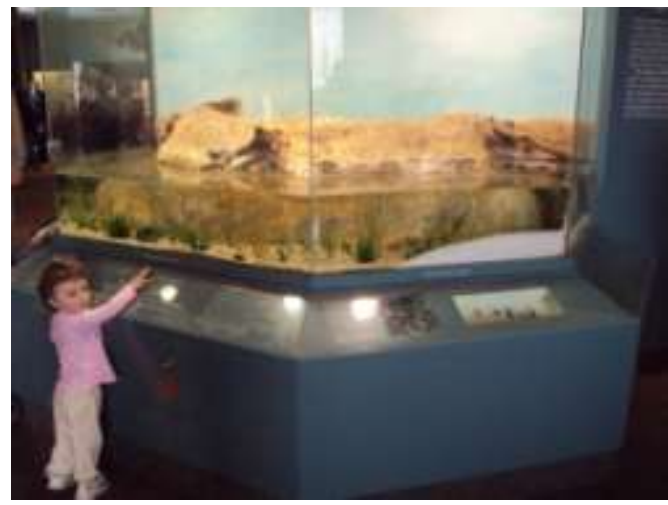

Figura 227. Exposição acessível para crianças no National Museum of Natural History.

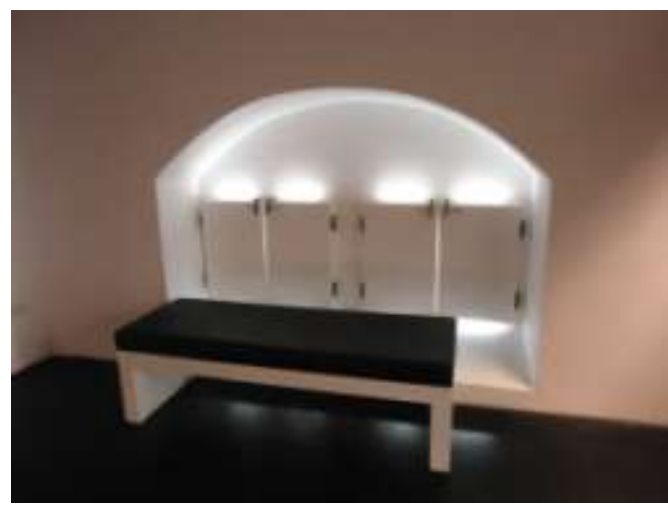

Figura 229. Área de descanso no museu Terra Mineralia.

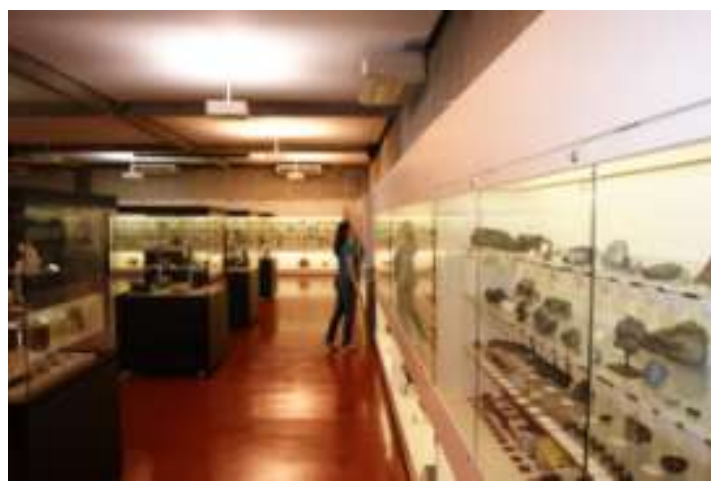

Figura 226. Pessoas com baixa estatura não conseguem alcançar todos os níveis das vitrinas. Foto: Veridiana Vianna.

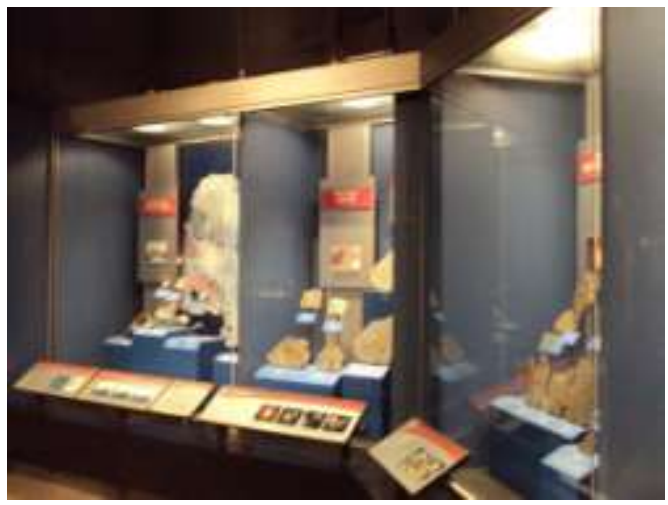

Figura 228. Exposição de meteoritos do National Museum of Natural History. Informações principais estão localizadas na parte inferior das vitrinas, para garantir o acesso à informação.

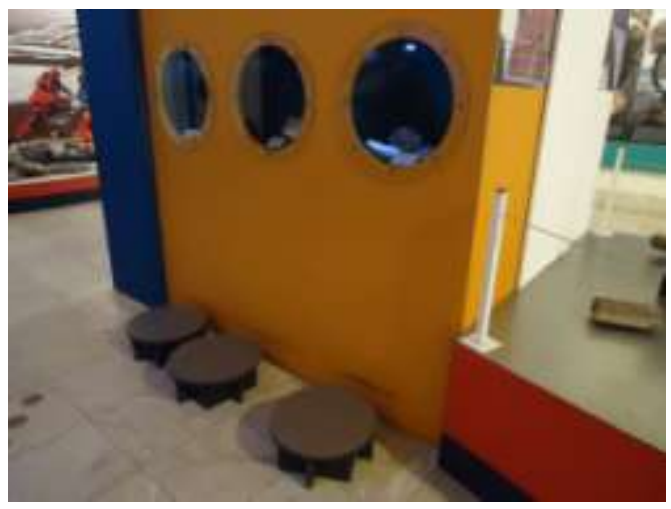

Figura 230. Outro exemplo de exposição com acesso para crianças e pessoas com baixa estatura. Museu Nacional (UFRJ). 


\section{2 - Reserva Técnica}

A reserva técnica do Museu de Geociências, chamada durante muito tempo de porão, está localizada no piso térreo do Instituto de Geociências (Figura 231). Nesse local encontram-se armazenadas a maioria das amostras do museu; mas há ainda dois outros locais para armazenamento. Quatro mapotecas estão localizadas no Laboratório Interativo de Cristalização (LIC) do museu, e um armário de madeira guarda exemplares em uma sala contígua à sala da administração do museu.

A causa da dispersão de amostras em três locais diferentes é a falta de espaço para ampliação da reserva técnica do museu.

$\mathrm{Na}$ reserva técnica propriamente dita, as amostras estão alocadas em quatro armários deslizantes (Figuras 232 e 233), organizadas de acordo com a classificação química aniônica, cuja indicação encontra-se na parte externa de cada armário (Figura 234). A parte interior não possui gavetas, apenas prateleiras sobre as quais as amostras ficam soltas (Figura 235), podendo se deslocar durante aberturas sucessivas do armário onde estão acondicionadas (Figura 236). A maioria das peças está protegida em embalagens de polietileno.

$\mathrm{Na}$ contramão das regras de conservação, a reserva técnica está localizada próxima a uma galeria subterrânea (Figuras 237 e 238) com encanamento de esgoto e tubulações diversas, em local úmido e inadequado, à mercê de insetos, ratos e outros tipos de pestes, que além de afetar o acervo (Figuras 239) podem ser nocivas à saúde dos funcionários (Figura 240). Há uma janela comum, sem qualquer tipo de filtros ou vedação, permitindo a entrada de luz do sol e umidade no local, e possibilitando que as amostras sejam afetadas pela variação de temperatura.

Outro grupo de amostras que inclui a coleção Wards de rochas e a coleção Schnyder está alocado no LIC, um espaço recente (instalado em uma sala que se encontrava sem utilização no fundo do museu) destinado à confecção de cristais de sais atóxicos para utilização didática. As quatro mapotecas estão, assim, descontextualizadas nesse espaço (Figura 241). No laboratório há também janelas que permitem a entrada de luz solar, umidade e variações de temperatura. Apesar de o espaço ser inadequado, as amostras estão bem alocadas nas gavetas, as quais estão forradas com plástico bolha para minimizar o movimento dos minerais (Figura 242).

Por fim, o último grupo de amostras está armazenado em um armário de madeira, com sete gavetas, numa sala chamada de depósito pelos funcionários do museu. Apesar de estar em um local totalmente inadequado, pois neste depósito guardam-se materiais para os mais diversos fins, este é o grupo de amostras que está mais protegido da ação dos fatores de 
degradação, pois o armário está ao abrigo da luz natural, umidade excessiva (apesar de as condições de UR não serem ideais) e variações bruscas de temperatura.

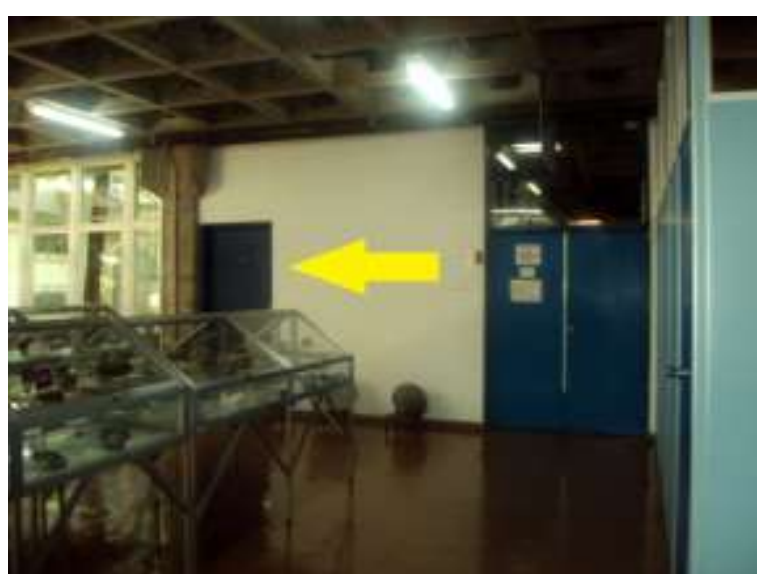

Figura 231. Vista do saguão onde está localizada a porta de acesso à reserva técnica, assinalada com a seta amarela.

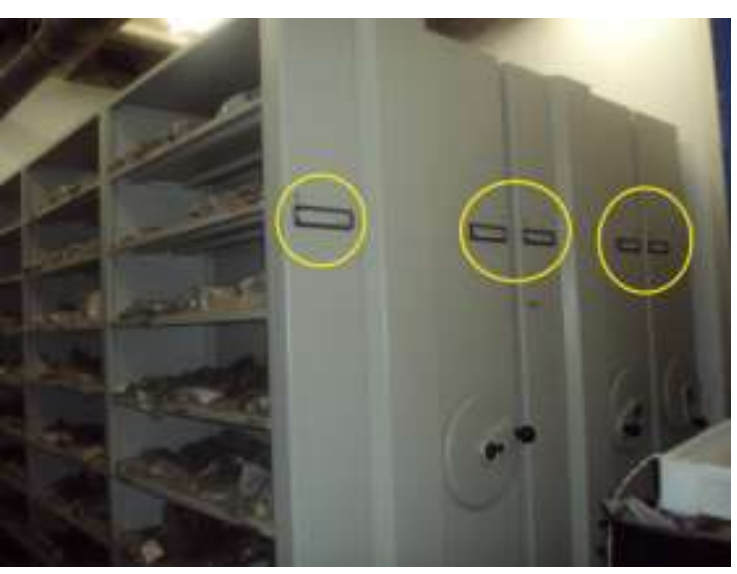

Figura 233. Armários deslizantes na reserva técnica. Os círculos amarelos indicam as etiquetas com a discriminação geral do que há em cada armário.

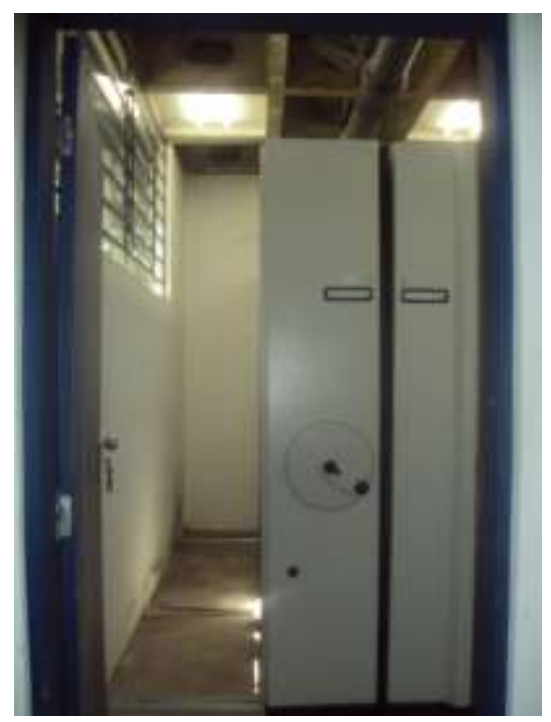

Figura 232. Reserva Técnica do Museu de Geociências. À esquerda, percebe-se a janela, que permite a entrada de iluminação natural e troca de temperatura e UR com o ambiente externo.

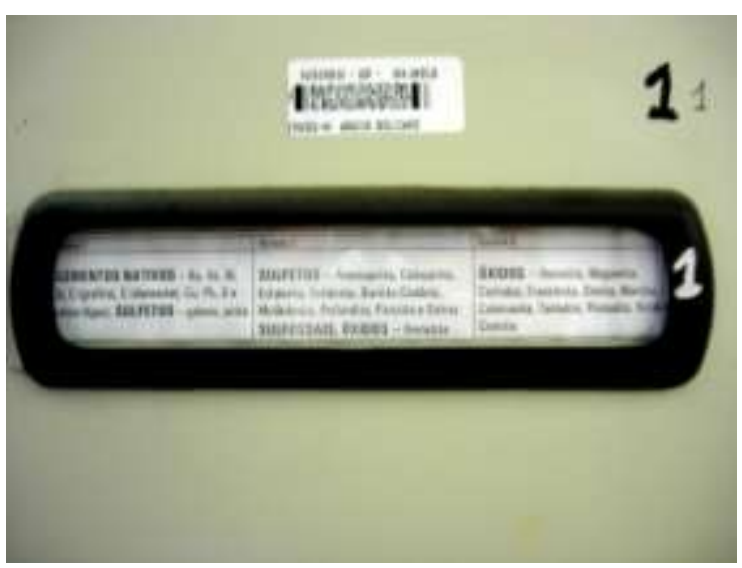

Figura 234. Detalhe da etiqueta indicativa descrita na figura 233. Foto: Ideval Souza Costa. 


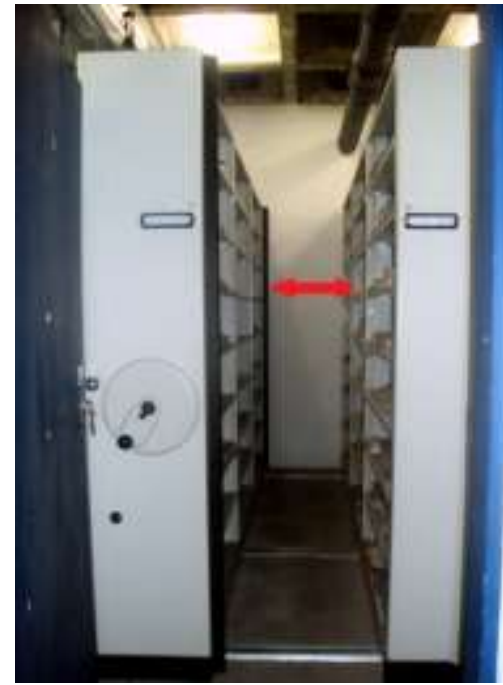

Figura 235. Vista de dois armários deslizantes abertos. A seta vermelha indica as prateleiras, sobre as quais estão os minerais soltos.

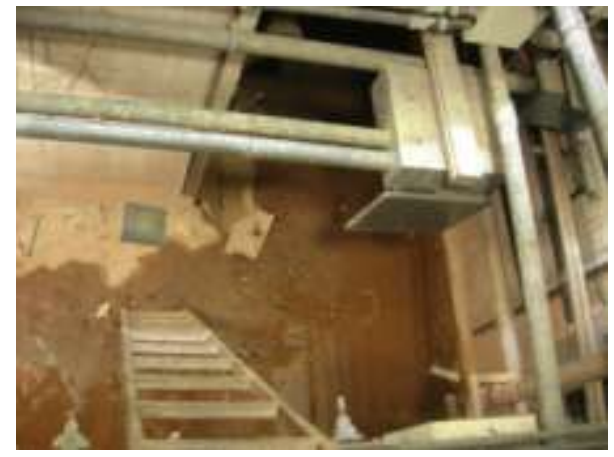

Figura 237. Galeria subterrânea cuja entrada é aberta e ao lado da reserva técnica. O ambiente é úmido, sujo e com ocorrência de animais nocivos.

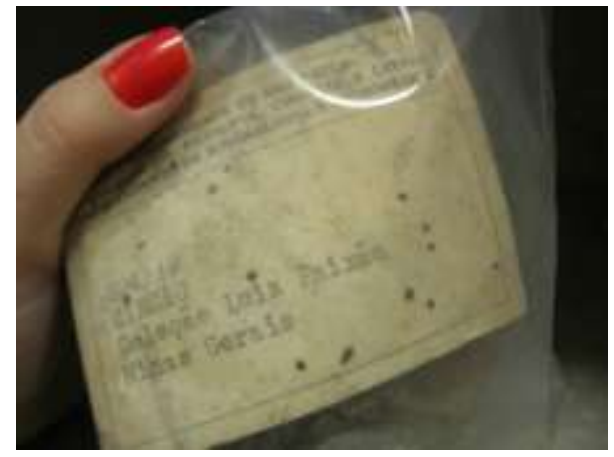

Figura 239. Etiqueta danificada pela ação de pestes frequentemente encontradas no local, traças e baratas.

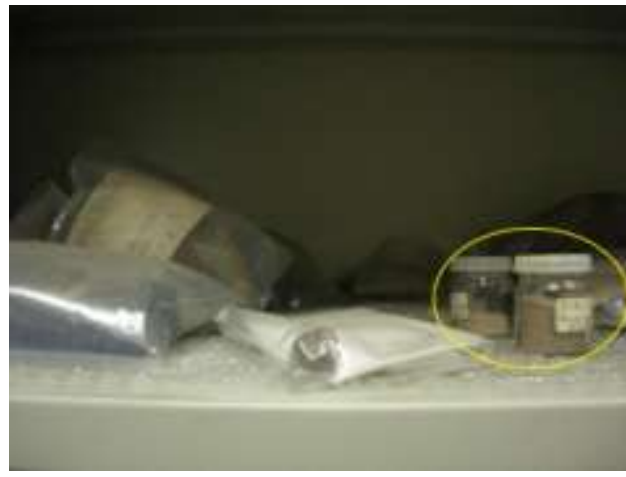

Figura 236. Exemplo de amostras vulneráveis à queda e consequente perda do exemplar em caso de abertura constante do armário.

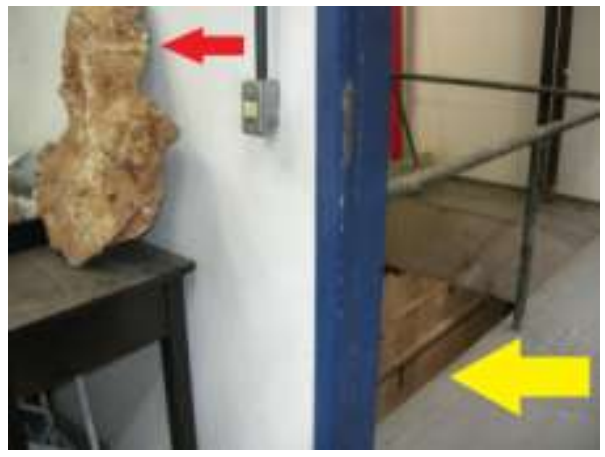

Figura 238. Galeria da foto 237 vista do interior da reserva técnica. A seta amarela indica a galeria e a seta vermelha indica um espeleotema, vulnerável à umidade vinda da galeria.

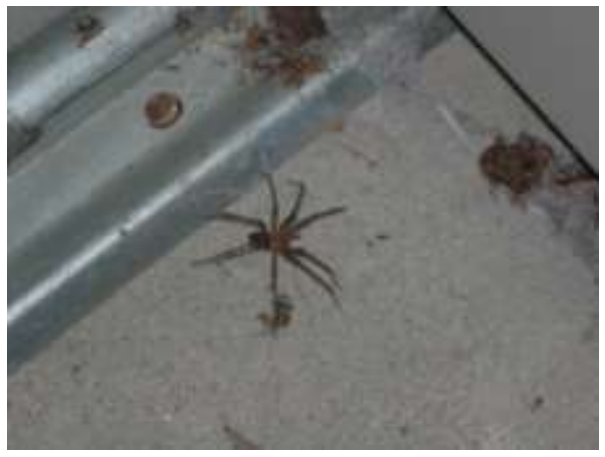

Figura 240. Aranha se esconde no trilho de deslizamento dos armários. Risco a saúde dos funcionários caso seja uma espécie peçonhenta. Foto: Daniel Machado. 


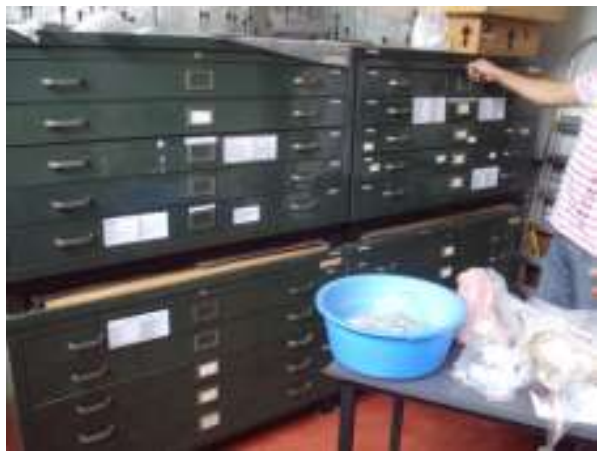

Figura 241. As quatro mapotecas localizadas no LIC. Acervo está bem acomodado no interior das gavetas, mas o espaço está descontextualizado.

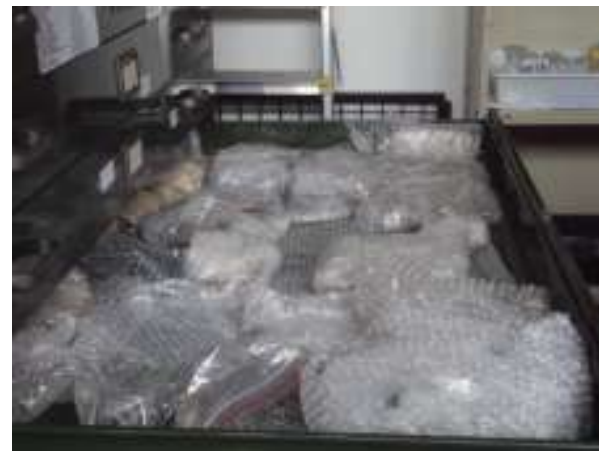

Figura 242. Gavetas da mapoteca são forradas com plástico bolha, a fim de evitar o deslocamento do material em seu interior. Amostras também são envoltas por esse material.

É de extrema importância para a conservação do acervo que as amostras fiquem centralizadas em um único espaço destinado à reserva técnica. Tal procedimento possibilita um controle mais acirrado do acervo, possibilitando que as amostras, depois de serem manuseadas, sejam recolocadas em seu local de origem, evitando erros no armazenamento. Outra questão envolve o tempo destinado a ações de limpeza e inventário. É muito mais produtivo a um funcionário trabalhar em um só lugar do que transitar em três ambientes distintos para fazer um inventário.

O investimento em equipamentos de conservação, como ar condicionado, desumidificadores, filtros UV, entre outros, é único, caso haja somente um espaço.

\section{Diagnóstico}

Após a observação atenta da exposição, tendo como base de análise o público a que a exposição do Museu de Geociências se destina, conclui-se, em primeiro lugar, que é mister a implementação de uma Política de Gerenciamento de Coleções para que seja definido qual é o público alvo do museu: o público clássico, formado por alunos de graduação em Geologia e geólogos; ou o público que constitui maior número, alunos do ensino regular.

A exibição é considerada inadequada a um público essencialmente escolar, que necessita de informações mais didáticas e objetivas, o que não ocorre na exposição. Sem o trabalho de mediação desenvolvido no museu, é praticamente impossível que um aluno se guie sozinho e sane as próprias dúvidas, apoiado apenas nas informações de etiquetas e placas. A exposição não possui qualquer indicativo de começo, meio e fim, não há sugestão de roteiro e não há guia que auxilie o visitante. Ademais, a quantidade repetitiva de minerais desestimula o visitante leigo e o faz perder o interesse já no meio da visita. Não há atividades lúdicas para crianças não alfabetizadas, apesar de elas serem presença constante no museu. 
A exposição é considerada adequada apenas aos alunos de graduação do curso de Geologia, que têm mineralogia na grade curricular e compreendem a organização do espaço. Mineralogistas profissionais, que conhecem a classificação sistemática dos minerais, também têm boa compreensão da exposição. Deve-se levar em conta que o Instituto possui um curso de Licenciatura em Geociências e Educação Ambiental, e a exposição deveria, por isso, agregar mais assuntos relativos às Geociências, como vulcões, ciclo das rochas, tectonismo e impactos da dinâmica terrestre no meio ambiente.

Como solução em curto prazo, a fim de melhorar a qualidade da visita, sugerem-se procedimentos em todos os campos citados:

1 - Diminuição do número de amostras nas vitrinas: O ideal seria a confecção de novos armários, com gavetas abaixo das vitrinas. As amostras expostas seriam apenas as que conservassem as funções expositivas descritas no texto. As demais amostras, selecionadas por uma equipe de curador e mineralogistas, estariam dispostas nas gavetas, disponíveis para o visitante cadeirante e os demais que se interessarem em abri-las. Há também a possibilidade de recolhimento de algumas amostras consideradas excedentes (após avaliação de professores do Instituto e equipe do Museu) (Figura 243) para a reserva técnica (é por isso que faz-se necessário também, investimentos nessa área). O Mineralogisches Museum - Universität Hamburg é um bom exemplo para a reorganização de amostras, pois se trata de um museu universitário, com pequeno orçamento e apenas um funcionário, situação semelhante ao Museu de Geociências. As vitrinas são forradas com feltro colorido, material de baixo custo, fácil manuseio e manutenção (aspiradores de pó são suficientes) e há em média vinte exemplares por vitrina, colocados em patamares distintos, preenchendo de forma mais homogênea o espaço das vitrinas e dando ao visitante uma melhor visualização (Figura 244).

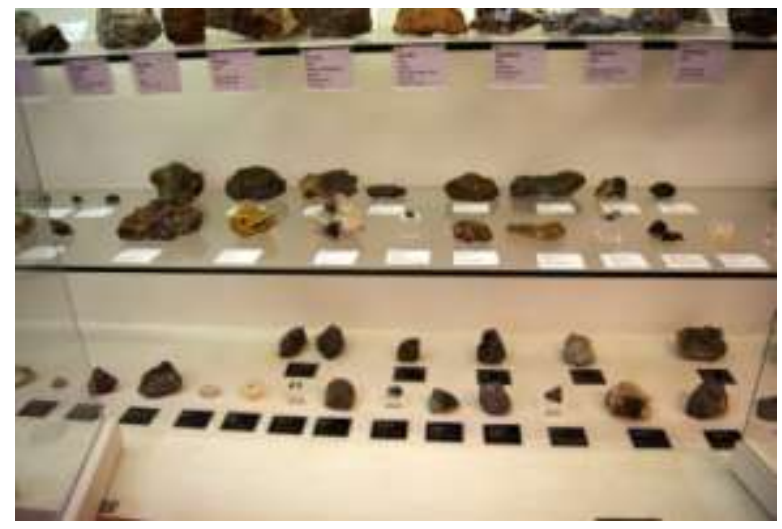

Figura 243. A vitrina com muitos exemplares faz com que o visitante desvie sua atenção e perca o interesse. 


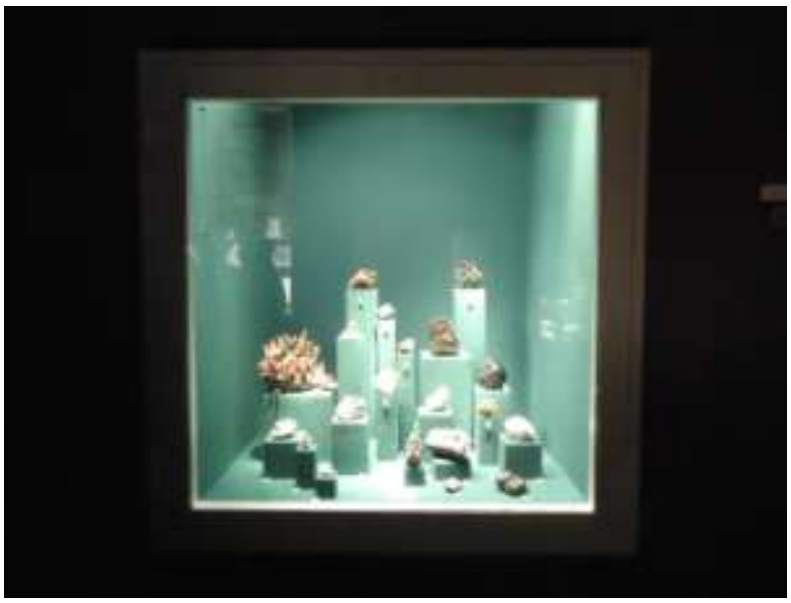

Figura 244. O Mineralogisches Museum - Universität Hamburg coloca em média vinte exemplares por vitrina.

2 - Realocação das amostras: Com um número reduzido de minerais nas vitrinas, seria possível realocar as amostras de maneira que nenhuma fique em desvantagem com relação ao observador. As amostras poderão ser posicionadas de modo que não haja minerais no fundo na vitrina, com apenas uma sequência de minerais. Tal procedimento resolveria também o problema da falta de uniformidade de tamanho. Amostras de volumes semelhantes poderiam ser colocadas próximas umas da outras (Figura 245).

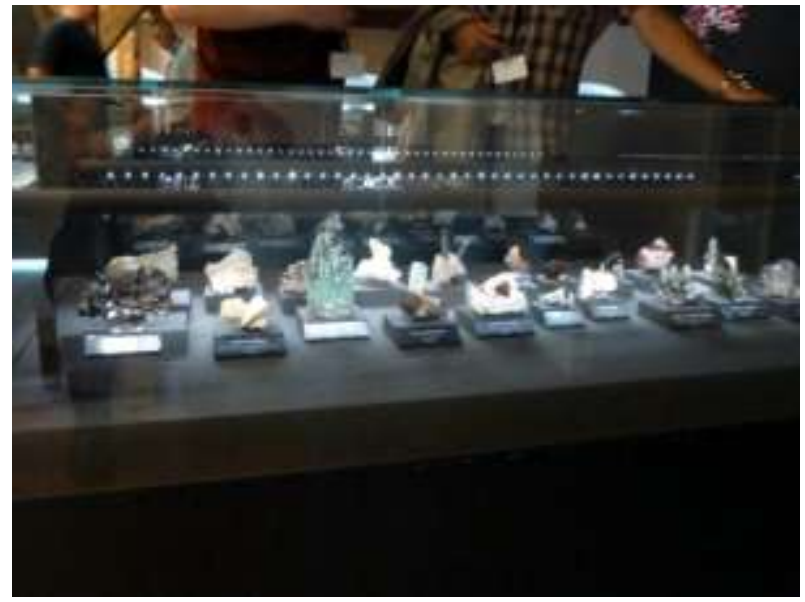

Figura 245. Vitrina de minerais do museu Terra Mineralia. Poucos minerais na mesma vitrina e todos do mesmo tamanho. Dessa forma, nenhum mineral tem maior destaque. Foto: Eliane A. Del Lama.

3 - Reposição de suportes: Ao rever a exposição, é possível atentar para os suportes que devem ser trocados, ou por estarem velhos, ou por não condizerem com o tamanho da amostra. Pode-se aproveitar a oportunidade para mudar os fixadores das amostras pequenas, substituindo-os por materiais mais novos e menos visíveis ao visitante (Figura 246). Com isso, amenizam-se os problemas de desproporcionalidade dos suportes com as amostras e dos fixadores. 


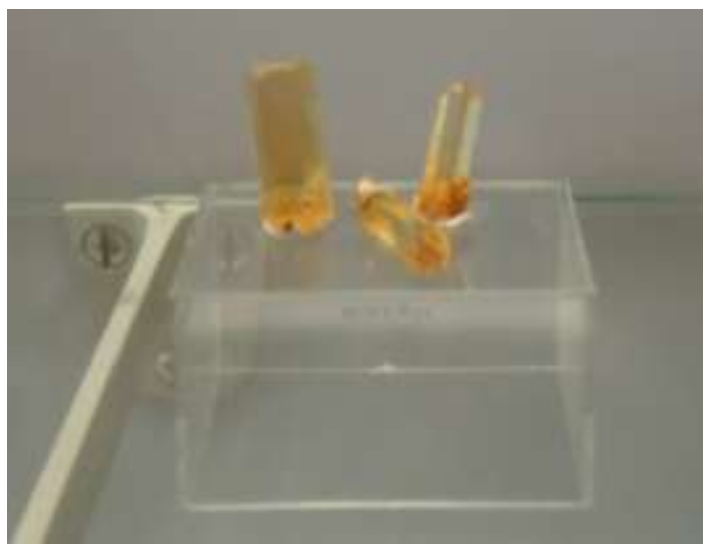

Figura 246. Exemplo de resina fixadora transparente que não afeta a visibilidade da amostra. Acervo: Mineralogisches Sammlungen - Technische Universität Berlin.

4 - Padronização das etiquetas: As etiquetas deveriam ser trocadas, observando o espaço necessário para a maior fórmula química. Esse espaço definiria as dimensões que devem ter as demais etiquetas da exposição. Uma vez que as etiquetas sejam substituídas, padronizam-se os nomes dos minerais, a fim de não confundir o visitante.

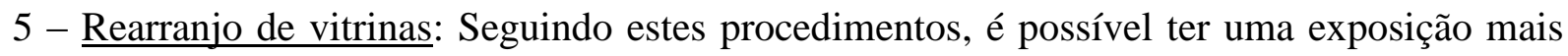
clara e objetiva, proporcionando ao visitante o melhor aproveitamento de seu tempo e uma melhor elaboração do conteúdo aprendido na visita. Uma maneira de chamar a atenção do público leigo, sem interferir na organização sistemática, é seguir a orientação do Mineralogisches Sammlungen - Technische Universität Berlin (Figura 247), mantendo a exposição sistemática ao redor do museu, colocando nas vitrinas móveis no centro do espaço exposições mais didáticas. Um exemplo foi a vitrina com minerais coloridos (Figura 248), que foram expostos durante quatro meses, a fim de chamar a atenção para a cor, uma das principais características de um mineral.

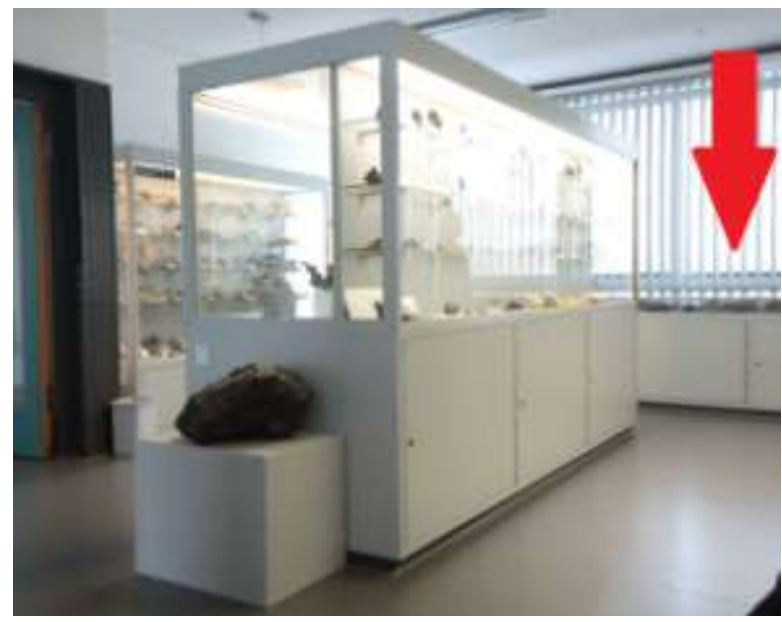

Figura 247. Mineralogisches Sammlungen - Technische Universität Berlin. Os minerais mais atrativos estão em vitrinas grandes, no centro do museu, enquanto a exposição sistemática está no entorno, em armários menores, indicados pela seta vermelha. 


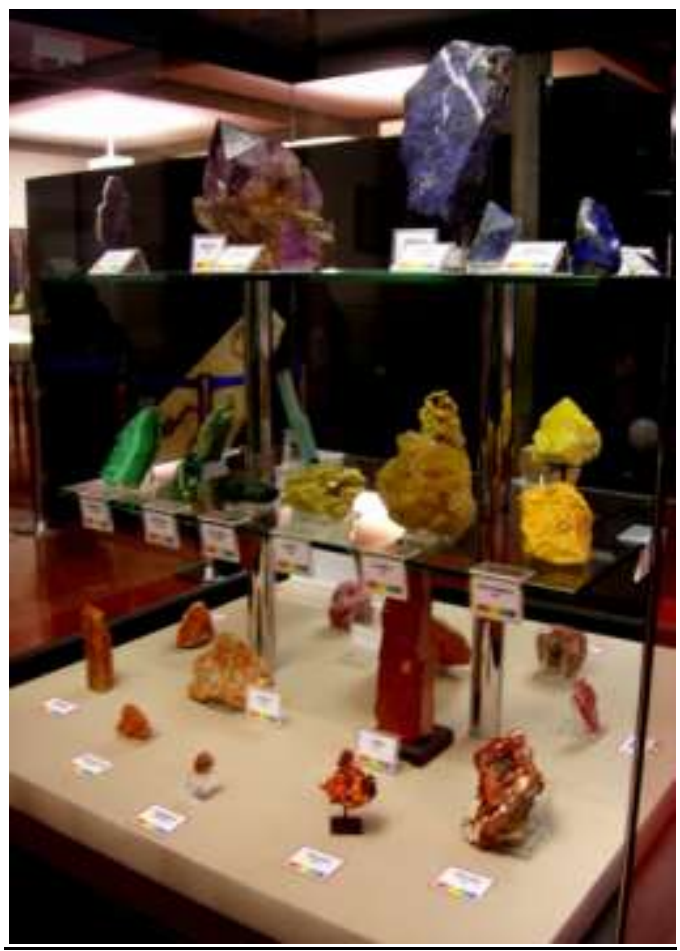

Figura 248. Vitrina organizada de modo a destacar a variação de cor nos minerais.

Em médio e longo prazo, faz-se necessária uma total reformulação do espaço. $\mathrm{O}$ Museu, intitulado de Geociências é, na verdade, um espaço predominantemente mineralógico. Faz-se necessário adequar seu acervo e sua exposição ao atual nome da instituição. O IGc possui atualmente um acervo médio de 30 mil exemplares de fósseis (entre animais e vegetais), pertencente à Coleção Científica de Paleontologia, que poderia ser exposto parcialmente. Para tanto, seria necessário uma readequação do espaço museológico a fim de acomodar a paleontologia e outras temáticas geológicas, como vulcanismo, tectônica de placas, hidrogeologia, ciclo das rochas, entre outras.

É interessante também adequar o museu ao novo perfil de público do século XXI, mais dinâmico e interativo. $\mathrm{O}$ museu carece de instalações multimídias que tornem o espaço ao mesmo tempo atraente e funcional. Totens informativos, vídeos, estruturas em três dimensões são algumas ideias a serem consideradas. A Geociências é um processo, faz-se e refaz-se a cada dia. O Museu pode e deve acompanhar esse movimento.

O Museu de Geociências necessita de um novo espaço para reserva técnica, ou ampliação do espaço atual, além de melhora no ambiente. A instalação de desumidificadores no espaço atual é emergencial, bem como vedação na janela para bloquear a entrada de umidade.

Uma reserva técnica ideal para este caso inclui: espaço suficiente para unificação de todo o acervo de reserva; instalação de mais armários deslizantes com gavetas; colocação de 
gavetas nos armários já existentes; espaço para uma bancada de trabalho dentro da sala de reserva, como ocorre no Mineralogisches Staatssammlung München (Figura 249) e em uma das reservas técnicas de meteoritos do NMHN (Figura 250) a fim de que os funcionários possam trabalhar e atender pesquisadores no mesmo espaço, evitando maiores deslocamentos de material. Apesar de os visitantes causarem impacto de temperatura e umidade no ambiente de reserva, onde esses fatores deveriam permanecer inalterados, ainda é melhor que o pesquisador utilize o ambiente de reserva, ao invés da amostra ser deslocada para outro local.

A instalação de um espaço próprio para a pesquisa faz parte do cotidiano de um museu e não deve ser ignorado. Firmar o museu como um espaço acadêmico também passa por oferecer boas condições de trabalho ao funcionário e boa condição de pesquisa para o público acadêmico (Figura 251).

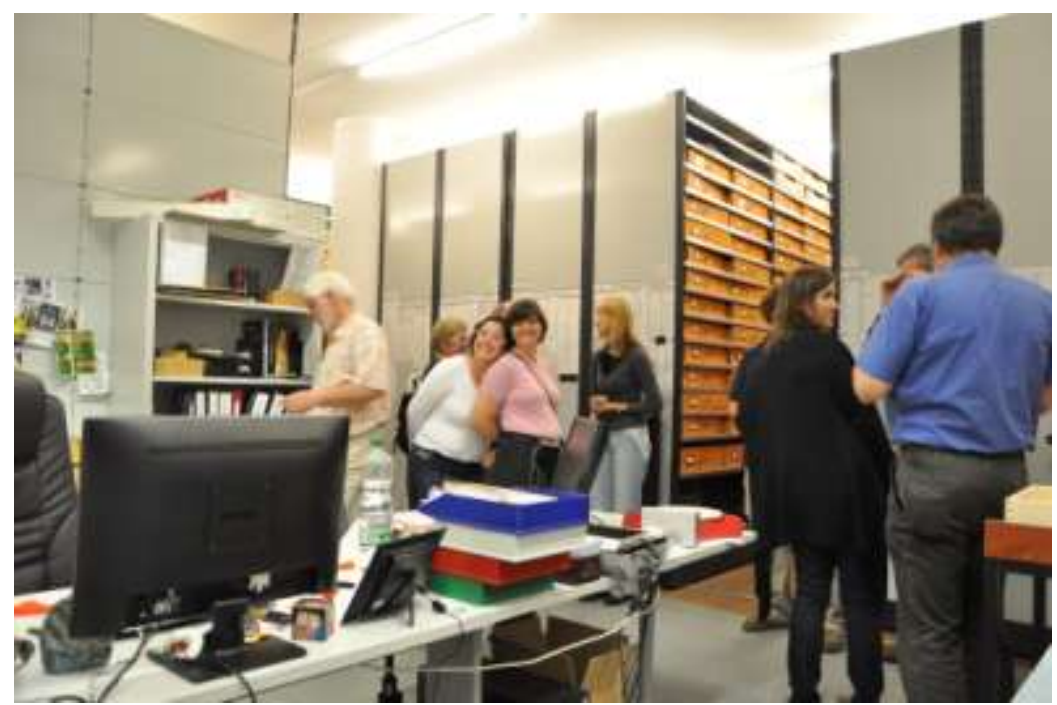

Figura 249. Reserva técnica do Mineralogisches Staatssammlung München. Ao fundo encontram-se os armários deslizantes. Na porção frontal da imagem está a bancada de trabalho dos funcionários, e à direita existem mesas para os pesquisadores analisarem o material solicitado. Foto: Lauro K. Dehira. 


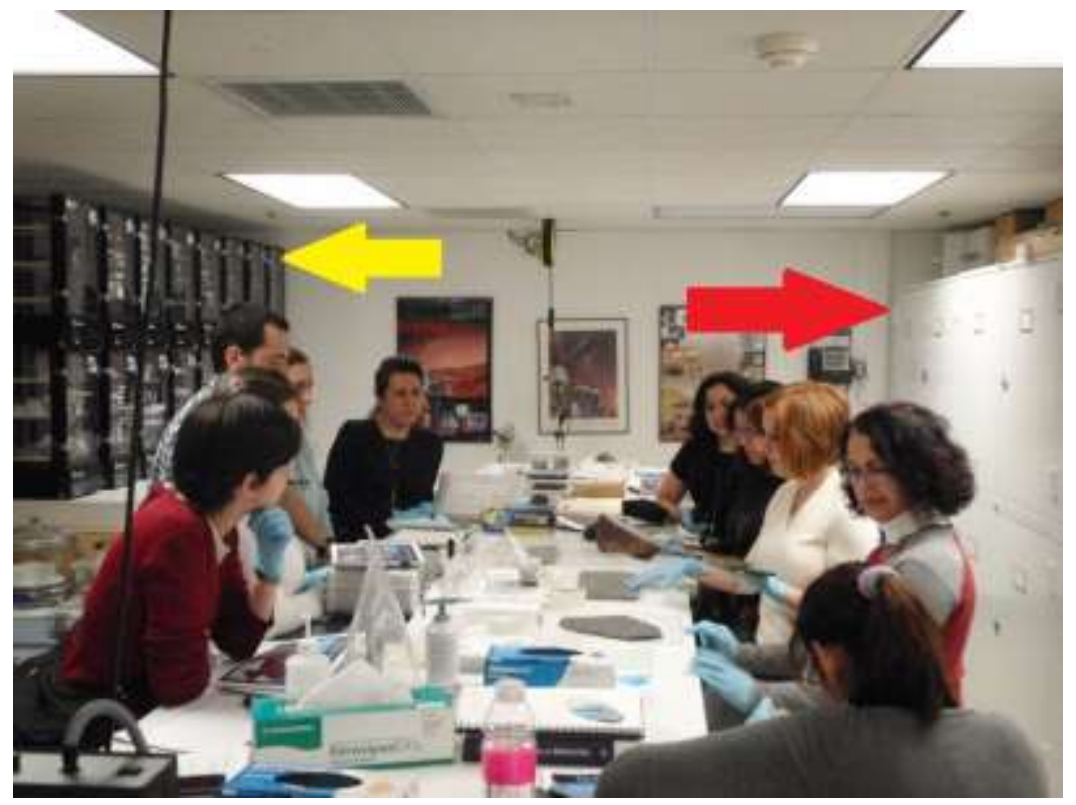

Figura 250. Reserva técnica de meteoritos do NMNH, edifício do National Mall. A seta amarela indica as cabines climatizadas com meteoritos metálicos de pequenas dimensões; a seta vermelha indica armários para amostras maiores. No centro está a bancada para pesquisadores. Foto: Cristina Castilho.

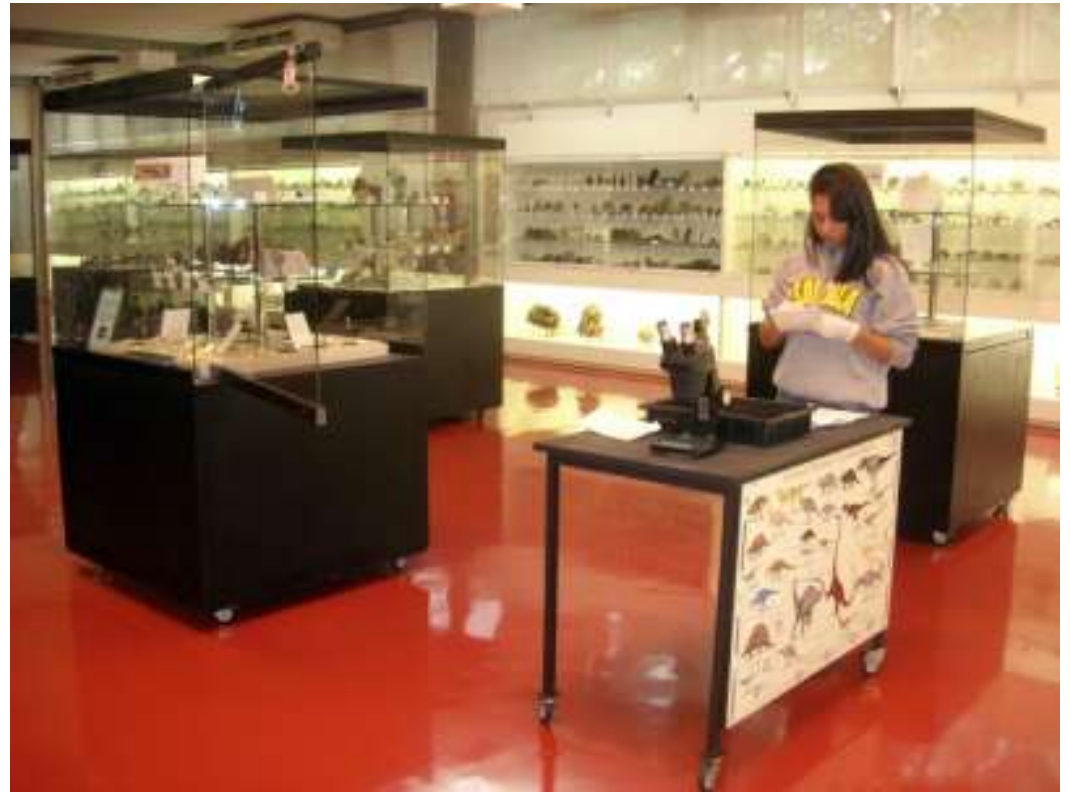

Figura 251. Sem um espaço destinado à pesquisa, o acervo fica vulnerável. Atualmente, a pesquisa com o acervo é realizada sempre as segundas feiras, dia em que o museu é fechado ao público, para que se possa trabalhar em segurança. A foto mostra a situação de vulnerabilidade do acervo, bem como o desconforto do pesquisador, que trabalha em espaço improvisado. 


\section{8 - Considerações Finais}

Coleções Geológicas são compostas por minerais, rochas, fósseis, meteoritos, espeleotemas, lâminas petrográficas e gemas. No entanto, este estudo aprofundou-se no tratamento de minerais, por serem estes os materiais que constituem a maior parte do acervo do Museu de Geociências da USP, objeto deste trabalho.

Este estudo pretendeu mostrar as principais dificuldades enfrentadas por profissionais que atuam em coleções geológicas, com base na observação de problemas encontrados no cotidiano do Museu de Geociências da USP, e sua comparação com outros museus do segmento, por critérios de status jurídico, dimensões espacial e de acervo, e grau de notoriedade da coleção.

Encontram-se atualmente, na área da museologia geológica, dois grupos distintos de profissionais. O primeiro e mais comum são os profissionais que atuam em Museus de Geociências e lidam diretamente com as amostras, mas não possuem formação na área, e desconhecem, por isso, muitos dos processos químicos que causam a perda de suas coleções. O segundo grupo é formado por geólogos ou geocientistas que têm o conhecimento teórico, ausente no primeiro grupo, mas não possuem conhecimentos museológicos, e muitas vezes não reconhecem a museologia como ciência. Além de boa vontade, atuar em acervos geológicos requer conhecimento em ambas as áreas, geociências e museologia.

Desta forma, pretende-se que este trabalho seja um guia técnico para os profissionais de acervos geológicos que não sejam geólogos. Por outro lado, pretendeu-se mostrar aos geólogos e outros profissionais com conhecimento geológico um pouco da vastidão do campo museológico. Foram apresentadas no Capítulo 4 as coleções museológicas que se destacam no Brasil, aliadas a um breve histórico do desenvolvimento da Museologia, ciência recente, desconhecida por muitos acadêmicos responsáveis por coleções. Para uma discussão mais completa, criou-se aqui o conceito de Museu Parâmetro, que se refere às coleções geológicas visitadas pela autora e que serviram como base de comparação com o Museu de Geociências da USP.

Esses museus, nacionais e internacionais, foram escolhidos devido a três fatores: por serem museus de grande porte, e possuírem recursos para cuidar de suas coleções da forma ideal; por serem museus de universidades, tendo assim semelhanças jurídicas e administrativas com o Museu de Geociências; e, por fim, pelo conteúdo de seu acervo.

Passadas as apresentações das coleções museológicas brasileiras e estrangeiras, o Capítulo 5 tratou sobre as cores nos minerais, com definições teóricas que auxiliam a 
compreensão do que se passa dentro da estrutura mineral e irá interferir em sua relação com problemas de conservação da cor em exposições.

O Capítulo 6 tratou detalhadamente dos problemas que afetam as coleções geológicas - decaimento de sulfetos, mudança de cores em minerais pela ação da luz, deliquescência de amostras, minerais radioativos, minerais tóxicos e asbestiformes e oxidação de meteoritos - e de suas causas, inadequação da taxa de umidade relativa do ar, variações de temperatura e iluminação do ambiente. Além disso, foram apresentados materiais de conservação utilizados atualmente em coleções de história natural, nem todos específicos para geologia, mas que podem ser adaptados às coleções geológicas.

O Capítulo 7 finaliza a discussão mostrando o Museu de Geociências da USP em detalhe, evidenciando suas falhas na exposição e conservação de amostras, diagnosticando assim seus principais problemas. Utilizando os museus parâmetros, foram apontadas sugestões de solução para melhora da exposição e reserva técnica, garantindo, dessa forma, a longevidade do acervo para que continue colaborando com a formação cultural das gerações atuais e futuras.

Observou-se com as visitas técnicas que os museus que abrigam coleções geológicas, de modo geral, sofrem com a falta de funcionários para cuidarem de áreas tão distintas como exposição, reserva técnica, conservação de espécimes e administração.

Um dos principais problemas detectados no Museu de Geociências da USP é a ausência de uma política de coleções que estabeleça diretrizes básicas para o funcionamento do museu. Além de procedimentos específicos do cotidiano da instituição, a política de coleções estabelece a missão da instituição, fator sine qua non para o gerenciamento consciente da instituição. A missão estabelece, entre outros pontos, o público alvo do museu. A definição desse público irá definir também o tipo de exposição adotada, o espaço a ser destinado, o discurso utilizado, entre outros pontos. A ausência da definição da missão prejudica o Museu, que não se define nem como um acervo científico, nem como um museu didático para os ensinos fundamental e médio. A missão do Museu de Geociências não está clara, nem para funcionários, nem para instituição. É necessário que as autoridades competentes (técnicos e conselho do Museu) estabeleçam a Política de Coleções, documento oficial da Instituição, que orienta seu funcionamento.

A qualificação de funcionários é outro problema para a maioria dos museus de geociências no Brasil. Os funcionários são, em sua maioria, docentes que acabam cuidando da coleção por acaso (e não tem a visão museológica) ou funcionários de nível médio, cuja especialização é nula, nem geológica e tampouco museológica. 
No entanto, esta pesquisa demonstra que, por ora, de tudo o que falta, é possível fazer muita coisa com o que se tem. O Museu encontra-se em um momento propício ao crescimento, no qual a comunidade acadêmica está abrindo os olhos para a importância da preservação de patrimônios.

O Museu é um dos cartões de visita do IGc, recebendo visitantes de vários países, interessados em conhecer o patrimônio geológico que aqui se preserva. A Universidade de São Paulo, instituição que abriga o Museu de Geociências, é a uma das universidades mais conceituadas da América Latina; o Museu, referência nacional. Por que não elevar o Museu de Geociências ao patamar de referência internacional que ocupa a Universidade? Não se espera com este trabalho que essas e outras questões aqui colocadas sejam respondidas prontamente. Espera-se que aqui se encontre um pouco do embasamento teórico necessário para uma discussão mais completa sobre o tema seja colocada na ordem do dia da academia. 


\section{Referências Bibliográficas:}

BALERDI, I. D. La memoria fragmentada: el museo y sus paradojas. Trea, Gijón, 2008.

BLOSS, F. D. Crystallography and crystal Chemistry. An introduction. Holt, Rinehart and Winston, Inc. Blacksburg, Virginia, 1971.

BEVAN, A.W.R. Metorites. In: The Care and Conservation of Geological Material: Minerals, Rocks, Meteorites and Lunar Finds. Butterworth-Heinemann, Oxford, 1992.

BRUNTON, C. H. C., Besterman, Tristram P., Cooper, John A. Guidelines for the Curation of Geological Materials. London, Geological Society, 1985.

BUTLER, C. J. Environmental effects on geological material: pyrite decay. In: Conservation of Geological Collections. Archetype Publications Ltd. London. 1994.

CARDOSO, E. M. Apostila Educativa. Radioatividade. Rio de Janeiro, Comissão Nacional de Energia Nuclear.

CERVÁVOLO, S. M. Delineamentos para uma teoria da Museologia. In: Anais do Museu Paulista. São Paulo. N. Sér. v.12. p. 237-268. jan./dez. 2004.

CHIELD, R. E. Conservation of Geological Collections. Archetype Publications Ltd. London. 1994.

CORNEJO, C. \& BARTORELlI, A. Minerais e Pedras Preciosas do Brasil. São Paulo, Solaris Edições Culturais, 2010.

DANA, J. D. \& DANA, E. S. Dana's new mineralogy. The system of Mineralogy of James D. Dana and Eduard S. Dana. $8^{\text {th }}$ Edition. New Yourk, J. Wiley and Sons, 1997.

DANIEL, Vinod. Storage in low-oxygen environments. In: Storage of Natural History Collections: a Preventive Conservation Approach. ROSE, C., HAWKS, C., GENOWAYS, H.H. Society for the Preservation of Natural History Collections. Iowa University, 1995.

DESVALLÉES, A. \& MAIRESSE, F. Key Concepts of Museology. Armand Colin, 2010.

DOLLERY, D. Damage to shale. In: Conservation of Geological Collections. Archetype Publications Ltd. London. 1994.

FIGUEIREDO, B. R. Arsênio no Brasil e exposição humana. In: SILVA, Roberto da. [et al.] Geologia Médica no Brasil: efeito dos materiais e fatores geológicos na saúde humana, animal e meio ambiente. Rio de Janeiro, CPRM, 2006. 
FIGUEIRÔA, S. F. de M. (org.). Um olhar sobre o passado. História das Ciências na América Latina. Campinas, SP: Editora da Unicamp. São Paulo, SP: Imprensa Oficial. 2000. Pags. 163-173.

GOMES, M. F. D. L. Museus Mineralógicos - armazéns de minerais ou parceiros do ensino? Três Perspectivas. In: Actas do I Seminário de Investigação Museológica dos países de língua portuguesa e espanhola. Volume 1. Pp. 248-258. Porto, Universidade do Porto, 2010.

HASQUIN, H. "For the progress of human knowledge: show the arts and science in the century of enlightenment". 2009.

HORÁK, J. M. Light induced color changes in minerals. In: Conservation of Geological Collections. Archetype Publications Ltd. London. 1994.

HOWIE, F. M. The Care and Conservation of Geological Material: Minerals, Rocks, Meteorites and Lunar Finds. Butterworth-Heinemann, Oxford, 1992.

IBRAM. Guia dos Museus Brasileiros. Brasília, Instituto Brasileiro de Museus, 2011.

KLEIN, C. \& DUTROW, B. Manual de Ciência dos Minerais. Rualdo Menegat (trad.). 23 ed. Porto Alegre: Bookman, 2012. 716p.

LAMBERT, M. Hazardous specimens and their control. In: Conservation of Geological Collections. Archetype Publications Ltd. London. 1994.

LEITE, J. R. C.. Contributo do Museu Nacional de História Natural para a divulgação do patrimônio geológico: caracterização do público do Departamento de Mineralogia e Geologia. 159p. Dissertação (Mestrado). Portugal, Universidade do Minho, 2009.

MARTINEZ, I. G. Dos Museologias. Las tradiciones anglosajona y mediterrânea: diferencias y contactos. Trea, Gijón, 2006.

MUNYER, M. J. How to...mark objects in museum collections. Part 1: barrier coats, pens, inks, paints. Illinois Association of Museums.1997.

MUSEUMS \& GALLERIES COMISSION. Maria Luiza Pacheco Fernandes (trad.). Planejamento de Exposições. In: Museologia, Roteiros Práticos. São Paulo, EDUSP, Vitae: 2001.

NASSAU, K. The origin of colors in minerals. In: American Mineralogist, Volume 63, pp. 219-229. New Jersey, 1978.

NASSAU, K. Conserving light sensitive minerals and gems. In: The Care and Conservation of Geological Material: Minerals, Rocks, Meteorites and Lunar Finds. Butterworth-Heinemann, Oxford, 1992. 
NASSAU, K. The Physics and Chemistry of Color - the fifteen causes of color. Wiley Interscience Publication. New York, 2001.

PARSONS, A.L. The Preservation of Minerals Specimens. In: American Mineralogist, volume 7, pgs. 59-63. 1922.

PARSONS, A. L. Additional data concerning the preservation of minerals. In: American Mineralogist, volume 11, pgs 79-82. 1926.

PETROV, A. A Scientific Study of the Absorption of Evil by Vivianite. 2006. Disponível em www.mindat.org. Acesso em 10/08/2012.

POST, J. E. The National Gem Collection. Smithsonian Institution. Harry N. Abbrams Incorporated, New York, 1997.

PRICE, M. The stability of Minerals. In: The Care and Conservation of Geological Material: Minerals, Rocks, Meteorites and Lunar Finds. Butterworth-Heinemann, Oxford, 1992.

SCARPELLI, W. Amianto, o que é importante considerar. in: SILVA, R. da. [et al.] Geologia Médica no Brasil: efeito dos materiais e fatores geológicos na saúde humana, animal e meio ambiente. Rio de Janeiro, CPRM, 2006.

STRUNZ, H. \& NICKEL, E. H. Strunz Mineralogical Tables. Chemical Structural Mineral Classification System. $9^{\text {th }}$ Edition. E. Schweizerbart'sche Verlagsbuchhandlung (Nägele u. Obermiller). Stuttgart, 2001.

SULLIVAN, B. \& CUMBERLAND, D. R. Use of Acryloid B-72 Lacquer for Labeling Museums Objects. In: Conserve O Gram, number 1/4. Washington, DC, Government Printing Office, 1993.

TEIXEIRA, W., FAIRCHIELD, T, TOLEDO, M.C.M E TAIOLI, F. (org.). Decifrando a Terra. São Paulo, Companhia Editora Nacional, 2009.

THORNTON, J. Adhesives and adhesion. Buffalo State College.2005.

WALLER, R. Temperature and humidity-sensitive mineralogical and petrological specimens. In: HOWIE, F. M. The Care and Conservation of Geological Material: Minerals, Rocks, Meteorites and Lunar Finds. Butterworth-Heinemann, Oxford, 1992.

ZHIGILEI, L. V. Crystal Defects. Department of Materials Science and Engineering. University of Virginia. Disponível em: http://people.virginia.edu/ 1z2n/mse201/mse201-defects.pdf

\section{Sites Pesquisados:}


www.igc.ufmg.br/casadagloria

acesso em 24/03/2012.

CASA DO RESTAURADOR:

http://www.casadorestaurador.com.br/restaura_3_13.htm

acesso em 25/11/2012.

CETESB

http://sistemasinter.cetesb.sp.gov.br/produtos/ficha_completa1.asp?consulta=CLO RETO\%20DE\%20VINILIDENO

acesso em 06/12/2012.

http://www.cetesb.sp.gov.br/userfiles/file/laboratorios/fit/cloreto_de_vinila.pdf

acesso em 06/12/2012.

COMISSÃO NACIONAL DE ENERGIA NUCLEAR - CNEN

www.cenen.gov.br

acesso em 25/06/2012.

ICOM - INTERNATIONAL COUNCIL OF MUSEUMS.

http://icom.museum/

acesso em 28/03/2012.

INFOPEDIA

www.infopedia.pt/\$polivinilideno

acesso em 08/08/2012.

http://www.infopedia.pt/\$arsina

acesso em 05/02/2012

INSTITUTO DE FÍSICA - UFGRS

www.if.ufrgs.br/crefi/radio/capitulo3.htm

acesso em 28/06/2012

KEEP SAFE MICROCLIMATES SYSTEMS:

http://keepsafe.ca/oxygen-free-display-storage/ageless-and-rp-system-oxygen-

absorbers/rp-system-oxygen-absorbers/

acesso em 28/11/2012

LABORATÓRIO DE ENGENHARIA DE POLÍMEROS E COMPÓSITOS DA UFMG

http://www.demet.ufmg.br/docentes/rodrigo/r3.htm

acesso em 02/08/2012.

LONDON NATURAL HISTORY MUSEUM

http://www.nhm.ac.uk/.

acesso em 30/03/2012. 
MINERALOGICAL DATABASE

http://www.mindat.org. acesso regular.

MINEROPAR - Serviço Geológico do Paraná http://www.mineropar.pr.gov.br/modules/conteudo/conteudo.php?conteudo=138 acesso em 17/04/2012.

MGC (Mitsubishi Gas Chemichal America, INC.):

http://www.mgc-a.com/AGELESS/RPSystemEffects.htm acesso em 28/11/2012.

MUSEU CÂMARA CASCUDO - UFRGN

http://acd.ufrn.br/geologia/sbp/cascudo.htm (desatualizado)

acesso em 15/05/2012.

MUSEU DA GEODIVERSIDADE - UFRJ

www.geologia.ufrj.br/museu

acesso em 07/04/2012.

MUSEU DAS CULTURAS DOM BOSCO.

http://www.mcdb.org.br/

acesso em 27/03/2012.

MUSEU DAS MINAS E DO METAL

http://www.mmm.org.br

acesso em 05/04/2012.

MUSEU DE CIÊNCIAS NATURAIS

http://www.ucs.br/ucs/museu/areadeatuacao/geociencias/geociencias acesso em 26/03/2012.

MUSEU DE CIÊNCIAS NATURAIS - UNICENTRO

http://www.unicentro.br/museu

acesso em 21/03/2012.

MUSEU DE CIÊNCIA E TÉCNICA DA ESCOLA DE MINAS - UFOP

www.museu.em.ufop.br/

acesso em 23/03/2012.

MUSEU DE CIÊNCIAS DA TERRA - DNPM

www.mme.gov.br/sgm/menu/entidades_vinculadas/Museu.html

acesso em 20/06/2012.

MUSEU DE GEOCIÊNCIAS DA UFPA

http://www.gmga.ufpa.br/ 
acesso em 15/05/2012.

MUSEU DE GEOCIÊNCIAS DA UNB.

HTTP://vsites.unb.br/ig/exte/museu/index.html

acesso em 25/03/2012.

MUSEU DE GEOLOGIA DA CPRM

www.cprm.gov.br/publique/cgi/cgilua.exe/sys/start.htm?sid=93

acesso em 03/05/2012.

MUSEU DE HISTÓRIA GEOLÓGICA DO RS - UNISINOS

http://www.unisinos.br/nit/index.php

acesso em 06/03/2012

MUSEU DE MINERAIS E ROCHAS - MMR DA UFPE

www.ufpe.br/geologia

acesso em 03/06/2012.

MUSEU DE MINERAIS E ROCHAS DA UFU

http://www.redemuseus.proex.ufu.br/minerais.htm

acesso em 06/03/2012

MUSEU DE MINERALOGIA E PETROLOGIA “LUIZ EGLERT”

www.museumin.urgs.br

acesso em 15/05/2012.

MUSEU DE MINERALOGIA “PROF. HEINZ EBERT”

www.rc.unesp.br/museudpm

acesso em 11/03/2011.

MUSEU DE MINERALOGIA VICTOR DEQUECH

http://www.geosol.com.br/geosol/site/php/default interna.php?id=5\&subId=11 acesso em 09/04/2012

MUSEU GEOLÓGICO DA BAHIA

$\underline{\text { www.sicm.ba.gov.br/Pagina.aspx?pagina }=\mathrm{mgb}}$

acesso em 15/05/2012.

MUSEU GEOLÓGICO VALDEMAR LEFÈVRE

www.mugeo.sp.gov.br

acesso em 01/08/2012.

MUSEU NACIONAL - UFRJ

http://www.museunacional.ufrj.br

acesso em 21/03/2012. 
MUSEU PARAENSE EMÍLIO GOELDI

www.museu-goeldi.br

acesso em 21/03/2012.

SMITHSONIAN NATIONAL MUSEUM OF NATURAL HISTORY

http://mineralsciences.si.edu/research/meteorites/antarctica/curation.htm acesso em 18/06/2012.

UNIVERSIDADE FEDERAL DO RIO DE JANEIRO - UNIRIO

http://www.unirio.br/museologia/escolademuseologia/apresentacao.htm

(ACESSO EM 28/01/2013)

UNIVERSIDADE DA VIRGINIA

http://people.virginia.edu/ lz2n/mse201/mse201-defects.pdf (acesso em 22/11/2012).

WIKIPEDIA

http://pt.wikipedia.org/wiki/Gabinete_de_curiosidades Acesso em 05 de abril de 2012. 